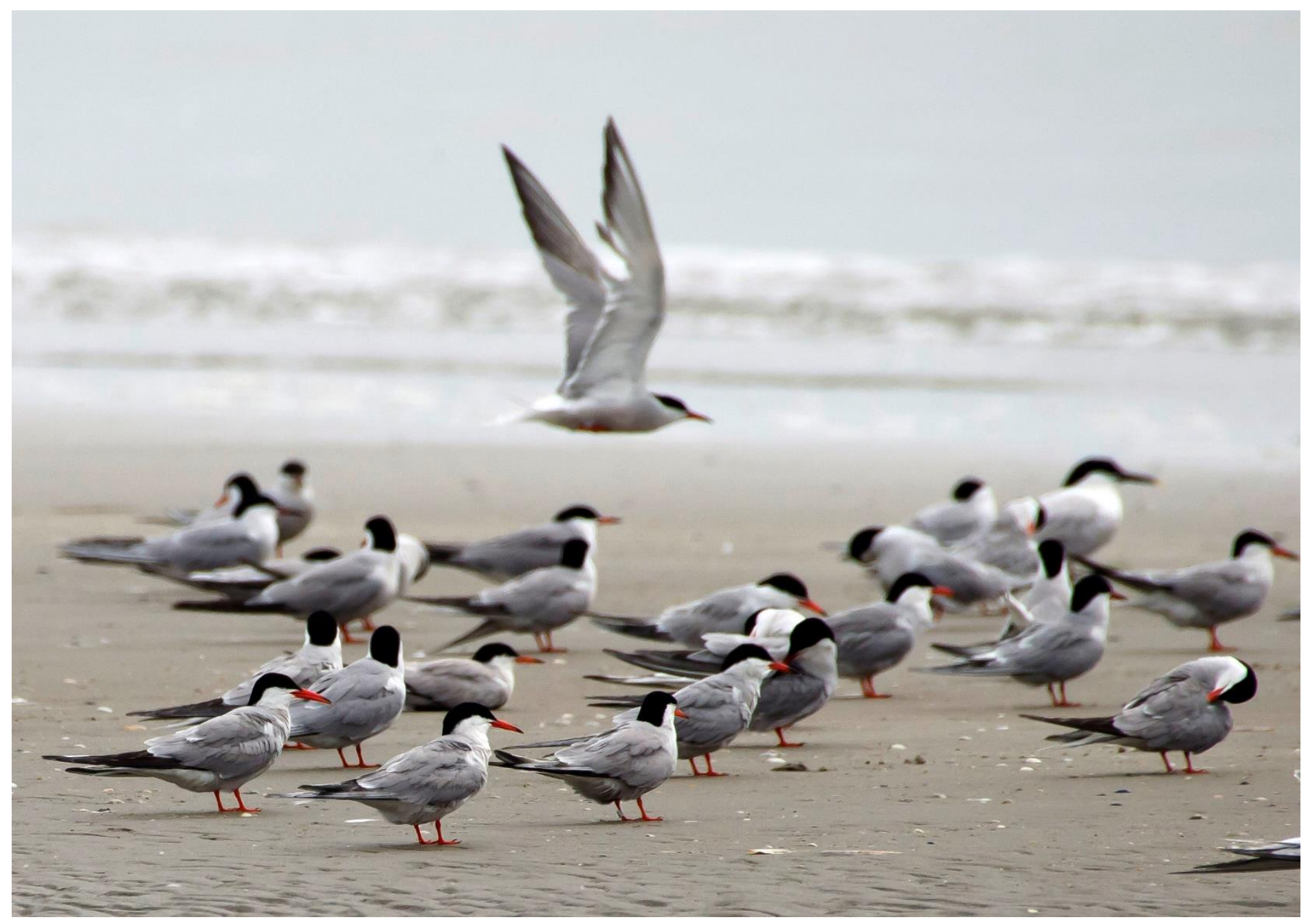

\title{
Eindrapportage monitoring- en onderzoeksprogramma Natuurcompensatie Voordelta (PMR-NCV)
}

Auteur(s): Theo Prins, Jaap van der Meer, Peter Herman
Wageningen University \&

Research rapport C053/20

Deltares:1230156-001-ZKS-

0001 


\title{
Eindrapportage monitoring- en onderzoeksprogramma Natuurcompensatie Voordelta
}

\author{
(PMR-NCV)
}

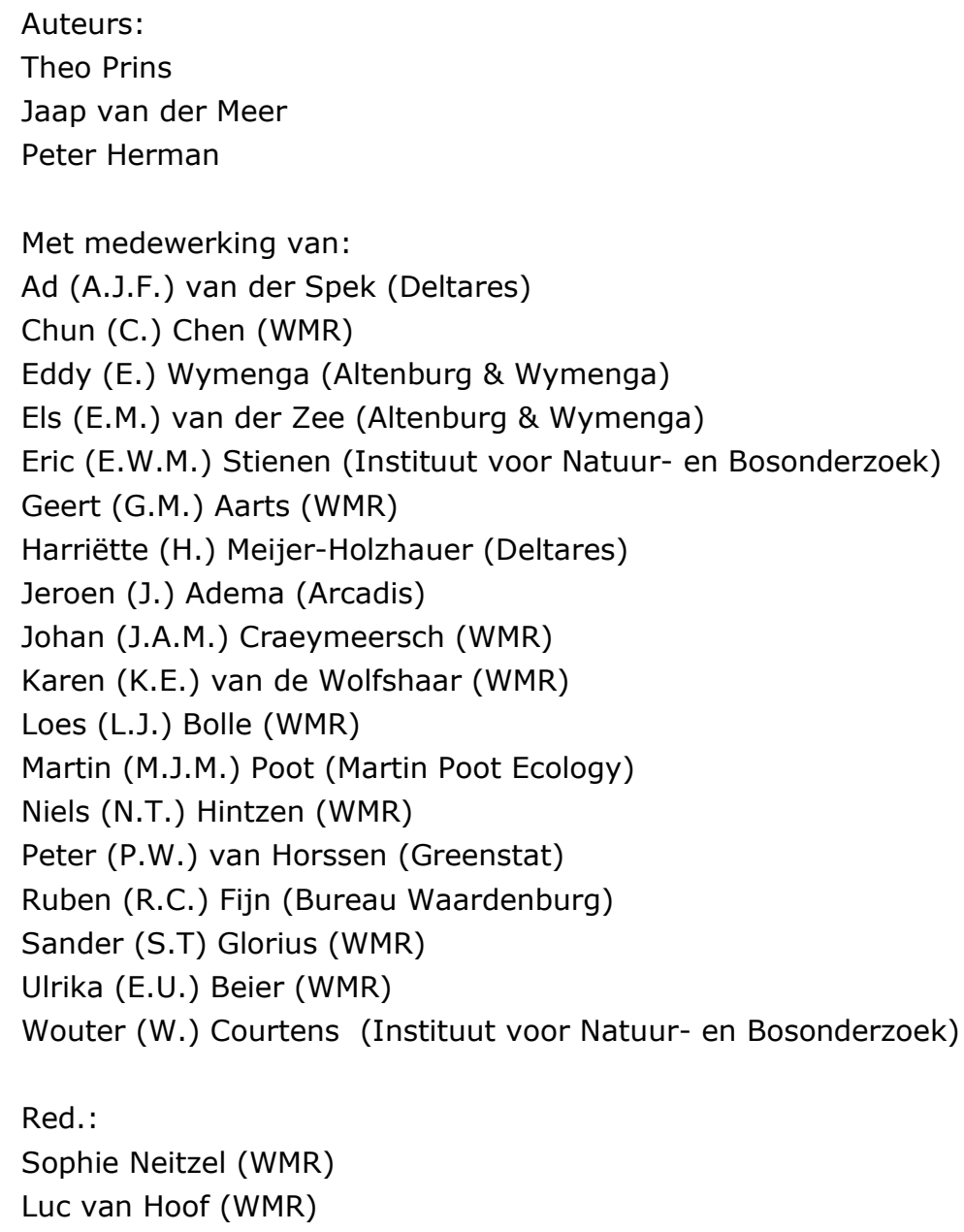


Keywords: Voordelta, Natuurcompensatie, Maasvlakte2, monitoring.

Opdrachtgever: Rijkswaterstaat Water, Verkeer en Leefomgeving

T.a.v.: Dr. Mennobart van Eerden

Postbus 17

8200 AA Lelystad

Dit rapport is gratis te downloaden van https://doi.org/10.18174/524298

Wageningen Marine Research verstrekt geen gedrukte exemplaren van rapporten.

Wageningen Marine Research is ISO 9001:2015 gecertificeerd.

Foto omslag: Olvin van Keeken

(C) Wageningen Marine Research

Wageningen Marine Research, instituut binnen de rechtspersoon Stichting

Wageningen Research, hierbij

vertegenwoordigd door Dr. M.C.Th.

Scholten, Algemeen directeur

KvK nr. 09098104

WMR BTW nr. NL 8113.83.696.B16.

Code BIC/SWIFT address: RABONL2U

IBAN code: NL 73 RABO 0373599285
Wageningen Marine Research aanvaardt geen aansprakelijkheid voor gevolgschade, noch voor schade welke voortvloeit uit toepassingen van de resultaten van werkzaamheden of andere gegevens verkregen van Wageningen Marine Research. Opdrachtgever vrijwaart Wageningen Marine Research van aanspraken van derden in verband met deze toepassing.

Alle rechten voorbehouden. Niets uit deze uitgave mag weergegeven en/of gepubliceerd worden, gefotokopieerd of op enige andere manier gebruikt worden zonder schriftelijke toestemming van de uitgever of auteur. 


\section{Inhoudsopgave}

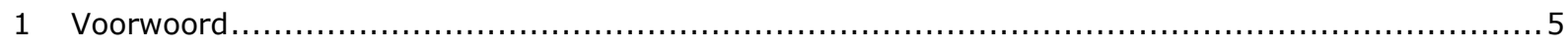

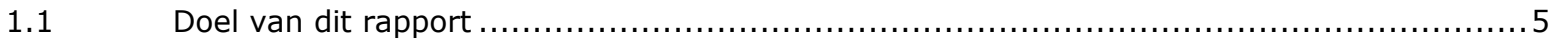

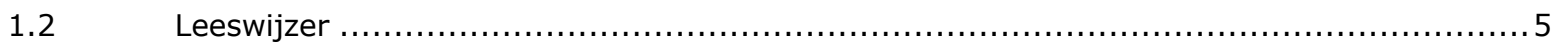

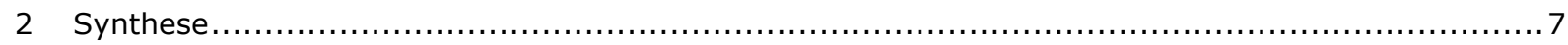

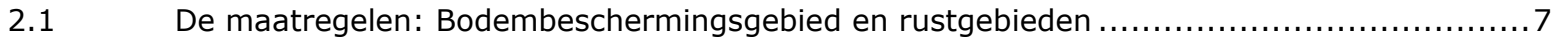

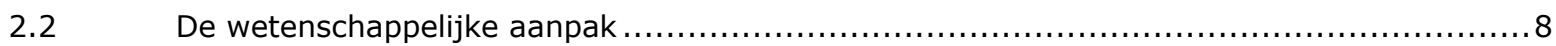

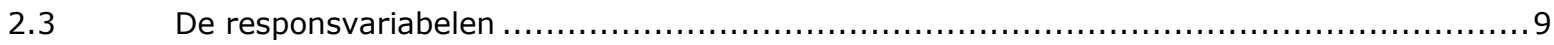

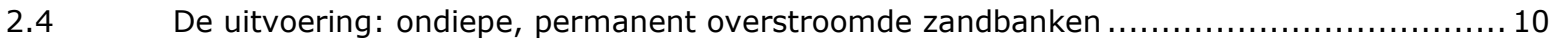

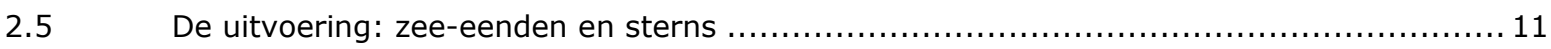

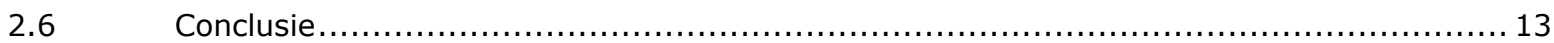

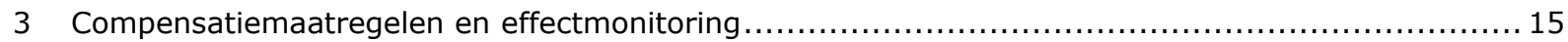

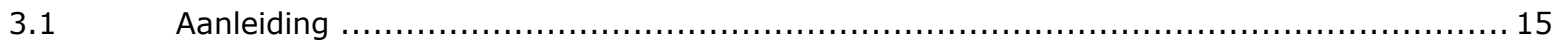

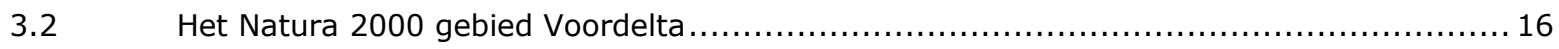

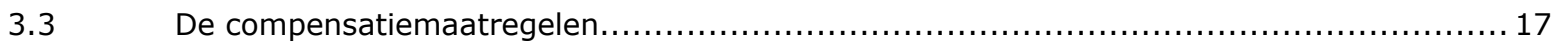

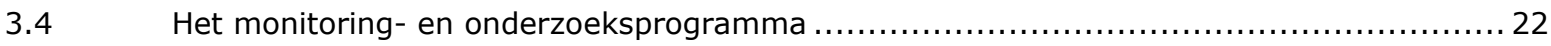

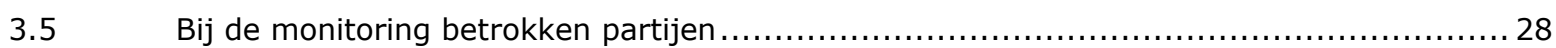

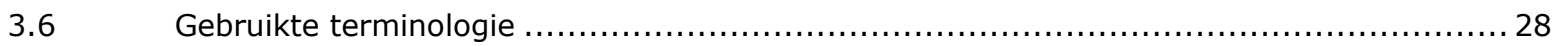

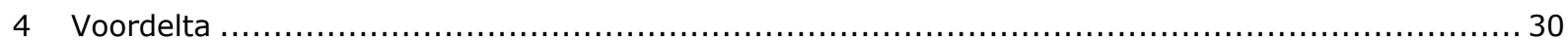

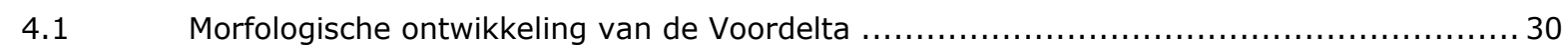

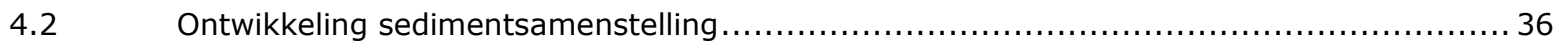

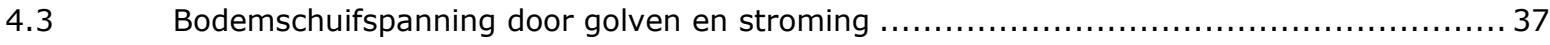

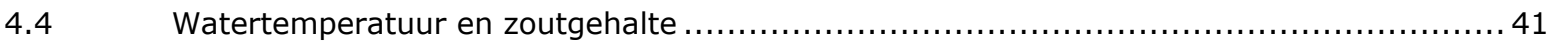

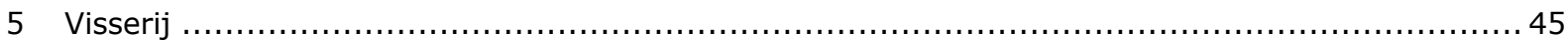

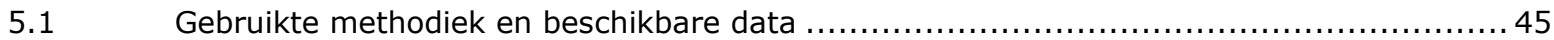

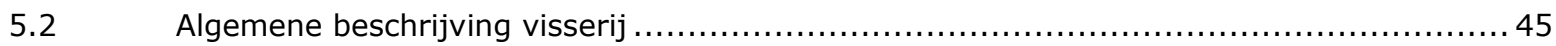

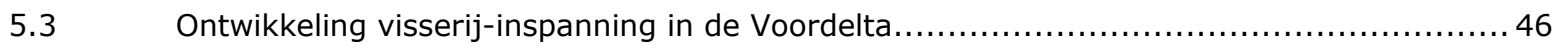

5.4 Ontwikkelingen visserij binnen en buiten de Voordelta $\ldots \ldots \ldots \ldots \ldots \ldots \ldots \ldots \ldots \ldots \ldots \ldots \ldots \ldots$

$5.5 \quad$ Effect van biomassa-onttrekking door visserij via vangsten en discards..................50

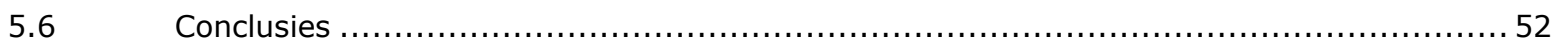




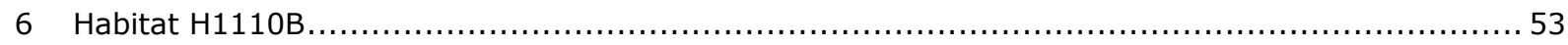

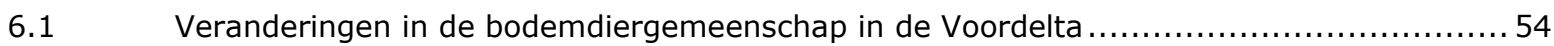

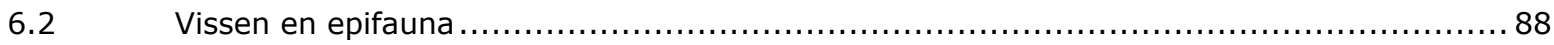

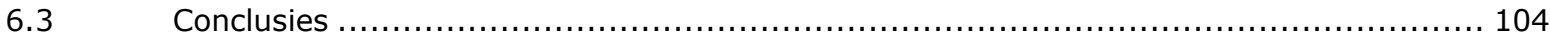

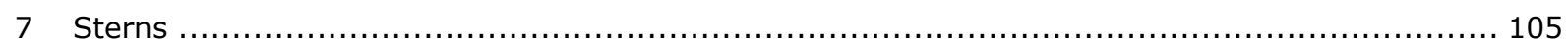

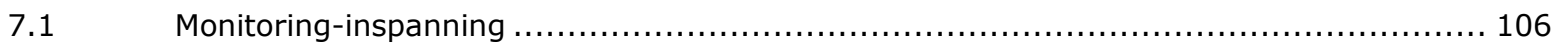

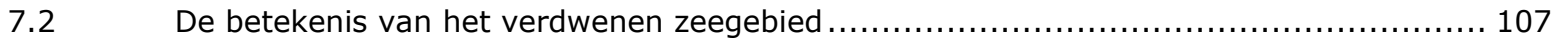

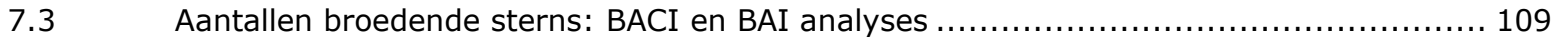

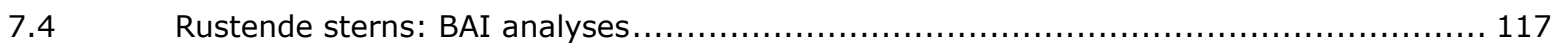

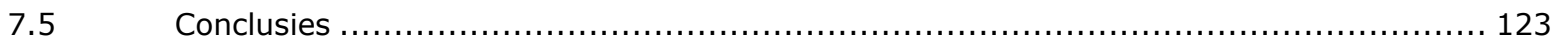

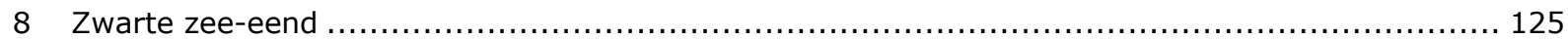

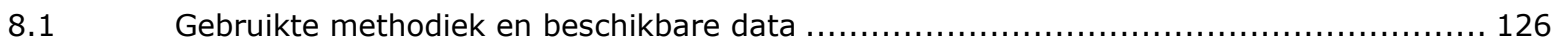

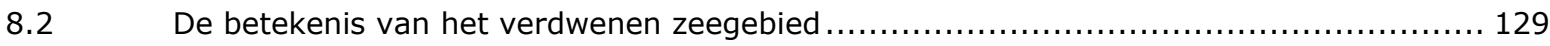

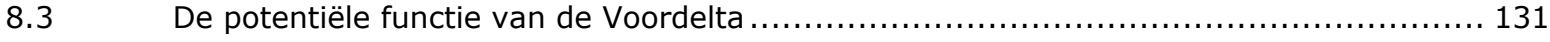

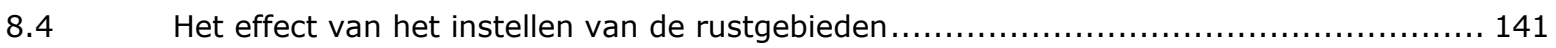

8.5 Aantallen in de Voordelta in vergelijking met andere gebieden........................ 144

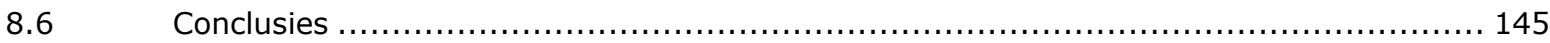

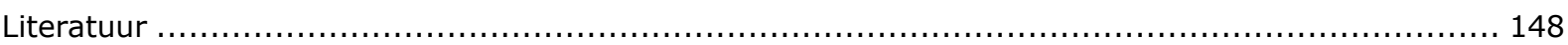

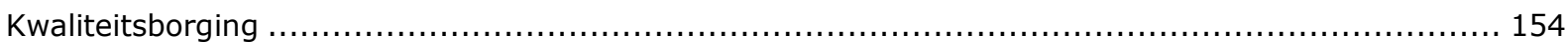

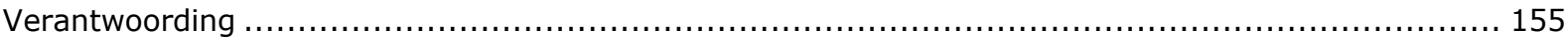

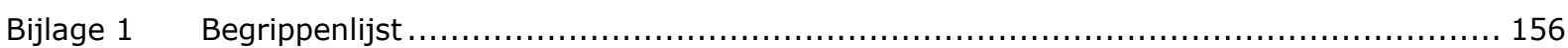

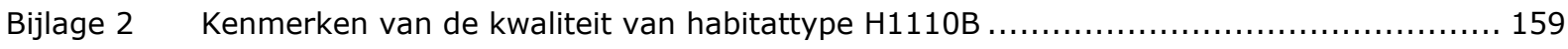

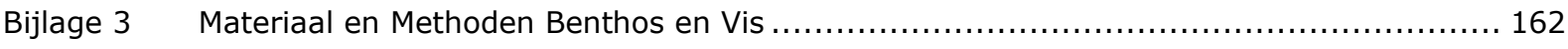

Bijlage 4 MEP evaluatievragen en onderzoeksvragen van het monitoringprogramma .............. 172

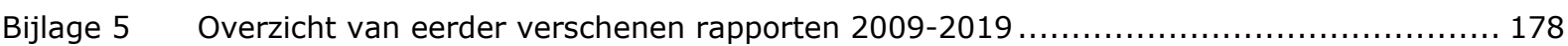




\section{$1 \quad$ Voorwoord}

\subsection{Doel van dit rapport}

In 2006 is een planologische kernbeslissing genomen over het Project Mainportontwikkeling Rotterdam (PMR). In dit kader is in 2008 begonnen met de aanleg van Maasvlakte 2. In samenhang daarmee zijn natuurcompensatiemaatregelen genomen in de Voordelta. Vanaf 2009 is in het kader van het project Natuurcompensatie Voordelta (PMR-NCV) een monitoring- en onderzoeksprogramma uitgevoerd in de Voordelta, voortvloeiend uit de monitoringverplichtingen in het kader van de vergunning op grond van de $\mathrm{Nb}$-wet 1998 voor de aanleg en aanwezigheid van Maasvlakte 2 en de bijbehorende natuurcompensatie. Het hier voorliggende rapport vormt de wetenschappelijke rapportage over de resultaten van het programma.

Het rapport geeft een synthese van de monitorings- en onderzoeksresultaten uit de nulmetingen (20042007) en de eerste (2009-2015) en tweede (2016-2018) fase van PMR-NCV, aangevuld met de resultaten van ander relevant onderzoek. Op grond hiervan worden de effecten van de natuurcompensatiemaatregelen beschreven. Dit rapport vormt een vervolg op de in 2018 gepubliceerde synthese (Tulp et al., 2018a). Het rapport omvat zowel een actualisatie van analyseresultaten en conclusies op basis van meetgegevens uit recente jaren die nog niet beschikbaar waren in 2018, als resultaten van nieuwe analyses. Vanwege de grote onderzoeksinspanning die verricht is, zou het te ver voeren om in dit rapport een volledig overzicht te geven van alle onderzoeks- en monitoringsresultaten. Het rapport beperkt zich tot de belangrijkste resultaten met het oog op beantwoorden van de vragen over de effecten van de natuurcompensatie.

\subsection{Leeswijzer}

In hoofdstuk 2 wordt een synthese gegeven van de resultaten van het onderzoek en wordt antwoord gegeven op de onderzoeksvragen die zijn geformuleerd bij de opzet van het monitoringprogramma.

De volgende hoofdstukken gaan in meer detail in op de achtergronden bij het monitoringprogramma en de resultaten.

Hoofdstuk 3 geeft achtergrondinformatie over de maatregelen voor natuurcompensatie en de opzet van het monitoringprogramma, en schetst de context voor het monitoringprogramma.

Hoofdstuk 4 geeft achtergrondinformatie over de Voordelta en de belangrijkste abiotische omstandigheden die invloed kunnen hebben op het ecologisch functioneren, in de periode waarin het monitoringprogramma is uitgevoerd. Deze informatie is gebruikt bij de analyses in de volgende hoofdstukken, en is met name van belang voor de resultaten van het onderzoek aan bodemdieren en vis in hoofdstuk 6.

Hoofdstuk 5 beschrijft de ontwikkelingen in de visserij op platvis, garnalen en schelpdieren in de Voordelta in de jaren 2004-2018.

In hoofdstuk 6 wordt een gedetailleerde beschrijving gegeven van de resultaten van analyses van de ontwikkelingen in bodemdieren en demersale (bij de zeebodem levende) vis. De resultaten en conclusies dienen ter beantwoording van de vragen over de effecten van de compensatiemaatregelen op de kwaliteit van habitattype H1110B. 
Hoofdstuk 7 gaat in op de resultaten en conclusies uit monitoring en onderzoek van de grote stern en visdief, ten behoeve van de beantwoording van de MEP vraag met betrekking tot de compensatiemaatregelen voor de sterns.

Hoofdstuk 8 beschrijft de resultaten en conclusies van monitoring en onderzoek van de zwarte zee-eend, met het oog op de beantwoording van de MEP vraag met betrekking tot de compensatiemaatregelen voor de zwarte zee-eend.

In de bijlagen zijn de MEP vragen opgenomen, en wordt een overzicht gegeven van alle rapporten die in de loop van het monitoring- en onderzoeksprogramma zijn verschenen. Daarnaast zijn er nog een aantal bijlagen met meer gedetailleerde methodologische informatie evenals een bergrippenlijst.

Alhoewel de individuele hoofdstukken goed als zelfstandige eenheden zijn te lezen is ervoor gekozen om begrippen en methodologieën daar waar zij voor de eerste keer worden gebruikt meer volledig te omschrijven en te definiëren. 


\section{Synthese}

De Passende Beoordeling (Heinis et al., 2007) verwachtte dat de aanleg van Maasvlakte 2 zou resulteren in een verlies van 2,8\% van het habitattype $\mathrm{H} 1110 \mathrm{~B}$ ("met zeewater van geringe diepte overstroomde zandbanken van de Noordzee kustzone") in de Voordelta, met als gevolg dat ook de foerageerfuncties voor de grote stern $(-1,7 \%)$, de visdief $(-5,9 \%)$ en de zwarte zee-eend $(-3,1 \%)$ achteruit zouden gaan. Voor deze als significant beoordeelde negatieve effecten moesten compensatiemaatregelen genomen worden om de totale natuurwaarde in de Voordelta in stand te houden. De maatregelen bestonden uit de instelling van een Bodembeschermingsgebied en van rustgebieden voor de drie vogelsoorten. In dit eindrapport is het onderzoek gepresenteerd dat als basis moet dienen om de vraag te kunnen beantwoorden of het verlies aan habitattype $\mathrm{H} 1110 \mathrm{~B}$ en aan foerageergebied van de drie vogelsoorten met deze maatregelen gecompenseerd is. Het rapport beschrijft de onderzoeksresultaten uit de periode vóór (T0: 2004-2007) en de twee fasen (T1: 2009-2015 en T2: 2016-2019) na de aanleg van Maasvlakte 2, aangevuld met enkele resultaten van ander relevant onderzoek.

\subsection{De maatregelen: Bodembeschermingsgebied en rustgebieden}

In het bijna 25.000 ha grote Bodembeschermingsgebied zijn boomkorvissers met wekkerkettingen en met schepen met een motorvermogen groter dan 260 pk sinds 2008 geweerd. In de ecologische onderbouwing (Lindeboom et al., 2002) van deze maatregel werd beredeneerd dat sluiting van een gebied voor bodemberoerende visserij met minimaal 10 maal de omvang van Maasvlakte 2 er voor zou zorgen dat het directe negatieve effect van Maasvlakte 2 op habitat H1110B in de Voordelta zou worden gecompenseerd. Die factor 10 stoelt op het onderzoek van Bergman et al. (1990), die hadden aangetoond dat "per trawlpassage van de boomkorvisserij minimaal 10\% van de karakteristieke bodemdiersoorten wordt gedood", met als veronderstelling dat zonder bodemberoerende visserij een $10 \%$ kwaliteitsverbetering mogelijk zou zijn. In een vervolgstudie (Rijnsdorp et al., 2006) werd bevestigd dat uitsluiting van deze vorm van visserij zou leiden tot een verhoging van de bodemdierenbiomassa met naar schatting 10 tot 21 procent. Samen met de verminderde vangst van vis in het gebied zou dit zorgen voor een toename in het voedselaanbod voor vogels en vissen en dus in verbetering van de kwaliteit van het gebied (Rijnsdorp et al., 2006, VenW, 2008). De verwachting was dus dat "de productie van voedsel voor vogels en vissen gelijk blijft aan die vóór de aanleg van Maasvlakte 2, waardoor het verlies aan soorten in de Voordelta als gevolg van de aanleg van Maasvlakte 2 ten minste wordt gecompenseerd" (VenW, 2008). Het Bodembeschermingsgebied is, met uitzondering van de rustgebieden, overigens wel toegankelijk voor andere vormen van visserij, waarvan garnalenvisserij de meest voorkomende visserij is.

Voor de zwarte zee-eend, grote stern en visdief zijn rustgebieden ingesteld: de Hinderplaat (grote stern en visdief), de Bollen van de Ooster (grote stern en zwarte zee-eend) en Bollen van het Nieuwe Zand (zwarte zee-eend). In 2013 is op basis van tussentijdse resultaten geconcludeerd dat de zwarte zeeeenden in de Voordelta zich voornamelijk buiten de rustgebieden Bollen van de Ooster en Bollen van het Nieuwe Zand bevonden (van Oostveen \& Koolmees, 2013). In 2016 zijn de begrenzingen van de rustgebieden voor de zwarte zee-eend (Bollen van de Ooster en Bollen van het Nieuwe Zand) daarom ruimer gemaakt en is de periode van sluiting van het gebied aangepast. Door een gerechtelijke uitspraak eind 2018 is deze maatregel echter weer teruggedraaid.

Om het verlies van 3,1\% van het potentiële foerageergebied van de zwarte zee-eend te compenseren, is "het wenselijk dat de totale hoeveelheid voor de zwarte zee-eend geschikt voedsel in de Voordelta niet verandert". Verwacht werd dat door de instelling van het Bodembeschermingsgebied de hoeveelheid 
voedsel voor de zwarte zee-eend in de Voordelta tenminste gelijk zou blijven. Het doel van het instellen van het rustgebied voor de zwarte zee-eend is dat "door het beperken van de verstoring door recreatie en scheepvaartbewegingen in de concentratiegebieden van de soort (...) het voor de zwarte zee-eend mogelijk is om optimaal van het voedselaanbod te profiteren". De beoogde draagkracht van het gebied en tevens instandhoudingsdoel, ingeschat op 9.700 vogels in het midden van de winter, zou op deze wijze niet in gevaar komen (VenW, 2008).

De ingestelde rustgebieden voor beide sternsoorten hebben tot doel om "in de zomerperiode op drooggevallen platen in de Voordelta zodanige rust te creëren dat de grote sterns en visdiefjes met hun jongen deze platen kunnen benutten om te rusten en gemakkelijker bij hun voedselgebieden op zee te komen" (VenW 2008). Bij het formuleren van de maatregel is er van uitgegaan dat de foerageerafstand voor grote stern en visdief niet te groot moet worden, "bij voorkeur minder dan vijftien kilometer en niet meer dan veertig kilometer" (VenW, 2008).

\subsection{De wetenschappelijke aanpak}

Om te kunnen toetsen of de compensatiemaatregelen het gewenste effect sorteren is het van belang dat van te voren duidelijk gemaakt wordt welke wetenschappelijke aanpak gevolgd wordt. Idealiter zou ten minste één van de volgende twee wegen bewandeld moeten worden: een puur statistische experimentele aanpak of een analytische benadering waarbij onderliggende mechanismen en processen bekend verondersteld worden en vervolgens wiskundig gemodelleerd worden.

De statistische experimentele benadering beschouwt het ingrijpen van de mens in een gebied als een grootschalig wetenschappelijk veldexperiment. Een veelgebruikte opzet van zo'n experiment is de zogenaamde BACI (Before-After-Control-Impact) opzet (Green, 1979). Naast metingen in het gebied waar de ingreep plaatsvindt (het Impact gebied) worden ook metingen gedaan in een referentiegebied (het Control gebied) dat afgezien van de ingreep vergelijkbaar moet zijn voor wat betreft omgevingsfactoren. Bovendien worden in beide gebieden herhaalde metingen zowel vóór (Before) als na (After) de ingreep gedaan. Door in de tijd de veranderingen in het Impact gebied te vergelijken met de veranderingen in het controle gebied kunnen de effecten van 'autonome' ontwikkelingen worden onderscheiden van de effecten van de ingreep (Green, 1979, Underwood, 1992; 1996).

De opzet is niet ideaal omdat er maar één ingreepgebied is en één referentiegebied. Noodgedwongen kan niet de variantie tussen gebieden als foutenterm gebruikt worden, in plaats daarvan moet de variantie binnen elk van de vier BACI combinaties (bijvoorbeeld de variantie tussen monsters of tussen jaargemiddelden) als foutenterm gebruikt worden. Er valt bijna nooit aan te ontkomen dat er maar één ingreepgebied is, maar de opzet kan dus sterk verbeterd worden door meerdere "onafhankelijke" controle gebieden te kiezen. Dit wordt wel een Beyond-BACI opzet genoemd.

Hoewel een BACI opzet een gangbare aanpak is in studies naar het effect van menselijk ingrepen in ecosystemen, moeten wij ons wel blijven realiseren dat de simpele BACI opzet niet voldoet aan de eisen die normaal gesproken aan een wetenschappelijk experiment gesteld worden. Er is noch sprake van randomisatie (ingreep en referentiegebieden worden niet aselect gekozen), noch van onafhankelijkheid (wat in het ingreep gebied plaatsvindt kan gevolgen hebben voor het nabij gelegen referentiegebied), noch van replicatie (er is maar één ingreepgebied en meestal maar één, of heel weinig referentiegebieden). Het is dus van belang om duidelijke criteria te hanteren om vast te stellen of er sprake is van een oorzaak-gevolg relatie als er een verschil in veranderingen gevonden wordt tussen het ingreepgebied en het referentiegebied (Stewart-Oaten, 1996). Als criteria worden genoemd door Stewart-Oaten (1996) en zie ook Schwarz (2013):

- Sterkte van de correlatie: Hoe sterker een relatie wordt gevonden in een serie van verschillende studies, hoe minder waarschijnlijk dat de relatie toevallig is of veroorzaakt door een andere, niet waargenomen, factor; 
- Consistentie van de waarnemingen: Er zijn meerdere studies die betrekking hebben op de gevonden verbanden en die hebben gelijke bevindingen;

- De relatie is specifiek: Het gevonden effect is alleen gecorreleerd met de vermoede oorzaak en andere oorzaken kunnen uitgesloten worden;

- Duidelijke opeenvolging in tijd: De oorzaak vindt in tijd plaats vóór het gevolg;

- Dosis-effect relatie: De waarde van de respons variabele verandert op een te verwachten, te verklaren wijze met het niveau van de sturende variabele;

- Biologisch of theoretisch plausibel: Het hypothetische oorzakelijk verband is consistent met biologische of theoretische kennis;

- Coherentie van de resultaten: De bevindingen zijn niet in conflict met geaccepteerde feiten m.b.t. de bestudeerde variabele;

- Experimenteel aangetoond: Er zijn ondersteunende experimentele of semi-experimentele waarnemingen.

De tweede analytische benadering is op een andere leest geschoeid. In deze benadering wordt er van uitgegaan dat er voldoende kwantitatieve kennis van het systeem is en dat de mechanismen die bepalen hoe de ingreep doorwerkt tot aan de respons goed bekend zijn. De kennis van deze mechanismen kan geformaliseerd worden in een wiskundig model en met dit model kan dan ook het effect van de ingreep op de respons doorgerekend worden. Misschien zijn niet alle modelparameters precies bekend en moet er nog een ijking plaatsvinden met behulp van lokaal verkregen gegevens, maar het uitgangspunt is dat de onderliggende relaties bekend zijn.

Helaas zijn levensgemeenschappen en ecosystemen zeer complex en ontbreekt kennis van de vele onderliggende mechanismen. Als een experimentele of pseudo-experimentele benadering niet mogelijk is grijpen ecologen terug op puur correlatieve analyses met alle daaraan verbonden valkuilen. Hoe ingewikkeld de statistische modellen tegenwoordig ook zijn, het gevaar dat waarde toegekend wordt aan een gevonden relatie als die tussen het aantal broedende ooievaars in een gebied en de geboortecijfers bij de plaatselijke menselijke bevolking blijft aanwezig. Bij correlatieve analyses op basis van waarnemingen is het dus nog belangrijker om de bovengenoemde criteria van Stewart-Oaten te hanteren dan in een BACI studie.

\subsection{De responsvariabelen}

Welke onderzoeksaanpak ook gekozen wordt, het is altijd van belang dat van te voren een duidelijke keuze gemaakt wordt welke responsvariabelen gebruikt worden op grond waarvan een uitspraak gedaan wordt.

De instelling van het Bodembeschermingsgebied moest leiden tot een $10 \%$ verbetering van de kwaliteit van Habitattype $\mathrm{H} 1110 \mathrm{~B}$, waarbij in eerste instantie totale bodemdierenbiomassa gebruikt zou worden als maat voor kwaliteit (LNV, 2008c). Later is toegevoegd dat bodemdierenbiomassa per soortgroep opgevoerd zou kunnen worden als "primaire maat voor de kwaliteit van habitattype H1110 in termen van voedselbeschikbaarheid voor vissen en vogels", en daarmee voor de ecologische winst (RWS, 2014). Nog later is gesteld dat aanvulling met andere indicatoren mogelijk is (EZ, 2015). De keuze voor alternatieve indicatoren is uitgebreid beschreven in eerdere rapporten (Prins et al., 2016, Tulp et al., 2018)

De instelling van rustgebieden voor de zwarte zee-eend moet, samen met de instelling van het Bodembeschermingsgebied, zorgen dat de potentiële foerageerfunctie van de Voordelta voor de zwarte zee-eend niet verandert door aanleg van Maasvlakte 2. Om uitspraken te kunnen doen over het behoud van de foerageerfunctie is inzicht in het voedselaanbod, het aantal vogels dat in de Voordelta verblijft (vertaald in vogeldagen) en in het gebruik van de rustgebieden nodig. Ook voor grote stern en visdief staat behoud van de potentiële foerageerfunctie voorop. In principe zouden daarmee ook voedselaanbod, aantallen vogels/vogeldagen en het gebruik van de rustgebieden als indicator gebruikt kunnen worden. Om praktische redenen (een goede schatting van vogeldagen op zee is praktisch niet uitvoerbaar onder 
meer vanwege de hoge kosten) is echter voor een deels andere aanpak gekozen met de nadruk op aantallen broedparen en broedsucces.

\subsection{De uitvoering: ondiepe, permanent overstroomde zandbanken}

Voor wat betreft het onderzoek naar het effect van de instelling van het Bodembeschermingsgebied op de kwaliteit van habitat $\mathrm{H} 1110 \mathrm{~B}$ is voor een simpele BACI opzet gekozen, omdat het qua onderzoekscapaciteit niet haalbaar was om meerdere referentiegebieden te bemonsteren. Het Bodembeschermingsgebied was het 'Impact' gebied waar als compensatiemaatregel de boomkorvisserij geweerd werd vanaf 2008, en in de rest van de Voordelta waar de boomkorvisserij niet geweerd werd is een 'Control' gebied als referentie geselecteerd. Nulmetingen zijn uitgevoerd in 2004-2005 om de toestand voor de ingreep vast te stellen. Vanaf 2009 tot 2019 zijn metingen uitgevoerd om de toestand na de ingreep te kunnen beschrijven. Voor zowel de bodemdieren als de vissen is een referentiegebied geselecteerd dat zo goed mogelijk aan de voorwaarden voldeed van gelijke omgevingsfactoren.

De BACI analyse waarmee het effect van de instelling van een Bodembeschermingsgebied op de totale bodemdierenbiomassa (de allereerst genoemde maat om de kwaliteit van dit habitattype H1110B uit te drukken) van de ondiepe zandbanken onderzocht is, heeft om meerdere redenen niet de uitkomst opgeleverd die van te voren verwacht werd. Ten eerste bleek uit het onderzoek dat er al voordat de beschermingsmaatregel van kracht werd, dus al in de zogeheten T0 situatie, nauwelijks met de wekkerkettingen-boomkor gevist werd in het latere Bodembeschermingsgebied. Ten tweede liep deze visserijvorm ook in het referentiegebied al in het begin van de onderzoeksperiode hard terug. Ten derde nam in dezelfde periode in de Voordelta de garnalenvisserij sterk toe en dan vooral in het Bodembeschermingsgebied, waar deze vorm van visserij niet verboden was. Kortom, de visserijdruk nam juist toe in het beschermingsgebied en af in het referentiegebied. Een BACI experiment wordt vaak een pseudo-experiment genoemd omdat de onderzoekers het gebied waar de ingreep plaats vindt niet aselect kunnen kiezen. In dit geval kwam het effect van de maatregel en van de ontwikkeling in de visserij zelfs niet overeen met de oorspronkelijke verwachting dat de intensiteit van de garnalenvisserij in het Bodembeschermingsgebied niet zou veranderen.

De eerste, voor de hand liggende vraag in een BACI studie is of de ingreep ook daadwerkelijk plaatsgevonden heeft in het ingreepgebied en of het referentiegebied zoals verwacht gevrijwaard is van een dergelijke ingreep. Hier kan deze vraag vertaald worden als: heeft de juridisch ingestelde maatregel geleid tot het beoogde doel, namelijk vermindering van de bodemberoering door visserij in het Bodembeschermingsgebied om aldaar zo een verbetering van de kwaliteit van habitat $\mathrm{H} 1110 \mathrm{~B}$ te bereiken? Het antwoord is neen. Er is in de Voordelta, ondanks de genomen wettelijke maatregel, geen gebied te vinden dat gevrijwaard is van bodemberoering door visserij. In het Bodembeschermingsgebied is bodemberoering door visserij toegenomen na het instellen van de maatregelen. In de rest van de Voordelta is plaatselijk de visserijdruk afgenomen, maar dat is niet toe te schrijven aan de maatregelen. Bovendien blijft in dat deel bodemberoerende visserij mogelijk en kunnen veranderingen van dergelijke visserij in de toekomst niet uitgesloten worden.

Naast de ingreep lijkt ook de respons van het bodemdierenleven heel anders uitgepakt te hebben dan verwacht. De bodemdierenbiomassa is in het referentiegebied afgenomen (terwijl de visserij ook afnam), terwijl die in het Bodembeschermingsgebied juist toenam (met toenemende garnalenvisserij). Het lijkt erop dat de Amerikaanse zwaardschede Ensis leei, een exoot die in de Voordelta een dominante rol speelt in de bodemdierengemeenschap, de elders gevonden negatieve relatie tussen bodemberoering door de visserij en bodemdierenbiomassa op zijn kop gooit. In andere gebieden zijn het vooral kleine, kortlevende bodemdieren die bij frequente bodemberoerende visserij profiteren ten gunste van kwetsbare langlevende en grote soorten. Hier lijkt juist de grotere langlevende zwaardschede beter bestand tegen bodemberoerende visserij. Deze soort is relatief mobiel, kan zich snel ingraven en kan zo overleven. Om meer zicht te krijgen op dit fenomeen en op hoe de hele bodemdierengemeenschap van 
de Voordelta reageert op de veranderingen in visserijdruk en abiotiek is daarom teruggegrepen op correlatieve analyses. Ook zijn andere responsvariabelen dan totale bodemdierenbiomassa onderzocht, waaronder verschillende biodiversiteitsmaten. Deze correlatieve analyses zouden dan aanwijzingen moeten geven of het verminderen van bodemberoerende visserijdruk in de Voordelta tot een verbetering van de kwaliteit van habitattype $\mathrm{H} 1110 \mathrm{~B}$ had kunnen leiden, los van het feit dat de visserijdruk in het Bodembeschermingsgebied alleen maar is toegenomen en in het referentiegebied is afgenomen.

Deze correlatieve zoektocht kan uiteindelijk samengevat worden in het zoeken naar antwoorden op twee vragen. De eerste vraag is of het aannemelijk gemaakt kan worden dat de bodemdiergemeenschap toeneemt in biomassa als de visserijdruk en dus de bodemberoering door visserij vermindert? Het antwoord is neen. In alle delen van de Voordelta waar de visserijdruk door boomkorvisserij is verminderd, is een daling van de bodemdierbiomassa geconstateerd. Omgekeerd is bij een verhoging van de visserijdruk door garnalenvisserij een verhoging van de bodemdierbiomassa vastgesteld. Als het effect van het wegnemen van visserijdruk zou zijn dat de biomassa toeneemt, dan is dat effect zo zwak dat het andere factoren die tot een omgekeerde ontwikkeling hebben geleid niet heeft kunnen tegenhouden.

De tweede vraag is of aannemelijk gemaakt kan worden dat de diversiteit van de bodemdiergemeenschap toeneemt als de visserijdruk en dus de bodemberoering door visserij vermindert? Hier ligt het antwoord genuanceerder. De causale relatie kan niet worden aangetoond, bij gebrek aan ondersteunende experimentele gegevens (één van de criteria van Stewart-Oaten), maar de beschikbare gegevens zijn niet in tegenstrijd met deze hypothese. Er wordt overal geconstateerd dat de diversiteit van de bodemdiergemeenschap is toegenomen. Die toename is het sterkst waar de visserijdruk het sterkst is afgenomen.

Kortom, het uitgevoerde onderzoek laat niet toe te concluderen dat in het Bodembeschermingsgebied het verminderen van visserijdruk een voldoende maatregel had kunnen zijn om daar een toename van de biomassa van bodemdieren te bewerkstelligen. De data spreken niet tegen dat het verminderen van visserijdruk een voldoende maatregel had kunnen zijn om een verhoging van de diversiteit van bodemdieren te bewerkstelligen. De genomen maatregelen hebben echter de bodemberoering door visserij in het Bodembeschermingsgebied niet gereduceerd. Door de ontwikkeling in de garnalenvisserij is de bodemberoering juist toegenomen. Als de bodemberoering door visserij wel was verminderd, dan zou dat niet voldoende zijn geweest om biomassacompensatie te bewerkstelligen, in ieder geval niet op de termijn van de onderzoeksperiode, maar wellicht wel om de kwaliteit van het gebied in termen van diversiteit te verhogen.

\subsection{De uitvoering: zee-eenden en sterns}

Het instellen van rustgebieden voor de zwarte zee-eend, in combinatie met het instellen van het Bodembeschermingsgebied, had als doel om de geschiktheid van de Voordelta als overwinteringsgebied voor de zwarte zee-eend na aanleg van Maasvlakte 2 gelijk te houden aan de situatie vóór aanleg. Het effect van de maatregel wordt beoordeeld door te bezien in welke mate de Voordelta haar potentiële foerageerfunctie voor de zwarte zee-eend heeft behouden. De monitoring richtte zich op het bepalen van aantallen vogels (en daarvan afgeleid aantal vogeldagen) in de Voordelta gedurende het winterhalfjaar. In een BACI analyse is de rest van Nederland aangewezen als referentiegebied. Als de verschillen in het aantal vogeldagen tussen de periode voor en na de aanleg van Maasvlakte 2 in de Voordelta niet anders zijn dan de verschillen in het referentiegebied kan geconcludeerd worden dat de compensatiemaatregelen blijkbaar gewerkt hebben.

Uit de tellingen in zowel de Voordelta als in de rest van Nederland bleek dat het aantal eenden dat in de winter hier verblijft sterk varieert van jaar op jaar. Het midwinteraantal in de Voordelta varieerde tussen 100 en 9000 en voor geheel Nederland lag dit tussen 6000 en 100.000. Deze aantallen (en zeker die in de Voordelta) zijn laag in vergelijking met de 1,6 miljoen eenden die in Duitsland en het Oostzeegebied 
overwinteren. Kleine veranderingen in de keuze die de eenden maken om al of niet te blijven in één van deze noordelijke gebieden langs de 'flyway' zullen al snel tot sterk wisselende aantallen in de Voordelta leiden. Statistisch gezien heeft de hieruit voortkomende grote jaar-op-jaar variatie in de Voordelta tot gevolg dat het onderscheidingsvermogen van de BACI test laag is. Een voor-na verschil zal erg groot moeten zijn wil het met een redelijke kans aangetoond kunnen worden. Een dergelijke test is dus weinig zinvol.

Om deze reden is er voor gekozen ook een modelbenadering te volgen: misschien komen de vogels niet elk jaar, maar er moet wel voldoende voedsel en rust zijn zodat ze, als ze komen, wel terecht kunnen. Daarom is een model opgezet om de potentiële aantallen overwinterende eenden, als functie van voedselaanbod en afwezigheid van verstoring, te kunnen berekenen. Het model beschrijft de energiehuishouding en het voedsel-zoekgedrag van de eenden.

Veranderingen in voedselaanbod zijn bepaald op basis van de biomassa van, als voedsel geschikte, schelpdieren. Veranderingen in verstoring zijn bepaald aan de hand van gegevens over de scheepvaart. Het specifieke effect van de rustgebieden is nader onderzocht door de ruimtelijke verspreiding van de eenden en het daadwerkelijk gebruik van de rustgebieden te bepalen. Het door het model voorspelde potentiële aantal eenden bleek nog steeds sterk te variëren van jaar op jaar, maar ook afgenomen na de aanleg van Maasvlakte 2. De variatie heeft grotendeels te maken met de variatie in voedselaanbod aan geschikte schelpdieren. Bij het beantwoorden van de vraag in hoeverre dit met de aanleg van Maasvlakte 2 , met de instelling van het Bodembeschermingsgebied of met visserij in zijn algemeenheid te maken heeft, komen dezelfde problemen om de hoek kijken als in de bovenstaande paragraaf over de ondiepe zandbanken aan de orde gesteld zijn. De processen die het voedselaanbod bepalen zijn immers niet gemodelleerd, maar op veldgegevens gebaseerd. De werking van verstoring door scheepvaart is wel gemodelleerd. Op basis van aannames over hoe scheepvaart de eenden verstoort, is modelmatig ingeschat dat toegenomen scheepsbewegingen in de laatste jaren (2015-2019) het potentiële aantal overwinterende eenden met ruim de helft heeft gereduceerd. De waarnemingen van het aantal zeeeenden en een analyse van statistische verbanden tussen aantal eenden en scheepvaart door visserij wijzen niet op een duidelijk negatief effect in de jaren met intensieve garnalenvisserij. Garnalenvisserij komt deels voor in dezelfde gebieden als waar zee-eenden worden waargenomen, maar terwijl garnalenvisserij vooral in het najaar en begin van de winter plaats vindt, zijn de eenden vooral aan het eind van de winter en het vroege voorjaar aanwezig. Het niet gelijktijdig voorkomen van garnalenvisserij en zwarte zee-eenden is daarom niet eenvoudig aan te merken als een effect van verstoring of niet. Tot slot, zowel berekeningen van potentiële aantallen eenden op basis van gegevens over het voedselaanbod als oude veldtellingen van zwarte zee-eenden gaven aan dat het zeegebied waar de Maasvlakte 2 is aangelegd geen foerageergebied voor de zwarte zee-eend geweest kan zijn.

Het instellen van rustgebieden voor grote stern en visdief had als doel de foerageerfunctie van de Voordelta na aanleg van Maasvlakte 2 gelijk te houden aan de situatie vóór aanleg. De maatregel is mede gericht op de vogels afkomstig uit broedkolonies in het noordelijk deel van het Deltagebied. Het direct bepalen van de foerageerfunctie door het monitoren van het voedselaanbod van pelagische prooien is methodisch lastig, omdat het om kleine pelagische vis gaat waarvan de bestanden moeilijk gekwantificeerd kunnen worden. Daarom is gekozen voor onderzoek en monitoring van aantallen broedparen, broedsucces en kwaliteit en kwantiteit van de door de vogels aangevoerde prooien.

De uitgevoerde BACI analyses, waar in dit geval wel gebruik gemaakt is van meerdere referentiegebieden, toonden aan dat de noordelijke Delta (voor de grote stern) en de Maasvlakte (voor de visdief) relatief gelijk gebleven zijn als broedgebied voor de sterns. Lokaal onderzoek laat zien dat er na de aanleg meer grote sterns in het noordelijk Deltagebied broedden dan in de jaren daarvoor en dat ze een beter broedsucces hadden. Kortom er is geen negatief effect aantoonbaar op de aantallen en broedsucces van stern en visdief. Het is de vraag ook in hoeverre de rustgebieden het voorspelde negatieve effect van de aanleg van de Maasvlakte hebben kunnen compenseren. Het statistische onderscheidingsvermogen is, mede veroorzaakt door de grote jaar-op-jaar variatie in koloniekeuze van 
sterns niet groot genoeg om het verschil te kunnen aantonen tussen geen achteruitgang en een achteruitgang van bijvoorbeeld $1,7 \%$ zoals voorspeld voor de grote stern.

Voor de visdief zijn, naast de statistische aanpak, ook modelberekeningen uitgevoerd om de gevolgen van langere vliegtijden tussen de foerageergebieden en de broedkolonie op de Maasvlakte voor de energiehuishouding van ouders en kuikens te achterhalen. Deze berekeningen voorspelden een afname in energieleverantie aan de kuikens van 15-20\%. Toch kon in het veld geen afname in broedsucces aangetoond worden. Het blijft daarom evenzeer onduidelijk of het mogelijke negatieve effect gecompenseerd is door een verbeterde voedselbeschikbaarheid door de ingestelde rustgebieden of dat de vele veronderstellingen die aan het model ten grondslag liggen voor verbetering vatbaar zijn. Het specifieke effect van de rustgebieden is nader onderzocht door onderzoek aan het gebruik van de rustgebieden door de sterns en de aanwezigheid van verstoring. De rustgebieden worden gebruikt,, maar door de grote variatie binnen en tussen jaren in het gebruik van de diverse rustgebieden konden hier geen conclusies over effectiviteit uit getrokken worden.

\subsection{Conclusie}

De Passende Beoordeling (Heinis et al., 2007) gaf aan dat door de aanleg van Maasvlakte 2 ondiepe overstroomde zandbanken (habitattype $\mathrm{H} 1110 \mathrm{~B}$ ) zouden verdwijnen en dat negatieve effecten op de lokale populaties van drie vogelsoorten niet uit te sluiten waren. Nu het langlopende en uitvoerige monitorings- en onderzoeksprogramma is afgerond kan geconcludeerd worden dat het areaalverlies aan zandbanken inderdaad in de verwachte omvang is opgetreden. Negatieve effecten waren niet aantoonbaar voor de grote stern, die het verloren gegane zeegebied sowieso nauwelijks gebruikte. Negatieve effecten waren wel aanwezig voor de op de Maasvlakte broedende visdief, die nu een langere vliegafstand heeft naar de belangrijkste foerageergebieden. Voor de zwarte zee-eend is het beeld niet eenduidig. De voedselbiomassa is niet afgenomen en veldgegevens konden de door de modellen aangegeven verstorende rol van garnalenvisserij bevestigen noch ontkennen. Maar net als voor de grote stern was het verdwenen zeegebied niet van betekenis voor deze zee-eend. In ieder geval is voor geen van de vogelsoorten gebleken dat eventuele negatieve ontwikkelingen ook aantoonbaar effect hebben gehad op de aantallen of de aanwezigheid in het gebied. Misschien zijn de negatieve effecten te klein om aangetoond te worden, of misschien betreffen ze niet de meest kritische aspecten van de biologie van de soorten, waardoor ze niet beperkend zijn voor de populatieontwikkeling in het gebied.

Voor het habitat $\mathrm{H} 1110 \mathrm{~B}$ is de belangrijkste vraag of de huidige toestand van het gebied, inclusief areaalverlies, beter, even goed of slechter is dan de toestand vóór de aanleg van Maasvlakte 2 . We hebben geconstateerd dat de verhoopte compensatie van de verloren biomassa niet is gerealiseerd of in elk geval niet aan de genomen maatregelen kan worden toegeschreven. We hebben anderzijds geconstateerd dat het gebied nog steeds functioneert als een dynamisch kustgebied, waarin de verschillende typen wateren blijven voorkomen en hun ecologische rol blijven vervullen. Na het verleggen van de kust is er nog steeds een kust, en dus ook, om een voorbeeld te geven, foerageergebied voor de visdief. Door de geomorfologische aanpassingen aan het verleggen van de kust blijven ondieptes en beschutte gebieden bestaan die habitat kunnen bieden aan, bijvoorbeeld, zeeeenden. In die zin zijn met het areaal niet alle ecologische functies van dat areaal verloren gegaan.

Anderzijds hebben we geconstateerd dat het gebied drukker is geworden. De sterke opkomst van de garnalenvisserij en de ontwikkeling van andere menselijke activiteiten hebben de druk op het gebied verhoogd, waardoor de overname van verloren ecologische functies wellicht minder volledig is verlopen dan kon worden verhoopt. De maatregelen die zijn genomen om de ecologische functies van het gebied te versterken, zijn niet allemaal even effectief gebleken omdat ze anders zijn uitgepakt dan gepland. De balans van functies, zowel ecologisch als voor menselijk gebruik, zal uiteindelijk bij de evaluatie van de genomen maatregelen de beslissende doorslag moeten geven. 
In de onderzoeksperiode is niet alleen gekeken naar de fysische, geomorfologische en ecologische ontwikkelingen in de Voordelta, maar is, om de veranderingen in perspectief te plaatsen, ook gekeken naar de situatie elders in Nederland en verder langs de Noordzeekusten. Dit heeft geleid tot nieuwe inzichten, bijvoorbeeld over de invloed van visserij op de bodemdier-, vis- en vogelpopulaties en levensgemeenschappen van kustwateren. Hiermee draagt het werk niet alleen bij aan de evaluatie van de natuurcompensatie, maar levert het ook kennis en data (de monitoringgegevens zijn publiekelijk beschikbaar) die ingezet kunnen worden voor het toekomstig beheer van de Nederlandse kustwateren. 


\section{Compensatiemaatregelen en effectmonitoring}

\subsection{Aanleiding}

In de jaren negentig is een verkenningsfase gestart om oplossingen te zoeken voor het ruimtegebrek van de Rotterdamse haven. Onderdeel van de oplossing was uitbreiding van de haven door landwinning en aanleg van een tweede Maasvlakte. Het besluitvormingsproces heeft uiteindelijk geresulteerd in een bestuursovereenkomst in 2005 en een planologische kernbeslissing in 2006. In dat besluit zijn twee doelstellingen vastgelegd, enerzijds versterken van de mainport Rotterdam en oplossen van het ruimtetekort voor haven- en industriële activiteiten in het Rotterdamse havengebied door de aanleg van Maasvlakte 2, en anderzijds het verbeteren van de kwaliteit van de leefomgeving (IenM, 2017).

In het Milieueffectrapport (MER; Berkenbosch et al., 2007) en de Passende Beoordeling (PB; Heinis et al., 2007) opgesteld ten behoeve van de besluitvorming over de aanleg van Maasvlakte 2, is ingeschat dat door de aanleg een oppervlakte van in totaal 2.455 hectare van habitattype H1110B ("permanent met zeewater van geringe diepte overstroomde zandbanken") verloren kan gaan. In deze schatting is naast het ruimtebeslag van Maasvlakte 2 zelf ook het verlies meegenomen door de erosie ten gevolge van een veranderende waterbeweging (erosiekuil) en een toegenomen getijslag. Dit verlies aan habitat H1110B impliceert ook een afname van potentieel foerageer- en leefgebied van de soorten waarvoor instandhoudingsdoelstellingen gelden in de Voordelta. In de PB is vastgesteld dat niet is uit te sluiten dat er een significant negatief effect is op het habitattype H1110B (het verlies van maximaal 2.455 ha oftewel 2,8\% van het totale areaal in de Voordelta) en als gevolg daarvan op de foerageerfunctie voor de grote stern $(-1,7 \%)$, de visdief $(-5,9 \%)$ en de zwarte zee-eend $(-3,1 \%)$. Voor deze als mogelijk significant beoordeelde negatieve effecten zijn maatregelen voorgeschreven om deze effecten te compenseren met als doel de totale natuurwaarde in de Voordelta in stand te houden.

De compensatiemaatregelen bestaan uit de instelling van een Bodembeschermingsgebied en daarbinnen instelling van rustgebieden voor de zwarte zee-eend, grote stern en visdief. De wijze waarop die compensatie plaats vindt is opgenomen in de vergunning voor Maasvlakte 2 op grond van de Natuurbeschermingswet 1998, het Aanwijzingsbesluit Voordelta (LNV, 2008a) en het daarbij horende Beheerplan Voordelta (VenW, 2008) en toegangsbeperkingsbesluiten. Deze compensatiemaatregelen moeten leiden tot kwaliteitsverhoging van het habitattype $\mathrm{H} 1110 \mathrm{~B}$ binnen het

Bodembeschermingsgebied en het gelijk houden van de kwaliteit van het leefgebied voor de zwarte zeeeend, grote stern en visdief in de Voordelta.

In de vergunning op grond van de $\mathrm{Nb}$-wet 1998 is eveneens voorgeschreven dat de effecten van de compensatiemaatregelen worden gevolgd door uitvoering van een monitoringprogramma, dat inzicht moet geven in de effectiviteit van de compensatiemaatregelen. In 2009, bij de aanvang van het monitoringprogramma van het Project Mainport Development Rotterdam - NatuurCompensatie Voordelta (PMR-NCV) zijn in het Monitorings- en Evaluatie Programma Natuurcompensatie (MEP-NCV) de vragen geformuleerd waarop het monitoringprogramma van de natuurcompensatie een antwoord dient te geven (VenW, 2009). In essentie gaat het daarbij om de vraag of door de getroffen compensatiemaatregelen het verlies aan habitattype $\mathrm{H} 1110 \mathrm{~B}$ en foerageergebied van zwarte zee-eend, grote stern en visdief als gevolg van Maasvlakte 2, voldoende gecompenseerd zijn. De vragen zijn verder uitgewerkt in deelvragen die ingaan op specifieke aspecten en het causale verband met de maatregelen (VenW, 2009). Dit MEPNCV is formeel vastgesteld door LNV. De MEP vragen zijn opgenomen in Bijlage 4. 
In 2009 is het monitoringprogramma PMR-NCV gestart dat de basis vormt voor de beantwoording van de MEP-vragen. De resultaten van het monitoringprogramma (inclusief nulmetingen) worden hier gerapporteerd.

\subsection{Het Natura 2000 gebied Voordelta}

De Voordelta is het gebied dat bestaat uit de ondiepe kustwateren voor de delta van Zuid-Holland en Zeeland (Figuur 3.1). Het betreft het gebied vanaf de Westerscheldemonding tot aan de Euro/Maasgeul. Door de ligging voor de Zuid-Hollandse- en Zeeuwse delta wijkt het gebied af van de kustwateren die verder noordelijk voor de Hollandse kust liggen. De Westerscheldemonding is als apart Natura 2000gebied (Vlakte van de Raan) aangewezen. De begrenzing van het Natura 2000 gebied Voordelta is vastgelegd in het aanwijzingsbesluit Voordelta en wijzigingsbesluiten (LNV, 2008a; LNV, 2009; EZ, 2013). De zeewaartse begrenzing is in 2013 verschoven van de rechtgetrokken NAP-20 m dieptelijn naar de doorgaande NAP-20 m dieptelijn, waardoor het gebied 6.852 ha kleiner is geworden. Het Natura 2000-gebied Voordelta heeft thans een oppervlak van ongeveer 83.530 hectare (EZ, 2013; RWS, 2016).

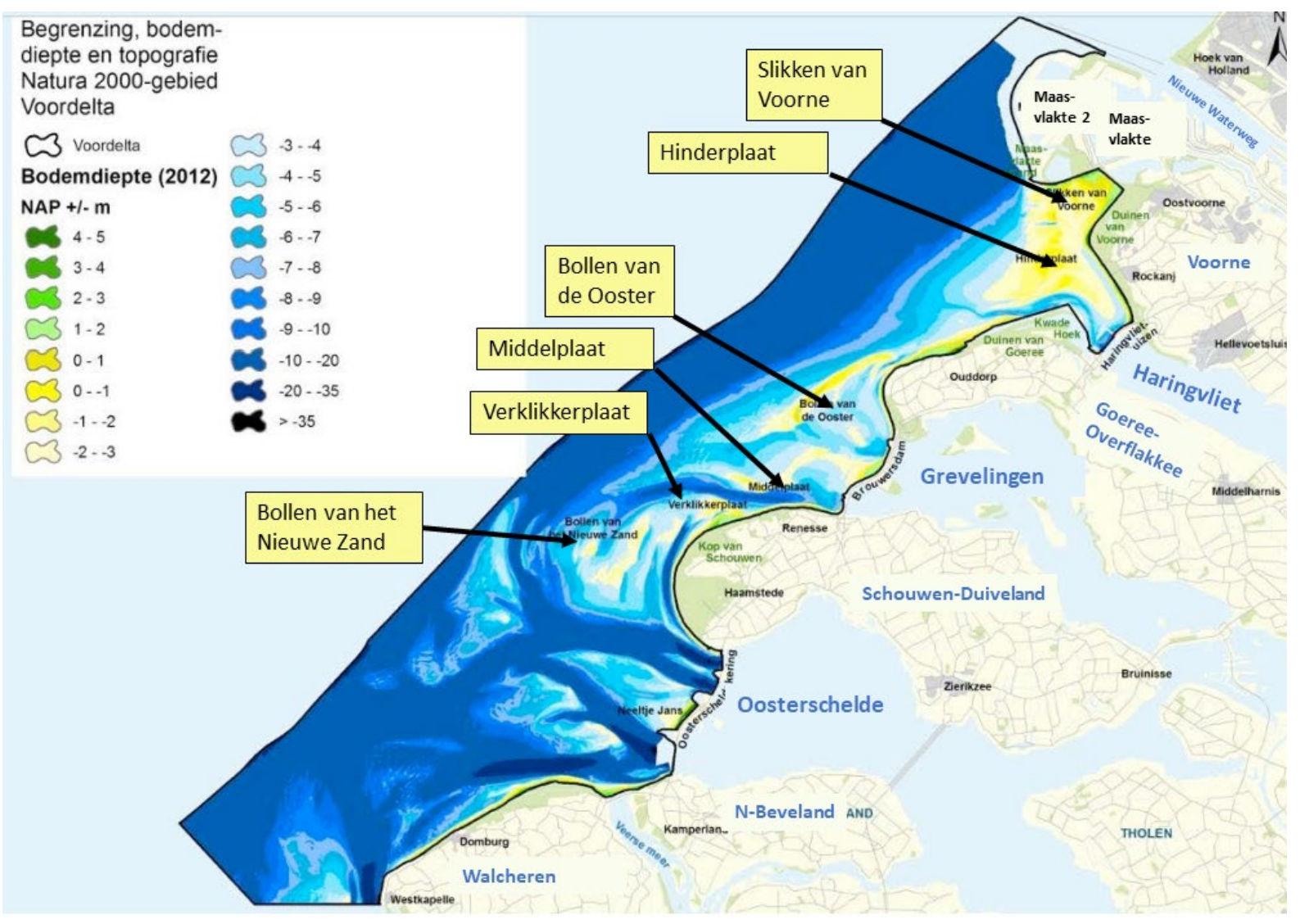

Figuur 3.1 Begrenzing van het Natura-2000 gebied Voordelta, met bodemdiepte, platen en topografie (bron: Figuur 2.1 uit RWS (2016)).

De Voordelta is sinds 2008 aangewezen als Natura 2000-gebied onder zowel de Habitatrichtlijn als de Vogelrichtlijn. Het grootste deel (80.409 ha) is gekarakteriseerd als habitattype H1110 (permanent overstroomde zandbanken); een kleiner deel bestaat uit habitattype H1140 (2.224 ha; slik- en zandplaten) en andere habitattypen (RWS, 2016). Het eerste Natura 2000 beheerplan voor de Voordelta had betrekking op de periode 2008 - 2014 (VenW, 2008). In 2013 is een evaluatie uitgevoerd (van Oostveen en Koolmees, 2013) waarin werd vastgesteld dat het oppervlak permanent overstroomde 
zandbanken (H1110) tussen 2007 en 2012 met 2.111 hectare $(2,4 \%)$ is afgenomen. Dit kwam grotendeels door de aanleg van Maasvlakte 2. Het oppervlak slik- en zandplaten $(\mathrm{H} 1140)$ is daarentegen iets toegenomen (16 hectare, $0,7 \%$ ).

\subsection{De compensatiemaatregelen}

\subsubsection{De maatregelen: Bodembeschermingsgebied en rustgebieden}

Het Bodembeschermingsgebied (BBG) en enkele van de rustgebieden in de Voordelta (Bollen van de Ooster, Bollen van het Nieuwe Zand en de Hinderplaat) behoren tot de natuurcompensatiemaatregelen voor Maasvlakte 2 (Tabel 3.1); daarnaast zijn enkele rustgebieden ingesteld ten behoeve van Natura 2000 (Figuur 3.2).

Uitgangspunt voor de compensatiemaatregelen was verminderen van verstoring door bodemberoerende visserij en daardoor verbeteren van de kwaliteit van habitattype H1110B en daarnaast vergroten van de rust voor zwarte zee-eend, grote stern en visdief. In het BBG worden boomkorvissers met wekkerkettingen en met schepen met een motorvermogen groter dan 260 pk sinds 2008 geweerd om de kwaliteit van habitattype $\mathrm{H} 1110 \mathrm{~B}$ te verbeteren (LNV, 2008b). Het BBG is wel toegankelijk voor andere vormen van visserij, waarvan garnalenvisserij de meest voorkomende visserij is. De begrenzingen en regimes van de rustgebieden zijn juridisch verankerd door het nemen van toegangsbeperkingsbesluiten (LNV, 2008c). Voor de zwarte zee-eend, grote stern en visdief zijn rustgebieden ingesteld: de Hinderplaat (grote stern en visdief), de Bollen van de Ooster (grote stern en zwarte zee-eend) en Bollen van het Nieuwe Zand (zwarte zee-eend). Tijdens de evaluatie van de compensatiemonitoring in 2013 (van Oostveen en Koolmees, 2013) is op basis van de tussentijdse resultaten van PMR-NCV (Prins et al., 2013) geconcludeerd dat de zwarte zee-eenden in de Voordelta zich voornamelijk buiten de rustgebieden Bollen van de Ooster en Bollen van het Nieuwe Zand bevonden. In 2016 zijn de begrenzingen van de rustgebieden voor de zwarte zee-eend (Bollen van de Ooster en Bollen van het Nieuwe Zand) daarom ruimer gemaakt en is de periode van sluiting van het gebied aangepast. Door een gerechtelijke uitspraak eind 2018 is deze maatregel echter weer teruggedraaid. 
Tabel 3.1 Overzicht van de natuurcompensatiemaatregelen in de Voordelta (LNV, 2008b; LNV, 2019).

\begin{tabular}{|c|c|c|}
\hline Maatregel & Toelichting & Doel \\
\hline $\begin{array}{l}\text { Bodembeschermingsgebied } \\
(29.836 \mathrm{ha})^{1}\end{array}$ & $\begin{array}{l}\text { In dit gebied is de boomkorvisserij met } \\
\text { wekkerkettingen en met schepen met } \\
\text { motorvermogen }>260 \mathrm{pk} \text { verboden. }\end{array}$ & $\begin{array}{l}\text { Verbetering van de } \\
\text { kwaliteit van } \\
\text { habitattype H1110B. }\end{array}$ \\
\hline $\begin{array}{l}\text { Rustgebied Hinderplaat (1250 } \\
\text { ha) }\end{array}$ & $\begin{array}{l}\text { Jaarrond alle activiteiten verboden met } \\
\text { beperkte uitzonderingen voor } \\
\text { kanotochten en visserij. }\end{array}$ & $\begin{array}{l}\text { Rust voor grote stern } \\
\text { en visdief. }\end{array}$ \\
\hline $\begin{array}{l}\text { Rustgebied Bollen van de } \\
\text { Ooster ( } 2740 \text { ha) }\end{array}$ & $\begin{array}{l}\text { Jaarrond alle activiteiten verboden in } \\
\text { een deel van het gebied, met } \\
\text { uitzondering van het noordoostelijk deel } \\
\text { voor windsurfen, golfsurfen en kanoën, } \\
\text { en een doorvaartcorridor voor } \\
\text { scheepvaart. } \\
\text { Winterrustgebied (november t/m } \\
\text { maart) voor het zuidoostelijk deel. }\end{array}$ & $\begin{array}{l}\text { Rust voor grote stern } \\
\text { en zwarte zee-eend. }\end{array}$ \\
\hline $\begin{array}{l}\text { Rustgebied Bollen van het } \\
\text { Nieuwe Zand (1310 ha) }\end{array}$ & $\begin{array}{l}\text { Winterrustgebied. Gesloten voor alle } \\
\text { activiteiten van } 1 \text { november tot } 15 \text { mei. }\end{array}$ & $\begin{array}{l}\text { Rust voor zwarte zee- } \\
\text { eend. }\end{array}$ \\
\hline
\end{tabular}

\footnotetext{
${ }^{1}$ Het Bodembeschermingsgebied heeft een oppervlak van 29.836 ha. Daarvan is 24.550 ha het 'netto' gebied nodig vanuit de compensatieopgave. Verder omvat het Bodembeschermingsgebied accentnatuurgebieden uit het Integraal Beleidsplan Voordelta, waar al beperkingen van kracht waren voor boomkorvisserij met wekkerkettingen, de vaargeul van het Slijkgat en een gebied met droogvallende platen. Alleen het 'netto' Bodembeschermingsgebied draagt bij aan de compensatieopgave (VenW, 2008).
} 


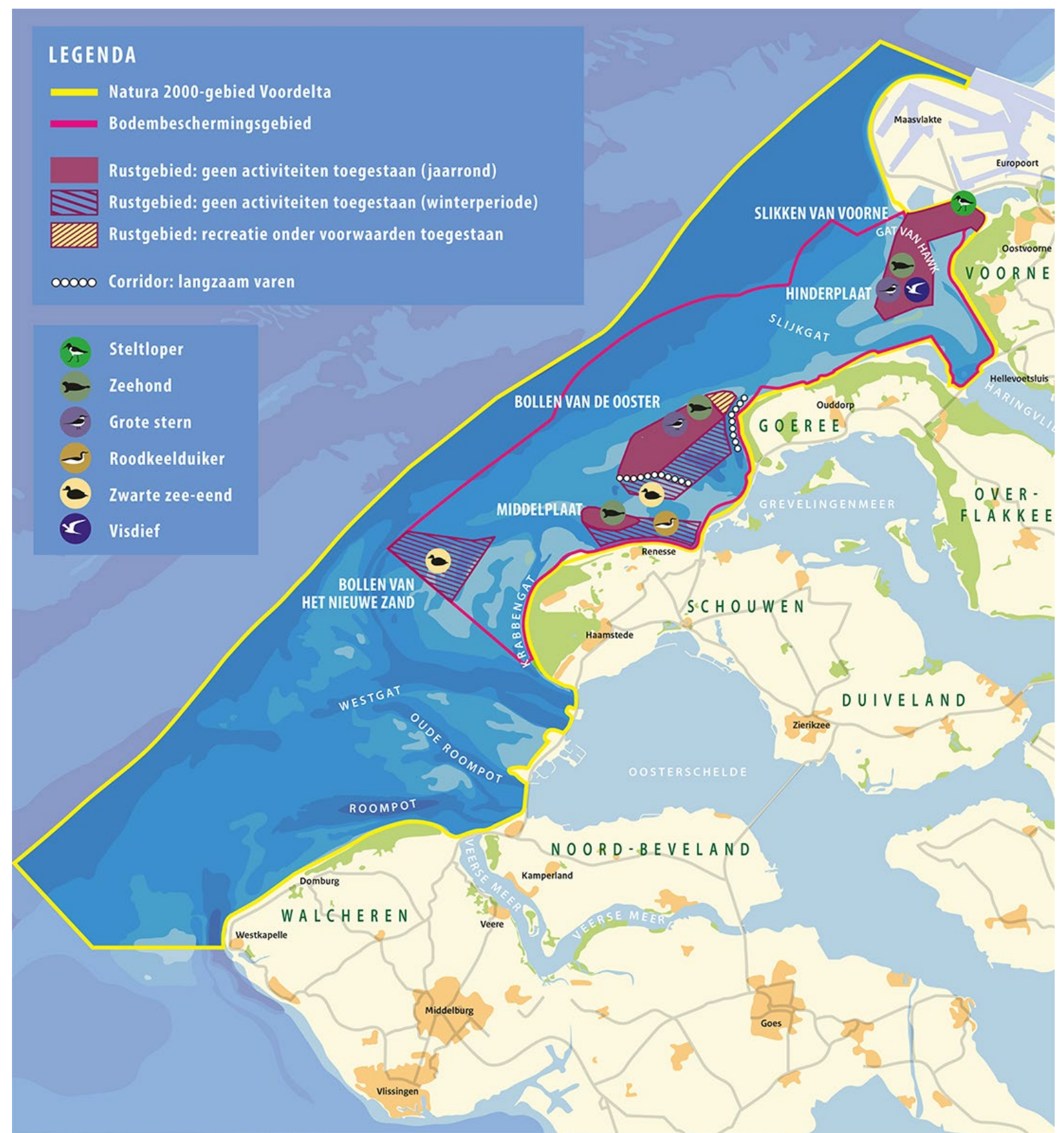

Figuur 3.2 Overzichtskaart van de Voordelta met het Natura 2000 gebied, het Bodembeschermingsgebied (rode begrenzing) en de rustgebieden Slikken van Voorne, Hinderplaat, Bollen van de Ooster, Middelplaat en Bollen van het Nieuwe Zand. Voor de natuurcompensatie zijn als rustgebieden aangewezen:

Hinderplaat (grote stern, visdief); Bollen van de Ooster (zwarte zee-eend, grote stern); Bollen van het Nieuwe Zand (zwarte zee-eend). Zie Tabel 3.1 voor details. De andere rustgebieden op de kaart zijn aangewezen voor steltlopers, zeehond en roodkeelduiker in het Beheerplan Natura 2000. Bron: https://rwsnatura2000.nl/gebieden/voordelta/vd_documenten/HandlerDownloadFiles.ashx?idnv=165532 4; download 8-5-2020) 


\subsubsection{Achtergrond bij de maatregel: Bodembeschermingsgebied}

De Voordelta was in 2000 als eerste gebied in Nederland aangewezen als speciale beschermingszone onder de EU Vogelrichtlijn en aangemeld als Habitatrichtlijn-gebied. In de PB (Heinis et al., 2007) is ingegaan op de vraag of bij landaanwinning voor Maasvlakte 2 compenserende maatregelen nodig zouden zijn. In een verkenning van mogelijkheden voor mitigatie en compensatie van landaanwinning en nader onderzoek ten behoeve van de adviesaanvraag bij de Europese Commissie, zijn verschillende mogelijkheden beoordeeld. De instelling van een zeereservaat werd gezien als enige maatregel die voldoende compensatie kon bieden voor het verlies aan areaal van habitattype 1110 (EC-PMR, 2001a; EC-PMR, 2001b). In de ecologische onderbouwing (Lindeboom et al., 2002) zijn de mogelijke maatregelen, de noodzakelijke omvang van het zeereservaat, de ecologische winst en de leemten in kennis beschreven. Gebaseerd op resultaten van Bergman et al. (1990), die had aangetoond dat "per trawlpassage minimaal 10\% van de karakteristieke bodemdiersoorten wordt gedood" (en met de aanname dat de bodemdierdichtheid en de visserij evenredig verdeeld zijn over het gebied), werd beredeneerd dat door sluiten van een gebied voor bodemberoerende visserij met minimaal 10 maal de omvang van het areaal dat verdween ten gevolge van Maasvlakte 2, het negatieve effect op habitattype H1110B in de Voordelta zou worden gecompenseerd.

In een vervolgstudie zijn de effecten van verschillende vormen van visserij verder gekwantificeerd, uitgaande van de al vastgestelde noodzaak van een 10\% kwaliteitsverbetering (Rijnsdorp et al., 2006). In die studie zijn ruimtelijke gegevens over visserij-intensiteit en bodemdiersamenstelling en -biomassa gecombineerd met kennis over sterfte van bodemdieren als gevolg van visserij, om een inschatting te maken van het effect van het uitsluiten van bepaalde vormen van bodemberoerende visserij. Uit de kwantificering van visserij-effecten in de Voordelta door Rijnsdorp et al. (2006) bleek dat het effect van bodemberoerende visserij werd gedomineerd door de boomkorvisserij van Eurokotters (boomkorvisserij met wekkerkettingen, op platvis, door schepen met een motorvermogen van 260-300 pk). Op basis van de studie werd ingeschat dat uitsluiting van deze vorm van visserij zou leiden tot een verhoging van de bodemdierenbiomassa met 10 tot 21 procent. Deze globale inschatting kan niet worden vertaald naar effecten op individuele soorten. Volgens Rijnsdorp et al. (2006) moet ook rekening worden gehouden met onzekerheden in de gebruikte modellen en uitgangspunten.

Het weren van de boomkorvisserij uit het Bodembeschermingsgebied vermindert ook de onttrekking van commerciële vis en de bijvangst van ondermaatse vis. De verhoging van de bodemdierenbiomassa en de verminderde vangst van vis in het gebied zouden samen zorgen voor een toename in het voedselaanbod voor vogels en vissen en verbetering van de kwaliteit van het gebied (Rijnsdorp et al., 2006; VenW, 2008). Door afname van visserijsterfte van bodemdieren zou ook een verschuiving kunnen optreden in het groottespectrum van bodemdieren, met een toename van het aandeel van grote soorten. Tevens werd veracht dat verlaging van de bevissingsfrequentie door boomkorvisserij zou kunnen leiden tot een toename in de biodiversiteit.

Het doel van het beperken van bodemberoerende visserij in het Bodembeschermingsgebied is "per oppervlakte-eenheid een ecologische winst te bereiken van ca. 10\%" (VenW, 2008). Daarmee wordt beoogd dat de natuurwaarde van de Voordelta gelijk blijft aan die van de periode vóór de aanleg van Maasvlakte 2, en "de productie van voedsel voor vogels en vissen gelijk blijft aan die vóór de aanleg van Maasvlakte 2, waardoor het verlies aan soorten in de Voordelta als gevolg van de aanleg van Maasvlakte 2 ten minste wordt gecompenseerd" (VenW, 2008).

\subsubsection{Achtergrond bij de maatregel: rustgebieden}

Ten aanzien van zwarte zee-eend, grote stern en visdief is geconcludeerd dat een compensatieopgave geldt, omdat niet uitgesloten kon worden (op basis van worst case aannamen) dat de aanleg en aanwezigheid van de Tweede Maasvlakte een significant negatief effect heeft op het potentiele foerageergebied van deze soorten (Heinis et al., 2007). 
Als gevolg van het ruimtebeslag van Maasvlakte 2 werd ingeschat dat maximaal 3,1\% van het potentiële foerageergebied van de zwarte zee-eend (Heinis et al., 2007) zou verdwijnen. Om dit verlies te compenseren, is "het wenselijk dat de totale hoeveelheid voor de zwarte zee-eend geschikt voedsel in de Voordelta niet verandert". De compensatieopgave betreft het verhogen van de kwaliteit van de Voordelta als foerageergebied. Verwacht werd dat door de te bereiken kwaliteitsverhoging als gevolg van het instellen van het Bodembeschermingsgebied de hoeveelheid voedsel in de Voordelta tenminste gelijk zou blijven.

Het doel van het instellen van het rustgebied voor de zwarte zee-eend is dat "door het beperken van de verstoring door recreatie en scheepvaartbewegingen in de concentratiegebieden van de soort (...) het voor de zwarte zee-eend mogelijk is om optimaal van het voedselaanbod te profiteren". De belangrijkste concentratiegebieden bij vaststelling van het Beheerplan in 2008, nl. gebieden bij de Bollen van de Ooster en de Bollen van het Nieuwe Zand, zijn als rustgebieden aangewezen. Het was de bedoeling dat hierdoor de effecten van Maasvlakte 2 op deze soort gecompenseerd worden en de gunstige staat van instandhouding (behoud van omvang en kwaliteit van het leefgebied met een draagkracht voor een populatie van gemiddeld 9.700 vogels (midwintertelling) niet in gevaar komt (VenW, 2008).

Door het ruimtebeslag en gebruik van Maasvlakte 2 was de voorspelling dat maximaal 1,8\% van het aantal vogeldagen ${ }^{2}$ van de grote stern en $5,9 \%$ van het aantal vogeldagen van de visdief (Heinis et al., 2007) zouden verdwijnen. Omdat de kwaliteit van het foerageergebied dichtbij de broedgebieden niet verbeterd kon worden, richtte de compensatieopgave zich op "het dichterbij brengen van de broedgebiedfunctie bij het foerageergebied" (VenW, 2008). De maatregel richt zich op de vogels die vanuit broedkolonies in Oosterschelde, Grevelingen en Haringvliet foerageren op kleine vis in ondiep water in de Voordelta. De drooggevallen platen in de rustgebieden Hinderplaat en Bollen van de Ooster worden in de periode tussen half juni en half september gebruikt door volwassen sterns en hun jongen om te rusten en van daar te foerageren. Het doel van de maatregel is om "in de zomerperiode op drooggevallen platen in de Voordelta zodanige rust te creëren dat de grote sterns en visdiefjes met hun jongen deze platen kunnen benutten om te rusten en gemakkelijker bij hun voedselgebieden op zee te komen" (VenW, 2008).

Bij het formuleren van de maatregel is er van uitgegaan dat de foerageerafstand voor grote stern en visdief niet te groot moet worden, "bij voorkeur minder dan vijftien kilometer en niet meer dan veertig kilometer" (VenW, 2008).

\subsubsection{Toetsing van het effect van de compensatiemaatregelen}

\subsubsection{Kwaliteit van habitattype H1110B}

De instelling van het Bodembeschermingsgebied moet leiden tot een $10 \%$ verbetering van de kwaliteit van Habitattype H1110B (LNV, 2008a; LNV, 2008d; VenW, 2008). Deze kwaliteitsverbetering is niet verder gespecificeerd, maar in het toegangsbeperkingsbesluit, waarin de instelling van het Bodembeschermingsgebied is vastgelegd (LNV, 2008b) wordt, met verwijzing naar Rijnsdorp et al. (2006), "verhoging van de bodemdierenbiomassa met minimaal 10\%" genoemd als te bereiken effect van het uitsluiten van boomkorvisserij met Eurokotters met een motorvermogen van meer dan 260 pk. In het monitorings- en evaluatieprogramma voor de natuurcompensatie (MEP-NCV; (VenW, 2009), opgesteld bij aanvang van het monitoringprogramma, is bodemdierenbiomassa per soortgroep opgevoerd als "primaire maat voor de kwaliteit van habitattype H1110 in termen van voedselbeschikbaarheid voor vissen en vogels".

In de tussentijdse evaluatie van de natuurcompensatie in 2014 is op basis van de op dat moment beschikbare (beperkte) tijdserie geconcludeerd dat er nog geen effect van de maatregel op bodemdierenbiomassa waarneembaar was (RWS, 2014). Op grond van nieuwe wetenschappelijke

\footnotetext{
${ }^{2}$ Vogeldagen zijn een veelgebruikte maat om gebruik van een gebied door vogels te kwantificeren. Elke dag dat één vogel in een gebied verblijft, telt als één vogeldag.
} 
inzichten (Diesing et al., 2013; Van Denderen et al., 2013; Bolam et al., 2014) is geconcludeerd dat eenduidige effecten van visserij op bodemdierenbiomassa (d.w.z. vermindering van visserij leidt tot toename van biomassa) niet waarschijnlijk zijn (Prins et al., 2014). In het monitoringsplan voor de $2^{e}$ fase van PMR-NCV zijn keuzes gemaakt voor andere indicatoren (Tulp et al., 2015); deze worden hieronder besproken. In reactie op het monitoringsplan is door het bevoegd gezag bevestigd dat het behalen van $10 \%$ ecologische winst binnen het Bodembeschermingsgebied een expliciet opgelegde inspanningsverplichting is, maar dat aanvulling met andere indicatoren dan de eerder genoemde biomassa, mogelijk is (EZ, 2015).

Overigens zijn al in de $1^{\mathrm{e}}$ fase van PMR-NCV andere indicatoren dan bodemdierbiomassa gebruikt om de effecten van het uitsluiten van visserij te onderzoeken. Bij het zoeken naar geschikte indicatoren voor de kwaliteit van habitattype $\mathrm{H} 1110 \mathrm{~B}$ is uitgegaan van de beschrijving van de kwaliteit van het habitattype, vastgelegd in het Natura 2000 profieldocument (EZ, 2014b). De keuze voor alternatieve indicatoren is uitgebreid beschreven in eerdere rapporten (Prins et al., 2016; Tulp et al., 2018) en is samengevat in Bijlage 2. Het habitattype $\mathrm{H} 1110$ bestaat uit permanent overstroomde zandbanken, tussenliggende laagten en geulen (die in beperkte mate dieper kunnen zijn dan 20 meter), harde structuren, lokaal hoge dichtheden van schelpdieren ("schelpdierbanken") en de waterkolom erboven. Biogene structuren als mosselbanken zijn geen kenmerkend onderdeel van H1110B. De kwaliteit van habitattype H1110B wordt omschreven in het profieldocument (EZ, 2014b) aan de hand van drie aspecten, namelijk 1) typische soorten, 2) abiotische kenmerken en 3) overige kenmerken van een goede structuur en functie. Een aantal indicatoren, dat aansluit op de bovengenoemde biotische kenmerken, is verder uitgewerkt in het kader van PMR-NCV. Deze vormen daarmee feitelijk een operationalisering van het begrip 'kwaliteit van habitattype H1110B'.

Kern bij de beoordeling van het effect van de compensatiemaatregel is dat de veranderingen in de indicatoren in samenhang bezien moeten worden, waarbij op basis van ecologische kennis en expert judgment getoetst moet worden in hoeverre de optredende veranderingen (omvang en richting van de veranderingen) gezamenlijk een plausibele aanwijzing vormen voor een positief effect van de compensatiemaatregel (uitsluiten boomkorvisserij) op de kwaliteit van habitat H1110B in de Voordelta.

\subsubsection{Instelling rustgebieden}

De instelling van rustgebieden voor de zwarte zee-eend moet, samen met de instelling van het Bodembeschermingsgebied, zorgen dat de potentiele foerageerfunctie van de Voordelta voor de zwarte zee-eend niet vermindert door aanleg van Maasvlakte 2. Om uitspraken te kunnen doen over het behoud van de foerageerfunctie is inzicht in het voedselaanbod, het aantal vogels dat in de Voordelta verblijft (vertaald in vogeldagen) en in het gebruik van de rustgebieden nodig. Deze factoren worden ook genoemd in het MEP-NCV.

Ook voor grote stern en visdief staat behoud van de potentiele foerageerfunctie voorop. In principe zouden daarmee ook voedselaanbod, aantallen vogels/vogeldagen en het gebruik van de rustgebieden als indicator gebruikt kunnen worden. Om praktische redenen is echter voor een deels andere aanpak gekozen bij het monitoren van de effecten van de compensatiemaatregelen. Hierop wordt nader ingegaan bij de beschrijving van het monitoring-en onderzoeksprogramma in de volgende paragraaf.

\subsection{Het monitoring- en onderzoeksprogramma}

\subsubsection{Tijdlijn en voorgaande rapportages}

In de periode 2004-2007 zijn zogenaamde nul-metingen uitgevoerd, waarin de uitgangssituatie (vóór aanleg van Maasvlakte 2) is beschreven. De opzet, methodiek en resultaten van dit monitoringprogramma zijn vastgelegd in een reeks rapporten (Asjes et al., 2004; Craeymeersch et al., 2004; Grift en Tulp, 2004; Craeymeersch et al., 2005a; Poot et al., 2005; Poot et al., 2006; Seegers et 
al., 2006; Steenbergen en Escaravage, 2006; Tulp et al., 2006; Couperus et al., 2007; Dekker, 2007; Couperus et al., 2008; Escaravage et al., 2008).

In voorbereiding op de monitoring van de effecten van de compensatiemaatregelen, zijn de toen beschikbare kennis over de Voordelta, de aannames en uitgangspunten bij de compensatiemaatregelen, de achterliggende hypotheses en de bijbehorende oorzaak-effectrelaties vastgelegd (RIKZ, 2007).

Het monitoringprogramma PMR-NCV is in 2009 van start gegaan (Heessen en Jak, 2009; Holzhauer en Prins, 2009). Bij de aanvang van het programma is in workshops uitgebreid aandacht besteed aan onderliggende hypotheses en kennis van oorzaak-effect relaties. Dit was van belang om de MEP vragen te vertalen naar meer concrete onderzoeksvragen voor het monitoringprogramma.

De $1^{\mathrm{e}}$ fase van de monitoring is afgerond met een rapportage in 2013 (Prins et al., 2014). Deze rapportage is beoordeeld door een onafhankelijke wetenschappelijke Auditcommissie.

Naar aanleiding van de resultaten uit de $1^{\text {e }}$ fase en in voorbereiding op de vervolgmonitoring, zijn 2014 en 2015 gebruikt als overbruggingsjaren voor herbezinning op de monitoringstrategie en de onderzoeksaanpak. In die twee jaren is de monitoring gedeeltelijk voortgezet, maar is daarnaast een verdiepingsslag gemaakt door het uitvoeren van verschillende gerichte onderzoekslijnen. In 2015 zijn ook de specificaties voor het monitoringprogramma 2016-2020 uitgewerkt. In 2016 is de $2^{\mathrm{e}}$ fase van start gegaan met een, op verschillende punten, aangepast monitoringsprogramma (Tulp et al., 2015). Na de tussenevaluatie van de effecten van Maasvlakte 2 en de compensatiemaatregelen (RWS, 2014) zijn de deelvragen van het MEP aangescherpt en ook de onderzoeksvragen aangescherpt (Tulp et al., 2015). De MEP vragen en onderzoeksvragen zijn opgenomen in Bijlage 4.

In 2016-2018 is het monitoringsprogramma in de $2^{\mathrm{e}}$ Fase uitgevoerd, met een aantal monitoringactiviteiten doorlopend tot in 2019. Een syntheserapport met een gedetailleerde tussentijdse rapportage van de resultaten van monitoring en onderzoek uit de nulmetingen (2004-2007) en de metingen uit $1^{\mathrm{e}}$ en $2^{\mathrm{e}}$ fase $(2009-2016 / 2017)$ is verschenen in 2018. In die rapportage is naast de resultaten van monitoring en onderzoek in de Voordelta, ook gebruikt gemaakt van resultaten van meetprogramma's in andere delen van de Nederlandse kustwateren (Tulp et al., 2018). Deze rapportage is beoordeeld door een onafhankelijke wetenschappelijke Auditcommissie. Het commentaar van de Auditcommissie is gebruikt bij het opstellen van het voorliggende rapport.

De hierboven genoemde rapporten bevatten de analyses en conclusies zoals die op het moment van rapportage geformuleerd konden worden. Daarnaast zijn er met regelmaat voortgangsrapportages en technische achtergrondrapportages over deelaspecten verschenen. Een compleet overzicht van alle rapporten is opgenomen in Bijlage 5. Het voorliggende rapport bouwt voort op de rapportage van 2018 (Tulp et al., 2018). Alle data, ook van de laatste monitoringjaren zijn nu meegenomen in de analyses. Er is voor gekozen om vooral aandacht te besteden aan de analyses, resultaten en conclusies die het meest relevant zijn voor de beantwoording van de onderzoeksvragen. Dat betekent dat dit rapport niet in detail alle analyses en resultaten omvat van de afgelopen tien jaar. Voor details wordt verwezen naar de eerdere rapporten vermeld in Bijlage 5. 
Tabel 3.2 Tijdlijn van de monitoring met belangrijkste rapportages

\begin{tabular}{|c|c|c|c|c|c|c|c|c|c|c|c|c|c|c|c|c|c|}
\hline & 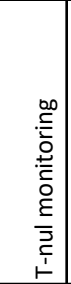 & 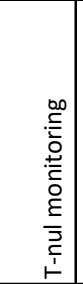 & 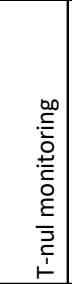 & 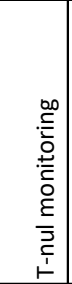 & 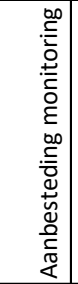 & 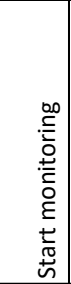 & & & & & & 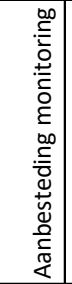 & & & 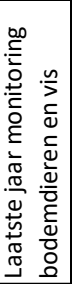 & 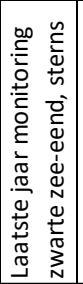 & \\
\hline Jaar & 2004 & 2005 & 2006 & 2007 & 2008 & 2009 & 2010 & 2011 & 2012 & 2013 & 2014 & 2015 & 2016 & 2017 & 2018 & \begin{tabular}{|l|}
2019 \\
\end{tabular} & 2020 \\
\hline \multicolumn{18}{|c|}{ 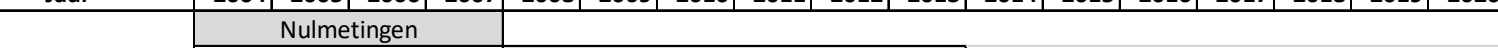 } \\
\hline \multirow{3}{*}{$\begin{array}{l}\text { Uitvoering } \\
\text { monitoring }\end{array}$} & & & & & \multicolumn{6}{|c|}{$1^{\mathrm{e}}$ Fase } & & & & & & & \\
\hline & & & & & & & & & & & \multicolumn{2}{|c|}{ Overbrugging } & & & & & \\
\hline & & & & & & & & & & & & & \multicolumn{5}{|c|}{$2^{\mathrm{e}}$ Fase } \\
\hline Rapporten & & & & $\begin{array}{l}\hat{o} \\
N \\
\tilde{N} \\
\frac{\vec{\alpha}}{\alpha}\end{array}$ & & $\begin{array}{l}\frac{1}{\pi} \\
\frac{2}{2} \\
\frac{\pi}{0} \\
\frac{1}{2} \\
\frac{0}{2} \\
\frac{5}{\pi} \\
\frac{\pi}{0} \\
\end{array}$ & & & & 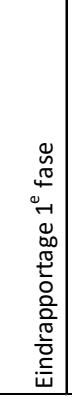 & 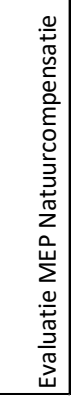 & 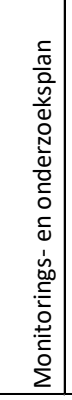 & & & 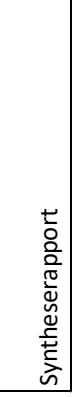 & & $\begin{array}{l}\frac{5}{0} \\
\frac{0}{2} \\
\frac{0}{0} \\
\frac{10}{0} \\
\frac{0}{4}\end{array}$ \\
\hline
\end{tabular}

\subsubsection{Het monitoring- en onderzoekprogramma PMR-NCV}

\subsubsection{Uitgangspunten bij het programma}

Het monitoring- en onderzoekprogramma is opgezet met het doel de effecten van de compensatiemaatregelen te kunnen vaststellen. $\mathrm{Er}$ is een brede invulling gegeven aan de meetbehoefte om voldoende informatie te verzamelen over het functioneren van de Voordelta en daarmee de waarneming van de effecten van de maatregelen in een bredere context te kunnen beoordelen. Bij aanvang van de monitoring in 2009 en bij voorbereiding van de $2^{\mathrm{e}}$ fase van de monitoring zijn effectketens en onderliggende hypotheses geformuleerd om de inzet van het onderzoek te structureren.

Er zijn, afhankelijk van de specifieke vragen, verschillende uitgangspunten gehanteerd bij de opzet van het programma:

\section{Compensatie verlies areaal H1110B}

Zoals hierboven beschreven, het instellen van het Bodembeschermingsgebied had als doel de kwaliteit van habitattype $\mathrm{H} 1110 \mathrm{~B}$ in dat gebied met $10 \%$ te verbeteren en zo te compenseren voor het verlies van areaal $\mathrm{H1110B}(\mathrm{EZ}, 2015)$. Om de verbetering van de kwaliteit van $\mathrm{H} 1110 \mathrm{~B}$ in het

Bodembeschermingsgebied vast te stellen, is in eerste instantie de monitoring gericht geweest op een vergelijking van de ontwikkeling in het Bodembeschermingsgebied met de ontwikkeling in de rest van de Voordelta, vóór en na de aanleg van Maasvlakte 2. Dit is een veelgebruikte werkwijze, een zogenaamde BACI (Before-After-Control-Impact) analyse (Green, 1979; zie Hoofdstuk 2). Het

Bodembeschermingsgebied was het 'Impact' gebied waar de boomkorvisserij geweerd werd na 2008, en de rest van de Voordelta het 'Control' gebied waar de boomkorvisserij niet geweerd werd als gevolg van de compensatiemaatregel.

Nulmetingen zijn uitgevoerd in 2004-2007 om de toestand voor de ingreep vast te stellen, delen van de Voordelta buiten het BBG dienden als referentiegebied. Idealiter worden bij een dergelijke onderzoeksaanpak meerdere referentiegebieden gebruikt (en nog beter: ook meerdere, random toegewezen, "impact" locaties). Ook moeten referentiegebieden, voor wat betreft omgevingsfactoren, bij voorkeur 
zoveel mogelijk vergelijkbaar zijn met het gebied waar de ingreep plaats vindt. Als het om werkelijke ingrepen gaat (zoals in de Voordelta het geval was) is dat in de praktijk echter zelden volledig uitvoerbaar. In het PMR-NCV monitoringprogramma zijn voor zowel de bodemdieren als de vissen referentiegebieden geselecteerd die zo goed mogelijk aan de voorwaarden voldoen, gegeven de ligging van het Bodembeschermingsgebied. Bij aanvang was al duidelijk dat er verschillen zijn tussen het Bodembeschermingsgebied en de referentiegebieden, omdat de Voordelta geen homogeen gebied is. Om zoveel mogelijk te corrigeren voor de variatie veroorzaakt door natuurlijke omgevingsfactoren, was de opzet om in de analyse van bodemdieren en vissen gebruik te maken van een habitatmodel waarin voorspellende omgevingsfactoren werden meegenomen.

De compensatie-opgave betreft een verbetering van de kwaliteit van $\mathrm{H} 1110 \mathrm{~B}$ als compensatie voor het verlies van areaal. In eerste instantie was daarom de aandacht vooral gericht op biomassa, omdat dit een kwantitatieve maat is die een simpele vergelijking mogelijk maakt tussen verlies door Maasvlakte 2 en toename in het Bodembeschermingsgebied. Vervolgens zijn ook andere indicatoren voor kwaliteit van H1110B gebruikt (Bijlage 2). Niet alle indicatoren zijn goed bruikbaar voor een kwantitatieve vergelijking; hoe vergelijk je bijvoorbeeld een verandering in biodiversiteit in het Bodembeschermingsgebied met verlies van areaal door Maasvlakte 2?

Gedurende het onderzoek bleek dat de BACI opzet, d.w.z. een vergelijking van het Bodembeschermingsgebied waar boomkorvisserij door de maatregel verdween na 2008 met de rest van de Voordelta als referentie, niet goed uitvoerbaar was. Vanwege het vrijwel ontbreken van visserij in het Bodembeschermingsgebied in de TO en het verdwijnen van deze visserij uit de rest van de Voordelta waren de verschillen in visserij-intensiteit niet zoals bij aanvang verwacht werd; een extra complicatie hierbij was de toename van de garnalenvisserij (zie ook hoofdstuk 5).

Als alternatief zijn vervolgens analyses uitgevoerd gericht op het vinden van statistische verbanden om de effecten van visserij op bodemdieren en vis te beschrijven. Het vaststellen van dit soort statistische verbanden zou een aanwijzing kunnen geven voor de plausibiliteit van effecten van veranderingen in visserij in de Voordelta op de kwaliteit van $\mathrm{H} 1110 \mathrm{~B}$. In tegenstelling tot de BACI-aanpak was duidelijk dat het niet mogelijk zou zijn harde conclusies over een oorzakelijk (causaal) verband vast te stellen. Door het ontbreken van een goede referentiesituatie (waar visserij niet veranderd was) kan namelijk niet uitgesloten worden dat er sprake is van een toevallige correlatie tussen veranderingen in visserij en veranderingen in bodemdieren of vis, in plaats van een oorzakelijk verband. Om dit soort correlaties beter te kunnen duiden, is niet alleen gebruik gemaakt van de gegevens van de Voordelta, maar zijn ook gegevens gebruikt die betrekking hebben op de rest van de Nederlandse kustwateren. Tevens is onderzocht, of er andere omgevingsfactoren dan visserij zijn die de waargenomen veranderingen over de periode 2004-2018 kunnen verklaren.

In het programma is zowel monitoring van bodemdieren als van demersale vis uitgevoerd, vanwege het feit dat demersale vis ook een onderdeel is van het habitat en er veel interacties zijn tussen bodemdieren en vis.

\section{Compensatie verlies foerageergebied zwarte zee-eend}

Het instellen van rustgebieden voor de zwarte zee-eend, in combinatie met het instellen van het Bodembeschermingsgebied, had als doel om de geschiktheid van de Voordelta als overwinteringsgebied voor de zwarte zee-eend na aanleg van Maasvlakte 2 gelijk te houden aan de situatie vóór aanleg. Het effect van de maatregel is vast te stellen door te bezien in welke mate de Voordelta haar potentiele foerageerfunctie voor de zwarte zee-eend heeft behouden. De monitoring richtte zich daarom op het bepalen van aantallen vogels (en daarvan afgeleid aantal vogeldagen) in de Voordelta gedurende het winterhalfjaar. Omdat die aantallen ook afhankelijk zijn van factoren buiten de Voordelta (bijv. de keuze tussen verschillende overwinteringsgebieden) is vervolgens ook een model opgezet om de potentiele aantallen overwinterende eenden, als functie van voedselaanbod en afwezigheid van verstoring, te kunnen berekenen. Veranderingen in voedselaanbod zijn bepaald door monitoring van de biomassa van, 
als voedsel geschikte, schelpdieren. Veranderingen in verstoring zijn bepaald door monitoring van menselijke activiteiten.

Het specifieke effect van de rustgebieden is nader onderzocht door de ruimtelijke verspreiding van de eenden en het daadwerkelijk gebruik van de rustgebieden te bepalen.

\section{Compensatie verlies foerageergebied grote stern en visdief}

Het instellen van rustgebieden voor grote stern en visdief had als doel de foerageerfunctie van de Voordelta na aanleg van Maasvlakte 2 gelijk te houden aan de situatie vóór aanleg. De maatregel is gericht op de broedkolonies in het noordelijk deel van het Deltagebied. Het direct bepalen van de foerageerfunctie door het monitoren van het voedselaanbod pelagische prooien is methodisch lastig, omdat het om kleine pelagische vis gaat die zeer mobiel is en waarvan de bestanden lastig gekwantificeerd kunnen worden op de schaal van de Voordelta. Daarom is gekozen voor onderzoek en monitoring van aantallen broedparen, broedsucces en kwaliteit en kwantiteit van de aangevoerde prooien. Het specifieke effect van de rustgebieden is nader onderzocht door onderzoek aan het gebruik van de rustgebieden door de sterns en de mate van verstoring.

\subsubsection{Globale beschrijving van uitgevoerde monitoring en onderzoek}

Volgend op het principebesluit voor aanleg van Maasvlakte 2, vastgelegd in de Planologische Kernbeslissing-plus Mainportontwikkeling Rotterdam (PKB + PMR) deel 4 van september 2003, is een monitoringprogramma gestart om de beginsituatie (TO) in de Voordelta vast te leggen. De TO monitoring was gericht op waarnemingen van bodemdieren, vis, diverse soorten vogels (futen en duikers, meeuwen en sterns, zee-eenden) en menselijk gebruik. De metingen zijn uitgevoerd in de jaren 2004-2007, waarbij vrijwel alle metingen betrekking hebben op 1 of 2 jaar in die periode.

De $1^{\mathrm{e}}$ fase van de monitoring voor PMR-NCV liep van $2009 \mathrm{t} / \mathrm{m}$ 2013. De opzet is beschreven in een plan van aanpak (Heessen en Jak, 2009; Holzhauer en Prins, 2009). Naast monitoring van bodemdieren en vis, tellingen van zwarte zee-eenden en sterns in de Voordelta, monitoring van aantallen broedparen en van broedsucces in kolonies van sterns is menselijk gebruik gemonitord en zijn de abiotische omstandigheden in de Voordelta beschreven via meetgegevens en hydrodynamische modellen. Oorspronkelijk was niet voorzien in het gedetailleerd beschrijven van de visserij-intensiteit van bodemberoerende visserij. In 2010 werd het mogelijk om de intensiteit van de boomkorvisserij in de Voordelta beter te kwantificeren, door het beter beschikbaar komen van VMS (Vessel Monitoring System) data (Bierman et al., 2009). Uit de analyse bleek dat in het Bodembeschermingsgebied de boomkorvisserij al in de TO (2005-2007) beperkt was in intensiteit, en ook in de referentiegebieden afnam vanaf 2004.

De resultaten aan het eind van de $1^{\mathrm{e}}$ fase (Prins et al., 2014) gaven aanleiding tot wijzigingen in het monitoringprogramma, onder andere vanwege het hierboven beschreven feit dat de oorspronkelijk bedoelde BACI-vergelijking tussen Bodembeschermingsgebied en referentiegebieden vóór en na het instellen van het Bodembeschermingsgebied niet meer bruikbaar was.

In 2014 is ook een overbruggingsjaar ingelast waarin geen monitoring is uitgevoerd van bodemdieren en vis om capaciteit vrij te maken voor het doen van aanvullende analyses met al verzamelde data.

In 2015 is de monitoring zoals die in de $1^{\mathrm{e}}$ fase werd uitgevoerd, weer grotendeels hervat. Wel zijn er wijzigingen doorgevoerd in de monitoring van bodemdieren:

- $\quad$ Bij de nulmetingen is, rekening houdend met de ruimtelijke verschillen in habitateigenschappen en bodemdiergemeenschappen, het onderzoeksgebied opgedeeld in vakken waarbinnen random locaties zijn gekozen, zodat er een gelijkmatige verdeling van de monsterlocaties was over het hele onderzoekgebied.

- In de bemonstering in de $1^{\mathrm{e}}$ fase van PMR-NCV zijn alle locaties bemonsterd die ook in de nulmetingen zijn bemonsterd (met uitzondering van het gebied waar Maasvlakte 2 is aangelegd 
en locaties westelijk van Maasvlakte 2). Daarnaast zijn 30 extra referentiegebieden ( $1 \mathrm{~km}^{2}$ ) toegevoegd ten westen van het Bodembeschermingsgebied, vanuit de verwachting dat de visserij daar zou intensiveren en er daarmee grotere verschillen in bodemberoering door visserij tussen verschillende delen van de Voordelta zouden ontstaan. In die westelijke referentiegebieden zijn 5 monsters per gebied genomen. Ook zijn extra monsterlocaties toegevoegd in concentratiegebieden van de zwarte zee-eend ten zuiden van het Bodembeschermingsgebied (Heessen en Jak, 2009). In totaal werden 411 locaties bemonsterd.

- In 2015 is het aantal monsterpunten in de referentiegebieden westelijk van het Bodembeschermingsgebied gereduceerd tot 1 per gebied, omdat uit de VMS analyses was gebleken dat er vrijwel geen boomkorvisserij plaatsvond in die gebieden. Bovendien zijn de monsterlocaties in de Haringvlietmonding vervallen, vanuit de overweging dat boomkorvisserij in dat gebied nooit heeft plaatsgevonden (Craeymeersch et al., 2017) en delen buiten het netto Bodembeschermingsgebied lagen (zie voetnoot bij Tabel 1.1). De overige monsterlocaties zijn gehandhaafd; in totaal werden 238 locaties bemonsterd.

In 2015 zijn eveneens wijzigingen aangebracht in de bemonstering van vis:

- De nulmetingen zijn uitgevoerd in het gebied waar Maasvlakte 2 gepland was, in het Bodembeschermingsgebied dat in juni 2008 is ingesteld, en in een meer naar het zuiden gelegen referentiegebied (Tulp et al., 2006; Couperus et al., 2008). Per jaar (2005, 2007) zijn 53 vistrekken gedaan in zowel voor- als najaar. De methodiek in de bemonstering was gelijk aan die van de Demersal Fish Survey (DFS).

- In de $1^{\mathrm{e}}$ fase zijn vistrekken gedaan in het Bodembeschermingsgebied en het voor Walcheren gelegen zuidelijke referentiegebied. In plaats van de trekken in het gebied van Maasvlakte 2 zijn extra trekken in het Bodembeschermingsgebied toegevoegd, zodat het aantal trekken gelijk was aan de nulmetingen (53 trekken in zowel voor- als najaar).

- Omdat de verschillen in boomkorvisserij tussen Bodembeschermingsgebied en referentiegebied verdwenen waren (en de BACI opzet losgelaten was), is vanaf 2015 de visbemonstering ingevuld door de al bestaande DFS survey (in het najaar) uit te breiden naar 25 locaties in de Voordelta (Tulp et al., 2015).

In 2016 is de $2^{\mathrm{e}}$ fase van PMR-NCV gestart. Belangrijkste wijzigingen/aanvullingen in het monitoringprogramma ten opzichte van de $1^{\mathrm{e}}$ fase waren:

- In aanvulling op het waarnemen van werkelijke aantallen zwarte zee-eenden in de Voordelta, is via modellering gewerkt aan het inschatten van het potentiele aantal zwarte zee-eenden middels een modelmatige aanpak.

- Voor grote stern en visdief zijn verschillende aanvullende onderzoeken uitgevoerd om meer begrip te krijgen van gebiedsgebruik en effecten van verstoring.

\subsubsection{Datamanagement}

Door de omvang, duur en breedte van het monitoringprogramma is een grote hoeveelheid data verzameld. Er is veel aandacht besteed aan het zoveel mogelijk eenduidig opslaan van de verzamelde data om de onderlinge uitwisseling van gegevens te vereenvoudigen. Daarnaast is gewerkt aan het beschikbaar maken van de data als publiek toegankelijke dataset. De basisdata uit de monitoring zijn beschikbaar via de dataviewer van Informatiehuis Marien (https://www.informatiehuismarien.nl/opendata/). 


\subsection{Bij de monitoring betrokken partijen}

Het monitoringprogramma is uitgevoerd in opdracht van Rijkswaterstaat - Water, Verkeer en leefomgeving (RWS-WVL).

Tijdens de nulmetingen, $1^{\mathrm{e}}$ fase en overbrugging naar de tweede fase (2009-2015) was de monitoring binnen het onderdeel PMR-NCV ondergebracht in een aantal percelen: Benthos, Vogels, Vis, Abiotiek en Gebruik. Deltares leidde het consortium met Wageningen Marine Research (voorheen IMARES) (Benthos en Vis), Lievense-CSO (Gebruik), Arcadis (voorheen Alkyon) (Abiotiek), het Instituut voor Natuur- en Bosonderzoek (INBO; Vogels), het Nederlands Instituut voor Onderzoek der Zee (NIOZ; Benthos) en Bureau Waardenburg (Vogels).

In de tweede fase (2016-2020) van de monitoring natuurcompensatie is met een deels nieuwe groep van onderzoeksbureaus gewerkt, onder leiding van een consortium van Wageningen Marine Research en Deltares. Een deel van de monitoring en onderzoek werd door Wageningen Marine Research (Benthos en Vis) uitgevoerd en een deel door Eurofins-AquaSense (Benthos), Arcadis (Abiotiek), Altenburg \& Wymenga met partners Bioconsult, Greenstat en Sjoerd Dirksen Ecology ${ }^{3}$ (Zwarte zee-eend) en Bureau Waardenburg met partner INBO (sterns).

\subsection{Gebruikte terminologie}

In dit rapport wordt de term "boomkorvisserij" gebruikt om de op platvis gerichte boomkorvisserij met wekkerkettingen, door Eurokotters met een motorvermogen 260-300 pk, te beschrijven. Van de boomkorvisserij in de Voordelta waren platviskotters (boomkorschepen met een motorvermogen van 260-300 pk) verantwoordelijk voor 99\% van de gepleegde inspanning in vis-uren in de jaren 2004-2007. Boomkorvisserij met kleiner motorvermogen komt vrijwel niet voor. Daarom is de analyse van visserij in dit hoofdstuk beperkt tot platviskotters (>260 pk). De schepen trekken twee sleepnetten over de zeebodem gericht op de vangst van platvis. De netten worden opengehouden door een stalen balk, de boom (4,5 meter breed). Aan de uiteinden van deze boom zitten zware stalen glijders (sloffen, een soort sleeën) die over de zeebodem glijden. Aan deze glijders zijn meerdere rijen kettingen (wekkerkettingen) bevestigd, die over de grond slepen en zo de platvis uit het zand op laten schrikken. De glijders en wekkerkettingen en een gevuld net dat over de bodem sleept veroorzaken bodemberoering en effecten op bodemdieren. De commerciële doelsoorten Noordzeebreed zijn schol en tong, waarbij bot en schar het grootste deel van de bijvangst vormen. Daarnaast wordt een deel van de vangst niet aangeland, hierbij gaat het om ondermaatse (commerciële) vissoorten, andere vissoorten en bodemdieren, die als 'discards' weer overboord gezet worden. Vanaf 2011 is er in de Voordelta ook visserij op platvis met de pulskor. Pulskorvisserij maakt geen gebruik van wekkerkettingen en heeft waarschijnlijk een minder groot effect op bodemdieren (ICES, 2018a).

Garnalenkotters: Garnalenvisserij wordt uitgevoerd met garnalen(boom)korren van 9 meter breed. Net als bij de gewone boomkor wordt aan iedere kant van het schip een net voortgesleept over de bodem. Garnalenkorren zijn lichter in gewicht dan boomkorren. Bovendien zijn deze niet voorzien van wekkerkettingen, maar van klossenpezen die over de bodem rollen. Hierdoor zijn de bodemberoering en effecten op bodemdieren minder groot dan bij platvistuig. Ook een vol net zal bodemberoering veroorzaken. Doelsoort is garnaal en er wordt in principe weinig vis bijgevangen ( 7\% op gewichtsbasis), door een verplichte zeeflap die vissen groter dan ca $10 \mathrm{~cm}$ weert (Tien et al., 2017a). Als de verplichte zeeflap niet wordt gebruikt (wat voorkomt), zal meer grote vis worden gevangen. Het is onbekend hoe vaak de zeeflap niet gebruikt wordt. Ook de garnalenvisserij zet ongewenste bijvangst weer overboord.

Schelpdiervisserij: Visserij waarbij met behulp van zuigkorren strandschelpen (Spisula) en zwaardschedes (Ensis) uit de bodem worden gezogen. Het sediment wordt hierbij eerst tot een diepte

\footnotetext{
${ }^{3}$ Sjoerd Dirksen is in september 2018 overleden
} 
van $30 \mathrm{~cm}$ in de bodem uitgezeefd, waarna de schelpdieren door water of lucht via zuigbuizen worden opgezogen aan boord. Zwaardschede is de belangrijkste doelsoort van de huidige Nederlandse schelpdiervisserij. Visserij op Spisula is in de Voordelta niet toegestaan (RWS, 2016).

Voor de naamgeving van soorten is ten behoeve van de leesbaarheid, een verschillende werkwijze gehanteerd voor bodemdieren, vissen en vogels. Voor vissen en vogels worden de Nederlandse namen gebruikt. Voor bodemdieren wordt de wetenschappelijke naam (volledig of verkort) gebruikt, omdat niet voor alle soorten bodemdieren Nederlandse namen bestaan of algemeen bekend zijn. In voorkomende gevallen, waar het algemene soorten betreft, wordt soms ook de Nederlandse naam gebruikt. De wetenschappelijke naamgeving is aan verandering onderhevig. De naamgeving in dit rapport is gebaseerd op de stand van zaken van maart 2020 in het World Register of Marine Species ${ }^{4}$ en voor de Nederlandse namen op het Soortenregister ${ }^{5}$. De wetenschappelijke naam van de Amerikaanse zwaardschede is recent gewijzigd van Ensis directus in Ensis leei. In eerdere rapportages is nog de naam Ensis directus gebruikt.

Voor deze en overige termen is een verklarende woordenlijst opgenomen in Bijlage 1.

\footnotetext{
${ }^{4}$ www.marinespecies.org

${ }^{5}$ https://www.nederlandsesoorten.nl/
} 


\section{$4 \quad$ Voordelta}

Dit hoofdstuk geeft een beschrijving van de kenmerken van de Voordelta en de ontwikkelingen in de natuurlijke factoren die van belang zijn voor de effecten van de natuurcompensatie. Kennis van de natuurlijke complexiteit en dynamiek van de Voordelta is van belang voor het interpreteren van de waarnemingen uit het monitoringprogramma. Gegevens over de abiotische omstandigheden hebben vooral een rol gespeeld bij de analyse van de gegevens van bodemdieren en vis in hoofdstuk 6.

De Voordelta wordt door de ondiepe ligging in de zuidwestelijke Delta gekarakteriseerd door een grote dynamiek en ruimtelijke verschillen in abiotische kenmerken zoals stroomsnelheid, golfwerking, sedimentsamenstelling en zoutgehalte. Zandbanken ontstaan en bewegen zich langzaam door het gebied. Daarnaast kan de Voordelta worden gezien als een relatief ondiepe, warme en voedselrijke rand van de Noordzee. Deze factoren samen bepalen welke soorten in het gebied kunnen voorkomen, en zijn van groot belang voor het begrijpen van het systeem in zijn geheel en ook voor het effect van de compensatiemaatregelen. Hieronder worden de belangrijkste trends en bijzonderheden besproken.

\subsection{Morfologische ontwikkeling van de Voordelta}

De Voordelta bestaat uit de met elkaar vergroeide buitendelta's van het Deltagebied. Door de geringe onderlinge afstand in verhouding tot hun omvang, konden de buitendelta's elkaar direct beïnvloeden en zijn ze uiteindelijk samen gegroeid tot één groot ondiep buitengebied. De morfodynamiek is mede sturend voor de natuurwaarden in het gebied. De plaats en omvang van zandbanken, getijgeulen en ondiepe platen veranderen voortdurend door de werking van getij en golven; de ontwikkelingen op langere termijn worden sterk beïnvloed door menselijke ingrepen.

De huidige situatie in de Voordelta is een gevolg van de uitvoering van de Deltawerken en de zeewaartse kustuitbreiding aan de noordzijde. Voor de ingrepen was het gebied een onderdeel van de kustzone van de Noordzee, met estuariene kenmerken als getijgeulen en ondiepten, lagere saliniteit en hogere troebelheid dan de wateren verder van de kust en langs de Hollandse kust (Wolff, 1973). Het gebied werd gevormd door de open zeegaten en estuaria van Westerschelde, Oosterschelde, Grevelingen en Haringvliet. Door de kleinere komberging van Grevelingen en Haringvliet (t.o.v. Westerschelde en Oosterschelde) werden deze buitendelta's gekenmerkt door relatief ondiepe geulen en uitgestrekte ondiepe platen. De aanleg van de Deltawerken heeft grote effecten gehad op de morfologische ontwikkeling van de buitendelta's, de gebieden van ondiepten en geulen aan de zeezijde van de mondingen van deze (voormalige) estuaria. Deze buitendelta's zijn sterk veranderd door verminderde uitwisseling met de Deltawateren en door veranderingen in fysische processen, zoals stromingspatronen, golfwerking, zoetwaterafvoer en transport van zand en slib (Elias en Van der Spek, 2014; Elias et al., 2016; van der Spek en Elias, 2019).

\subsubsection{Processen en dynamiek}

Hoe werkt in het algemeen het proces van vorming van buitendelta's? De getijstroming door het zeegat perst zich door een relatief nauwe opening, waardoor het water sneller gaat stromen. Sneller stromend water brengt niet alleen meer zand in beweging, maar kan ook meer zand vervoeren. Na passeren van het zeegat komt de ebstroom in ruimer water waardoor zijn snelheid afneemt en het meegevoerde zand bezinkt. Hierdoor ontstaan ondiepe banken waar de golven op breken. Brekende golven brengen zand terug naar het zeegat en naar de aangrenzende kusten. Op deze manier ontstaat er een evenwicht tussen zeewaarts transport door de ebstroom en landwaarts transport door de golven. Een verandering in een van de twee factoren leidt tot verandering van de morfologie: bij toename van zandtransport door 
de ebstroom (of afname van de golfenergie) groeit de delta, bij toename van de golfenergie (of afname van het eb-transport) krimpt de delta.

Door variaties in de getijstroming en grootte en richting van de golven kunnen geulen en platen van vorm veranderen of zich verplaatsen, zonder dat de buitendelta daarbij duidelijk van vorm of omvang verandert.

Doordat de getijgolf van zuid naar noord langs de kust loopt en het getijverschil in die richting ook afneemt (van 3,35 m bij Westkapelle naar 1,75 m bij Hoek van Holland) verschillen de waterstanden tussen de buitendelta's waardoor ook noord-zuidgerichte stromen in de Voordelta een rol spelen. Hierdoor wordt zand tussen de buitendelta's uitgewisseld. Daarnaast leidt golfgedreven zandtransport langs de eilandkusten tot verplaatsing van zand van de ene buitendelta naar de andere. Deze aanvoer van zand leidt tot de vorming van strandhaken (zandbanken die aan de kust vastgroeien) in het volgende zeegat. Een voorbeeld hiervan is de Verklikkerplaat.

\subsubsection{Het effect van menselijke ingrepen op de buitendelta's}

Vanwege de verzanding van de Maasmonding werd in de $19^{\mathrm{e}}$ eeuw de landtong De Beer doorgegraven om Het Scheur en Nieuwe Maas te verbinden met zee. Hierdoor ontstond de Nieuwe Waterweg. De daarop volgende verdiepingen van de Nieuwe Waterweg, om een bruikbare scheepvaartgeul te krijgen, en de uitbreiding van de Rotterdamse havens vergrootten de getijdebieten door dit kunstmatige zeegat en bezegelden daarmee het lot van de resterende (Brielse) Maas. Afgesloten van de aanvoer van rivierwater bleef er een zeearm over die door voortgaande verzilting een bedreiging voor omliggende land werd, en die kwetsbaar bleef voor overstromingen tijdens stormvloeden. Dit leidde tot het besluit de Brielse Maas af te sluiten, hetgeen in 1950 gebeurde. De daaropvolgende ontwikkelingen in de buitendelta van de Brielse Maas illustreren de gevolgen van afsluiting van een zeegat: de aanzienlijk reductie in getijstroming in de monding start twee ontwikkelingen: 1 . De aanvoer van zand door de ebstroming valt grotendeels weg, waardoor golfwerking de overhand krijgt. De eerste gevolgen daarvan worden zichtbaar aan de zeewaartse rand van de delta die sterk erodeert. Een deel van het zand wordt in landwaartse richting verplaatst en vormt zandbanken. 2 . De dwarsdoorsnede van de geulen is veel te groot voor de hoeveelheid water dat er nog doorheen stroomt, waardoor de stroomsnelheden laag zijn en er veel sediment bezinkt. Slib wordt aangevoerd met het zeewater, zand afkomstig van afbraak van de omliggende zandplaten verdwijnt ook in geul.

Met de tijd wordt de omvang van de buitendelta kleiner door erosie van de zeewaartse rand. Ook de verdeling van zandbanken verandert: golven bouwen nieuwe banken op aan de rand, bestaande banken worden steeds verder landwaarts verplaatst. Oorspronkelijk door de getijstroming opgebouwde banken worden afgebroken door de golven, waarbij het grootste deel van het zand landwaarts verplaatst wordt. Een duidelijk voorbeeld hiervan is de Middelplaat in de Grevelingenmonding. Deze west-oost gerichte plaat werd afgebroken, waarbij het zand richting de Brouwersdam verplaatst werd waar het een breed strand vormde. Een deel van dit zand werd door de wind verder geblazen en vormde duinen op de dam zelf. Na uitputting van de zandvoorraad door het verdwijnen van de Middelplaat nam het strand weer in omvang af.

Bij de afbraak van de rand van de buitendelta wordt zand niet alleen landwaarts verplaatst maar ook zijdelings, evenwijdig aan de rand. De zandtransporten langs de kusten van de eilanden worden hierdoor groter, waardoor de strandhaken in het stroomafwaartse zeegat aangroeien. De ontwikkeling van de Kwade Hoek op de noordwestpunt van Goeree illustreert deze ontwikkeling.

Door het grotendeels wegvallen van in- en uitstroom neemt het belang van de noord-zuid stroming van het Noordzeegetij toe. Hierdoor verandert de oriëntatie van met name de zeewaartse delen van de getijgeulen: ze draaien bij in de richting van deze stroming. De toegenomen noord-zuid stroming verruimt de al aanwezige kortsluitgeulen tussen de buitendelta's en vergroot de zandtransporten. Een fraai voorbeeld hiervan is de ontwikkeling van het Krabbengat voor de Kop van Schouwen. 


\subsubsection{Ontwikkeling van de buitendelta's na afsluiting van de zeegaten}

De buitendelta's van Haringvliet, Grevelingen en Oosterschelde veranderden na de Deltawerken. De ingrepen verschilden per zeegat: de Haringvlietdam heeft spuisluizen voor rivierwater, de Grevelingendam is gesloten, de Oosterschelde is een stormvloedkering. Toch komen de gevolgen deels overeen.

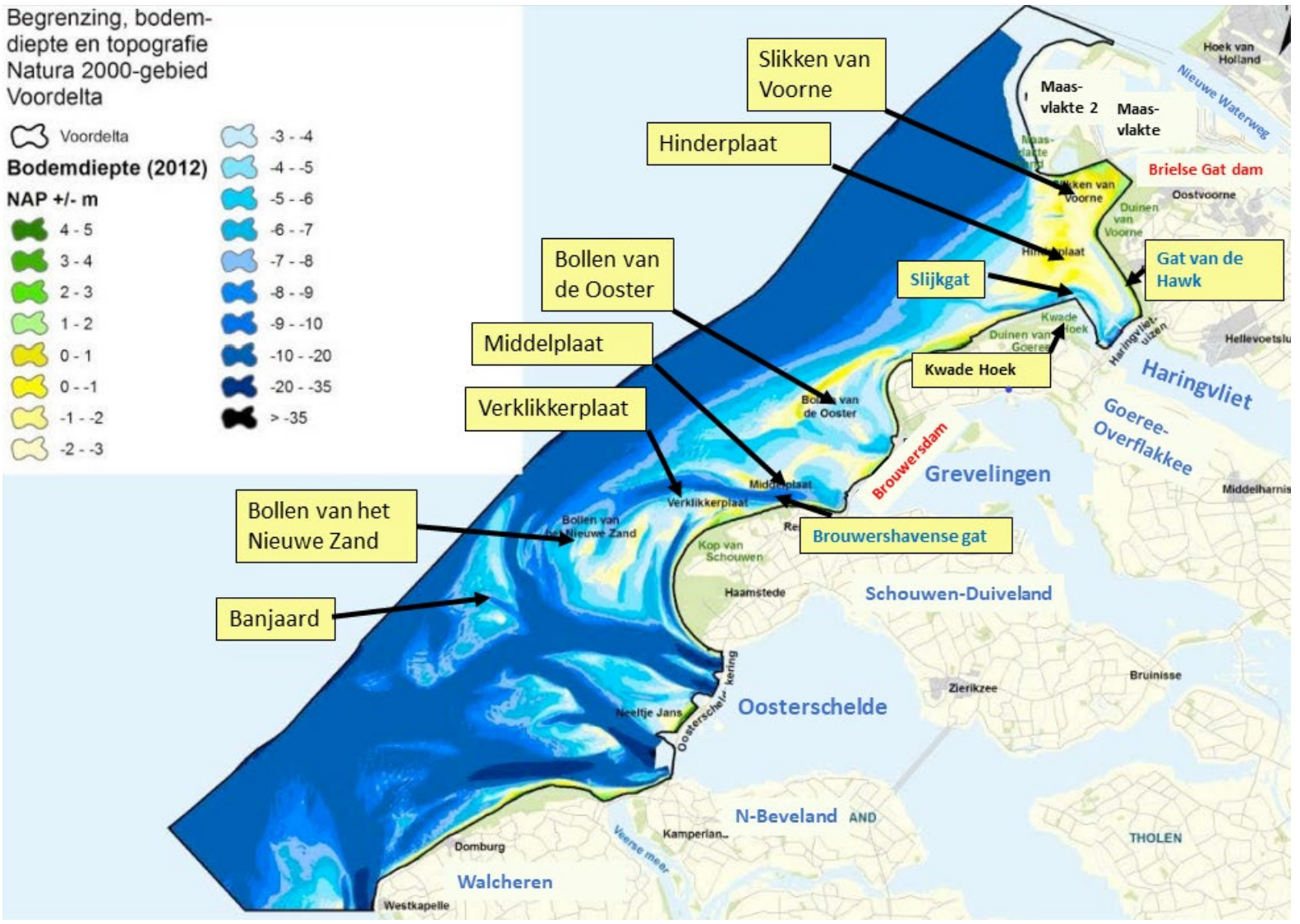

Figuur 4.1. Kaart van Voordelta met topografische aanduidingen.

\subsubsection{Haringvliet}

De werkzaamheden in de monding van het Haringvliet duurden 15 jaar (1957 - 1970) door de bouw van de spuisluizen en de reconstructie van de zuidoever. In dezelfde periode (1964-1976) werd de kust van het eiland Rozenburg zeewaarts verlegd door het opspuiten van de Maasvlakte en de bouw van de Brielse Gatdam (1966). Door de verkleining van de doorsnede van het zeegat veranderde het stromingspatroon aanzienlijk en traden er al grote veranderingen op in de buitendelta voordat de afsluiting gereed was. Het radiale geulpatroon met platen tussen de geulen werd vervangen door de Hinderplaat, een zandbank evenwijdig aan de kust waar de geulen omheen liepen. Door de afnemende stroomsnelheden verondiepten de geulen, de gemiddelde diepte in de buitendelta nam af. De zeewaartse rand van de buitendelta werd verder aangetast. De Hinderplaat groeide in hoogte en lengte, waarbij de kortsluitgeul Gat van de Hawk aan zijn noordkant steeds belangrijker werd voor de doorstroming in het gebied. De geulen vulden op met zand en vooral slib en de Kwade Hoek op de noordoostpunt van Goeree breidde aanzienlijk uit.

In 1986-1987 werd de Maasvlakte uitgebreid met de Slufter waardoor de kust hier weer verder zeewaarts kwam te liggen. Het Gat van de Hawk verdween door deze uitbreiding waardoor er twee kilometer zuidelijker een geul door de Hinderplaat gebaggerd moest worden, het Hindergat. De ringdijk van de Slufter was uitgevoerd in zand, waardoor deze met zandsuppleties onderhouden moest worden. 
Door de golfgedreven stroming werd zand naar het zuiden verplaatst, naar de Haringvliet buitendelta. Grootschalige landaanwinning, zoals de aanleg van Maasvlakte 1 en later Maasvlakte 2, brengt grote hoeveelheden extra zand in het kustsysteem. Door verliezen tijdens aanleg en erosie daarna hebben aangrenzende gebieden veel extra zand ontvangen. Daarnaast neemt met uitbouw van de kust de afscherming van golven aan de lijzijde toe waardoor een rustiger milieu ontstaat waar meer sediment afgezet kan worden.

Bij de Hinderplaat schoven de platen steeds verder landwaarts op en werden langer, hoger en smaller. Uiteindelijk brak de Hinderplaat in het midden van de jaren ' 90 door, waarna dit deel van de buitendelta veranderde in een Wad-achtig landschap met platen en ondiepe geulen, dat relatief snel naar het oosten uitbreidde. Ook in de rest van het gebied groeiden de platen verder aaneen. Van de geulen bleef alleen het Slijkgat over, dat door baggeren open gehouden moet worden. Aanvoer van zand van de eroderende Grevelingen buitendelta voedde de uitbouw van de Kwade Hoek en later de zeewaartse uitbouw van de kust van Goeree.

Tussen 2008 en 2012 werd de Maasvlakte weer verder uitgebreid met Maasvlakte 2, waardoor de buitendelta nog verder in de luwte kwam te liggen door afscherming van golven uit noordelijke richtingen. Golven die op de kust van Maasvlakte 2 breken, transporteren zand naar het zuiden, richting de buitendelta.

\subsubsection{Grevelingen}

De buitendelta van de Grevelingen werd al beïnvloed door de bouw van de Grevelingendam aan zijn landwaartse kant. Hierdoor namen de getijdebieten met ca. 15\% af. De afsluiting van het zeegat met de Brouwersdam (1965-1971) zette grootschalige veranderingen in gang: in 5 jaar tijd verplaatste de rand van de buitendelta zich meer dan $1 \mathrm{~km}$ landwaarts en groeiden de banken aan de noordzijde uit tot de Bollen van de Ooster. In de daaropvolgende jaren zette deze ontwikkeling door waarbij de Bollen van de Ooster aangroeiden in lengte en hoogte. Een deel van het geërodeerde zand werd naar het noordoosten afgevoerd, langs de kust van Goeree. De getijgeul Brouwershavense Gat vulde snel op met vooral slib, met name dicht bij de dam. Het zeewaartse deel van de geul verlegde zich in zuidelijke richting. Het reliëf van de buitendelta vlakte af en het gebied werd ondieper. De Middelplaat werd door golfwerking afgebroken, het zand werd naar de dam verplaatst. Aan de zuidzijde breidden de Bollen van het Nieuwe Zand sterk uit, gevoed met zand aangevoerd uit de Oosterschelde buitendelta.

\subsubsection{Oosterschelde}

De buitendelta van de Oosterschelde groeide aanvankelijk door de Deltawerken. Door de aanleg van de Volkerakdam (1957-1969) nam het getijdebiet in de monding toe waardoor er zand werd afgezet aan het zeewaartse eind van de ebgeulen. De bouw van de stormvloedkering en de compartimentering van het estuarium maakten hieraan een eind. Het getijdebiet nam af en de totale doorsnede van het zeegat eveneens. Doordat de getijstroming voor het belangrijkste deel in stand bleef, bleef het geulpatroon op de buitendelta in stand. De stroomsnelheden namen wel af en de aanvoer van zand stagneerde: de dorpels van de stormvloedkering en de ontgrondingskuilen aan weerszijden van de kering blokkeren het zandtransport. Door de afgenomen getijstroming en het wegvallen van de aanvoer van zand begonnen golven het deltafront (de zeewaartse rand van de buitendelta) te eroderen. Omdat het Noordzeegetij onveranderd was werd het grootste deel van het zand naar het noorden afgevoerd. De Banjaard werd lager en de geulen kregen een meer noord-zuid strekking. De uitbouw van de Bollen van het Nieuwe Zand aan het noordelijke einde van het Krabbengat drukte het Brouwershavense Gat naar het noorden, terwijl deze geul verder zeewaarts juist naar het zuiden afboog en een ebschild opbouwde op de Banjaard. Door de verlaging van de Banjaard nam de golfaanval op de Kop van Schouwen toe.

\subsubsection{Toekomstige ontwikkelingen}

Samenvattend zijn de gevolgen van verstoring van het dynamisch evenwicht op de buitendelta's te beschrijven als toename van de erosie door golven, die het eerst merkbaar wordt aan het deltafront. Het geërodeerde zand wordt voor een deel landwaarts verplaatst waar het een bank vormt, en voor een deel 
kustlangs verplaatst in de richting van een aangrenzende buitendelta. Het door de getijstroming opgebouwde reliëf vlakt af en de getijgeulen vullen op met sediment. Door de toegenomen invloed van het Noordzeegetij krijgen de resterende getijgeulen een noord-zuid oriëntatie en wordt zand naar het noorden verplaatst (Figuur 4.2). In de buitendelta van de Oosterschelde wordt zand getransporteerd van de Banjaard naar de buitendelta van de Grevelingen, en van de Grevelingenmonding gaat zand naar de Haringvlietmonding. De sedimentatie in de Haringvlietmonding wordt versterkt door golfgedreven zandtransport vanuit het noorden, voorheen van de Slufterdam en tegenwoordig vanaf Maasvlakte 2. Aanvoer van zoetwater en slib via de spuisluizen kan de afzetting van slib hier verder versterken.

Nu de grootste morfologische veranderingen in de Voordelta voorbij lijken te zijn, is de vraag wat er de komende tijd nog te verwachten valt. Het mondingsgebied van het Haringvliet heeft een grote aanvoer van sediment, zowel vanuit het noorden als vanuit het zuiden. Ook ligt het gebied goed beschut waardoor het aangevoerde sediment ook grotendeels tot afzetting zal komen. Hierdoor zal de monding steeds verder opvullen, waarbij het oppervlak intergetijdengebied toeneemt. Op de lange duur zal het gebied grotendeels verlanden. Het mondingsgebied van de Grevelingen ligt minder beschut. Het gebied strekt zich uit tussen de Banjaard in het zuiden en de westpunt van Goeree in het noorden. Doorstroming van het Noordzeegetij lijkt een belangrijke rol te spelen, met name tijdens vloed. Hierdoor verlaat meer zand het gebied dan er vanaf de Banjaard bij komt. De Bollen van de Ooster groeien naar het noorden aan. Het is op dit moment niet duidelijk of ze gaan samengroeien met de kust van Goeree. De banken en ondiepe platen zullen langzaam verder naar binnen schuiven, waarbij het Brouwershavense Gat smaller wordt. Grootschalige verlanding ligt hier niet voor de hand. De toekomstige veranderingen op de buitendelta van de Oosterschelde zullen zich concentreren rond de Banjaard. Grote aanpassingen zijn hier niet te verwachten. De geulen Krabbengat en Brouwershavense Gat zullen nog langzaam doorontwikkelen, waarbij het Krabbengat de Bollen van het Nieuwe Zand voedt en de monding van het Brouwershavense gat zijn ebschild verder opbouwt. De Geul van de Banjaard zit ingeklemd tussen de Banjaard en het langzaam terugtrekkende deltafront en heeft daardoor niet veel bewegingsruimte. De gemiddelde diepte op de Banjaard zal eerder toenemen dan afnemen. 


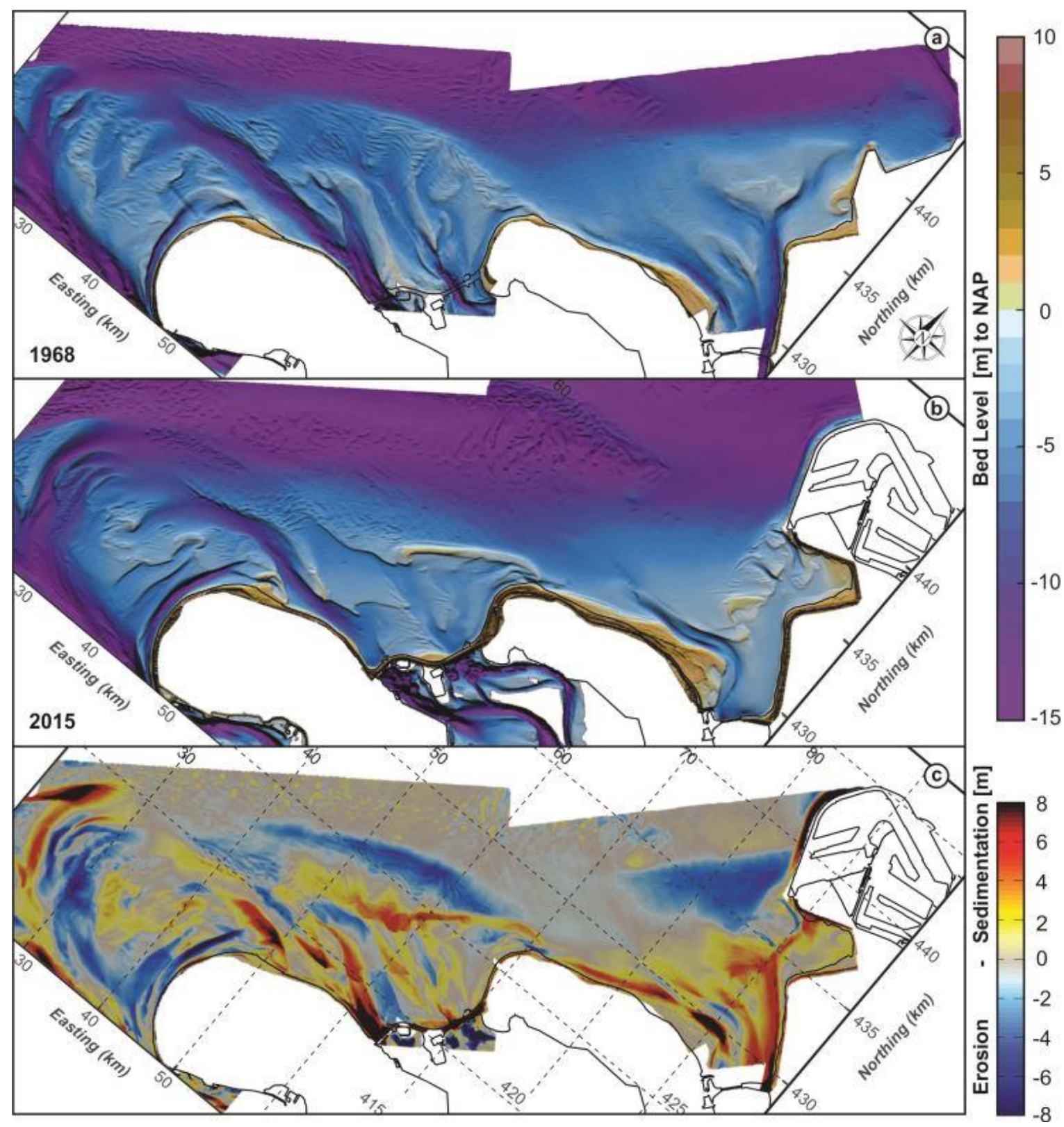

Figuur 4.2. Morfologie van de Voordelta in 1968 (top) en 2015 (midden). De verschilkaart (onder) laat zien waar sedimentatie (in gele en rode kleuren) en waar erosie (in blauw) is opgetreden over de periode 1968-2015 (uit: Elias et al., 2016).

Door de morfologische ontwikkelingen is het areaal boven gemiddeld laagwater sinds 1970 toegenomen. In totaal is hierdoor sinds 1990 het areaal beneden laagwater (habitattype H1110) met ongeveer 20 ha/jaar afgenomen. Dit is verwaarloosbaar ten opzichte van de bijna 90.000 ha H1110 in de Voordelta in 2007. Het areaal intergetijdengebied is in totaal met ongeveer 15 ha/jaar sinds 1990 toegenomen. Tussen 2007 en 2012 is het areaal van habitattype H1110 vooral afgenomen door de aanleg van Maasvlakte 2 (1.917 ha). Daarnaast is een klein deel (196 ha) als gevolg van opslibbing veranderd in habitattype H1140 (van Oostveen en Koolmees, 2013). 


\subsection{Ontwikkeling sedimentsamenstelling}

In de Voordelta onderscheidt de monding van het Haringvliet zich van de rest van het gebied door een veel slibrijker sediment. De westelijke rand van het Bodembeschermingsgebied heeft over het algemeen grover sediment dan de meer landwaarts gelegen delen. Het Bodembeschermingsgebied onderscheidt zich ook door een wat fijnere sedimentsamenstelling dan het zuidelijk referentiegebied voor de kust van Walcheren. Deze verschillen worden geïllustreerd door kaarten met de gemiddelde samenstelling over de T0 periode (2004-2007), de T1 (2008-2015) en T2 (2016-2019). De D50, D10 en D90 in Figuur 4.3 geven respectievelijk de mediane korrelgrootte, de 10-percentiel van de korrelgrootte (de fijne fractie van het sediment) en de 90-percentiel van de korrelgrootte (de grove fractie van het sediment).

Over de gehele periode van monitoring in PMR-NCV zijn kleine veranderingen opgetreden in de sedimentsamenstelling. In Figuur 4.4 wordt het verschil tussen de T0 en de T2 getoond. Voor de T2 periode zijn geen data meer beschikbaar voor het Maasvlakte 2 gebied en de Haringvliet monding. Met name in het noordelijk deel van het Bodembeschermingsgebied en in het gebied bij de Bollen van de Ooster en langs de kust van Goeree is het sediment wat slibrijker geworden. Bij de kop van Schouwen in het zuidelijk deel van het Bodembeschermingsgebied is het sediment wat grover geworden. Deze veranderingen zijn waarschijnlijk het gevolg van veranderingen in morfologie, stroomsnelheden en golfwerking.
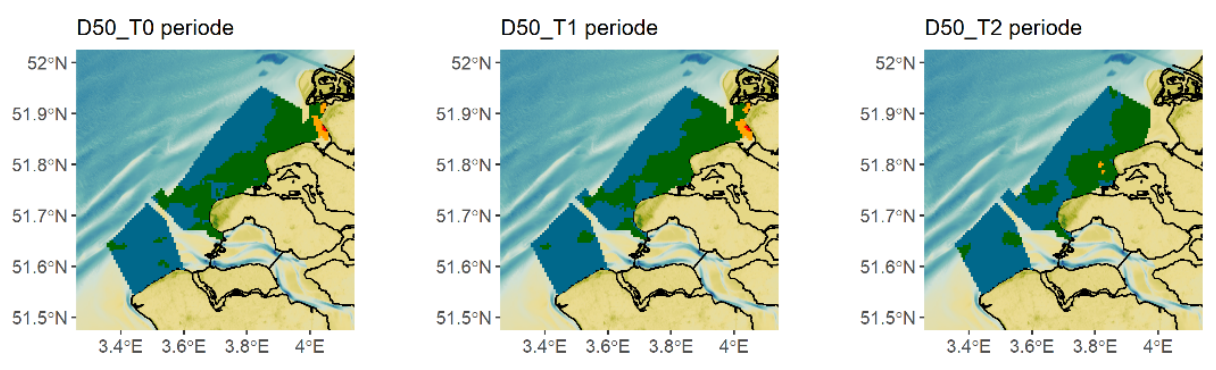

D10_T0 periode
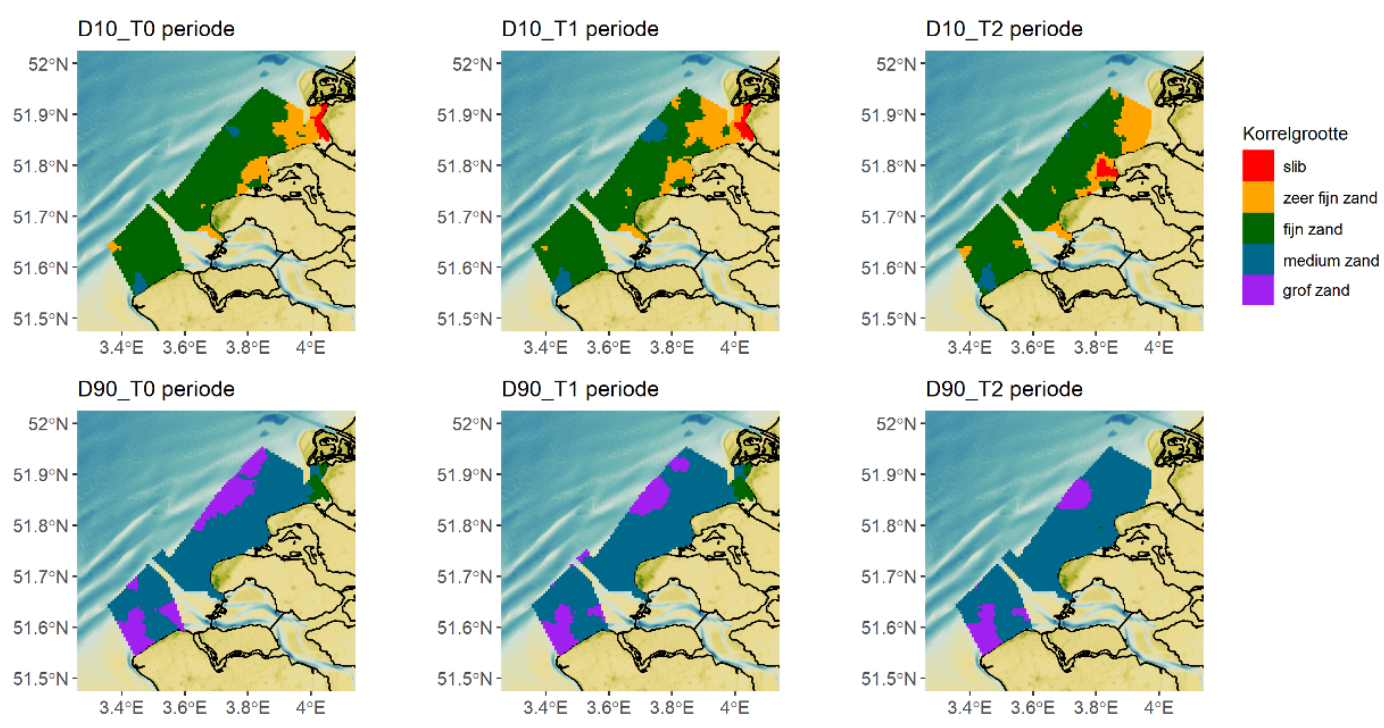

Figuur 4.3. Korrelgrootteverdeling van het sediment, uitgedrukt in de mediane korrelgrootte en de 10 en 90-percentiel, in de T0 (2004-2007), T1 (2008-2015) en T2 (2016-2018). De kaarten zijn gebaseerd op een interpolatie van de sedimentgegevens uit de bodemdierbemonstering. slib: <63 $\mu m$, zeer fijn zand: 63-125 $\mu \mathrm{m}$, fijn zand: 125-250 $\mu \mathrm{m}$, medium fijn zand: 250-500 $\mu \mathrm{m}$, grof zand: >500 $\mu \mathrm{m}$. 
Gemiddelde D50: T2-T0
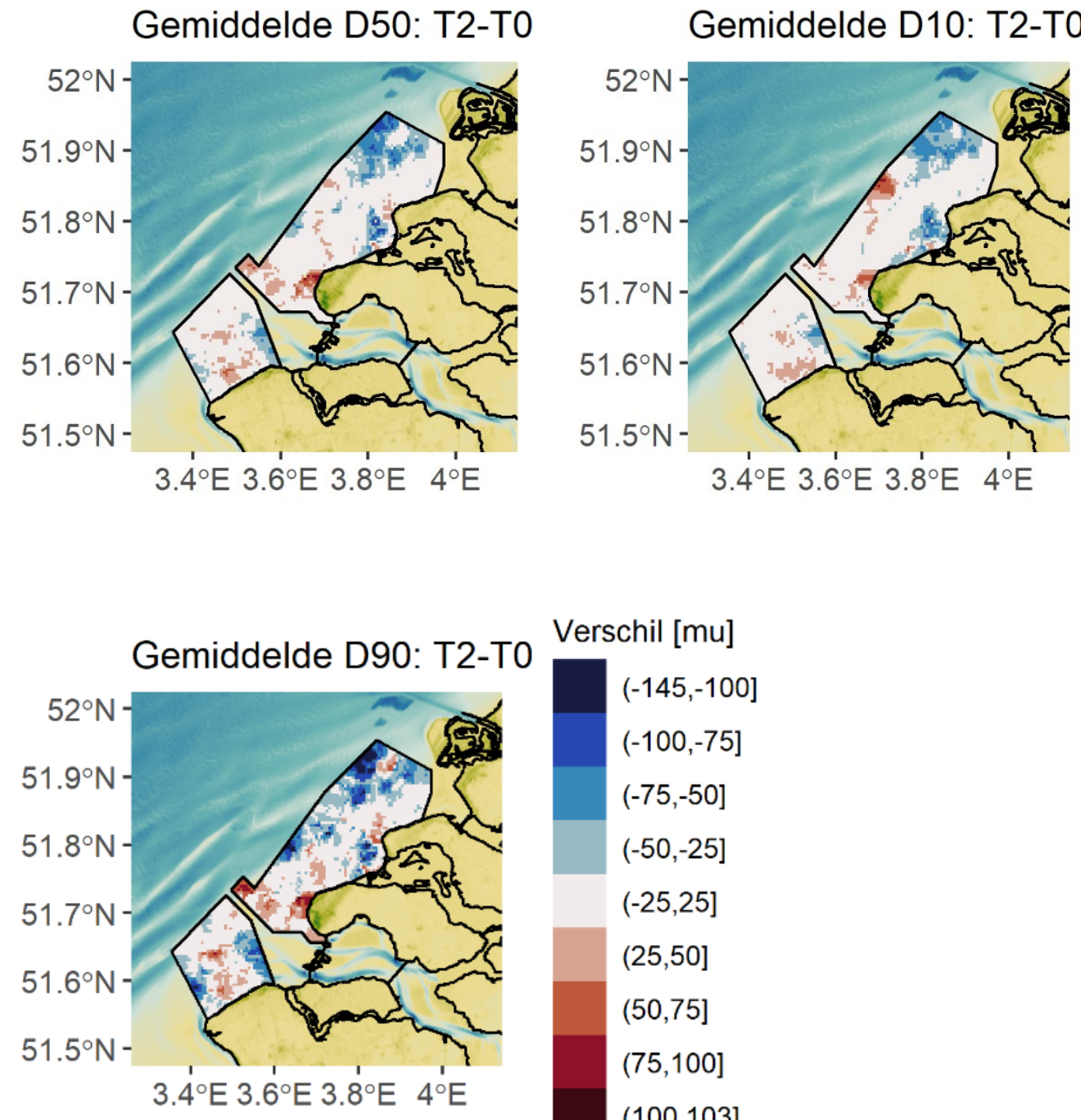

Verschil [mu]

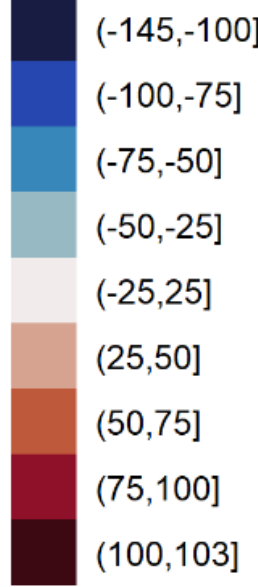

Figuur 4.4. Verandering (in $\mu \mathrm{m}$ ) in korrelgrootteverdeling van het sediment, uitgedrukt in de mediane korrelgrootte, 10- en 90-percentiel, over de periode TO-T2.

\subsection{Bodemschuifspanning door golven en stroming}

Hier wordt een beschrijving gegeven van de bodemschuifspanning door golven en stroming, en de verdeling in de tijd en over de Voordelta.

\subsubsection{Golven}

De dominante windrichting in de Voordelta is ZW, en als gevolg hiervan is de dominante golfrichting vanuit ZW naar NO. Windrichting, windsnelheid en strijklengte zijn van invloed op de golfrichting en de golfhoogte. De effecten van golven op het bodemleven zijn het sterkst in die delen van de Voordelta waar de golven de bodem 'raken' en leiden tot een hoge bodemschuifspanning. Dit is, als gevolg van de dominante windrichting, vooral het geval aan de westzijde van de ondiepere delen in de Voordelta.

De bodemschuifspanning door golven in de Voordelta is gemodelleerd voor een fijnmazig ruimtelijk raster (Adema, 2018). Figuur 4.5 geeft ter illustratie het gemiddelde ruimtelijke patroon van de 
bodemschuifspanning door golven in de Voordelta. De ruimtelijke verdeling hangt samen met windsnelheid, diepte, waterstand en windrichting. Bij NW wind heeft de wind de langste strijklengte en het meeste effect op de golfhoogte. De hoogste kans op hogere bodemschuifspanning komt voor in die delen van de Voordelta waar de golven bij de zeewaartse helling van de ondiepere banken komen, in Figuur 4.5 te zien als een strook evenwijdig aan de kust, waar de bodem ondieper wordt. Aan de landwaartse zijde wordt de kans op overschrijding juist weer kleiner doordat dit gebied meer in de luwte ligt. Figuur 4.6 geeft nog een illustratie van dit ruimtelijk patroon, voor een periode van stormachtige wind ( $8 \mathrm{Bft}$ ) uit NW richting in augustus 2012. Ook deze figuur laat zien dat de hoogste bodemschuifspanning door golfwerking optreedt in een strook landwaarts van de 12,5 m dieptecontour. Verder landwaarts is de bodemschuifspanning door golven weer lager.

Hogere windsnelheden leiden tot hogere bodemschuifspanning, vooral in de buitendelta's van Haringvliet en Grevelingen. Stormen, hier gedefinieerd als perioden met windsnelheden van 9 Bft of meer gedurende minimaal twee achtereenvolgende uren (KNMI data Hoek van Holland), kwamen gemiddeld ongeveer eens in de twee jaar voor; perioden met meer dan $8 \mathrm{Bft}$ gemiddeld ongeveer 4 keer per jaar. Er zijn relatief beperkte verschillen tussen jaren in de frequentie en zwaarte van stormen (Figuur 4.7). In de jaren waarin monitoring van bodemdieren is uitgevoerd, waren 2015, 2016 en 2017 jaren met relatief veel storm (en verhoogde bodemschuifspanning door golven).

Stormen kunnen leiden tot omwoeling van de bodem in ondiepe delen waardoor bodemdieren worden losgewoeld. Bij lage watertemperaturen kunnen dan massaal (stervende of dode) schelpdieren aanspoelen op het strand (Cadée, 2002; Dannheim en Rumohr, 2011).

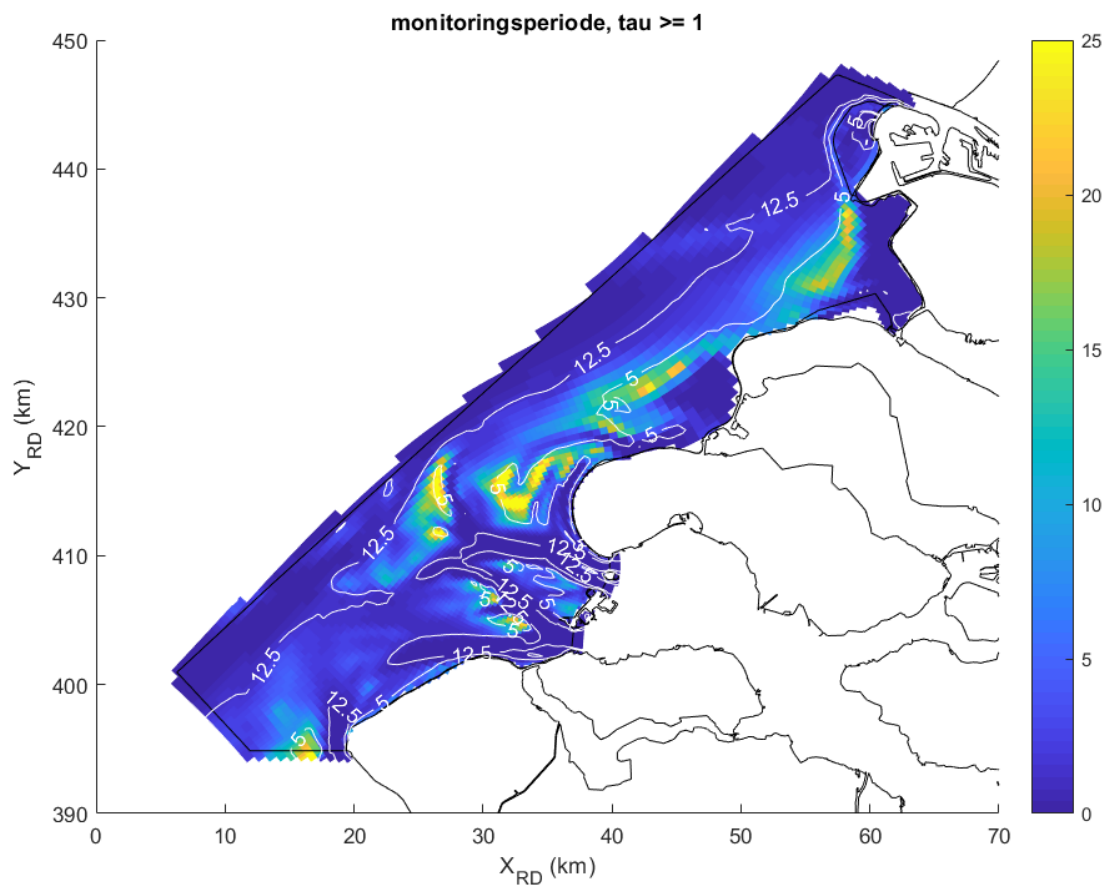

Figuur 4.5 Percentage van de tijd dat de bodemschuifspanning door golven boven $1 \mathrm{~N} / \mathrm{m}^{2}$ uitkomt in de gehele monitoringsperiode 2004-2016 (Adema, 2018). De witte contouren geven de diepte in meters weer. 


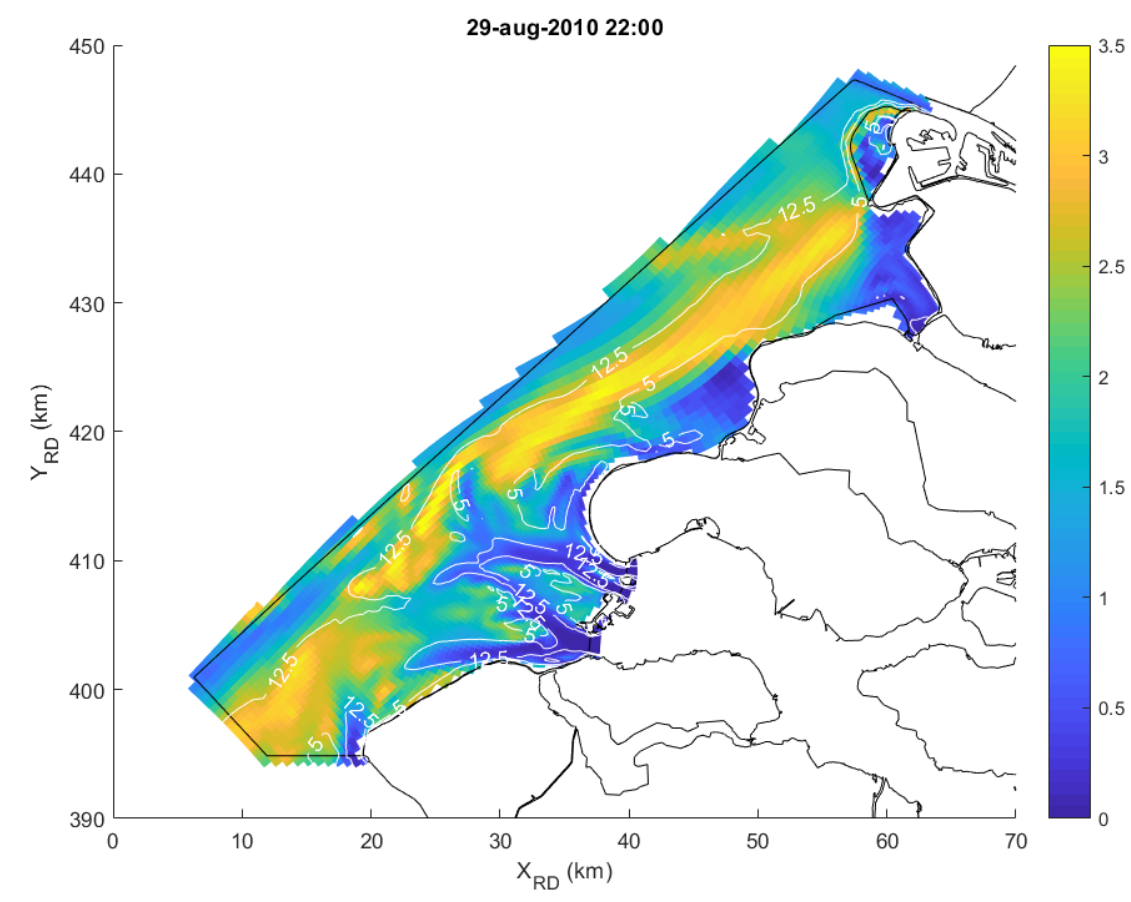

Figuur 4.6 Bodemschuifspanning (in $\mathrm{N} / \mathrm{m}^{2}$ ) door golven op 29 augustus 2010 om 22:00 uur, tijdens een periode met stormachtige wind ( $8 \mathrm{Bft}$, uit NW). De witte contouren geven de diepte in meters weer (Adema, 2018).

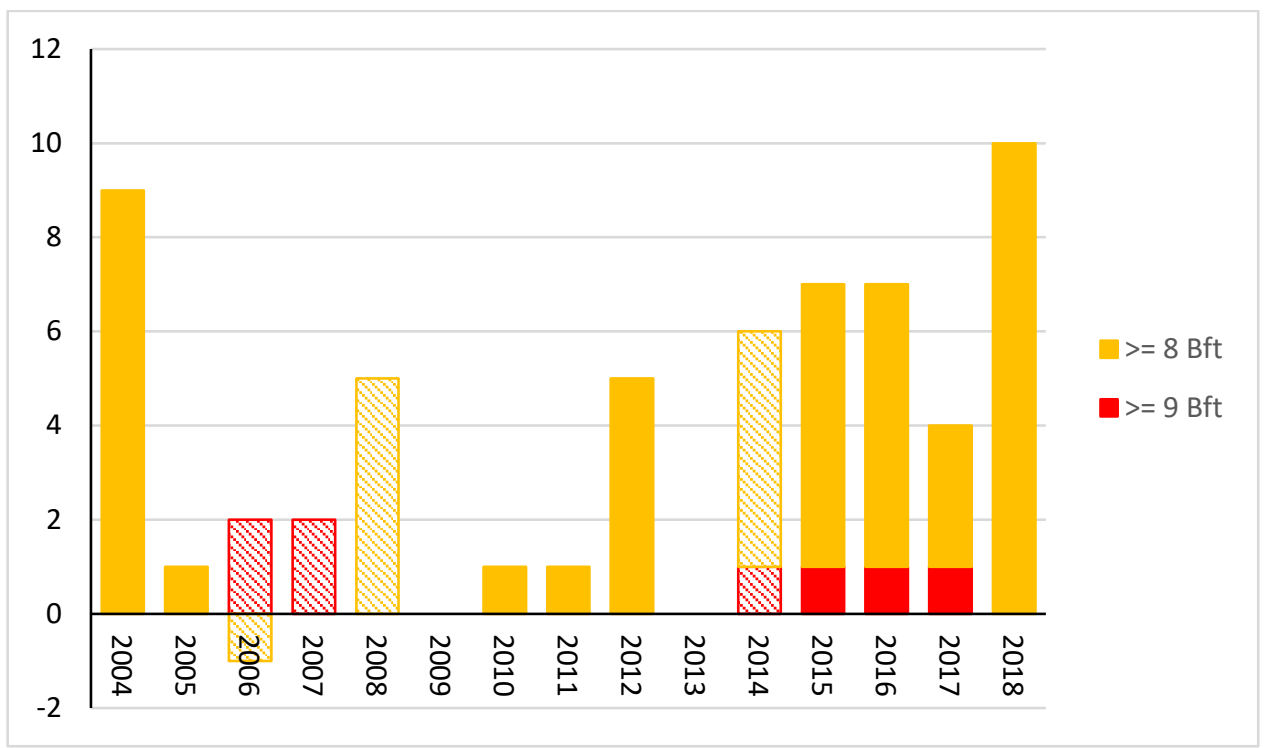

Figuur 4.7 Aantal malen in het jaar voorafgaand aan de benthosbemonstering (okt-sep) met een aaneengesloten periode van minimaal twee uur met windkracht $\geq 9 \mathrm{Bft}$ (rode balk) of windkracht $\geq 8 \mathrm{Bft}$ (rode+oranje balk) (Adema, 2019). De gearceerde balken zijn jaren zonder bodemdierbemonstering. 


\subsubsection{Stroming}

Hoge bodemschuifspanning als gevolg van getijstroming komt voor in de diepere geulen in de Voordelta. Figuur 4.8 laat de ruimtelijke verdeling van stroomsnelheden in de Voordelta zien (zowel bij de bodem als aan het oppervlak). In de diepe geulen is de bodemschuifspanning door golven verwaarloosbaar, terwijl de bodemschuifspanning als gevolg van de getijstroom hoge pieken $\left(3 \mathrm{~N} / \mathrm{m}^{2}\right)$ kan vertonen. In de ondiepere delen van de Voordelta is de bodemschuifspanning door stroming juist relatief laag ten opzichte van de bodemschuifspanning door golven.
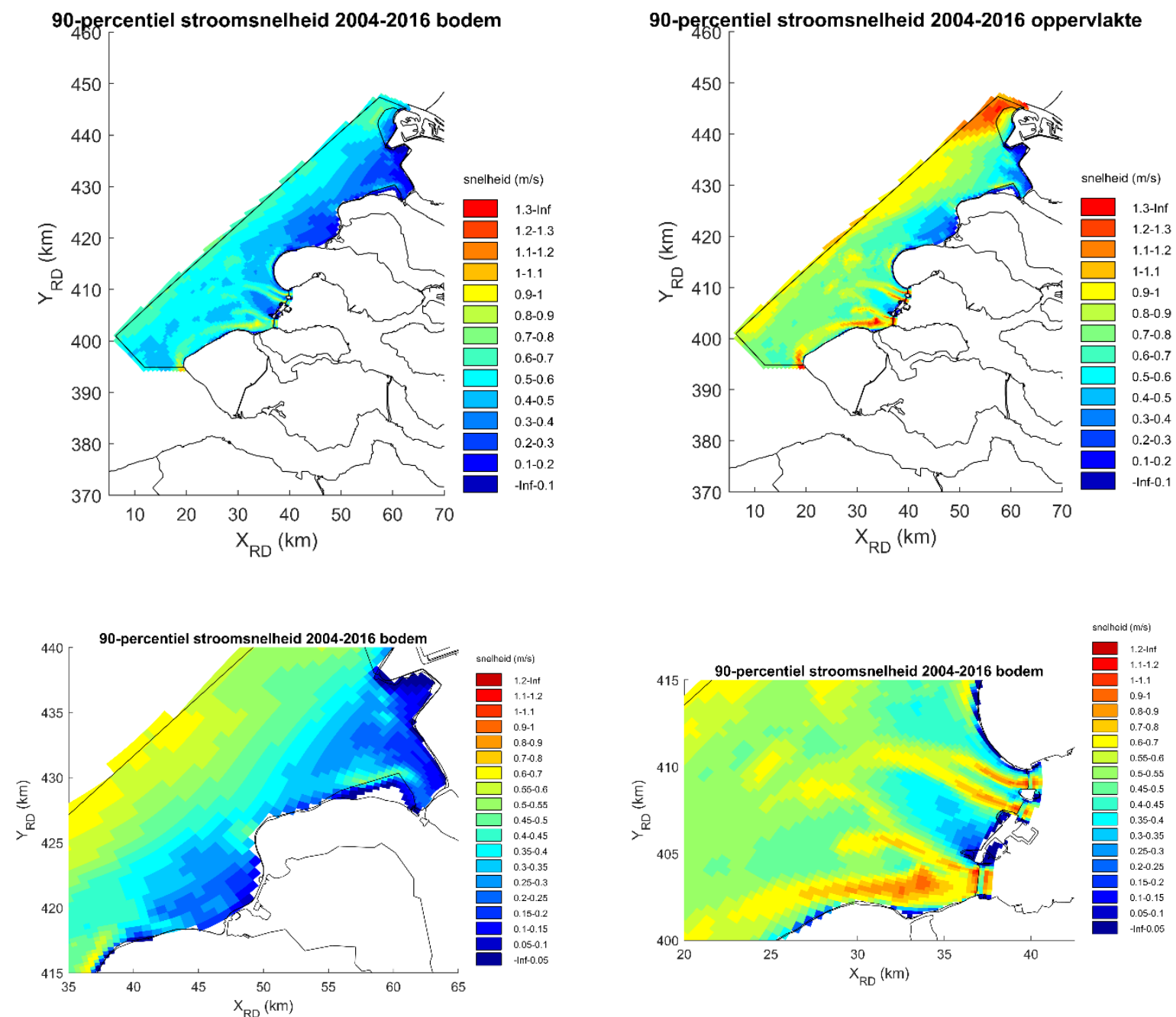

Figuur 4.8 De stroomsnelheid (90-percentiel voor de periode 2004-2016) bij de bodem (links boven) en het oppervlak (rechts boven) in de Voordelta en in meer detail in het gebied van Grevelingen- en Haringvliet-monding (links onder) en Oosterschelde-monding (rechts onder). 


\subsection{Watertemperatuur en zoutgehalte}

\subsubsection{Temperatuur}

Figuur 4.9 geeft de watertemperaturen per jaar (gemiddelde en 5- en 95-percentielen; MWTL data Vlissingen), voor de periode 1960-2017. Dit is het meetpunt dat het meest nabij de Voordelta ligt waarvoor een meetreeks voor een dergelijk lange periode beschikbaar is. Er is een stijging waar te nemen in de watertemperatuur van gemiddeld $0,024^{\circ} \mathrm{C} / \mathrm{jaar}$. Een stijgende trend is ook waargenomen bij andere meetstations langs de Nederlandse kust (van Aken, 2010; Adema, 2016).

Het is bekend dat strenge winters kunnen leiden tot sterfte van bodemdieren en veranderingen in dichtheden en soortensamenstelling. Wintersterfte treedt op in het intergetijdengebied door vorst en ijsgang (Beukema, 1979; Dekker en Beukema, 1999), maar ook in het sublitoraal door lage watertemperaturen (Reiss et al., 2006; Kröncke et al., 2013). Sinds 1990 zijn er slechts twee relatief koude winters geweest (1995/1996, 1996/1997), waarin het Hellmann-getal (een maat voor de kou in de maanden november-maart) boven de 100 kwam (data KNMI). De effecten van deze winters zijn ook terug te zien in de lagere 5-percentielen van de zeewatertemperatuur in 1996 en 1997 in Figuur 4.9. De winters in de monitoringjaren voor PMR-NCV (Figuur 4.10) waren normaal (2009-2013) of zacht tot zeer zacht (2004-2008, 2014-2018).

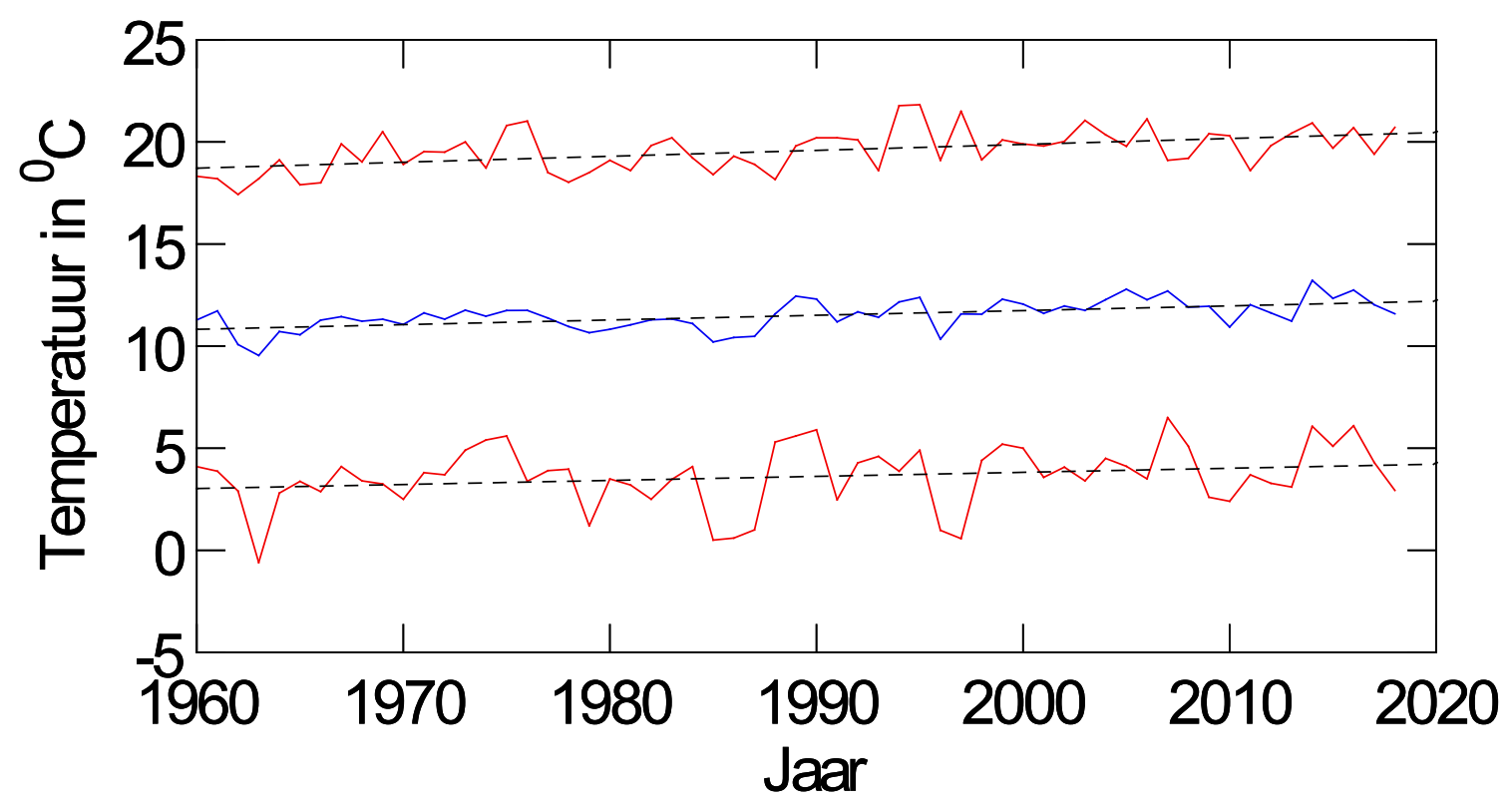

Figuur 4.9. Jaargemiddelde (blauwe lijn) en 5- en 95-percentiel (rode lijnen) van de zeewatertemperatuur bij Vlissingen, met de lineaire trends in elk van deze parameters. 


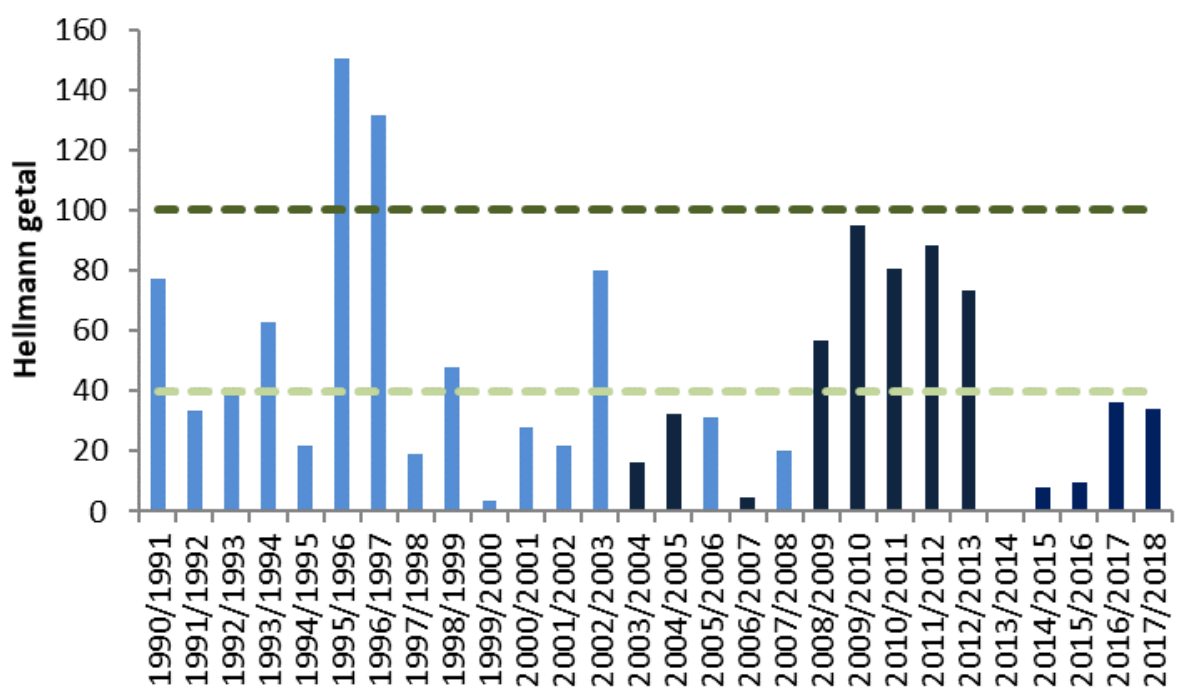

Figuur 4.10. Hellmann getal voor de winters in 1990-2017. De classificatie is als volgt: $H<10$ buitengewoon zacht; $H<20$ zeer zacht; $H<40$ zacht (lichtgroene stippellijn); $H<100$ normaal; $H>100$ koud (donkergroene stippellijn); H>160 zeer koud (data: KNMI).

\subsubsection{Rivierafvoer en saliniteit}

\subsubsection{Rivierafvoer}

De waterkwaliteit en saliniteit van de Voordelta wordt beïnvloed door de afvoer van de rivieren Schelde, Maas en Rijn, waarbij de rivier de Rijn veruit de hoogste afvoer heeft. Sinds de voltooiing van de Deltawerken gaat de rivierafvoer vooral via de Nieuwe Waterweg en in mindere mate via het Haringvliet. Door de sterke invloed van de rivieren is de Voordelta, evenals de rest van de Nederlandse kustwateren, een hoog productief gebied met relatief hoge concentraties voedingsstoffen en fytoplankton.

De afvoer van zoetwater via de Haringvlietsluizen is erg variabel, afhankelijk van de totale rivierafvoer (Figuur 4.11). Tijdens hoge rivierafvoeren wordt veel rivierwater gespuid via het Haringvliet, terwijl bij lage rivierafvoeren er soms in het geheel geen water via de Haringvlietsluizen wordt afgevoerd.

Vergeleken met het langjarig gemiddelde vanaf 1990, waren de afvoeren in het winterhalfjaar tijdens de monitoringperiode van PMR-NCV relatief laag. De winters van 2012/2013 en 2017/2018 hadden een hogere afvoer dan gemiddeld, maar veel lager dan de hoge afvoeren ( $>1600 \mathrm{~m}^{3} \mathrm{~s}^{-1}$ ) in de natte winters van 93/94, 94/95, 98/99 en 03/04. Van de zomerhalfjaren hadden 2013 en 2016 een relatief hoge afvoer. 

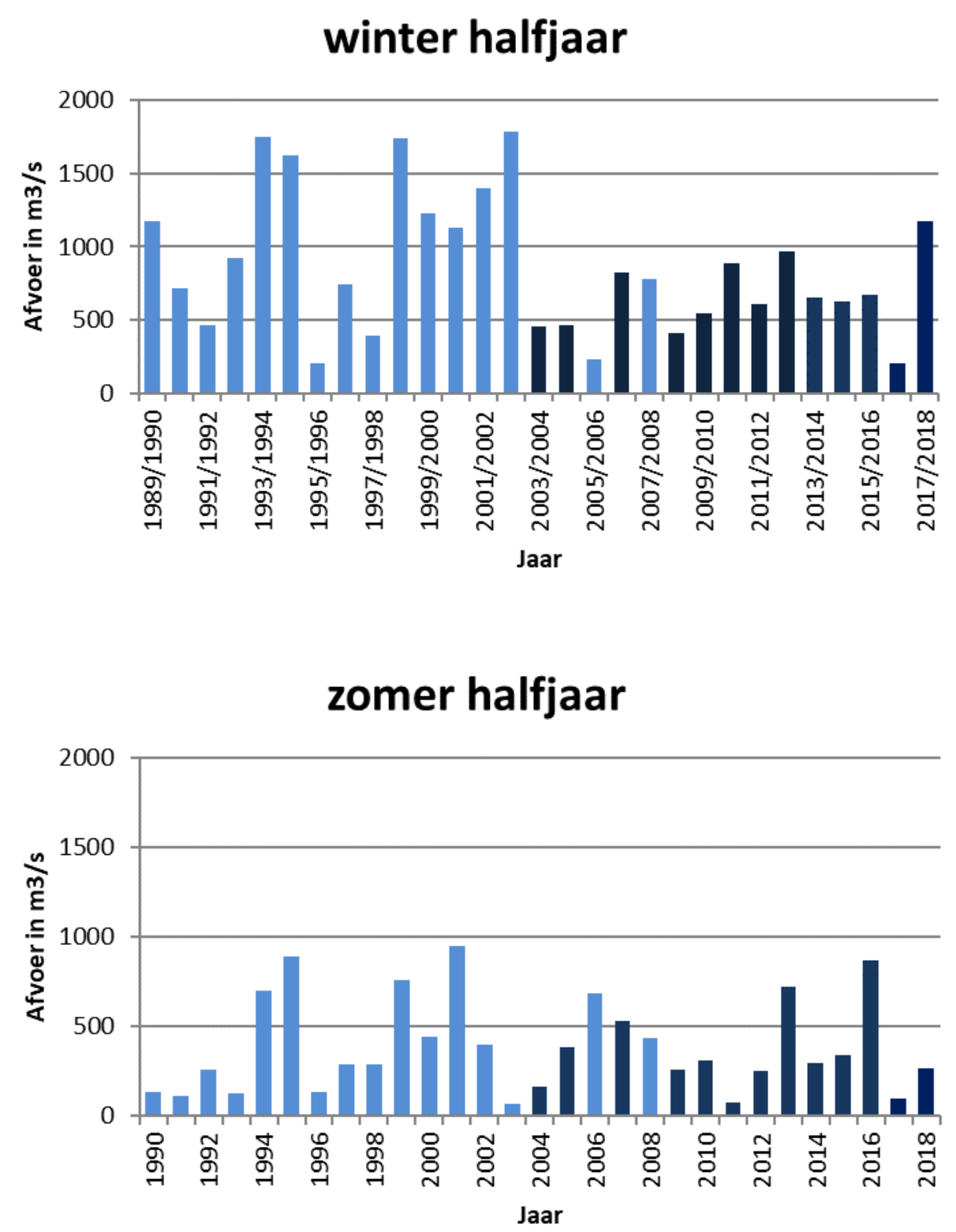

Figuur 4.11 Staafdiagram met gemiddeld spuidebiet van het Haringvliet in het winterhalfjaar (oktobermaart; boven) en het zomerhalfjaar (april-september) voor 1989 - 2016 (data: RWS). De donkerblauwe balken geven de jaren weer waarin monitoring voor PMR-NCV heeft plaatsgevonden.

\subsubsection{Saliniteit}

Het grootste deel van de Voordelta is zout (saliniteit $>30 \mathrm{psu}$ ). Alleen in het noordelijk deel van de Voordelta komen lagere zoutconcentraties voor door de uitstroom van het Haringvliet (Figuur 4.12). De saliniteit in de Haringvlietmonding is als gevolg van de directe invloed van de afvoer van het Haringvliet zeer variabel. Bij hoge rivierafvoeren kan een groter deel van de Voordelta tijdelijk te maken hebben met verlaagde zoutgehaltes; in de Haringvlietmonding kunnen de zoutgehaltes zelfs tot beneden de 10 dalen, wat tot sterfte van bodemdieren kan leiden. In 1995 is sterfte van bodemdieren in de Voordelta vastgesteld bij een saliniteit lager dan 5 (Craeymeersch et al., 1996). Het effect van het spuiwater op de saliniteit in de Voordelta is vooral te zien in de directe omgeving van de Haringvlietsluizen. Met het Kierbesluit is het beheer van de Haringvlietsluizen veranderd. Dit besluit is in het najaar van 2018 ingegaan en heeft geen invloed gehad in de periode waarin het monitoringprogramma is uitgevoerd. 
Modelresultaten laten zien dat de veranderingen in saliniteit in de Haringvlietmonding als gevolg van de aanleg van Maasvlakte 2 aanmerkelijk kleiner zijn dan de al bestaande variatie in saliniteit in dat gebied (Prins et al., 2014).

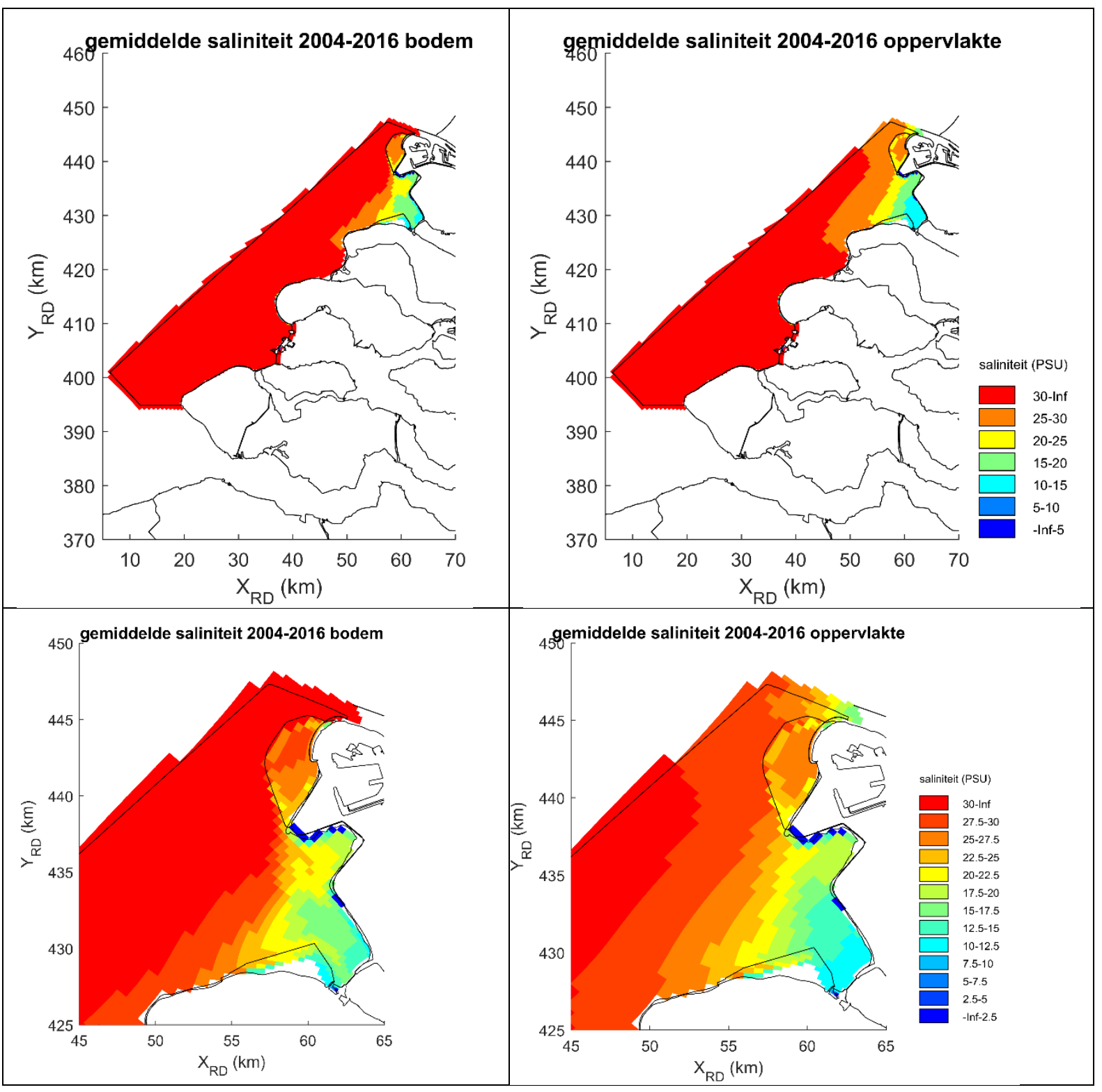

Figuur 4.12 Gemiddelde saliniteit in de Voordelta in de periode 2004-2016, bij de bodem (boven links) en aan het oppervlak (boven rechts), en in meer detail in de Haringvlietmonding bij de bodem (onder links) en aan het oppervlak (onder rechts). 


\section{$5 \quad$ Visserij}

Dit hoofdstuk geeft een overzicht van de ontwikkelingen in boomkorvisserij en garnalenvisserij in de Voordelta sinds 2004. Deze ontwikkelingen worden vergeleken met de ontwikkelingen elders in de Nederlandse kustwateren.

\subsection{Gebruikte methodiek en beschikbare data}

Voor de analyses van visserij-inspanning is gebruik gemaakt van logboekgegevens en de beschikbare data uit het satelliet volgsysteem VMS (Vessel Monitoring System dat visserijvaartuigen op basis van Europese regelgeving verplicht aan boord moeten voeren). Een gedetailleerde uitleg van de gebruikte opwerkingsmethodiek is beschreven in Hintzen et al. (2014) en Hintzen (2019).

De VMS-gegevens over positie, snelheid en vaarrichting zijn opgewerkt naar totale visserij-inspanning, waarbij de inspanning op verschillende wijzen kan worden beschreven, bijvoorbeeld als de hoeveelheid tijd die vissend in een bepaald gebied wordt doorgebracht (vis-uren), of het aandeel van het totale oppervlak dat jaarlijks met een bepaalde intensiteit wordt bevist. De vis-uren geven inzicht in de totale visserij-inspanning, terwijl de tweede berekening meer inzicht geeft in de omvang van de bodemberoering per locatie.

Met de invoering van AIS (Automatic Identification System) is in principe de mogelijkheid ontstaan om de AIS data, die positie, snelheid en scheepsgegevens bevatten met een veel hogere frequentie van verzamelen dan de VMS data, te gebruiken om de visserij-intensiteit te bepalen. Een vergelijkende studie heeft laten zien dat visserij-intensiteit bepaald op basis van VMS data op zichzelf al accuraat is (Hintzen et al., 2014). Bovendien is AIS pas vanaf 2008 geleidelijk ingevoerd voor de garnalenvisserij, zodat AIS data niet voor de gehele periode die voor PMR-NCV van belang is, beschikbaar zijn (Hintzen et al., 2014).

\subsection{Algemene beschrijving visserij}

De visserij in de Voordelta is onder te verdelen in zes categorieën actieve visserijen, nl. boomkorschepen en pulskorschepen vissend op platvis (260-300 PK), boomkorschepen vissend op garnaal, de schelpdiervisserij, bordenvisserij, schotse zegenvisserij en twee categorieën passieve visserij, nl. staandwant- en fuikenvisserij. De meeste vis-uren worden gemaakt door boomkorvisserij op platvis met schepen >260 pk, garnalenvisserij en schelpdiervisserij. Boomkorvisserij $>260$ pk is sinds 2008 in het Bodembeschermingsgebied niet toegestaan. Garnalenvisserij en schelpdiervisserij komen wel voor in het Bodembeschermingsgebied. Bordenvisserij komt vooral voor in de noordwestelijke hoek en in het zuiden van de Voordelta. Platvisvisserij $<260$ pk en fuikenvisserij vinden vrijwel uitsluitend plaats bij de monding van het Haringvliet. Staandwant- en Schotse zegenvisserij vinden hoofdzakelijk langs de diepere randen van de Voordelta plaats (Tien et al., 2017a). Niet alle visserijtypen veroorzaken bodemberoering. 


\subsection{Ontwikkeling visserij-inspanning in de Voordelta}

\subsubsection{Boomkor- en garnalenvisserij}

In de gehele Voordelta is de visserij op platvis afgenomen vanaf 2004. Vanaf 2011 is de visserij met boomkor en wekkerkettingen verder afgenomen in aantal vaartuigen, maar is de totale inspanning in visuren ongeveer stabiel gebleven door toename van de pulsvisserij. De garnalenvisserij is vooral na 2011 sterk in intensiteit toegenomen, met de hoogste aantallen vis-uren in 2016 en 2017.

Om een goede vergelijking te kunnen maken tussen het Bodembeschermingsgebied (29.836 ha) en de rest van de Voordelta die ruim 2 maal zo groot is ( 83.534 ha), zijn de vis-uren uitgedrukt in uur per hectare (Figuur 5.1). De boomkorvisserij in het Bodembeschermingsgebied was ook vóór instelling van het Bodembeschermingsgebied in 2008 al minder intensief dan in de rest van de Voordelta. Dit patroon volgt ook uit een statistische (BACI) analyse van de verandering in visserij. De intensiteit van de boomkorvisserij in de rest van de Voordelta is significant hoger dan die in het gebied waar het BBG is ingesteld, zowel in de T0 als daarna. De afname in visserij is in beide gebieden echter gelijk. De conclusie is daarom dat er feitelijk geen verandering in het relatieve ruimtelijk patroon is opgetreden. Het Bodembeschermingsgebied was al een marginaal gebied voor boomkorvisserij vóór het instellen van de bodembescherming; na 2008 is de boomkorvisserij grotendeels verdwenen uit de gehele Voordelta. Een zelfde vergelijking voor garnalenvisserij laat zien dat de garnalenvisserij altijd al intensiever was in het Bodembeschermingsgebied, en ook sterker in intensiteit is toegenomen in het Bodembeschermingsgebied dan in de rest van de Voordelta.

Deze twee visserijen vertonen een duidelijk verschillende seizoensritmiek. Visserij op platvis vindt vooral plaats in voorjaar en vroege zomer. Garnalenvisserij is vooral actief in de late zomer en het najaar. Deze verdeling over seizoenen is gelijk gebleven over de periode 2004-2018.

Figuren 5.2 en 5.3 laten zien hoe de visserij-inspanning ruimtelijk verdeeld was in de Voordelta. Omdat het patroon over de jaren heen geleidelijk is veranderd is een selectie gemaakt van drie jaren die als illustratie dienen: de jaren 2004 (T0, jaar met nog relatief veel vis-uren van platvisvisserij), 2012 (vier jaar na instelling van het Bodembeschermingsgebied) en 2017 (jaar met hoogste aantal vis-uren van garnalenvisserij). De visserij op platvis is in de hele Voordelta en ook in een strook van $7 \mathrm{~km}$ daarbuiten sterk afgenomen in intensiteit. De laatste jaren komt deze visserij vrijwel alleen nog voor bij de Maasvlakte en bij de monding van de Westerschelde; dit is voornamelijk pulsvisserij (zie ook Figuur 5.1).

De garnalenvisserij daarentegen vindt plaats in de hele Voordelta en de Westerschelde monding, en nauwelijks ten westen van de Voordelta. De intensiteit in de Voordelta is duidelijk toegenomen vanaf 2004, met een piek in 2017. In 2018 is de garnalenvisserij sterk afgenomen. Recente resultaten (Hintzen, 2019) laten een verdere afname in 2019 zien. Ook analyses van AIS data voor 2009-2018 (van Moorsel et al., 2020a) tonen dit patroon. 


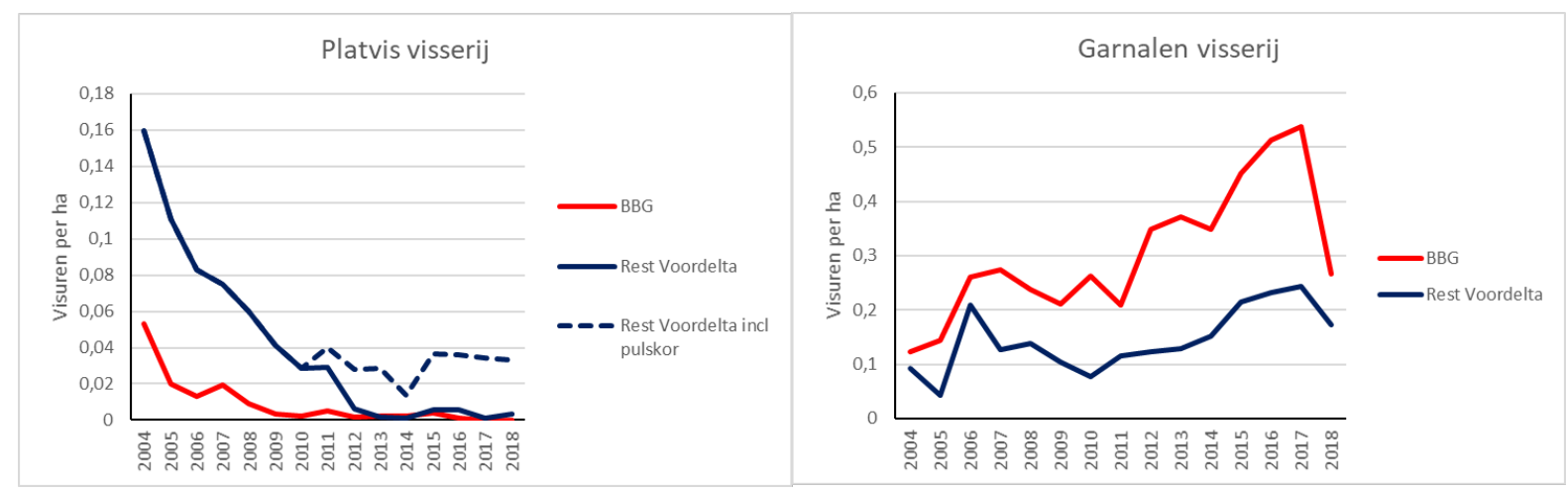

Figuur 5.1. Aantal vis-uren uitgedrukt in uren/ha in het Bodembeschermingsgebied en de rest van de Voordelta, voor visserij op platvis (links) en garnalenvisserij (rechts). Bij de visserij op platvis is boomkorvisserij (doorgetrokken lijn) en pulsvisserij (onderbroken lijn) onderscheiden. Data op basis van VMS en logboekgegevens.
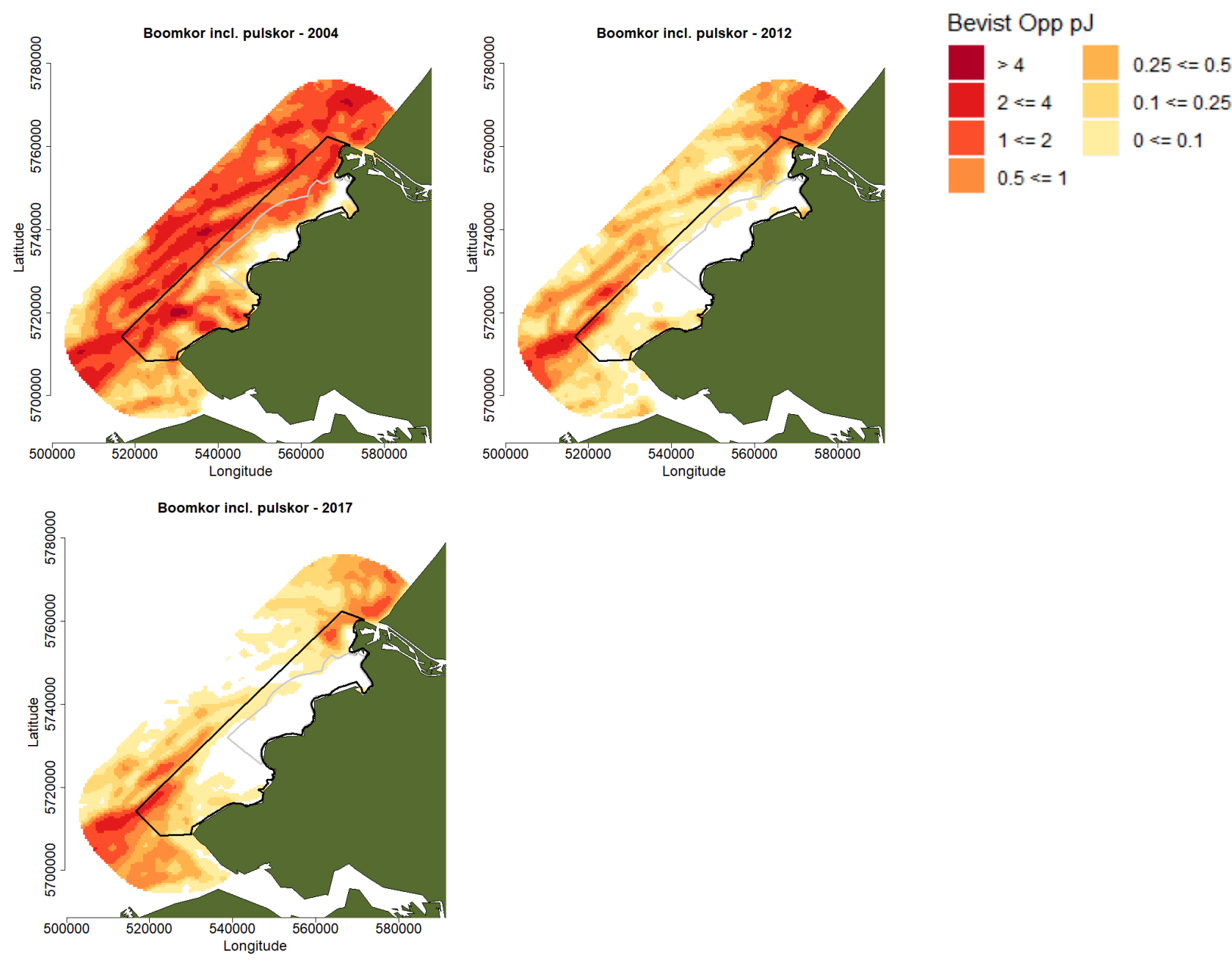

Figuur 5.2. Visserij-intensiteit van platviskotters (incl. pulskor) in de Voordelta in 2004, 2012 en 2017. Visserij-intensiteit is uitgedrukt in bevist oppervlak per kalenderjaar (aantal keren per jaar dat het gehele oppervlak van 0,25 $\mathrm{km}^{2}$ bevist is, per vak van $0,5 * 0,5 \mathrm{~km}$ ). Zwarte omlijning = Voordelta, grijze omlijning $=B B G$. Hoe roder, hoe intensiever de visserij is geweest. 

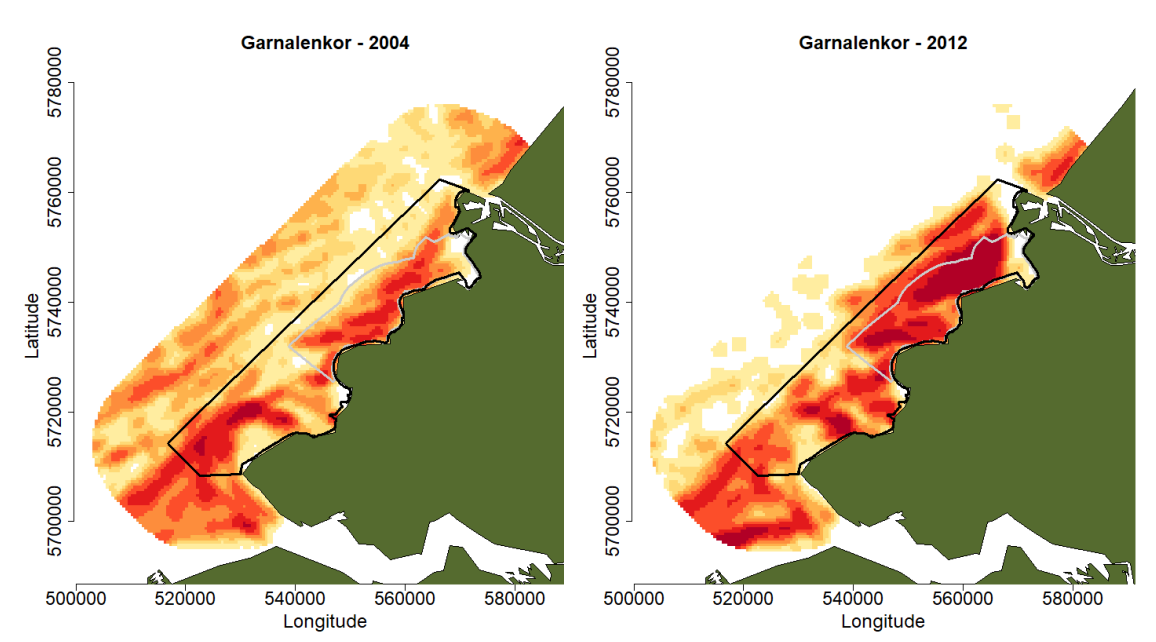

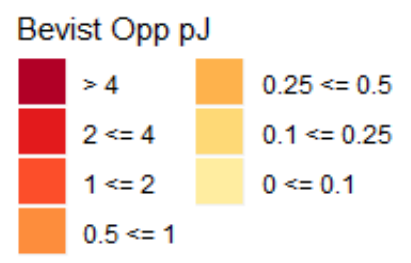

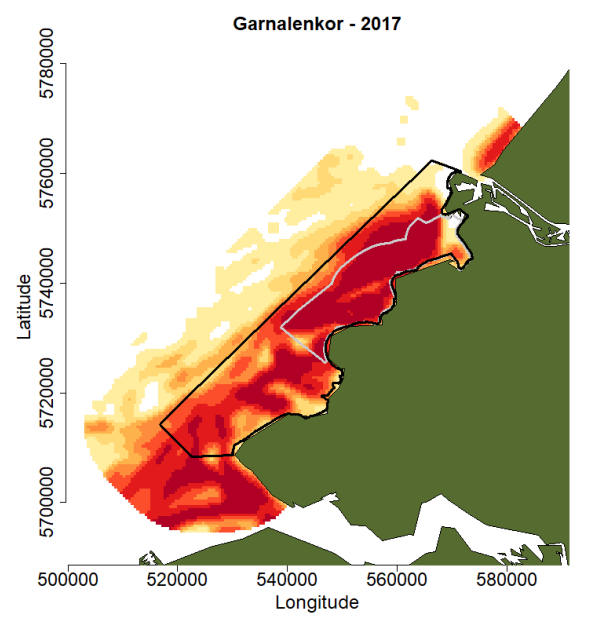

Figuur 5.3. Visserij-intensiteit van garnalenkotters in de Voordelta in 2004, 2012 en 2017. Visserijintensiteit is uitgedrukt in bevist oppervlak per kalenderjaar (aantal keren per jaar dat het gehele oppervlak van 0,25 $\mathrm{km}^{2}$ bevist is, per vak van 0,5*0,5 km). Zwarte omlijning = Voordelta, grijze omlijning $=B B G$.

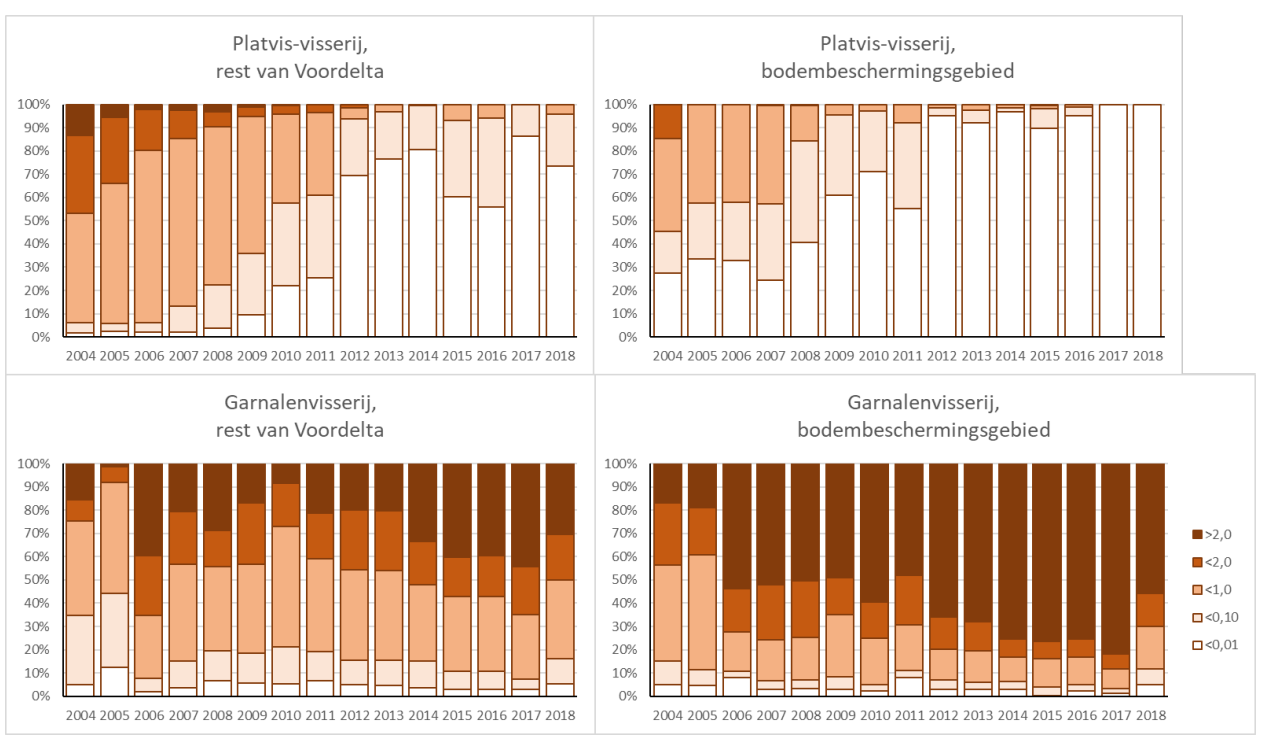

Figuur 5.4. Tijdserie van de gemiddelde visserij-intensiteit van de boomkor- en garnalenvisserij in het Bodembeschermingsgebied en de rest van Voordelta. De visserij-intensiteit is berekend als bevist oppervlak per jaar (aantal keren per jaar dat het gehele oppervlak van 0,25 $\mathrm{km}^{2}$ bevist is, per vak van $0,5 * 0,5 \mathrm{~km})$, en ingedeeld in een aantal klassen (zie legenda). 
Het oppervlak dat met een bepaalde intensiteit bevist wordt is weergegeven in Figuur 5.4. In het Bodembeschermingsgebied werd in grote delen (ca. 30\%) al nauwelijks op platvis gevist in 2004. $\mathrm{Na}$ 2008 was boomkorvisserij op platvis zo goed als afwezig (zie ook Figuur 5.1 en 5.2). Opgemerkt moet worden dat in de verwerking van VMS onderscheid tussen vissen en varen wordt gemaakt op basis van vaarsnelheden. Nabij de kust, waar vaarsnelheden doorgaans lager zijn, is daarmee deze indeling minder betrouwbaar, en kunnen dus langzaam varende schepen abusievelijk als 'vissend' worden gekenmerkt waardoor het aantal vis-uren overschat kan worden (de Vries en Glorius, 2018). Deze foute classificatie verklaart waarom er nog een beperkte inspanning van boomkorvisserij in het Bodembeschermingsgebied na 2008 lijkt te zijn. In de rest van de Voordelta werd een iets groter deel van het oppervlak met hogere intensiteit bevist, maar ook daar was de visserij-intensiteit na 2008 in het grootste deel van het gebied zeer laag.

De visserij-inspanning en de mate van bodemberoering door garnalenvisserij is in het Bodembeschermingsgebied gedurende de gehele beschouwde periode hoger dan in de rest van de Voordelta. In de gehele Voordelta is het oppervlak dat in een jaar niet of nauwelijks bevist wordt door garnalenvisserij (d.w.z. minder dan $10 \%$ van het oppervlak van een rastercel van $0,25 \mathrm{~km}^{2}$ in een jaar bevist), vanaf 2008 minder dan $5 \%$ in het Bodembeschermingsgebied en minder dan $15 \%$ in de rest van de Voordelta.

\subsubsection{Schelpdiervisserij}

De schelpdiervisserij in de Voordelta richt zich op Ensis, waarbij op de grotere exemplaren $(>10 \mathrm{~cm})$ wordt gevist. VMS data van schelpdiervisserij zijn beschikbaar voor de jaren vanaf 2009. De schelpdiervisserij is de laatste jaren (2016-2018) toegenomen. Als het gaat om effecten van deze visserij op de Voordelta, is het zinvol te kijken naar het oppervlak dat bevist wordt en de hoeveelheid Ensis die opgevist wordt. Uit de VMS gegevens blijkt dat het beviste oppervlak in het Bodembeschermingsgebied is verdubbeld sinds 2016, maar nooit meer dan $1 \%$ van het totale oppervlak is geweest en in het gehele Natura 2000 gebied nooit meer dan 1,5\%.

$\mathrm{Er}$ is een quotum van 5,5 miljoen $\mathrm{kg}$ versgewicht (vlees+schelp) voor de hoeveelheid Ensis die jaarlijks maximaal opgevist mag worden. De totale hoeveelheid Ensis die in de Voordelta jaarlijks is opgevist sinds 2010, varieerde tussen 1.500 en 5.400 ton (B.Keus, pers. med.). Die 5.400 ton was $8 \%$ van het totale bestand van Ensis in de Voordelta zoals bepaald in de WOT Schelpdiervisserij (Troost et al., 2019). Daarbij moet opgemerkt worden dat de bestandsschattingen van de WOT Schelpdiervisserij een onderschatting zijn van het werkelijke bestand, omdat de grotere schelpen zich diep in het sediment kunnen terugtrekken en daarom deels gemist worden in de bestandsopname (Troost et al., 2019).

In 2010 is, met een Nb-wet vergunning, mosselzaad opgevist. Visserij op Spisula is sinds het ingaan van het Natura 2000 beheerplan in de Voordelta niet toegestaan (VenW, 2008; RWS, 2016).

\subsection{Ontwikkelingen visserij binnen en buiten de Voordelta}

\subsubsection{Visserij op platvis}

Al eerder (Tien et al., 2017a) is vastgesteld dat de afname in de boomkorvisserij Noordzeebreed lijkt te hebben plaatsgevonden. Binnen de Voordelta lijkt er wel een extra grote afname te zijn. De omvang van visserij op platvis stabiliseerde in de Voordelta rond 2008/2009 op een laag en basaal niveau. Het zou kunnen dat de instelling van het Bodembeschermingsgebied en de aanleg van Maasvlakte 2 hier een rol bij hebben gespeeld, bijvoorbeeld door fragmentatie en verlies aan visserijgrond. Echter, uit interviews met vissers bleek dat de instelling van het BBG niet echt invloed lijkt te hebben gehad op de boomkorvisserij. In de voor boomkorvisserij gesloten gebieden visten de meeste vissers al niet meer voor 2008. Als verklaringen voor de achteruitgang noemden de vissers andere factoren zoals 
bijvoorbeeld de Deltawerken, verandering in stromingen, verminderde natuurlijke productiviteit en klimaatverandering (Tien et al., 2017a).

\subsubsection{Garnalenvisserij}

De garnalenvisserij is over de periode 2004-2018 geïntensiveerd in de Voordelta. Om na te gaan of deze ontwikkeling uniek is voor de Voordelta of op een grotere ruimtelijke schaal speelt, is de Nederlandse kust opgedeeld in 5 delen (Figuur 5.5). Voor ieder van de vijf gebieden is bepaald met welke visserijintensiteit deze zijn bevist. Een visserij-intensiteit van 1 betekent dat een afgebakend gebied gemiddeld in een jaar 1 maal volledig is bevist. Een grotere intensiteit betekent dus een hogere inspanning van de visserij. In de verschillende gebieden wordt met verschillende intensiteit gevist. De relatieve toename vanaf 2008-2011 naar een piek tussen 2014-2017 is het grootst in de Voordelta (verdubbeling) en langs de kust van Noord-Holland (+70\%). De ontwikkeling in het gebied tussen Hoek van Holland en IJmuiden en tussen Den Helder en Duitsland is wat minder groot $(+40 \%)$.

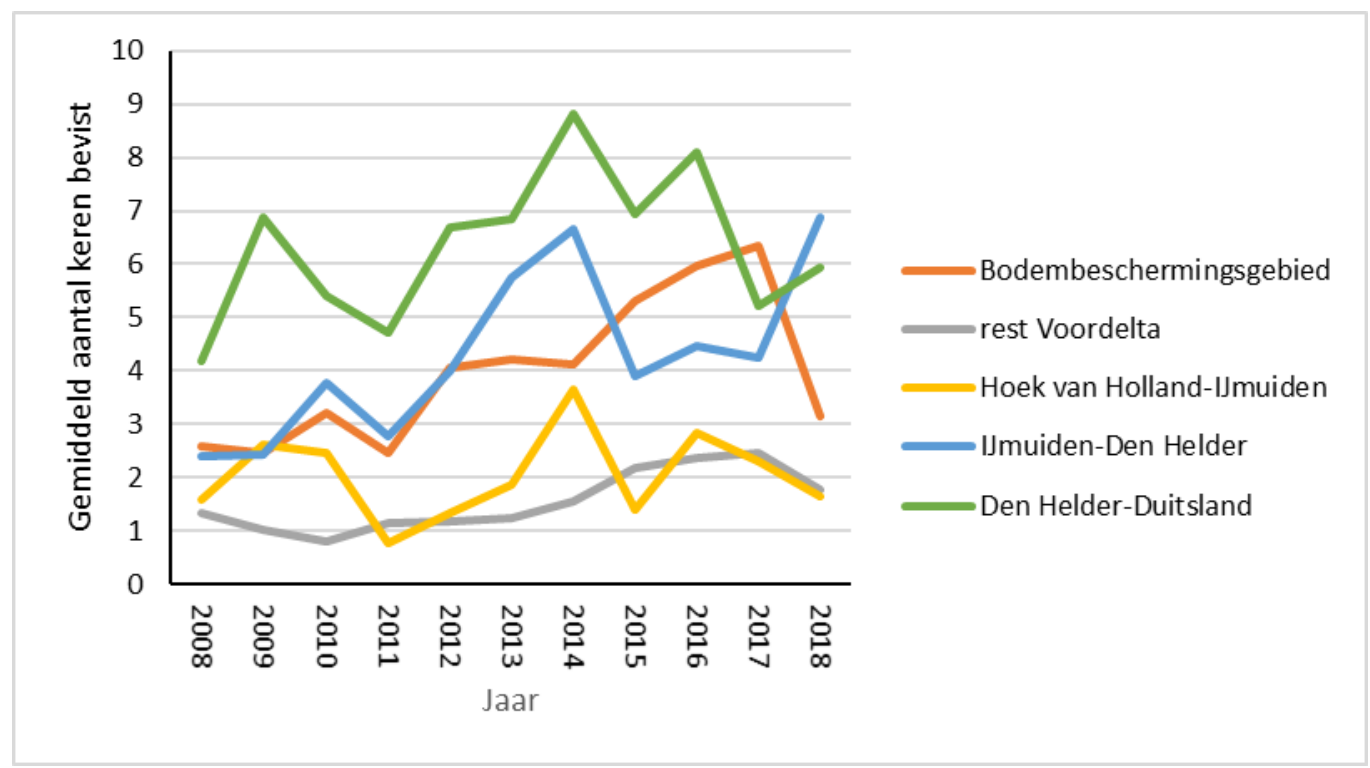

Figuur 5.5. De verandering in visserij-intensiteit (uitgedrukt als gemiddeld aantal keren bevist per jaar voor het gehele gebied) door garnalenschepen in het Bodembeschermingsgebied, de rest van de Voordelta, en andere deelgebieden langs de Nederlandse kust.

\subsection{Effect van biomassa-onttrekking door visserij via vangsten en discards}

Tulp et al. (2018) hebben een schatting gemaakt van de totale aanlandingen (commerciële doelsoorten en bijvangst) door visserij in de Voordelta, en de hoeveelheid discards als gevolg van de boomkor- en garnalenvisserij in de Voordelta. Ondanks dat in deze schattingen grote onzekerheden zitten en het voor sommige groepen aan data ontbreekt, geeft deze schatting een indicatie van de hoeveelheid biomassa die via visserij in de Voordelta aan het systeem wordt onttrokken, of die, in het geval van discards, als (grotendeels dode) biomassa als voedsel voor aaseters in het ecosysteem beschikbaar komt.

Aanlandingen zijn berekend op basis van de VMS- en logboekgegevens van de schepen. Daarmee kan een inschatting worden gemaakt van de hoeveelheid vis die gevangen is en daarmee uit de Voordelta verwijderd (Tien et al., 2017a). Met behulp van informatie uit logboeken, VMS en discard- 
monitoringsprogramma's kunnen schattingen gemaakt worden van de onttrekkingen (aanlandingen en discards) van vis en bodemdieren. Daarbij is ook gebruik gemaakt van resultaten van het

Garnalenvisserij-experiment Voordelta (Schellekens et al., 2014) en recent onderzoek naar discards van garnalenvisserij (Glorius et al., 2015).

De aantallen en biomassa van andere bodemdiersoorten dan garnaal in de discards zijn niet betrouwbaar te schatten. Uit de garnalenvisserij zijn alleen biomassaschattingen van garnalendiscards beschikbaar, terwijl ook andere benthossoorten gevangen en weer overboord gezet worden. Uit de boomkorvisserij zijn de schattingen van benthosdiscards niet representatief genoeg vanwege het ontbreken van monsterpunten in de Voordelta. Geschat is dat zeesterren, slangsterren en zwemkrabben het grootste deel van de discards vormen (Tien et al., 2017a).

De onttrekking van vis en garnalen door de platviskotters is sterk afgenomen tussen 2004 en 2015 (Tabel 5.1). Tussen de T0 (2006-2008) en de T1 (2009-2013) is de jaarlijkse onttrekking (aanlandingen + discards) meer dan gehalveerd van 851 naar 322 ton biomassa en tussen T1 en T2 nog verder afgenomen naar 244 ton biomassa (2014-2015). De belangrijkste commerciële soorten die aangeland worden (94\% van het totaal) zijn bot, tong, schar en schol. De discards bestonden uit 62 soorten vis, waarvan schar $(23 \%)$, schol $(12 \%)$, tong $(5 \%)$, hondshaai $(5 \%)$ en bot $(5 \%)$ de belangrijkste soorten waren tussen 2004 en 2015 (Tien et al., 2017a).

De onttrekking van vis en garnalen door de garnalenvisserij, via aanlandingen en discards, is veel groter dan de onttrekking door de boomkorvisserij (Tabel 5.1). Ook is deze onttrekking juist toegenomen over de periode $2006-2015^{6}$. De aanlandingen bestaan vooral uit garnaal (93\%) en daarnaast voornamelijk schar en bot. De meest gediscarde soort is garnaal ( $86 \%$ van de totale discards), met daarnaast wijting (4\%) en schol (2\%) als belangrijkste soorten (Tien et al., 2017a). Vergelijkbare schattingen volgen uit gegevens van het in de Voordelta uitgevoerde garnalenexperiment en onderzoek aan discards van garnalenvisserij in Natura 2000 gebieden (Schellekens et al., 2014; Glorius et al., 2015; Tien et al., 2017a).

Om de invloed van de door visserij veroorzaakte sterfte op de lokale populatie te kunnen berekenen is ook informatie over de bestandsgrootte nodig; er zijn echter geen betrouwbare kwantitatieve gegevens beschikbaar op de schaal van de Voordelta zodat het effect van visserij op visbestanden niet te bepalen is.

Voor garnaal is wel een schatting van het bestand te maken, voor het DFS gebied 401 dat de Voordelta en de Vlakte van de Raan omvat. De relatieve onttrekking van garnaal (onttrekking ten opzichte van het totale bestand) is in dit gebied op jaarbasis substantieel (Tien et al., 2017a; Tulp et al., 2018). Door de tijd heen is de onttrekking afgenomen van T0 (14\%) naar T1 (9\%), maar toegenomen in T2 (18\%). Het grootste deel van de discards in de garnalenvisserij bestaat uit ondermaatse garnalen (Tien et al., 2017a). Ook op niet-commerciële vissoorten kan de visserij een substantieel effect hebben gehad, maar om dat te schatten ontbreken methoden en gegevens.

\footnotetext{
${ }^{6}$ nb. voor 2004-2005 zijn geen logboekgegevens beschikbaar
} 
Tabel 5.1. Gemiddelde onttrekking (aanlanding en discards, in ton biomassa) per jaar voor drie periodes: 2006-2008, 2009-2013 en 2014-2015, voor zowel platviskotters als garnalenkotters. De onttrekking is opgedeeld in vis en garnalen en onderverdeeld in aanlandingen (cursief) en discards. Voor de garnalenkotters zijn alleen gegevens beschikbaar vanaf 2006. Voor meer details, zie Tien et al. (2017a). Voor de jaren 2016-2018 zijn geen gegevens uitgewerkt.

\begin{tabular}{|c|c|c|c|c|c|c|}
\hline & \multicolumn{3}{|c|}{ Platviskotters } & \multicolumn{3}{|c|}{ Garnalenkotters } \\
\hline & 2006- & 2009- & 2014- & 2006- & 2009- & 2014- \\
\hline & 2008 & 2013 & 2015 & 2008 & 2013 & 2015 \\
\hline Aanlandling vis & 772 & 302 & 229 & 76 & 68 & 70 \\
\hline Discards vis & 74 & 20 & 15 & 109 & 110 & 203 \\
\hline Totaal vis & 846 & 322 & 244 & 185 & 178 & 273 \\
\hline $\begin{array}{l}\text { Aanlanding } \\
\text { garnaal }\end{array}$ & 5 & 0,3 & 0,2 & 860 & 863 & 1613 \\
\hline Discards garnaal & 0 & 0 & 0 & 883 & 653 & 796 \\
\hline Totaal garnaal & 5 & 0,3 & 0,2 & 1743 & 1516 & 2409 \\
\hline
\end{tabular}

\subsection{Conclusies}

De ontwikkeling in gepleegde inspanning van de platvisvissers is niet uniek voor de Voordelta.

Noordzeebreed is de boomkorvisserij sterk afgenomen door een afname van het aantal actieve schepen, al is de inspanning in de Voordelta wel harder afgenomen. Vooral de inspanning per schip is in de Voordelta forser afgenomen, wat er op kan duiden dat vissers het gebied grotendeels overslaan in hun visserij (Tien et al., 2017a). Deze ontwikkeling is niet specifiek voor de periode rond en na de instelling van het Bodembeschermingsgebied en dus niet de duiden als een directe respons op de compensatiemaatregelen. De grootste afname vond al eerder plaats. Rond 2008-2009 lijkt de inspanning op een laag niveau te stabiliseren. De verminderde inspanning lijkt niet gerelateerd te zijn met de bestandsontwikkelingen in de doelsoorten van de visserij sinds 2004 (Tien et al., 2017a).

De ontwikkeling in de garnalenvisserij in de Voordelta volgt de ontwikkeling van de hele vloot in de Nederlandse kustwateren, zij het dat de groei in het Bodembeschermingsgebied groter is dan in de overige kustgebieden. Ook deze ontwikkeling lijkt niet beïnvloed te zijn door de instelling van het Bodembeschermingsgebied, wat ook niet te verwachten was aangezien voor garnalenvisserij geen beperkingen gelden in het Bodembeschermingsgebied.

Het effect van de veranderingen in visserij in het Bodembeschermingsgebied en de rest van de Voordelta is omgekeerd aan wat de intentie van de compensatiemaatregel was. De boomkorvisserij was al goeddeels afwezig in het Bodembeschermingsgebied voordat deze visserij daar uitgebannen werd, dus de instelling van het Bodembeschermingsgebied heeft niet geresulteerd in een substantiële afname van deze visserij. De garnalenvisserij, waarvan verwacht werd dat deze min of meer gelijk zou blijven op het niveau van de T0-periode (VenW, 2008), is juist sterk in intensiteit toegenomen in het Bodembeschermingsgebied. Slechts een klein deel $(<15 \%)$ van de Voordelta lijkt de laatste jaren niet of nauwelijks bevist te worden door garnalenvisserij en daarmee vrij te zijn van enige vorm van bodemberoering. 


\section{Habitat H1110B}

Zoals in hoofdstuk 3 al gepresenteerd, de instelling van het Bodembeschermingsgebied moest leiden tot een $10 \%$ verbetering van de kwaliteit van Habitattype H1110B (LNV, 2008a; LNV, 2008d; VenW, 2008). Deze kwaliteitsverbetering is niet nader gespecificeerd, maar in het toegangsbeperkingsbesluit waarin de instelling van het Bodembeschermingsgebied is vastgelegd (LNV, 2008b) wordt, met verwijzing naar Rijnsdorp et al. (2006), "verhoging van de bodemdierenbiomassa met minimaal 10\%" genoemd als vooropgesteld effect. In het monitorings- en evaluatieprogramma voor de natuurcompensatie (MEP-NCV; VenW, (2009)) wordt bodemdierenbiomassa per soortgroep opgevoerd als "primaire maat voor de kwaliteit van habitattype $H 1110 B$ in termen van voedselbeschikbaarheid voor vissen en vogels", en daarmee voor de ecologische winst.

Dit is vertaald in de MEP-vragen 1c en 1d uit de oorspronkelijke lijst van vragen in het MEP-NCV (VenW, 2009) (zie ook bijlage 5):

c) Treedt er voldoende toename op van de bodemdierenbiomassa per soortgroep en de hoeveelheid voedsel voor beschermde/typische soorten ten opzichte van de situatie vóór de aanleg van MV2 in het Bodembeschermingsgebied ten opzichte van de rest van de Voordelta en zo ja, komt deze (minimaal) overeen met het verlies als gevolg van het ruimtebeslag van MV2, de ontwikkeling van de erosiekuil en de toename van de getijslag?

d) Is de waargenomen toename toe te schrijven aan de getroffen maatregelen (afgenomen bodemberoering in het Bodembeschermingsgebied) of ook aan andere factoren?

Op grond van nieuwe wetenschappelijke inzichten, is bij de afronding van de $1^{\mathrm{e}}$ fase van PMR-NCV geconcludeerd dat eenduidige effecten van visserij op bodemdierenbiomassa niet waarschijnlijk zijn (Prins et al., 2014). In het monitoringsplan voor de $2^{\mathrm{e}}$ fase van PMR-NCV zijn keuzes gemaakt voor andere indicatoren (Tulp et al., 2015). In reactie op dat monitoringsplan is door het bevoegd gezag bevestigd dat het behalen van $10 \%$ ecologische winst binnen het Bodembeschermingsgebied een expliciet opgelegde inspanningsverplichting is, maar dat aanvulling met andere indicatoren dan de eerder genoemde (totale biomassa), mogelijk is (EZ, 2015). Dit komt overeen met de vragen $1 \mathrm{c}$ en $1 \mathrm{~d}$ uit de geherformuleerde MEP vragen uit 2015:

c) Zijn er positieve trends waar te nemen in de aanwezigheid en dichtheid van typische soorten en in de kenmerken van een goede structuur en functie van het habitattype H1110B in de Voordelta sinds het begin van de afname van de boomkorvisserij uit de Voordelta rond de laatste eeuwwisseling?

d) Zijn de waargenomen trends toe te schrijven aan de afgenomen bodemberoering ten gevolge van de afname van de grote boomkorvisserij met wekkerkettingen in de gehele Voordelta of ook aan andere factoren?

Bij de oorspronkelijke formulering van de doelstelling van de monitoring en evaluatie, die sterk gefocust was op biomassa, was er een natuurlijke maat waaraan kon worden getoetst of voldoende compensatie was geboden. "(minimaal) overeen [komen] met het verlies als gevolg van het ruimtebeslag van Maasvlakte 2, de ontwikkeling van de erosiekuil en de toename van de getijslag" stelt een duidelijk criterium. Omdat bodembescherming was ingesteld in een gebied dat ongeveer tienmaal groter is dan het gebied dat is verloren gegaan, is een stijging van de biomassa met $10 \%$ de maatstaf waaraan de compensatiemaatregel kan worden getoetst. De formulering van de vragen laat binnen die maatstaf ruimte voor interpretatie. In tegenstelling daarmee is er geen maatstaf voor de andere indicatoren van

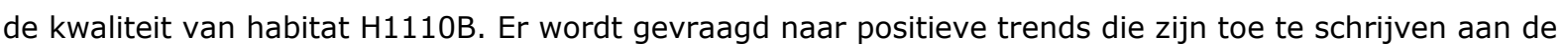


afgenomen bodemberoering door de grote boomkorvisserij met wekkerkettingen, maar het wordt verder niet gespecifieerd hoe sterk deze trends moeten zijn om voldoende te compenseren. Opvallend is ook dat in de nieuwe vraag 1d) niet langer sprake is van de genomen maatregelen als causale factor voor het verbeteren van de kwaliteit van het habitat H1110B in de Voordelta, maar dat wordt gevraagd of de afgenomen boomkorvisserij daarvan de oorzaak is. Toch blijft de context van de huidige studie de evaluatie van de genomen compensatiemaatregelen, en bovendien is het alleen binnen het Bodembeschermingsgebied (BBG) zeker dat de afname van de boomkorvisserij met wekkerkettingen duurzaam is. Wij blijven in dit hoofdstuk daarom de aandacht houden bij de vraag of de genomen maatregelen voldoende zijn geweest om de nodige verbetering van de kwaliteit van het habitat $\mathrm{H} 1110 \mathrm{~B}$ te bewerkstelligen.

In dit hoofdstuk onderzoeken wij veranderingen in zowel de bodemdieren als de vis- en epifauna in het habitat H1110B. Beide ecosysteemcomponenten zijn belangrijk voor de biodiversiteit en het ecologisch functioneren van het kustsysteem. Zij worden beiden gebruikt als voedsel door vogels en zeezoogdieren en hebben sterke onderlinge ecologische verbanden. Toch zullen wij bodemdieren en vissen grotendeels afzonderlijk bespreken, omdat de kennis over deze groepen gebaseerd is op twee verschillende datasets en een sterk verschillende methodologie. Pas na de afzonderlijke bespreking van bodemdieren en vis (met epifauna) wordt de samenhang tussen beide besproken.

Voor bodemdieren onderzoeken wij in de eerste plaats of de biomassa, die door de constructie van Maasvlakte 2 is verloren gegaan, door de uitgevoerde compensatiemaatregelen is gecompenseerd. Behalve biomassa betrekken wij ook andere variabelen in de beschouwing, om een zo volledig mogelijk beeld van de veranderingen in de bodemdiersamenstelling te schetsen. Daartoe analyseren wij, op basis van de beschikbare gegevens uit de monitoring, of de verwachtingen zoals die bestonden bij het instellen van het BBG, zijn gerealiseerd in de praktijk. Deze analyse is gebaseerd op vele deelanalyses die in het syntheserapport (Tulp et al., 2018) in detail zijn gerapporteerd, en die hier alleen kort worden samengevat. Uitgaande van de conclusies van die analyses, zijn extra analysestappen gezet die hier in groter detail worden besproken.

Voor vis en epifauna zijn in de eerste fase van het PMR monitoringprogramma uitgebreide analyses uitgevoerd naar verschillen in Bodembeschermingsgebied en referentiegebied. Daarna is de nadruk verlegd naar een vergelijking van trends in de Voordelta met trends op de ruimere schaal van de Nederlandse kustzone. De analyses die daarover zijn gerapporteerd in het syntheserapport (Tulp et al., 2018) zijn geactualiseerd met alle recente gegevens, en verder verfijnd qua methodologie. In dit rapport worden vooral deze updates gepresenteerd en besproken. De centrale vraag in deze analyses is of de samenstelling van de vis- en epifauna is veranderd als gevolg van het teruglopen van de zware boomkorvisserij met wekkerkettingen en de opkomst van garnalenvisserij en pulsvisserij. Gedetailleerde gegevens uit de Voordelta worden vergeleken met gegevens van een ruimer gebied in de kustzone, om zo het perspectief op vergelijkbare trends elders te houden en een bredere range van verstoringen (en temporele trends daarin) door visserij te kunnen analyseren.

\subsection{Veranderingen in de bodemdiergemeenschap in de Voordelta}

\subsubsection{Overzicht van eerdere analyses van de bodemdiergemeenschap}

Bij de analyse van de resultaten van de eerste fase van het monitoringprogramma (Prins et al., 2014), was het gebruik van een BACI ("Before-After-Control-Impact") analyse een centraal deel van het onderzoek. In dit geval bestond de "Impact" uit het wegvallen van visserijdruk door boomkorvisserij met wekkerkettingen in het BBG, terwijl dit in het controlegebied (referentiegebied; REF) zou blijven bestaan. Before-After verwijst naar vóór en na 2008, waarop het BBG is ingesteld. Er moest echter worden vastgesteld dat er de facto geen verschil in behandeling is geweest tussen BBG en REF, omdat na 2008 de grote boomkorvisserij met wekkerkettingen zo goed als volledig uit de gehele Voordelta was verdwenen, en er tegelijkertijd meer garnalenvisserij in het BBG was gekomen dan in REF. 
In het syntheserapport (Tulp et al., 2018) is een aantal analyses gepresenteerd van de relatie tussen bodemdierfauna en visserij in de Voordelta, die voortbouwden op de resultaten van de eerste fase (Prins et al., 2014). Voor de analyses in het syntheserapport is daarom het onderscheid in BBG en REF losgelaten, en is gezocht naar statistische relaties tussen visserij en bodemdiergemeenschap over de grenzen van deze deelgebieden heen, en ook buiten de Voordelta in het hele Nederlandse kustgebied (op basis van de jaarlijkse WOT schelpdiersurvey). De analyses in het syntheserapport zijn gebaseerd op de data tot respectievelijk 2015 en 2016 . Sommige analyses, bijvoorbeeld de linear mixed models die verderop worden besproken, of de basis BACI analyses van de verschillende indicatoren, zijn herhaald met de volledige dataset tot en met 2018. Dat gaf nooit aanleiding tot een verandering in de significantie van de onderzochte factoren. In dit rapport worden de nieuwe resultaten daarom maar kort behandeld. Verder zullen wij vooral bespreken hoe de conclusies uit de analyses van het syntheserapport de basis hebben gevormd voor de voorliggende nieuwe analyses in dit rapport. Alle resultaten die in dit rapport worden getoond zijn gebaseerd op de volledige dataset (tot en met 2018) die op een uniforme manier taxonomisch is gelumpt (zie Bijlage 3 ).

\subsubsection{Relaties van kwaliteitsindicatoren met abiotiek en visserij-inspanning}

De volgende indicatoren zijn gebruikt voor de kwaliteit van het habitat H1110B:

- totale biomassa

- biomassa van voedsel voor zee-eenden

- aantal taxa

- gemiddeld individueel gewicht

- $\quad$ aandeel grote soorten

- $\quad 95 e$ percentiel van de lengteverdeling van Ensis

In deze analyse staat de vraag centraal of de verschillende indicatoren significant worden beïnvloed door de intensiteit van de visserij, waarbij een onderscheid is gemaakt tussen boomkorvisserij met wekkerkettingen, en garnalenvisserij. Omdat andere factoren, bijvoorbeeld diepte, zoutgehalte of stroming, ook invloed uitoefenen op de indicatoren, is gepoogd zo goed mogelijk te compenseren voor de effecten van deze cofactoren. Het effect van de visserij wordt daarom samen met deze cofactoren in een gemeenschappelijk model geanalyseerd.

Voor elk van de indicatoren zijn twee types statistische modellen opgezet: linear mixed models waarin behalve visserij ook covariaten (abiotische omstandigheden) zijn meegenomen, en R-INLA modellen, Bayesiaanse modellen die expliciet rekening houden met autocorrelatie in ruimte en tijd, en die de invloed van covariaten en van visserij op de toetsvariabelen nagaan aan de hand van trendlijnen, zogenaamde 'smoothers' met confidentie-intervallen (deze laatste analyses zijn afzonderlijk gerapporteerd door Zuur, Highland Statistics). In die analyse wordt de invloed van de sturende variabelen niet-lineair beschreven. Door toetsing van de betrouwbaarheid van de schatting wordt bepaald of een factor in tenminste een deel van zijn range een significante invloed uitoefent op de doelvariabele.

De linear mixed model analyse is opnieuw uitgevoerd met dezelfde dataset die ook in de rest van dit document wordt gebruikt. Voor de vergelijkbaarheid met andere analyses is een extra indicator toegevoegd: de som van log-getransformeerde dichtheden van soorten ("SumLogN"). Deze maat is verwant aan de diversiteitsmaat die is gebruikt in Van Moorsel et al. (2020). Het is een maat die gevoelig is voor veranderingen in alle soorten, van de zeldzame tot de algemene. Bij alle analyses is station_id als random factor gebruikt, en rekening gehouden met temporele en ruimtelijke autocorrelatie. De resultaten worden samengevat in Tabel 6.1. 
Tabel 6.1. Resultaten van een linear mixed model analysis met station_id als random factor, abiotische en visserijvariabelen als fixed factors, en een variantiemodel dat rekening houdt met autocorrelatie in ruimte en tijd. Significante factoren hebben een gekleurd vakje (groen: positieve relatie; rood: negatieve of geen relatie). De getallen in de vakjes geven de geschatte coëfficiënt.'tau' staat voor bodemschuifspanning $(\mathrm{Pa})$, opgesplitst naar fysisch proces: door golfbeweging of door getijstroming.

\begin{tabular}{|l|c|c|c|l|l|c|c|}
\hline verklarende factoren & $\begin{array}{l}\text { totale } \\
\text { biomassa } \\
\text { (Btot) }\end{array}$ & $\begin{array}{l}\text { biomassa } \\
\text { voor vogels } \\
\text { (Bvogel) }\end{array}$ & $\begin{array}{l}\text { aantal taxa } \\
\text { (S) }\end{array}$ & $\begin{array}{l}\text { gem. ind. } \\
\text { gewicht } \\
\text { (indw) }\end{array}$ & $\begin{array}{l}\text { aandeel } \\
\text { grote } \\
\text { soorten } \\
\text { (W95) }\end{array}$ & $\begin{array}{l}\text { max lengte } \\
\text { Ensis (L95) }\end{array}$ & SumLogN \\
\hline diepte & 0.03 & 0.05 & 0.12 & 0.06 & 0.02 & - & 0.04 \\
\hline mediane korrel & 0.00 & 0.00 & 0.00 & - & - & 0.04 & 0.00 \\
\hline saliniteit & -0.11 & -0.21 & -0.35 & -0.53 & -0.09 & -5.78 & -0.09 \\
\hline tau golven & -0.45 & - & -0.95 & - & - & -8.35 & -0.46 \\
\hline tau stroming & -0.07 & -0.13 & -0.11 & -0.21 & -0.04 & - & -0.05 \\
\hline boomkorvisserij & 0.06 & 0.24 & -0.38 & 0.63 & 0.20 & -10.50 & -0.15 \\
\hline garnalenvisserij & 0.09 & 0.22 & 0.55 & - & - & - & 0.22 \\
\hline
\end{tabular}

De analyse toont aan dat een aantal cofactoren de doelvariabelen significant beïnvloeden. Diepte heeft bijvoorbeeld een positieve invloed op alle variabelen, behalve op de maximale lengte van Ensis. Monsters van diepere zones hebben, alle andere dingen gelijk gehouden, meer biomassa, meer biomassa voor vogels, meer taxa, meer grote soorten en een grotere diversiteit (uitgedrukt als SumLogN). De responsvariabelen nemen over het algemeen af als de korrelgrootte, saliniteit en bodemschuifspanningen toenemen. Je vindt de rijkste fauna (met betrekking tot biomassa en/of diversiteit) dus in relatief diepe, fysisch onberoerde, fijnzandige sedimenten dicht bij de kust waar de saliniteit wat lager is.

Na compensatie voor al deze cofactoren, blijkt dat zowel garnalenvisserij als boomkorvisserij met wekkerkettingen een significante positieve relatie hebben met biomassa van bodemdieren (zowel totaal als prooien voor zwarte zee-eend). De relatie tussen visserij en de andere variabelen is minder coherent. Boomkorvisserij correleert negatief met diversiteitsmaten (aantal taxa, sumLogN) en maximale lengte van Ensis, en positief met individueel gewicht en aandeel grote soorten. Die laatste twee maten zijn vooral bepaald door het aandeel van Ensis in de gemeenschap, omdat Ensis veruit de meest dominante grote soort is in de gemeenschap. Garnalenvisserij heeft een positieve correlatie met diversiteit (aantal taxa, SumLogN), naast de eerder genoemde positieve correlatie met biomassa. Vele van deze correlaties zijn onverwacht. Over het algemeen wordt in de literatuur beschreven dat intensieve visserij, vooral met boomkorren met wekkerkettingen, leidt tot een dominantie van kleine soorten in de gemeenschap en tot lagere biomassa dan verwacht zonder visserij. De hier geobserveerde positieve relaties behoeven dus nadere analyse.

De R-INLA analyse, die moeilijker kort is samen te vatten, bevestigt grosso modo het beeld uit de linear mixed model analyse, maar schat de invloed van autocorrelatie groter in dan de linear mixed models. We verwijzen naar het syntheserapport (Tulp et al., 2018) voor details, want deze analyse is niet meer herhaald met de volledige dataset. Boomkorvisserij heeft een significant positieve invloed op biomassa bij een hoger dan gemiddelde intensiteit van visserij; garnalenvisserij correleert positief met biomassa over het hele bereik van visserij-inspanningen. 


\subsubsection{Trait-based analyse}

In deze analyse worden soorten beschreven door hun ecologische kenmerken eerder dan door hun taxonomische identiteit. Het voorkomen van de ecologische kenmerken onder de aangetroffen individuen in de monsters, wordt gerelateerd aan de fysische omstandigheden en aan de visserijdruk. Zowel boomkorvisserij als garnalenvisserij hadden een significante invloed op de samenstelling en ecologische karakteristieken van de bodemdierfauna, maar in vergelijking met de abiotische factoren verklaarde dit slechts een klein deel van de variantie. Bovendien werd een onverwacht patroon aangetroffen in de resultaten. Visserijdruk bleek bevorderend te zijn voor grote, sessiele, diepgravende soorten filterfeeders, die eerder aan de hand van literatuur (Bolam et al., 2014) juist als gevoelig voor visserijdruk waren aangemerkt. Dit onverwachte resultaat is te verklaren doordat Ensis een positieve relatie lijkt te hebben met de visserijdruk, terwijl het toch een grote ( $15 \mathrm{~cm}$ lengte) en langlevende (tot 8 jaar) soort betreft. De snelheid waarmee Ensis zich kan ingraven in het sediment maakt de soort waarschijnlijk minder kwetsbaar voor visserijdruk, waardoor het aspect 'diepgravend' de overhand neemt op alle andere ecologische kenmerken. Men zou kunnen aanvoeren dat een apart ecologisch kenmerk voor 'ontsnappingsgedrag' zou moeten worden toegevoegd. De positieve relatie tussen Ensis en visserijdruk was een belangrijke aanwijzing die we in de nieuwe analyses nader hebben uitgewerkt.

\subsubsection{Analyse van deelgebieden}

Voor de analyse van effecten van de twee types visserij (boomkor en garnaal), zijn gebieden uitgezocht die aan de volgende voorwaarden voldeden: in ongeveer de helft van het gebied werd of wordt intensief gevist en in de andere helft niet, zodat sprake is van een "bevist" en "controle" deelgebied binnen het gebied; de twee deelgebieden, bevist en controle, liggen vlak bij elkaar en zijn qua abiotiek zo goed mogelijk vergelijkbaar.

Binnen deze gebieden kan dan het effect van visserij op de bodemdieren worden onderzocht door beviste en onbeviste deelgebieden met elkaar te vergelijken. Omdat informatie in de tijd beschikbaar is en bovendien de bevissingsintensiteit niet constant was over de tijd, kan ook worden onderzocht of de fauna in de twee deelgebieden op dezelfde manier verandert in de tijd. De analyse is beschrijvend van aard, en had vooral tot doel te identificeren hoe de fauna in beviste en onbeviste gebieden verschilt, en hoe dat verandert met de verandering van de intensiteit van de visserij.

Binnen het gebied waar boomkorvisserij is onderzocht, is de intensiteit van de visserij na de eerste jaren overal afgenomen. Voor het garnalenvisserijgebied geldt het omgekeerde: hier is de intensiteit in het beviste deelgebied in de tijd toegenomen. Analyse van de abiotiek leert dat de 'controle' niet perfect was: beviste en controle deelgebieden verschilden van elkaar in abiotisch opzicht. Dit is logisch, want de vissers hebben/hadden vrije keuze, en zouden waarschijnlijk homogeen over het gehele gebied hebben gevist als dat werkelijk homogeen en dus voor de visserij overal even gunstig was geweest.

De analyse van de bodemdierfauna in beide gebieden heeft één opvallend resultaat. Het multivariate analysediagram wordt volledig beheerst door één enkele soort: Ensis. Deze soort neemt een volledig onafhankelijke en dominante positie in ten opzichte van alle andere soorten.

In het onderzoeksgebied voor garnalenvisserij is de biomassa van Ensis in controle en bevist deelgebied aanvankelijk ongeveer gelijk. In de loop van de tijd neemt het verschil toe, waarbij het beviste deelgebied een steeds grotere Ensis biomassa kent, relatief tot de biomassa in het onbeviste gebied. In het boomkorgebied is de tendens omgekeerd. Hier is het verschil aanvankelijk (toen de boomkorvisserij in het beviste deelgebied nog intensief was) groot, maar neemt het in de loop der tijd af.

Behalve deze rol van Ensis, die lijkt toe te nemen in biomassa bij verhoging van de visserijdruk, zijn ook de patronen in de andere soorten interessant. Voor het boomkorvisserijgebied zien we soorten zoals bijvoorbeeld $A b r a$ die aanvankelijk, dus bij hoge visintensiteit, een lage dichtheid hadden in zowel controle als bevist gebied, maar die zich daarna vooral in het (voormalig) bevist gebied ontwikkelen. Andere soorten, b.v. de aasetende fuikhoorns Tritia reticulata, zijn aanvankelijk vooral aanwezig in bevist gebied maar verdwijnen overal in de loop der tijd. Soorten die typisch zijn voor het onbevist gebied (bijv. 
de amfipode Urothoe brevicornis) zijn relatief stabiel aanwezig in dat gebied. Deze patronen suggereren dat de respons op visserij, of op het stoppen daarvan, niet onmiddellijk gebeurt, en dat het stoppen van de visserijdruk kan leiden tot differentiatie van gebieden die onder de eerdere visserijdruk homogeen en weinig divers waren. Deze uitkomsten van het onderzoek zijn belangrijke startpunten voor de verdere analyse.

De resultaten van deze studie vormen geen hard bewijs van een causaal verband tussen visserijdruk (als oorzaak) en samenstelling van de bodemdiergemeenschap (als gevolg). Er is immers geen sprake van een experimentele opzet, maar van een beschrijvende analyse achteraf van gebieden die (door beslissingen van de vissers) wel of niet intensief werden bevist. Maar de resultaten suggereren wel een correlatie tussen visserijdruk en samenstelling van de bodemdiergemeenschap. Zij tonen ook aan dat, als de bodemdieren reageren op visserijdruk, die reactie traag is en uitgesmeerd over meerdere jaren en meerdere recruteringsgebeurtenissen van belangrijke soorten. Er lijkt geen respons op veranderingen in visserij binnen het jaar op te treden. De uitzonderlijk lange duur van de monitoringinspanning (tien jaar na het instellen van het bodembeschermingsbesluit) is wat dat betreft een sterke troef van de huidige dataset.

\subsubsection{Analyse van de WOT schelpdiersurvey}

Gegevens verzameld in de schelpdiersurvey langs de gehele Nederlandse kust, zijn vergeleken met gegevens over visserij-intensiteit zoals geschat uit VMS (over de relatief korte serie van 10 jaar) en uit logboeken (per ICES kwadrant, over twintig jaar). Dit heeft geresulteerd in een aantal trendlijnen van soorten in verschillende gedeeltes van de kust, die over het algemeen gelijkaardige trends over de tijd laten zien. De relatie met visserijdruk is hieruit echter moeilijk vast te stellen. Waar een aanwijzing voor relaties werd gevonden, is die vaak verschillend tussen verschillende vormen van visserij, of tussen verschillende deelgebieden. Het is daarom moeilijk uit deze analyses eenduidige conclusies te trekken. Wel is een aandachtspunt dat nu nog alleen gekeken is naar relaties tussen visserij en fauna in hetzelfde jaar, maar dat het beeld anders zou kunnen zijn als rekening wordt gehouden met langere responstijden.

\subsubsection{Conclusies uit de voorgaande analyses}

Uit de eerdere analyses zijn een aantal verrassende conclusies naar voren gekomen, die de aanleiding waren tot nader onderzoek. De belangrijkste hiervan zijn:

- De belangrijke rol van Ensis, de Amerikaanse zwaardschede, in de respons van de gemeenschap. Bij herhaling zien wij dat analyses wijzen op een positieve correlatie tussen Ensis en visserijdruk, terwijl het een grote, langlevende soort betreft die normaal als uiterst gevoelig voor visserijdruk zou worden geklasseerd.

- De tendens tot positieve relaties tussen visserijdruk, vooral van boomkorvisserij, met de totale biomassa van de gemeenschap. Dit kan verband houden met het voorkomen en de biomassa van Ensis, en is dus niet onafhankelijk van het vorige punt.

- De tendens tot negatieve relaties tussen intensiteit van boomkorvisserij en diversiteit van de bodemdiergemeenschap; bij garnalenvisserij is deze tendens niet duidelijk, en lijkt een toename van diversiteit onafhankelijk van de visserij-intensiteit het beeld te domineren.

- De suggestie dat de respons op het wegvallen van de visserijdruk uit boomkorvisserij veel langer duurt dan één jaar. Daardoor is het mogelijk dat de effecten van visserij op de gemeenschappen moeilijk te ontdekken zijn wanneer structuur van de gemeenschap alleen wordt vergeleken met de visserijdruk in hetzelfde jaar, terwijl dit in werkelijkheid een proces van vele jaren zou kunnen vergen. Over het algemeen lijkt het nuttiger de relaties tussen visserijdruk en gemeenschappen te onderzoeken op een veel langere tijdsbasis dan een enkel jaar.

- De suggestie dat visserijdruk homogeniserend kan werken, d.w.z. dat in periodes van sterke visserij, de verschillen tussen sterk beviste en onbeviste gebieden veel minder uitgesproken zijn dan ze zouden zijn als ze langdurig onbevist waren gebleven. Sommige gemeenschapskenmerken verschijnen als gevolg van visserijdruk, maar andere verdwijnen door de visserij en verschijnen pas opnieuw na een voldoende lange periode van rust. 
Voortbouwend op deze tussentijdse bevindingen is de volgende analysestrategie voor aanvullende analyses gevolgd.

- De totale onderzoeksperiode is opgesplitst in drie periodes: T0, vóór de aanleg van de tweede Maasvlakte en vóór de instelling van het Bodembeschermingsgebied in 2008 en de jaren omvattend dat er in een gedeelte van de Voordelta nog substantiële boomkorvisserij plaatsvond; T1 (2009-2013), de eerste vijf jaar na het instellen van het BBG, en de periode waarin overal in de Voordelta de boomkorvisserij (vrijwel) was verdwenen, terwijl de garnalenvisserij in opkomst was; T2 (2015-2018), de periode van zeer sterke garnalenvisserij (vooral in het BBG) en langdurige (vrijwel) afwezigheid van boomkorvisserij in het gehele gebied.

- Voor het analyseren van de relatie tussen visserij en bodemdieren is ervoor gekozen vooral te kijken naar verschillen tussen de drie periodes. Daardoor wordt de jaarlijkse tijdschaal losgelaten en wordt rekening gehouden met een mogelijk veel langzamere aanpassing van de fauna aan de omstandigheden (waaronder visserijdruk).

- $\quad$ Er wordt in de eerste plaats naar biomassa gekeken. Niet alleen is dat het oorspronkelijke criterium voor de natuurcompensatie, het blijkt ook uit de eerdere analyses dat hier onvermoede relaties met visserij zouden kunnen spelen.

- De analyse wordt opnieuw opgebouwd vanuit de BACI analyse, als eerste stap om de onderliggende hypothese dat stoppen met boomkorvisserij zal compenseren voor verloren gegane fauna, te testen. De resultaten van de BACI analyse worden echter nader onderzocht, in het bijzonder om na te gaan of de oorspronkelijke hypotheses over het verband tussen visserijdruk en kenmerken van de bodemdiergemeenschap in dit geval geldig waren.

\subsubsection{BACI analyse van biomassa en diversiteit van de bodemdiergemeenschap}

\subsubsection{Hypothese}

Ten opzichte van de situatie vóór de aanleg van Maasvlakte 2, is er in het BBG, relatief tot de rest van de Voordelta, een toename opgetreden in totale biomassa van bodemdieren. Deze toename is even groot of groter dan de hoeveelheid biomassa die is verloren gegaan door de aanleg van Maasvlakte 2.

Bij uitbreiding wordt voor andere indicatoren van structuur en functie van de bodemdiergemeenschap onderzocht of er in het BBG, relatief tot de rest van de Voordelta, een verhoging van dichtheid of diversiteit is opgetreden in dezelfde orde van $10 \%$ ten opzichte van de oorspronkelijke waarde.

\subsubsection{Methode}

De hypothesetoets volgt een BACI (Before-After-Control-Impact) benadering. Om een zo evenwichtig mogelijke dekking van de ruimte te bereiken, zijn niet alle monsterpunten gebruikt (zie Bijlage 3 ).

Er worden twee gebieden gedefinieerd: Bodembeschermingsgebied (BBG) en referentiegebied (REF). Het referentiegebied bevindt zich ten westen en ten zuiden van het BBG. Vooral ten westen van het BBG is het referentiegebied smal. Er is gekozen voor het volgen van de $20 \mathrm{~m}$ dieptelijn, omdat anders gebieden met sterk afwijkende diepte en overige abiotiek (niet binnen karakteristieken H1110B) zouden worden gebruikt als referentie, wat de vergelijkbaarheid met BBG niet ten goede zou komen. Het referentiegebied ten zuiden van het BBG omvat wel de volledige gradiënt van de kust tot de $20 \mathrm{~m}$ lijn.

De BACI analyse onderzoekt of er een significante interactie is tussen tijd en ruimte, m.a.w. of de responsvariabele een andere ontwikkeling over de tijd heeft in het BBG dan in het referentiegebied. Dat wijst op invloed van de maatregel die alleen in het BBG is genomen. In tegenstelling tot eerdere analyses (Prins et al., 2014) is in de huidige BACI-analyse niet gecorrigeerd voor diepte, sediment, stroming of andere abiotiek. Aangenomen is dat deze variabelen niet wezenlijk zijn veranderd binnen zowel BBG als REF, en dat de verschillen die voortkomen uit het verschil in abiotiek tussen de deelgebieden dus niet zijn veranderd in de tijd. Er wordt verder in de analyse nader ingegaan op deze aanname. Merk op dat 
het selecteren van datapunten met een zo evenwichtig mogelijke spreiding in ruimte en tijd de noodzaak voor compensatie voor abiotiek aanzienlijk heeft verminderd.

Een belangrijk verschil tussen de BACI die hier wordt gepresenteerd, en eerdere BACI-analyses, bijvoorbeeld in het syntheserapport, is dat in de huidige analyse onderscheid wordt gemaakt tussen drie, in plaats van twee periodes. Behalve T0, wordt voor de tijd na de ingreep onderscheid gemaakt tussen T1 en T2, gedefinieerd zoals eerder aangegeven. Dit laat toe om snelle en trage responsen in de gemeenschap te onderscheiden. Over het algemeen verduidelijkt deze opsplitsing de tendensen in de data, zoals die ook uit de BACI met slechts twee perioden kwamen. Soms maakt dit het verschil tussen significante (huidige analyse) en net niet significante (analyses syntheserapport) responsen. Waar sprake is van een langzame trend in de gemeenschap, zal die in de analyse met drie periodes grotendeels als een signaal worden opgepakt, terwijl deze evolutie vooral als ruis wordt beschouwd in de analyse met een hele lange post-ingreep periode.

Bijkomend wordt getest of het verschil tussen BBG en REF de $10 \%$ heeft overschreden. Voor biomassa is dit de drempelwaarde die nodig is om de verloren biomassa door Maasvlakte 2 kwantitatief te compenseren.

Ten opzichte van eerdere analyses is een andere set van indicatoren gekozen. Biomassa als voedsel voor vogels is niet langer onderzocht, omdat het nauw samenhangt met totale biomassa en bovendien niet beperkend is gebleken voor de zee-eenden (zie ook Hoofdstuk 8). Gemiddeld individueel gewicht, aandeel grote soorten en maximale lengte van Ensis worden allemaal bepaald door het aandeel van Ensis in de gemeenschap, en zijn daarom geen indicator voor de gevoeligheid voor visserij zoals aanvankelijk was aangenomen. Deze indicatoren zijn vervangen door de Simpson diversiteit op biomassabasis, die een synoptische samenvatting geeft van de verdeling van biomassa over de soorten.

Een gemeenschap die sterk gedomineerd wordt door 1 of 2 soorten, wordt gezien als minder divers dan een gemeenschap waarin veel soorten in ongeveer gelijke aantallen voorkomen. Hetzelfde geldt voor biomassa: als 1 of 2 soorten de biomassa volledig domineren wordt dat gezien als minder divers dan wanneer het aandeel biomassa over meerdere soorten verdeeld is. De Simpson diversiteitsindex is een maat voor diversiteit waarbij rekening gehouden wordt met zowel het aantal soorten als met het relatieve aandeel van de soorten in het totaal. De Simpson index op biomassabasis wordt berekend als:

$$
D=1-\lambda=1-\sum_{i=1}^{S} p_{i}^{2}
$$

(waarin S het aantal soorten in het monster is, en $\mathrm{p}_{\mathrm{i}}$ de fractie van de biomassa die tot soort i behoort).

Verder is als biodiversiteitsmaat, gebaseerd op dichtheden, de som van log-getransformeerde dichtheden gebruikt, die ook in de eerdere linear mixed models al is gepresenteerd.

De variabelen zijn getransformeerd om zo normaal mogelijk verdeelde residuen te hebben, en om te voldoen aan de vereisten van homogene variantie.

\subsubsection{Resultaten}

De resultaten worden grafisch samengevat in Figuur 6.1 d.m.v. box-and-whisker plots van de verschillende variabelen in BBG en REF in de verschillende periodes. Aan de hand van deze figuren kunnen verschuivingen in de mediaan vergeleken worden met de variatie in de gegevens.

De resultaten van de BACI toetsen (ANOVA tabellen) worden samengevat in Tabel 6.2. Uit deze tabel kan afgeleid worden of de gebieden onderling significant verschillen, of er een verschil is tussen periodes en of er sprake is van significante interactie tussen gebied en tijd. Dat laatste kan als indicatie worden gebruikt voor een effect van de maatregel. 
De coëfficiënten van het BACI model laten toe de gefitte gemiddelden voor de variabelen in elk gebied voor elke periode te berekenen. Omdat de variabelen getransformeerd zijn, is het intuïtief moeilijk in te schatten hoe belangrijk eventuele verschuivingen zijn. Daarom zijn in Tabel 6.3 deze waarden teruggetransformeerd naar de oorspronkelijke eenheden. Er is ook aangeduid wat de ratio tussen BBG en REF is in de verschillende periodes en hoe groot het verschil tussen de gebieden is (procentueel ten opzichte van REF). Het gewogen gemiddelde van de variabelen voor de Voordelta is berekend, waarbij gewogen is voor het relatieve aandeel van de twee gebieden in de totale oppervlakte. Die verhouding is $35 \%$ BBG en $65 \%$ REF

Tabel 6.2. Samenvatting van de ANOVA-tabellen van de BACI analyses voor de verschillende onderzochte variabelen. Gegeven zijn de F-waarden en de bijbehorende kansen dat deze door toeval worden verklaard zonder dat er sprake is van echte verschillen. Significantieniveau is met sterren aangeduid (ns niet significant; $*<0.05 ; * *<0.01 ; * * *<0.001$ ).

\begin{tabular}{|c|c|c|c|c|c|c|c|c|c|}
\hline \multirow[b]{3}{*}{ Totale biomassa } & \multicolumn{2}{|l|}{ Gebied } & \multicolumn{3}{|c|}{ Periode } & \multicolumn{3}{|c|}{ Gebied:Periode } & \\
\hline & $F_{1,2694}$ & $\mathrm{p}$ & & $F_{2,2694}$ & $\mathrm{p}$ & & $F_{2,2694}$ & $\mathrm{p}$ & \\
\hline & 99 & $<<0.001$ & $* * *$ & 12 & $<<0.001$ & $* * *$ & 12 & $<<0.001$ & $* * *$ \\
\hline Totale dichtheid & 103 & $<<0.001$ & $* * *$ & 57 & $<<0.001$ & $* * *$ & 11 & $<<0.001$ & $* * *$ \\
\hline Aantal soorten & 64 & $<<0.001$ & $* * *$ & 62.5 & $<<0.001$ & $* * *$ & 0.7 & 0.5 & ns \\
\hline Simpson & 6.6 & 0.01 & $*$ & 105.1 & $<<0.001$ & $* * *$ & 4.5 & 0.01 & * \\
\hline SumLogDen & 25 & $<<0.001$ & $* * *$ & 38 & $<<0.001$ & $* * *$ & 2.6 & 0.08 & ns \\
\hline
\end{tabular}

Tabel 6.3. Uit het BACI model geschatte gemiddelde waardes voor de variabelen in de gebieden BBG (Bodembeschermingsgebied) en REF (referentiegebied), tijdens de verschillende periodes. Deze waarden zijn terugtransformaties van de getransformeerde waarden waarmee het model heeft gerekend, en zijn dus uitgedrukt in de oorspronkelijke eenheden. Tevens is de ratio tussen BBG en REF aangegeven, het procentuele verschil in BBG ten opzichte van REF, en het gewogen gemiddelde voor de hele Voordelta, uitgaande van $35 \%$ van de oppervlakte in $B B G$.

\begin{tabular}{|c|c|c|c|c|c|c|}
\hline & & BG & REF & BBG/REF & (BBG-REF)/REF & Voordelta \\
\hline \multirow{3}{*}{$\begin{array}{l}\text { Totale Biomassa } \\
(\text { gAFDW.m-2) }\end{array}$} & T0 & 14 & 12 & 1.2 & $17 \%$ & 12.7 \\
\hline & $\mathrm{T} 1$ & 20 & 10 & 2 & $100 \%$ & 13.5 \\
\hline & $\mathrm{T} 2$ & 17 & 6 & 2.8 & $183 \%$ & 9.9 \\
\hline \multirow[t]{3}{*}{ Totale Dichtheid (n.m-2) } & T0 & 429 & 402 & 1.1 & $7 \%$ & 411.5 \\
\hline & $\mathrm{T} 1$ & 1178 & 552 & 2.1 & $113 \%$ & 771.1 \\
\hline & $\mathrm{T} 2$ & 1222 & 730 & 1.7 & $67 \%$ & 902.2 \\
\hline \multirow[t]{3}{*}{ Aantal soorten } & T0 & 15 & 13 & 1.1 & $13 \%$ & 13.7 \\
\hline & $\mathrm{T} 1$ & 18 & 15 & 1.2 & $18 \%$ & 16.1 \\
\hline & $\mathrm{T} 2$ & 20 & 18 & 1.1 & $13 \%$ & 18.4 \\
\hline \multirow[t]{3}{*}{ Simpson } & T0 & 0.40 & 0.38 & 1.0 & $4 \%$ & 0.39 \\
\hline & $\mathrm{T} 1$ & 0.41 & 0.43 & 1.0 & $-5 \%$ & 0.43 \\
\hline & $\mathrm{T} 2$ & 0.54 & 0.61 & 0.9 & $-12 \%$ & 0.58 \\
\hline \multirow[t]{3}{*}{ SumLogDen } & T0 & 37 & 35 & 1.1 & $5 \%$ & 36.1 \\
\hline & $\mathrm{T} 1$ & 49 & 44 & 1.1 & $12 \%$ & 45.4 \\
\hline & $\mathrm{T} 2$ & 57 & 48 & 1.2 & $20 \%$ & 51.1 \\
\hline
\end{tabular}



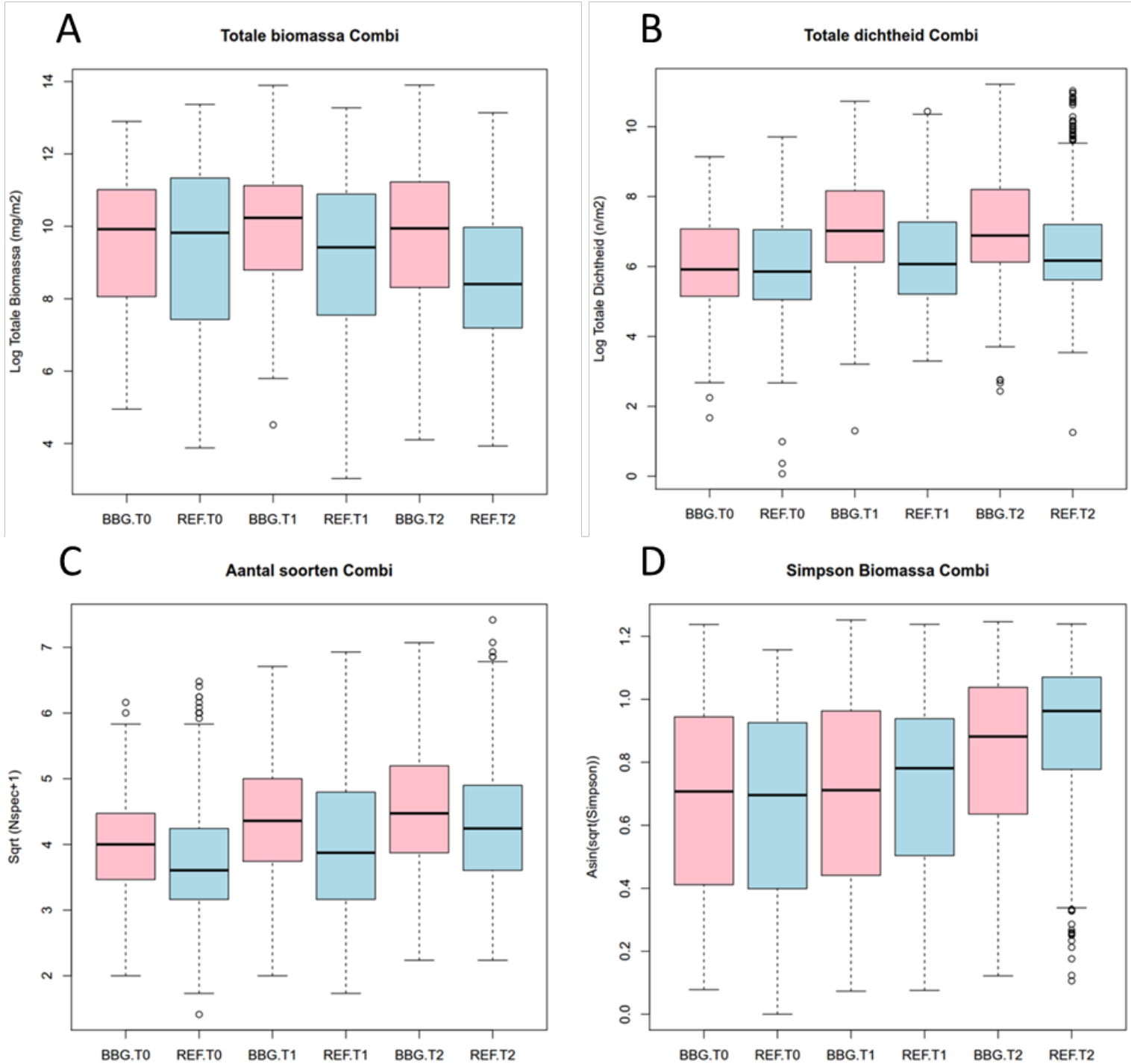

D Simpson Biomassa Combi

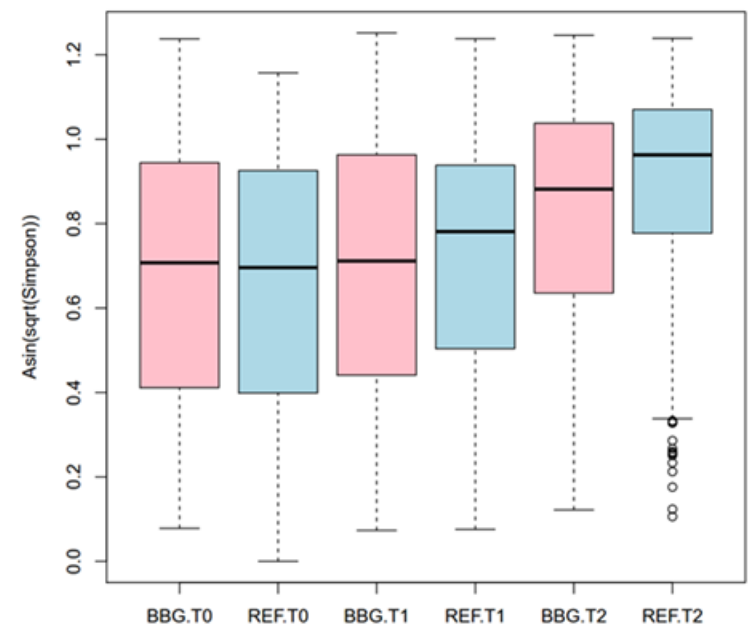

E

Som log dichtheid

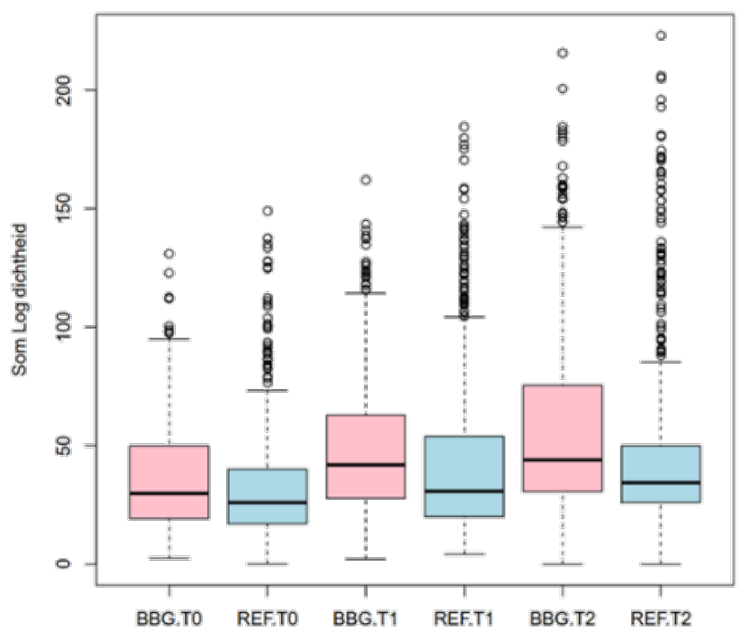

Figuur 6.1. Box-and-whisker plots ter illustratie van de BACI analyses van de verschillende toetsvariabelen in de twee gebieden en drie periodes. Roze kolommen zijn BBG, blauwe zijn REF. 


\subsection{Totale biomassa}

Voor totale biomassa geeft de BACI analyse aan dat deze significant verschilt tussen BBG en REF, significant verandert in de tijd, en dat de verandering significant verschillend is tussen BBG en REF (Tabel 6.2). De biomassa blijft ongeveer gelijk in BBG, maar neemt in de loop van de tijd af in REF (Figuur 6.1 A).

Globaal over de hele Voordelta is de gewogen gemiddelde biomassa zeer licht toegenomen tussen T0 en T1, maar daarna afgenomen (Tabel 6.3). In BBG is tussen T0 en T2 een lichte toename gevonden. Dit bevestigt dat BBG, relatief tot REF, aanzienlijk is verbeterd. Ten opzichte van het verschil tussen BBG en $\mathrm{REF}$ in TO $(2 \mathrm{~g} \mathrm{AFDW} / \mathrm{m} 2)$ is het verschil in T2 $(11 \mathrm{~g} \mathrm{AFDW} / \mathrm{m} 2)$ meer dan vervijfvoudigd. De biomassa in BBG is tussen T0 en T2 met $21 \%$ toegenomen, terwijl ze in REF met $50 \%$ is gedaald. Deze veranderingen overschrijden ruimschoots de verwachte toename van $10 \%$, in absolute zin tussen T0 en $\mathrm{T} 2$ in het BBG, maar zeker in relatieve zin als een toename van biomassa in BBG, relatief tot de veranderingen geobserveerd in REF.

Het resultaat suggereert dat er door een autonome evolutie een dalende trend is opgetreden in het hele gebied, maar een relatieve verbetering in BBG ten opzichte van de rest van het gebied. Die relatieve verbetering is precies het patroon dat was verwacht bij een succesvolle compensatie.

\subsection{Totale dichtheid}

De totale dichtheid neemt over het gehele gebied toe, maar significant sterker in BBG dan in REF (Tabel 6.2, Figuur 6.1). Dit volgt niet volledig de trends in biomassa. Het gemiddelde gewicht van de individuen is in beide gebieden afgenomen. In de geschatte absolute toename van de dichtheden in beide gebieden (Tabel 6.3) zien we een bijna drievoudige toename in BBG, en iets minder dan een verdubbeling in REF. In de Voordelta als geheel is de totale dichtheid meer dan verdubbeld. Ten opzichte van REF, is er een sterkere toename in BBG.

Ook dit resultaat kan worden geïnterpreteerd als een relatief sterkere verbetering in BBG dan in REF, overeenkomstig de oorspronkelijke verwachtingen.

\subsection{Aantal soorten}

Biodiversiteit, uitgedrukt als aantal soorten per monster, is over het hele gebied toegenomen. De biodiversiteit in REF is wat lager dan in BBG, maar de trend in de tijd is gelijk. De verhouding tussen BBG en REF is dezelfde gebleven in de drie periodes. $\mathrm{Er}$ is geen significante interactie tussen gebied en tijd.

Dit resultaat is niet in overeenstemming met de verwachte relatieve verbetering in BBG ten opzichte van REF.

\subsection{Simpson diversiteitsindex op biomassabasis}

Over het gehele gebied zien we in de loop der jaren een sterke toename van de Simpson diversiteit. De toename is in REF iets (licht significant) sterker dan in BBG. Deze sterkere toename van de diversiteit in $R E F$, vergeleken met $B B G$, is tegengesteld aan de geformuleerde verwachtingen.

\subsection{Som van log-getransformeerde dichtheden}

Over het gehele gebied zien we in de loop der jaren een sterke toename van de som van loggetransformeerde dichtheden. De waarde is hoger in BBG dan in REF, en dat verschil blijft over de tijd ongeveer constant. $\mathrm{Er}$ is geen significante gebied*periode interactie die wijst op een andere ontwikkeling in één van de twee deelgebieden. Dit resultaat is dus niet in overeenstemming met een verwachte relatieve verbetering in BBG ten opzichte van REF. 


\subsubsection{Deelconclusies}

De uitkomsten van de BACI voor totale biomassa van bodemdieren voldoet kwalitatief en kwantitatief aan de verwachtingen. In de loop der jaren is de biomassa in BBG licht toegenomen in absolute zin, maar vooral sterk verhoogd ten opzichte van REF. Die toename van het verschil tussen BBG en REF is hoog significant.

Ook voor totale dichtheid werd een significante tijd*gebied interactie gevonden, waarbij BBG in de loop der jaren een sneller stijgende totale dichtheid had dan REF. Overigens impliceert dit, in combinatie met de gegevens over biomassa, dat de gemiddelde grootte van de individuen in beide gebieden is afgenomen. In BBG is het gemiddelde gewicht afgenomen met ongeveer een factor 2 , in REF met bijna een factor 4. Deze afname in individueel gewicht is niet in overeenstemming met de veronderstelde selectieve invloed van bodemberoering door visserij - de verwachting was immers dat door afname van de visserij in BBG het gemiddelde gewicht per individu zou stijgen, terwijl het in REF ongeveer gelijk zou blijven.

De drie diversiteitsmaten (aantal soorten per monster, Simpson diversiteit op biomassabasis, som van loggetransformeerde dichtheden) tonen globaal een gelijkaardig patroon. Diversiteit is over het hele gebied toegenomen in de tijd. Dit is ongeveer in dezelfde mate het geval voor BBG en REF. Alleen voor Simpson diversiteit is er een licht significante interactieterm gevonden, met een licht hogere toename in REF dan in BBG. De toename in diversiteit tussen T0 en T2 over de Voordelta als geheel is sterk. Aantal soorten is met $33 \%$ toegenomen tussen T0 en T2, Simpson diversiteit met $50 \%$ en som van loggetransformeerde dichtheden met $42 \%$. De toename in het hele gebied, bijna zonder interactie tussen gebied en tijd, is niet in overeenstemming met de verwachting.

Hoewel globaal overeenkomstig met het verwachte resultaat, is de BACI van totale biomassa strijdig met de onderliggende hypotheses van Rijnsdorp et al. (2006). We weten immers dat de visserijdruk sterker is gedaald in REF dan in BBG, zowel voor boomkorvisserij (die in beide gebieden zo goed als verdween) als voor garnalenvisserij (die overal is toegenomen, maar veel sterker in BBG). Bij geldigheid van het model van Rijnsdorp et al. (2006), en gegeven de niet voorziene ontwikkeling van de visserijdruk door garnalenvisserij, had de voorspelling geluid dat de biomassa zou zijn toegenomen in REF, en afgenomen of gelijk gebleven (afhankelijk hoe sterk men het effect van de opgetreden toename van de garnalenvisserij weegt) in BBG. Dat is niet geobserveerd. Er is dus reden nader te onderzoeken of de aannames van Rijnsdorp et al. (2006) over de effecten van visserijdruk op de biomassa van bodemdieren geldig zijn. Deze conclusie was ook al uit eerdere analyses (Craeymeersch et al., 2017; Tulp et al., 2018) naar voren gekomen.

Bij deze analyse kan tevens onderzocht worden of de trends in diversiteit, die niet overeenkomen met de verwachtingen van Rijnsdorp et al. (2006) bevredigend kunnen worden verklaard.

\subsubsection{Nader onderzoek van de relatie tussen visserij en bodemdieren}

Het ontwerp van de compensatie voor de aanleg van Maasvlakte 2 is gebaseerd op een rapport door Rijnsdorp et al. (2006), waarin het effect van bodemberoerende visserij op bodemdieren wordt gekwantificeerd, en vervolgens gebruikt als basis voor een schatting van het effect van het opheffen van deze visserij in een deel van de Voordelta. De kwantificering van het effect van bodemberoerende visserij op bodemdieren was gebaseerd op waarnemingen over de effecten van visserij in diepere delen in de centrale Noordzee (Duplisea et al., 2002). De kwantificering van visserij-intensiteit was gebaseerd op gegevens over boomkor-, garnalen-, borden- en schelpdiervisserij in de Voordelta afkomstig uit de VIRIS database (Visserij Registratie en Informatie Systeem) over de jaren 2001-2005. Naast deze gegevens is gebruik gemaakt van beschikbare data uit het satelliet volgsysteem (VMS, Vessel Monitoring System) waarmee elke twee uur scheepscode, positie en vaarsnelheid worden vastgelegd. Door combinatie van de VMS data, beschikbaar voor de jaren 2001-2004, en de gegevens uit de VIRIS database is een ruimtelijk gedifferentieerd beeld vervaardigd van de bevissingsfrequenties in de Voordelta door verschillende vormen van bodemberoerende visserij (boomkor, garnalenkor, bordentrawl). Voor het 
ruimtelijk patroon van de bodemdieren in de Voordelta is uitgegaan van gegevens over 2004, afkomstig uit de eerste T0 metingen (Craeymeersch et al., 2004).

Om een beter begrip te krijgen van het verband tussen de ontwikkeling van de totale biomassa en de visserij-inspanning, analyseren wij nader de grondslagen en validatie van het model van Rijnsdorp et al. (2006). Wij stellen achtereenvolgens de volgende vragen:

1. Waren de voorspellingen van Rijnsdorp et al., in het licht van de nu beschikbare informatie, gebaseerd op voldoende nauwkeurige kaarten van visserij-intensiteit en biomassa van bodemdieren?

2. Kan de veronderstelde relatie tussen intensiteit van boomkorvisserij en biomassa van bodemdieren (op basis van Duplisea et al. (2002)) worden bevestigd aan de hand van de verzamelde gegevens?

3. Kan een weging tussen de effecten van boomkorvisserij en garnalenvisserij worden gemaakt, en kan daaruit een nieuwe evaluatie gemaakt worden van het effect van de genomen maatregelen?

\subsubsection{Methode}

\subsection{Geldigheid van de voorspelling in het licht van de nu beschikbare gegevens}

Op basis van de toen beschikbare kennis concludeerden Rijnsdorp et al. (2006) dat voldoende compensatie voor de aanleg van Maasvlakte 2 zou worden geboden door de instelling van een Bodembeschermingsgebied. Sinds 2006 is onze kennis over de ruimtelijke verdeling van de visserijinspanning verbeterd, voornamelijk als gevolg van verbeterde algoritmes voor de inschatting van visserij-inspanning, en voor de interpretatie van VMS gegevens. Ook beschikken wij over een tweede bemonstering van de bodemdieren in de T0 situatie in 2005. Nagegaan wordt of Rijnsdorp et al., mochten ze in 2006 die kennis van nu al hebben gehad, nog steeds de verwachting zouden hebben uitgesproken dat het BBG de nodige compensatie kon leveren. De analyse maakt gebruikt van de door Rijnsdorp et al. (2006) geschatte positieve gevolgen van het uitbannen van boomkorvisserij, alsook van de achteraf vastgestelde ruimtelijke verdeling van visserij-inspanning op basis van opnieuw geïnterpreteerde VMS gegevens, en van de achteraf vastgestelde ruimtelijke verdeling van de bodemdierenbiomassa op basis van de bemonsteringen van 2004 en 2005.

\subsection{Relatie tussen visserijverstoring en biomassa van bodemdieren}

De huidige dataset biedt een unieke gelegenheid om de onderliggende relatie tussen verstoring door visserij en biomassa van bodemdieren te onderzoeken. De intensiteit van de boomkorvisserij is over het gehele gebied sterk afgenomen in de tijd en is nu overal vrijwel nul. Tussen T0 en T2 is een sterke vermindering opgetreden in die gebieden die intensief werden bevist gedurende T0, terwijl in andere gebieden bijna geen vermindering in visserijdruk is opgetreden, omdat de visserij tijdens T0 ook al laag was. Ruimtelijk kan vergeleken worden hoe deze vermindering in de visserijdruk correleert met een verandering in biomassa tussen T0 en T2. Verwacht wordt, volgens de Rijnsdorp-hypothese, dat een negatief verband zal bestaan tussen beide (afname in bevissing leidt tot een toename in biomassa).

In het gebied is de intensiteit van de garnalenvisserij sterk toegenomen. Voor deze visserij is op dezelfde wijze de relatie onderzocht tussen verandering in visserij-intensiteit en verandering in biomassa. $\mathrm{Na}$ vergelijking van de hellingen van de regressielijnen (delta-biomassa versus delta-boomkorvisserij enerzijds, en delta-biomassa versus delta-garnalenvisserij anderzijds) is een wegingsfactor bepaald, die toelaat de intensiteit van beide vormen van visserij (in termen van aantal bevissingen per jaar) bij elkaar op te tellen en een eenduidig verband tussen verandering in visserij en verandering in biomassa op te stellen.

De analyse is gebaseerd op dezelfde monsterpunten als de BACI (zie Bijlage 3). Waar voor een monsterpunt een waarneming in T0 of T2 ontbrak, is dat geschat uit de interpolatiekaarten van de 
biomassa voor die periode ${ }^{7}$. Door de verandering van de bemonsteringsstrategie gedurende de drie periodes T0, T1 en T2, zijn er slechts weinig punten in de ruimte waarvoor volledige tijdseries bestaan. De analyse kan niet tot die punten beperkt worden, omdat dan bijvoorbeeld het hele westelijke referentiegebied wegvalt. In het syntheserapport en in de linear mixed models (zie 6.1.1.1) is daarmee omgegaan door gebruik te maken van cofactoren die toelaten de variabele van belang te schatten, waarna alsnog een schatting kan worden gemaakt van het toegevoegde effect van visserij-intensiteit. Deze strategie heeft als bijkomend voordeel dat een deel van de ruis in de relatie tussen respons en visserij-intensiteit door de cofactoren wordt verklaard, maar is anderzijds beperkt door de voorspelbaarheid van de respons op basis van de cofactoren. Hier is gekozen voor een eenvoudigere aanpak, waarbij ruimtelijke interpolatie is gebruikt om de ontbrekende waarden te schatten uit omliggende, maar niet ruimtelijk samenvallende punten. Er is een selectie van punten doorgevoerd om alle deelgebieden zo evenwichtig mogelijk in de dataset op te nemen. Cofactoren zijn niet gebruikt, enerzijds omdat met de interpolatie minder behoefte was aan de schattingen op basis van cofactoren, anderzijds om de ruimtelijke interpolatie niet zeer ingewikkeld en onzeker te maken. Een gevolg is dat er wellicht meer ruis aanwezig is in de getoonde relaties, die gedeeltelijk door cofactoren had kunnen verklaard worden. Als tegenover die ruis het signaal (correlatie met visserij-intensiteit) toch nog significant blijkt te zijn, dan versterkt dat de conclusie over het bestaan van een correlatie. De analyse is bovendien complementair aan de eerdere analyses met cofactoren, waardoor een conclusie op een combinatie van beide kan worden gebaseerd.

De analyse is herhaald voor andere variabelen: aantal soorten, totale dichtheid, Simpson diversiteit op biomassabasis. Voor deze analyse zijn de toets-variabelen getransformeerd op dezelfde wijze als voor de BACI testen.

\subsubsection{Resultaten}

\subsection{Geldigheid van de voorspelling in het licht van de nu beschikbare gegevens}

De ruimtelijke verdeling van de visserij-intensiteit door boomkorren, en van biomassagegevens van bodemdieren uit Rijnsdorp et al. (2006) wordt vergeleken met de huidig beschikbare schatting in Figuur 6.2. De patronen in de geschatte visserij-intensiteit komen globaal overeen, maar er zijn ook verschillen. Binnen het gebied van het latere BBG (zwarte lijn in rechtse figuur) bleek de visserij-intensiteit achteraf lager te liggen dan door Rijnsdorp et al. (2006) geschat. De intensiteit voor de kust van Walcheren was hoger in de huidig beschikbare analyse dan in de schatting van Rijnsdorp et al. (2006).

Ook voor wat betreft de biomassa van bodemdieren vinden we patronen die gelijkend, maar niet identiek zijn. De kaart uit Rijnsdorp et al. (2006) betreft alleen 'hard benthos', vooral schelpdieren, maar dat is veruit de grootste groep wat betreft biomassa. De recente kaart is gebaseerd op resultaten van 2004 en 2005. Beide kaarten hebben de monsters van 2004 gemeenschappelijk.

We presenteren deze kaarten niet om Rijnsdorp et al. (2006) achteraf te corrigeren, maar om na te gaan of de uitspraken die destijds met de kennis van toen zijn gedaan, in het licht van de nu beschikbare data nog steeds dezelfde zouden zijn gebleven. Met betrekking tot de visserij-inspanning stellen we daarbij vast dat er verschillen zijn, die voortkomen uit het gebruik van verschillende bronnen (destijds zijn naast VMS gegevens ook databases op basis van aanlanding en logboekgegevens gebruikt, recent zijn schattingen alleen op VMS gebaseerd), maar die niet zo groot zijn dat ze een kwalitatief zeer verschillend beeld geven. Voor bodemdieren zijn de gevonden verschillen gemakkelijk te verklaren uit het gebruik van twee monstercampagnes in plaats van één, maar ook hier zijn de patronen consistent.

\footnotetext{
${ }^{7}$ De interpolaties zijn gemaakt met kriging, een geostatistische techniek die de interpolatieschatting optimaliseert op basis van de ruimtelijke variantiestructuur van de dataset. Die laatste wordt uitgedrukt in een zogenaamd variogram, een plot die aangeeft hoe de verschillen tussen waarnemingen toenemen met de afstand tussen de waarnemingspunten. Na fitting van een theoretisch model op het variogram kan de beste interpolatie met kriging worden gevonden.
} 


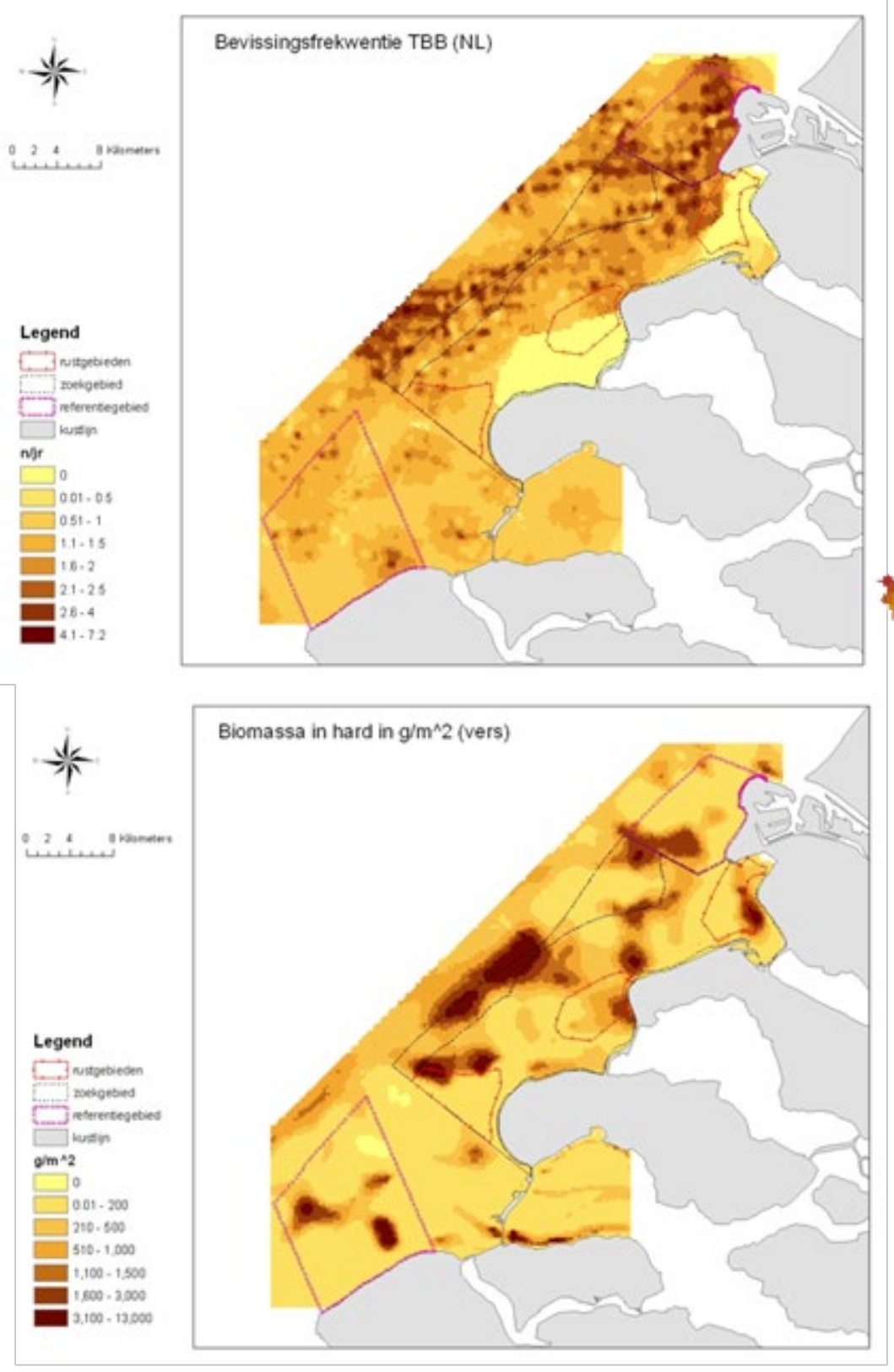

Rijnsdorp et al. 2006
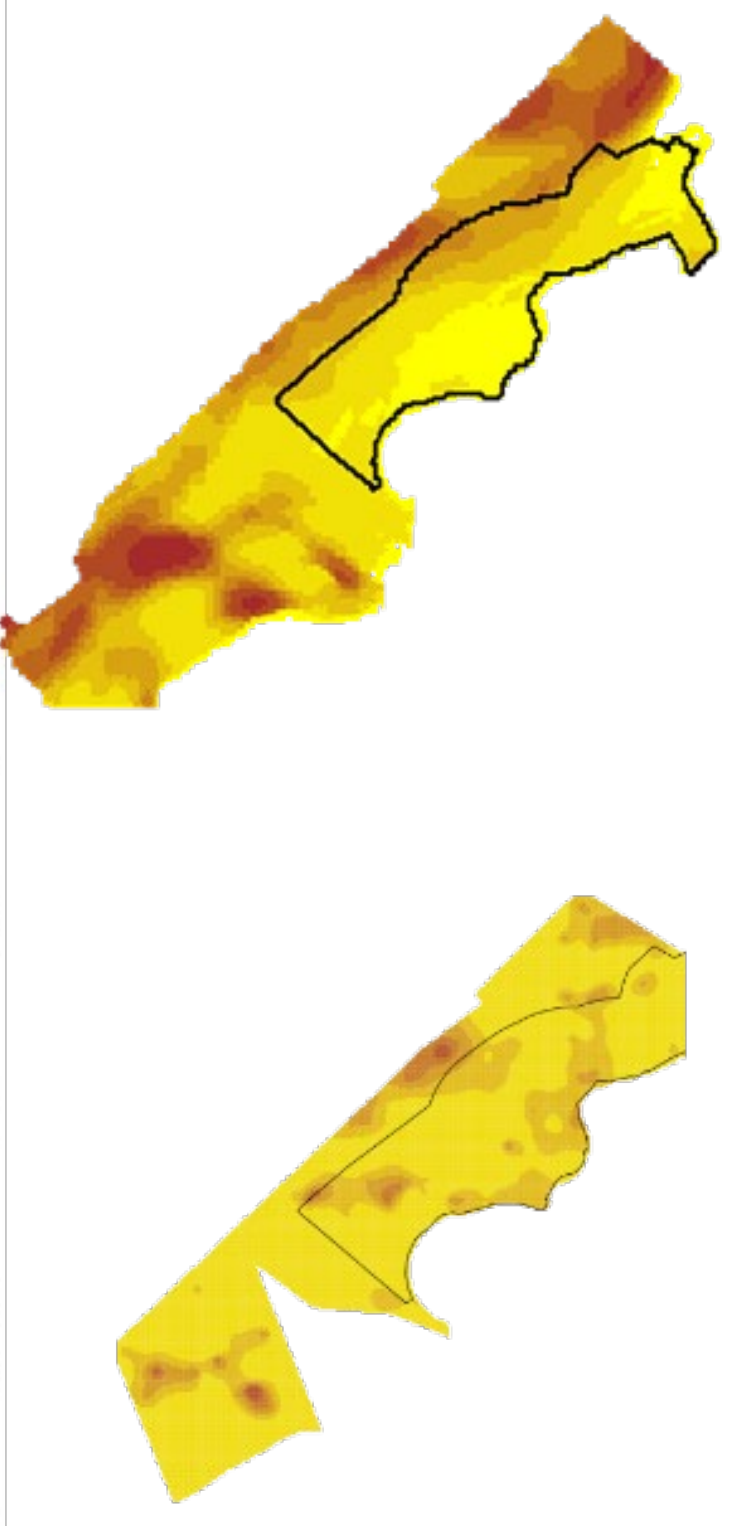

PMR database

Figuur 6.2. Boven: vergelijking van de ruimtelijke verdeling van boomkorvisserij-intensiteit in T0 zoals gehanteerd door Rijnsdorp et al. (2006), en de nieuwste schatting van deze intensiteit op basis van VMS met de meest recente algoritmes (voor de jaren 2003-2005). Beneden: ruimtelijke verdeling van biomassa van bodemdieren in T0 zoals gehanteerd door Rijnsdorp et al. (2006) op basis van de gegevens uit 2004, en de schatting van deze biomassaverdeling op basis van alle monsters van TO (2004 en 2005). De biomassawaarden van de TO data zijn van asvrij drooggewicht naar versgewicht zonder schelp omgerekend met een conversiefactor van 15\%. De recente schatting is ruimtelijk beperkt tot de zones die in TO, T1 en T2 zijn bemonsterd, waardoor de Haringvlietmond is weggevallen. Voor de vergelijking zijn dezelfde klassegrenzen gehanteerd, en gelijkende kleuren gekozen.

De verwachte relatieve toename van de bodemdierbiomassa in het BBG, na wegvallen van de boomkorvisserij, en berekend volgens de responscurve van Rijnsdorp et al. (2006), maar met de herberekende visserij-inspanning en benthosgegevens, wordt getoond in Figuur 6.3. De ruimtelijk 
gemiddelde toename van de bodemdierbiomassa bedraagt 13,7\%. Dat is iets lager dan geschat door Rijnsdorp et al. (2006), maar boven de grens van 10\% die nodig was om de verloren biomassa in Maasvlakte 2 te compenseren.

De belangrijkste reden waarom de huidige schatting lager uitvalt dan die van Rijnsdorp et al. (2006), is de lagere schatting (op basis van VMS met de huidige algoritmes) van de visserij-intensiteit in het BBG tijdens T0. Andere verschillen betreffen de precieze afbakening van het Bodembeschermingsgebied (bij Rijnsdorp et al. (2006) een zoekgebied van 30.600 ha dat enkele meer zeewaartse, en intensiever beviste delen bevat, in vergelijking met het uiteindelijk vastgestelde Bodembeschermingsgebied), en de biomassaverdeling van de bodemdieren.

Ook ten tijde van het instellen van het BBG was de visserij-activiteit in het BBG marginaal, in vergelijking met de intensiteit in de rest van de Voordelta. Toch leidde dit tot een voldoende voorspelde toename van bodemdierbiomassa, omdat de responscurve van Rijnsdorp et al. (2006) een zeer grote gevoeligheid voorspelt van bodemdieren voor lichte bodemberoering. Daarom wordt er, ondanks een bevissing die zelden de frequentie van eenmaal per jaar overschrijdt, toch een toename in biomassa tot bijna $50 \%$ voorspeld voor bepaalde zones.

Het model van Rijnsdorp et al. (2006) kan ook toegepast worden op het referentiegebied, mocht alle visserij uit dat gebied verdwijnen. De voorspelling van het model is dat de biomassa van de bodemdieren daar zou toenemen met $47,4 \%$ t.o.v. de biomassa op T0.

\section{Verwachte biomassatoename (\%)}

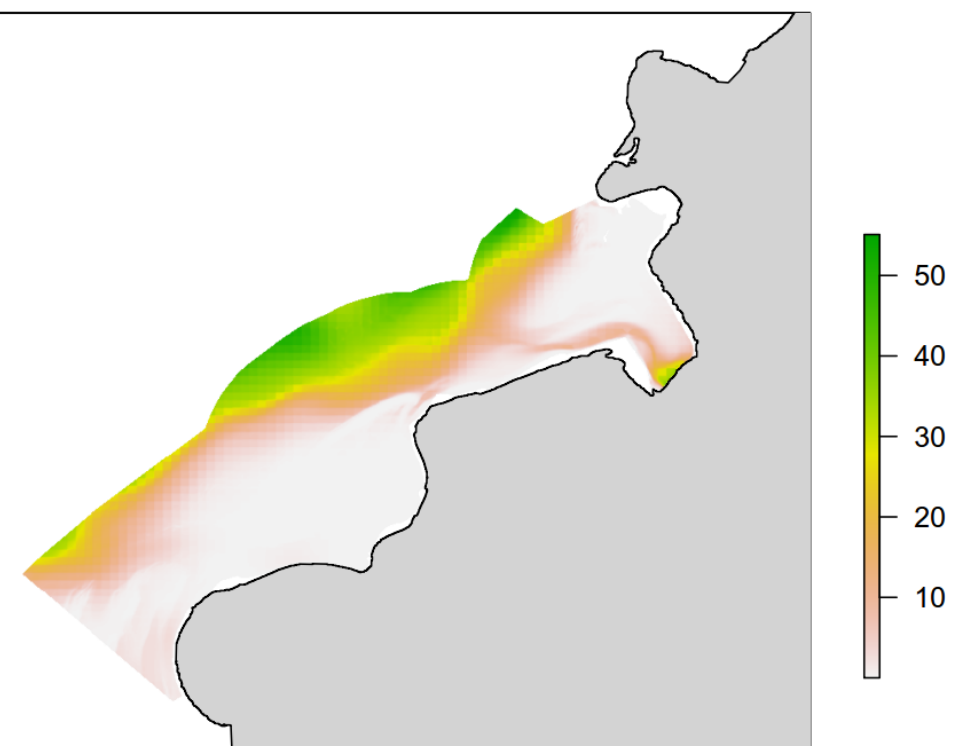

Figuur 6.3. Voorspelde relatieve toename van de biomassa van bodemdieren (\%) bij volledig verdwijnen van de boomkorvisserij uit het Bodembeschermingsgebied BBG, volgens de hypothese en het rekenmodel van Rijnsdorp et al. (2006) maar gebaseerd op alle nu beschikbare gegevens over visserijdruk door boomkorvisserij en bodemdieren.

\subsection{Relatie tussen visserijverstoring en biomassa van bodemdieren}

De verandering in de biomassa over de tijd (T2-T0) is zeer significant $(p<<0,001)$ gecorreleerd met de verandering in de bevissingsintensiteit over de tijd (Figuur 6.4). Dit geldt zowel voor de boomkorvisserij als voor de garnalenvisserij. De helling van de relatie is sterker (ongeveer een factor 6) voor de boomkorvisserij dan voor de garnalenvisserij (merk op dat in Figuur 6.4 de x-as een heel andere schaal 
heeft voor boomkorvisserij dan voor garnalenvisserij; bij garnalenvisserij nemen de waarden op de $y$-as veel minder toe per eenheid variatie op de $x$-as). Beide regressies kunnen bij elkaar aansluiten als garnalenvisserij zesmaal lager wordt gewogen dan boomkorvisserij. Op die manier kan een gemeenschappelijke regressielijn van verandering in biomassa versus verandering in gewogen visserijdruk worden opgesteld.

De consistente en significante relaties zijn volledig tegengesteld aan de hypotheses van het Rijnsdorpmodel, maar bevestigen eerdere resultaten van de linear mixed models (paragraaf 6.1.1.1) De gegevens tonen dat met een toename van de visserijdruk, een toename van de biomassa van de bodemdieren is gevonden. Omgekeerd is met een afname van de visserijdruk een sterke afname in bodemdierbiomassa gevonden. De veranderingen in biomassa zijn groot, in rekening brengend dat de biomassagegevens zijn getransformeerd voor deze analyse. Na terugtransformatie blijkt dat bij een vermindering van boomkorvisserij van 6 naar 0 (ongeveer de geobserveerde maximale range) een vermindering van de biomassa met een factor 7 wordt voorspeld. De respons werd gevonden voor zowel boomkorvisserij als garnalenvisserij, maar is veel sterker per eenheid beroering door boomkorvisserij dan voor de garnalenvisserij.

$\mathrm{Er}$ is in deze relatie niet gecorrigeerd voor de vele abiotische factoren (bijvoorbeeld diepte, zoutgehalte, sterkte van de stroming en verstoring door golven) waarvan we weten dat die mede bepalend zijn voor de samenstelling en biomassa van de bodemdiergemeenschap. De aanzienlijke ruis rond de gevonden relatie vindt zijn verklaring hierin, maar doet niets af aan het systematische patroon in de relatie.

De observatie van een vermindering in biomassa met vermindering van de visserijdruk is in lijn met de eerder gerapporteerde respons van de bodemdiergemeenschap (Craeymeersch et al., 2017; Tulp et al., 2018) waarin de nadruk werd gelegd op de enigszins paradoxale rol van Ensis in de respons van de bodemdieren, als grote diepgravende soort die toch een eerder positieve relatie met visserijdruk vertoont. 

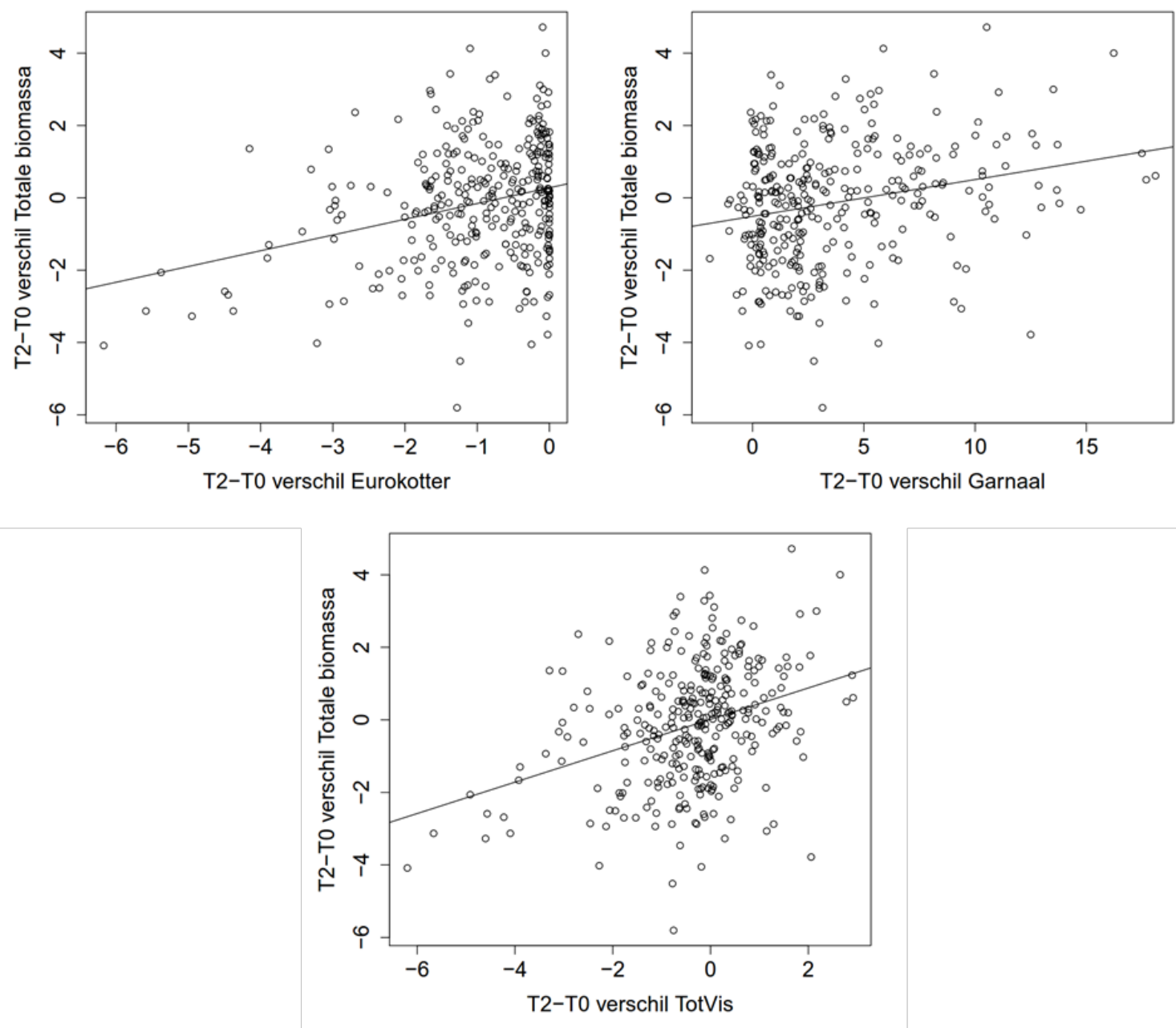

Figuur 6.4. Verandering in (log-getransformeerde) totale biomassa van bodemdieren tussen T2 en TO, ten opzichte van (a) de verandering in visserijdruk met boomkorren (b) de verandering in visserijdruk met garnalenkorren en (c) de verandering in totale visserijdruk waarbij garnalenvisserij $1 / 6$ gewogen is t.o.v. boomkorvisserij. De getoonde relaties zijn zeer significant $(p<<0.001)$.

De andere variabelen vertonen eveneens een relatie met de verandering in de intensiteit van de visserij (Figuur 6.5). Voor totale dichtheid en aantal soorten is de relatie zwak of afwezig (totale dichtheid: $p=0,004$; aantal soorten: $p=0,15)$. De relatie met Simpson's diversiteitsindex op biomassabasis met totale visserijdruk is sterk $\left(p<10^{-8}\right)$ maar dat komt vooral door een zeer significante relatie met boomkorvisserij $\left(p<10^{-9}\right)$, terwijl de relatie niet significant $(p=0,09)$ is voor de garnalenvisserij. Veranderingen in de gemeenschap worden vooral gereflecteerd in de totale biomassa, en verder in de biomassaverdeling over de soorten. Met verlaagde visserij-inspanning correleert een licht verminderde totale dichtheid, een onveranderd aantal soorten, en een veel gelijkmatigere verdeling van de (verlaagde) biomassa over de soorten. 

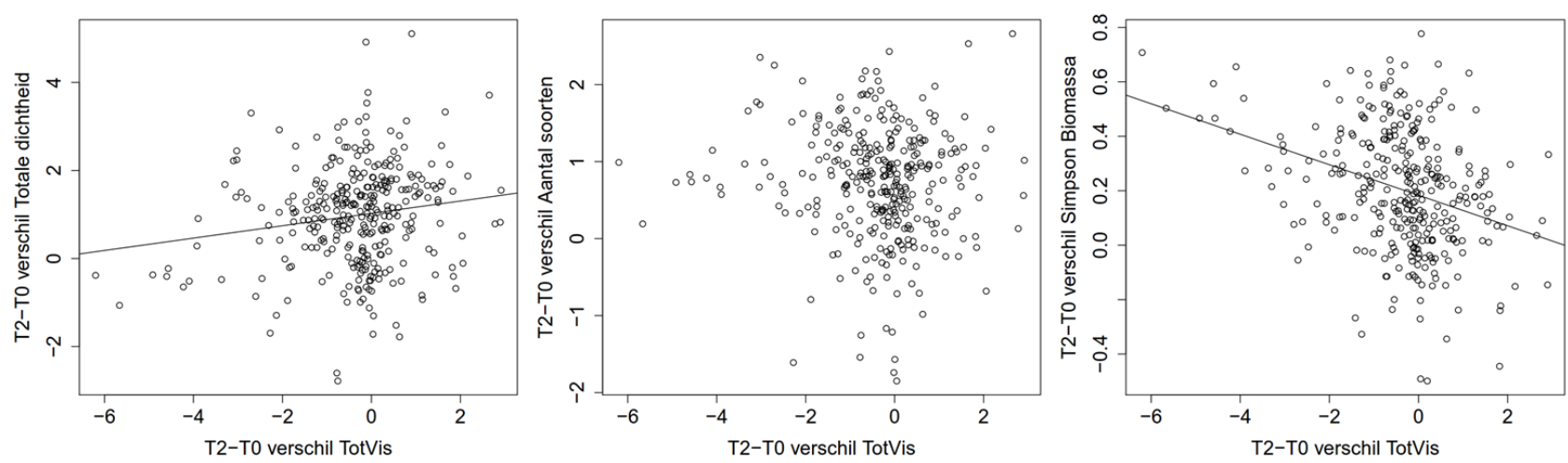

Figuur 6.5. Geobserveerde veranderingen in (a) log-getransformeerde totale dichtheid van bodemdieren, (b) sqrt-getransformeerd aantal soorten per monster en (c) arcsin(sqrt) getransformeerde Simpson's diversiteit op biomassabasis, ten opzichte van de verandering in totale visserijdruk. Alle verschillen zijn tussen periode T2 en periode TO.

Het ruimtelijke patroon van de veranderingen in totale biomassa en in Simpson diversiteit wordt vergeleken met de contourlijnen van verandering in totale visserijdruk (boomkor- plus garnalenvisserij) in Figuur 6.6. Beide ruimtelijke patronen zijn met elkaar, en met de verandering in visserijdruk gecorreleerd.

Verder is opvallend dat zowel de verandering in de visserijdruk, als de verandering in de bodemdiergemeenschap, een ruimtelijk coherent patroon vertoont. Vooral in het zuidelijke en westelijke deel van het gebied (beiden behorend tot REF) is de visserijdruk sterk afgenomen en zien we de sterkste veranderingen in biomassa en biomassaverdeling. Daarbij zijn de veranderingen in biomassa ook ruimtelijk gecorreleerd met de veranderingen in Simpson diversiteit: hoe hoger de biomassa, hoe lager de diversiteit. Dat is veroorzaakt door de dominante rol van Ensis: waar de biomassa van deze soort zeer hoog is, neemt ze het overgrote deel van de biomassa van de gemeenschap in en is de diversiteit dus laag. 

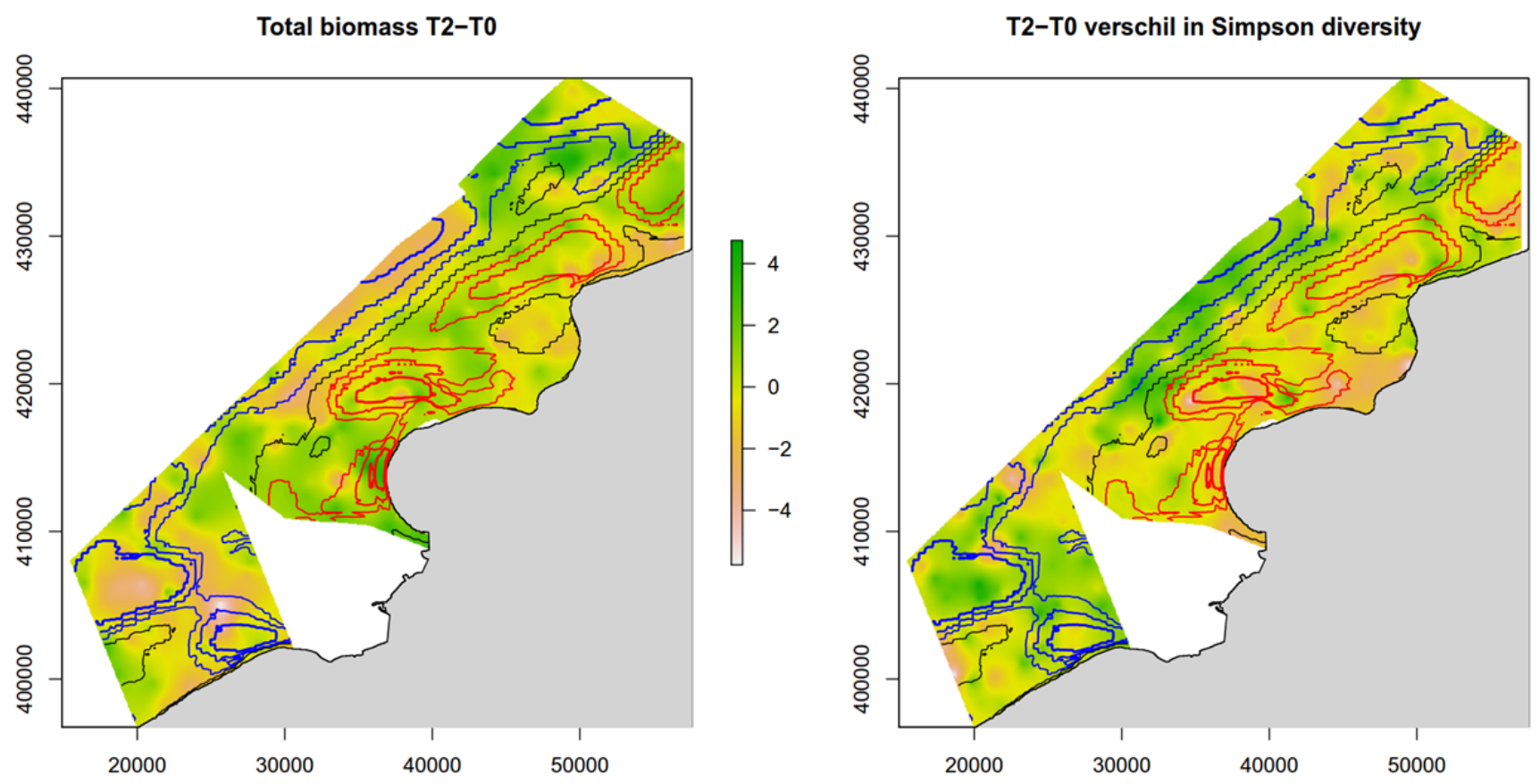

Figuur 6.6. Ruimtelijk patroon van de veranderingen tussen TO en T2 in totale biomassa en in Simpson diversiteit. Negatieve waarden zijn verminderingen in de loop der tijd. Contourlijnen geven de verandering in de tijd van de totale visserijdruk weer (garnalenvisserij is $1 / 6$ gewogen t.o.v. boomkorvisserij). Blauwe contourlijnen komen overeen met een vermindering van visserijdruk, rode met een vermeerdering. De dikte van de contourlijnen geeft de intensiteit weer.

Het zuidelijke en westelijke deel, voornamelijk REF, waar de grootste veranderingen zijn opgetreden in biomassa en diversiteit, vormt tevens het gebied waarin ook fysische veranderingen zijn opgetreden. Door de aanleg van Maasvlakte 2 is de getijstroming uit de kust geduwd. Stroomsnelheden zijn iets verhoogd in het zeewaartse deel van het studiegebied, en verlaagd in het meest kustnabije deel (Figuur 6.7b). We hebben daarom onderzocht of de veranderingen in biomassa of biomassaverdeling over soorten correleren met veranderingen in omgevingsvariabelen, bijvoorbeeld schuifspanning uit stroming en/of golven, korrelgrootteverdeling of zoutgehalte. $\mathrm{Er}$ is geen enkele significante correlatie gevonden. Als voorbeeld toont Figuur 6.7 de relatie tussen veranderingen in totale biomassa en veranderingen in totale schuifspanning uit golven en stroming. Deze relatie is niet significant $(p>0,05)$. 

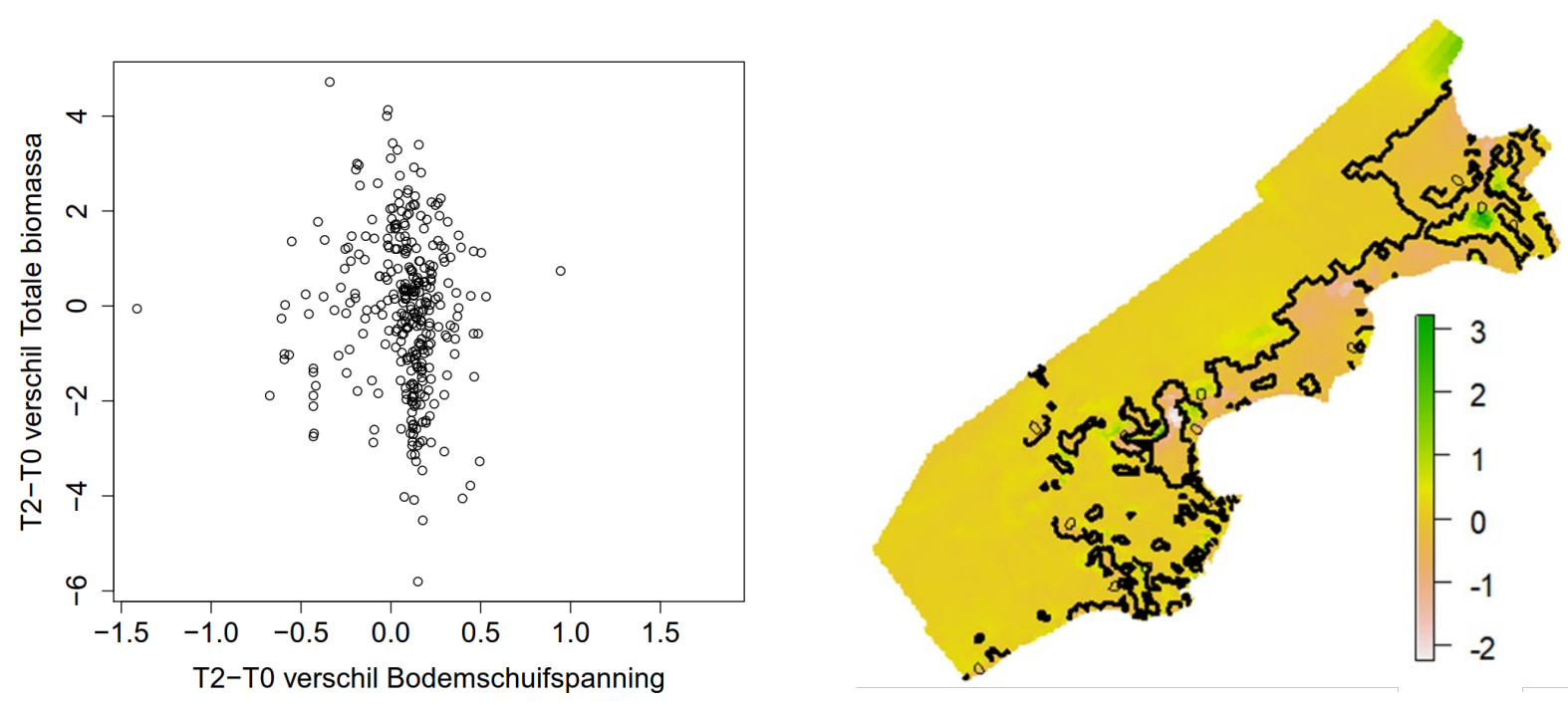

Figuur 6.7. (a) Veranderingen in totale biomassa versus veranderingen in totale bodemschuifspanning uit golven en stroming $(b)$ ruimtelijk patroon van de veranderingen tussen TO en T2 in totale bodemschuifspanning.

\subsubsection{Deelconclusies}

Sinds de publicatie van het rapport van Rijnsdorp et al. (2006) zijn onze schattingen van de ruimtelijke verdeling van visserij-intensiteit tijdens TO, en van de biomassa van bodemdieren bijgesteld. Dat levert lichte verschillen op met de schattingen die destijds zijn gemaakt, maar geen kwalitatief andere voorspellingen. Het model dat door Rijnsdorp et al. (2006) is gebruikt, voorspelt ook op basis van de laatste gegevens dat het stopzetten van boomkorvisserij in het BBG leidt tot meer dan $10 \%$ toename van de biomassa.

Een vergelijking van de verandering in bodemdierfauna tussen T0 en T2, met de veranderingen in boomkor- en garnalenvisserij in dezelfde periode, toont aan dat een vermindering van visserijdruk correleert met een vermindering van totale biomassa en een verhoging van de Simpson diversiteit op biomassabasis. Correlaties met veranderingen in dichtheid en aantal soorten zijn zwak of afwezig. Een ruimtelijke analyse bevestigt de correlaties, omdat de grootste veranderingen in biomassa en Simpson diversiteit optreden in de zones met de sterkste verandering in visserij-intensiteit.

De analyse is gebaseerd op temporele verschillen en houdt geen rekening met cofactoren. Cofactoren als diepte, zoutgehalte of korrelgrootteverdeling van het sediment variëren weinig over de tijd voor vaste punten. Sterkere variatie is er in de bodemschuifspanning, als gevolg van de constructie van Maasvlakte 2 en van morfologische aanpassingen. Deze temporele veranderingen vertonen echter geen correlatie met temporele veranderingen in de hier onderzochte indicatoren.

\subsubsection{Veranderingen in indicatoren voor biodiversiteit}

Het ruimtelijk patroon in de verandering van de Simpson diversiteitsindex wordt getoond in Figuur 6.6b. De grootste verhogingen van deze diversiteit zijn geobserveerd in de gebieden die in T0 het sterkst werden bevist met boomkorren. Lage toename of zelfs afname wordt geobserveerd in gebieden die in T1 en T2 het sterkst werden bevist door de garnalenvisserij. Figuur 6.8 toont de relatie tussen absolute en relatieve biomassaverdeling over soorten met de verandering in de intensiteit van de visserij. Er zijn vier klassen gedefinieerd: sterk verlaagde, matig verlaagde, neutrale en stijgende visserijdruk. De gemiddelde opbouw van de biomassa over de tijd voor deze klassen wordt getoond in cumulatieve curves, waarbij de onderste curve de meest dominante soort (Ensis leei) toont, gevolgd door de tweede 
biomassadominante soort en zo verder. De figuren illustreren dat de afname van biomassa sterk was waar de visserijdruk is verminderd, terwijl eerder een toename zichtbaar is in de klasse van monsterpunten waar de visserijdruk is toegenomen. Het aandeel van Ensis leei was in de eerste jaren overal heel hoog, maar neemt in de loop der jaren af (dit wordt best geïllustreerd in de figuren met de relatieve opbouw van de biomassa). De afname van de biomassa van Ensis leei is, in absolute termen, veruit het sterkst in de monsterpunten die tijdens T0 het sterkst werden bevist.

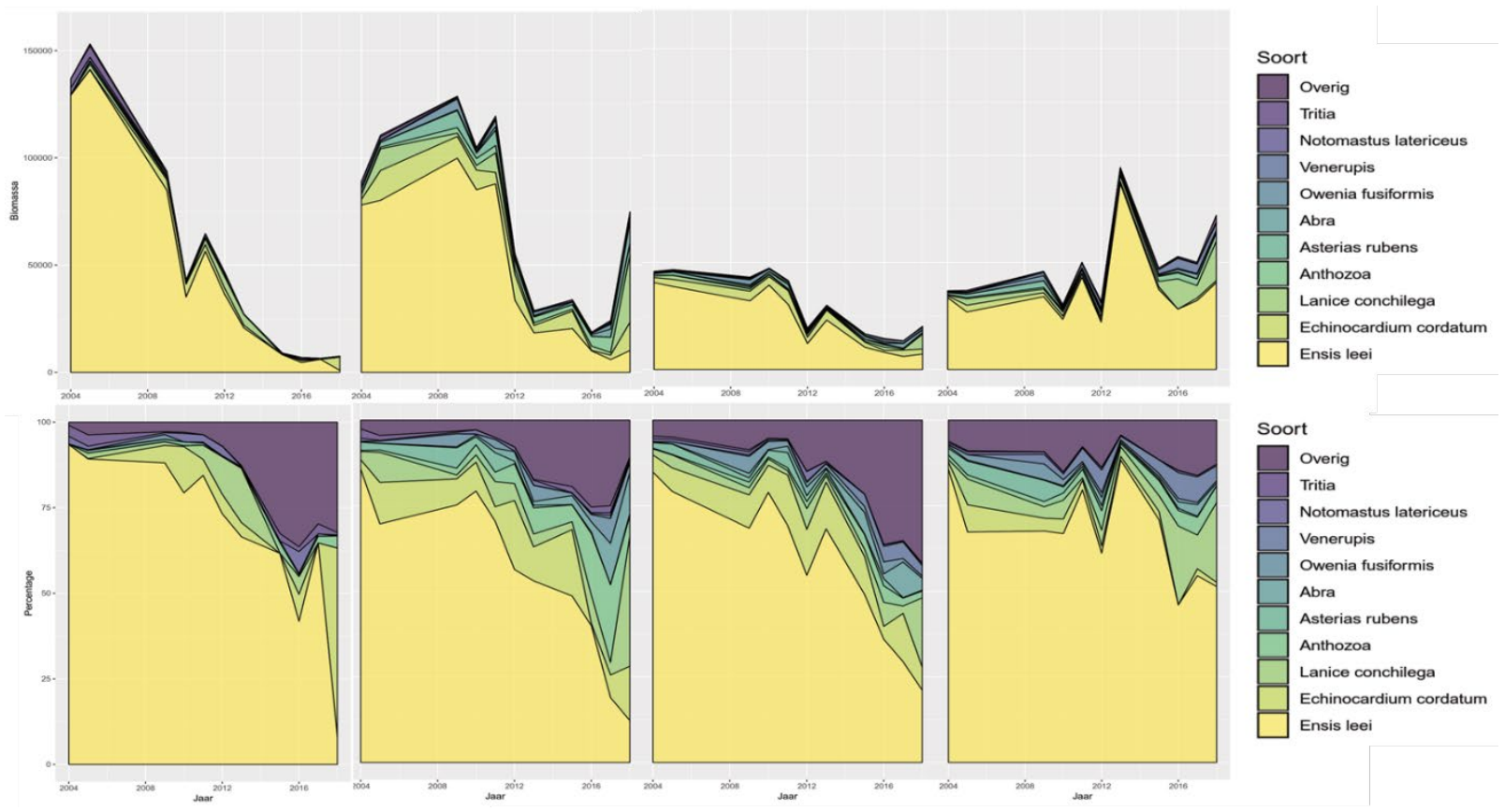

Figuur 6.8. Veranderingen in de cumulatieve biomassaverdeling over de soorten. Observatiepunten zijn gemiddeld in vier klassen, van links naar rechts. Links de klasse waarin de totale visserijdruk het sterkst is verminderd tussen TO en T2, en rechts een klasse waarin de totale visserijdruk is verhoogd. Voor totale visserijdruk is garnalenvisserij gewogen als 1/6 van boomkorvisserij. In elk van de bovenste figuren wordt de opbouw van de totale absolute biomassa door de soorten cumulatief getoond over de jaren. De onderste figuren tonen de relatieve verdeling van de biomassa over de soorten. De volgorde van de soorten is dezelfde in alle figuren, en werd bepaald door hun dominantierank in de totale dataset.

\subsubsection{Veranderingen in biodiversiteit op dichtheidsbasis}

Als maat voor de biodiversiteit op dichtheidsbasis, is de som van de log-getransformeerde dichtheden van de soorten in de gemeenschap gebruikt. Deze maat is even gevoelig voor een relatieve stijging in de dichtheid van de zeldzame soorten als in de meest abundante soorten. Het is daarom een maat die een volledig ander aspect van de gemeenschapssamenstelling weergeeft dan de Simpson diversiteitsmaat op biomassabasis. De laatste wordt vooral bepaald door het aandeel van de meest dominante soorten in de totale biomassa. Zij weegt de dichtheden dus naar individueel gewicht, en kijkt daarnaast vooral naar de dominante soorten.

De som van log-getransformeerde dichtheden vertoont een duidelijke stijging over het gehele gebied tijdens de studieperiode. In het BBG zijn de waarden in de meeste jaren iets hoger dan in REF, maar de stijging wordt in beide gebieden waargenomen (Figuur 6.9). 


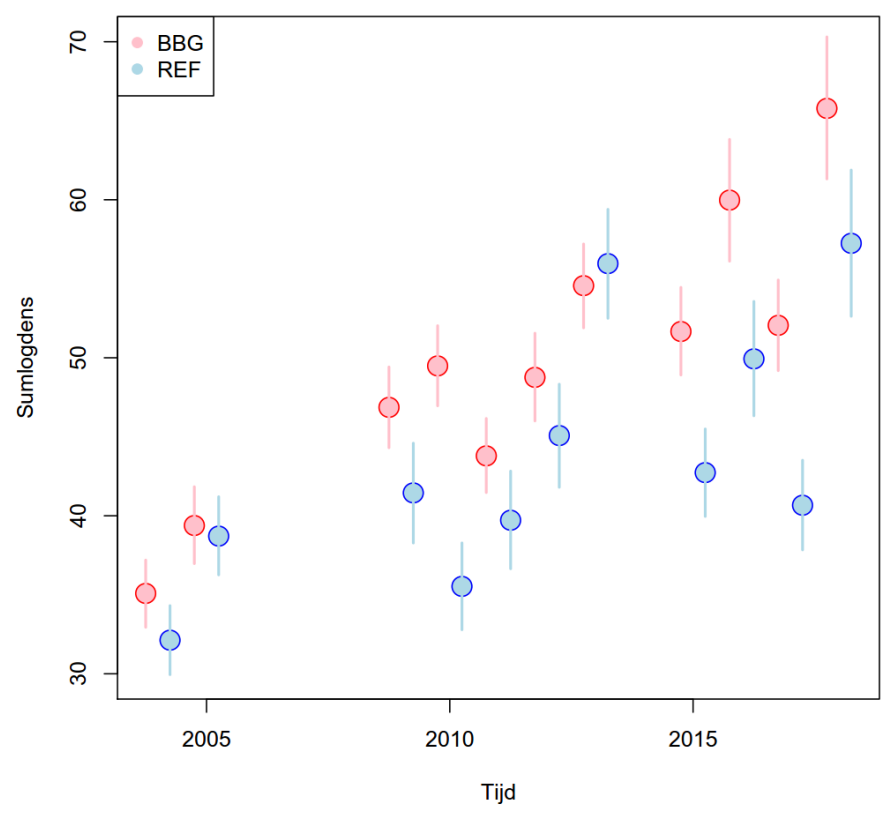

Figuur 6.9. Gemiddelde som van log-getransformeerde dichtheden van alle soorten per jaar en per gebied. Standaardfouten van het gemiddelde geven de variabiliteit tussen punten weer.

Een BACI analyse (zie hoofdstuk 2) toonde aan dat er een significant verschil bestaat tussen de twee gebieden en de drie perioden, maar geen significante interactie, m.a.w. geen significant verschil in hoe de twee gebieden in de tijd zijn veranderd.

Het ruimtelijk patroon van de som van log-getransformeerde dichtheden over de drie perioden geeft het volgende beeld (Figuur 6.10). Tijdens T0 was deze diversiteitsmaat over het algemeen laag, met hier en daar een uitschieter naar boven. Over de jaren wordt de achtergrondwaarde hoger. Locaties met zeer lage waarden tijdens T0, verhogen in de loop der tijd, maar er zijn ook een aantal locaties met hoge piekwaarden in T0 waarvan de waardes verminderen. Ondanks variabiliteit blijven de grotere ruimtelijke patronen tussen de periodes bewaard. Plaatselijke factoren, bijvoorbeeld diepte en blootstelling aan stroming en golven, hebben een invloed op de soortensamenstelling en diversiteit. Hierin zijn tijdens de studieperiode lokale veranderingen opgetreden door morfologische aanpassingen, naast een algemene lichte toename van de schuifspanning in het zeewaartse deel van de Voordelta (Figuur 6.7). Toch blijven die factoren over het grootste deel van het studiegebied grotendeels onveranderd in de tijd.

Naast plaatselijke variaties ontstaan er duidelijke zones met hoge diversiteit, op plaatsen waar dat voorheen niet het geval was. Het noorden van het studiegebied is een voorbeeld, in een soort sikkelvormige boog om de ondieptes van de Bollen van Goeree. Verder tonen de noordzijde van de Oosterscheldemonding en een gebiedje langs de noordkust van Schouwen ook een opvallende stijging. In dit gebied is deze mogelijk gebonden aan morfologische aanpassingen in het platen- en geulenpatroon. 


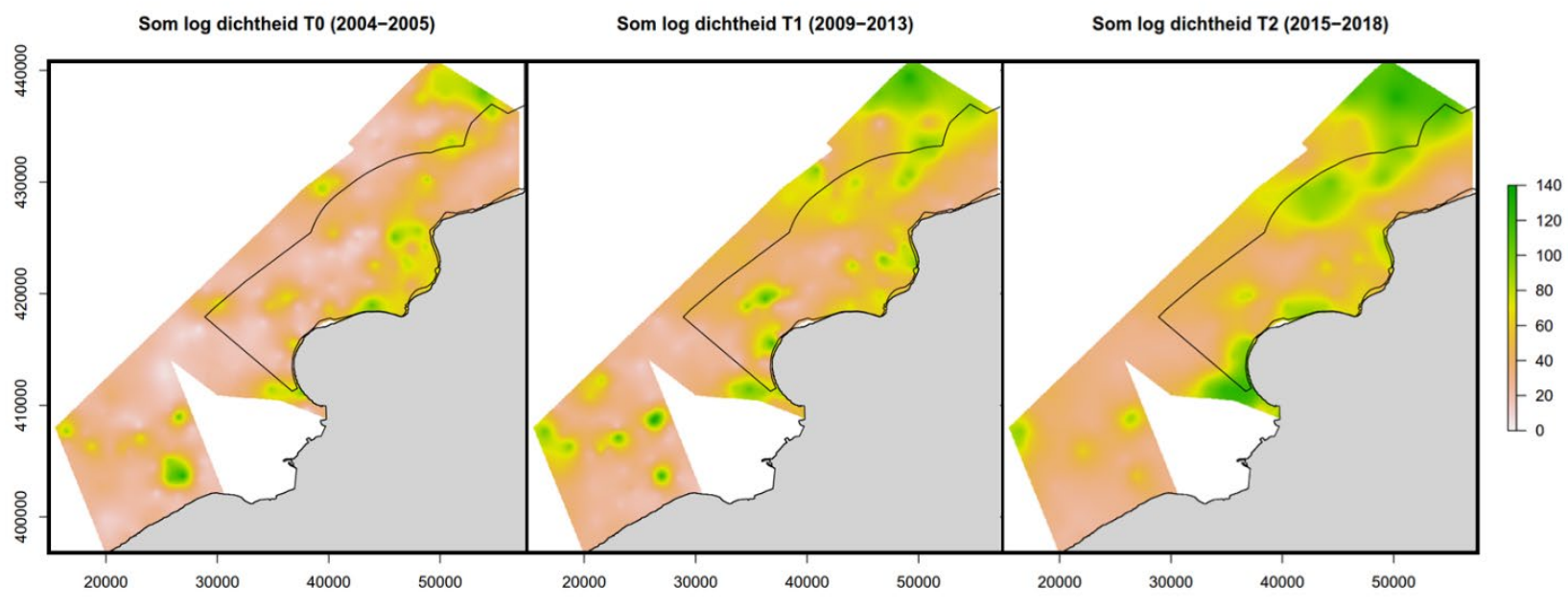

Figuur 6.10. Ruimtelijk patroon van de diversiteitsmaat 'som van log-getransformeerde dichtheden' voor de drie periodes.

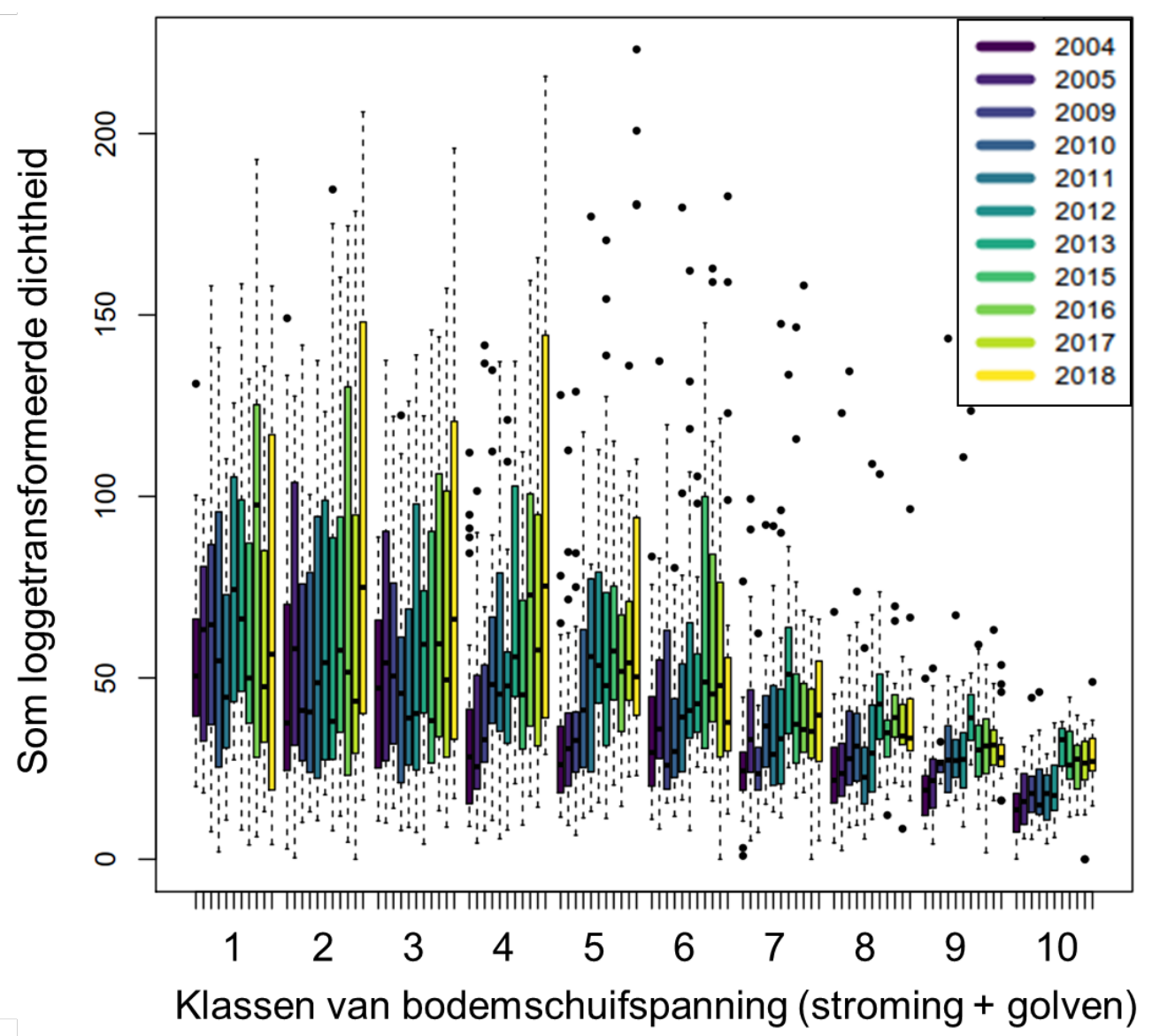

Figuur 6.11. Som van de log-getransformeerde dichtheden, als functie van de totale (stroming+golven) mediane bodemschuifspanning per jaar. De bodemschuifspanning is in 10 klassen met een gelijk aantal monsters verdeeld voor deze analyse. Binnen elk van die klassen wordt getoond hoe de indicator verandert over de tijd. 
We hebben geen duidelijke correlatie gevonden tussen de stijging van de diversiteit op dichtheidsbasis en één van de bestudeerde omgevingsvariabelen, of één van de maten voor visserij-intensiteit. Noch de veranderingen in boomkorvisserij, noch die in garnalenvisserij correleren heel duidelijk met de veranderingen in diversiteit.

De som van log-getransformeerde dichtheden correleert globaal met bodemschuifspanning. De hoogste diversiteit wordt gevonden op de fysisch minst blootgestelde plaatsen (Figuur 6.11). Maar binnen elk van de klassen van bodemschuifspanning, op de eerste na, observeren we ongeveer dezelfde stijging van som van log-getransformeerde dichtheden over de tijd. In de groep stations met de laagste bodemschuifspanning, tegen de Brouwersdam, is geen stijging van diversiteit in de tijd te merken omdat de diversiteit tijdens T0 reeds vrij hoog was. De meest uitgesproken stijging over de tijd is er bij gemiddelde bodemschuifspanning, een klasse die het gebied in het noorden van het studiegebied omvat.

We vermoeden dat de verandering in deze diversiteitsmaat, die vooral wordt bepaald door de relatief zeldzame en kleine soorten, eerder van biologische dan van fysische factoren afhankelijk is. Daarvoor hebben we twee sleutelsoorten bekeken: de biomassadominant Ensis leei, en de predator/omnivoor Ophiura ophiura, de slangster, die in de visserijgegevens uit de Demersal Fish Survey (DFS, zie paragraaf 6.2.2.1) grote schommelingen in de tijd vertoont in de hele Nederlandse kustzone.

\subsubsection{Veranderingen in de biomassa van Ensis leei}

Over de tijd is er een sterke afname van Ensis leei in het meest zeewaartse gebied ter hoogte van Walcheren, en ten westen van het BBG (Figuur 6.12). In het BBG is de biomassa min of meer stabiel, maar concentreert ze zich voornamelijk in de gebieden met intensieve garnalenvisserij. In de periode T0 is de biomassa vooral geassocieerd met gebieden met hoge visserijdruk door boomkorvisserij. Alleen de zone voor de Brouwersdam vormt hierop een uitzondering. Deze zone (waar garnalenvisserij afwezig is) is ook in T2 nog steeds een gebied met hoge dichtheden van Ensis.

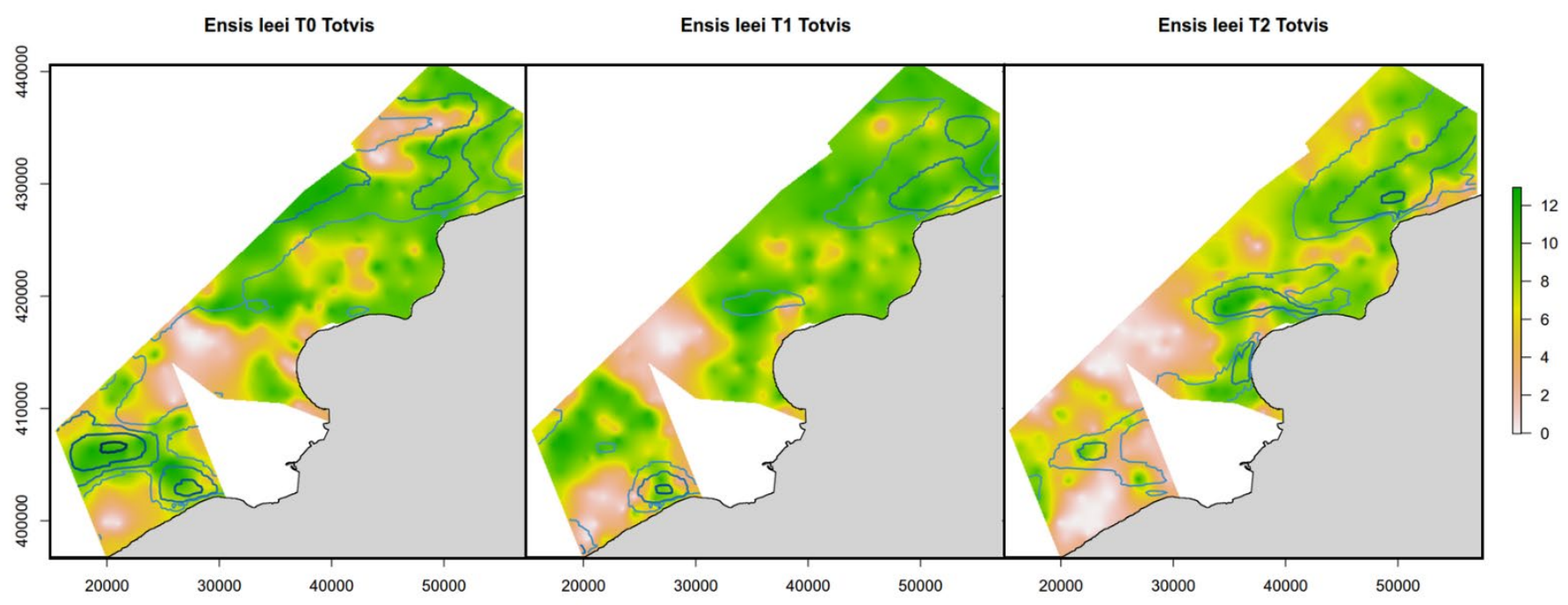

Figuur 6.12. Biomassa (log-getransformeerd) van Ensis leei, met daarop gesuperponeerd isolijnen van totale visserij-intensiteit (waarbij garnalenvisserij een gewicht 1/6 kreeg t.o.v. boomkorvisserij). De visserijdruk in TO komt bijna uitsluitend voort uit boomkorvisserij. In T2 is alleen garnalenvisserij van belang. De isolijnen zijn gekleurd van lichtblauw naar donkerblauw bij stijgende visserij-intensiteit.

De veranderingen in de biomassa van Ensis leei zijn grotendeels verantwoordelijk voor de veranderingen in totale biomassa bodemdieren (Figuur 6.8). Wellicht bepaalt de soort ook, door concurrentie, hoe de andere soorten zich in de gemeenschap kunnen verhouden. 
Ensis leei is een zeer mobiele soort, die zich razendsnel verticaal kan bewegen door het sediment en ook in staat is te zwemmen. Daardoor is ze waarschijnlijk zeer goed bestand tegen visserijdruk. De soort is voor vestiging afhankelijk van recruteringspieken die niet elk jaar voorkomen. Op de langere termijn moet de aanwezigheid van biomassa dus ook te maken hebben met de ruimtelijke verspreiding van de goede recruteringsplaatsen, en daarmee misschien ook met de aanwezigheid van predatoren. De zeer belangrijke rol van predatie in de recrutering van schelpdieren is voor kokkels en mosselen in de Waddenzee bijvoorbeeld zeer goed aangetoond (Beukema en Dekker, 2014). Vergelijkbare detailstudies ontbreken voor de kustzone, maar de statistische patronen in de recrutering, met vele jaren waarin recrutering laag is en nu en dan een jaar met een sterke piek (Perdon et al., 2019), zijn gelijkaardig aan wat wordt geobserveerd bij schelpdieren op het wad. Witbaard et al. (2015) beschrijven hoe een cohort, na een hoge recrutering, langzaam in dichtheid terugloopt over meerdere jaren. Deze auteurs stellen dat recrutering niet wordt geobserveerd bij een hoge dichtheid van grote exemplaren.

\subsubsection{Veranderingen in de biomassa van de slangster Ophiura ophiura}

Eén van de meest opvallende trends bij de vis- en epifauna (zie paragraaf 6.2.2.1) is de sterke ontwikkeling van slangsterren vanaf ongeveer 2009. Deze ontwikkeling is sterker in de Voordelta dan in andere Nederlandse kustgebieden qua aantallen, maar de timing is gelijkaardig. Slangsterren zijn predatoren en omnivoren. Zij kunnen zich onder andere voeden met dode organismen, en worden daardoor mogelijk bevorderd door visserij als veel discards op de bodem terechtkomen. Zij zijn ook predatoren op Polychaeten en kleinere schelpdieren. In de boomkorvisserij worden ze vaak in grote hoeveelheden mee opgevist. $\mathrm{Er}$ is in de literatuur controverse over hun overlevingskans na opvissen. Deze wordt relatief hoog ingeschat door meerdere auteurs (Kaiser en Spencer, 1995; Bergman en van Santbrink, 2000), maar Bergmann en Moore (2001) betwijfelen deze resultaten en stellen dat de overleving op een termijn van meerdere weken nihil is. Met experimenten die 60 uur duurden, konden Depestele et al., (2014) de hoge mortaliteit niet bevestigen. Zij observeerden een overleving van $96 \%$ na deze 2,5 dagen. Het blijft onduidelijk of er een relatie is tussen slangsterren en visserij, en wat de precieze aard van die relatie is.

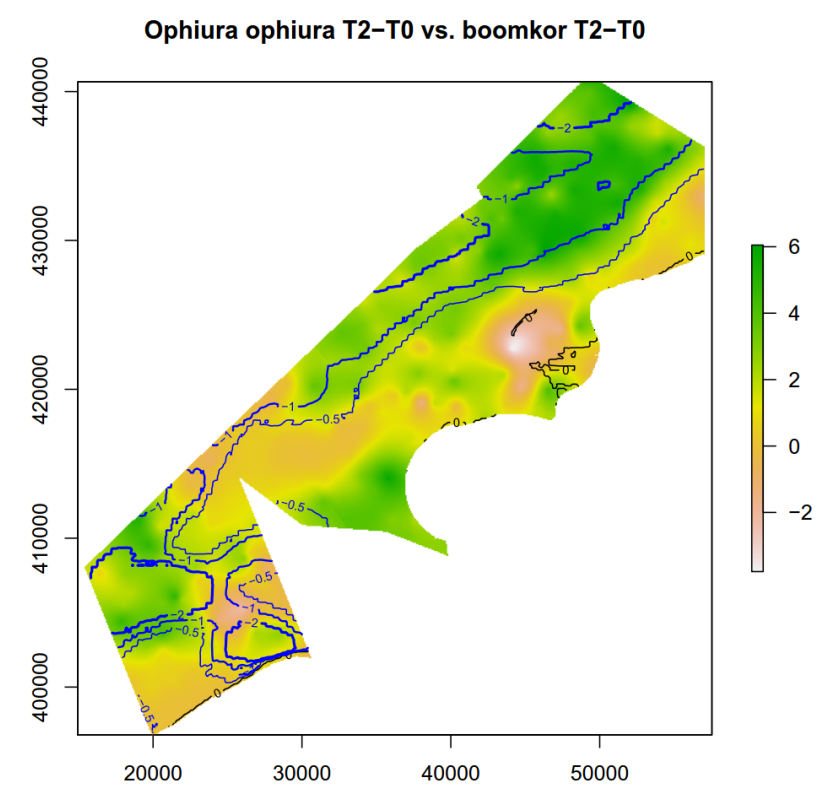

Figuur 6.13. Veranderingen in de biomassa van Ophiura ophiura tussen T0 en T2. Gesuperponeerd zijn contourlijnen van de verandering in intensiteit van boomkorvisserij in dezelfde periode. Op een klein gebied in de noordelijke Oosterscheldemond na, zijn toenames van slangsterren ruimtelijk sterk gecorreleerd met afname van de boomkorvisserij. 
In de Voordelta zijn de veranderingen in het voorkomen van slangsterren ruimtelijk gecorreleerd met de veranderingen in de visserij-intensiteit, vooral door boomkorvisserij (Figuur 6.13). We vonden geen ruimtelijke correlatie met veranderingen in garnalenvisserij.

\subsubsection{Deelconclusies}

Analyse van de biomassaverdeling over de soorten in gemeenschappen die een verschillende trend in visserijdruk hebben ondergaan, toont duidelijk de centrale rol aan van Ensis leei in het structureren van deze gemeenschappen.

In tegenstelling tot de Simpson diversiteit op biomassabasis, is de trend in diversiteit op dichtheidsbasis (som van loggetransformeerde dichtheden) niet duidelijk gecorreleerd met veranderingen in visserijdruk. Hoewel de diversiteit een duidelijk negatief verband heeft met bodemschuifspanning, en over het algemeen het hoogst is in weinig blootgestelde gebieden, neemt de diversiteit in ongeveer alle klassen van bodemschuifspanning op dezelfde wijze toe in de tijd.

Wij vermoeden dat biologische relaties een rol spelen in de bepaling van de diversiteit van de gemeenschappen. De ruimtelijke verspreiding in de Voordelta van twee sleutelsoorten, Ensis leei en de slangster Ophiura ophiura, vertoont een patroon dat gerelateerd is aan de ruimtelijke verspreiding van alle visserij (in het geval van $E$. leei) of boomkorvisserij (in het geval van $O$. ophiura).

Recruteringsprocessen zouden belangrijk kunnen zijn in de link tussen de bodemdiergemeenschap en visserij, maar het ontbreekt aan gedetailleerd inzicht in deze processen.

\subsubsection{Discussie bodemdieren}

\subsubsection{Relatie visserij-biomassa afgeleid uit monitoring Voordelta}

De waargenomen veranderingen in totale biomassa en in de verdeling van biomassa over de soorten correleren met de ruimtelijke verdeling van de verandering in visserij-inspanning. De visserij-inspanning door boomkorvisserij is vooral afgenomen in het westelijke en zuidelijke referentiegebied. De afname in het BBG was minder omdat bij aanvang van de studie al weinig boomkorvisserij in het BBG voorkwam. Dit patroon in visserij correspondeert met het gebied waar de biomassa van Ensis leei, en daardoor de totale biomassa, is afgenomen. In het BBG is de totale visserij-inspanning (door garnalenvisserij) toegenomen. Dit komt overeen met de zone waarin de biomassa licht is toegenomen. De data wijzen op een correlatie tussen toename van visserijdruk en toename van biomassa, en vice versa. Deze correlatie is in duidelijke tegenspraak met de verwachtingen uitgesproken in het rapport van Rijnsdorp et al. (2006).

\subsection{Ruimtelijke selectiviteit van visserij}

We kunnen echter niet concluderen dat de waargenomen correlatie ook als een causale relatie is te interpreteren. Daarbij spelen meerdere overwegingen. Allereerst is de ruimtelijke selectiviteit van de visserij van belang. Visserij concentreert zich - uiteraard - op plaatsen met veel vis. Dat zijn meestal ook plaatsen met een rijke bodemdiergemeenschap. Die ruimtelijke selectiviteit van vissers leidt dus tot een positieve correlatie tussen visserij-inspanning en rijkdom van de bodemdiergemeenschap. Voor de garnalenvisserij in de Voordelta, die tussen T0 en T2 sterk is toegenomen, zou dit een verklaring kunnen leveren voor de positieve correlatie tussen toename van de visserij en toename van de biomassa. Bij de uitvoering van hun (verhoogde) inspanning kunnen de vissers zich richten op die plaatsen waar ook de biomassa van bodemdieren is toegenomen, wat kan leiden tot de geobserveerde correlatie.

Een dergelijke redenering is echter waarschijnlijk niet van toepassing voor de boomkorvisserij. De intensiteit van de visserij is sinds het begin van de jaren 2000 sterk afgenomen, maar de relatieve ruimtelijke patronen zijn gelijk gebleven. Er zijn geen aanwijzingen dat de vissers selectief hun activiteit hebben verlaagd in gebieden waar, voorafgaand aan die beslissing, de biomassa al was achteruitgegaan. Ook voor het gebied als geheel geldt dat de achteruitgang van de biomassa, en de gelijkere verdeling van de biomassa over de soorten, is geobserveerd enkele jaren nadat de visserij was verminderd. 
Onderzoek bij vissers toonde ook aan dat de boomkorvloot de Voordelta heeft verlaten om redenen die weinig of niets met de natuurcompensatiemaatregelen in de Voordelta te maken hebben, en de afname van boomkorvisserij speelt ook in andere delen van de Nederlandse kustwateren. We concluderen daarom dat de correlatie in ruimte en tijd tussen de vermindering van de biomassa van bodemdieren en de vermindering van de activiteit van de boomkorvisserij, niet zijn veroorzaakt door een (eventueel indirecte) respons van de visserij op de ontwikkeling van bodemdieren. Het feit dat de correlatie tussen bodemdieren en boomkorvisserij, op gelijkaardige maar minder intensieve manier is herhaald met de garnalenvisserij (maar dan omgekeerd), suggereert bovendien dat beide vormen van visserij procesmatig een zelfde relatie met bodemdiergemeenschappen hebben. Dat makt het minder waarschijnlijk dat ruimtelijke selectiviteit voor garnalenvisserij wel, maar voor boomkorvisserij niet van invloed is geweest.

\subsection{Veranderingen in omgeving}

Een tweede alternatieve verklaring voor de geobserveerde correlatie tussen bodemdierenbiomassa en intensiteit van de boomkorvisserij, is dat iets is veranderd in de omgevingsvariabelen, waardoor de biomassa is afgenomen op plaatsen die voorheen het meest geschikt waren voor visserij. In het geval van de Voordelta is de meest voor de hand liggende externe oorzaak een verandering van stromings- en sedimentatiepatronen. Het gebied is al morfologisch in evolutie sinds de jaren 1960 (zie hoofdstuk 4), in respons op de veranderingen aan de kust en de uitbreiding van de haven. De morfologische veranderingen leiden tot een ruimtelijke verschuiving van de plaatsen waar golfenergie tot maximale bodemschuifspanning leidt. Dergelijke veranderingen zijn opgetreden tijdens de duur van de monitoringstudie, maar de effecten zijn lokaal en spelen niet op de schaal van het gehele gebied waar de grote veranderingen in bodemdierfauna worden geobserveerd. Wel op de schaal van het gehele gebied zijn de recente wijzigingen in de getijstroming als gevolg van de aanleg van de Maasvlakte 2 . Deze aanleg heeft de getijstroming verder van de kust geduwd, met luwere condities dicht bij de kust, en ruwere condities verder op zee als gevolg. Dit patroon kan inderdaad worden teruggevonden in de resultaten van de modelstudies (Figuur 6.7). In het westelijke en zuidelijke gebied is de schuifspanning licht toegenomen (met ongeveer $0,1 \mathrm{~Pa}$ ), terwijl ze in de gebieden nabij de kust van Schouwen en Goeree, en in het gebied ten zuidwesten van Maasvlakte 2, licht is afgenomen met ongeveer 0,1-0,5 Pa. Met uitzondering van lokale fluctuaties die te maken hebben met migratie van enkele geulen en platen, is de verandering vrij homogeen. Alleen op grove schaal komt het patroon overeen met het patroon in de verandering van biomassa van Ensis. Wij hebben de verandering in bodemschuifspanning toegevoegd aan het lineair model voor de verklaring van biomassaveranderingen, maar dit leverde geen significante termen (voor direct effect van bodemschuifspanning of voor interactie met verandering in visserij) op (niet getoonde resultaten). Het lijkt weinig waarschijnlijk dat de kleine veranderingen in bodemschuifspanning (orde 0,1 Pa in een range van 0-6 Pa) een alternatieve verklaring als gemeenschappelijke externe factor kunnen vormen.

\subsection{Biologische interacties}

Een derde alternatieve verklaring voor de correlatie is dat deze het gevolg is van ruimtelijk heterogene biologische processen in de bodemdiergemeenschap die niet gerelateerd zijn aan veranderingen in de visserijdruk. Van Hoey et al. (2007) beschrijven een serie veranderingen in een Abra alba gemeenschap voor de Belgische kust, die het gevolg waren van een sterke recrutering van Spisula subtruncata. Deze biomassadominant beïnvloedde de andere soorten waarschijnlijk via directe concurrentie, maar ook via de abiotische condities in het sediment. Na de recrutering verhoogde het slibgehalte van het sediment en trad massamortaliteit van juveniele Spisula en andere schelpdieren op. De dichtheid van veel geassocieerde soorten, bv. Spio, Magelona, Lanice, Donax en andere, nam drastisch af als gevolg van deze veranderingen. Het duurde meerdere jaren voordat de gemeenschap ongeveer in de oude staat terugkeerde, met opnieuw een overwegend fijnzandig sediment en de karakteristieke levensgemeenschap.

In de tijdserie van de Voordelta zijn analogieën te vinden met deze ontwikkeling, zij het ook met duidelijke verschillen. Bij het begin van de PMR tijdserie was niet Spisula maar Ensis leei de biomassadominant. Hoewel uit experimenteel werk bekend is dat Ensis leei het sediment met slib kan 
aanrijken (Witbaard et al., 2017) zijn er in de sedimentgegevens van de Voordelta geen argumenten te vinden voor interspecifieke interacties via beïnvloeding van het sediment. Slibgehalte is bij iedere bodemdierbemonstering bepaald als onderdeel van de korrelgrootte-analyse, dus variaties hierin zouden in de dataset duidelijk naar voren moeten komen. Van Moorsel et al. (2020) hebben in meer detail naar de korrelgrootte in de monsters gekeken, maar geen opvallende trends gevonden. Wat wel gelijkaardig is tussen de Voordelta en de recrutering beschreven door van Hoey et al. (2007), is dat de hoge biomassa van de dominante soort geassocieerd is met een lage dichtheid en biomassa van secundaire soorten. Dit zijn bovendien overwegend dezelfde soorten als gerapporteerd door van Hoey et al. (2007). De ontwikkeling van de biomassa van enkele van deze soorten wordt geïllustreerd in Figuur 6.14. De ruimtelijke patronen in de ontwikkeling van elk van deze soorten zijn niet identiek, maar samen tonen zij een sterke toename van de biomassa in het gebied dat tijdens T0 sterk werd gedomineerd door Ensis leei, en waar die soort aanzienlijk in biomassa is teruggelopen.

\subsection{Visserij en recruteringsprocessen van fauna}

De centrale vraag is dan of boomkorvisserij een rol heeft gespeeld in de recrutering van Ensis leei tijdens 8de jaren 1990 of begin jaren 2000. De verspreiding van biomassa van de soort tijdens T0 komt grotendeels, maar niet volledig overeen met de verspreiding van de visserij met boomkorren (Figuur 6.12). De hoge biomassa in het gebied vóór de Brouwersdam vormt een uitzondering op de correlatie, maar overigens is de overeenkomst groot. De verspreiding van de soort in T2 heeft ook een opvallende overeenkomst met de verspreiding van de garnalenvisserij. De ruimtelijke verspreiding van Ensis leei wordt sterk bepaald door omgevingsfactoren, in het bijzonder de diepte en waarschijnlijk ook de samenstelling van het sediment (Witbaard et al., 2017). Die kenmerkende factoren zijn in de Voordelta niet in dezelfde mate veranderd als de visserijdruk, waardoor ze geen duidelijke alternatieve verklaring vormen.

Oude gegevens over de bodemdieren in de Voordelta uit de jaren 1980 (Craeymeersch et al., 1990) tonen aan dat de structuur van de gemeenschap in de jaren 1980 sterker leek op de structuur in de T2 periode van PMR dan op die van de T0 periode. Kenmerkende soorten als Spio, Fabulina, Spisula hebben verspreidingen die sterk lijken op die uit de T2 periode (Figuur 6.14). Voor andere soorten, zoals Magelona en Abra, overtreffen de dichtheden in T2 die van de jaren tachtig, maar zijn de ruimtelijke patronen zeer gelijkend. Merk op dat de bemonsteringsdichtheid in de jaren tachtig lager was dan in het PMR programma, en dat er alleen met een boxcore (niet met een combinatie boxcore-schaaf) is gewerkt. Dit beperkt de absolute vergelijkbaarheid van de cijfers enigszins. 


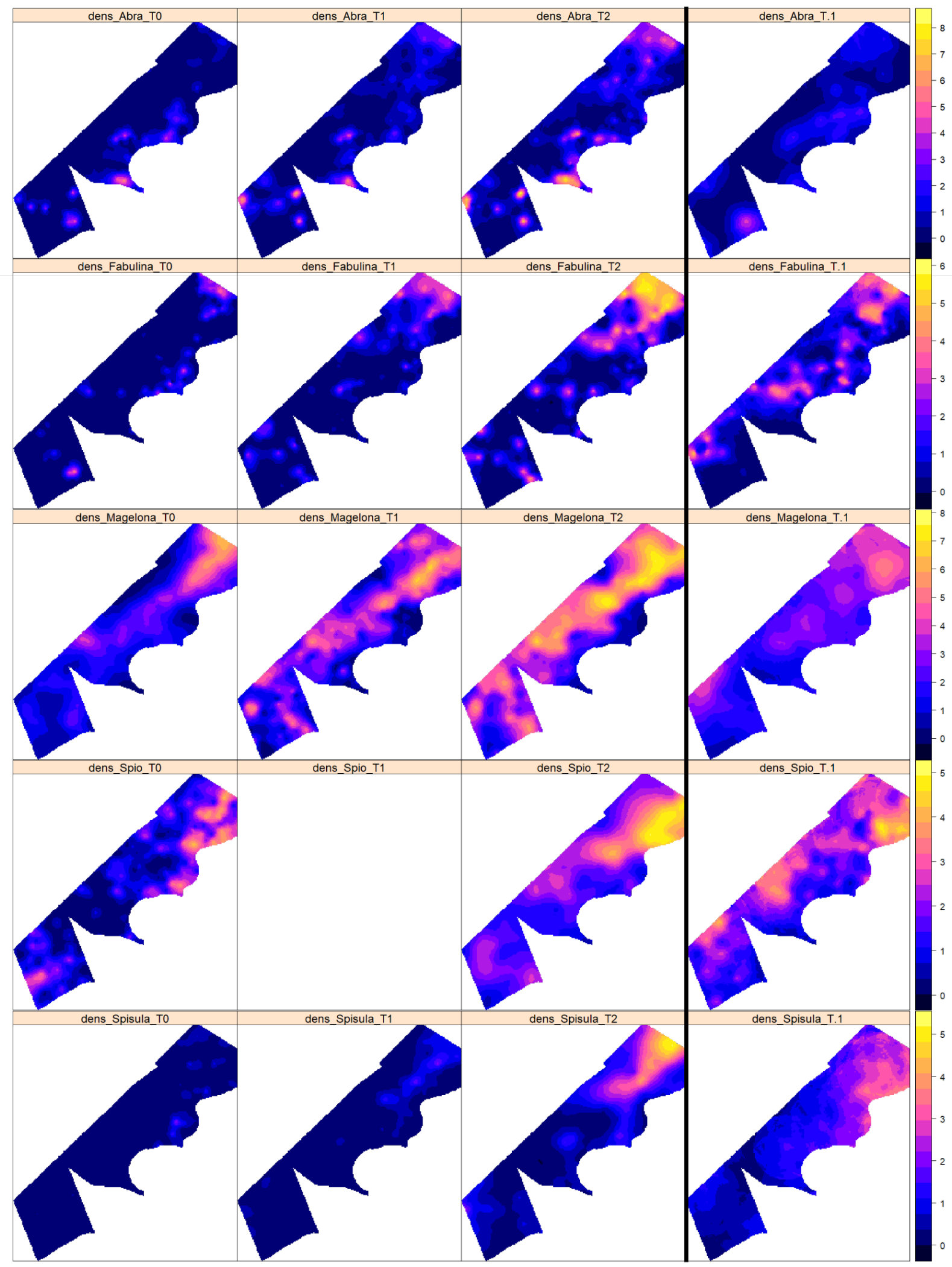

Figuur 6.14. Ruimtelijk verspreidingspatroon tijdens de periodes T0, T1 en T2 en in de jaren 1984-1986 ("T-1") van een aantal soorten uit de Abra alba gemeenschap: Abra alba, Fabulina fabula, Magelona, Spio, Spiophanes, Spisula. De schalen verschillen per soort, maar zijn voor de vier periodes per soort gelijk. Alle figuren zijn gebaseerd op log-getransformeerde dichtheid. De periode $T$-1 is volledig rechts weergegeven, om gemakkelijker te kunnen vergelijken met de periode $T 2$. 


\subsubsection{Experimentele benaderingen van visserij-bodemdier relaties}

Dat er een mogelijk causale relatie bestaat tussen het voorkomen van Ensis leei en visserij, wordt aangetoond door Tulp et al. (2020), die een sterke toename van Ensis na experimentele bevissing in de Waddenzee beschrijven. Zij tonen ook experimenteel aan dat de 'evenness' van de gemeenschap exponentieel afneemt bij intensieve bevissing. Het betreft garnalenvisserij die is toegepast in een experiment met een controlegebied dat visserijvrij is gebleven. De respons is gevonden op zeer korte termijn (minder dan twee maanden na de bevissing), en suggereert dat actief gedrag van Ensis aan de basis hiervan kan liggen. Ensis leei kan visserijtuigen goed ontwijken en is in staat om zeer snel leeg habitat te koloniseren. Jonge individuen kunnen migreren met behulp van een byssusdraad; oudere individuen kunnen het sediment verlaten en zich zwemmend voortbewegen (Swennen et al., 1985). De tijdschaal van de respons beschreven door Tulp et al. (2020) verschilt van de hier beschreven waarnemingen in de Voordelta, die veeleer op de tijdschaal van recruteringsprocessen dan op die van actieve verplaatsing spelen. Het is mogelijk dat recrutering van de soort wordt bevorderd door verstoring van sediment en het wegnemen van concurrenten of predatoren.

Een experiment in de Voordelta, bedoeld om de effecten van garnalenvisserij op bodemdieren na te gaan, leverde niet hetzelfde resultaat op als het experiment in de Waddenzee (Schellekens et al., 2014). In zes proefgebieden was een strook ( $75 \mathrm{~m}$ breed) regelmatig experimenteel bevist, terwijl een aangrenzende strook van dezelfde breedte in principe niet werd bevist. In de praktijk was er toch vissserij-activiteit in de controlestrook, waardoor dit experiment niet volledig is gelukt. De grote variatie tussen proefgebieden, en binnen de proefgebieden tussen verschillende delen van de experimentele stroken, maakte het niet mogelijk een significant effect van visserij te detecteren. Het is mogelijk dat effecten van visserij op een grotere schaal spelen dan de zeer smalle stroken die hier als proefvakken waren gebruikt. Het grootste verschil zat echter in de intensiteit van de experimentele bevissing, die in het Voordelta-experiment laag was (6 keer per jaar éénmaal vissen) en in de Waddenzee veel hoger (1 tot 4 passages per week). Effecten in de Waddenzeestudie traden vooral op bij de hogere intensiteiten van bevissing (Tulp, pers. comm.).

\subsubsection{Kennis van visserij-bodemdier relaties uit andere studies. BENTHIS}

Eerdere studies naar de effecten van boomkorvisserij op bodemdieren kwamen tot duidelijke conclusies over effecten in dieper water met fysisch relatief onberoerde sedimenten. Hiddink et al. (2017) baseerden zich op een meta-analyse om een vermindering van de bodemdierbiomassa met toenemende intensiteit van visserijverstoring te beschrijven. Deze publicatie is onderdeel van het project BENTHIS, dat uitgebreid onderzoek naar de relatie tussen visserij en bodemdieren heeft gedaan. Eén van de resultaten is een classificatie van bodemberoerende visserij-activiteiten, waaruit blijkt dat het effect op bodemdieren vooral schaalt met de diepte tot waar het tuig de bodem binnendringt. Hoewel positieve veranderingen van bodemdierbiomassa met visserijverstoring weinig of niet worden beschreven, komen ze wel voor in de metastudie van Hiddink et al. (2017), al is het niet duidelijk of hier sprake is van een causaal positief verband of het ontbreken van een verband in aanwezigheid van natuurlijke variatie.

Hiddink et al. (2017) beschrijven een oplopende relatie tussen hersteltijd en de ernst van de aantasting van het bodemdierleven door visserij. Hersteltijden kunnen oplopen tot tien jaar wanneer de aantasting van de oorspronkelijke gemeenschap zeer sterk is. Als intensieve verstoring door visserij inderdaad aanleiding geeft tot zeer lange hersteltijden, dan kan worden verwacht dat bij die intensieve verstoringen de onmiddellijke mortaliteit van bodemdieren na passage van een vistuig klein is: door de lange hersteltijd is er immers nog (bijna) niets om opnieuw dood te maken. Het illustreert dat gemakkelijk een situatie van 'shifting baselines' kan ontstaan: een situatie waarin weinig of niets verandert bij een lichte toename of afname van de verstorende factor, niet omdat die factor niet van belang is maar precies omdat die factor zo belangrijk is dat het hele systeem eraan aangepast is en niet onmiddellijk naar de onverstoorde toestand kan terugkeren.

Rijnsdorp et al. (2018) gaan vooral in op veranderingen in functionele kenmerken van bodemdieren als gevolg van verstoringen. Vooral langlevende, traag reproducerende soorten verminderen in biomassa als gevolg van visserij, omdat zelfs een occasionele verstoring pas over een lange periode kan worden 
hersteld. Ook andere kenmerken kunnen in de respons een rol spelen. Meestal zijn kenmerken van soorten sterk onderling gecorreleerd, zodat het vaak niet duidelijk is welke kenmerken de meest directe relatie hebben met de oorzakelijke factor zoals visserij en welke kenmerken covariëren met die kenmerken die rechtstreeks worden beïnvloed (Beauchard et al., 2017).

Over het algemeen worden kleinere of geen effecten van visserij beschreven in mobiele sedimenten die sterk onder invloed staan van natuurlijke fysische factoren, zoals de zandige delen van het NCP die worden gekarakteriseerd door zandgolven (Rijnsdorp et al., 2018; van Denderen et al. 2014). Dat kan een gevolg zijn van de grote variatie en relatief lage gemiddelde biomassa in fysisch verstoorde sedimenten, het optreden van natuurlijke verstoring die zo hoog is dat visserijverstoring ertegen in het niet valt, of de selectieve overleving van mobiele en kleine soorten die vistuigen gemakkelijk kunnen ontwijken of zich als populatie zeer snel kunnen herstellen.

Hoewel elk van de elementen in de recente studies naar visserij-bodemdier interacties kunnen leiden tot een nuancering en bijstelling van de hypotheses die gebruikt zijn door Rijnsdorp et al. (2006) als basis voor de compensatie, zijn er geen elementen die echt in tegenstrijd zijn met de opvattingen zoals die in 2006 golden, en zoals die bijvoorbeeld in het model van Duplisea et al. (2002) zijn verwoord. Ook de resultaten van het BENTHIS programma tonen aan dat, als regel, een toename van visserijverstoring leidt tot een afname van biomassa van bodemdieren, en dan vooral van de kwetsbare soorten bodemdieren. Nuanceringen zijn dat de effecten in het model van Duplisea et al. (2002) waarschijnlijk zijn overschat, zeker voor toepassing in mobiele sedimenten. Op basis van de meer recente inschattingen van het effect van bodemberoerende visserij op bodemdieren zou niet zijn voorspeld dat het verbieden van boomkorvisserij in het Bodembeschermingsgebied tot een toename van $10 \%$ van de bodemdierbiomassa zou leiden. Echter, de geobserveerde afname van de biomassa op de punten waar de visserij is afgenomen in intensiteit is in kwalitatieve tegenspraak met het model van Duplisea et al. (2002) en wordt ook op basis van de recente resultaten van BENTHIS niet verwacht.

Hintzen en Beier (2020) hebben de rekenmethode uit het BENTHIS project (Rijnsdorp et al., 2016) toegepast op de Voordelta, en een inschatting gemaakt van de effecten die volgens de huidige stand van de kennis worden verwacht na het stoppen van de boomkorvisserij in het gebied, of na het toenemen van de garnalenvisserij. Verschillende scenario's geven verschillende resultaten, maar de essentie van hun resultaten is dat voor geen enkel scenario van visserij in de Voordelta een verandering in bodemdierbiomassa van meer dan enkele procentpunten wordt verwacht. De verwachte effecten zijn één tot twee orden van grootte kleiner dan de geobserveerde veranderingen in de biomassa van de bodemdieren. Kwalitatief wordt verwacht dat vermindering van visserij aanleiding geeft tot (een zeer kleine) verhoging van biomassa van de bodemdieren.

\subsubsection{Dynamiek van de invasie door Ensis leei in de Nederlandse kustzone}

Het is mogelijk dat de afname van de biomassa en de verhoging van de diversiteit op biomassabasis, die op vele punten van de Voordelta is waargenomen tussen T0 en T2, volledig onafhankelijk is van de ontwikkeling van de visserij-inspanning en als een autonoom proces moet worden beschreven. Dit proces zou een voorbeeld kunnen zijn van een invasieve soort (Ensis leei) die na een aanvankelijke invasie de eerste ziektes of vijanden ontmoet, en als gevolg daarvan aanzienlijk in dominantie afneemt. Op de schaal van de Nederlandse kust wordt dit echter niet waargenomen. De populatie van Ensis leei is exponentieel gegroeid tussen 2000 en 2010. Die ontwikkeling is synchroon verlopen over de Nederlandse kustzone. Daarna is de populatiegrootte sterk wisselend van jaar tot jaar, zonder duidelijke trend (Perdon et al. 2019, zie Figuur 6.15). De laatste tien jaren zijn er sterke schommelingen in de totale dichtheid. Die hangen samen met jaren van hoge en lage recrutering. Ondanks die schommelingen is er geen sprake van het instorten van een invasieve exoot na een aanvankelijke periode van expansie. 


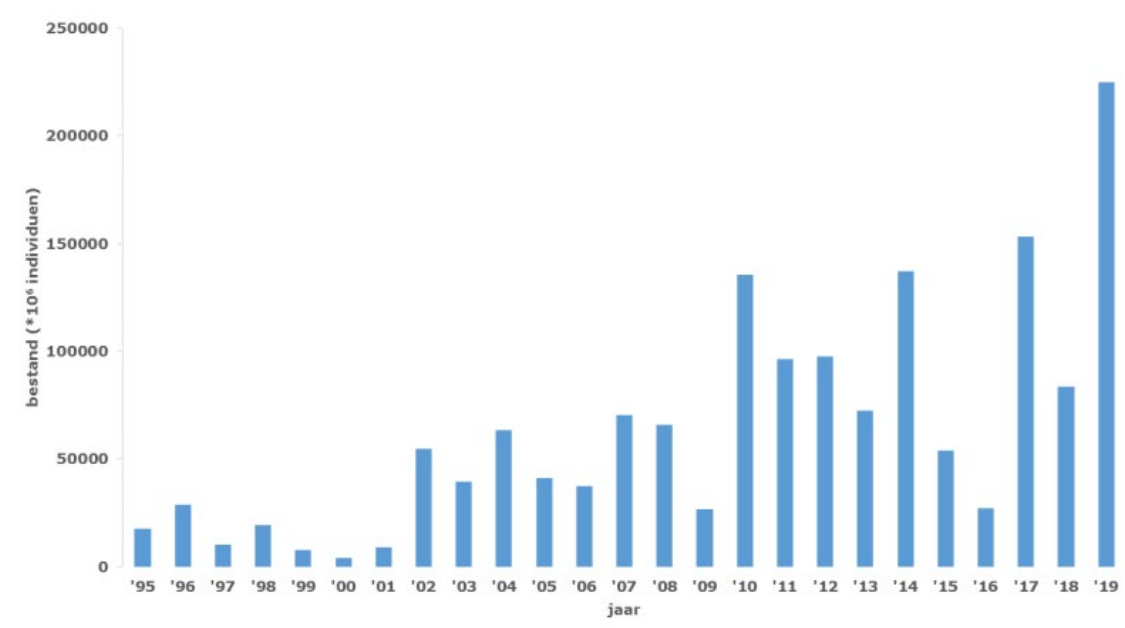

Figuur 6.15. Ontwikkeling van het bestand van Ensis leei in de Nederlandse kustwateren, gebaseerd op de jaarlijkse WOT schelpdiersurvey. Overgenomen uit Perdon et al. (2019).

Ensis leei is een grote en langlevende soort, maar in tegenstelling tot de meeste andere soorten met die kenmerken, is het een soort met een uitzonderlijke mobiliteit die een bescherming kan bieden tegen de effecten van visserij. Individuen van Ensis leei die worden opgevist, hebben een redelijk grote kans beschadigd te zijn en te sterven (Depestele et al., 2014). Dat effect is echter beperkt omdat de soort slechts een lage kans heeft te worden opgevist. Mobiliteit kan de individuen bovendien toelaten lege ruimte snel te koloniseren, zodat het netto effect van visserij misschien zelfs positief kan zijn. Door die combinatie van kenmerken neemt Ensis leei een bijzondere plaats in de gemeenschap in. De soort combineert eigenschappen van een mobiele kleine tweekleppige als Donax vittatus, met een lichaamsgrootte en levensduur die overeenkomen met die van soorten die gewoonlijk zeer gevoelig zijn voor verstoring door visserij. In gemeenschappen die door Ensis leei worden gedomineerd, kan de respons op visserijverstoring dus sterk verschillen van wat men op basis van de ecologische kenmerken van de soorten (zoals levensduur, lichaamsgrootte etc.) zou kunnen verwachten.

Bovendien zijn er aanwijzingen dat de soort zeer competitief is en daardoor de samenstelling van de rest van de gemeenschap sterk bepaalt. In het experiment van de Zandmotor (Herman et al., in prep.) is de recrutering van Ensis leei kort na de aanleg van de Zandmotor snel verminderd. Er werd nog enkele jaren een grote biomassa van overlevende adulten aangetroffen, maar ongeveer vier jaar na de aanleg is de biomassa van Ensis bijna weggevallen. De totale biomassa van de gemeenschap was significant verhoogd in de twee jaren van dominantie van adulte Ensis, maar keerde daarna terug naar hetzelfde niveau als voor de aanleg van de Zandmotor. Die totale biomassa was echter over enkele tientallen soorten verdeeld, in contrast tot de jaren waarin Ensis domineerde en op zichzelf $85 \%$ van de totale biomassa uitmaakte.

Op de schaal van de Nederlandse kust zijn hoge dichtheden van juveniele Ensis leei ruimtelijk sterk gekoppeld aan zones met intensieve garnalenvisserij (Figuur 6.16). Hoge dichtheden komen voor in de Voordelta, rond IJmuiden, aan de Noord-Hollandse kust en boven de Oostelijke Waddeneilanden. Elk van deze gebieden kent intense garnalenvisserij, die zich zeewaarts ongeveer even ver uitstrekt als de hotspots van juveniele biomassa. De correlatie tussen visserij en juveniele biomassa is opvallend veel sterker dan die met de biomassa van de grote individuen. Optimale overleving valt ruimtelijk niet samen met optimale recrutering (Witbaard et al., 2015), en het is vooral het laatste dat ruimtelijk correleert met de patronen in de visserij. Opgemerkt dient te worden dat een dergelijke ruimtelijke correlatie ook zeer goed het gevolg kan zijn van ruimtelijk selectieve visserij, d.w.z. dat garnalenvissers selectief de gebieden opzoeken met een bodemdierleven (of abiotiek) dat wordt gekenmerkt door hoge biomassa van jonge Ensis leei. Hoewel consistent met de observaties in de Voordelta, leveren deze observaties dus geen bewijs voor een causaal verband tussen visserij en ontwikkeling van Ensis leei. 

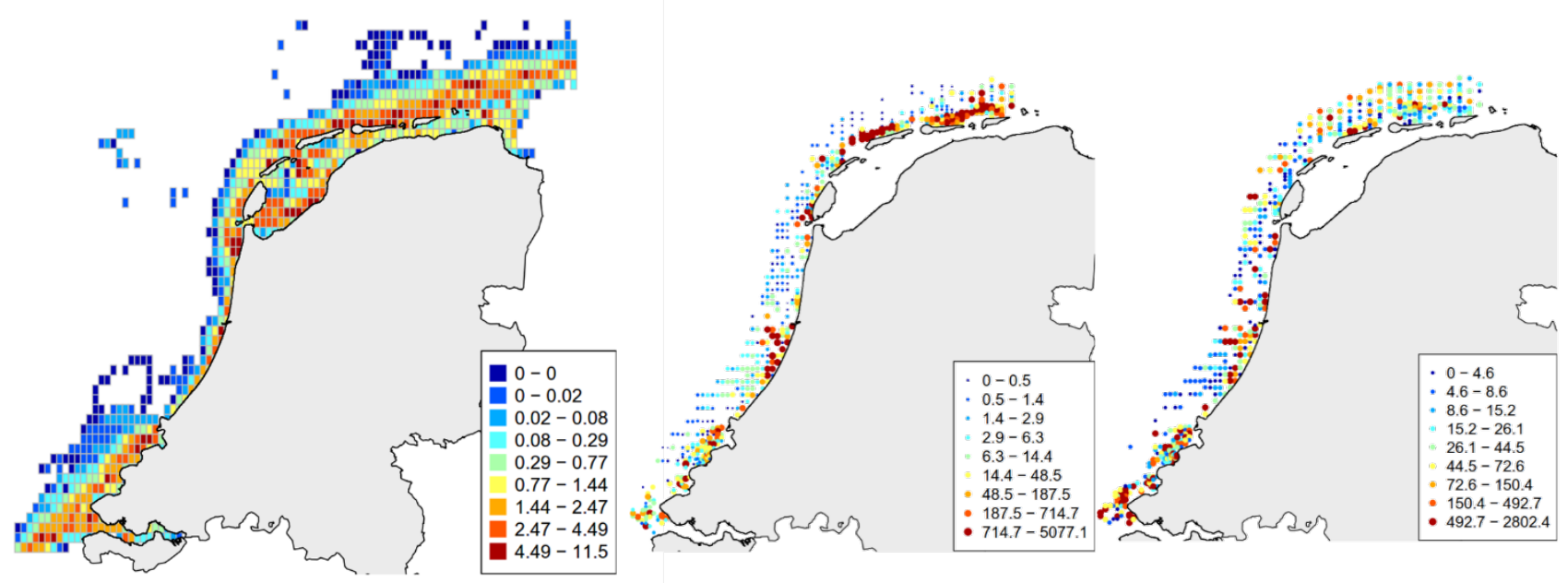

Figuur 6.16. Intensiteit van de garnalenvisserij in 2017 (links) vergeleken met de ruimtelijke verdeling van de biomassa van kleine Ensis (midden) en grote Ensis (rechts) in 2019. De intensiteit van garnalenvisserij is overgenomen uit ICES, (2018b). Biomassa van Ensis is gebaseerd op de data van Perdon et al. (2019).

\subsubsection{Responstijd van bodemdiergemeenschappen}

Bodemdiergemeenschappen die ernstig verstoord worden door natuurlijke of menselijke invloeden, hebben meestal lange tijd nodig om terug te keren tot de oorspronkelijke staat, als die terugkeer al mogelijk is. De sterke verstoring door uitzonderlijk sterke broedval van Spisula subtruncata beschreven door van Hoey et al. (2007) was jaren later nog steeds merkbaar in de gemeenschap, die nooit meer helemaal terugkeerde naar de uitgangssituatie. Van der Meer et al. (2019) beschrijven het herstel van intertidale mosselbanken in de Waddenzee na het massaal wegvissen ervan in 1990, als een proces met een tijdschaal van enkele decennia. De oesterbanken in de Noordzee zijn nooit meer hersteld van het wegvissen in de negentiende eeuw en zijn nu functioneel uitgestorven. In bijna alle gevallen is de erratische en onvoorspelbare aard van de recruteringsprocessen van schelpdieren de reden voor de lange herstelduur. Voor succesvol herstel is een combinatie van factoren nodig die zich maar af en toe voordoet. Daarom duurt het duurt lang voordat recrutering helpt om oorspronkelijke situaties te herstellen. Waar de recrutering ook nog dichtheidsafhankelijk is, met larven die veel succesvoller recruteren waar adulten aanwezig zijn dan elders, is de herstelduur nog langer. Dit is het geval bij de mossel in de Waddenzee, en in nog sterkere mate bij de oester in de Noordzee.

Kaiser et al. (2006) beschrijven dat herstel van de bodemdiergemeenschap na bodemberoering door visserij zich uitstrekt over meerdere jaren. In de Nederlandse kustzone vonden Bergman et al. (2014) voor een windmolenpark na vijf jaar sluiting voor visserij nog geen significante verschillen t.o.v. nabijgelegen beviste gebieden. Dat was wel het geval voor een gebied met gaswinning dat al 20 jaar gesloten was voor visserij (Duineveld et al., 2007). In vergelijking met beviste controlegebieden waren de soortenrijkdom, dichtheden van kwetsbare tweekleppigen en dichtheden van slijkgarnalen toegenomen. Craeymeersch et al. (2015) stelden in de Noord-Hollandse kustzone een toename van venusschelpen (Chamelea striatula) vast, die pas 7 jaar na een sterke afname van de visserij-intensiteit duidelijk werd. De soort is gevoelig voor bodemberoering (Wijnhoven et al., 2013), en als deze toename inderdaad gerelateerd is aan een vermindering in visserijdruk, dan wijst ook dit op een lange rekolonisatieperiode. 
In de PMR dataset observeren we eveneens langzame en langdurige veranderingen in gemeenschapssamenstelling. De vermindering van het relatieve en absolute belang van de Ensis biomassa in de gebieden die voorheen intensief werden bevist met boomkorren, en de toename van de aanwezigheid, biomassa en dichtheid van andere soorten, is een proces dat zich over een tijdsduur van minimaal 10 jaar heeft uitgestrekt. De PMR dataset is uitzonderlijk door de lange duur waarover de effecten van de maatregelen zijn gemonitord. Het is gebleken uit de analyse van de recente resultaten dat deze inspanning heeft geresulteerd in een veel duidelijker beeld van de ontwikkelingen dan wat mogelijk zou zijn geweest met alleen de data van T0 en T1. De ruimtelijke patronen in T2 zijn veel duidelijker dan in $T 1$, een periode die in vele opzichten eerder een overgangsperiode was. Op dit ogenblik is het Bodembeschermingsgebied nog niet vrij van visserijdruk, omdat er intensieve garnalenvisserij en ook schelpdiervisserij plaatsvindt. Mocht deze druk worden gestopt, dan zou opnieuw wellicht een tiental jaren nodig zijn om te observeren of, en welke, effecten dit heeft op de bodemdiergemeenschap.

\subsubsection{Deelconclusies voor het onderdeel bodemdieren}

1. De intensiteit van de visserij door boomkor- en garnalenvisserij in de Voordelta is sterk veranderd sinds de instelling van het BBG in 2008, maar anders dan in de opzet voor natuurcompensatie gepland. De boomkorvisserij is in het gehele gebied, dus zowel in BBG als in REF, zo goed als verdwenen sinds 2008. Er is geen verschil in snelheid van afname tussen BBG en REF. De garnalenvisserij is sterk toegenomen in de tijd, en deze toename is significant veel sterker in BBG dan in REF.

2. Gemiddeld over de gehele Voordelta is de biomassa van de bodemdieren in de loop der tijd licht verminderd. De diversiteit van de bodemdiergemeenschap, zowel uitgedrukt op biomassabasis als op dichtheidsbasis, is toegenomen. De dichtheid van bodemdieren is toegenomen en het gemiddelde individuele gewicht is gedaald.

3. De biomassa is aanzienlijk verminderd in het referentiegebied, en (licht) toegenomen in het Bodembeschermingsgebied tussen T0 en T2. Er is een significante interactie tussen gebied en tijd. Dit impliceert dat de processen die hebben geleid tot een verandering van de biomassa niet in beide gebieden op gelijke wijze hebben plaatsgevonden.

4. Rijnsdorp et al. (2006) voorspelden een toename van de biomassa van bodemdieren bij een afname van visserijdruk. De gegevens waarop deze voorspelling was gebaseerd waren niet perfect, maar voldoende robuust om - gegeven hun aannames - een correcte voorspelling te maken.

5. De basishypothese van Rijnsdorp et al. (2006), dat vermindering van visserijdruk zou leiden tot een toename van de biomassa van bodemdieren, wordt door de observaties tegengesproken. Er is, integendeel, een significante vermindering van biomassa bij vermindering van visserijdruk door boomkorren waargenomen. In kwantitatieve zin is het model dat Rijnsdorp et al. (2006) hebben gebruikt door recentere kennis achterhaald, zoals ook blijkt uit de toepassing van het BENTHIS model door Hintzen en Beier (2020). In kwalitatieve zin is dat niet het geval. Veruit de meeste, ook recente, waarnemingen wijzen er op dat toename van visserijdruk gewoonlijk leidt tot een afname van biomassa van bodemdieren maar dat de intensiteit verschillend is in verschillende habitats.

6. In delen van de Voordelta waar de garnalenvisserij is toegenomen in intensiteit, wordt een vermeerdering van biomassa van bodemdieren waargenomen. De helling van de regressielijn tussen visserij en biomassa is zesmaal lager voor garnalenvisserij dan voor boomkorvisserij.

7. De onverwachte positieve correlatie tussen visserijdruk en biomassa wordt veroorzaakt door de biomassa van Ensis leei. Het blijkt dat dichtheden van deze soort hoger zijn in gebieden met hoge visserijdruk. Op de schaal van de Nederlandse kustzone is er een opvallende ruimtelijke correlatie tussen de recrutering van Ensis en de intensiteit van de garnalenvisserij.

8. De diversiteit van de biomassaverdeling in de gemeenschap neemt af wanneer de biomassa van Ensis leei toeneemt. Bij vermindering van visserijdruk verkleint het aandeel van Ensis in de gemeenschap en wordt de totale biomassa gelijkelijker over de soorten verdeeld. Dit is meer 
uitgesproken in REF dan in BBG, in overeenstemming met het feit dat in REF de visserijdruk is afgenomen, terwijl die plaatselijk in BBG sterk is gestegen.

9. Op dichtheidsbasis is de diversiteit van de bodemdiergemeenschap over de jaren sterk gestegen. De stijging is niet significant anders in BBG dan in REF. De ruimtelijke patronen van verandering in de diversiteit op dichtheidsbasis zijn kleiner van schaal dan de grote gebieden BBG en REF. De sterkste toename concentreert zich vooral in een zone in het noordwesten van het studiegebied, met enkele andere kleinere hotspots, maar wordt vergezeld van een algemene toename van het achtergrondniveau in alle stations.

10. De geobserveerde veranderingen in de dominante soorten van de gemeenschap vertonen een opvallende gelijkenis met veranderingen beschreven in de literatuur voor een Abra alba gemeenschap die werd verstoord door een uitzonderlijk sterke broedval van Spisula subtruncata. Het is mogelijk dat een sterke recrutering van Ensis leei aanleiding heeft gegeven tot de gecorreleerde veranderingen in de bodemiergemeenschap van de Voordelta. Over het algemeen komt de bodemdiergemeenschap in T2, op het einde van de studieperiode, beter overeen met de gemeenschap in de jaren 1980, dan het geval was tijdens T0 en T1.

11. De waargenomen relatieve toename van biomassa in het Bodembeschermingsgebied ten opzichte van het referentiegebied, moet worden toegeschreven aan de combinatie van twee ontwikkelingen: (1) door een sterke toename van de garnalenvisserij is de visserijdruk in BBG toegenomen terwijl hij door een afname van de boomkorvisserij in REF is gedaald en (2) de biomassa is toegenomen met de toename van visserijdruk in plaats van gedaald. Met betrekking tot biomassa van de bodemdieren kan dus worden geconstateerd dat de veronderstellingen die aan de oorsprong van de bestuurlijke maatregelen hebben gelegen, in de praktijk precies omgekeerd hebben uitgepakt.

\subsection{Vissen en epifauna}

Vissen zijn niet alleen (ten dele) doelsoorten van de visserij, maar het zijn ook soorten die integraal deel uitmaken van het ecosysteem in Habitat $\mathrm{H} 110 \mathrm{~B}$, en daarin vaak essentiële rollen vervullen. Vissen zijn predatoren van bodemdieren, en prooi van andere vissen, zeezoogdieren en vogels. Met name voor die laatste twee groepen is de samenstelling van de visfauna van belang om de kwaliteit van het habitat uit te drukken. In dit hoofdstuk onderzoeken we of het instellen van het Bodembeschermingsgebied, en de veranderingen die daarmee gepaard zijn gegaan, van invloed is geweest op de ecologische rol van vissen als belangrijke soorten van habitat H1110B.

In de analyse van de vis- en epifauna zijn dezelfde vragen als voor de rest van habitat $\mathrm{H} 1110 \mathrm{~B}$ leidend. $\mathrm{Er}$ is voor deze groepen geen duidelijk kwantitatief doel voor compensatie gedefinieerd. Veeleer worden zij beschouwd als elementen die worden beschouwd om de kwaliteit van het habitat, en de reactie daarvan op de ingestelde maatregelen, te evalueren. In het bijzonder zijn de volgende vragen aan bod gekomen in de analyse:

- Heeft het instellen van een Bodembeschermingsgebied met verbod op boomkorvisserij geleid tot een verschil in de ontwikkeling van de visfauna in dit BBG, vergeleken met het referentiegebied REF?

- Kan er, los van de feitelijke ontwikkelingen van de visserij in REF en BBG, een verband worden aangetoond tussen de intensiteit van bodemberoerende visserij en de ontwikkeling van de visfauna?

Tijdens de T0-metingen in 2005 en 2007 en in de eerste fase van PMR-NCV zijn de ontwikkelingen in de demersale visgemeenschap onderzocht door bemonsteringen in BBG en REF. De bemonsteringsopzet was gericht op het onderzoeken van gebiedsverschillen (BACI-analyse) tussen BBG en referentiegebied. 
In de tweede fase is de visbemonstering in omvang gereduceerd en inhoudelijk anders ingestoken: in plaats van een zeer uitgebreid bemonsteringsprogramma gericht op een BACI-analyse (53 trekken in voor- en najaar), is overgegaan op een bemonstering alleen in het najaar, met een lagere intensiteit. De focus daarvan lag op het vergelijken van ontwikkelingen in de Voordelta als geheel ten opzichte van de Nederlandse kustzone buiten de Voordelta. De bemonstering sloot aan op de Demersal Fish Survey (DFS), en voegde aan de standaard 11-14 locaties in de Voordelta 13 extra locaties toe. Details over de bemonstering, locaties, en methodes worden gegeven in Bijlage 3.

\subsubsection{BACI analyses T1-T0}

In het eindrapport van de eerste fase (Tulp et al., 2014) is uitgebreid aandacht besteed aan BACI analyses van meerdere indicatoren van de visfauna, waarbij gecorrigeerd werd voor abiotische variabelen. Een groot aantal variabelen werd onderzocht op temporele trend, verschillen tussen BBG en $R E F$, en interactie tussen gebied en tijd. Een significante bijdrage van die laatste term werd geïnterpreteerd als evidentie voor het optreden van een effect van de beschermingsmaatregel. De volgende lijst vat voor meerdere indicatoren de statistische toetsen en hun conclusies samen. Voor details verwijzen wij naar Tulp et al. (2014).

- $\quad$ Dichtheid per soort, totale dichtheid van alle vis, totaal aantal soorten per trek. Om de kracht van de statistische analyse te verhogen, is zo veel mogelijk gecompenseerd voor omgevingsvariabelen die een deel van de variantie significant verklaren. Voor schol, schar en tong zijn de analyses ook per leeftijdsgroep uitgevoerd. Er zijn geen significante gebied*tijd interacties gevonden. Hieruit kan worden geconcludeerd dat het instellen van de beschermingsmaatregelen in BBG, niet hebben geleid tot een verschillende ontwikkeling in de tijd in BBG en REF, voor wat betreft dichtheid van vissoorten (of leeftijdsklassen binnen soorten) en aantal soorten per trek. De oorspronkelijke verwachting was dat boomkorvisserij zou verdwijnen uit BBG en intensief zou blijven in REF, en dat dit verschil (na instellen van BBG) ertoe zou leiden dat de dichtheid van vissen in BBG, relatief tot REF, zou toenemen. In de praktijk is de visserij-intensiteit echter anders ontwikkeld, en het is dan ook logisch dat een dergelijk effect van de genomen maatregelen in het BBG niet kon worden teruggevonden.

- Leeftijdsopbouw van schol, schar, tong en bot voor de hele periode (T0 - T1), en bijkomend voor kleine pieterman, pitvis, schurftvis en dwergtong alleen voor de T1 periode. Er zijn geen significante gebied*tijd interacties gevonden voor de vier soorten die zowel in T0 als in T1 waren bemonsterd, en geen gebiedseffecten voor de soorten die alleen in T1 zijn bemonsterd. Dus ook wat betreft deze detailindicatoren die iets kunnen zeggen over relatieve overleving van verschillende grootteklassen, zijn geen effecten gevonden die kunnen worden toegeschreven aan de instelling van het BBG.

- $\quad$ Gemiddelde lengte per soort. Er zijn geen significante gebied*tijd interacties gevonden in de gemiddelde lengte. Dit komt overeen met het gebrek aan significante effecten op de leeftijdsopbouw, omdat er een duidelijke correlatie is tussen leeftijd en lengte. Voor enkele soorten zijn significante veranderingen in de tijd geconstateerd, maar deze waren constant over de ruimte. Voor andere soorten waren er significante verschillen in de ruimte, maar deze bleven constant in de tijd. Meerdere soorten toonden ook een significant seizoenseffect, dat over de periodes en gebieden constant was. Gemiddelde lengte blijkt dus een tamelijk variabele, en waarschijnlijk ook gevoelige indicator te zijn voor veranderingen in de omgeving of in de populatie (of beide), maar ook deze indicator gaf geen aanleiding te concluderen dat de instelling van het BBG iets significants had veranderd aan de visgemeenschap.

- Analyse door middel van linear mixed models tussen het voorkomen of de dichtheid van vissoorten en de lokale visserijdruk door boomkor- en garnalenvisserij. Voor een aantal soorten zijn significante correlaties gevonden. Zandspiering correleert negatief met beide visserijen. Grondels en garnaal correleren positief met boomkorvisserij; bot, garnaal en totaal vis correleren positief met garnalenvisserij. De positieve correlaties worden over het algemeen geïnterpreteerd als het gevolg van de voorkeuren van de vissers voor gebieden met rijkere visstand. De negatieve correlatie van zandspieringen met visserij-inspanning kan veroorzaakt 
zijn door verstoring van de bodem, waarin deze soorten een groot deel van hun leven doorbrengen. Daarom is deze relatie in T2 nader onderzocht. De significante correlaties tonen aan dat noch de vissen, noch de vissers, willekeurig over de ruimte zijn verdeeld. De ruimtelijke selectiviteit van de visserij is meestal de doorslaggevende factor, die leidt tot positieve correlaties tussen visserij-inspanning en populatiegrootte.

- Maagvulling en conditie als indicator voor de mogelijkheid van vissen om voedsel te vinden. Voor schol werd een significante gebied*periode interactie gevonden. In het referentiegebied was de maagvulling verminderd, terwijl ze in BBG gelijk was gebleven. Voor alle andere soorten werden geen effecten beschreven.

- Dieet van de vissen. Er zijn geen grote veranderingen in het dieet waargenomen, en geen verschillen die aan het instellen van het BBG kunnen worden toegewezen. De soortensamenstelling van de maaginhoud van de vissen verschilt ten opzichte van de soortensamenstelling in de bodem. Vissen zijn selectief. Hun voedselkeuze selecteert vooral soorten die resistent zijn tegen verstoring door visserij. Het is, in principe, mogelijk dat hogere visserij-intensiteit leidt tot meer visserij-resistente soorten in de bodemdiergemeenschap, en daardoor tot meer geprefereerd voedsel voor vis.

- Groei van jonge schol, schar en tong. Er is geen effect van de bodembeschermingsmaatregel gevonden op de groeisnelheid van deze soorten.

- Conditie van de vissen. Voor de meeste soorten werd geen effect gedetecteerd. Grondels tonen een significante interactie tussen gebied en periode. Hun conditie was verbeterd in het referentiegebied, ten opzichte van het BBG.

Concluderend kan worden gesteld dat de uitgebreide analyses:

- $\quad$ in een aantal gevallen verschillen tussen het referentiegebied en BBG hebben aangetoond. Deze gebieden verschillen in hun omgevingskenmerken, en voor verschillende soorten is het ene, dan wel het andere gebied optimaler als habitat;

- $\quad$ in een aantal gevallen trends in de tijd hebben aangetoond. Zowel positieve als negatieve trends zijn waargenomen. Deze trends zijn over het algemeen gemeenschappelijk in beide gebieden, en overigens vaak ook in de rest van de Nederlandse kustzone;

- $\quad$ slechts in hoge uitzondering significante gebied*periode interacties hebben aangetoond. Gezien het groot aantal negatieve resultaten, en het wisselende teken van de interacties (soms is BBG verbeterd, soms REF) kan geen groot gewicht aan deze observaties worden verleend. In totaal zijn 10 variabelen voor gemiddeld 10-20 soorten onderzocht. Per variabele is een Bonferronicorrectie toegepast, omdat de evaluatie van een enkele variabele (bv. 'dichtheid') door de vele soorten en groepen binnen soorten al snel tot een veelvoud van testen leidde. Door de Bonferroni-correctie is de overall kans om binnen één variabele een onterecht significant resultaat te vinden, ongeveer $5 \%$. Over de 10 onderzochte variabelen is er dan nog steeds een kans van ongeveer $40 \%$ om zo'n onterecht significant resultaat te vinden. De enkele 'significante' resultaten in deze hoeveelheid vergelijkingen kunnen dus niet tot vergaande conclusies leiden.

\subsubsection{Analyses gedurende T2.}

De negatieve correlatie van zandspieringen met visserij-inspanning, die werd gedetecteerd tijdens T0 en T1, kan veroorzaakt zijn door verstoring van de bodem, waarin deze soorten een groot deel van hun leven doorbrengen. Eerder is een significant negatief verband vastgesteld tussen aanwezigheid van zandspiering en visserij-intensiteit (Tien et al., 2017b). In een hernieuwde analyse met meer jaren is echter gebleken dat ruimtelijke patronen veel belangrijker zijn en er slechts een zwak verband is met visserij. De verspreiding van (kleine) zandspiering en visserij zijn ruimtelijk gescheiden, en er zijn geen duidelijke aanwijzingen voor een causaal verband (Tulp et al., 2018). Analyses voor latere jaren 
ondersteunen dit beeld; de verspreiding van zandspiering hangt vooral af van het slibgehalte van het sediment en stroomsnelheid.

In de synthese uit 2018 (Tulp et al., 2018) is de BACI opzet losgelaten en zijn ontwikkelingen in dichtheden, leeftijdsopbouw en conditie onderzocht voor een gebied op grotere schaal (de Voordelta in vergelijking met de Noord- en Zuid-Hollandse kust) en in relatie tot de ontwikkelingen in visserijintensiteit. Deze analyses zijn voor het eindrapport opnieuw uitgevoerd en alleen deze updates worden hieronder besproken.

Voor de vergelijking tussen trends en patronen in de Voordelta met trends en patronen in de rest van de Nederlandse kustzone zijn resultaten van de Demersal Fish Survey (DFS) sinds ongeveer 1970 gebruikt. Voor de laatste jaren zijn bijkomende DFS monsters in de Voordelta genomen, die toelieten te controleren hoe representatief de 'klassieke' DFS-monsterpunten van de Voordelta waren voor het gebied. Geen opvallende verschillen zijn daarbij aan het licht gekomen. De volgende resultaten uit dit onderzoek worden besproken: belangrijke trends in de visfauna van de Nederlandse kust over de laatste vijf decennia, belangrijke trends in de epifauna van de Nederlandse kust over deze periode, multivariate analyse van trends in ruimte en tijd van vis en epifauna, en relatie van trends en patronen met de intensiteit van verschillende vormen van visserij.

\subsubsection{Trends in visfauna in de Voordelta en de Nederlandse kustwateren}

Door middel van een lengte-biomassa plot voor alle belangrijke vissoorten worden de ontwikkelingen in de visfauna langs de Nederlandse kust duidelijk gemaakt (Figuur 6.17). Deze manier van weergave geeft een indruk van de verandering in 1) de verdeling van de soorten, 2) de totale visbiomassa en 3) de lengteverdeling. De meest dominante soorten in biomassa zijn schol, schar, grondels, wijting, tong, en bot. Over het algemeen zijn de ontwikkelingen in de Voordelta en de Hollandse kustzone vergelijkbaar. Een aantal ontwikkelingen valt op. De grotere vissen $(>40 \mathrm{~cm})$ verdwijnen gaandeweg de decennia uit het spectrum in alle gebieden, ook vanaf 2010 neemt dit aandeel nog verder af. De rol van schol is veranderd: dichtheden zijn veel lager en de grotere schol is verdwenen. De dominante rol van schol is in de laatste periode overgenomen door schar, vooral in de groep met lengte $20-30 \mathrm{~cm}$.

Zandspieringachtigen en dwergtong komen op in de laatste periodes. 


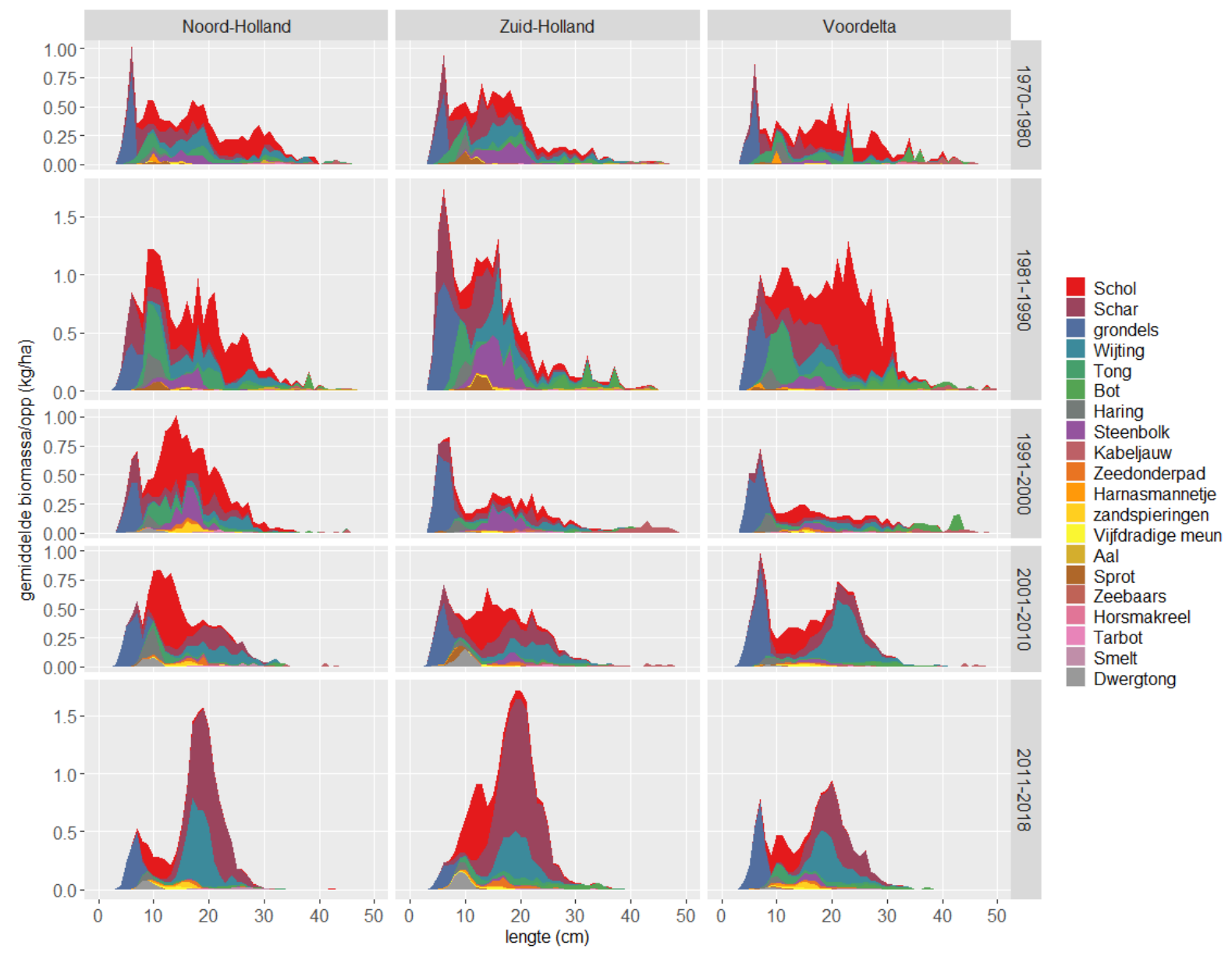

Figuur 6.17. Lengte-biomassa plot van de visfauna in delen van de Nederlandse kustwateren, gegroepeerd per decennium sinds 1970. De y-assen hebben dezelfde schaal maar een verschillende lengte aangepast aan het maximum. De biomassawaarden zijn niet gecorrigeerd voor vangstefficiëntie. Ze laten toe vergelijkingen in ruimte en tijd te maken, maar geven geen absolute schatting van aanwezige visbiomassa. De bemonsteringen zijn uitgevoerd in het najaar. Sommige soorten zijn samengevoegd in soortgroepen, zoals b.v. zandspieringen, grondels en pitvissen.

Gemiddeld over de verschillende delen van de Nederlandse kust en over de decennia (Figuur 6.18) wordt de hoogste biomassa gevonden in de jaren 1980, en dit in alle gebieden, zij het met aanzienlijke variatie tussen jaren. Daarna daalt de gemiddelde biomassa tot een minimum eind jaren 1990, waarna ze weer licht lijkt te stijgen. Hoewel er flinke variatie is tussen deelgebieden binnen elk jaar, lijken er weinig systematische verschillen tussen deelgebieden te bestaan op de langere termijn. De gerapporteerde biomassawaarden hebben geen correctie voor vangstefficiëntie van het net. Die is heel variabel en moeilijk te schatten, zie Aarts et al. (2019). De gerapporteerde waarden laten toe gebieden en jaren onderling te vergelijken, maar ze geven geen absolute schatting van de hoeveelheid in de natuur aanwezige visbiomassa. 


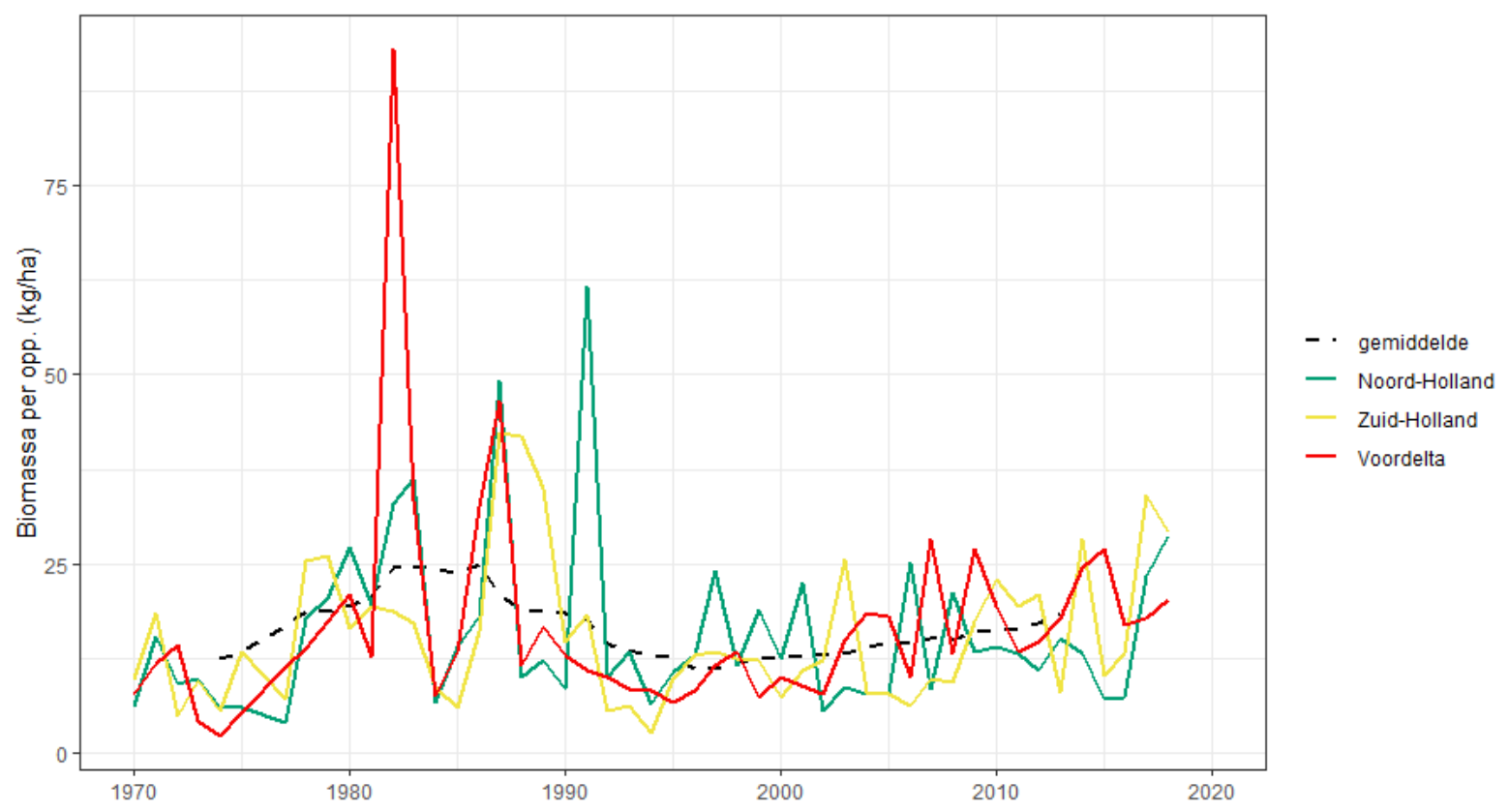

Figuur 6.18. Totale visbiomassa in de deelgebieden Voordelta, Zuid-Holland en Noord-Holland, op basis van de DFS. De gebroken lijn is een 10-jarig lopend gemiddelde op basis van de drie deelgebieden samen. Bij deze biomassaschattingen is geen correctie voor vangstefficiëntie toegepast. Waarden zijn onderling vergelijkbaar (tussen deelgebieden of tussen jaren) maar zijn geen absolute schatting van aanwezige biomassa.

Een groot aandeel van de vangst in de visbemonsteringen bestaat uit epibenthos. Omdat epibenthische soorten samen met vis in kustgebieden een gemeenschap vormen hebben we de ontwikkeling in aantallen van de zes meest voorkomende epibenthos soorten/groepen op een rij gezet voor de Voordelta en de Zuid- en Noord-Hollandse kust (Figuur 6.19). Met name voor de Voordelta valt de enorme toename in slangsterren vanaf 2009 op. Ook in de jaren tussen 1970 en 1990 kwamen af en toe pieken voor, maar recentelijk is dit een jaarlijks fenomeen dat veel minder prominent is in de Noord- en ZuidHollandse kustzone. Ook zeesterren vertonen af en toe pieken, bijvoorbeeld tussen 1985 en 1989 en in 2010 en 2011.

De vergelijking van demersale vissen en epifauna langs de Nederlandse kust toont dat er in de loop der jaren grote verschuivingen in de fauna zijn opgetreden. De meeste verschuivingen, b.v. de overname van de dominante rol van schol door schar, doen zich langs de hele kust voor en zijn niet specifiek voor de Voordelta. Ook de verschuiving naar kleinere soorten, of kleinere exemplaren binnen een soort, is een trend langs de hele Nederlandse kust. De sterke ontwikkeling van slangsterren in de jaren 1980, en opnieuw sinds 2010, is een fenomeen dat sterker is in de Voordelta dan in andere delen van de Nederlandse kust, al worden de stijgingen en dalingen overal ongeveer in dezelfde periodes gezien. 


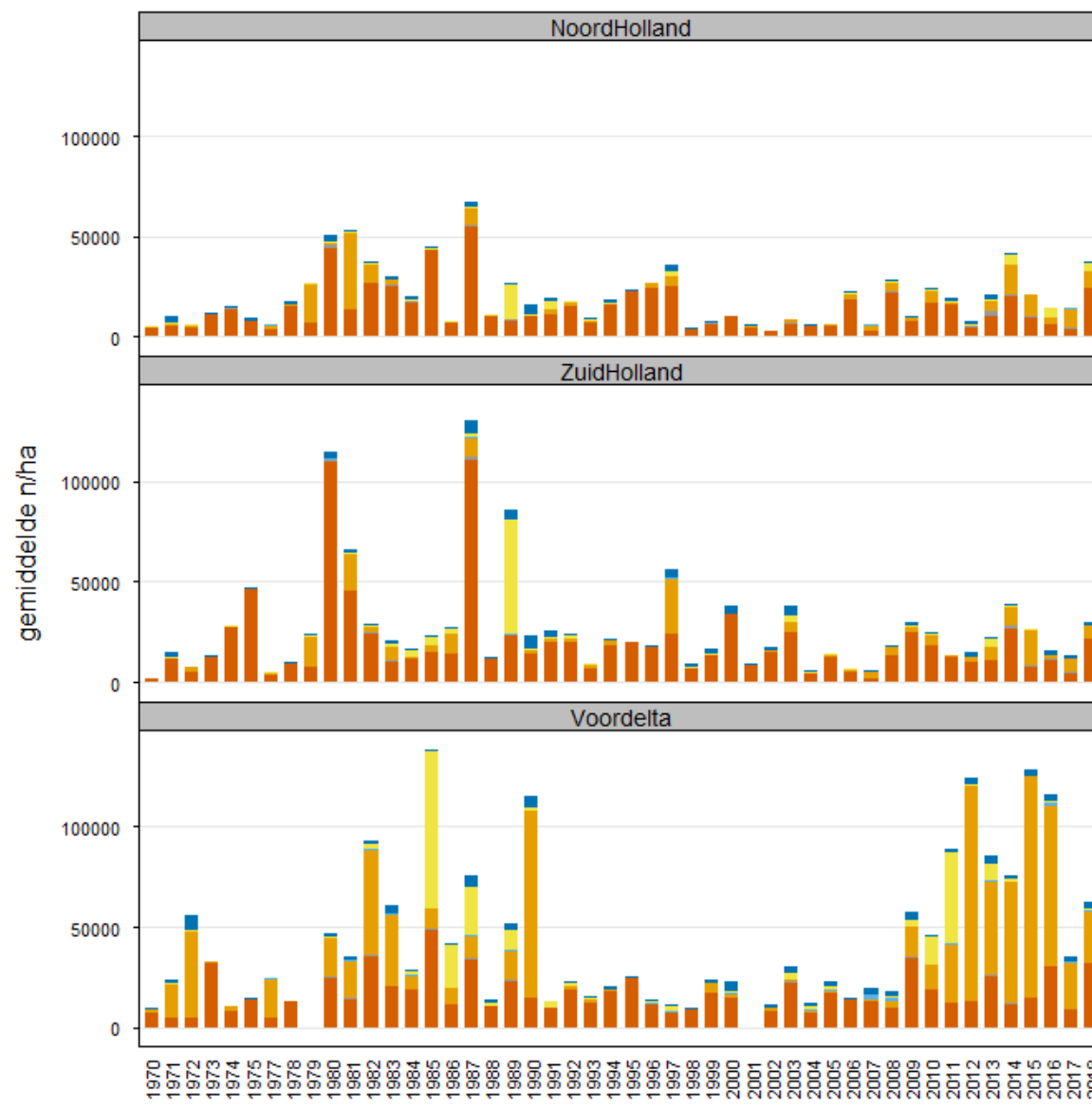

Gewone garnaal heremietkreeften slangsterren Strandkrab

Zeester zwemkrabben

Figuur 6.19. Gemiddelde dichtheid van enkele talrijke epibenthische soorten schaaldieren en stekelhuidigen die worden gevangen in de DFS. De verschillende soorten heremietkreeften, slangsterren en zwemkrabben zijn samengevoegd in soortgroepen.

\subsubsection{Verkenning van trends in de samenstelling van de visgemeenschap}

Een Detrended Correspondence Analysis (DCA) projecteert de samenstelling van een gemeenschap op een tweedimensionaal vlak langs twee assen. Deze assen zijn zo gekozen dat ze de variatie in de gemeenschap maximaal weergeven.

De analyse van de tijdserie van 1970-2018 voor de drie deelgebieden laat eenzelfde ontwikkeling in de tijd zien (Figuur 6.20; de drie lijnen volgen ongeveer dezelfde route van rechtsonder, via linksonder en linksboven naar rechtsboven in de biplot). Soorten die opvallen zijn kabeljauw en aal, die wel nog in de jaren 1970 voorkwamen maar sterk zijn afgenomen en mul, kleine pieterman, zandspieringen, dwergtong en schurftvis die vooral recent een opmars hebben laten zien en geclusterd rechtsboven voorkomen. Soorten die weinig ontwikkeling hebben laten zien bevinden zich in het centrum van de biplot: garnaal, wijting, strandkrab, grondels.

De drie deelgebieden Voordelta, Zuid-Holland en Noord-Holland vertonen een parallelle ontwikkeling in de tijd, maar blijven ook gedurende de gehele periode onderscheiden van elkaar. Daarbij gelijkt NoordHolland beter op de Voordelta dan Zuid-Holland. In vergelijking met zowel Zuid- als Noord-Holland heeft de Voordelta minder pelagische vis en meer epibenthos, terwijl de trends van de vissoorten vergelijkbaar zijn. 


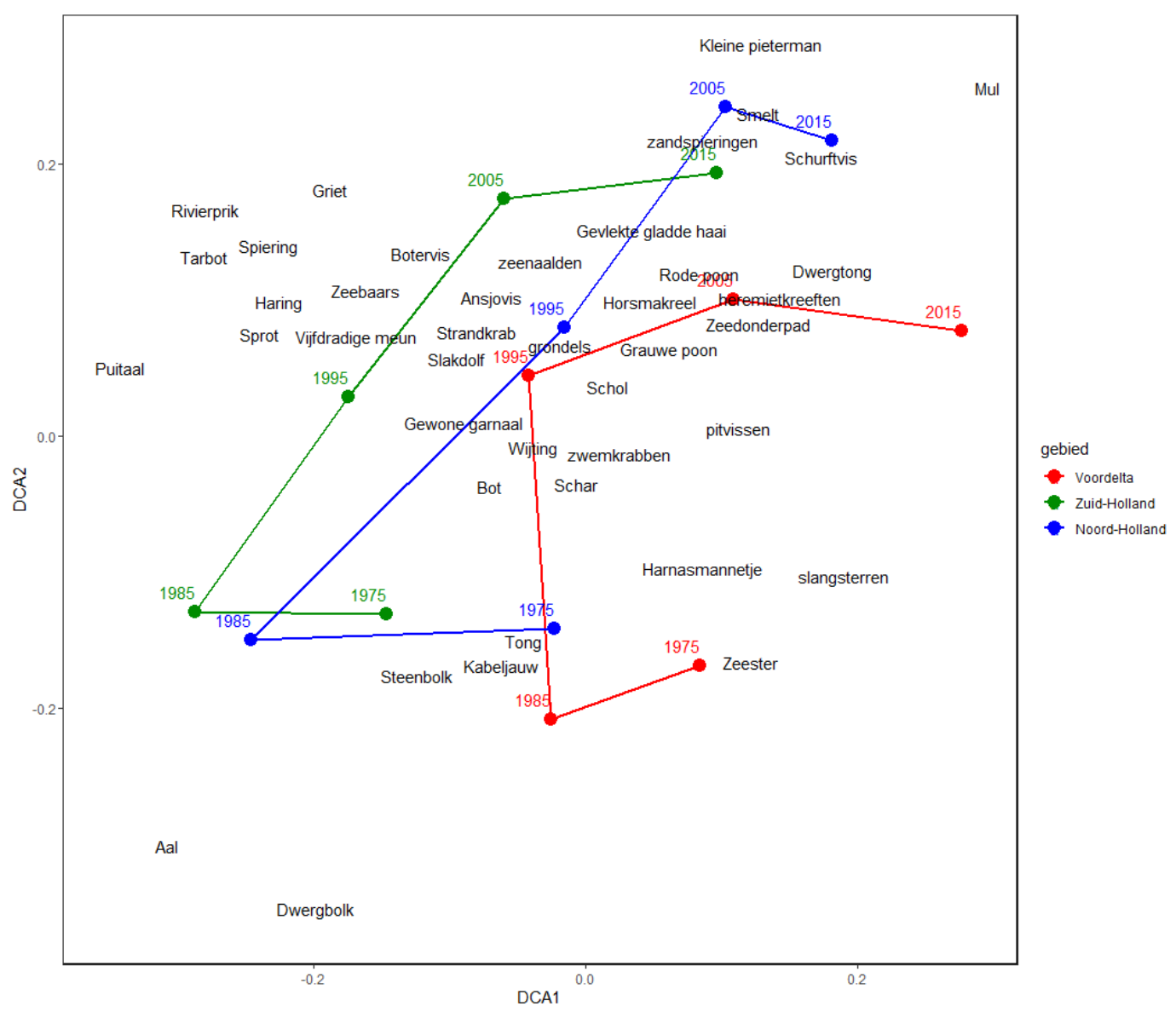

Figuur 6.20. DCA analyse van de DFS data 1970-2018 voor drie deelgebieden Voordelta, Zuid- en NoordHolland met de centroïden per periode van 10 jaar (het getal geeft het midden in de serie aan: 1975 staat voor tijdvak 1970-1979, etc.). De analyse is uitgevoerd voor de drie gebieden samen.

De DCA plot toont een ontwikkeling tussen de jaren 1970 en 1980 die ongeveer het omgekeerde is (m.b.t. de eerste as) van de ontwikkeling tussen de jaren 2000 en de jaren 2010. Onder meer de ontwikkeling van slangsterren heeft hieraan bijgedragen, maar ook de aanwezigheid van soorten als zeester, pitvissen, zeedonderpad, en afwezigheid van tarbot, haring, sprot tijdens de surveys.

Na de jaren 2000 zien we een lichte trend naar verhoging van de visbiomassa (Figuur 6.17), een terugkeer van slangsterren (Figuur 6.19) en een tendens van terugkeer dichter bij de situatie in de jaren 1970 in het diagram van de DCA, tenminste op de eerste (horizontale) as (Figuur 6.20). Toch is er nog duidelijk onderscheid tussen die decennia.

\subsubsection{Trendanalyse van vis per soort en soortsgroep.}

In deze analyse werden GAMM modellen gemaakt voor de verschillende soorten (al dan niet opgedeeld in 0-groep en $1+$ groep) en soortsgroepen (mariene juvenielen, estuariene residenten) van vis. Ook enkele soorten epibenthos zijn op dezelfde manier geanalyseerd. De modellen gebruiken diepte en een random ruimtelijke component als cofactoren, omdat gebleken is in alle analyses dat diepte een bepalende factor is voor wat in de DFS wordt gevangen. Daarnaast was het duidelijk dat ruimtelijke autocorrelatie een rol speelde in de resultaten. Na correctie voor deze cofactoren bepaalt het model vooral de respons van de variabelen op de factor "jaar": het opstellen van een trend voor de groep over de tijd, in de deelgebieden Voordelta, Zuid-Holland, Noord-Holland en Waddenkust. De voorspellingen zijn, door het gebruik van spline smoothers, continu in de tijd maar kunnen sterk niet-lineair zijn over de jaren. Een voorbeeld van zo'n voorspellingen met smoothers wordt getoond in Figuur 6.21: het toont de 'gladde' (smooth) curves in de tijd van de verwachte totale visbiomassa in de vier deelgebieden van de Nederlandse kust. In elk 
van die gebieden is de verwachte totale visbiomassa geplot voor de mediane diepte van het kustsegment. Voor andere dieptes zouden andere, licht gewijzigde curves gelden. Bij het vergelijken van de curves van de verschillende gebieden valt op dat de curve voor de Voordelta traag fluctueert op een schaal van decennia, terwijl de curve voor de Waddenkust een belangrijke component heeft die fluctueert op de schaal van enkele jaren. Elk van deze smoothers heeft termen op verschillende tijdschalen. Door de fitting wordt bepaald welke fluctuaties dominant zijn. Daardoor geeft het gefitte model ook informatie over de belangrijkste tijdschalen waarop de variabelen fluctueren.

De voorspelde waarden zijn achteraf gecorreleerd met de gemiddelde visserij-inspanning in de vier deelgebieden over de tijd, opgesplitst voor boomkor, garnalenkor en pulskor. Omdat de beschikbare gegevens over visserij-intensiteit beperkt zijn tot de periode vanaf 2006 kon dit alleen voor de periode 2006-2018 uitgevoerd worden. Per deelgebied en per jaar is de trendwaarde voor de voorspelde biomassa van de soorten en soortsgroepen gekoppeld aan de trendwaarde voor de intensiteit van de drie visserijen. Spearman rang-correlatiecoëfficiënten (Tabel 6.4) geven aan of sprake is van significante correlatie tussen deze gekoppelde waarden.

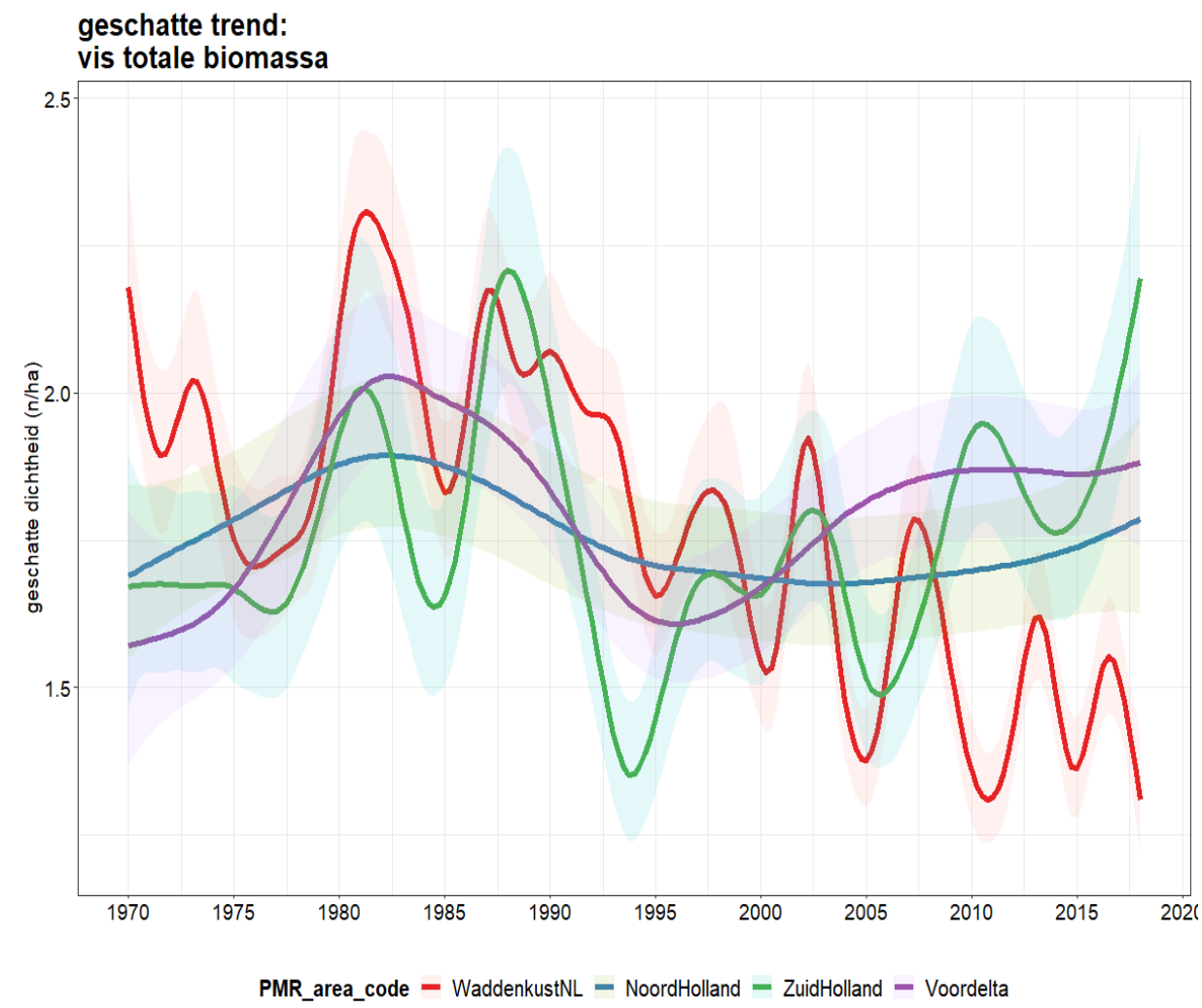

Figuur 6.21. Totale visbiomassa, na transformatie, met 95\% betrouwbaarheidsinterval voor elk deelgebied over de loop der jaren. Dichtheid is geschat voor de mediane waterdiepte van elk deelgebied en is daarom tussen deelgebieden niet vergelijkbaar. De mate van fluctuatie op korte en langere termijn varieert tussen de series, afhankelijk van de gefitte waarden van de vijf parameters die de GAMM smoother bepalen.

Voor de Voordelta zijn er 9 soorten die een negatieve, en 2 soorten die een positieve relatie met boomkorintensiteit vertonen. De patronen zijn vergelijkbaar tussen de drie deelgebieden langs de Hollandse kust. Significante en hoge $(>0.8)$ correlaties (+ en -) met de garnalenvisserij zijn alleen gevonden voor de Noord-Hollandse kust. Het resulterende patroon vertoont een opvallende spiegeling tussen de correlaties met boomkorintensiteit (een variabele die sterk achteruitgaat in de tijd) en die van pulskorintensiteit (een stijgende variabele in de tijd). De correlaties met garnalenintensiteit zijn gelijkaardig in teken met die van pulskor, maar in de meeste gevallen iets minder sterk. De analyse 
geeft globaal aan welke soorten over het algemeen stijgen of dalen in de tijd. Deze analyse leidt niet tot conclusies inzake causale relaties met visserij-intensiteit.

Tabel 6.4. Spearman correlatiecoëfficiënten tussen de lange-termijn trends van de soorten en de trends in de visserij-intensiteit, voor vier deelgebieden van de Nederlandse kust. De getallen zijn gekleurd als ze significant zijn en een Spearman correlatiecoëfficiënt groter dan 0,8 hebben. Negatieve correlaties zijn roze gekleurd, positieve groen. De variabelen (rijen) zijn geordend volgens hun gemiddelde correlatie met boomkoractiviteit, van meest positief correlerend met boomkoractiviteit bovenaan, tot meest negatief ermee correlerend onderaan.

\begin{tabular}{|c|c|c|c|c|c|c|c|c|c|c|c|c|}
\hline & & & Bkor & & & & Gar & & & & Pkor & \\
\hline & $\begin{array}{l}\frac{\pi}{0} \\
\frac{0}{0} \\
\frac{0}{0} \\
>\end{array}$ & 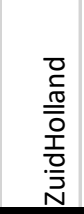 & 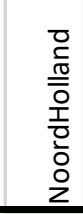 & 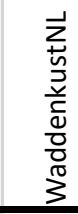 & $\begin{array}{l}\frac{\pi}{0} \\
\frac{1}{0} \\
\frac{0}{0} \\
0 \\
>\end{array}$ & 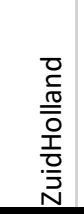 & 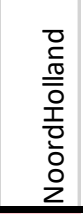 & 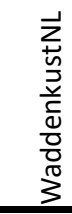 & $\begin{array}{l}\frac{\pi}{ \pm} \\
\frac{\pi}{0} \\
0 \\
0\end{array}$ & 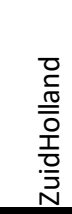 & 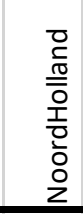 & 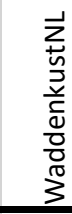 \\
\hline pitvissen & 0.92 & 0.44 & 0.81 & 0.39 & -0.56 & -0.39 & -0.9 & -0.36 & -0.71 & 0.04 & -0.76 & -0.23 \\
\hline kleine pieterman & 0.91 & 0.91 & 0.81 & -0.75 & -0.58 & 0.1 & -0.9 & 0.37 & -0.71 & -0.54 & -0.76 & 0.57 \\
\hline schar 0 groep & 0.27 & 0.2 & 0.59 & 0.52 & -0.29 & 0.2 & -0.47 & -0.32 & -0.43 & -0.28 & -0.72 & -0.35 \\
\hline schol 0 groep & -0.03 & -0.25 & 0.65 & 0.91 & -0.11 & -0.28 & -0.57 & -0.62 & -0.17 & 0.37 & -0.47 & -0.64 \\
\hline mariene juvenielen & 0.34 & -0.35 & 0.48 & 0.54 & -0.07 & -0.07 & -0.34 & -0.48 & -0.58 & 0.23 & -0.31 & -0.52 \\
\hline dwergtong & -0.32 & -0.83 & 0.84 & 0.91 & -0.18 & 0.08 & -0.84 & -0.62 & 0.62 & 0.63 & -0.76 & -0.64 \\
\hline bot 1+ groep & -0.61 & -0.86 & 0.81 & 0.91 & 0.03 & 0.02 & -0.9 & -0.6 & 0.62 & 0.59 & -0.76 & -0.64 \\
\hline tong 1+ groep & -0.92 & -0.74 & 0.81 & 0.91 & 0.56 & -0.27 & -0.9 & -0.62 & 0.71 & 0.79 & -0.76 & -0.64 \\
\hline residente soorten & -0.72 & 0.12 & 0.09 & -0.01 & 0.14 & -0.21 & -0.08 & -0.04 & 0.84 & 0.19 & 0.14 & 0.08 \\
\hline zeedonderpad & -0.05 & -0.86 & -0.49 & 0.52 & -0.35 & 0.02 & 0.45 & -0.27 & 0.37 & 0.59 & 0.54 & -0.38 \\
\hline tong 0 groep & $\mid-0.69$ & -0.57 & 0.81 & -0.59 & 0.26 & -0.16 & -0.9 & 0.29 & 0.53 & 0.5 & -0.76 & 0.46 \\
\hline zwemkrabben & -0.92 & -0.89 & 0.81 & -0.35 & 0.56 & -0.13 & -0.9 & 0.32 & 0.71 & 0.72 & -0.76 & 0.3 \\
\hline wijting & -0.62 & -0.91 & -0.81 & 0.91 & 0.74 & -0.12 & 0.9 & -0.62 & 0.15 & 0.59 & 0.76 & -0.64 \\
\hline garnaal & -0.92 & 0.01 & -0.32 & -0.58 & 0.56 & -0.13 & 0.44 & 0.49 & 0.71 & 0.16 & 0.63 & 0.6 \\
\hline schurftvis & -0.92 & 0.26 & -0.88 & -0.62 & 0.56 & -0.21 & 0.84 & 0.27 & 0.71 & 0.42 & 0.6 & 0.5 \\
\hline schar 1+ groep & -0.55 & -0.86 & -0.84 & -0.43 & 0.47 & 0.02 & 0.88 & 0.41 & 0.26 & 0.59 & 0.76 & 0.09 \\
\hline heremietkreeften & -0.53 & -0.73 & -0.81 & -0.66 & 0.03 & 0.17 & 0.9 & 0.59 & 0.75 & 0.59 & 0.76 & 0.44 \\
\hline schol 1+ groep & -0.83 & -0.86 & -0.84 & -0.26 & 0.55 & 0.02 & 0.89 & 0.25 & 0.75 & 0.59 & 0.76 & 0.14 \\
\hline vijfdradige meun & -0.92 & -0.86 & -0.81 & -0.33 & 0.56 & 0.02 & 0.9 & 0.31 & 0.71 & 0.59 & 0.76 & 0.23 \\
\hline harnasmannetje & -0.92 & -0.36 & -0.81 & -0.88 & 0.56 & -0.19 & 0.9 & 0.68 & 0.71 & 0.79 & 0.76 & 0.57 \\
\hline slangsterren & -0.87 & -0.86 & -0.81 & -0.91 & 0.56 & 0.02 & 0.9 & 0.62 & 0.73 & 0.59 & 0.76 & 0.64 \\
\hline bot 0 groep & -0.92 & & & & 0.56 & & & & 0.71 & & & \\
\hline
\end{tabular}

\subsubsection{Ruimtelijke statistische modellen}

De trendanalyses per deelgebied, zoals hierboven geschetst, zijn verder verfijnd om twee nadelen te kunnen ondervangen. Ten eerste is rekening gehouden met veel meer cofactoren. Ten tweede is de benadering van correlaties per deelgebied opgegeven, en is er een koppeling gemaakt tussen populaties en visserij-intensiteit op trekniveau.

Op basis van de Demersal Fish Survey langs de hele Nederlandse kust, en in de tijd voor de periode dat VMS-metingen van visserij-intensiteit beschikbaar zijn (sinds 2007) zijn ruimtelijke modellen gebouwd in R-INLA die de dichtheid van de vissoorten beschrijven als een functie van de tijd (jaar), omgevingsvariabelen (fysisch, chemisch, biologisch) en visserij-intensiteit (boomkor, garnalenkor, pulskor). In deze modellen wordt een relatie beschreven tussen de populaties en de omgevingsvariabelen, tijd en visserij, maar wordt ook rekening gehouden met ruimtelijke autocorrelatie, de tendens dat een punt in de ruimte gewoonlijk beter lijkt op naburige punten dan op verafgelegen punten. 
Door zowel de afhankelijkheden en de autocorrelatie zorgvuldig aan de data af te wegen, kunnen kaarten van voorspelde dichtheden worden geproduceerd. Een voorbeeld van dergelijke kaarten wordt getoond in Figuur 6.22.
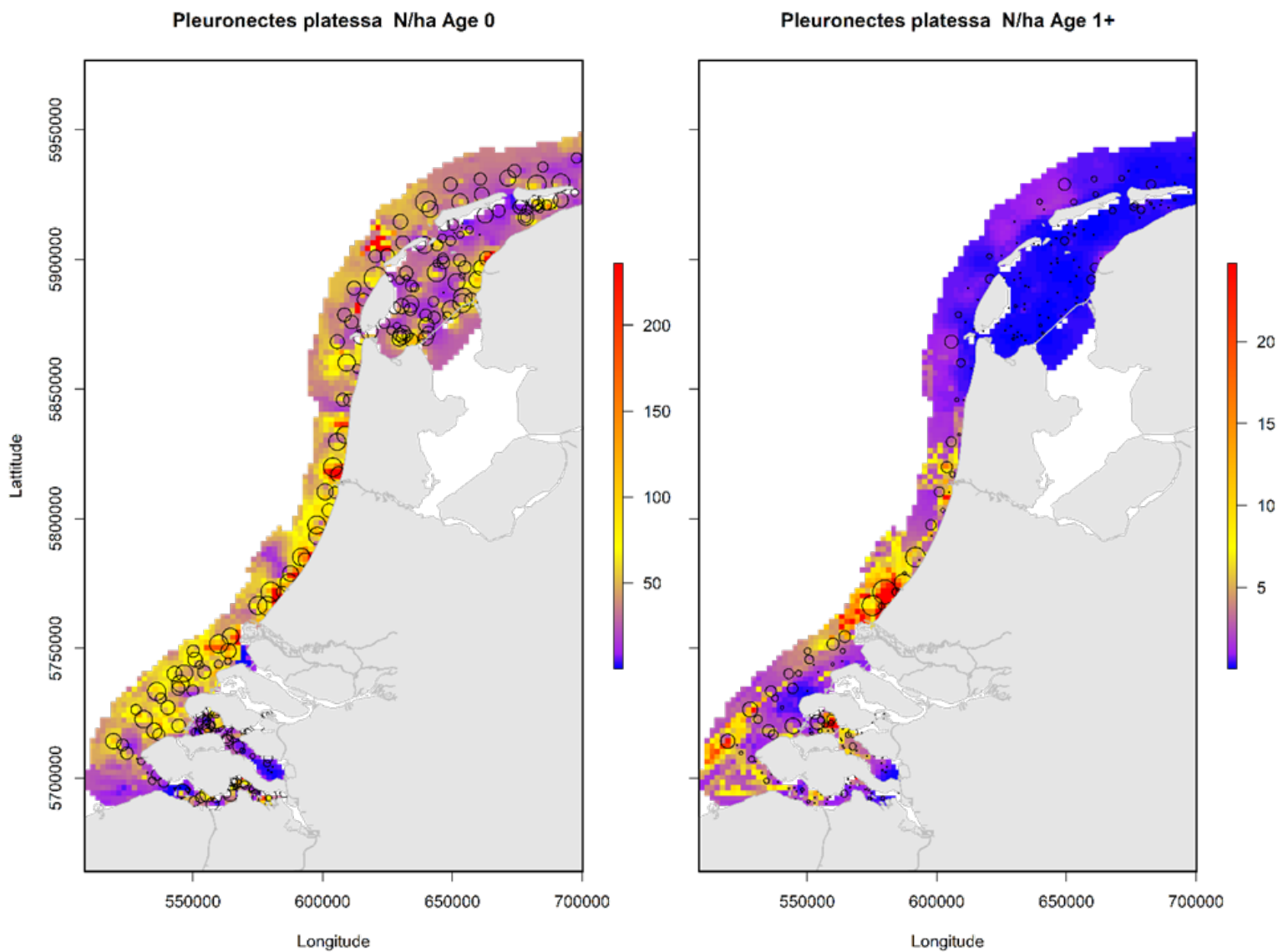

Figuur 6.22. Voorbeeld van kaart van voorspelde dichtheden ( $\mathrm{h} / \mathrm{ha}$ ) van 0-groep en 1-groep schol in het DFS gebied in 2018. De cirkels geven de waarnemingen weer, de kleuren geven de modelvoorspellingen.

De kaarten maken de data inzichtelijk en helpen bij het vaststellen van bijzondere patronen in de ruimtelijke verdeling van de populaties. Voor de analyse in het kader van PMR is vooral aandacht besteed aan de aard van de relatie tussen de verschillende vissoorten en hun omgeving, en aan de relatie tussen dichtheid van de vissoorten en bevissing.

Deze modellen zijn gebouwd om de volgende vragen te beantwoorden:

- Welke omgevingsvariabelen (inclusief visserij-inspanning) zijn het meest sturend voor de waargenomen vangsten van de verschillende soorten in de kustzone?

- Hoe ziet deze (niet-)lineaire relatie tussen de soorten en de belangrijkste variabelen eruit?

- Kunnen we gebruik maken van deze afhankelijkheid om beter de verspreiding van de soort in kaart te brengen?

$\mathrm{Bij}$ het fitten van het model is een automatische selectieprocedure ingebouwd die uit de 21 beschikbare cofactoren die variabelen selecteert die de toetsvariabele het beste verklaren. Per toetsvariabele kan een maximum van vijf cofactoren worden geselecteerd, maar het aantal kan kleiner zijn als geen significante relaties worden gevonden. Voor alle vissoorten (met één uitzondering) was de factor 'jaar' de belangrijkste cofactor, die als eerste in het model werd opgenomen. De factor jaar kan de bekende jaar- 
tot-jaar variatie in dichtheden van vissen opvangen, maar kan ook een deel van de variatie in visserijintensiteit voorstellen. Immers, het ruimtelijke patroon van de visserij is van jaar tot jaar gewoonlijk vrij stabiel, maar de totale intensiteit van de verschillende vormen van visserij is over de loop der jaren voor de drie vistuigen sterk veranderd. De factor 'jaar' en de factor 'visserijdruk' door de drie types visserij zijn met elkaar "in concurrentie" als verklarende factor. Verwacht zou kunnen worden dat visserijdruk, die zowel temporele als ruimtelijke componenten heeft, als eerste zou worden gekozen. Dat was duidelijk niet het geval. De ruimtelijke variabiliteit in de gegevens over visserijdruk hadden kennelijk weinig verklarend vermogen. De belangrijkste bron van variatie in de dataset is jaar-tot-jaar variatie. Dit kan te maken hebben met populatieprocessen in de vispopulaties, die zich afspelen op de schaal van de hele Noordzee. Maar ook synchrone veranderingen in de visserij langs de kust, die worden gestuurd door de markt, de politiek en de ontwikkelingen in de sector, leiden vooral tot temporele variatie.

De cofactoren die na de factor 'jaar' aan de modellen worden toegevoegd, variëren sterk van soort tot soort. Er is geen duidelijk patroon te ontdekken in de relatie tussen fysische factoren en de verschillende populaties. Ook voor wat betreft het effect van visserij is het beeld niet heel duidelijk. Er zijn 21 soorten of soortsgroepen gemodelleerd, en voor iedere variabele zijn 21 potentiële cofactoren beschouwd.

Gemiddeld zijn 4 cofactoren per variabele in het model ingebouwd (totaal 87). Visserij-inspanning (3 variabelen, $1 / 7$ van het totaal aantal van 21 cofactoren) is 12 keer ( $1 / 7$ van het totaal van 87 selecties) geselecteerd: 5 maal boomkorvisserij, 4 maal garnalenvisserij, 3 maal pulskorvisserij. Boomkorvisserij had een effect op bot 1 dat varieerde van positief tot negatief maar nergens significant afweek van 0 ; een negatief effect dat onafhankelijk was van de intensiteit op schar 0 en heremietkreeft, en een negatief effect dat sterker werd met de intensiteit op vijfdradige meun en schar 1. Garnalenvisserij had altijd een positief effect (bij vijfdradige meun, garnaal, heremietkreeft, strandkrab) dat toenam met de intensiteit van de visserij. Pulskor had een sterk negatief effect op schol 1 en wijting, en een sterk positief effect op estuariene residenten. De effecten van pulskor namen niet toe of af met de intensiteit van de visserij. De relaties worden getoond in Figuur 6.23.

De interpretatie van deze resultaten in termen van effecten van visserij op de vis- en epifauna is onduidelijk. Behalve trends in ruimte en tijd, kan ook het ruimtelijk selectief karakter van de visserij een grote invloed uitoefenen. Het positief effect van garnalenvisserij op garnaal kan alleen worden verklaard als een gevolg van het selectief volgen van de visgemeenschap door de visserij. 


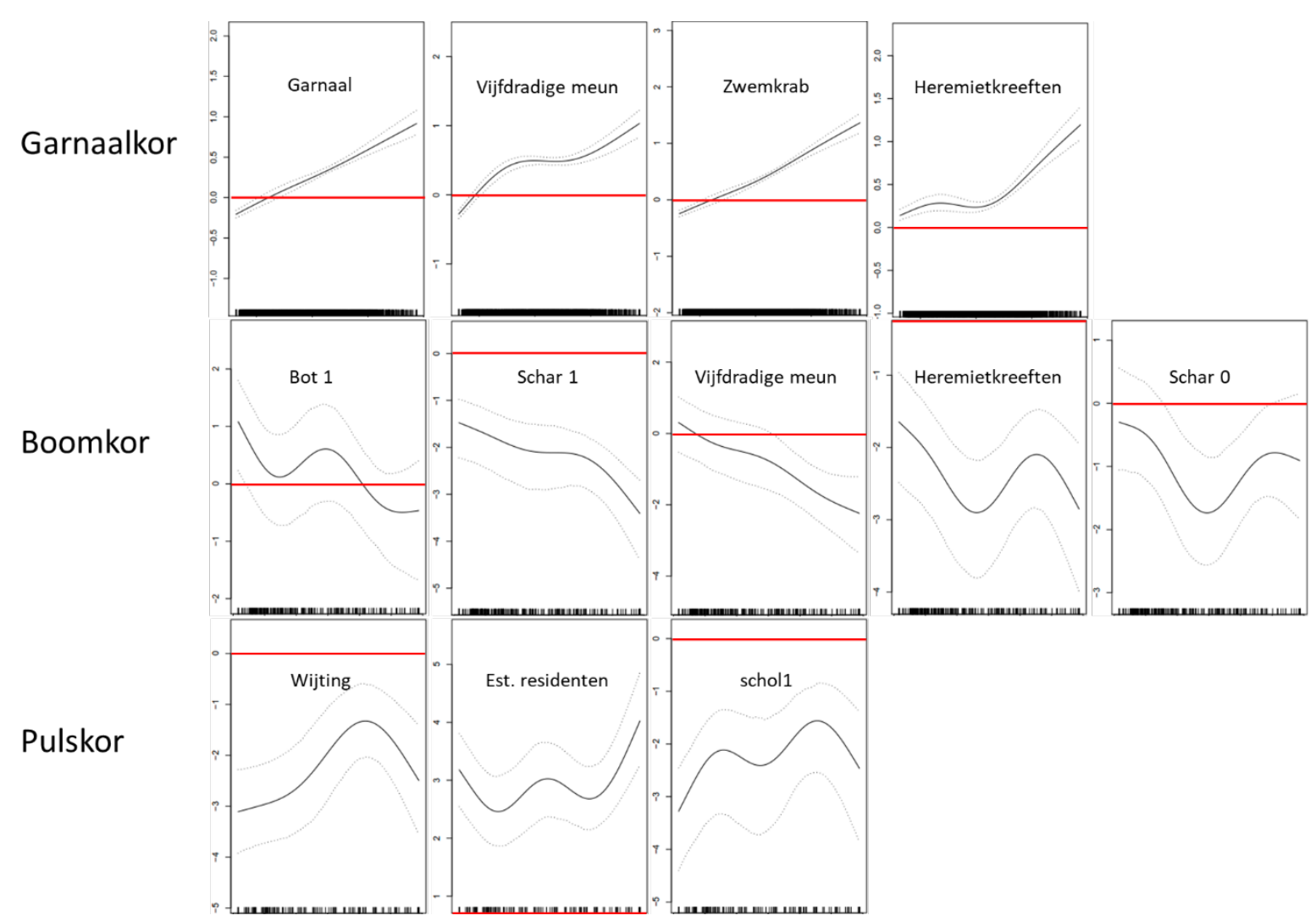

Figuur 6.23. Alle significante relaties gevonden in de ruimtelijke modellen voor 21 vis- en epifauna soorten en soortsgroepen met drie vormen van visserij. De figuren tonen de invloed op de responsvariabele als een functie van de visserij-intensiteit op de $x$-as. De rode lijnen geven het nulpunt in de respons weer. Responsen die boven deze lijn vallen zijn positief, onder de lijn negatief. Waar 0 buiten de $y$-as van de figuur viel, is een rode lijn bovenaan of onderaan de $y$-as geplaatst.

\subsubsection{Multivariate analyse van de relatie tussen visgemeenschap, omgeving en visserij.}

Voor de relatief korte tijdserie van de Voordelta (2006 -2017, de periode waarover visserijgegevens beschikbaar zijn) is de significantie van de relatie met een aantal abiotische variabelen onderzocht met een Constrained Correspondence Analysis (CCA). De omgeving is gekarakteriseerd aan de hand van windkracht en -richting tijdens de bemonstering, sedimentsamenstelling, stroomsnelheid en golven in de week voorafgaand aan de trek, temperatuur en saliniteit, en intensiteit van visserij met boomkor, garnalenkor en pulskor in de twee maanden voorafgaand aan de trek.

Methodologische details van de analyse worden gegeven in het syntheserapport (Tulp et al., 2018). Kort samengevat worden in de analyse de volgende stappen gezet. De samenstelling van de visfauna wordt lineair gerelateerd aan twee sets van factoren: enerzijds de abiotische variabelen en de jaarlijkse fluctuaties, anderzijds de visserij-intensiteit (er zijn aparte analyses voor boomkor, pulskor en garnalenvisserij). Het deel dat wordt verklaard door de abiotische gegevens wordt niet nader beschouwd - dit zijn voor deze analyse de cofactoren waarvoor moet worden gecorrigeerd. Het deel dat wordt verklaard door de visserij wordt grafisch onderzocht naar opvallende correlaties met bepaalde soorten in de gemeenschap. Er wordt ook getest of dit een significant deel van de totale variatie betreft. Dat gebeurt met een randomisatietest, waarbij het effect van de visserij (echte data) wordt vergeleken met het effect van pseudodata, verkregen door de echte data door elkaar te husselen. Als de echte data meer variatie verklaren dan de extreme random data (er wordt 999 keer geprobeerd), dan zijn ze significant. 
De biplots laten de verdeling van de soorten zien in relatie tot de jaren en de visserijdruk, na correctie voor abiotische factoren. Soorten die aan de randen vallen van de biplot zijn soorten die 'hard trekken' aan de verdeling. Dat kunnen invloedrijke soorten zijn die sterke veranderingen laten zien in een bepaalde periode, maar ook de wat zeldzamere soorten.

In beide analyses (met de drie typen visserij), is er een statistisch significant effect van visserijdruk op de samenstelling van de gemeenschap (boomkorvisserij $p=0,006$, garnalenvisserij $p=0,001$, pulskorvisserij $p=0,021)$. De bijdrage aan de totaal verklaarde variantie is echter gering: $0,6 \%$ voor de boomkorvisserij, $1,1 \%$ voor de garnalenvisserij en $0,4 \%$ voor de pulskorvisserij. In deze analyses is het jaareffect veel sterker en ook sterk gecorreleerd met het visserij effect: de boomkorvisserij is sterk afgenomen met de jaren, de garnalenvisserij is juist sterk toegenomen. Daardoor kan statistisch niet goed onderscheid worden gemaakt tussen het jaareffect en het visserij-effect. De biplots (Figuur 6.24) tonen hoe de samenstelling van de gemeenschap correleert met de visserijfactoren, maar vooral ook met de verschillen tussen jaren.
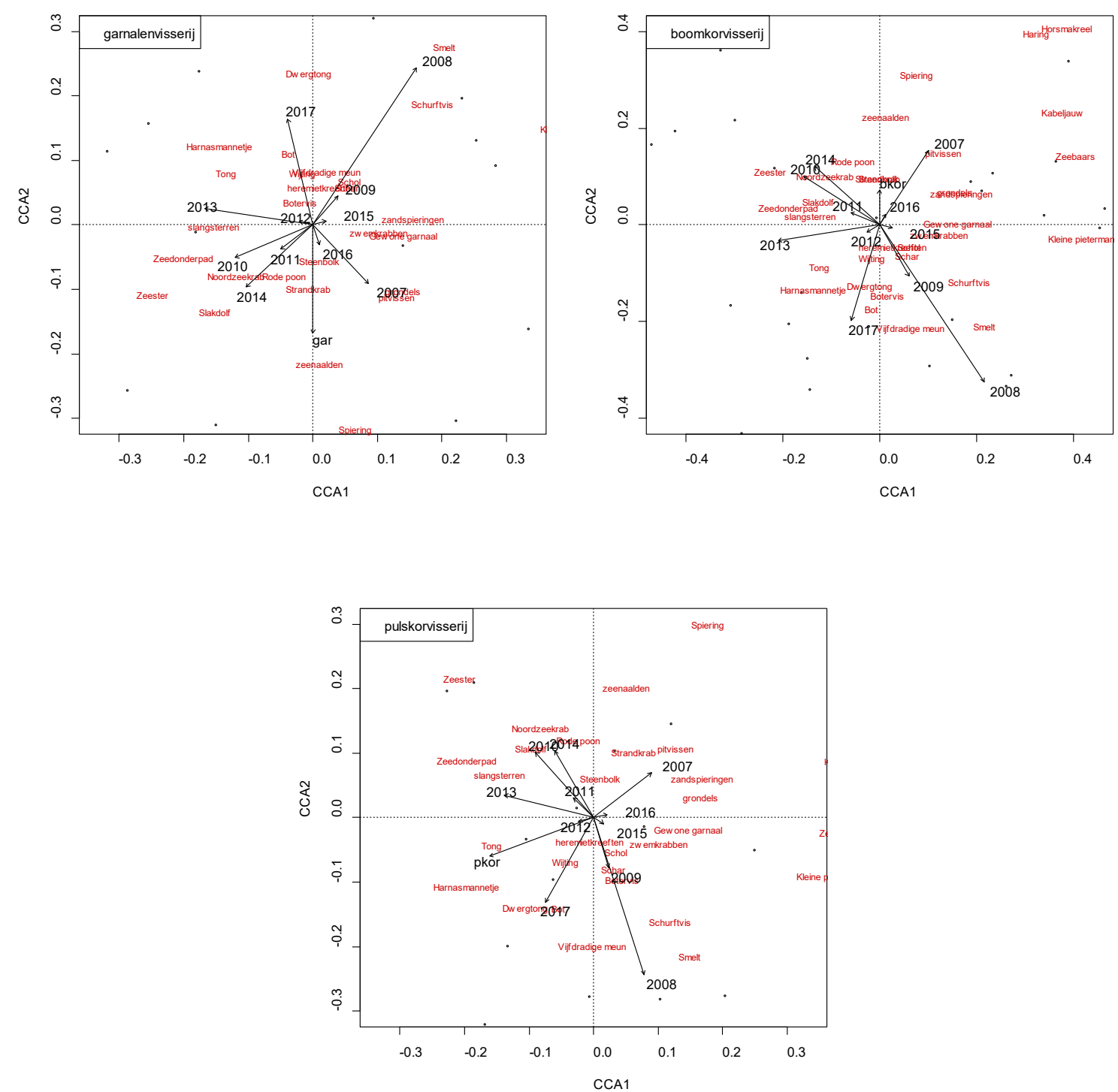

Figuur 6.24. CCA analyse van de DFS Voordelta data 2006-2017. Er is gecorrigeerd voor abiotische variabelen (windsnelheid, diepte, stroomsnelheid, saliniteit, temperatuur, sediment (bodemschuifspanning), factor jaar en visserijdruk door garnalenvisserij, pulskorvisserij en boomkorvisserij worden in de biplots onderzocht. 
Uit deze analyse wordt het volgende geconcludeerd:

- In de Voordelta zijn diverse abiotische factoren en de inspanning door boomkorvisserij en garnalenvisserij statistisch significante voorspellende variabelen voor de verandering in de gemeenschap van vissen en epibenthos in de periode 2006-2017. Visserijinspanning draagt bij aan het verklaren van de verschuivingen, maar de abiotische variabelen verklaren een veel groter deel van de variantie.

- Omdat de visserij-inspanning systematisch varieert over de jaren, met een afnemende trend in boomkorvisserij en een toenemende trend in pulskorvisserij en garnalenvisserij, kunnen effecten van visserij gemakkelijk verward worden met jaar-tot-jaar variatie. Statistisch kunnen beiden bijzonder moeilijk worden gescheiden.

\subsubsection{Discussie visserijgegevens}

Het effect van visserij en van het instellen van het bodembeschermingsbesluit op de visstand in de Voordelta, is vergeleken met de rest van de Nederlandse kustzone.

In het Bodembeschermingsgebied zijn beperkende maatregelen opgelegd aan de visserij. Daarnaast heeft in het referentiegebied een sterke afname van boomkorvisserij plaatsgevonden, die is gedreven door externe factoren en geen rechtstreeks gevolg van het gevoerde beleid. Tenslotte is, vooral in BBG maar ook in REF, de intensiteit van de garnalenvisserij sterk toegenomen over de jaren. In dit hoofdstuk hebben we ons afgevraagd of de maatregelen, en eventueel de extern gedreven ontwikkelingen, een invloed hebben gehad op de samenstelling, biomassa en dichtheid van de visfauna en de epifauna.

Het is, logischerwijze, te verwachten dat visserij een invloed uitoefent op de visfauna. Visserij heeft immers de bedoeling dit te doen, door vis of andere doelsoorten zoals garnaal, aan het systeem te onttrekken. Deze onttrekking kan substantieel zijn. Voor commerciële soorten is mortaliteit door visserij vaak vergelijkbaar met of groter dan natuurlijke mortaliteit. Of dat ook zo is voor soorten die niet zelf de doelsoorten zijn van de visserij is moeilijk na te gaan, omdat voor de niet-commerciële soorten de statistieken van vangst, discards en de populatie veel minder goed zijn uitgewerkt.

Veeleer dan de algemene vraag naar invloed van visserij op de commerciële vissoorten, is voor PMR van belang om vissen en epifauna te beschouwen als deel van de gemeenschap van habitat H1110B. Deze soorten maken deel uit van de biodiversiteit van het systeem, functioneren als predatoren op de bodemfauna, worden zelf als prooi gegeten door vogels en zeezoogdieren, en kunnen dus ecologische verschuivingen in het ecosysteem indiceren. De centrale vraag voor deze rapportage is of veranderingen in de visserij-intensiteit gevolgen hebben gehad op deze ecologische rol van vis en epifauna in het ecosysteem. Dat omvat naast commerciële soorten, ook de niet-commerciële soorten die ecologisch een belangrijke functie kunnen vervullen.

Het detecteren van een dergelijke invloed, gebaseerd op de visserijgegevens van de intensieve bemonsteringen in de Voordelta tijdens T0 en T1, of op basis van de uitgebreide DFS tijdens T2, is niet gemakkelijk gebleken. De ruimtelijke dekking van de surveys is beperkt, zeker in het licht van de grote variatie aan abiotische factoren (b.v. diepte, temperatuursregime, korrelgroottesamenstelling, stroomsnelheid, golven) die zich in de kustzone op relatief kleine ruimtelijke schaal voordoen.

De belangrijkste moeilijkheid is dat vissers geen toevallig gebruik van de ruimte maken, maar gericht hun activiteiten concentreren op die gebieden waar de hoogste vangst kan worden verwacht. Over het algemeen zijn dat biologisch rijke gebieden, omdat er een sterke ruimtelijke correlatie bestaat tussen de biomassa, diversiteit en groeisnelheid van bodemdieren en het voorkomen van (commercieel) bevisbare populaties. Ook als visserij een negatieve invloed uitoefent op de biomassa en dichtheid van vis en epifauna, bestaat de mogelijkheid dat door de vrije keuze aan visgronden, de positieve relatie tussen visserij en doelsoorten het correlatiebeeld zal overheersen. Dit is bijvoorbeeld gebleken uit de positieve relaties tussen intensiteit van garnalenvisserij en populatiedichtheid van de garnaal in de ruimtelijke modellering. 
Een tweede moeilijkheid is dat visserij een substantieel deel van de populatie van die doelsoorten, en van de andere geassocieerde soorten, kan wegnemen uit het systeem. De soorten die in de DFS survey worden gerapporteerd zijn allemaal soorten die in principe door de boomkor- en garnalenvisserij kunnen worden gevangen, hetzij als hoofdvangst hetzij als bijvangst. De overleving van de bijvangst is variabel en vaak niet zeer goed gekend, maar de visserij is zeker een bron van mortaliteit voor deze soorten (FAO, 2011), al kan ze ook voor aasetende soorten een bron van voedsel zijn. Als visserij zich concentreert in gebieden met de hoogste concentratie aan doelsoorten, en op deze plaatsen de concentratie substantieel vermindert, dan zal visserij dus leiden tot het uitvlakken van gradiënten in concentratie. Verwacht kan worden dat zonder visserij het contrast in populatiedichtheid van vis- en epifauna tussen optimale en suboptimale gebieden groter zal zijn dan met visserij. Immers, visserij reduceert selectief de dichtheid in de voor de doelsoorten optimale leefgebieden, maar verandert weinig in de suboptimale gebieden. Het gevolg is dat in een gebied waar sinds jaar en dag intensief wordt gevist, een correlatie-analyse tussen visserij-inspanning en dichtheid van doelsoorten (of direct daarmee geassocieerde soorten) slechts een beperkte correlatie zal opleveren. Naarmate het wegnemen van biomassa kwantitatief belangrijker wordt, en het visserij-effect dus in de natuur belangrijker wordt, verwacht men een zwakkere correlatie tussen inspanning en voorkomen van doelsoorten.

Een derde moeilijkheid is dat de responstijd van de ecologische gemeenschap, inclusief dus vissen en epifauna, op veranderingen in visserij-intensiteit vrij lang kan zijn. Vooral bij het snel verminderen van de visserijdruk, zoals is gebeurd met de boomkorvisserij in de Nederlandse kust rond 2005-2010, kan verwacht worden dat het jaren duurt voordat de ecologische gemeenschap zich daaraan heeft aangepast. Bij een correlatie-analyse die uitgaat van gekoppelde visserij-dichtheid gegevens binnen hetzelfde jaar, kan dat een relatie maskeren, zelfs als er een sterk causaal verband zou bestaan. In het geval van de Nederlandse kust komt daarbij dat de vermindering van de boomkorvisserij gepaard is gegaan met de synchrone vermeerdering van de garnalenvisserij en pulskorvisserij, waardoor gemengde signalen met elk waarschijnlijk een lange responstijd zorgen voor een complexe respons van de biologische gemeenschap op de veranderingen in de visserij (aannemend dat een causaal verband sterk aanwezig is). De kans om dit patroon terug te vinden in een statistische analyse die impliciet uitgaat van een vrijwel onmiddellijke (binnen een jaar) respons, is waarschijnlijk klein en de mogelijkheden om de relatie te onderzoeken met verschillende tijdsintervallen (b.v. sprongen van 3 of meer jaar) is nog erg beperkt met een dataserie vanaf 2006 .

\subsubsection{Conclusies over vis- en epifauna}

Om al deze redenen moeten we concluderen dat het uit de voorliggende gegevens noch voor de Voordelta, noch voor de Nederlandse kust in het algemeen, uit de analyses duidelijk is geworden dat de gemeenschap van vissen en epifauna wordt beïnvloed of beperkt door de visserij-inspanning in het verleden of in de huidige situatie. Hoewel een dergelijk causaal verband waarschijnlijk is, gezien het doel van de visserij om deze fauna te beïnvloeden, is het toch zo goed als onmogelijk het aan de hand van bestaande data te detecteren. Uit de voorliggende gegevens kan dan ook voor de Voordelta geen conclusie worden getrokken over de mate waarin de dichtheid of biomassa van vissen en epifauna door de veranderingen in de visserij positief of negatief zijn beïnvloed.

Noch op de schaal van de Nederlandse kustzone, noch op de schaal van de Voordelta, beschikken we over referentiegebieden die langdurig onberoerd zijn gebleven door visserij, en die derhalve zouden toelaten te concluderen hoe de trends in vissen en epifauna er zonder de invloed van visserij zouden uitzien. Het instellen van een Bodembeschermingsgebied, waarin de bodem en de daarbij horende ecologische gemeenschap effectief wordt beschermd over een groot en gevarieerd gebied en gedurende een lange periode, zou wat dat betreft een zeer grote vooruitgang betekenen ten opzichte van de huidige situatie. 


\subsection{Conclusies}

De centrale vraagstelling voor $\mathrm{H} 1110 \mathrm{~B}$ was of er positieve trends waar te nemen zijn in de aanwezigheid en dichtheid van typische soorten en in de kenmerken van een goede structuur en functie van het habitattype H1110B in de Voordelta sinds het begin van de afname van de boomkorvisserij uit de Voordelta rond de laatste eeuwwisseling en of deze waargenomen trends toe te schrijven zijn aan de afgenomen bodemberoering ten gevolge van de afname van de grote boomkorvisserij met wekkerkettingen in de gehele Voordelta of ook aan andere factoren.

In de monitoringperiode zijn sterke verschuivingen opgetreden in de samenstelling, biomassa en diversiteit van de bodemdiergemeenschap. Die verschuivingen, vooral van indicatoren die gerelateerd zijn aan biomassa, vallen in ruimte en tijd samen met verschuivingen in de visserij maar zijn tegengesteld aan de verwachtingen. De ontwikkeling van de invasieve soort Ensis leei, mogelijk in directe relatie met de visserijdruk, heeft daarin een sleutelrol gespeeld. We constateren een toenemende totale biomassa met toenemende visserijdruk, zowel van boomkorvisserij als van garnalenvisserij, al is het effect van die laatste minder sterk. Er is verder geconstateerd dat de diversiteit op biomassabasis is toegenomen met verminderde visserijdruk door boomkorvisserij. Dat heeft zich vooral in het referentiegebied gemanifesteerd. Binnen de gemeenschap zijn biologische interacties veranderd. Wellicht hebben die aanleiding gegeven tot de geconstateerde stijgende trend in de diversiteit op dichtheidsbasis, vooral een reflectie van toegenomen diversiteit in kleine en weinig talrijke soorten, die geen duidelijke relatie vertoont met visserij of met omgevingsvariabelen.

De visgemeenschap is te variabel gebleken om sterke statistische relaties met visserijdruk te constateren. Er zijn significante, maar zwakke signalen van de invloed van visserij op de gemeenschap teruggevonden. De trends in de Voordelta zijn over het algemeen vergelijkbaar met trends in de rest van de Nederlandse kustzone. Het instellen van het Bodembeschermingsgebied heeft geen duidelijk herkenbaar effect gehad op vis- en epifauna in de Voordelta, maar heeft ook geen gebied gecreëerd dat vrij is van visserijdruk. Door het ontbreken van een referentiegebied zonder visserij en met voldoende ruimtelijke variatie in abiotiek, kunnen effecten van visserij op vis en epifauna niet onderscheiden worden. 


\section{$7 \quad$ Sterns}

Het Milieueffectrapport (MER; Berkenbosch et al., 2007)) en de Passende Beoordeling (PB; Heinis et al., 2007) voorspelden dat de aanleg van Maasvlakte 2 een significant negatief effect zou kunnen hebben op de foerageerfuncties (uitgedrukt als in het gebied doorgebrachte aantal vogeldagen) van het Natura 2000 -gebied Voordelta voor de grote stern $(-1,7 \%)$ en de visdief $(-5,9 \%)$. Dit mogelijke effect wordt grotendeels veroorzaakt door het wegvallen van een foerageergebied ter grootte van 2.455 ha, hetgeen gelijk is aan $2,8 \%$ van de oppervlakte van het Natura 2000-gebied. Maatregelen moesten genomen worden om deze als mogelijk significant beoordeelde effecten te compenseren, met als doel de kwaliteit van de Voordelta in stand te houden. De compensatiemaatregelen bestonden uit de instelling van een Bodembeschermingsgebied en van diverse rustgebieden: de Hinderplaat voor zowel de grote stern als de visdief en de Bollen van de Ooster voor de grote stern (Figuur 7.1). Het Bodembeschermingsgebied zou voor meer voedsel moeten zorgen en de rustgebieden zouden er voor moeten zorgen dat de vogels met name na het broedseizoen dichter bij de foerageergebieden konden verblijven.

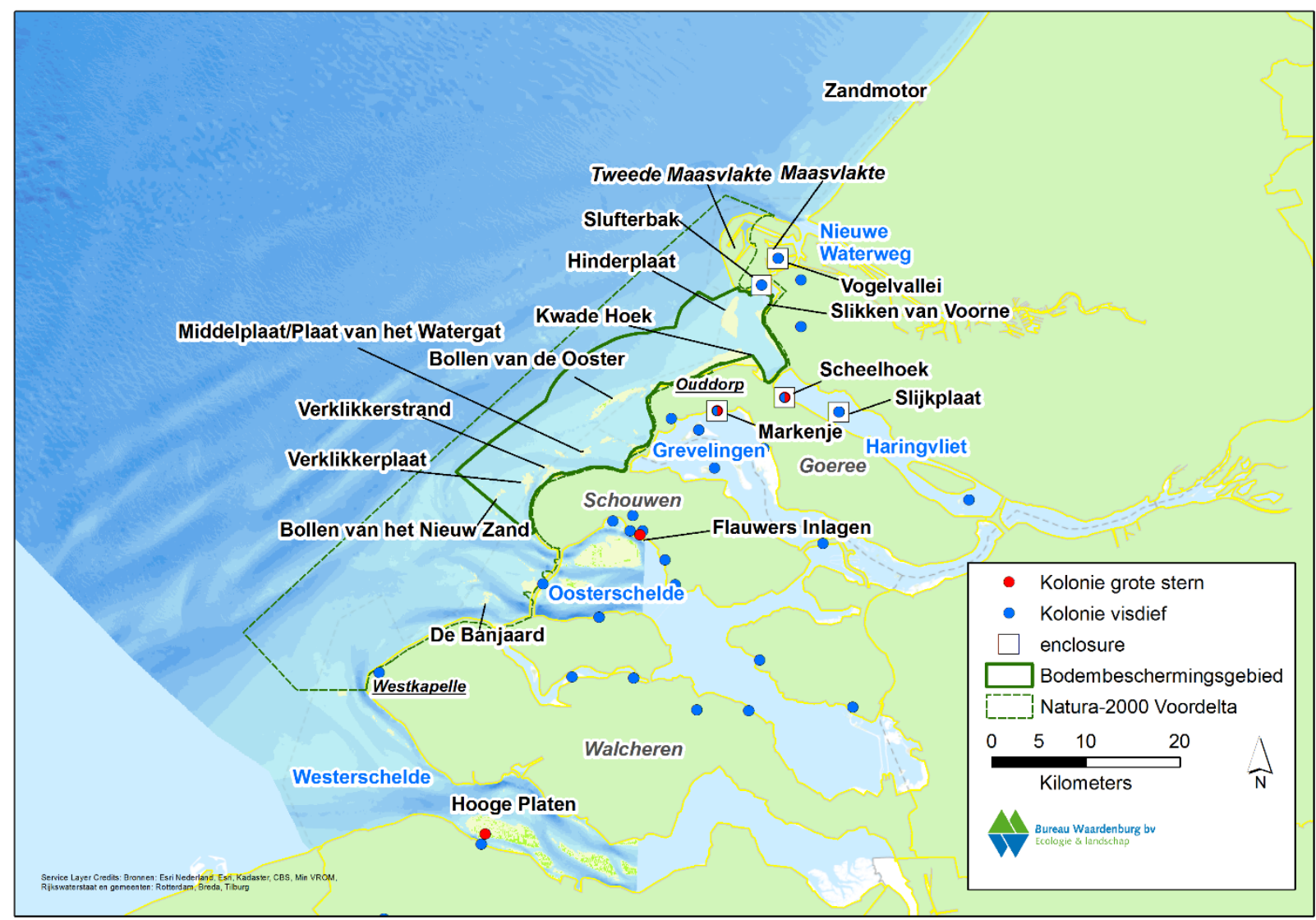

Figuur 7.1. Overzichtskaart van de Voordelta met de in dit hoofdstuk gebruikte locaties. Tevens zijn de broedkolonies van grote stern en visdief weergegeven. Enclosures in de kolonies maken het mogelijk broedsucces nauwkeuriger te meten.

Om te bepalen of het verlies aan foerageergebied van beide sternsoorten voldoende gecompenseerd wordt door deze maatregelen (dit is de belangrijkste MEP-vraag voor deze vogels) is een onderzoeksprogramma opgezet. Idealiter volgt het onderzoek een zogeheten Before-After-ControlImpact (BACI) opzet (voor details zie Hoofdstuk 2), dat wil zeggen dat in het gebied waar de gevolgen 
van de aanleg én van de compensatiemaatregelen verwacht worden (het ingreep of Impact gebied) en in een aantal referentiegebieden (of Control gebieden) zowel vóór (Before) als na (After) de ingreep gemeten wordt hoe de soort ervoor staat. Als responsvariabele die de natuurwaarde van het gebied voor de vogels zo goed mogelijk weergeeft, zou het aantal in het gebied doorgebrachte vogeldagen gebruikt kunnen worden. Als de verandering in zo'n responsvariabele in de tijd (dus het verschil tussen na en vóór) niet verschilt tussen het ingreep- en de referentiegebieden is blijkbaar de grootte van het mogelijk negatieve effect van de ingreep gelijk geweest aan het tegengestelde effect van de compensatiemaatregelen. Hoe groot het negatieve en het tegenovergestelde positieve effect in absolute zin geweest zijn kan echter nooit achterhaald worden.

Omdat het aantal in het gebied doorgebrachte vogeldagen moeilijk te bepalen is, kan beter het aantal broedparen of het aantal groot geworden kuikens gebruikt worden als responsvariabele. Voor de grote stern, die gemakkelijk wisselt tussen nabijgelegen kolonies en ook foerageert in een groot zeegebied, is het hele noordelijke Deltagebied als ingreepgebied gekozen en vijf gebieden elders in het zuidelijke Noordzeegebied als referentiegebieden (één gebied ten zuiden van het ingreepgebied, één gebied in Engeland en drie in de Waddenzee, zie ook Figuur 7.5). Voor de visdief, die veel dichter in de buurt van zijn broedkolonie foerageert, is een iets andere keus gemaakt. Hier is het gebied rond de Maasvlakte het ingreepgebied. De vogels uit de kolonies foerageren alleen in dit gebied en kunnen ook gebruik maken van het aangewezen rustgebied voor visdieven op de Hinderplaat. Als referentiegebieden zijn de verschillende bekkens en zee-armen uit het Deltagebied gekozen (zie ook Figuur 7.6).

Het uitgebreide onderzoek in de ingreepgebieden zelf, dat deels vóór (de zogeheten T0 in 2005 en 2006), maar grotendeels pas na de ingreep is gestart (bestaande uit twee fasen 2009-2013 en 20162019) heeft veel meer gegevens opgeleverd, maar deze kunnen dus meestal alleen gebruikt worden in een BAI (Before-After-Impact) analyse of zelfs slechts in een beschrijving van de AI (After-Impact) situatie. De zeggingskracht van dergelijke analyses is zwakker dan van een BACI. Een BAI analyse laat zien of er al of niet een verandering is opgetreden in het ingreep gebied (hier het noordelijk Delta gebied voor de grote stern en de Maasvlakte voor de visdief), maar dat geeft geen duidelijk antwoord op de vraag of die veranderingen iets met de ingreep te maken hebben gehad. Nog minder zeggingskracht heeft een AI analyse, waarin hooguit een trend na de ingreep waargenomen kan worden.

Tenslotte is er nog een BI (Before-Impact) analyse uitgevoerd in het door de aanleg van de Maasvlakte 2 verdwenen foerageergebied. Doel van deze analyse is om nog een keer kritisch naar de in de MER en PB geschatte directe effecten van de aanleg van Maasvlakte 2 op de sterns te bekijken.

\subsection{Monitoring-inspanning}

De waarnemingen gedaan in het kader van het PMR-NCV programma zijn op te delen in (1) waarnemingen in het foerageergebied, (2) waarnemingen in de rustgebieden en (3) waarnemingen in de broedkolonies. Bij waarnemingen in het foerageergebied gaat het hoofdzakelijk om vliegtuigtellingen in het gehele Deltagebied, die uitgevoerd zijn in de T0 fase voor de aanleg (2005:9 tellingen, 2006:9), in de eerste fase na de aanleg (2009:9 tellingen, 2010:17, 2011:12, 2012:11, 2013:13) en in de tweede fase (2016:6 tellingen, 2017:6, 2018:6, 2019:5).

Het aantal vogels dat zich in de rustgebieden ophield is zowel tijdens de vliegtuigtellingen als regelmatig vanaf land geteld. Ook zijn waarnemingen gedaan van het menselijk gebruik van de rustgebieden, waarbij vooral het plaatbezoek door wandelaars of watersporters een belangrijke verstoring vormt voor sterns. De resultaten van de vliegtuigtellingen zijn gebruikt om te onderzoeken of er indicaties zijn van toenemende verstoring van de vogels in de rustgebieden.

In alle broedkolonies is gedurende de hele periode van 2005-2019 het aantal broedparen geteld en het broedsucces bepaald. Daarnaast is er vanaf 2009 broedbiologisch onderzoek uitgevoerd in diverse kolonies van de grote stern (Scheelhoek en de Slijkplaat in het Haringvliet, Markenje in de Grevelingen, afhankelijk van de vestiging van grote sterns en de onderzoeksmogelijkheden). Onderzoek aan de visdief 
is uitgevoerd in diverse kolonies in Haringvliet, Grevelingen, op de Maasvlakte en op het visdiefeiland in de Slufter. Vanuit schuilhutten is vastgelegd wat er aan prooien werd meebracht voor de jongen en uit faeces is het dieet van de adulten onderzocht. Gedurende het onderzoek zijn seizoensgebonden en jaarlijkse veranderingen in de samenstelling van het voedsel van zowel oudervogels (grote stern) als kuikens (grote stern, visdief) gemeten. Ook is geprobeerd de effecten van de voedselsamenstelling op de groei, conditie en overleving van de kuikens te bepalen. Er zijn geen systematische directe metingen aan voedselbeschikbaarheid op zee gedaan. Informatie over de voedselsituatie is afgeleid uit de aangebrachte prooien en het dieetonderzoek.

Voor verdere details omtrent de gebruikte veld- en analysemethodes verwijzen we naar Tulp et al. (2018) en vooral naar Poot et al. (2014).

\subsection{De betekenis van het verdwenen zeegebied}

Op basis van de gegevens uit de vliegtuigtellingen tijdens de T0-meting (2005-2006) is allereerst door middel van extrapolatie bepaald hoeveel sterns zich gemiddeld in het verdwenen zeegebied van Maasvlakte 2 ophielden. Onderscheid is gemaakt tussen sterns op doortocht en foeragerende sterns. Ook is gekeken hoeveel sterns er rusten langs de zeewering van Maasvlakte 1 en hoe dat veranderd is na de aanleg, waarbij een nieuwe zeewering van Maasvlakte 2 ontstond. Het aantal rustende sterns is voor en na de aanleg in zowel het Maasvlaktegebied als in de gehele Delta geschat.

\subsubsection{Foeragerende sterns}

In het verdwenen zeegebied van Maasvlakte bevonden zich tot maximaal 90 vliegende grote sterns en tot 330 vliegende visdieven. Naast vliegende grote sterns waarvan geen direct herleidbaar gedrag genoteerd is, zijn tijdens de T0-meting in het gebied van de latere Maasvlakte 2 ook foeragerende grote sterns aangetroffen. Grote sterns visten met name langs het toenmalige strand, maar ook nabij de overgang van het strand naar de harde zeewering. Dergelijk gedrag werd tijdens de aanleg in 2009 veel minder gezien, maar in de jaren daarop zijn langs het nieuwe strand weer veelvuldig vissende grote sterns gezien (Tulp et al., 2018). Een recent ontwikkeld habitatmodel, op basis van foerageertrips in 2012-2015 en 2017 van gezenderde grote sterns uit de bij het Haringvliet gelegen kolonies Scheelhoek en Slijkplaat, schatte dat ongeveer $1,1 \%$ van alle foerageertijd in het verdwenen zeegebied werd doorgebracht (Figuur 7.2, Fijn et al., 2019). Deze schatting komt goed overeen met de schatting van $1,4 \%$ uit de PB.

Oorspronkelijk werd het zeegebied, en met name de kust van Maasvlakte 1, voornamelijk gebruikt door foeragerende visdieven, dit in tegenstelling tot grote sterns die het gebied slechts doorkruisten. Tijdens de aanleg van Maasvlakte 2, in 2009 en 2010, foerageerden grote aantallen visdieven in het zeegebied en de zandsuppletieschepen trokken massaal foeragerende visdieven aan. Visdieven worden aangetrokken door turbulent water en in de Voordelta foerageren ze in het bijzonder in spui-openingen en dichtbij de kust net achter de branding. Na aanleg van Maasvlakte 2 zijn foeragerende visdieven vooral langs de kusten van Maasvlakte 2 aangetroffen en in veel kleinere aantallen verder op zee (Tulp et al., 2018).

Samenvattend, het gebied waar nu de Tweede Maasvlakte ligt en het aangrenzende zeegebied hadden geen essentiële foerageerfunctie voor grote sterns en ook zijn er geen aanwijzingen dat de aantallen grote sterns die er wel foerageerden zijn afgenomen na aanleg van Maasvlakte 2. Deze gebieden hadden wel een essentiële foerageerfunctie voor visdieven die broeden op de Maasvlakte. Deze functie lijkt echter volledig overgenomen door het gebied voor de nieuwe zeewering rond Maasvlakte 2. De extra vliegkosten die dit met zich meegebracht heeft en de gevolgen hiervan voor het broedsucces van de visdief komen nog aan de orde. 

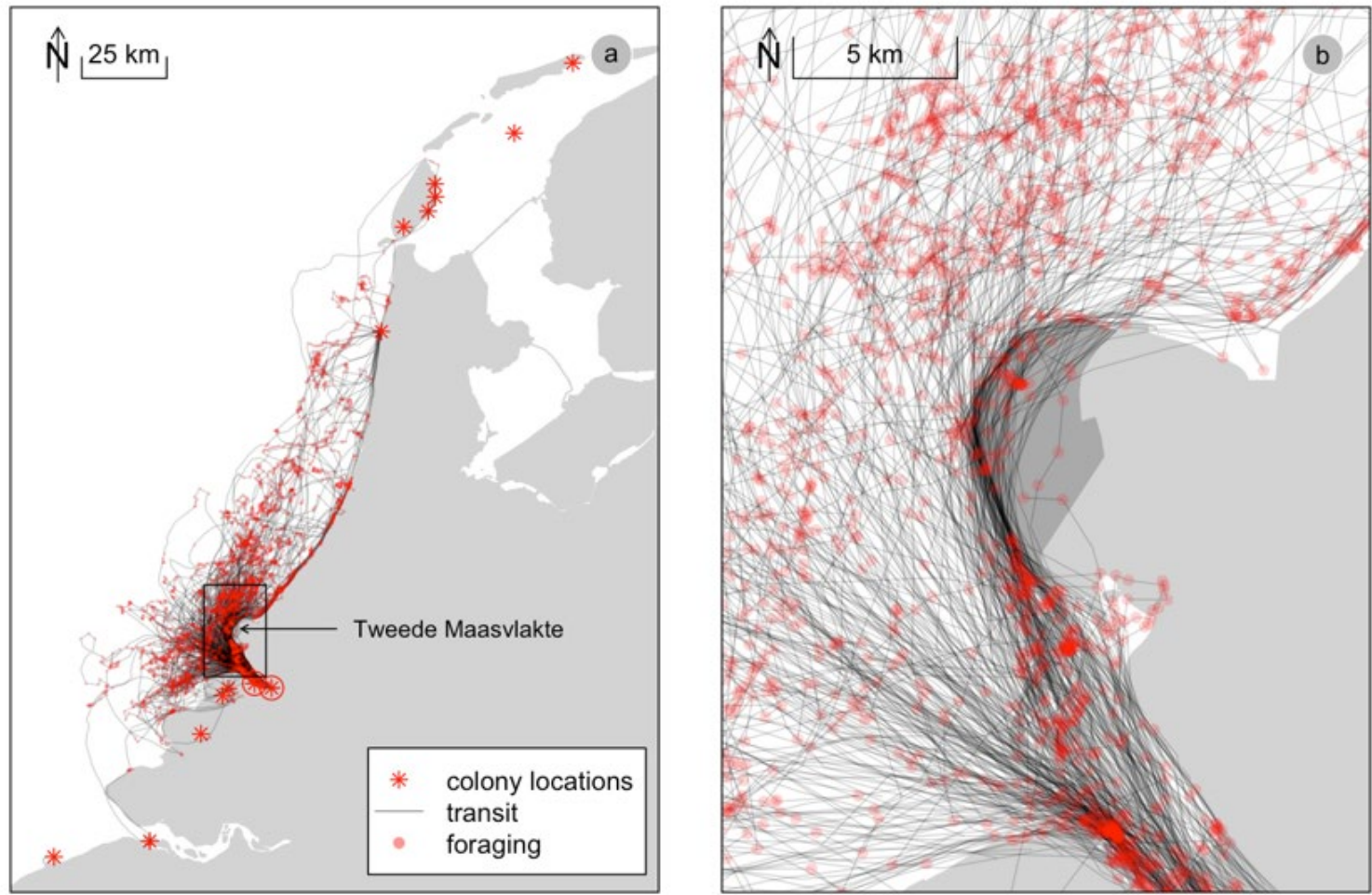

Figuur 7.2. Overzicht van vliegtrajecten (grijze lijnen) en foerageerspots (kleine rode cirkels) van grote sterns uit de kolonies Scheelhoek en Slijkplaat, in 2012-2015 en 2017 (uit Fijn et al. 2019)

\subsubsection{Rustende grote sterns}

Behalve dat ze er foerageerden, rustten grote sterns tijdens de T0-meting ook relatief vaak op het strand van Maasvlakte 1. Het zwaartepunt van rustende grote sterns lag op de zuidpunt, het Slufterstrand. Deze functie is overgenomen door het strand van Maasvlakte 2 en de aantallen rustende grote sterns zijn tot 2017 niet veranderd, noch in het gebied rond de Maasvlakte noch in de gehele Voordelta (Figuur 7.3). In 2018 en 2019 werd een schiereiland op de Tweede Maasvlakte als rustgebied gebruikt in juli en augustus, maar de geplande bebouwing zal hier een eind aan maken.

Figuur 7.3. Gemiddeld aantal rustende grote sterns per vliegtuigtelling in het Maasvlakte gebied (links) en in de gehele Voordelta (rechts). In 2007, 2008, 2014 en 2015 is niet geteld.
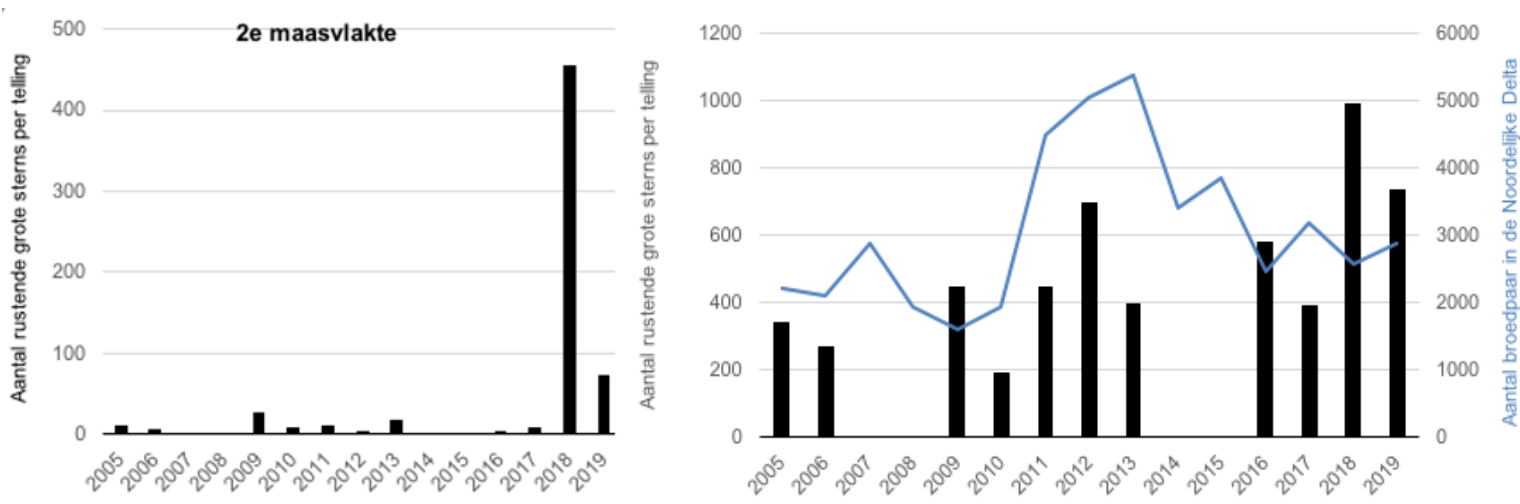
De rust in het gebied is mogelijk wel afgenomen door de goede toegankelijkheid van het strand van Maasvlakte 2 waardoor strandbezoek en kite-surf activiteiten zijn toegenomen (van Oostveen en Koolmees, 2013). De aantallen rustende grote sterns zijn daarentegen niet significant afgenomen. De hoeveelheid potentieel rustgebied (aantal kilometer strand) is toegenomen in de nieuwe situatie. Er zijn dus geen concrete aanwijzingen dat kwaliteit en omvang van het leefgebied is afgenomen.

\subsubsection{Rustende visdieven}

Tijdens de nulmeting rustten en foerageerden visdieven op en bij het strand van Maasvlakte 1 , en lag het zwaartepunt van rustende visdieven op de zuidpunt, het Slufterstrand. Deze functie is deels overgenomen door het strand van Maasvlakte 2, maar de aantallen rustende visdieven zijn erg variabel (Figuur 7.4). Nog altijd is met name de zuidpunt, het Slufterstrand, in gebruik door visdieven, maar de aantallen nemen af, wat er op kan duiden dat de kwaliteit van het rustgebied is afgenomen. De aantallen van deze soort in de gehele Voordelta zijn echter ook afgenomen.
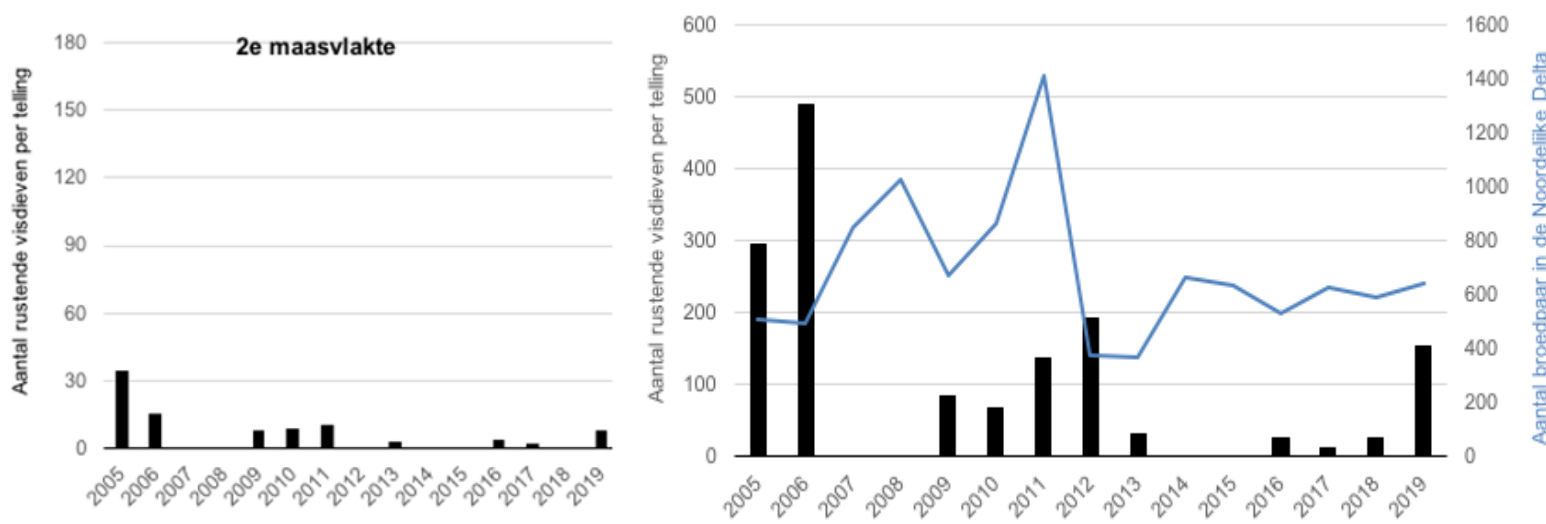

Figuur 7.4. Gemiddeld aantal rustende visdieven per vliegtuigtelling in het Maasvlakte gebied (links) en in de gehele Voordelta (rechts) uitgezet voor de verschillende jaren. In 2007, 2008, 2014 en 2015 is niet geteld.

\subsection{Aantallen broedende sterns: BACI en BAI analyses}

Een Before-After-Control-Impact (BACI) benadering is gevolgd met als responsvariabele het aantal broedparen. De veranderingen in aantal broedparen in de periode van vóór (Before) tot na (After) de ingreep in het gebied waar de gevolgen van de aanleg én van de compensatiemaatregelen verwacht worden (het ingreep of Impact gebied) is vergeleken met de veranderingen in een referentiegebied (of Control gebied).

\subsubsection{Broedende grote sterns in de noordelijke Delta en de rest van het Noordzeegebied voor en na de aanleg van Maasvlakte 2}

Grote sterns die broeden in kolonies grenzend aan de Voordelta gebruiken deze, en ook gebieden verder uit de kust, als foerageergebied (Poot et al., 2014). De aantallen sterns die gebruik maken van het Bodembeschermingsgebied (als onderdeel van de Voordelta) zullen dan ook sterk samenhangen met de populatie-ontwikkeling van sterns in de verschillende noordelijke Delta-kolonies.

De broedpopulatie van de grote stern in het hele Deltagebied was eind jaren zeventig en begin jaren tachtig met ca. 4.000 paren lange tijd stabiel. Daarna volgde een afname tot ongeveer 2.500 paar, mede door de ontwikkeling van de kolonie in Zeebrugge. In de jaren negentig en het begin van de $21^{\mathrm{e}}$ eeuw was het voorkomen in het Nederlandse Deltagebied (vrijwel) beperkt tot twee grote kolonies: de 
Hompelvoet in het Grevelingenmeer en de Hooge Platen in de Westerschelde. Rond de eeuwwisseling bleef het aantal broedparen van de grote stern in het Deltagebied weer redelijk stabiel (ca. 6.000 paren). In 2004 brak een nieuwe, meer dynamische periode aan en tussen 2004 en 2012 wisselden perioden met hoge aantallen en lage aantallen elkaar af. Grote sterns vestigden zich in 2004 voor het eerst sinds decennia weer in kolonies aan het Haringvliet en de Oosterschelde en verlieten in 2005 en masse het Grevelingenmeer.

In de periode tussen 2005, het begin van de T0-meting van PMR-NCV en 2019 vertoonden de aantallen grote sterns die broeden in het noordelijke Deltagebied geen duidelijke trend, maar hebben wel fluctuaties plaatsgevonden in aantallen broedparen (Figuur 7.5) en bezetting van kolonielocaties (Fijn et al., 2016). In de periode 2005-2010 lag de grootste kolonie wisselend in Haringvliet en Oosterschelde. In de noordelijke Delta waren de aantallen vlak na de start van de aanleg van Maasvlakte 2 (2011-2012) het hoogst. In recente jaren nemen de aantallen grote sterns af in het noordelijk Delta-gebied (Figuur 7.5), mogelijk ten gevolge van een toename van het beschikbare broedgebied in combinatie met gunstige voedselomstandigheden elders in Nederland, zoals op Texel. Of er daadwerkelijk een nettoemigratie vanuit de Delta naar de Waddeneilanden plaatsvindt zal moeten blijken uit toekomstige analyse van ringgegevens.

De BACI-analyse liet geen significant verschil zien in de log-ratio van het gemiddeld aantal broedparen vóór en na de aanleg tussen het noordelijke Deltagebied en de vijf referentiegebieden $(p=0,74)$. Ook wanneer de periode 2015-2019 als de periode na de aanleg gekozen wordt (rekening houdend met een mogelijke overgangsperiode na de aanleg totdat een meer stabiele situatie is bereikt) was er geen effect waarneembaar $(p=0,99)$. 

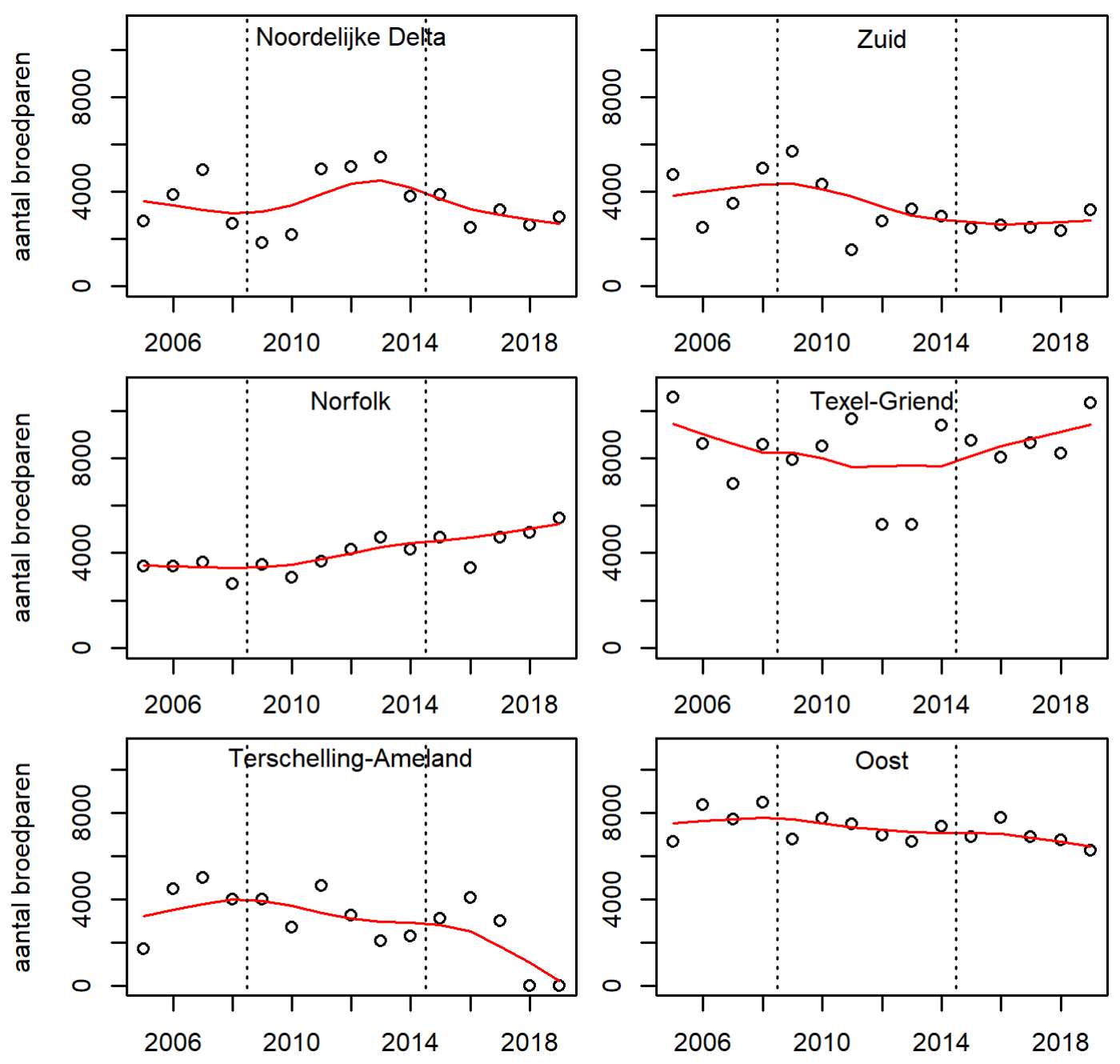

jaar

jaar

Figuur 7.5. Aantallen broedparen van grote sterns in het noordelijk Deltagebied (het Impact gebied) en in vijf referentiegebieden verspreid over de gehele zuidelijke Noordzee tussen 2005 en 2019. Zuid is het gebied van de Westerschelde tot in Frankrijk, oost van Sleeswijk-Holstein tot in Denemarken. Data afkomstig van P. Thellier, INBO, DPM, Zeeuws Landschap, N. Lawton (Natural England), A. Tejala (National Trust), M. Leopold (WMR), B. Spaans (VWG-Texel), M. Plomp (Vogelinformatiecentrum Texel), E. Menkveld, D. Lutterop (Natuurmonumenten), A. Brenninkmeijer (A\&W), T. Bregnballe, J. Gregersen (Aarhus University), B. Hälterlein (Verein Jordsand). De verticale stippellijnen geven de grenzen weer van de in de BACI analyse gehanteerde perioden.

\subsubsection{Broedende visdieven op de Maasvlakte en de rest van het Deltagebied voor en na de aanleg van Maasvlakte 2}

Visdieven die broeden in kolonies dicht aan de kust in de Delta, gebruiken uitsluitend de kustzone van de Voordelta als foerageergebied (Poot et al., 2014; Fijn et al., 2016), hetgeen ook in de Passende Beoordeling is aangenomen. Visdieven uit de kolonies op de Scheelhoek hebben een relatief beperkt foerageergebied dat zich concentreert rond de uitstroomopening van de Haringvlietsluizen. Tijdens hoogwater, als er weinig uitstroom van zoetwater is, wijken de dieren uit naar de Kwade Hoek en de Haringvlietmonding. Hetzelfde geldt voor vogels van Markenje die voornamelijk lokaal op het Grevelingenmeer en langs de Brouwersdam foerageren. Vanwege deze relatief korte foerageerafstand van visdieven tijdens het broedseizoen (tot ongeveer $10 \mathrm{~km}$ van de kolonie), verwachten we dat de 
meeste visdiefkolonies in het Deltagebied weinig tot geen nadeel hebben ondervonden van de aanleg van Maasvlakte 2. Alleen de kolonies op het Visdiefeiland in de Slufter en in de Vogelvallei ondervinden potentieel hinder van de aanleg van Maasvlakte 2 omdat deze een deel van het voorheen gebruikte foerageergebied inneemt en ze dus mogelijk verder moeten vliegen.

De aantallen broedende visdieven variëren sterk tussen de verschillende jaren, en er is geen eenduidig patroon in de aantallen broedparen in de verschillende deelgebieden van het Nederlandse Deltagebied (Figuur 7.6) en in de bezetting van kolonielocaties (Fijn et al., 2016). Gemiddeld genomen zijn de totale aantallen broedparen na de aanleg van Maasvlakte 2 in de gehele Delta iets lager dan daarvoor. Dit geldt echter niet voor de aantallen op de Maasvlakte zelf, die gemiddeld iets hoger lijken te zijn dan voor de aanleg. In recente jaren nemen de aantallen broedende visdieven vooral in het Haringvliet verder af, maar de aantallen op en rond de Maasvlakte zijn relatief stabiel (Figuur 7.6)
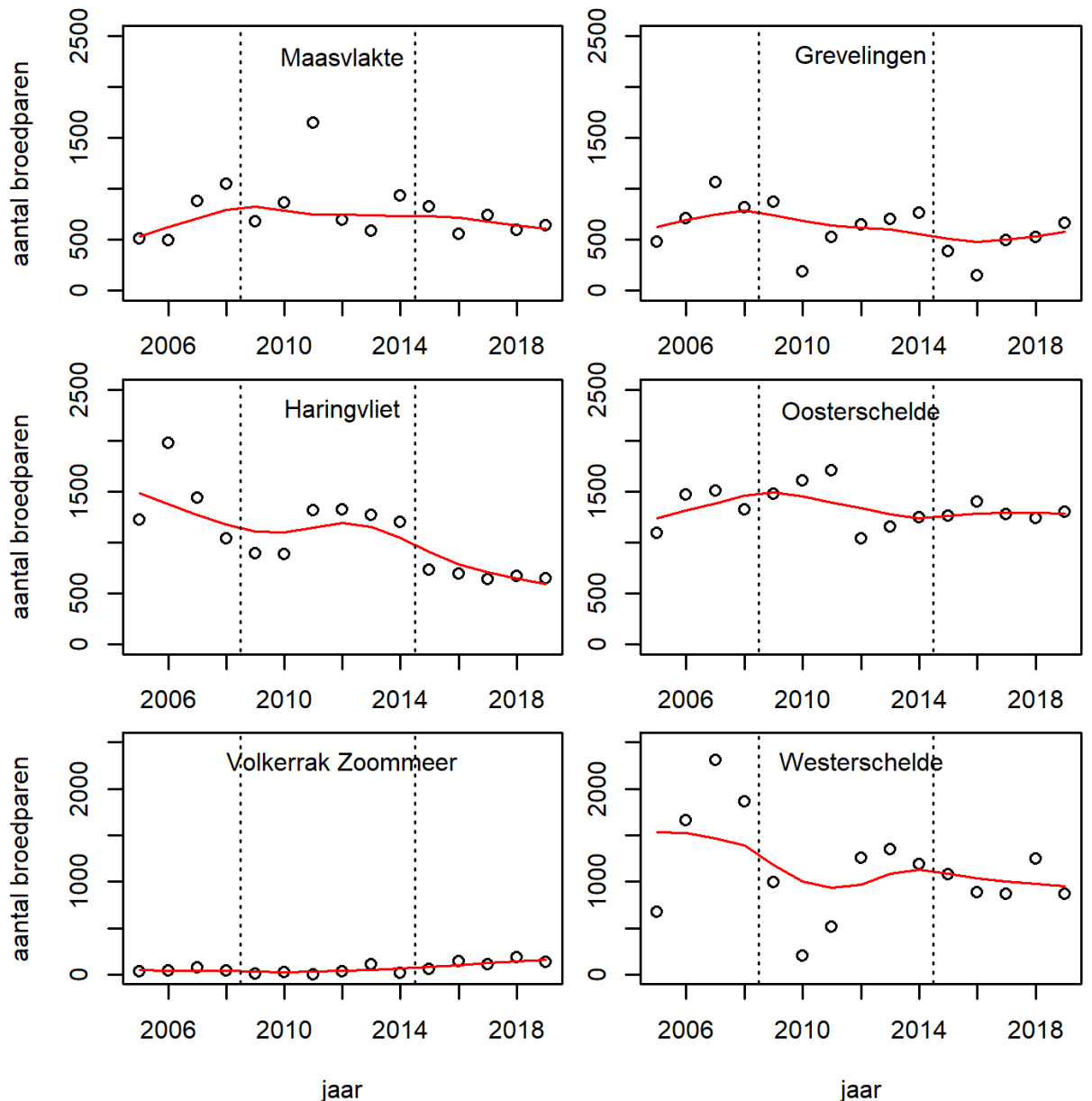

Figuur 7.6. Aantallen broedparen van visdieven op de Maasvlakte (ingreepgebied) en binnen vijf overige referentiegebieden in het Deltagebied tussen 2005 en 2019.

De BACI analyse gaf ook geen aanwijzing dat de verandering in gemiddeld aantal broedparen op de Maasvlakte na de aanleg van Maasvlakte 2 verschilde van veranderingen zoals waargenomen in de referentiegebieden ( $p=0,27$ en $p=0,19$ als de periode na 2014 genomen wordt). Maasvlakte 2 is aangelegd in Natura 2000-gebied Voordelta, een gebied dat is aangewezen voor onder andere visdieven. Op basis van de aantallen vogels in de kolonies (als maat voor de aantallen die van de Voordelta als foerageergebied gebruik kunnen maken), lijkt de aanleg van Maasvlakte 2 dus niet tot een verslechtering van de functie van de Voordelta als foerageergebied voor visdieven te hebben geleid. De conclusie is dan ook te rechtvaardigen dat de aanleg geen effect heeft op het gestelde instandhoudingsdoel voor de foerageerfunctie voor visdieven in de Voordelta. De omvang van het gebied is wel afgenomen, maar de 
kwaliteit lijkt er niet onder te hebben geleden, want de aantallen broedparen zijn onveranderd of zelfs gestegen.

\subsubsection{Broedsucces van grote sterns en visdieven in de Delta voor en na de aanleg van Maasvlakte 2}

Een belangrijke voorwaarde voor het duurzaam voortbestaan van populaties is het behalen van voldoende broedsucces in de kolonies. Tijdens alle fases van PMR-NCV zijn voor alle kolonies van de grote stern in het noordelijk Deltagebied broedsuccesdata verzameld. Voor de visdief is hetzelfde gebeurd op de Maasvlakte.

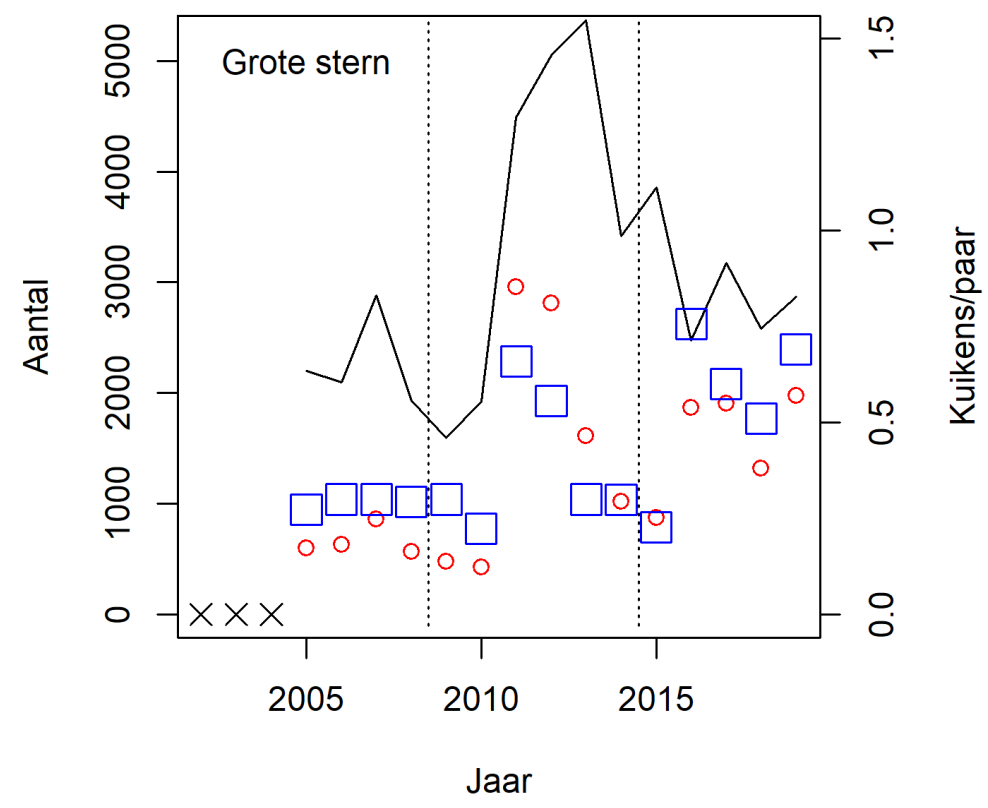

Figuur 7.7. Totaal aantal uitgevlogen jonge grote sterns (rode cirkels), aantal broedparen in de kolonies in het noordelijk Deltagebied (doorgetrokken zwarte lijn) en het broedsucces uitgedrukt in aantal uitgevlogen kuikens per broedpaar (blauwe vierkanten). De kruisjes geven de jaren aan waarin geen metingen gedaan zijn.

Het totaal aantal jonge grote sterns dat jaarlijks in de noordelijke kolonies in de Delta (Scheelhoek, Slijkplaat, Markenje) wordt grootgebracht varieert tussen de 430 en 3.000 (Figuur 7.7). Opvallend is de lage jongenproductie in de periode tot 2011 en de relatief hoge aantallen broedparen gecombineerd met een hoog broedsucces in de jaren vlak na de start van de aanleg (2011-2012). Ook de laatste jaren (vanaf 2016) is het broedsucces relatief hoog. 


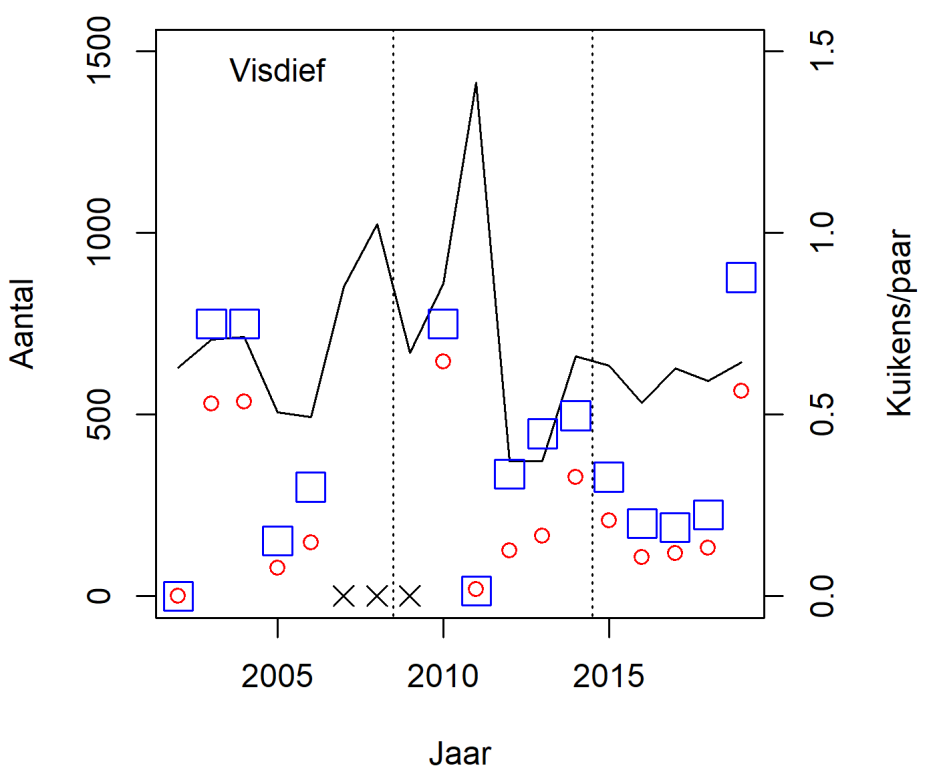

Figuur 7.8. Totaal aantal uitgevlogen jonge visdieven (rode cirkels), aantal broedparen in de kolonies van het Maasvlakte gebied(doorgetrokken zwarte lijn) en het broedsucces uitgedrukt in aantal uitgevlogen kuikens per broedpaar (blauwe vierkanten). De kruisjes geven de jaren aan waarin geen metingen van het broedsucces gedaan zijn.

Het totaal aantal jonge visdieven dat jaarlijks op de Maasvlakte wordt grootgebracht varieert tussen de 0 en 650 kuikens (Figuur 7.8). De variatie tussen jaren is veel groter dan bij de grote stern en er zijn jaren waarin helemaal geen kuiken worden grootgebracht (2002 en 2011). In sommige andere jaren zoals bijvoorbeeld 2010, toen er zeer veel gefoerageerd werd achter de zandsuppletieschepen in het Maasvlakte 2 gebied, is het broedsucces juist relatief hoog. Er is geen duidelijke trend in broedsucces bij de visdief op de Maasvlakte.

Recent zijn door SOVON Vogelonderzoek Nederland, Vogeltrekstation, Delta Project Management en het Instituut voor Natuur- en Bosonderzoek de broedsuccesdata van grote sterns en visdieven in de Delta geanalyseerd voor een veel langere periode (Schekkerman et al., 2017). Hieruit blijkt dat het broedsucces in grote sternkolonies in het Deltagebied geen trendbreuk laat zien tussen T0 en T1 (Figuur 7.9). Wel varieert het broedsucces in deze kolonies sterk tussen jaren en is alleen in de Oosterschelde een significante neergaande langjarige trend te zien (Figuur 7.9). In het Haringvliet neemt het broedsucces toe, maar deze trend is niet significant. Naar verwachting is een gemiddeld broedsucces van ongeveer 0,5 jong per paar voldoende om een stabiele populatie van deze langlevende soort te kunnen waarborgen (Schekkerman et al., 2017). Voor visdieven blijkt geen trendbreuk tussen T0 en T1 in broedsucces van kolonies in het Deltagebied (Figuur 7.10). Wel varieert het broedsucces in deze kolonies sterk tussen jaren en is er een algemeen neergaande langjarige trend te zien. Opvallend is dat het broedsucces in het Haringvliet juist sterk is toegenomen over de afgelopen jaren, wat mogelijk mede veroorzaakt wordt door het kort houden van de vegetatie in de enclosure waar de metingen plaatsvonden op de Scheelhoekeilanden. 

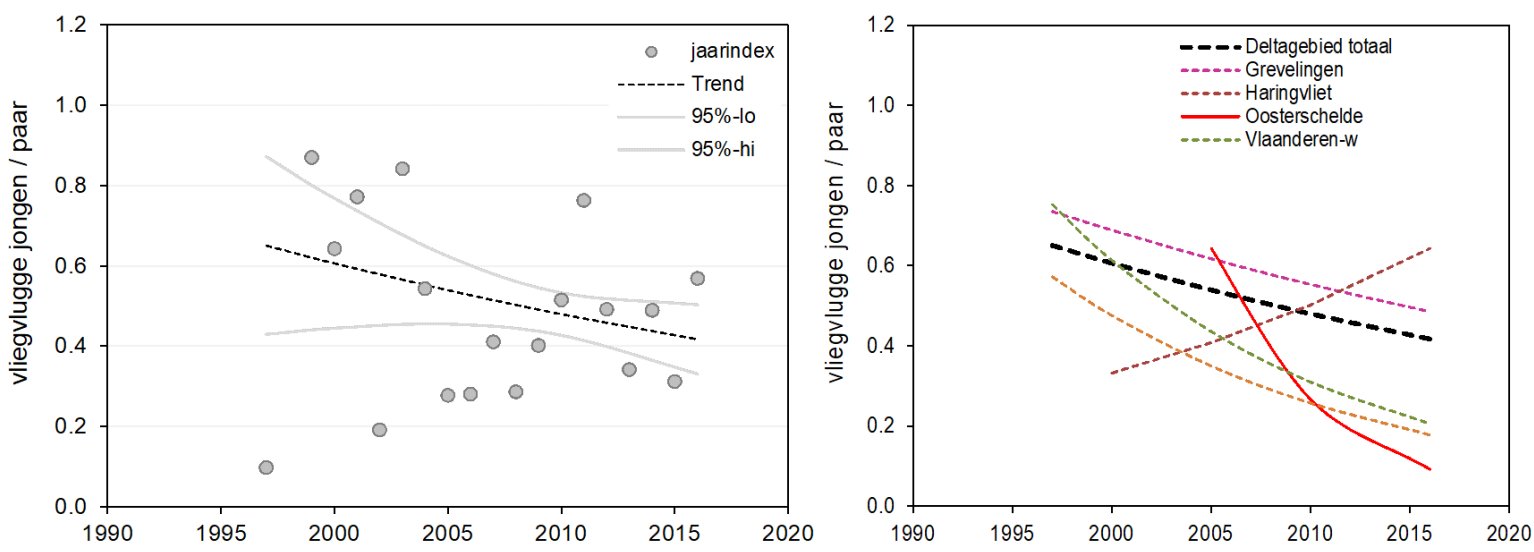

Figuur 7.9. Ontwikkeling van het reproductiesucces van Grote Sterns in het Deltagebied. Weergegeven is het jaargemiddelde (stippen) en trend met 95\% betrouwbaarheidsinterval (lijnen) voor het hele Deltagebied (links) en per bekken (rechts, doorgetrokken streep is significant, gestippeld is niet significant). Hierbij moet worden opgemerkt dat de trend voor de noordelijke Delta de meest recente jaren gebaseerd is op enclosure waarnemingen terwijl in de eerste jaren een kolonie-gemiddelde werd bepaald. Overgenomen uit Schekkerman et al. (2017).
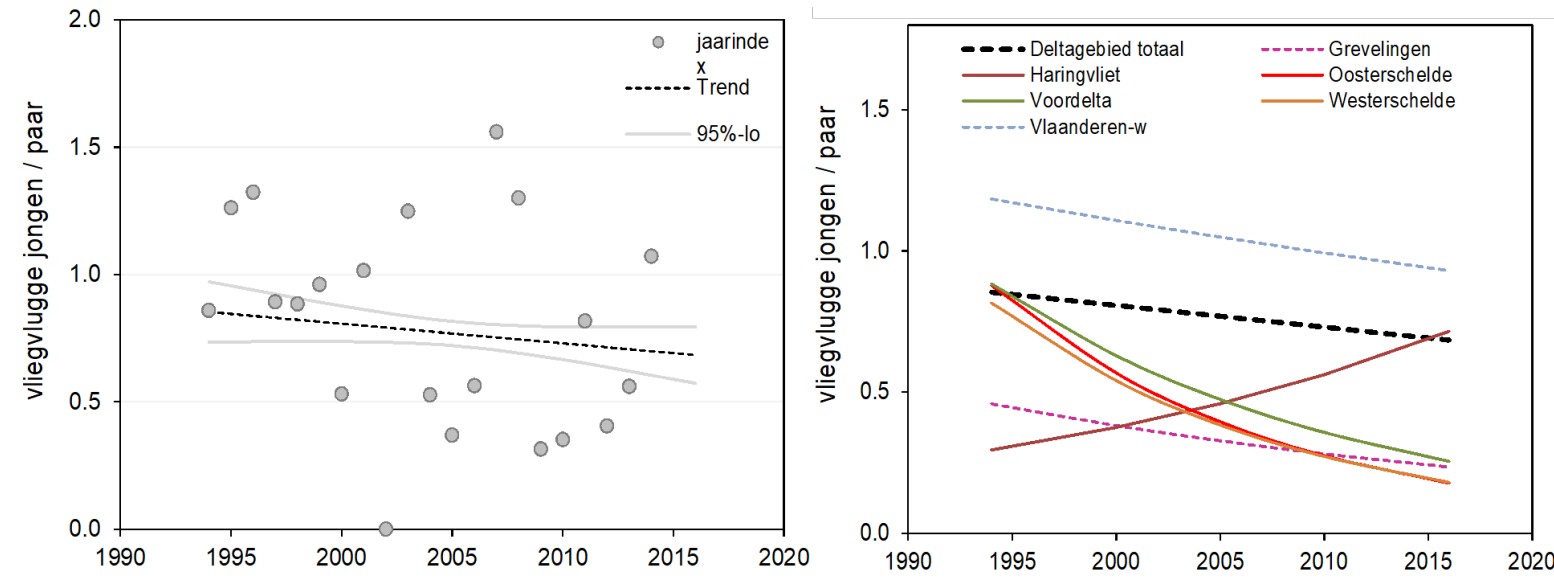

Figuur 7.10. Ontwikkeling van het reproductiesucces van visdieven in het Deltagebied. Links: jaargemiddelden(stippen) en trend met 95\% betrouwbaarheidsinterval (lijnen) voor het Deltagebied als geheel. Rechts: trends in deelregio's met voldoende gegevens. Trends die significant afwijken van 0 (= broedsucces stabiel) zijn weergegeven als doorgetrokken lijn, overige met een gebroken lijn. Overgenomen uit Schekkerman et al. (2017).

Tulp et al. (2018) hebben geprobeerd het broedsucces van grote sterns te relateren aan het voedselaanbod van haringachtigen en zandspiering. Duidelijk is geworden dat vooral de aanvoer van haringachtigen (tripduur en prooilengte) bepalend is voor de conditie en de overleving van de kuikens en daarmee van het broedsucces (Figuur 7.11). Deze aanvoer houdt waarschijnlijk rechtstreeks verband met de beschikbaarheid van haring in de foerageergebieden. Helaas waren de visbemonsteringen niet optimaal om het aanbod (lengteverdeling en dichtheden) van deze vissen te meten. De grotere haring 
die aan de kuikens gevoerd wordt, komt weinig voor in de bodemvisbemonstering en wordt waarschijnlijk van verder op zee uit dieper water gehaald, onbereikbaar voor het gebruikte vistuig. Dit blijkt ook uit de GPS waarnemingen en de tijd die de vogels nodig hebben voor het aanbrengen van voedsel. Zandspieringen zijn minder belangrijk voor de kuikens dan haringachtigen. Niettemin speelt zandspiering bij gebrek aan (bijv. in 2013) of moeilijke vangbaarheid van haringachtigen (bijv. stormperiode 2017) een belangrijke rol als voedsel voor de kuikens. Voedsel is sterk bepalend voor het broedsucces, maar Tulp et al. (2018) konden op basis van de visbemonsteringen dus niet zeggen of het voedselaanbod veranderd is na de aanleg van Maasvlakte 2.
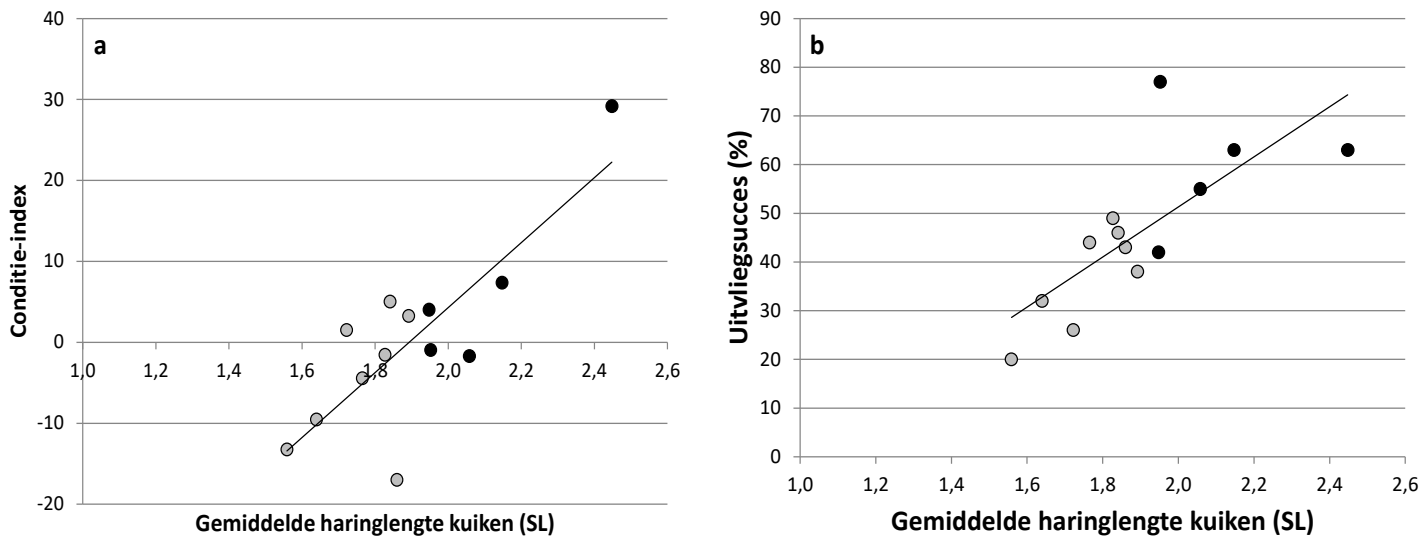

Figuur 7.11 Relatie tussen de gemiddelde haringlengte (Staartlengte: SL) in het kuikendieet van grote sterns en (a) de conditie van vliegvlug geworden kuikens (gewicht-leeftijd) en (b) het uitvliegsucces. Markenje (zwarte bollen) en de Scheelhoek (grijze bollen), 2009-2017.

\subsubsection{Effect vergrote vliegafstand visdieven van Maasvlakte 2-kolonie}

Op basis van voedselprotocollen gemaakt in 2017 is een energetisch model opgesteld voor de kolonie op het Visdiefeiland in de Slufter met als doel het effect van Maasvlakte 2 op de energieaanvoer naar de kolonie in te schatten. Door de aanleg van Maasvlakte 2 is voor vogels van het Visdiefeiland de afstand tot hun noordwestelijk gelegen foerageergebied toegenomen. Met informatie over de aanvliegroutes van visdieven die naar de kolonie terugkeren met een prooi voor de kuikens in combinatie met de soortensamenstelling van de aangevoerde prooien, kan een relatieve inschatting gemaakt worden van het belang van de verschillende foerageergebieden in de omgeving van het Visdiefeiland. Dit biedt de mogelijkheid om de consequentie van een langere vliegroute te evalueren in energetische termen.

De meeste prooien worden via het noord- en zuidwesten naar de kolonie aangevoerd, terwijl de noordelijke route zelden wordt bevlogen (Figuur 7.12). De hoogste energieaanvoer loopt via de noordwestelijke route. De verklaring hiervoor is dat aangebrachte haringachtigen (de voornaamste prooisoort) langs de noordwestelijke route gemiddeld 0,75 snavellengtes $(2,7 \mathrm{~cm})$ groter zijn dan deze die via het zuidwesten worden aangebracht. 


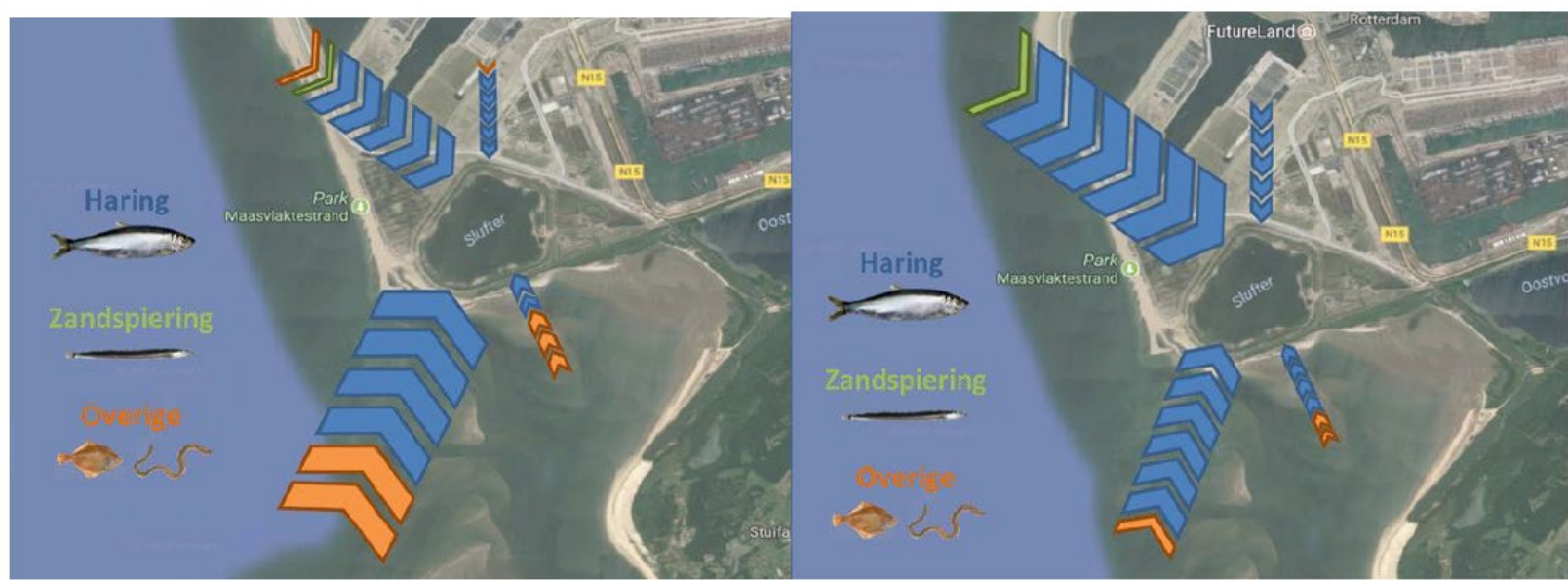

Figuur 7.12. Gemiddelde prooiaanvoer per uur (links) en gemiddelde energieaanvoer per uur (rechts) voor de verschillende soortgroepen (haring in blauw, zandspiering in geel en overige in oranje) en aanvoerroutes naar het Visdiefeiland in 2017.

Door de aanleg van Maasvlakte 2 werd de noordwestelijke aanvoerroute voor het Visdiefeiland verlengd met ongeveer $7 \mathrm{~km}$. De foerageertijd is nu 57 minuten, waar vóór de aanleg van Maasvlakte 2 visdieven slechts 45 minuten nodig hadden, waardoor ze $26 \%$ meer prooien (en dus ook meer energie) konden aanvoeren via deze route. Doordat het belang van de noordwestelijke route gedurende het broedseizoen toeneemt, kan de langere vliegafstand langs deze route vooral aan het einde van het broedseizoen een wezenlijk verschil betekenen voor het broedsucces van de kolonie. Net voor het uitvliegen van de kuikens (laatste dagen van juni) zou de verminderde energietoevoer via de noordwestelijke route een afname van 15 tot $20 \%$ van de totale energieaanvoer naar de kolonie betekenen, ten opzichte van de situatie voor aanleg van Maasvlakte 2.

Samengevat, in 2017 liepen de belangrijkste aanvoerroutes van voedsel voor visdief-kuikens op het Visdiefeiland via het zuid- en het noordwesten. De noordwestelijke route over Maasvlakte 2 was op energetisch vlak de belangrijkste route, omdat uit deze richting meer en grotere haringachtigen werden aangebracht dan via de andere routes. Of dit een jaarlijks patroon is kan op basis van de beschikbare gegevens niet geconcludeerd worden. Uit energetische berekeningen blijkt dat de toegenomen vliegduur als gevolg van de aanleg van Maasvlakte 2 een negatief gevolg gehad kan hebben op de kuikenconditie en het uitvliegsucces. Een dergelijke afname werd echter niet waargenomen in het veld en het blijft daarom de vraag of het mogelijke negatieve effect gecompenseerd is door een verbeterde voedselbeschikbaarheid of dat de vele veronderstellingen die aan het model ten grondslag liggen voor verbetering vatbaar zijn.

\subsection{Rustende sterns: BAI analyses}

Eén van de compensatiemaatregelen betrof het instellen van rustgebieden voor sterns: de Bollen van de Ooster en de Hinderplaat, met als doel dat na het broedseizoen de ouders met hun jongen dichter bij de foerageergebieden konden rusten.

\subsubsection{Rustende grote sterns}

Rustende grote sterns bleken een duidelijke voorkeur te hebben voor specifieke platen en stranden binnen de Voordelta. Ze waren vooral te vinden op de Bollen van het Nieuwe Zand, de Verklikkerplaat, de Bollen van de Ooster, het strand van Goeree, de Kwade Hoek, de Hinderplaat en op de zachte zeeweringen van Maasvlakte 1 en Maasvlakte 2 (Figuur 7.13). De getelde aantallen rustende grote sterns 
varieerden sterk: tussen de 0 en 2.500 individuen. De grootste groepen zijn aangetroffen op het Verklikkerstrand, de Bollen van de Ooster en op stranden in het Maasvlakte-gebied: in 2009 op de nieuw opgespoten eilanden en de laatste jaren meer op de zuidpunt nabij de Hinderplaat (Figuur 7.14).

Met name in het voorseizoen (april, begin mei) en opnieuw rond het uitvliegen van de jongen werd er veel gebruik gemaakt van de platen. De exacte ligging van de rustlocaties van grote sterns is niet veranderd tussen de periode van de nulmetingen en de jaren na 2009. De laatste twee jaren in het onderzoek (2018 en 2019) hebben grote groepen grote sterns gerust aan de binnenkant van de Tweede Maasvlakte (Figuur 7.14), maar door toekomstige bebouwing zal hier spoedig een eind aan komen. Opvallend is verder dat het Verklikkerstrand en de Verklikkerplaat enorm in trek zijn bij grote sterns. De aantallen op de Bollen van de Ooster vertonen grote variatie tussen jaren, met bijvoorbeeld zeer lage aantallen in 2010, 2013 en 2017, terwijl in 2011, 2012 en 2016 dit gebied één van de kernrustgebieden was. De aantallen in het recent aangewezen rustgebied Middelplaat nemen de laatste jaren toe, maar zijn nog steeds het laagst van alle aangewezen rustgebieden in de Voordelta.

Het relatieve gebruik van de verschillende rustgebieden wisselt met name onder invloed van de ligging van de broedkolonies. In jaren dat de kolonies in het noordelijk Deltagebied (Haringvliet en Grevelingenmeer) veel paren herbergen, rusten er per telling gemiddeld meer dieren op de Bollen van de Ooster, op de Verklikkerplaat en de Kwade Hoek. Op de Bollen van het Nieuwe Zand is een dergelijke stijging zeer beperkt, mogelijk doordat deze zandplaten maar kort beschikbaar zijn door de lage ligging omdat ze verder van de kolonies afliggen. Opvallend is dat bij hogere aantallen broedparen de aantallen op de Hinderplaat en Maasvlakte niet sterk veranderen.

Tijdens de T0-meting werd door grote sterns relatief weinig gebruik gemaakt van de Verklikkerplaat terwijl dit gebied de laatste jaren veruit de hoogste aantallen rustende grote sterns herbergt. Rond het uitvliegen van de jongen begin juli, nemen de aantallen in de rustgebieden op de Bollen van de Ooster en de Hinderplaat toe, waarschijnlijk omdat deze het dichtst bij de kolonies op Markenje en Scheelhoek liggen. 

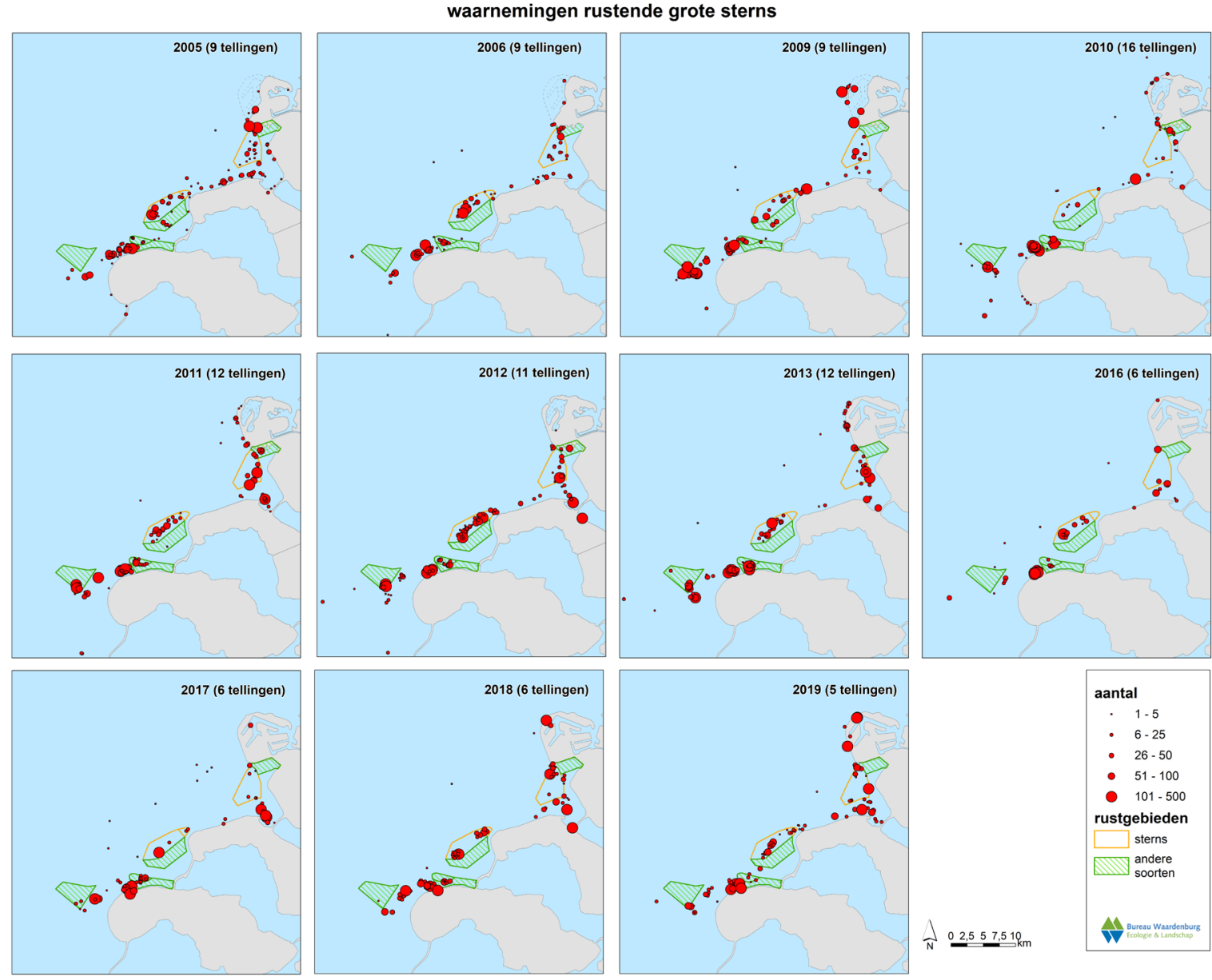

Figuur 7.13. Verspreiding van alle getelde groepen rustende grote sterns tijdens de TO-meting voor de aanleg van Maasvlakte 2 (2005 en 2006) en tijdens de fase T1 en T2 van PMR-NCV (vanaf 2009). Nb. de telinspanning varieert per jaar; in jaren met minder tellingen zal dus een minder compleet beeld van de verspreiding gegeven worden.

De eerste grote sterns komen in de laatste week van maart aan in de Voordelta en al redelijk snel daarna, in de eerste twee weken van april, worden de seizoens-maxima bereikt. Waarschijnlijk is een aanzienlijk deel van deze vogels doortrekker uit noordelijkere broedgebieden. Dit is door een beperkte afleesinspanning van kleurringen, veroorzaakt door de onbereikbaarheid van verzamelplaatsen en het relatief schuwe gedrag in deze periode, echter niet met zekerheid te zeggen. In ieder geval worden in deze periode de ingestelde rustgebieden, maar ook gebieden die niet als rustgebied zijn aangewezen zoals de Verklikkerplaat, intensief gebruikt door grote aantallen grote sterns die zich hier verzamelen alvorens naar de kolonies te gaan. In 2019 zijn wel veel kleurringen afgelezen en in dat jaar bleken ook vele broedvogels van elders in het voorseizoen gebruik te maken van rustgebieden in de Voordelta, met name op de Hinderplaat en het Verklikkerstrand/plaat. Gedurende het broedseizoen maken kleinere aantallen grote sterns gebruik van de rustgebieden. Dit zijn waarschijnlijk vooral vogels die niet gepaard zijn en/of jonge vogels die niet broeden maar uitsluitend de kolonies verkennen (kleurringgegevens Ringgroep Delta: BuWa, DPM, INBO), en vogels waarvan het broedsel verloren is gegaan (zenderdata Bureau Waardenburg).

Tijdens een periode van ongeveer twee weken rond het uitvliegen van de jongen zijn de ingestelde rustgebieden veel in gebruik door ouders met hun uitgevlogen jongen. Relatief kort na het uitvliegen lijkt het erop dat het merendeel van de lokaal geboren jongen met hun ouders de Voordelta verlaten en naar het noorden vliegen of (in mindere mate) zuidwaarts. Later in het seizoen, in de loop van september, is 
er vaak nog een piek in de rustgebieden van vogels die op doortrek zijn naar zuidelijk gelegen overwinteringsplaatsen.

In eerdere jaren is met name de Hinderplaat nog frequent door mensen bezocht (Seegers et al., 2014), maar tijdens de vliegtuigtellingen van de fase T2 van PMR-NCV en het veldwerk hebben we dat niet meer vastgesteld. Het enige gebied dat regelmatig bezocht wordt is de Verklikkerplaat. Daar waar strandbezoek wel is toegestaan, zoals op het Verklikkerstrand en een groot deel van de zachte zeewering van Maasvlakte 2, blijkt dat verstoring van rustende sterns wel optreedt (Fijn et al., 2016) en dan vooral door wandelaars met honden. De gemiddelde verstoringsafstand van vogels is ongeveer 50-75 meter voor wandelaars, en groter voor honden en hardlopers. Verstoring van rustende sterns betekent dat de dieren opvliegen. Uit onze waarnemingen blijkt dat grote sterns na verstoring het gebied meestal toch niet verlaten, maar ergens in de nabije omgeving relatief snel weer gaan zitten. Dit bleek ook uit eerder onderzoek naar verstoring in de Delta (Poot et al., 2014) en werd bevestigd door latere observaties uit 2016-2018. In sommige gebieden waar grote sterns rusten, komen dergelijke lokale verstoringen veel voor, maar in deze gebieden zijn ook altijd wel stukken plaat of strand aanwezig waarop dieren kunnen rusten. Een goed voorbeeld dat rust niet allesbepalend is, is het relatief nieuw ingestelde rustgebied van de Middelplaat, vlakbij het Verklikkerstrand. Ondanks dat er weinig verstoring voorkomt (slechts 1 keer vastgesteld), wordt het toch maar zelden gebruikt en dan ook nog door maar kleine aantallen grote sterns.
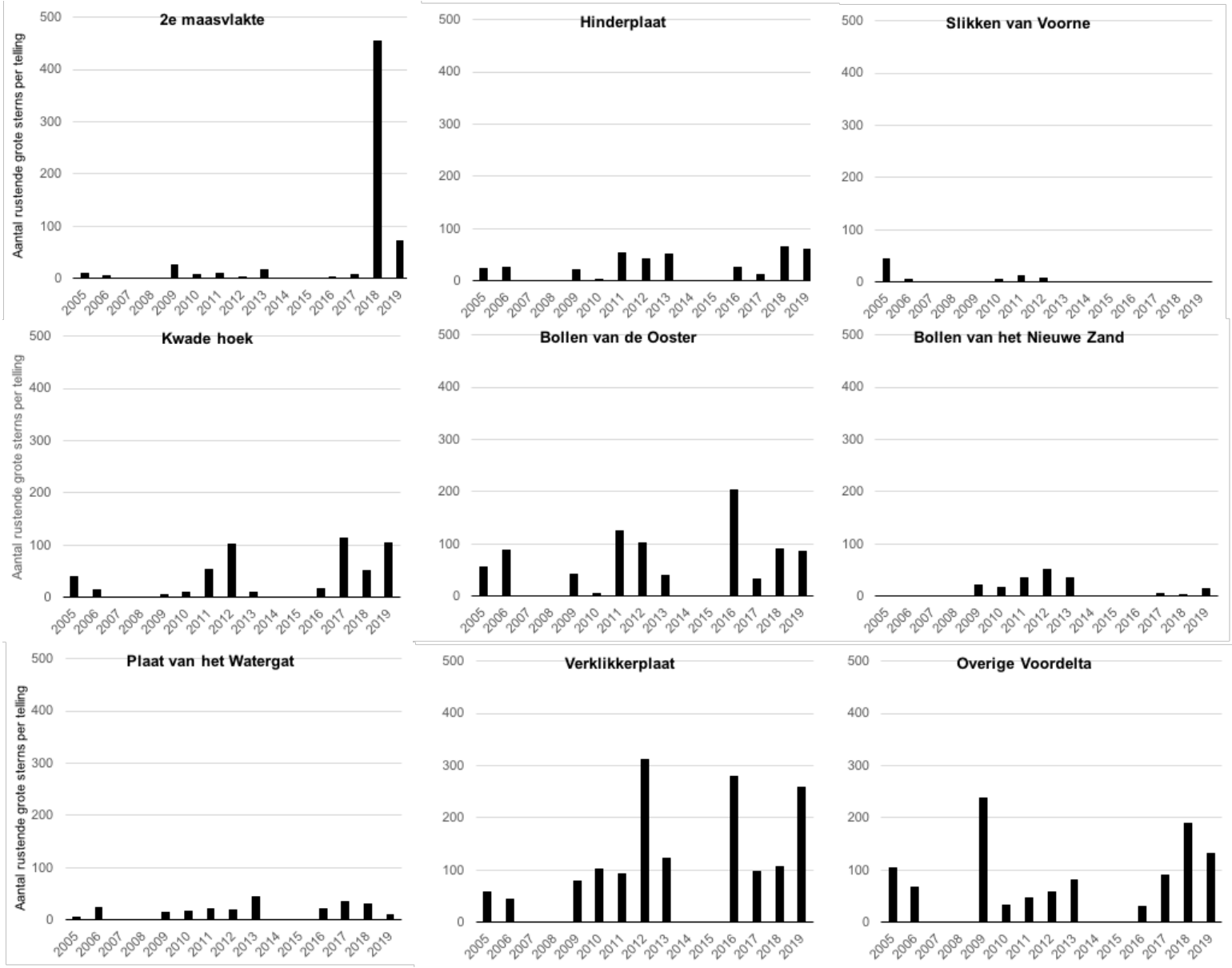

Figuur 7.14. Gemiddelde aantallen rustende grote sterns tijdens de vliegtuigtellingen uitgezet per jaar en per deelgebied. 


\subsubsection{Rustende visdieven}

Rustende visdieven bleken een voorkeur te hebben voor platen en stranden binnen de Voordelta, en waren te vinden op de Bollen van het Nieuwe Zand, de Verklikkerplaat, de Bollen van de Ooster, het strand van Goeree, de Kwade Hoek, de Hinderplaat en op de zachte zeeweringen van Maasvlakte 1 en Maasvlakte 2, maar ook op diverse stranden (Figuur 7.15). Per telling varieerden de aantallen rustende visdieven sterk tussen de 0 en 1.800 individuen. De grootste groepen zijn aangetroffen op het Verklikkerstrand (sinds 2015 geen aangewezen rustgebied meer), de Bollen van de Ooster en op stranden in het Maasvlakte-gebied: in 2009 op de nieuw opgespoten eilanden en de laatste jaren meer op de zuidpunt nabij de Hinderplaat. Het gebruik van aangewezen en niet aangewezen rustgebieden in de Voordelta varieert sterk per jaar (Figuur 7.16). De laatste jaren (vanaf 2016) worden alle stranden en platen, waaronder de zachte zeewering van de Maasvlakte, maar weinig gebruikt. De aantallen op de Bollen van de Ooster variëren sterk tussen jaren, met bijvoorbeeld zeer lage aantallen in 2009 en 2010 en hogere aantallen in 2011 en 2012.
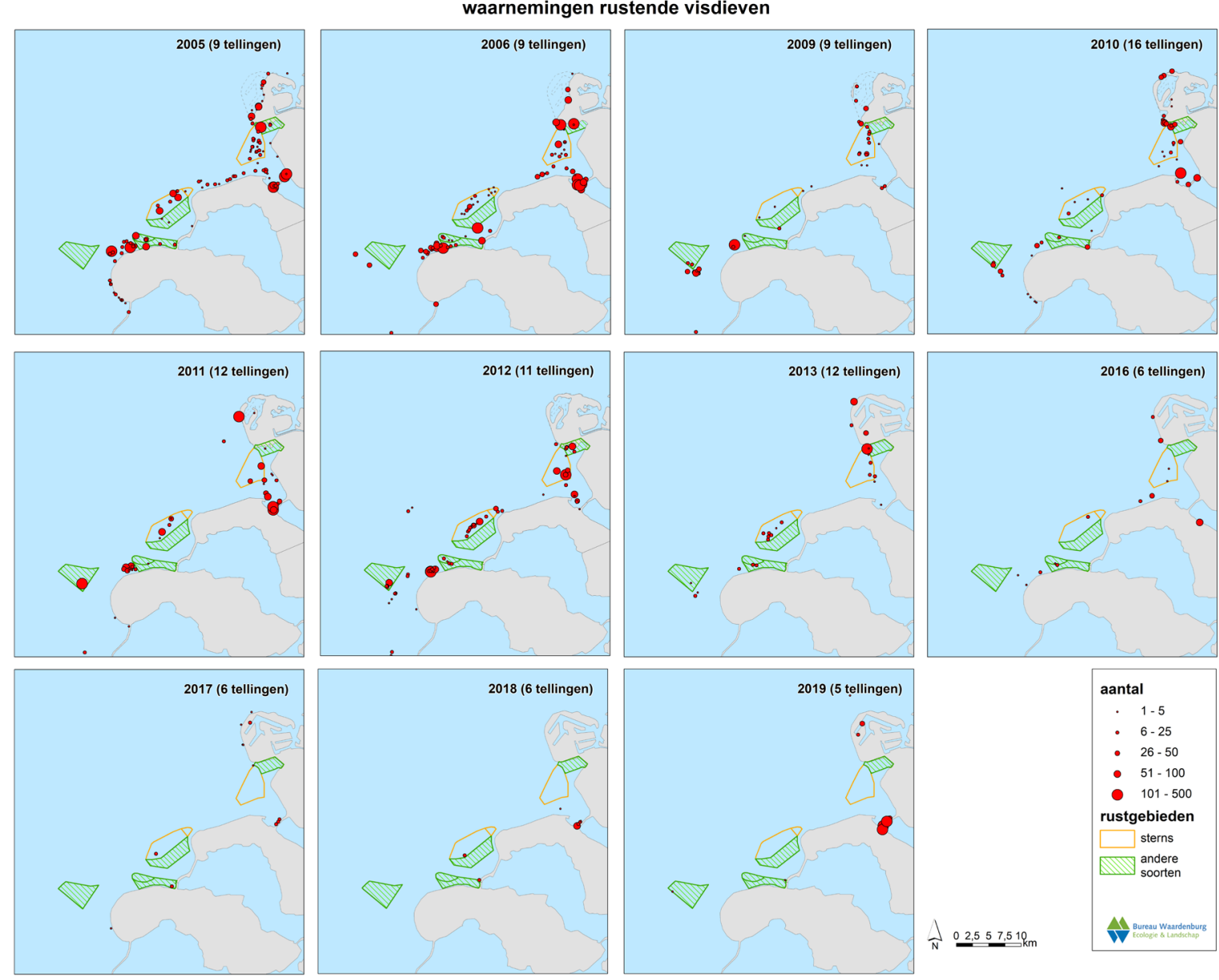

Figuur 7.15 Verspreiding van alle getelde groepen rustende visdieven tijdens de T0-meting (2005-2006) en tijdens de fase T1 en T2 (vanaf 2009) van PMR-NCV. Let op dat de telinspanning per jaar verschilt. $\mathrm{Nb}$. de telinspanning varieert per jaar; in jaren met minder tellingen zal dus een minder compleet beeld van de verspreiding gegeven worden.

De eerste visdieven komen in de loop van april aan in de Delta en worden dan meteen in de verschillende rustgebieden gezien. In de loop van mei nemen de aantallen af omdat de dieren tijdens het broedseizoen met name in de kolonies en langs de kust te vinden zijn. De dieren die in deze periode gebruik maken van de rustgebieden zijn waarschijnlijk vogels met een mislukt broedsel (alhoewel op basis van de gegevens verkregen uit de VHF zenders ook bekend is dat visdieven relatief snel een nieuw 
broedsel in een andere kolonie kunnen starten) en vogels die dat seizoen niet tot broeden komen. De seizoens-maxima van rustende visdieven worden rond het uitvliegen van de jongen bereikt en vanuit de kleurringdata weten we dat het hier ook om lokale dieren gaat. In tegenstelling tot de grote sterns blijven de meeste visdieven wel relatief lang in de Delta aanwezig, en worden in de loop van het seizoen aangevuld met dieren uit noordelijkere broedgebieden. Op basis van de vliegtuigtellingen en het aangevoerde voedsel in de kolonie is het onwaarschijnlijk dat visdieven tijdens foerageertochten voor hun jongen in de kolonies gebruik maken van de rustgebieden.

In de jaren 2009, 2011-2013, 2016 en 2017 zijn land-tellingen van rustende juveniele grote sterns en visdieven verricht. Met name op de Verklikkerplaat en de Bollen van de Ooster zijn relatief grote aantallen rustende visdieven aangetroffen na het uitvliegen van de jongen. Het betrof hier vaak adulte vogels met kleurringen uit de Delta die daar al dan niet met hun jongen aanwezig waren. Uit deze observaties blijkt dat ook voor visdieven de platen na het uitvliegen van belang zijn voor het grootbrengen van de kuikens en het is aannemelijk dat dit de ouders een energetische voorsprong geeft omdat ze, zeker in het geval van de Bollen van de Ooster, minder ver hoeven te vliegen om voedsel aan te brengen naar hun wachtende jongen.

Sinds 2012 worden jaarlijks kleine aantallen adulte visdieven in de kolonies in de noordelijke Delta van een kleurring voorzien waarmee ze goed te volgen zijn tijdens hun verdere leven. Na het uitvliegen van de jongen (juli) komen de meeste terugmeldingen van vogels die lokaal in de Delta blijven (Verklikkerstrand, inlagen). Daarna volgen aflezingen uit zuidelijkere broedgebieden en een enkele in noordelijkere gebieden zoals de Putten bij Petten en de Balgzandpolder bij Den Helder. Dit sterkt onze indruk dat visdieven veel minder dan grote sterns naar noordelijke gebieden trekken.

De reacties van visdieven en grote sterns op verstoringsbronnen op platen en stranden komt in grote lijnen overeen. De soorten zitten ook vaak in gemengde groepen. De verstoringsafstand is ongeveer hetzelfde en verstoringen worden bijna uitsluitend vastgesteld buiten de rustgebieden op de Verklikkerplaat/strand en de stranden van de zachte zeewering van Maasvlakte 2. Ook visdieven gaan relatief snel weer zitten na menselijke verstoring en verlaten het gebied meestal niet. 

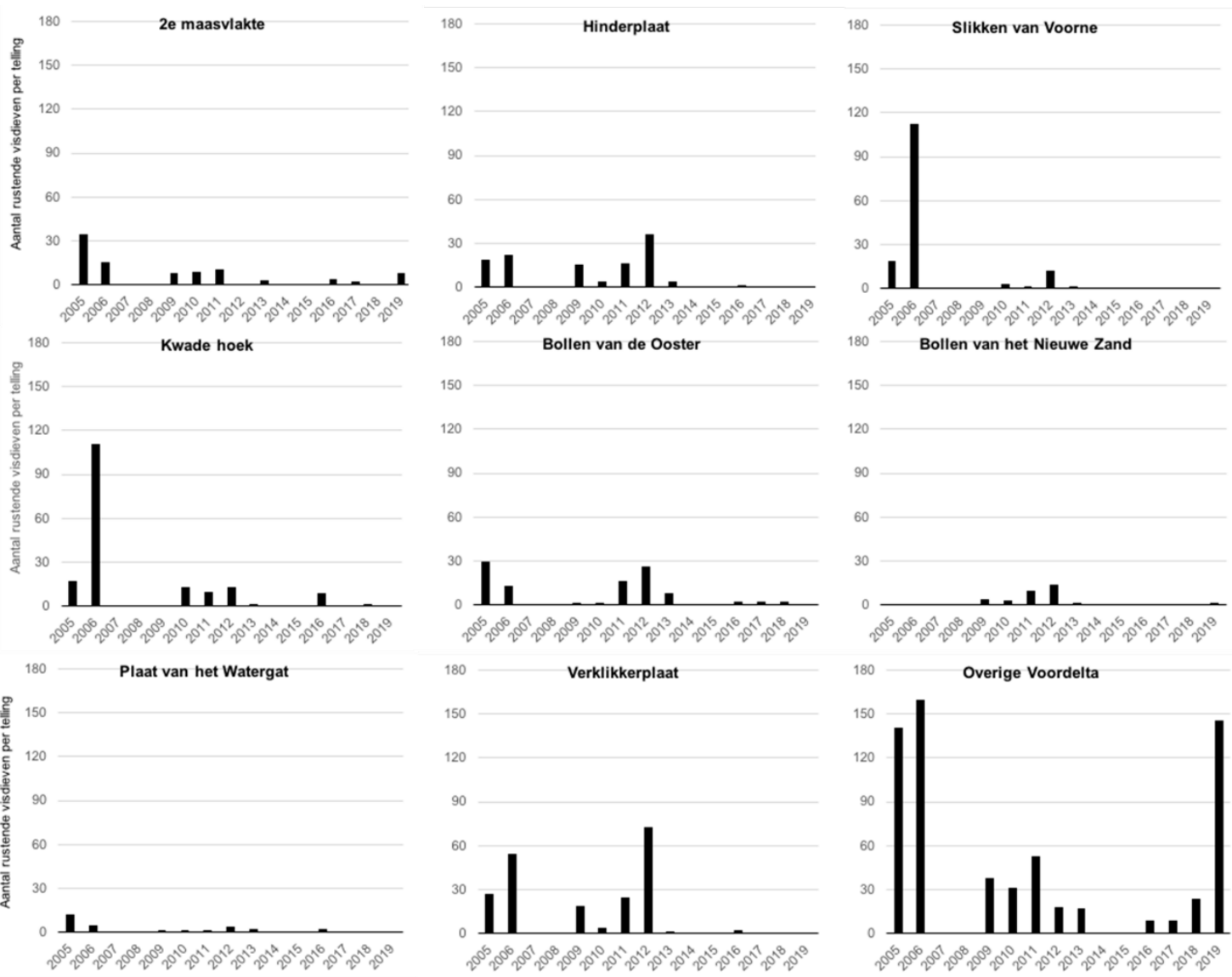

Figuur 7.16. Gemiddelde aantallen rustende visdieven tijdens de vliegtuigtellingen per jaar en per deelgebied.

\subsection{Conclusies}

\subsubsection{Het verdwenen zeegebied}

Grote sterns doorkruisten het gebied waar Maasvlakte 2 is aangelegd tussen foerageergebieden en broedgebieden. Ook foerageerden ze langs het strand van de Maasvlakte. Na aanleg foerageren grote sterns langs het hele strand van Maasvlakte 2, en rusten ze vooral op de zuidpunt van Maasvlakte 2 . Het verdwenen zeegebied had geen essentiële foerageerfunctie, en er is geen daling in het aantal rustende sterns in het Maasvlakte gebied. Er zijn geen concrete aanwijzingen dat kwaliteit van het leefgebied van grote sterns in de Voordelta is verslechterd.

Het verdwenen zeegebied diende als foerageergebied voor visdieven, en op het strand van Maasvlakte 1 werd gerust. Tijdens de aanleg van Maasvlakte 2 foerageerden visdieven zeer veel in het zeegebied van Maasvlakte 2 en dan vooral rond de suppletieschepen. Na aanleg foerageerden ze langs het nieuwe strand en rustten de dieren met name op de zuidpunt van Maasvlakte 2. Het verdwenen zeegebied had een essentiële foerageerfunctie voor broedende visdieven op de Maasvlakte en die functie lijkt overgenomen door het gebied voor het nieuwe strand van Maasvlakte 2. De mate waarin is echter niet te kwantificeren op basis van de beschikbare informatie. Uit energetische berekeningen blijkt dat de toegenomen vliegduur tussen de kolonie op Maasvlakte 2 en het foerageergebied als gevolg van de aanleg van Maasvlakte 2 een negatieve invloed gehad kan hebben op de kuikenconditie en het uitvliegsucces. Deze modelvoorspellingen konden echter niet bevestigd worden door de waarnemingen in het veld. 


\subsubsection{Broedende sterns}

Het aantal broedparen van grote sterns in het noordelijk Deltagebied laat geen duidelijke trend en het gebied wijkt daarmee ook niet af van wat er in de rest van de zuidelijke Noordzee gebeurt (BACIbenadering). In de noordelijke kolonies, die potentieel het meest worden beïnvloed door Maasvlakte 2, was het aantal uitgevlogen jongen na de aanleg van Maasvlakte 2 hoger dan in de T0 (BAI-benadering). Het uitvliegsucces van grote sterns hangt waarschijnlijk sterk af van het voedselaanbod in een gebied dat tot ver buiten de Voordelta reikt. De aanvoer van grotere haring blijkt sterk te correleren met broedsucces.

De aantallen broedparen van de visdief lijken de laatste jaren enigszins af te nemen in de Delta. De aantallen broedparen op de Maasvlakte zelf zijn relatief stabiel. Deze kolonie is de enige waarvan de vogels in de buurt van het aanleggebied foerageren en waarvan dus een effect van Maasvlakte 2 te verwachten is. $\mathrm{Er}$ is geen trendbreuk in het broedsucces van visdieven in de hele Delta tussen de periode voor en na de aanleg van Maasvlakte 2. Ook de Maasvlakte laat geen veranderingen zien in broedsucces.

\subsubsection{Rustende sterns}

De grootste aantallen rustende grote sterns zitten buiten de aangewezen rustgebieden. Veruit de grootste aantallen rustende sterns zitten elk voorjaar op de Verklikkerplaat/het Verklikkerstrand. Dit gebied lijkt een belangrijke rol te vervullen tijdens de paarvorming en tijdens de doortrek. Ook worden hier in juli juveniele grote sterns gevoerd door hun ouders. Het rustgebied op de Hinderplaat wordt relatief weinig gebruikt door rustende grote sterns. Het ingestelde rustgebied op de Bollen van de Ooster wordt elk jaar vlak na het uitvliegen gebruikt door grote sterns met hun jongen. Buiten de ingestelde rustgebieden worden veel rustende grote sterns op de zuidpunt van Maasvlakte 2 gezien en in recente jaren werden ook grote groepen rustende sterns aan de binnenkant van de Tweede Maasvlakte vastgesteld in juni - augustus. Grote sterns uit de Delta verblijven een periode van enkele dagen tot zo'n vier weken na het uitvliegen van de jongen in de Delta. Ook door grote sterns van buiten de Delta wordt gebruik gemaakt van de Voordelta en de rustgebieden.

Rustende visdieven worden met name aangetroffen op de Verklikkerplaat, Bollen van de Ooster, Hinderplaat/Westplaat en de stranden van Maasvlakte 2. Na het uitvliegen worden de Verklikkerplaat en de Bollen van de Ooster gebruikt door ouders met hun jongen. Visdieven maken weinig gebruik van het rustgebied op de Middelplaat. Buiten de ingestelde rustgebieden worden veel rustende visdieven op de zuidpunt van Maasvlakte 2 gezien. Voor alle stranden en platen geldt dat het gebruik de laatste jaren is afgenomen. Er zijn aanwijzingen dat lokaal broedende visdieven langer in het Deltagebied blijven hangen dan grote sterns. Of de aangewezen rustgebieden essentieel zijn voor de visdief in de Voordelta kunnen we niet kwantificeren. 


\section{$8 \quad$ Zwarte zee-eend}

In het Milieueffectrapport (MER; Berkenbosch et al., 2007) en de Passende Beoordeling (PB; Heinis et al., 2007) is vastgesteld dat door het ruimtebeslag van Maasvlakte 2, het ontstaan van een erosiekuil en verstoring door geluid niet is uit te sluiten dat er een significant negatief effect is op de foerageerfuncties voor de zwarte zee-eend $(-3,1 \%)$. Dat verlies is berekend als het gevolg van het verlies aan foerageergebied.

Om deze als significant beoordeelde negatieve effecten te compenseren is het Bodembeschermingsgebied ingesteld dat moet zorgen dat de kwaliteit van het BBG als foerageergebied verbetert en daardoor de totale hoeveelheid voor de zwarte zee-eend geschikt voedsel in de Voordelta ten minste gelijk blijft. Binnen het Bodembeschermingsgebied zijn twee rustgebieden (Bollen van de Ooster, Bollen van het Nieuwe Zand) aangewezen, met als doel verstoring door scheepvaart en recreatie te beperken zodat de zwarte zee-eend optimaal van het voedselaanbod in de Voordelta kan profiteren. De combinatie van rustgebieden en Bodembeschermingsgebied moeten de negatieve effecten compenseren zodat de gunstige staat van instandhouding (behoud van omvang en kwaliteit van het leefgebied met een draagkracht voor een populatie van gemiddeld 9.700 vogels (midwintertelling)) niet in gevaar komt.

In dit hoofdstuk worden de resultaten van monitoring en onderzoek aan de zwarte zee-eend gepresenteerd, met het doel onderbouwing te leveren voor de beantwoording van de MEP-vraag: "Wordt het verlies aan foerageergebied van de zwarte zee-eend als gevolg van de aanleg en het gebruik van Maasvlakte 2 voldoende gecompenseerd?"

Om het effect van de compensatiemaatregelen te bepalen is een monitoring- en onderzoeksprogramma opgezet. Idealiter volgt het onderzoek een zogeheten Before-After-Control-Impact (BACI) opzet (voor details zie Hoofdstuk 2). Als responsvariabele kan bijvoorbeeld het aantal zee-eenden dat in het gebied verblijft gebruikt worden. Als de verandering in een dergelijke responsvariabele in de tijd (dus het verschil tussen vóór en na) niet verschilt tussen het ingreep- en het referentie-gebied is er blijkbaar voldoende gecompenseerd. Voor deze vergelijking zijn gegevens beschikbaar uit mid-wintertellingen van het MWTL programma. Het aantal zwarte zee-eenden in de Voordelta (het Impact gebied) in de winter kan worden vergeleken met de aantallen in het Waddengebied als controle-gebied.

De uitgebreide monitoring in de Voordelta zelf in het kader van PMR-NCV, die deels vóór (in de T0 in 2004/2005 en 2005/2006), maar grotendeels na de ingreep is uitgevoerd (in 2009-2019), heeft veel meer gegevens opgeleverd, maar deze kunnen alleen gebruikt worden in een BAI (Before-After-Impact) analyse. De zeggingskracht van zo'n analyse is zwakker dan van een BACI. Een BAI analyse laat zien of er al of niet een verandering is opgetreden in het ingreep gebied (hier de Voordelta), maar dat geeft geen duidelijk antwoord op de vraag of die veranderingen iets met de ingreep te maken hebben gehad. Voor deze BAI analyse zijn de tellingen in de Voordelta in de jaren 2004-2018 gebruikt. Ook zijn resultaten van berekeningen met een energiebudget-model gebruikt, dat de potentiële aantallen zeeeenden in de Voordelta schat en daarmee een inschatting geeft van de potentiële draagkracht van het gebied.

Voort is er nog een BI (Before-Impact) analyse uitgevoerd in het door de aanleg van de Maasvlakte 2 verdwenen foerageergebied. Doel van deze analyse is om nog een keer kritisch naar de in de MER en PB geschatte directe effecten van de aanleg op de zwarte zee-eend te kijken. 


\subsection{Gebruikte methodiek en beschikbare data}

Voor de beantwoording van de MEP-vraag en onderzoeksvragen zijn twee lijnen gevolgd in het PMR-NCV programma: via tellingen en observaties enerzijds en via scenarioberekeningen met een energetisch model anderzijds. Evenals in de T0 is van 2009 tot 2019 monitoring uitgevoerd waarbij de aantallen en de verspreiding van de zwarte zee-eend in de Voordelta zijn vastgelegd, aanvullend op de al lopende MWTL metingen. Deze waarnemingen geven een goed beeld van de aanwezigheid van zwarte zeeeenden in de Voordelta. De uitgebreide tellingen in de Voordelta zijn aangevuld met (minder frequente) waarnemingen van zwarte zee-eenden langs andere delen van de Nederlandse kust en voor de Belgische kust, om de waargenomen aantallen en trends in de Voordelta in een breder verband te kunnen duiden. De tellingen in de Voordelta zijn gebruikt in een statistische analyse om het verband tussen voorkomen van eenden enerzijds en omgevingsfactoren als voedselbeschikbaarheid en scheepvaart anderzijds nader te onderzoeken.

In de tussentijdse rapportage in 2014 (Prins et al., 2014) is vastgesteld dat het aantal zwarte zeeeenden in de Voordelta veel lager was dan de maximale aantallen die tussen 1975-2000 zijn waargenomen, en ook laag ten opzichte van het aantal eenden in de Nederlandse kustwateren. Of zwarte zee-eenden in de Voordelta verblijven is niet alleen afhankelijk van de situatie in de Voordelta maar ook van de situatie in alternatieve overwinteringsgebieden.

Om te kunnen evalueren of de potentiële functie van de Voordelta voor zwarte zee-eenden in stand is gebleven, ook wanneer er lage aantallen eenden in de Voordelta worden waargenomen, is een energiebudget-model ontwikkeld. Doel van de modelontwikkeling was om te berekenen hoe groot het potentiële aantal zwarte zee-eenden is waarvoor in de Voordelta voldoende voedsel en rust is, op grond van gegevens over voedsel en verstoring. Dit levert inzicht in de potentiële functie van de Voordelta als foerageer- en rustgebied voor zwarte zee-eenden, los van het feit of de eenden daadwerkelijk overwinteren in het gebied.

\subsubsection{Monitoring}

\subsubsection{Tellingen}

De ontwikkelingen (aantallen, gebiedsgebruik, verspreiding) in de populatie zwarte zee-eenden in de Voordelta zijn onderzocht door middel van vliegtuigtellingen in het kader van PMR-NCV, aangevuld met tellingen uit de reguliere MWTL monitoring. In aanvulling daarop zijn gedragsobservaties vanaf land gedaan in een aantal jaren (zie Hoofdstuk 4 in Prins et al. (2014)). Gegevens van vliegtuigtellingen zijn beschikbaar voor de maanden oktober-mei van twee jaren in de T0 (2004/2005, 2005/2006) en voor de jaren vanaf 2008/2009 t/m 2018/2019. De gegevens zijn aangevuld met tellingen van MWTL in 2007 en 2008.

Voor de vergelijking met de ontwikkelingen in aantal zwarte zee-eenden in andere kustgebieden (met name de Noord-Hollandse kust en Wadden kust) zijn monitoringresultaten uit het MWTL programma gebruikt (midwinter tellingen) aangevuld met monitoringgegevens van PMR-NCV voor maart/april van de jaren 2009-2019 (Tabel 8.1). 
Tabel 8.1 Overzicht van aantal uitgevoerde tellingen van zwarte zee-eenden vanuit een vliegtuig, in de Voordelta en langs de kust van Holland en de Waddeneilanden, in verschillende periodes en monitoringsjaren (PMR-NCV en MWTL).

\begin{tabular}{|l|c|c|c|}
\hline Jaren & $\begin{array}{c}2004 / 2005- \\
2005 / 2006\end{array}$ & $\begin{array}{c}2006 / 2007- \\
2007 / 2008\end{array}$ & $\begin{array}{c}2008 / 2009- \\
2018 / 2019\end{array}$ \\
\hline Aantal monitorings-jaren & 2 & 2 & 11 \\
\hline $\begin{array}{l}\text { Voordelta } \\
\text { oktober-mei (PMR-NCV) }\end{array}$ & 31 & 204 \\
\hline $\begin{array}{l}\text { Voordelta, Hollandse kust, } \\
\text { Wadden } \\
\text { januari (MWTL) }\end{array}$ & 2 & 0 & 21 \\
\hline $\begin{array}{l}\text { Voordelta, Hollandse kust, } \\
\text { Wadden } \\
\text { maart-april (PMR-NCV) }\end{array}$ & 0 & & 11 \\
\hline
\end{tabular}

\subsubsection{Dieet}

Om de beschikbaarheid van voedsel in de Voordelta te bepalen, is gebruik gemaakt van de resultaten van het bodemdieronderzoek in de Voordelta (zie Hoofdstuk 4). Gegevens over de dichtheden, afmetingen en biomassa van schelpdieren zijn beschikbaar voor 2004-2005 en 2009-2018 (met uitzondering van 2014).

Op basis van kennis over het dieet van de zwarte zee-eend, afkomstig uit de veldwaarnemingen, maagonderzoek en literatuur (ICES, 2005; Brinkman et al., 2007; Skov et al., 2008; Kottsieper et al., 2019; Schwemmer et al., 2019)) is het voor de zwarte zee-eend geschikte hoofdvoedsel in de Voordelta beschreven aan de hand van de grootte en vorm van de schelpen. Zes soorten schelpdieren zijn beschouwd als de belangrijkste potentiële voedselbron voor zwarte zee-eenden in de Voordelta: Amerikaanse zwaardschede (Ensis leei) met een schelplengte van 40-100 mm, en de volgende soorten met een schelplengte van 15-35 mm: witte dunschaal (Abra alba), zaagje (Donax vittatus), nonnetje (Limecola balthica), halfgeknotte strandschelp (Spisula subtruncata) en rechtsgestreepte platschelp (Fabulina fabula). Aangenomen is dat met de biomassa van deze soorten het grootste deel van de profijtelijke prooien van zwarte zee-eenden wordt beschreven. Van zwarte zee-eenden is bekend dat ze Amerikaanse zwaardschede tot een lengte van ca. $10 \mathrm{~cm}$ kunnen eten. Enerzijds wordt dit als minder geprefereerd voedsel beschouwd vanwege de door de vogels lastig te hanteren schelpvorm (Leopold et al., 2015; Fijn et al., 2017)), anderzijds zijn er auteurs die wijzen op de veel gunstiger vlees/schelp ratio in vergelijking met de andere hiervoor genoemde schelpdiersoorten (Kottsieper et al., 2019; Schwemmer et al., 2019). Andere mogelijke prooisoorten zijn de mossel (Mytilus edulis) en de kokkel (Cerastoderma edule), maar deze twee soorten kwamen in hogere dichtheden alleen voor in het mondingsgebied van het Haringvliet bij de Slikken van Voorne, waar al meer dan 20 jaar geen zwarte zee-eenden zijn waargenomen.

\subsubsection{Verstoring}

Voor de winterhalfjaren van 2009/2010 t/m 2018/2019 zijn geanonimiseerde AIS-data verkregen en opgewerkt om de intensiteit van de scheepvaart in de Voordelta te kwantificeren (Van Horssen et al., 2020). Aangenomen is dat met de AIS data het grootste deel van de scheepvaart in de voor de zwarte zee-eenden relevante periode beschreven wordt. Deze opgewerkte AIS data zijn gebruikt in een statistische analyse en in de modellering van draagkracht voor potentiële aantallen eenden. De AIS data geven ook informatie over het type schip, in verschillende categorieën. Voor de statistische analyses zijn deze geaggregeerd naar visserij, beroepsvaart, recreatievaart en een restcategorie waar het type onbekend was (Van Horssen et al., 2020). 


\subsubsection{Modellering van potentiële aantallen zwarte zee-eenden}

Er is een model ontwikkeld voor de zwarte zee-eend, waarmee op basis van aanwezige en benutbare hoeveelheden geschikt voedsel berekend kan worden hoeveel eenden gedurende een bepaalde periode in een gebied potentieel kunnen verblijven en overleven. De ontwikkeling van het model is gebaseerd op een model voor de eidereend in de Waddenzee (Brinkman et al., 2003). Bij de ontwikkeling van dit eidereend model is intensief gebruik gemaakt van eerder onderzoek aan kuif- en toppereenden (de Leeuw, 1997).

Het model berekent het aantal eenden dat in een gebied kan verblijven op basis van gegevens over het beschikbare voedsel en andere omgevingsfactoren. Bij die analyse wordt gebruik gemaakt van een energiebudget-model dat berekent hoeveel energie de eenden binnen krijgen via het voedsel en hoeveel energie de eenden verbruiken tijdens het verblijf in het gebied. De ontwikkeling en de opzet van het model is beschreven in achtergrondrapporten (Brinkman, 2015; van de Wolfshaar et al., 2018).

In de toepassing van het model in de Voordelta is gebruik gemaakt van de verdeling van de Voordelta in rastercellen (oppervlak ca. 1,2 $\mathrm{km}^{2}$ ) van de bodemdierbemonstering. Voor iedere rastercel wordt berekend hoeveel zwarte zee-eenden er gedurende de maanden september tot en met april kunnen verblijven en overleven. Het model maakt berekeningen voor een individuele eend, gebaseerd op een aantal kenmerken specifiek voor de zwarte zee-eend, zoals het energieverbruik bij zwemmen, vliegen, duiken en het verteren van voedsel. Daarnaast maakt het model gebruik van gegevens die specifiek zijn voor iedere rastercel: het lokale voedselaanbod bepaald op grond van de dichtheid, per lengteklasse, van de schelpdieren, diepte, stroomsnelheid en de frequentie van verstoring door scheepvaart. Andere omgevingsomstandigheden zoals lucht- en watertemperatuur zijn gelijk voor alle rastercellen.

Voor de berekening van het potentieel aanwezig voedselaanbod zijn de resultaten van de bodemdierbemonstering van het voorafgaande najaar gebruikt. Voor de inschatting van verstoring door scheepvaart is gebruik gemaakt van AIS data, opgewerkt tot een gemiddelde per maand. Voor de overige omgevingsfactoren (klimatologie, stroomsnelheid, diepte) zijn meetgegevens en resultaten uit modellering van stroomsnelheden gebruikt.

Een aantal aannames in de toepassing van het model (Brinkman, 2015; van de Wolfshaar et al., 2018) is van belang bij de interpretatie van de resultaten:

- Het model berekent hoeveel eenden gedurende de gehele periode van 8 maanden (september april) in een rastercel kan verblijven en foerageren. Indien de omstandigheden in een rastercel dusdanig zijn dat één of meerdere eenden onvoldoende voedsel binnen kunnen krijgen om de dagelijkse energiebehoefte te dekken van begin tot eind van die periode (door bijvoorbeeld onvoldoende voedsel, waterdiepte, stroomsnelheid of verstoring) is de draagkracht voor eenden in die cel nul.

- Omdat zwarte zee-eenden in groepen leven, is een ondergrens van 100 eenden per rastercel gebruikt. Als het berekende potentiële aantal in een rastercel kleiner dan 100 was, is het aantal op nul gesteld.

- In de berekeningen is geen rekening gehouden met dichtheidsafhankelijke processen, zoals het effect van de dichtheid van prooien op de foerageerefficiëntie. Voor Ensis is gerekend met één schelp per duik, voor de overige tweekleppigen was dat vijf.

- De energie die het voedsel oplevert verschilt per soort, afhankelijk van de schelplengte van een individu en daarmee bijvoorbeeld de beschikbare hoeveelheid vlees en de kosten voor het kraken van de schelp.

- De foerageertijd verandert in de loop van de winter als gevolg van de afname in de hoeveelheid beschikbaar voedsel door gewichtsverlies van de schelpdieren en door predatie door de eenden, maar ook door veranderingen in de energievraag van de eenden door abiotische omstandigheden zoals temperatuur.

- $\quad$ De duiktijd is afhankelijk van de diepte maar niet van de dichtheid van het voedsel. Er wordt met een vaste zoektijd bij de bodem gerekend. 
- Aspecten van het gedrag van de eenden, zoals onderlinge interacties of dag/nacht ritmiek zijn niet in het model meegenomen.

- In eerdere berekeningen (Tulp et al., 2018) is aangenomen dat alle voedsel beschikbaar is. Dit geeft een overschatting. Op basis van onderzoek aan andere duik-eenden is nu aangenomen dat een vaste fractie van $30 \%$ van het totaal beschikbare voedselaanbod ook daadwerkelijk beschikbaar is als voedsel (de Leeuw, 1997).

- Eveneens is in afwijking van de eerdere berekeningen (Tulp et al., 2018) de zwem- en vliegtijd vanwege afdrijven door stroming afhankelijk gemaakt van de stroomsnelheid ter plaatse. Zo worden de kosten om op een plek te blijven hoger in gebieden met een harde stroming t.o.v. meer beschutte gebieden (Williams et al., 2014).

- Aangenomen is dat scheepvaart eenden tot op een afstand van $1 \mathrm{~km}$ verstoort, en dat iedere verstoring als effect heeft dat de eenden wegvliegen en gedurende een uur niet foerageren (Schwemmer et al., 2011; Fliessbach et al., 2019). Verschil met eerdere berekeningen (Tulp et al., 2018) is dat de scheepvaart nu is uitgedrukt in een gemiddelde frequentie van verstoring per rastercel per maand in plaats van gemiddeld over de gehele periode.

Met deze uitgangspunten geeft het model een schatting van het potentiële aantal zwarte zee-eenden dat gedurende het winterhalfjaar in de Voordelta kan verblijven op grond van het voedselaanbod, de mate van verstoring door scheepvaart en andere omgevingsfactoren zoals diepte, stroomsnelheid en temperatuur.

\subsection{De betekenis van het verdwenen zeegebied}

Voor de zwarte zee-eend zijn compensatiemaatregelen genomen, omdat in de Passende Beoordeling is geconcludeerd dat de aanleg en aanwezigheid van Maasvlakte 2 zou kunnen leiden tot verlies van potentieel foerageergebied. Deze inschatting was gebaseerd op het berekende verlies van areaal potentieel foerageergebied en niet op waargenomen aantallen eenden in het noordelijk deel van de Voordelta, omdat vanwege de lage en sterk fluctuerende waargenomen aantallen eenden een vertekend beeld zou kunnen ontstaan (Heinis et al., 2007).

In het in 2018 verschenen syntheserapport is uitgebreid gerapporteerd over de historische waarnemingen van zwarte zee-eenden in de Voordelta (Tulp et al., 2018). De bevindingen worden hier samengevat.

\subsubsection{Historische waarnemingen}

In de Voordelta zijn in de jaren tussen 1975 en 1996 wintermaxima van gemiddeld 15.000 zwarte zeeeenden geteld, met maximale aantallen tot 28.000 eenden in de maanden december-maart.

Baptist and Meininger (1996) hebben een overzicht gegeven van gebieden in de Voordelta die voor de zwarte zee-eend van betekenis waren in de periode 1975-1995. Op basis van figuur 4.5 in hun publicatie is Figuur 8.1 in dit rapport samengesteld. Uit deze figuur wordt duidelijk dat in die periode het gebied dat later Maasvlakte 2 zou worden, geen betekenis had voor zwarte zee-eenden. In de periode 1975-1985 werd ruim $75 \%$ van de vogels aangetroffen in de Haringvlietmonding, in het Slijkgat en ten oosten van de Hinderplaat. Nadien verschoven de concentraties eenden naar de Grevelingenmonding, de Banjaard voor de kust van Schouwen en de Oosterschelde-monding (Baptist en Meininger, 1996).

De aantallen tijdens midwintertellingen (januari) in de Voordelta tussen 1990-2006 waren sterk wisselend met maximaal zo'n 9.000 vogels (2003). In het vroege voorjaar (maart-april) werden gemiddeld de hoogste aantallen waargenomen, met maxima tot 25.000 in april 2002 (Berrevoets et al., 2002; Berrevoets en Arts, 2003; Hoekstein en Lilipaly, 2003; Berrevoets et al., 2005). 
Ook in de winters van 2000-2004 (vóór het begin van de PMR-NCV monitoring) zijn de grootste concentraties zwarte zee-eenden waargenomen bij de Brouwersdam en in de Oosterschelde-monding bij de Bollen van het Nieuwe Zand (Berrevoets et al., 2005). Uit MWTL tellingen van 1994/1995-2004/2005 uit een vliegtuig en vanaf de kust blijkt dat er geen zwarte zee-eenden zijn waargenomen in het gebied waar nu Maasvlakte 2 ligt of in de wateren ten westen daarvan.

\subsubsection{Waarnemingen van zwarte zee-eenden in T0}

Tijdens de T0-metingen in 2004/2005 en 2005/2006 zijn waarnemingen gedaan in zowel het winterhalfjaar (oktober-maart) als in het voorjaar (april-mei). In die jaren zijn evenmin zwarte zeeeenden waargenomen in het Maasvlakte 2 gebied (Figuur 8.1).

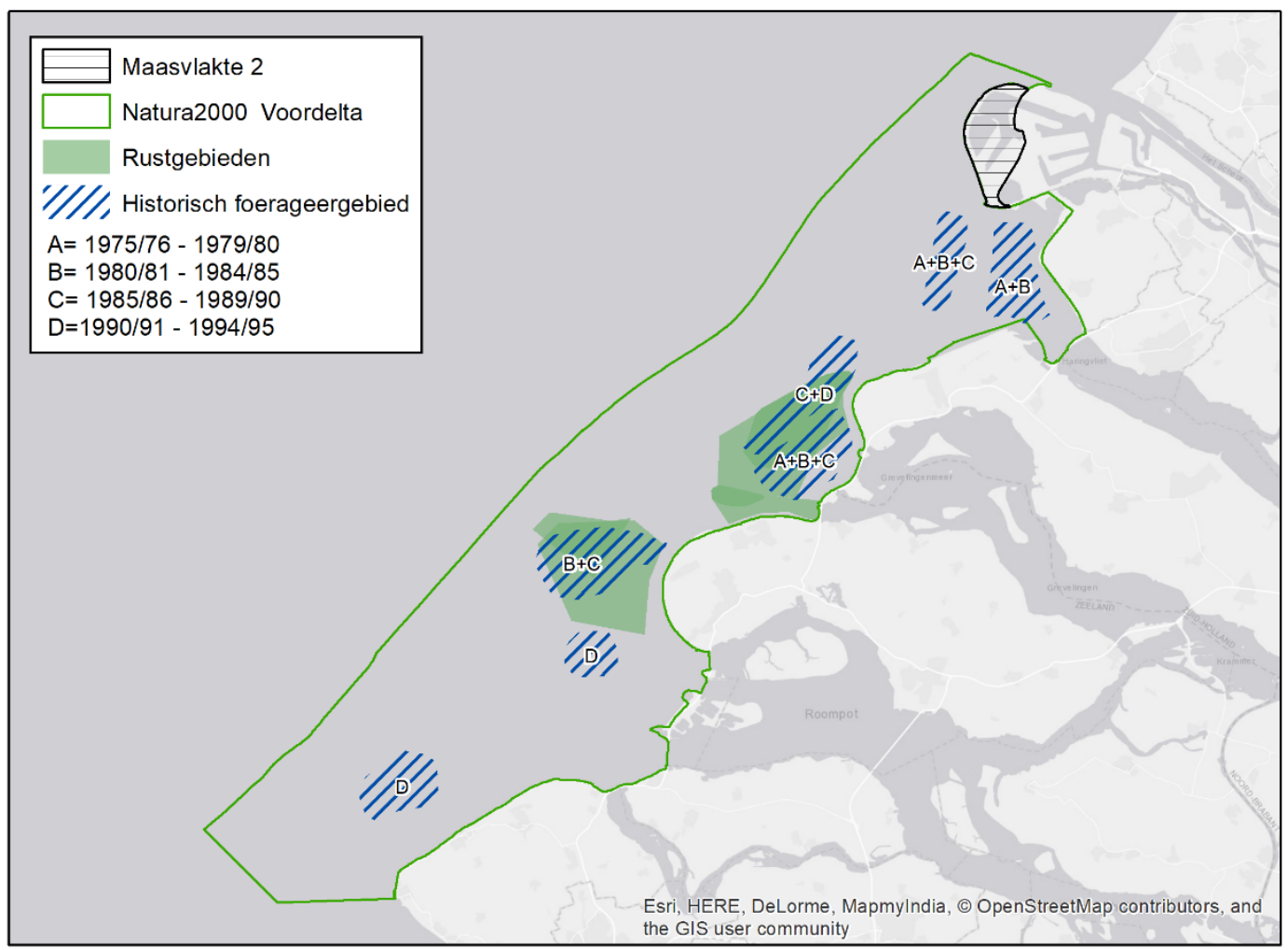

Figuur 8.1. Belangrijke gebieden voor zwarte zee-eenden in de Voordelta in de periode 1975-1995 (gebaseerd op figuur 4.5 van Baptist and Meininger (1996)). Aangegeven zijn de begrenzing van het Natura 2000-gebied Voordelta, het Maasvlakte 2 gebied en de rustgebieden (inclusief de uitbreiding die tijdelijk van kracht was tussen 2016-2018).

\subsubsection{Voedselaanbod in T0}

Op basis van de bodemdierbemonstering in 2004 en 2005 is een schatting gemaakt van het voedselaanbod voor zwarte zee-eenden in het gebied dat verloren is gegaan als gevolg van de aanleg van Maasvlakte 2 . Het voedselaanbod is bepaald door de totale biomassa van de prooisoorten van zwarte zee-eenden te schatten. Ongeveer de helft van het gebied lag dieper dan ca. $15 \mathrm{~m}$. Deze diepte is aangehouden als de maximale diepte tot waar zwarte zee-eenden succesvol kunnen foerageren, omdat zwarte zee-eenden in de Voordelta vrijwel alleen worden waargenomen in de ondiepere delen tot $15 \mathrm{~m}$ (Prins et al., 2014; Van Horssen et al., 2020). In zowel 2004 als 2005 was het aandeel van het Maasvlakte 2 gebied in het totale voedselaanbod voor zwarte zee-eenden in de Voordelta, minder dan $0,5 \%$. 
Eerder uitgevoerde modelberekeningen waarvan de resultaten zijn gerapporteerd in Tulp et al. (2018) gaven aan dat, op basis van het voedselaanbod in het Maasvlakte 2 gebied in 2004 en 2005, het potentieel aantal zwarte zee-eenden in dit gebied nul was. Dat betekent dus dat in de PB het verlies van potentieel foerageergebied overschat is.

\subsection{De potentiële functie van de Voordelta}

De potentiële functie van de Voordelta als foerageer- en rustgebied voor de zwarte zee-eend wordt allereerst besproken aan de hand van tellingen van werkelijk waargenomen aantallen in de Voordelta. Vervolgens wordt ingegaan op de ontwikkeling in het voedselaanbod in de Voordelta sinds 2004. Dat voedselaanbod, in combinatie met aanwezigheid van scheepvaart en andere lokale omstandigheden is toegepast om met het energiebudget-model het potentiële aantal zwarte zee-eenden te schatten wat eveneens een beeld geeft van de potentiële functie van de Voordelta sinds 2004. De veldwaarnemingen van zwarte zee-eenden zijn ook gebruikt om statistische verbanden met omgevingsfactoren en aanwezigheid van scheepvaart te onderzoeken. Tot slot worden de waarnemingen in de Voordelta vergeleken met de ontwikkelingen in aantallen zwarte zee-eenden elders in Nederland en in NW Europa.

\subsubsection{Waarnemingen van zwarte zee-eenden in de Voordelta}

\subsubsection{Vergelijking van MWTL midwinter tellingen: BACI analyse}

Rijkswaterstaat organiseert jaarlijks in januari een telling van overwinterende zee-eenden in de Nederlandse kustwateren (Voordelta, Hollandse kust, Wadden kust) en de Waddenzee. Deze telling wordt sinds 1993 uitgevoerd in het kader van het MWTL programma. De telgegevens van zwarte zee-eenden voor de jaren 1993-2019 zijn gerapporteerd door Lilipaly et al. (2019). De totale aantallen zwarte zeeeenden in Nederland in deze tellingen tonen grote jaarlijkse verschillen, variërend van minder dan 6.000 (2009) tot meer dan 100.000 (1999). In de Voordelta is het hoogste waargenomen aantal 9.136 eenden $^{8}$ in 2003, in 2000 en 2001 zijn minder dan 100 eenden geteld. De midwintertellingen vertonen voor de aantallen in heel Nederland een negatieve langetermijntrend sinds 1993 (Lilipaly et al., 2019), maar sinds 2005 is deze, afnemende trend niet significant (SOVON, 2020).

De gegevens bieden de mogelijkheid een BACI analyse te doen, met de Voordelta als impactgebied en de rest van de Nederlandse wateren als referentie, en de telgegevens te verdelen over de periode vóór de aanleg van Maasvlakte 2 (1993-2008) en de periode sinds de aanleg en de compensatiemaatregelen (2009-2019). Het belangrijkste resultaat uit deze analyse is dat er geen significant verschil is tussen de periode vóór en na $(p>0,05)$. Ook is de interactieterm gebied*periode niet significant, wat er op wijst dat de ontwikkeling in midwinteraantallen in de Voordelta niet afwijkt van die in de rest van Nederland. Door de grote jaarlijkse variatie is het onderscheidingsvermogen van de statistische toets overigens laag.

In een analyse van de aantalsontwikkelingen in de Voordelta door van Roomen et al. (2020) zijn de trends in aantallen over de periode 1998-2018 vergeleken met de trends elders in Nederland, op grond van data uit de MTWL tellingen. Uit die analyse is geconcludeerd dat het aantal zwarte zee-eenden in de Voordelta een dalende lijn vertoont en er geen verschil is met de landelijke trend die ook dalend is (van Roomen et al., 2020).

\subsubsection{Vergelijking van overwinterende aantallen in de Voordelta: BAI analyse}

Zowel vóór (2004-2005) als na de aanleg van Maasvlakte 2 (2009-2019) zijn de zwarte zee-eenden geteld in de maanden oktober-mei, met gemiddeld twee tellingen per maand. In Tabel 8.2 zijn de maxima per jaar weergegeven. De maxima van de zwarte zee-eend in de Voordelta vertonen grote jaarlijkse verschillen. De jaren met relatief hoge maximale aantallen betreffen altijd de voorjaarsperiode (april of mei). In vergelijking met de TO is het waargenomen maximum aantal gemiddeld lager in de

\footnotetext{
${ }^{8}$ het instandhoudingsdoel voor de Voordelta is 9.700 eenden
} 
jaren vanaf 2009. De aantallen eenden in de Voordelta vertonen echter zeer sterke fluctuaties op de korte termijn (dagen), zodat het waargenomen maximum afhankelijk is van het moment dat een telling wordt uitgevoerd en een minder robuuste maat is dan het gemiddelde aantal of het aantal vogeldagen over een reeks van maanden.

De zwarte zee-eenden worden voornamelijk waargenomen in, of nabij het Bodembeschermingsgebied: bij de Brouwersdam en Bollen van de Ooster, ten westen van Schouwen en in het gebied rond de Bollen van het Nieuwe Zand (Figuur 8.2). In 2016/2017 en 2017/2018 is ook een relatief grote groep zwarte zee-eenden waargenomen ten zuidwesten van Maasvlakte 2, waar op dat moment een relatief grote bank van de halfgeknotte strandschelp (Spisula subtruncata) aanwezig was (Dirksen et al., 2017; Troost et al., 2017; van der Zee et al., 2018).

Het totale gebruik van het gebied door zee-eenden is in vogeldagen uitgedrukt, een gebruikelijke maat voor het verblijf (aantal getelde vogels vermenigvuldigd met het aantal dagen dat ze in het gebied verblijven). Figuur 8.3 geeft het aantal vogeldagen voor het winterhalfjaar, het voorjaar en de gehele telperiode. De verschillen tussen jaren zijn erg groot. Over het gehele telseizoen oktober-mei bezien, zijn vanaf 2008 zowel de drie laagste jaren (2014/2015, 2015/2016, 2018/2019) als het jaar met het hoogste aantal vogeldagen (2012/2013) waargenomen. In het winterhalfjaar (oktober-maart) is het aantal vogeldagen in de meeste jaren na 2008 lager dan in de T0, maar 2008/2009 heeft juist het hoogste aantal vogeldagen. In het voorjaar (april-mei) is het beeld nog gevarieerder: er zijn van jaar op jaar grote verschillen, met twee jaren $(2014,2018)$ die vergelijkbaar zijn met de T0 jaren. Een analyse van jaarindexen en trends gebaseerd op de getelde aantallen, uitgevoerd met het trendprogramma TRIM van het CBS ( $R$ package rtrim) geeft een vergelijkbaar beeld, met een significant dalende trend in het winterhalfjaar en geen trend in het voorjaar.

Vergelijking van het aantal vogeldagen vóór en na 2008 toont aan dat er geen significant verschil is tussen beide perioden. De analyse van de langjarige trends (1998-2018) in de Voordelta laat eveneens zien dat het aantal zwarte zee-eenden in de Voordelta een dalende lijn vertoont maar dat er geen sprake is van een trendbreuk rond 2008 en evenmin een verschil met de landelijke trend (van Roomen et al., 2020). Deze resultaten wijzen er op dat er geen effect is van Maasvlakte 2 en de compensatiemaatregelen op het aantal zwarte zee-eenden dat in de Voordelta overwintert.

Tabel 8.2. Het maximum aantal zwarte zee-eenden in de Voordelta op basis van vliegtuigtellingen. * alleen MWTL tellingen

\begin{tabular}{llll}
\hline Periode & monitorings-jaar & maximum & $\begin{array}{l}\text { maand waarin } \\
\text { maximum } \\
\text { geteld is }\end{array}$ \\
\hline T-nul & $2004-2005$ & 9.078 & april \\
\cline { 2 - 4 } & $2005-2006$ & 10.244 & mei \\
\cline { 2 - 4 } $2006-2007 *$ & 4.510 & maart \\
\hline T1/T2 & $2007-2008 *$ & 2.634 & november \\
\cline { 2 - 4 } & $2008-2009$ & 5.225 & april \\
\cline { 2 - 4 } $2010-2010$ & 2.005 & december \\
\cline { 2 - 4 } $2011-2012$ & 3.400 & mei \\
\hline $2012-2013$ & 3.205 & februari \\
\hline $2013-2014$ & 7.780 & april \\
\cline { 2 - 4 } $2014-2015$ & 880 & november \\
\hline $2015-2016$ & 830 & november \\
\hline $2016-2017$ & 1.485 & januari \\
$2017-2018$ & 12.562 & april \\
$2018-2019$ & 820 & februari \\
\hline
\end{tabular}



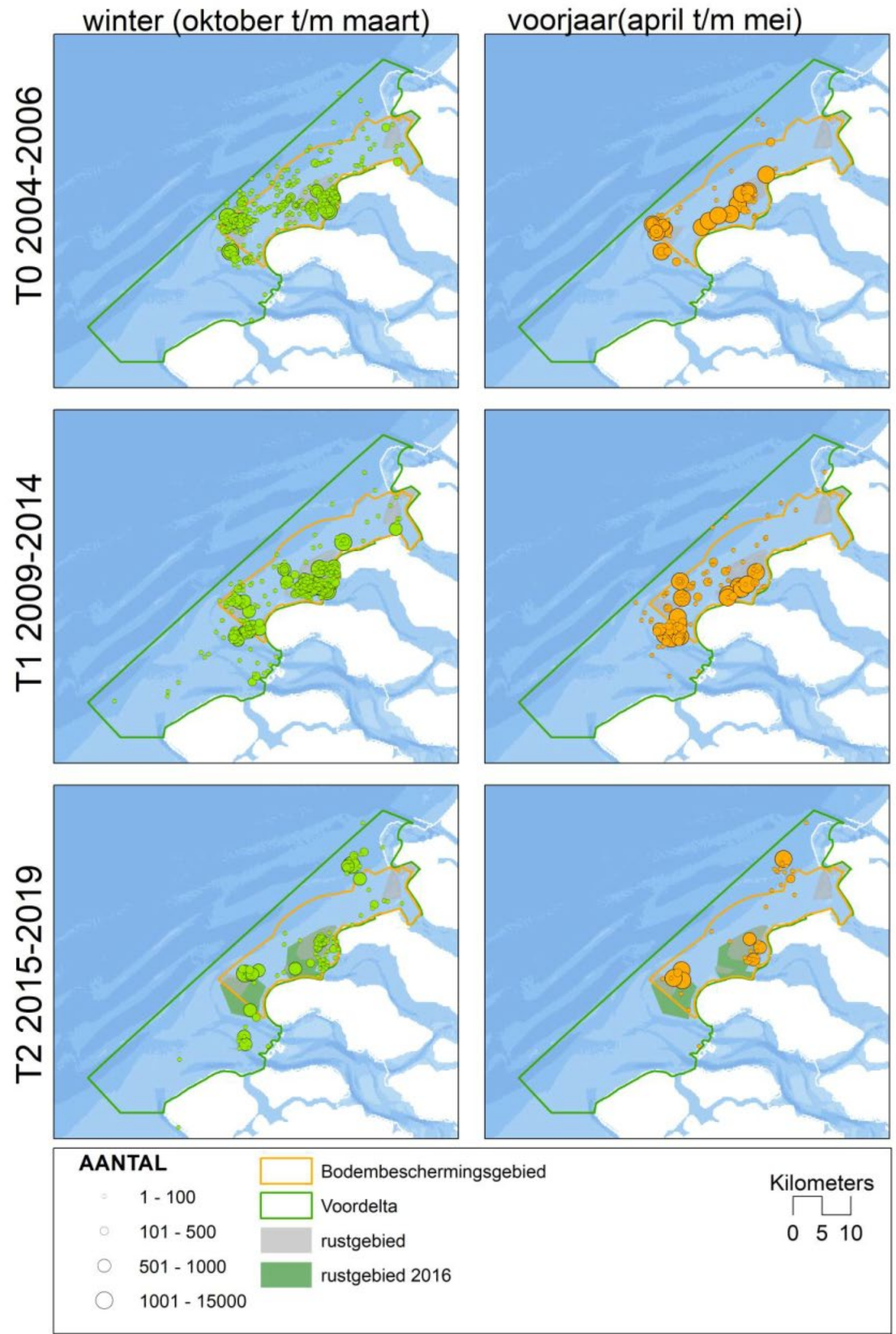

Figuur 8.2. Verspreiding van zwarte zee-eenden (gemiddelde aantal) in winterhalfjaar (oktober $t / m$ maart) en voorjaar (april/mei) in TO, T1 en T2. 

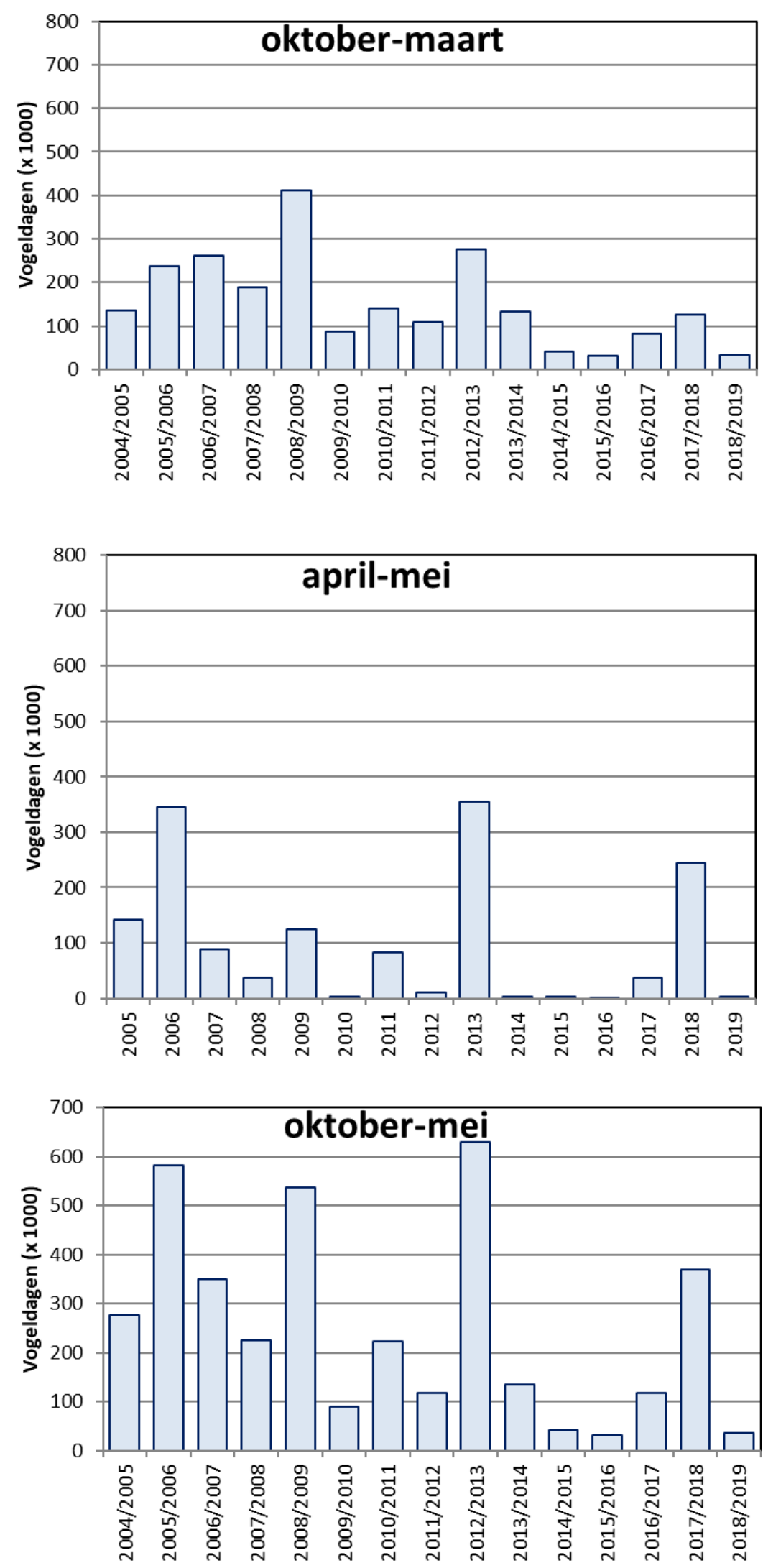

- Bollen vd Ooster $\quad$ Bollen vh Nieuwe Zand $\quad$ rest Voordelta

Figuur 8.3. Totaal aantal vogeldagen van de zwarte zee-eend in de twee rustgebieden en de rest van de Voordelta tijdens het winterhaljaar (boven), voorjaar (midden) en de periode oktober-mei (onder). 


\subsubsection{Voedselaanbod voor zwarte zee-eenden in de Voordelta}

Van de vier soorten met de hoogste biomassa-dichtheden (te weten Ensis leei, Abra alba, Limecola balthica, Spisula subtruncata) blijkt uit de resultaten van de bodemdierbemonstering (zie hoofdstuk 6 voor detail) dat Ensis in veel hogere dichtheden voorkomt dan de andere soorten. Spisula vertoont vanaf 2015 ook op een aantal locaties relatief hogere dichtheden (Figuur 8.4). Abra alba is op enkele locaties in dichtheden van 5-15 g asvrij drooggewicht per $\mathrm{m}^{2}$ waargenomen in 2011, 2012, 2017 en 2018. Van belang daarbij is dat de soorten vaak in lokale schelpdierbanken voorkomen die met het bemonsteringprogramma niet altijd opgemerkt worden. Gegevens van de WOT Schelpdiersurvey, waarin met een veel uitgebreider meetnet ieder voorjaar de bestanden van schelpdieren in de Voordelta worden gekwantificeerd, zijn daarom gebruikt voor aanvullende informatie over de schelpdierbestanden in de Voordelta.

In Figuur 8.5 wordt de totale biomassa van de vier soorten weergegeven voor twee dieptezones in de Voordelta (tot $15 \mathrm{~m}$ en dieper dan $15 \mathrm{~m}$ ). Deze twee zones zijn onderscheiden omdat zwarte zee-eenden in de Voordelta vrijwel alleen worden waargenomen in de ondiepere delen tot $15 \mathrm{~m}$. Voor de T0 periode wordt het totale voedselaanbod beschreven in de Voordelta inclusief het gebied dat door aanleg van Maasvlakte 2 is verdwenen. Het voorkomen van voor zee-eenden geschikte prooien varieert tussen jaren. De opsplitsing naar diepte laat zien dat de biomassa dieper dan $15 \mathrm{~m}$ laag is en een gestage daling van de biomassa van deze soorten schelpdieren optreedt in de loop van de jaren. In de ondiepere delen tot 15 m diepte varieert het aanbod tussen jaren, met in 2009/2010 het laagste aanbod. Het voedselaanbod wordt sterk gedomineerd door Ensis, de andere soorten dragen minder bij aan de hoeveelheid geschikt voedsel. Vanaf 2015 is de halfgeknotte strandschelp (Spisula subtruncata) in de Voordelta, maar ook elders in de Nederlandse kustzone, sterk toegenomen in aantallen en biomassa (Troost et al., 2017; Perdon et al., 2018). Deze toename is zichtbaar vanaf 2015/2016 in Figuur 8.5. Ook andere soorten schelpdieren zijn toegenomen in aantal. Maar ook in deze latere jaren vormde Ensis in de bodemdierbemonstering het grootste deel ( $>70 \%$ ) van de biomassa van schelpdieren in de Voordelta (Figuur 8.5). Uit de WOT Schelpdiersurvey komt een iets ander beeld; sinds 2017 zijn de bestanden van Ensis <11 cm en van Spisula ongeveer even groot (Perdon et al., 2016; Troost et al., 2017; Perdon et al., 2018; Perdon et al., 2019).

Er is geen significant verschil tussen T0 en T1 in de totale biomassa van schelpdieren geschikt als prooi voor de zwarte zee-eend in het gebied ondieper dan $15 \mathrm{~m}$. De totale biomassa van de halfgeknotte strandschelp is wel significant toegenomen $(n=11, p<0,01)$.

In 2016-2018 is een bank met hoge dichtheden van de halfgeknotte strandschelp opgekomen in het gebied ten zuidwesten van Maasvlakte 2 buiten het Bodembeschermingsgebied (Perdon et al., 2016; Troost et al., 2017). Op die plek zijn in een aantal jaren ook concentraties zwarte zee-eenden waargenomen (zie Figuur 8.2). 
Amerikaanse zwaardschede (Ensis leei)

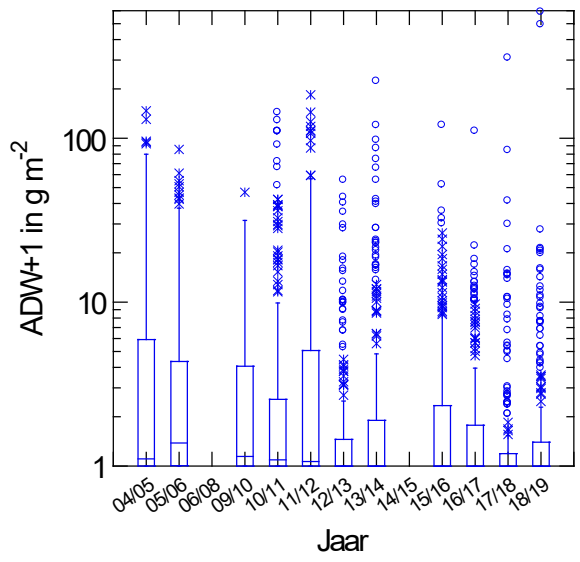

strandschelp (Spisula spp.)

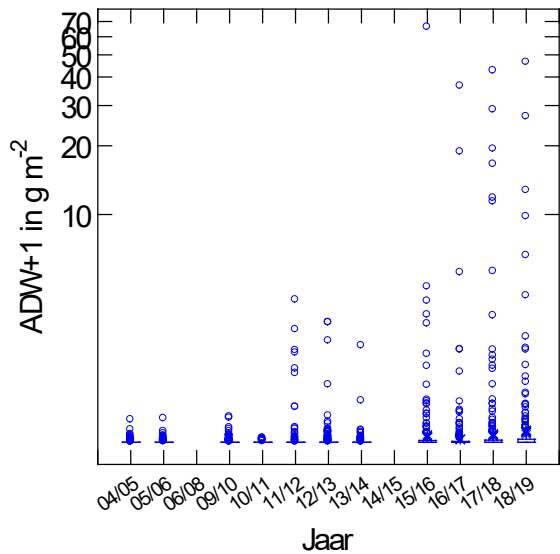

Figuur 8.4 Boxplots van gemiddelde biomassa per rastercel in $1+g$ asvrij drooggewicht/m², van de Amerikaanse zwaardschede (links) en 3 soorten Spisula (rechts) in de schelplengtes die voor zwarte zeeeenden eetbaar zijn. De gegevens van alle rastercellen worden hier getoond. Let op: de verticale as is een log-schaal en verschilt tussen beide figuren. In 2006-2008 en 2014 zijn geen bodemdiermonsters verzameld.

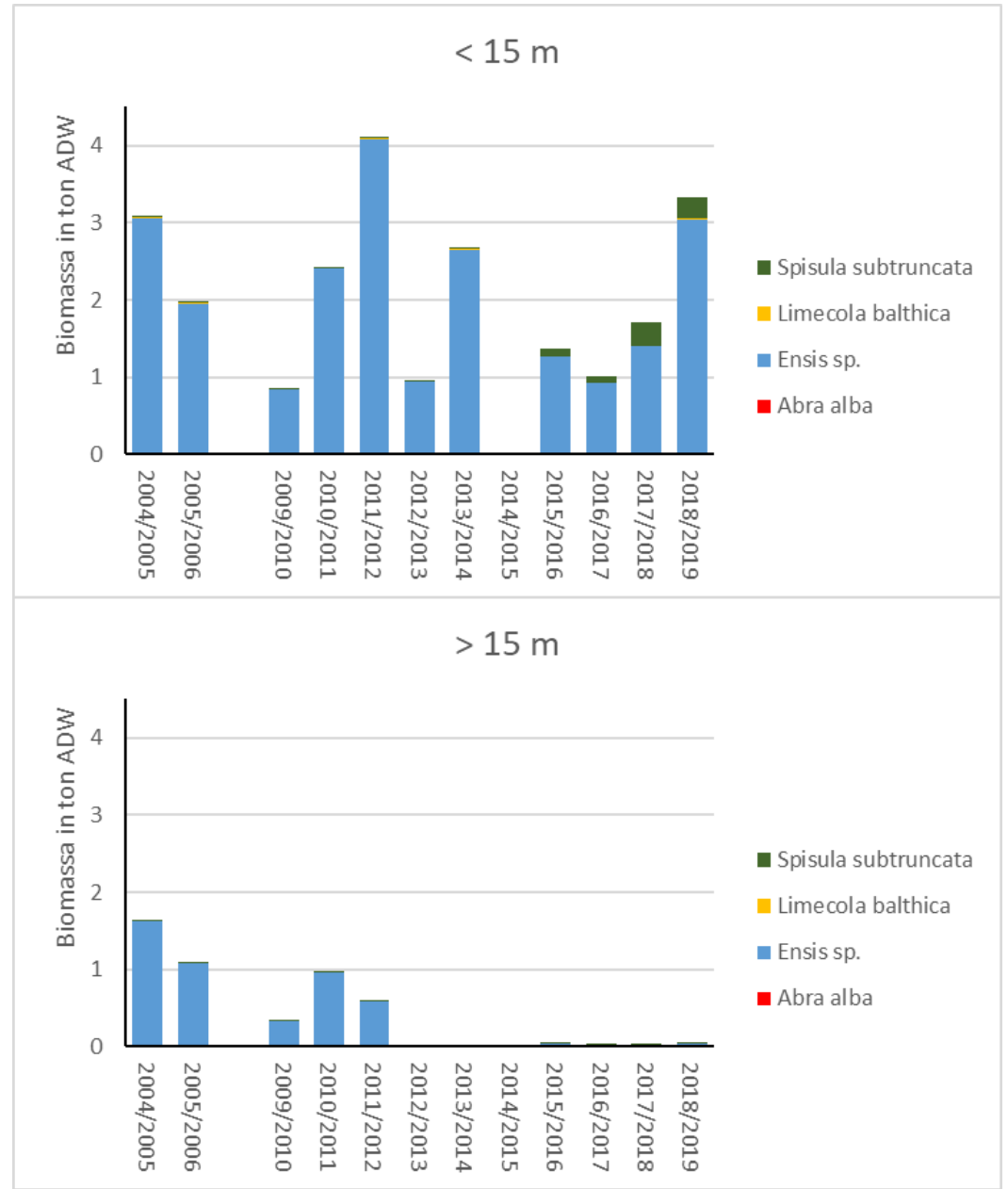

Figuur 8.5 Totale biomassa in de gehele Voordelta (incl. Maasvlakte 2 gebied) van de vier meest voorkomende soorten schelpdieren (in schelplengtes die voor zwarte zee-eenden eetbaar zijn) voor de jaren met bemonsteringen in de herfst in de periode 2004 - 2018, opgesplitst naar waterdiepte: minder dan 15 m en dieper dan 15 m. In 2006-2008 en 2014 zijn geen bodemdiermonsters verzameld. 


\subsubsection{Berekening van potentiële aantallen zwarte zee-eenden in de Voordelta}

Met het energiebudget-model voor de zwarte zee-eend (van de Wolfshaar et al., 2018) wordt het aantal eenden berekend dat in de Voordelta kan verblijven, op basis van gegevens over het voedselaanbod, andere omgevingsfactoren zoals diepte, stroomsnelheid en weersomstandigheden en gegevens over de intensiteit van scheepvaart. Berekeningen zijn uitgevoerd voor de twee T0 jaren en voor 2009/2010 t/m 2017/2018, met uitzondering van 2014/2015 omdat in 2014 geen bodemdiergegevens verzameld zijn. Met het model wordt vooral de potentiële foerageerfunctie van de Voordelta berekend, d.w.z. het aantal eenden dat potentieel in een rastercel kan verblijven en foerageren op basis van de beschikbare hoeveelheid voedsel, de lokale omstandigheden en de ingeschatte verstoring door scheepvaart. Het model rekent daarbij met aanwezigheid van eenden gedurende de hele periode vanaf het najaar.

De berekeningen zijn uitgevoerd met Ensis en Spisula als voedsel, de waargenomen scheepvaartbewegingen en fysische en meteorologische omstandigheden. Het model voorspelt dat het grootste deel van de eenden (gemiddeld 80\%) in het Bodembeschermingsgebied voorkomt. Dit hangt samen met het voedselaanbod en de geringere diepte in vergelijking met andere delen van de Voordelta. De modelresultaten zijn uitgedrukt in een potentieel aantal eenden dat gedurende de gehele periode september-april in de Voordelta kan overleven. De modelresultaten laten grote jaarlijkse verschillen zien in de jaren vanaf 2009 (Figuur 8.6). De verschillen tussen jaren kunnen deels verklaard worden door verschillen in aanbod en beschikbaarheid van geschikt voedsel, daarnaast speelt ook de inschatting van verstoring door scheepvaart een rol (Figuur 8.7) en de invloed van stroomsnelheid en meteorologie.

De met het model berekende potentiële aantal zwarte zee-eenden volgt deels de ontwikkeling in totale biomassa van prooien, maar opvallend is het lage potentiële aantal eenden in met name 2012/2013 toen het totale voedselaanbod in het gebied ondieper dan $15 \mathrm{~m}$ relatief hoog was. De potentiële aantallen zijn niet direct vergelijkbaar met de waargenomen aantallen vogeldagen; het model kan hoge potentiële aantallen voorspellen terwijl in werkelijkheid de eenden niet aanwezig zijn. Aan de andere kant zou verwacht kunnen worden dat hoge waargenomen aantallen vogeldagen wel weerspiegeld worden in de modelresultaten.

In een vergelijking met waarnemingen (Figuur 8.8) vallen een aantal zaken op. Volgens de modelresultaten zijn 2004/2005 en 2011/2012 de jaren met het hoogste potentiële aantal eenden maar in de tellingen waren dit geen jaren met een uitzonderlijk hoog aantal vogeldagen. Tevens valt op dat van de drie jaren met het hoogste waargenomen aantal vogeldagen, twee jaren (2012/2013, 2017/2018) zeer lage potentiële aantallen eenden hebben.

Wanneer in de modelberekeningen verstoring door de huidige intensiteit van scheepvaart buiten beschouwing wordt gelaten, zijn de potentiële aantallen zwarte zee-eenden uiteraard hoger dan met verstoring (Figuur 8.8). Voor de hele Voordelta berekent het model in de jaren met de hoogste potentiële aantallen een toename van $15-20 \%$ als alle scheepvaart afwezig zou zijn. In met name de laatste jaren berekent het model een relatief groot effect van verstoring door scheepvaart (30-40\%). Dit hangt samen met de toename in garnalenvisserij in die periode. De inschatting van verstoring kan echter niet volledig het verschil tussen waarnemingen en modelschattingen voor 2012/2013 verklaren. Dit suggereert dat het model in sommige gevallen mogelijk een onderschatting geeft van het potentiële aantal eenden. Voor deze onderschatting zijn verschillende verklaringen mogelijk, bijvoorbeeld onjuistheden in de inschatting van het voedselaanbod, of in de aannames over de beschikbaarheid van voedsel en de voedselverwerving, de aannames over de mate van verstoring door scheepvaart, of het feit dat het model rekent met een verblijftijd van een half jaar terwijl de hoge aantallen eenden in werkelijkheid korter in de Voordelta verblijven, en in de genoemde jaren vooral in de periode april-mei.

Voor de interpretatie van de modelresultaten in relatie tot de aanleg van Maasvlakte 2 en de genomen compensatiemaatregelen, is vooral de vergelijking van de berekende potentiële aantallen vóór en na aanleg van belang. Veel van de jaren na 2008 hebben berekende lagere potentiële aantallen dan de T0. Het verschil tussen vóór en na is net niet statistisch significant $(p=0,05)$ als gevolg van de hoge jaarlijkse variatie en de hoge potentiële aantallen in 2011/2012. Opdelen van de waarnemingen in T0, T1 
en T2 zoals gedaan voor bodemdierenbiomassa (hoofdstuk 4) levert geen andere resultaten; het aantal waarnemingen per periode is dan te laag om significante verschillen vast te stellen.

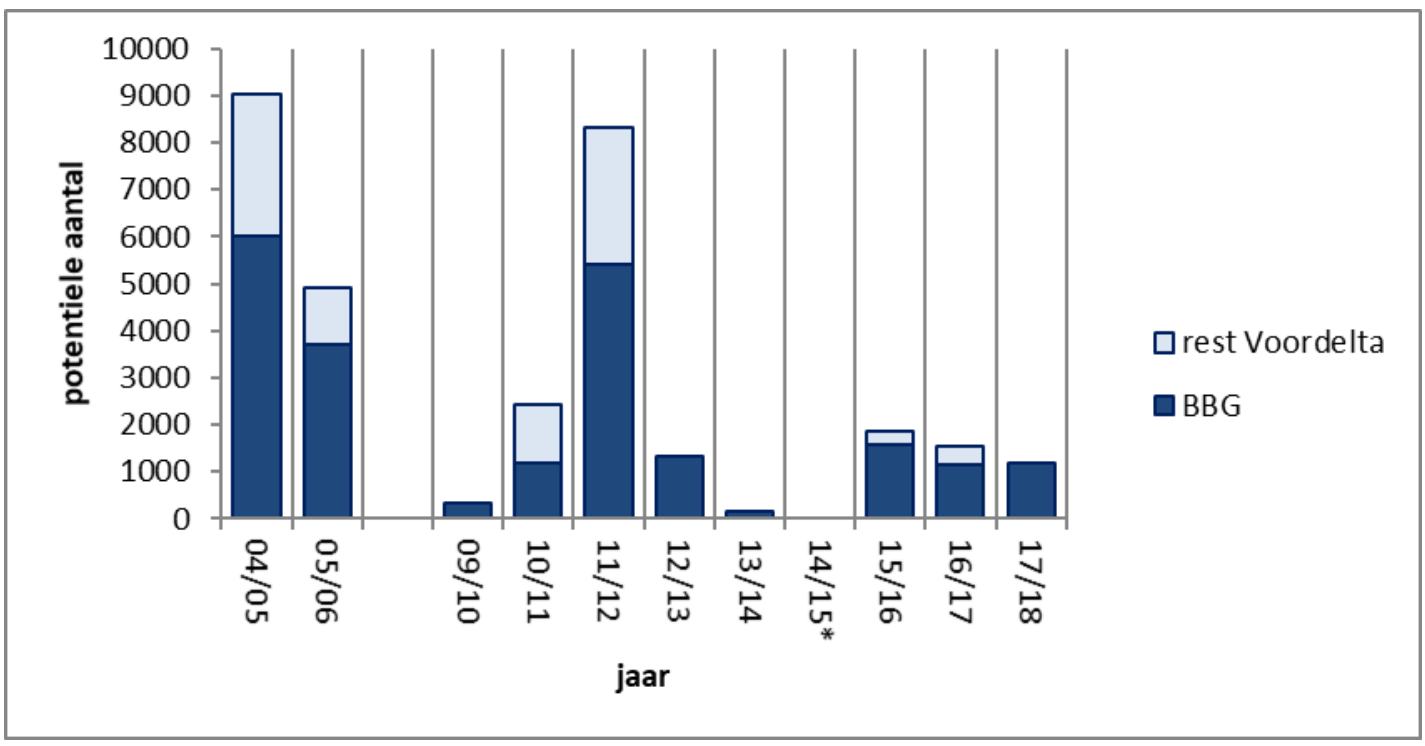

Figuur 8.6. Het potentiële aantal zwarte zee-eenden dat gedurende de periode september-april in de Voordelta kan verblijven, met Ensis en Spisula als voedsel en met de huidige intensiteit van scheepvaart; Bodembeschermingsgebied (BBG) en de rest van de Voordelta zijn onderscheiden. *Voor het jaar $2014 / 2015$ is geen berekening uitgevoerd vanwege het niet beschikbaar zijn van biomassa gegevens van schelpdieren.

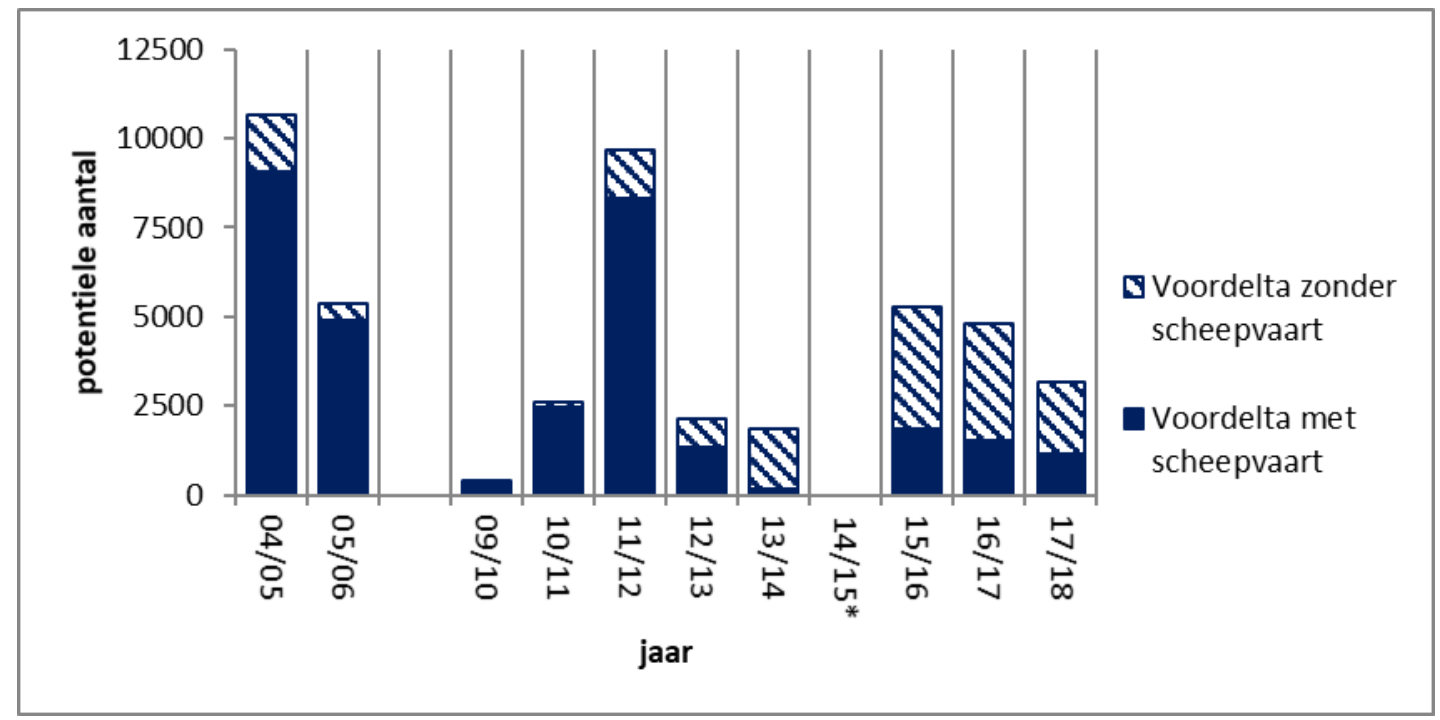

Figuur 8.7. Het potentiële aantal zwarte zee-eenden in de Voordelta met de waargenomen intensiteit van scheepvaart (blauw; zelfde data als in Figuur 7.6) en het potentiële extra aantal eenden zonder scheepvaart (gearceerd). *Voor het jaar 2014/2015 is geen berekening uitgevoerd vanwege het niet beschikbaar zijn van biomassa gegevens van schelpdieren. 

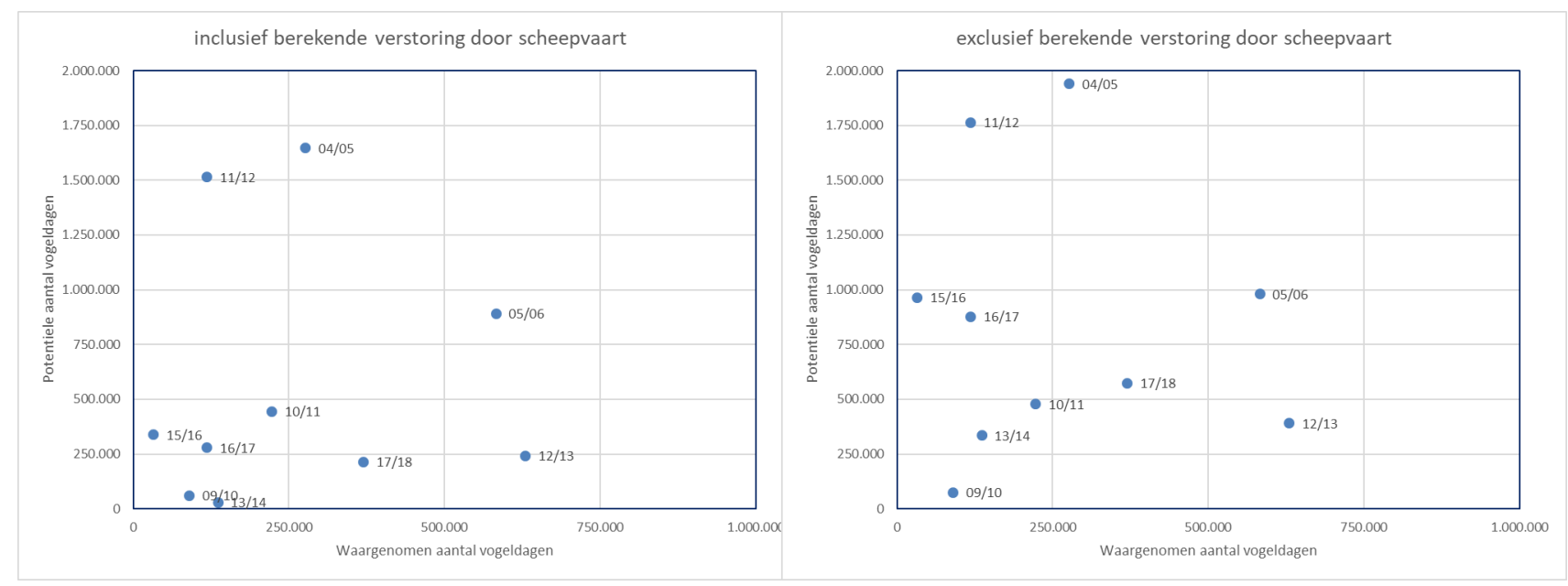

Figuur 8.8. Vergelijking van het potentiële aantal vogeldagen met het waargenomen aantal vogeldagen in de Voordelta. De linker figuur geeft het potentiële aantal vogeldagen met verstoring door scheepvaart berekend uit de aantallen in Fig. 8.6. De rechter figuur geeft het potentiële aantal vogeldagen zonder verstoring berekend uit de aantallen in Fig. 8.7.

\subsubsection{Statistische analyse van verstoring door scheepvaart}

Eerder is een statistische analyse uitgevoerd van de relatie tussen waargenomen aantal zwarte zeeeenden en omgevingsvariabelen, zoals het lokale voedselaanbod, diepte en stroomsnelheid, en verstoring door scheepvaart (Zuur et al., 2014). Uit deze analyse bleek verstoring (door scheepvaart) een belangrijke verklarende factor voor de door het statistisch model voorspelde aantallen eenden, in combinatie met andere factoren: het statistische model voorspelde meer zee-eenden in ondieper water, met meer voedsel, bij lage bodemstroomsnelheid en met weinig scheepvaart.

De analyse door Zuur et al. (2014) was gebaseerd op een beperkt aantal jaren (2009-2012). Daarom is deze analyse nu herhaald met de gehele dataset voor de telseizoenen (oktober-mei) van de periode 2009-2018 (Van Horssen et al., 2020). Voor deze analyse is gebruik gemaakt van de indeling van de Voordelta in rastercellen zoals gebruikt in het bodemdieronderzoek en in de modellering van de energiebudgetten. In de analyse is het verband onderzocht van het aantal eenden in een rastercel (inclusief waarnemingen met nul eenden per cel) met diepte, voedselaanbod en voorkomen van scheepvaart. De T0 jaren zijn niet meegenomen omdat voor die jaren onvoldoende AIS data beschikbaar zijn, nodig om het voorkomen van scheepvaart te berekenen. In de nu herhaalde analyse is bovendien gebruik gemaakt van een kwantificering van de scheepvaart ten tijde van de tellingen in plaats van het gemiddelde over het winterhalfjaar zoals in de eerdere analyse gebruikt. Scheepvaart is onderscheiden in vier categorieën (visserij, beroepsvaart, recreatievaart, onbekend). Verder onderscheid in typen visserij is niet mogelijk op basis van de AIS data. De meest voorkomende visserij in de jaren 2009-2018 is garnalenvisserij en op beperktere schaal Ensis-visserij (zie ook hoofdstuk 5). Voor de beschrijving van het voedselaanbod zijn verschillende soorten schelpdieren onderscheiden (Ensis, Spisula subtruncata, Abra alba, Limecola balthica).

Verstoring door scheepvaart is berekend door per rastercel, per kwartier, de aanwezigheid van scheepvaart (binnen een buffer van 1500 meter) te tellen op basis van de AIS data. Deze worden vervolgens gesommeerd tot aantal verstoringen per 24 uur. Over de jaren heen is de zo berekende verstoring in het middendeel van de Voordelta waar zwarte zee-eenden voornamelijk verblijven (zie kaart in Figuur 8.10) toegenomen, vooral door toename van visserij (Figuur 8.9). 


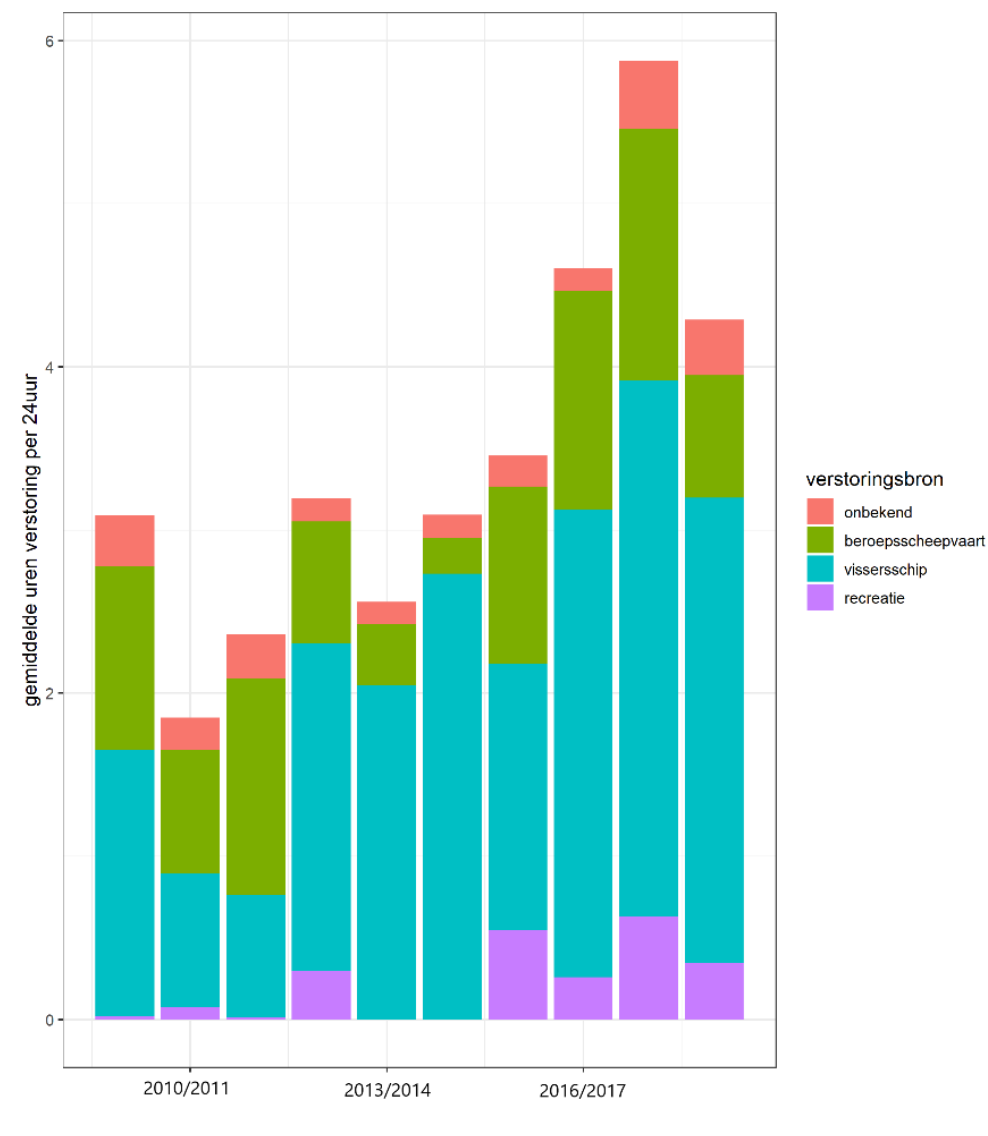

Figuur 8.9. Berekende verstoring (op basis van AIS) uitgedrukt in gemiddelde aantal uren per etmaal met aanwezigheid van scheepvaart in het middengebied van de Voordelta (zie ook Figuur 8.10).

De ruimtelijke verdeling van scheepvaart is geillustreerd met kaarten voor 2009/2010 (het eerste jaar met data) en 2018/2019 (het laatste jaar). Duidelijk is dat de monding van het Haringvliet een druk gebied is met vooral aanwezigheid van vissersschepen en (andere) beroepsvaart. Vissersschepen komen verspreid door het gebied voor, met het zwaartepunt in de maanden oktober-december, maar in latere jaren is er ook in de maanden januari-mei vrij veel scheepvaart van vissers. Vissersschepen komen vooral voor in het gebied ten westen van het Haringvliet, de kop van Goeree en bij de Bollen van het Nieuwe Zand. Het ruimtelijk patroon in voorkomen van visserij overlapt deels met het patroon van voorkomen van schelpdierbestanden (Ensis, Spisula), en ook met de gebieden waar concentraties van zwarte zee-eenden zijn waargenomen (zie Figuur 8.2).

Uit de statistische analyse komt in grote lijnen een vergelijkbaar beeld als uit de eerdere resultaten (Zuur et al., 2014; Tulp et al., 2018). Zwarte zee-eenden komen in de Voordelta vooral voor in gebieden met een diepte van 2-15 m. Het aantal zwarte zee-eenden vertoont een positieve correlatie met de biomassa van de schelpdieren; de biomassa van Ensis voorspelt het beste de ruimtelijke verdeling van zwarte zeeeenden in de Voordelta. Concentraties van zwarte zee-eenden worden vooral waargenomen in gebieden waar minder scheepvaart voorkomt. De analyses wijzen erop dat voedselaanbod, diepte, en verstoring door scheepvaart de factoren zijn die van bepalende invloed lijken te zijn op de verspreiding van de zwarte zee-eend in de Voordelta. Met deze analyses wordt echter alleen een gemiddeld beeld van de ruimtelijke verspreiding van zwarte zee-eenden in relatie tot omgevingsfactoren gegeven (cf. Leopold et al., 2013).

Het model beschrijft de aantallen en verspreiding van zwarte zee-eenden op een langere tijdschaal en zegt niets over directe of relatief kortdurende effecten, zoals lokale uitputting van voedsel of de verplaatsing van zwarte zee-eenden als reactie op passerende schepen. "Eenmalige" gebeurtenissen zoals het seizoen 2017/2018 met zeer hoge aantallen eenden in april in de Voordelta en het seizoen 
2018/2019 met juiste hele lage aantallen in de Voordelta zijn met deze analyses lastig te verklaren. Hierbij spelen mogelijk ook juist processen op landelijke of fly-way schaal een belangrijke rol.

2009/2010
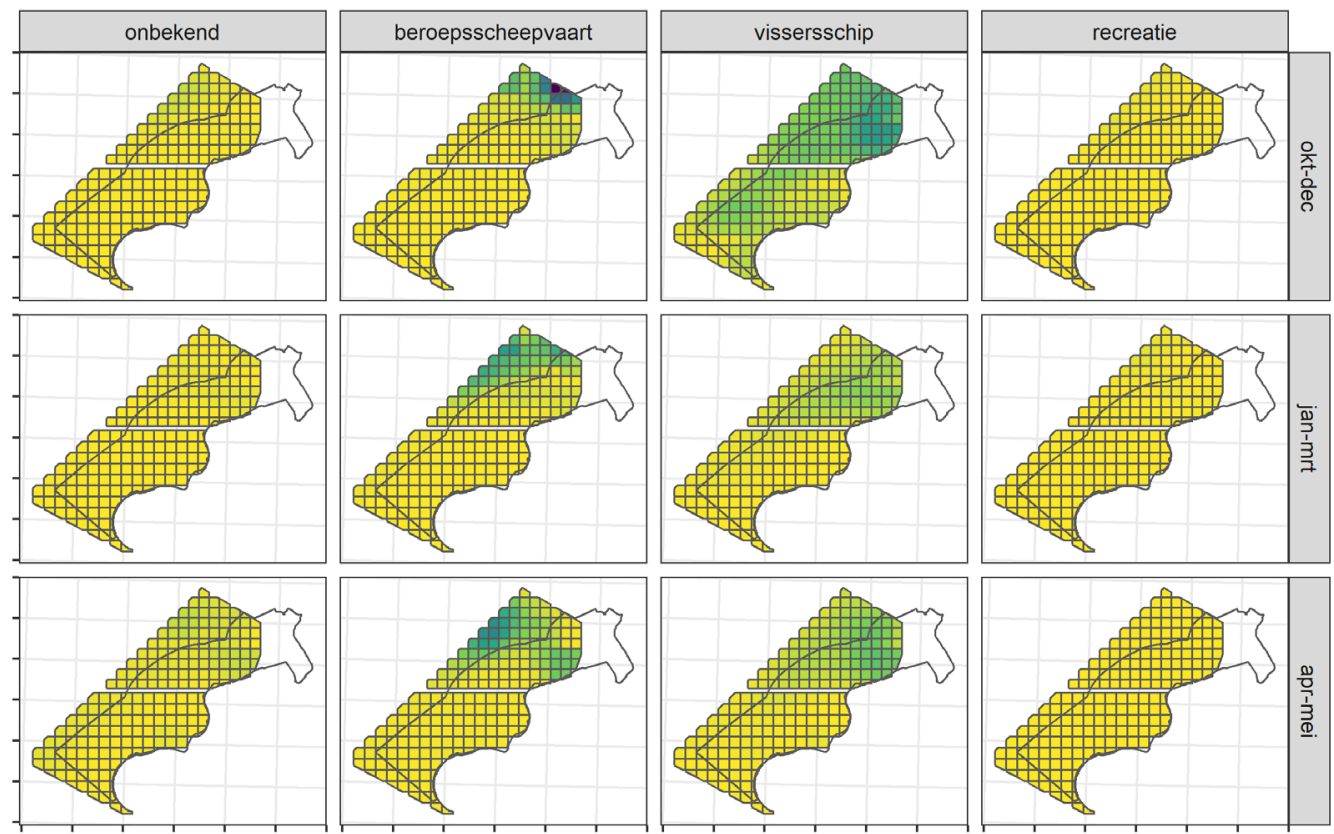

:20108/2019
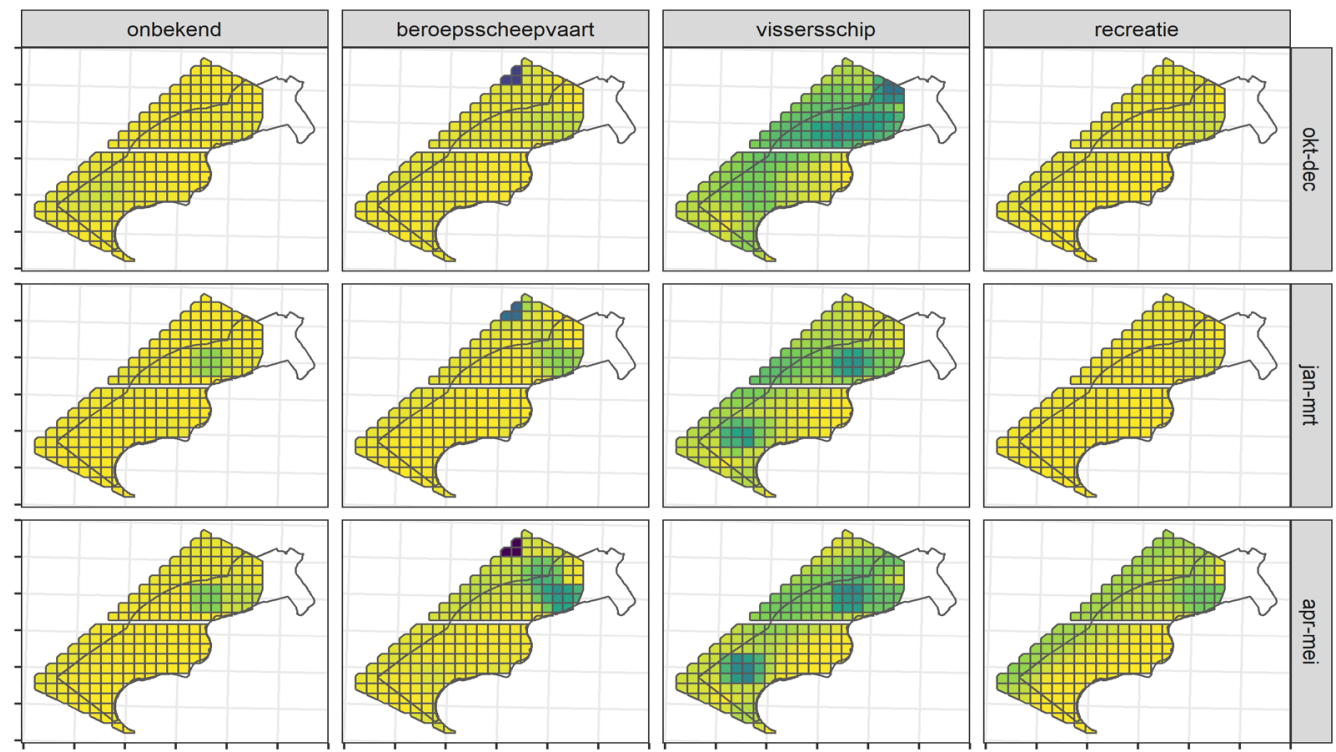

gemiddelde verstoring

(uur/24uur)

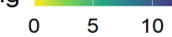

Figuur 8.10. Berekende verstoring (op basis van AIS) uitgedrukt in gemiddelde aantal uren per etmaal. Uitgesplitst per categorie scheepvaart en voor drie periodes in de telseizoenen 2009/2010 (boven) en 2018/2019 (onder).

\subsection{Het effect van het instellen van de rustgebieden}

De rustgebieden Bollen van de Ooster en Bollen van het Nieuwe Zand zijn ingesteld om de verstoring van zwarte zee-eenden door menselijke activiteiten in de Voordelta te verminderen. De rustgebieden zijn (mede) aangewezen op grond van de aanwezigheid van zee-eenden in de jaren vóór de aanwijzing. 
Gedurende het winterhalfjaar zijn de twee rustgebieden Bollen van het Nieuwe Zand en Bollen van de Ooster gesloten voor menselijke activiteiten om verstoring te beperken. Het aandeel van de rustgebieden in het totaal aantal vogeldagen varieert tussen $1 \%$ en $53 \%$ (gemiddeld $21 \%$; Figuur 8.11 ). Uit de kaart in Figuur 8.2 blijkt dat de grootste concentraties van zwarte zee-eenden te vinden zijn in het gebied rond de Bollen van de Ooster en de Bollen van het Nieuwe Zand, grotendeels binnen het

Bodembeschermingsgebied. De zee-eenden worden deels binnen, deels buiten de begrenzing van de rustgebieden waargenomen.

In 2016 is de begrenzing en de periode van sluiting van de rustgebieden aangepast (gebied vergroot en restricties aangepast). Dat besluit is in 2018 weer teruggedraaid na een gerechtelijke uitspraak en sindsdien zijn de oorspronkelijke begrenzing en restricties weer van kracht. Het is vanwege de korte duur van die aanpassing niet mogelijk om conclusies te trekken over het effect van de veranderde begrenzing en periode van sluiting.

Overigens blijken de rustgebieden niet helemaal gevrijwaard van scheepvaart tijdens de periode van sluiting. Zowel in de Bollen van de Ooster als de Bollen van het Nieuwe Zand wordt, met name langs de randen van de gebieden, garnalenvisserij waargenomen. Vooral in de Bollen van het Nieuwe Zand komt dit relatief veel voor (de Vries en Glorius, 2018). 

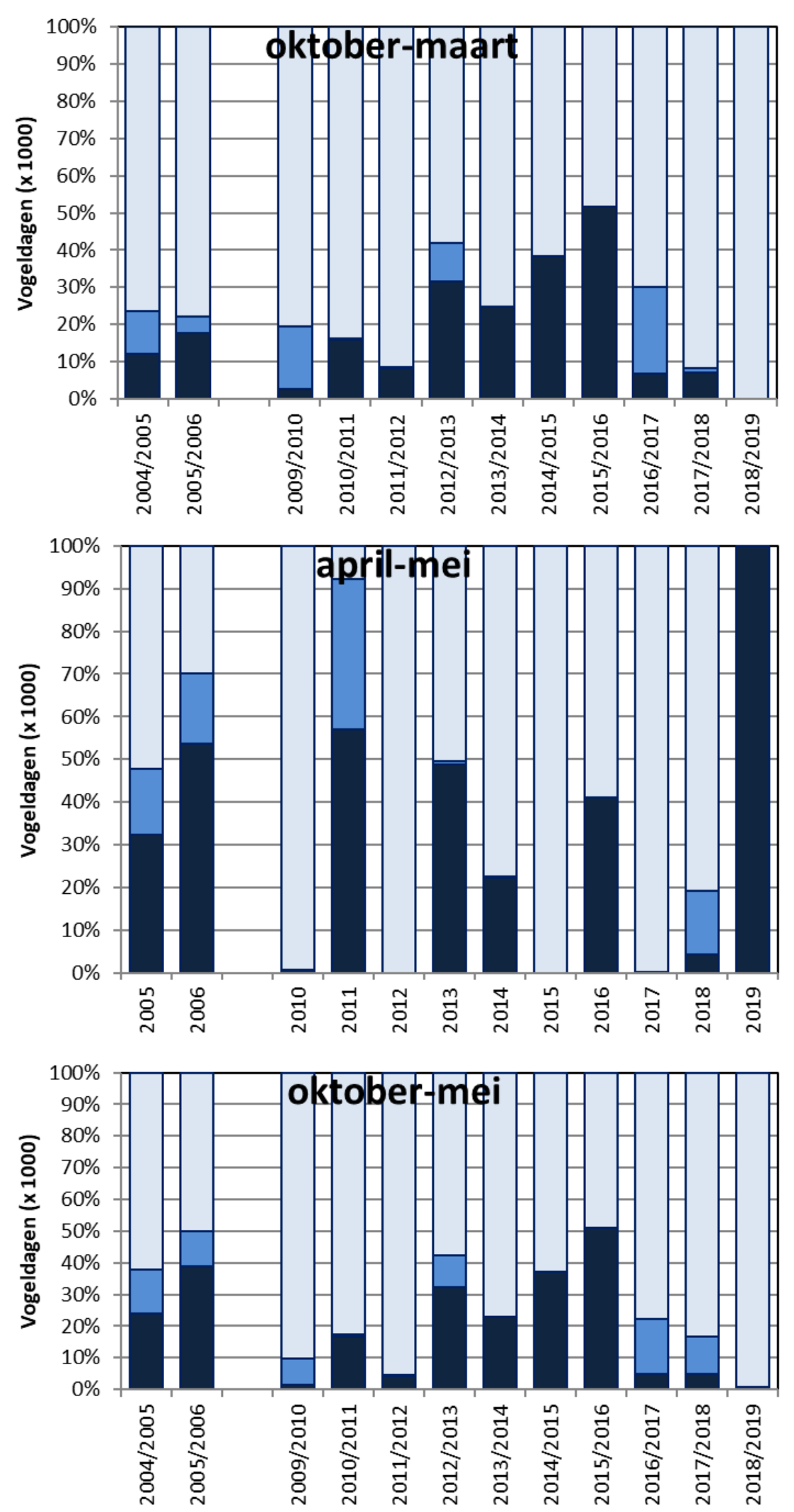

Bollen vd Ooster $\quad$ B Bollen vh Nieuwe Zand $\quad$ rest Voordelta

Figuur 8.11. Procentuele verdeling van de vogeldagen binnen de begrenzing van de rustgebieden Bollen van het Nieuwe Zand (BVNZ) en Bollen van de Ooster (BVO) en in de rest van de Voordelta, in de T-nul (vóór 2008) als na instelling van de rustgebieden (na 2008). 


\subsection{Aantallen in de Voordelta in vergelijking met andere gebieden}

\subsubsection{Nederlandse en Belgische kustwateren}

In de Nederlandse kustwateren zijn drie gebieden van belang voor zwarte zee-eenden. De grootste aantallen worden in het algemeen langs de Noordzeekust van de Waddeneilanden waargenomen.

Daarnaast zijn de Voordelta en de kust van Noord-Holland gebieden waar zwarte zee-eenden verblijven. Dit blijkt uit zowel de midwintertellingen die sinds 1993 in het kader van het MWTL programma worden uitgevoerd als uit de tellingen in maart/april die in PMR-NCV kader zijn uitgevoerd. De midwinteraantallen in de Voordelta zijn in vrijwel alle jaren sinds 2000 slechts een klein deel van het totale aantal in de Nederlandse kustwateren (Lilipaly et al., 2019). In de maart/april tellingen die in het kader van PMR-NCV zijn uitgevoerd, is het aandeel van de Voordelta in veel tellingen niet hoger dan $5 \%$ van het totaal, maar in sommige jaren meer dan $20 \%$ (Figuur 8.11).

In 2018 en 2019 zijn in combinatie met de PMR-NCV tellingen in de Voordelta ook in de Belgische kustwateren vanuit dit programma extra tellingen uitgevoerd (van der Zee et al., 2019). In april 2018 zijn in de Voordelta meer dan 12.000 zwarte zee-eenden geteld en werden voor de Belgische kust ruim 1.100 eenden waargenomen. In de winter van 2018/2019 daarentegen was het maximale aantal in de Voordelta 565, en werden voor de Belgische kust 1.000-2.000 eenden geteld tussen december en mei.

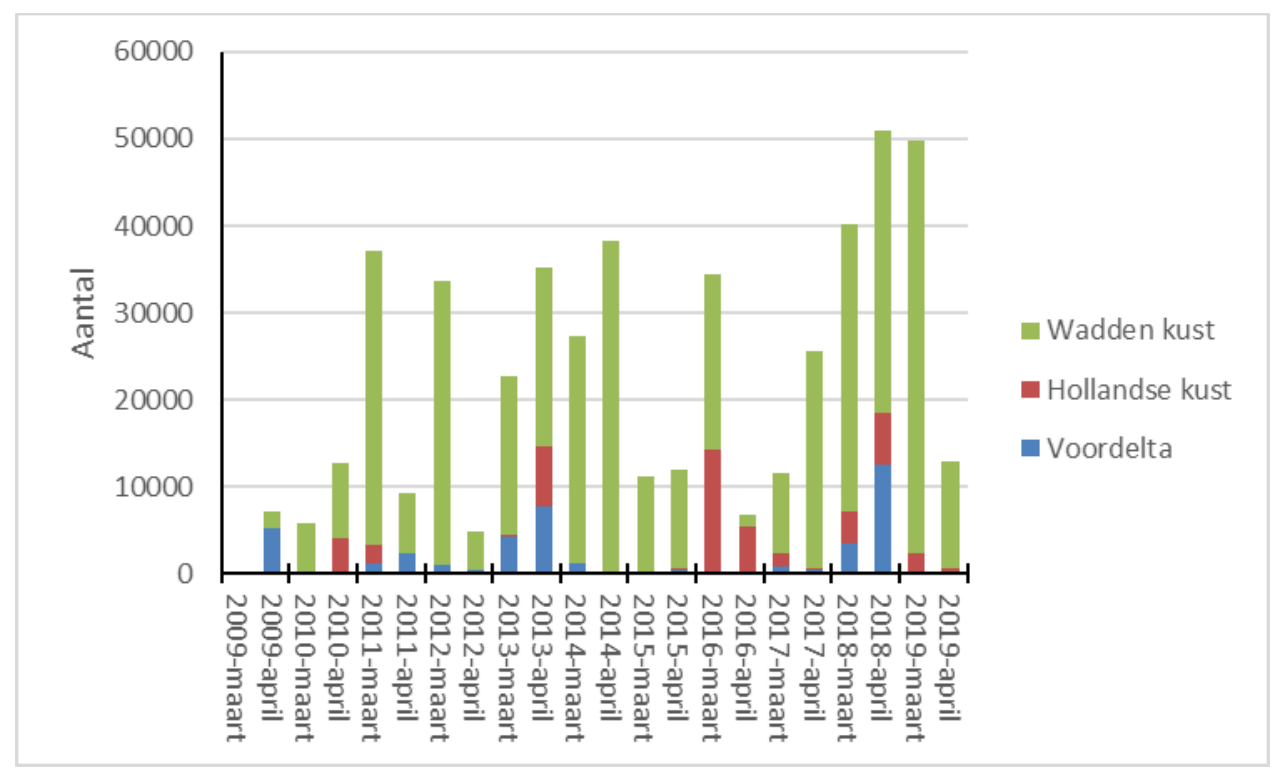

Figuur 8.11. Totaal aantal zwarte zee-eenden geteld langs de kust van de Waddeneilanden, de Hollandse kust en de Voordelta, in maart en april van de jaren 2009-2019.

\subsubsection{NW Europa}

De zwarte zee-eenden die in Nederland overwinteren, maken deel uit van de 'W Siberia \& N Europe/W Europe \& NW Africa' - populatie; voor deze populatie is de meest recente schatting van het aantal vogels bepaald op 600.000 - 1.200.000 vogels (Wetlands International, 2016). Voor zover beschikbaar, zijn aantallen in de belangrijkste overwinteringsgebieden ten noorden en zuiden van Nederland in Tabel 8.3 samengevat. Deze gegevens zijn gebaseerd op literatuur en informatie van onderzoekers in de verschillende landen (zie Tulp et al. (2018) en van der Zee et al. (2019) voor details). Veruit de hoogste aantallen zwarte zee-eenden worden geteld in de Duitse en Deense wateren in de Noordzee en in de 
Oostzee (Skov et al., 2011). Samenvattend lijken de aantallen ten noorden van Nederland toe te nemen, terwijl in Nederland en landen ten zuiden afnemende aantallen laten zien.

Tabel 8.3. Overzicht van aantallen zwarte zee-eenden in verschillende Europese landen buiten de broedperiode.

\begin{tabular}{lcccccc}
\hline & Gemiddeld & & \multicolumn{2}{c}{ Maximum laatste 10 jaar } & \multicolumn{2}{c}{ Hoogste maximum geteld } \\
Land & aantal & Periode & Aantal & Jaar & Aantal & Jaar \\
\hline Denemarken & 600.000 & $2008-2019$ & 600.000 & $2015 / 2016$ & 950.000 & $1992 / 1993$ \\
Duitsland & 1.000 .000 & $2011-2016$ & 1.050 .000 & $2015 / 2016$ & 1.050 .000 & $2015 / 2016$ \\
Nederland & 70.000 & $1990-2019$ & 65.000 & $2017 / 2018$ & 140.000 & $1992 / 1993$ \\
België & 2.000 & $1990-2019$ & 7.000 & $2018 / 2019$ & 10.000 & voor 2008 \\
Frankrijk & 20.000 & $2008-2017$ & 23.000 & $2016 / 2017$ & 58.000 & $1988 / 1989$ \\
Spanje & 5.000 & $2008-2019$ & 7.000 & $2009 / 2010$ & 10.000 & vóór 2008 \\
Portugal & 15.000 & $2008-2019$ & 20.000 & $2015 / 2016$ & 27.000 & vóór 2008 \\
Verenigd Koninkrijk & 135.000 & $2008-2019$ & 135.000 & $2014 / 2015$ & 150.000 & vóór 2008 \\
\hline
\end{tabular}

\subsection{Conclusies}

In dit hoofdstuk worden de resultaten van monitoring en onderzoek aan de zwarte zee-eend samengevat, met het doel onderbouwing te leveren voor de beantwoording van de MEP-vraag: Wordt het verlies aan foerageergebied van de zwarte zee-eend als gevolg van de aanleg en het gebruik van Maasvlakte 2 voldoende gecompenseerd? Bij de MEP vragen zijn deelvragen geformuleerd over het belang van het verlies van foerageergebied als gevolg van Maasvlakte 2, het effect van het instellen van het Bodembeschermingsgebied en het effect van het instellen van de rustgebieden.

\subsubsection{Verlies aan foerageergebied door de aanwezigheid van Maasvlakte 2}

De eerste deelvraag van de MEP vraag gaat over het daadwerkelijk verloren gegane potentiële foerageergebied. Enerzijds gaat het dan om het totale oppervlak zeegebied dat verloren is gegaan, maar tegelijkertijd vraagt dit om een nadere beschouwing van het feitelijke verlies van foerageergebied voor de zwarte zee-eend, veroorzaakt door de aanleg en het gebruik van Maasvlakte 2. De systematiek van een Passende Beoordeling, waar het er om gaat met zekerheid te stellen dat er geen aantasting is van natuurlijke kenmerken, leidt tot een 'worst case' benadering indien er onzekerheden in data of kennis zijn. De 'worst case' inschatting was dat er 3,1\% verlies van potentieel foerageergebied kon optreden.

De analyse van alle beschikbare gegevens leidt tot de eenduidige conclusie dat het gebied waar Maasvlakte 2 is aangelegd, in de periode waarvoor telgegevens beschikbaar zijn (vanaf 1975) nooit van enige betekenis is geweest voor de zwarte zee-eend als verblijf- of foerageergebied. Ook blijkt uit de gegevens over voedselbeschikbaarheid en berekeningen van het potentiële aantal zwarte zee-eenden in dit gebied, dat dit gebied geen potentiële foerageerfunctie had voor zwarte zee-eenden. Met deze inzichten kan geconcludeerd worden dat er feitelijk geen sprake is van een verlies van foerageergebied van de zwarte zee-eend in het zeegebied waar Maasvlakte 2 aangelegd is, en dat daarmee het negatieve effect van Maasvlakte 2 afwezig is.

\subsubsection{Belang van de Voordelta en het Bodembeschermingsgebied}

De tweede deelvraag bij de MEP-vraag richt zich op de bijdrage van het Bodembeschermingsgebied: heeft de instelling van dat gebied geleid tot een gelijkblijvende (potentiële) functie van het gebied voor zwarte zee-eenden, in termen van voedselbeschikbaarheid. 
Gegevens uit het verleden laten zien dat in de Voordelta eind vorige eeuw grotere aantallen zwarte zeeeenden zijn waargenomen dan tegenwoordig. Tussen 1975-1980 werden gemiddelde wintermaxima geteld van zo'n 15.000, en maximale aantallen tot 28.000 zwarte zee-eenden in de maanden decembermaart (Baptist en Meininger, 1996). In de jaren tachtig en begin jaren negentig waren de aantallen lager met maxima tussen 2.000-10.000, met uitzonderlijk hoge aantallen in koude winters (Baptist en Meininger, 1996). De aantallen tijdens midwintertellingen in de Voordelta tussen 1990-2006 waren sterk wisselend met maximaal zo'n 9.000 vogels (2003). In het vroege voorjaar werden gemiddeld de hoogste aantallen waargenomen, met maxima tot 25.000 in april 2002 (Berrevoets et al., 2002; Berrevoets en Arts, 2003; Hoekstein en Lilipaly, 2003;Berrevoets et al., 2005). De aantallen zwarte zee-eenden in de Voordelta kunnen sterk variëren als gevolg van uitwisseling met de kustgebieden van de Waddeneilanden, België en het noorden van Frankrijk, de Theems-monding, en jaarlijks wisselende migratie vanuit de noordelijke gebieden als de Duitse en Deense kustwateren (Leopold et al., 1995; Seys, 2001). Er is geen verband gevonden tussen aantallen zwarte zee-eenden in de Voordelta en het al of niet optreden van strenge winters in Nederland (Berrevoets et al., 2002).

De monitoring in het veld laat sterk wisselende, maar over langere termijn geleidelijk afnemende aantallen zwarte zee-eenden in de Voordelta (voornamelijk binnen het Bodembeschermingsgebied) zien. Het aantal vogeldagen is gebruikt als indicator omdat deze een geïntegreerd beeld voor de gehele winter en voorjaar geeft. Op basis van de vergelijking van midwinteraantallen in Voordelta en rest van Nederland voor 1993-2019, de getelde maximum aantallen en vogeldagen over de periode 2004-2019, en analyse van de langetermijntrends in aantallen door van Roomen et al. (2020) kan geconcludeerd worden dat er geen aanwijzingen zijn dat de functie van de Voordelta als rust- en foerageergebied is veranderd door de aanleg van Maasvlakte 2.

Hoewel verschillende soorten schelpdieren in voor zee-eenden geschikte afmetingen in de Voordelta zijn aangetroffen in de monitoringperiode van PMR-NCV, bestaat het voedselaanbod voor een groot deel uit Ensis. De totale hoeveelheid voedsel op bereikbare diepte $(<15 \mathrm{~m})$ geeft een indicatie van het totale voedselaanbod. Maar voor het daadwerkelijk beschikbaar zijn van geschikt voedsel spelen ook andere factoren een rol zoals stroomsnelheid en verstoring. De laatste jaren nemen ook andere soorten schelpdieren weer in aantal toe. Het gaat hierbij vooral om de halfgeknotte strandschelp (Spisula subtruncata), maar ook de witte dunschaal ( $A b r a$ alba) levert een grotere bijdrage aan het voedselaanbod. De opkomst sinds 2016 van een bank van Spisula subtruncata ten zuidwesten van Maasvlakte 2 heeft geleid tot een relatief grote geconcentreerde groep zwarte zee-eenden in 2016/2017 in dit deel van de Voordelta. In de daarop volgende twee jaren zijn hier ook weer groepen zwarte zeeeenden waargenomen, maar zaten eenden ook meer op andere plekken in de Voordelta.

Het voedselaanbod over 2004-2018, uitgedrukt als totale prooi-biomassa in het gebied ondieper dan $15 \mathrm{~m}$, is niet veranderd wat er op duidt dat voor wat betreft voedselomstandigheden er geen verandering is opgetreden in de potentiële foerageerfunctie van de Voordelta. Wel is er, door de opkomst van andere schelpdieren als Spisula en Abra, mogelijk in kwalitatieve zin wat veranderd.

Met het energiebudget-model kan een schatting worden gemaakt van de potentiële draagkracht voor aantallen zwarte zee-eenden in de Voordelta, uitgaande van lokale omstandigheden zoals voedselaanbod, fysische factoren zoals temperatuur, diepte en stroomsnelheid en gebruik makend van aannames over het verstorende effect van scheepvaart. Na afronding van de $1^{\mathrm{e}}$ fase van PMR-NCV is gekozen voor de ontwikkeling van het model, om een beter inzicht te krijgen in de potentiële functie van de Voordelta voor zwarte zee-eenden in aanvulling op de veldwaarnemingen. De potentiële functie van het gebied kan goed zijn zonder dat het tot uitdrukking komt in werkelijk waargenomen aantallen eenden in een telseizoen, als er door oorzaken buiten de Voordelta weinig of geen eenden naar de Voordelta komen.

De potentiële aantallen zwarte zee-eenden die het model voorspelt zijn niet onrealistisch. De hoogste aantallen die ooit in de Voordelta zijn waargenomen, lagen in de orde van 20.000 - 30.000. Deze aantallen kunnen gedurende kortere tijd voorkomen in de Voordelta. De potentiële aantallen uit de modelschattingen kunnen worden omgerekend naar vogeldagen; die liggen dan tussen ca. 30.000- 
1.500.000. Dit is redelijk vergelijkbaar met de range in waargenomen vogeldagen (ca. 50.000-750.000). Wel lijkt het potentiële aantal in een aantal jaren laag in vergelijking met het werkelijk waargenomen aantal vogeldagen. De modelresultaten lijken te wijzen op een lager potentieel aantal eenden in de meeste jaren na 2008, hoewel het verschil met de T0 niet significant is. De modelresultaten wijken in een aantal jaren met hoge waargenomen aantallen eenden ook sterk af van de waarnemingen. Er is geen eenduidige verklaring voor deze verschillen.

De waarnemingen van het aantal zwarte zee-eenden in de Voordelta laten zien dat er geen significante afname is opgetreden in het aantal vogeldagen, sinds de aanleg van Maasvlakte 2 . Er is evenmin een trendbreuk in het relatieve aandeel van de Voordelta ten opzichte van de andere delen van de Nederlandse kustwateren. De daling in het aantal eenden in de Voordelta ten opzichte van waarnemingen van decennia geleden lijken onderdeel van een trend die ook elders in Nederland en langs de kust van Frankrijk en België is waargenomen.

Zowel de modelresultaten als de veldwaarnemingen geven geen duidelijke aanwijzingen dat de potentiële functie van de Voordelta als foerageergebied is verslechterd sinds de aanleg van Maasvlakte 2.

\subsubsection{Belang van de rustgebieden}

In de Voordelta wordt de zwarte zee-eend voornamelijk in of langs de randen van het Bodembeschermingsgebied waargenomen. De eenden verblijven deels binnen de begrenzing van de aangewezen rustgebieden. $\mathrm{Er}$ is geen duidelijke verandering in de ruimtelijke verdeling van de eenden opgetreden na de instelling van de rustgebieden.

Het is bekend dat zwarte zee-eenden gevoelig zijn voor verstoring door scheepvaart (Schwemmer et al., 2011; Fliessbach et al., 2019). Uit statistische analyses komt naar voren dat naast voedsel en waterdiepte het voorkomen van scheepvaart een belangrijke verklarende factor is die de ruimtelijke verspreiding van zee-eenden in de Voordelta verklaart. Dit sluit aan bij de waarnemingen dat buiten de rustgebieden zwarte zee-eenden in de Voordelta vooral voorkomen op locaties waar scheepvaart niet of beperkt voorkomt. Uit de analyse van AIS data blijkt dat scheepvaart, vooral van vissersschepen, als potentiële bron van verstoring is toegenomen in het middendeel van de Voordelta. Het gaat hierbij om garnalenvisserij maar mogelijk ook om schelpdiervisserij. Deze visserijen komen deels voor in dezelfde gebieden waar zwarte zee-eenden worden waargenomen. De statistische analyses geven echter geen uitsluitsel over het effect van visserij op het voorkomen van eenden, dit zou nadere analyse vereisen. Hierbij speelt mee dat garnalenvisserij deels voorkomt in dezelfde gebieden als waar zee-eenden worden waargenomen, maar vooral in het najaar en begin van de winter plaatsvindt. De eenden zijn vooral aan het eind van de winter en het vroege voorjaar aanwezig. Het niet gelijktijdig voorkomen van garnalenvisserij en de aanwezigheid van zwarte zee-eenden is op basis van de beschikbare gegevens niet aan te merken als een effect van verstoring, maar het kan ook niet uitgesloten worden dat verstoring door scheepvaart een rol speelt bij de verdeling van aantal eenden over de maanden in de periode oktober-mei.

De berekeningen met het energiebudget-model geven aan dat, met de aannames die gedaan zijn over verstoring door scheepvaart, scheepvaart potentieel een verstoringsbron kan zijn die van invloed is op de foerageerfunctie van de Voordelta. 


\section{Literatuur}

Aarts, G., Brasseur, S. M. J. M., Poos, J. J., Schop, J., Kirkwood, R., van Kooten, T., Mull, E., et al. 2019. Topdown pressure on a coastal ecosystem by harbor seals. Ecosphere, 10.

Adema, J. 2016. Datarapport PMR-NCV Perceel Abiotiek. Simulaties 2014 en analyse lange termijn trends. ICES Document 1 april 2016. 64 pp.

Adema, J. 2018. Datarapport PMR-NCV perceel Abiotiek. Simulaties 2016 en analyse alternatieve aanpak bodemschuifspanningen golven. ICES Document 12 januari 2018. 46 + bijlage pp.

Adema, J. 2019. Datarapport PMR-NCV perceel abiotiek. Simulaties 2018 en analyse monitoringsperiode 20042018. ICES Document Rapport nr 084022067 0.1. 53 pp.

Asjes, J., Craeymeersch, J., Escaravage, V., Grift, R. E., Tulp, I., Bult, T., and Villars, N. 2004. Strategy of approach for the baseline study Maasvlakte 2, Lot 2: benthic fauna and Lot 3: fish and fish larvae. ICES Document Version 30th September 2004. 86 pp.

Baptist, H. J. M., and Meininger, P. L. 1996. Vogels van de Voordelta 1975-95. ICES Document Rapport RIKZ 96.018. $110 \mathrm{pp}$.

Beauchard, O., Veríssimo, H., Queirós, A. M., and Herman, P. M. J. 2017. The use of multiple biological traits in marine community ecology and its potential in ecological indicator development. Ecological Indicators, 76: 81-96.

Bergman, M. J. N., Fonds, M., Hup, M., Lewis, W., van der Puyl, P., Stam, A., and den Uyl, D. 1990. Direct effects of beamtrawl fishing on benthic fauna of the North Sea - a pilot study. pp. 33-57. RIVO, NIOZ, RWS DNZ, IJmuiden.

Bergman, M. J. N., Ubels, S. M., Duineveld, G. C. A., and Meesters, E. W. G. 2014. Effects of a 5-year trawling ban on the local benthic community in a wind farm in the Dutch coastal zone. Ices Journal of Marine Science, 72: 962-972.

Bergman, M. J. N., and van Santbrink, J. W. 2000. Fishing mortality of populations of megafauna in sandy sediments. The effects of fishing on non-target species and habitats: biological, conservation and socio-economic issues: 49-68.

Bergmann, M., and Moore, P. G. 2001. Mortality of Asterias rubens and Ophiura ophiura discarded in the Nephrops fishery of the Clyde Sea area, Scotland. Ices Journal of Marine Science, 58: 531-542.

Berkenbosch, R. J., Meulepas, G. J. M., Brouwer, L., Van Ledden, M., Heinis, F., Vertegaal, C. T. M., Van Zanten, M., et al. 2007. Milieueffectrapport Aanleg Maasvlakte 2 Hoofdrapport. . ICES Document Eindrapport 9R7008.A1/R011/MVZ/IBA/Rott1. 477 + Bijl. pp.

Berrevoets, C. M., and Arts, F. A. 2003. Midwintertelling van zee-eenden in de Waddenzee en de Nederlandse kustwateren, januari 2003. ICES Document Rapport RIKZ/2003.008. 20 pp.

Berrevoets, C. M., Strucker, R. C. W., Arts, F. A., Lilipaly, S. J., and Meininger, P. L. 2005. Watervogels en zeezoogdieren in de zoute Delta 2003/2004, inclusief de tellingen in 2002/2003. ICES Document Rapport RIKZ/2005.011. 134 pp.

Berrevoets, C. M., Strucker, R. C. W., and Meininger, P. L. 2002. Watervogels in de zoute Delta 2000/2001. ICES Document Rapport RIKZ/2002.002. 86 pp.

Beukema, J. J. 1979. Biomass and species richness of the macrobenthic animals living on a tidal flat area in the Dutch Wadden Sea: Effects of a severe winter. Netherlands Journal of Sea Research, 13: 203-223.

Beukema, J. J., and Dekker, R. 2014. Variability in predator abundance links winter temperatures and bivalve recruitment: correlative evidence from long-term data in a tidal flat. Marine Ecology Progress Series, 513: $1-15$.

Bierman, S., Miller, D., Quirijns, F., and Van Hal, R. 2009. Intensiteit boomkorvisserij in de Voordelta. ICES Document Rapport C144/09. 41 pp.

Bolam, S. G., Coggan, R. C., Eggleton, J., Diesing, M., and Stephens, D. 2014. Sensitivity of macrobenthic secondary production to trawling in the English sector of the Greater North Sea: A biological trait approach. Journal of Sea Research, 85: 162-177.

Brinkman, A. G. 2015. Voorstel draagkrachtmodel Zwarte Zee-eend in de Voordelta. ICES Document Rapport C053/15. $57 \mathrm{pp}$.

Brinkman, A. G., De Leeuw, J. J., Leopold, M. F., Smit, C. J., and Tulp, I. Y. M. 2007. Voedselecologie van een zestal schelpdieretende vogels ICES Document Rapport C078/07. $122 \mathrm{pp}$.

Brinkman, A. G., Ens, B. J., and Kats, R. 2003. Modelling the energy budget and prey choice of Eider ducks. ICES Document Alterra-rapport $839135 \mathrm{pp}$.

Cadée, G. C. 2002. Massaal aanspoelen van juveniele Ensis directus. Het Zeepaard, 62: 120-124.

Couperus, A. S., Dijkman-Dulkes, A., Hintzen, N., Leijzer, T., Pasterkamp, T., Westerink, H. J., and Van Willigen, J. 2007. Baseline studie vis MVII: veldwerkrapportage najaar 2007 ICES Document Rapport C132/07. 9 pp.

Couperus, A. S., Van Damme, C. J. G., Tulp, I. Y. M., Tribuhl, S. V., Pennock, I., and Heessen, H. J. L. 2008. Vis in de Voordelta: nulmetingen 2007 in het kader van de aanleg van de Tweede Maasvlakte. ICES Document Rapport C06/08. $61 \mathrm{pp}$.

Craeymeersch, J. A., Brummelhuis, E. B. M., Dimmers, W., Engelberts, A., Markusse, M. M., Schout, P., and Verschuure, J. M. 1996. Effecten van de schelpdiervisserij op het bodemleven in de Voordelta. Fase rapport over de onderdelen 'natuurlijke ontwikkeling' en effecten schelpdiervisserij'. 48 pp. 
Craeymeersch, J. A., Hamerlynck, O., Hostens, K., Vanreusel, A., and Vincx, M. 1990. De ekologische ontwikkeling van de Voordelta, deelrapport 1. De huidige ekologische situatie van de Voordelta.

Craeymeersch, J. A. M., Escaravage, V., Adema, J., Asch, M. v., Tulp, I. Y. M., and Prins, T. 2015. PMR Monitoring natuurcompensatie Voordelta - bodemdieren 2004 - 2013.

Craeymeersch, J. A. M., Escaravage, V., and Perdon, J. 2004. Baseline study MEP-MV2. Veldwerkrapportage najaar 2004. ICES Document Rapport C085/04. 19 pp.

Craeymeersch, J. A. M., Escaravage, V., and Perdon, J. 2005a. Baseline study MEP-MV2 Lot 2: bodemdieren Voortgangsverslag juni 2005. ICES Document Rapport C027/05.

Craeymeersch, J. A. M., Escaravage, V., and Perdon, J. 2005b. Baseline study MEP-MV2. Veldwerkrapportage bodemdieren najaar 2005. ICES Document Rapport C079/05. 18 pp.

Craeymeersch, J., Escaravage, V., 2014. Perceel Benthos, in: Prins, T., van der Kolff, G. (Eds.), PMR Monitoring natuurcompensatie Voordelta. Eindrapport 1e fase 2009-2013 deel B. Deltares, Delft, pp. 19-154.

Craeymeersch, J.A., Perdon, J., Jol, J., Brummelhuis, E., van Asch, M., 2016. PMR Monitoring Natuurcompensatie Voordelta - bodemdieren. Datarapport campagne bodemschaaf 2015-multivariate analyse 2004-2013. IMARES rapport C073.16. 38 pp.

Craeymeersch, J. A. M., Perdon, J., Jol, J., Brummelhuis, E. B. M., and Van Asch, M. 2017. PMR Monitoring Natuurcompensatie Voordelta - bodemdieren. Datarapport campagne bodemschaaf 2015 multivariate analyses 2004-2013 ICES Document rapport C073.16. 35 pp.

Craeymeersch, J., Perdon, K., van Zwol, J., Jol, J., Brummelhuis, E., van Asch, M., 2019. PMR Monitoring Natuurcompensatie Voordelta - bodemdieren. Veld- en datarapport campagnes met bodemschaaf in 2016, 2017 en 2018. Wageningen Marine Research rapport C059/19. 29 pp.

Dannheim, J., and Rumohr, H. 2011. The fate of an immigrant: Ensis directus in the eastern German Bight. Helgoland Marine Research, 66: 307-317.

de Leeuw, J. J. 1997. Demanding divers. Ecological energetics of food exploitation by diving ducks. p. 178. Universiteit Groningen.

de Vries, P., and Glorius, S. 2018. Activiteiten van de vissersvloot in de toegangsbeperkte gebieden in de Voordelta. Periode 2008 tot en met 2017. ICES Document Rapport C090/18. 41 pp.

Dekker, R., and Beukema, J. J. 1999. Relations of summer and winter temperatures with dynamics and growth of two bivalves, Tellina tenuis and Abra tenuis, on the northern edge of their intertidal distribution. Journal of Sea Research, 42: 207-220.

Dekker, W. 2007. Visbemonstering in de Voordelta: statistische betrouwbaarheid van de nulmetingen in het kader van de aanleg van de Tweede Maasvlakte. ICES Document Rapport C050/07. 21 pp.

Depestele, J., Desender, M., Benoît, H. P., Polet, H., and Vincx, M. 2014. Short-term survival of discarded target fish and non-target invertebrate species in the "eurocutter" beam trawl fishery of the southern North Sea. Fisheries Research, 154: 82-92.

Diesing, M., Stephens, D., and Aldridge, J. 2013. A proposed method for assessing the extent of the seabed significantly affected by demersal fishing in the Greater North Sea. ICES Journal of Marine Science, 70: 1085-1096.

Dirksen, S., Van Horssen, P. W., de Jong, R., and van der Zee, E. 2017. PMR NCV monitoring zwarte zeeeenden Voordelta. Jaarrapport 2016-2017. ICES Document A\&W-rapport 2379. 26 pp.

Duineveld, G. C. A., Bergman, M. J. N., and Lavaleye, M. S. S. 2007. Effects of an area closed to fisheries on the composition of the benthic fauna in the southern North Sea. Ices Journal of Marine Science, 64: 899-908.

Duplisea, D. E., Jennings, S., Warr, K. J., and Dinmore, T. A. 2002. A size-based model of the impacts of bottom trawling on benthic community structure. Canadian Journal of Fisheries and Aquatic Sciences, 59: 1785-1795.

EC-PMR 2001a. Advies over natuurcompensatie bij een tweede Maasvlakte. ICES Document november 2001. $227 \mathrm{pp}$.

EC-PMR 2001b. Mogelijkheden voor mitigatie en compensatie voor natuurschade bij landaanwinning en zandwinning. $47 \mathrm{pp}$.

Elias, E. P. L., and Van der Spek, A. J. F. 2014. Grootschalige morfologische veranderingen in de Voordelta 1964 - 2013. . ICES Document 1207724-001. 57 + fig pp.

Elias, E. P. L., van der Spek, A. J. F., and Lazar, M. 2016. The 'Voordelta', the contiguous ebb-tidal deltas in the SW Netherlands: large-scale morphological changes and sediment budget 1965-2013; impacts of large-scale engineering. Netherlands Journal of Geosciences - Geologie en Mijnbouw: 1-27.

Escaravage, V., Bergmeijer, M. A., Dekker, A., Engelberts, A. M., Sistermans, W. C. H., and De Witte-Dek, L. A 2008. Nulmeting MEP-MV2, Drie jaar bodemdieren waarnemingen (2004-2005-2007). ICES Document Monitor Taskforce publication series 2008-7. 48 pp.

EZ 2013. Wijzigingsbesluit Natura 2000-gebied Voordelta. ICES Document Programmadirectie Natura 2000, PDN/2013-113/2.

EZ 2014a. Leeswijzer Natura 2000 profielen. ICES Document Versie september 2014. 70 pp.

EZ 2014b. Profieldocument H1110 Permanent overstroomde zandbanken. ICES Document Versie 2014. 20 pp.

EZ 2015. NB-wet 1998; goedkeuring Monitoringsplan NCV 2016-2019. ICES Document Brief met kenmerk DGAN-NB/ 15173698, 22 december 2015.

FAO 2011. International Guidelines on Bycatch Management and Reduction of Discards. 73 pp.

Fijn, R.C., W. Courtens, S.J. Lilipaly, J. de Jong, R.J. Jonkvorst and E.W.M. Stienen (2019). PMR-NCV onderzoek sterns in de Delta en Voordelta. Jaarrapport 2019. Culemborg, Bureau Waardenburg, Rapport nr. 19-241, 104 pp.

Fijn, R., Leopold, M., Dirksen, S., Arts, F., Van Asch, M., Baptist, M., Craeymeersch, J., et al. 2017. Een concentratie van Zwarte Zee-eenden in de Hollandse kustzone toont het belang aan van schelpdieren en rust Limosa, 90: 97-117. 
Fijn, R. C., De Jong, J., Jonkvorst, R. J., Engels, B., Gyimesi, A., Heunks, C., Boudewijn, T. J., et al. 2016. PMRNCV Jaarrapport Vogels 2015. Voortgang onderzoek sterns \& zee-eenden in de Voordelta en Delta. ICES Document Rapport nr 16-080. 83 pp.

Fliessbach, K. L., Borkenhagen, K., Guse, N., Markones, N., Schwemmer, P., and Garthe, S. 2019. A Ship Traffic Disturbance Vulnerability Index for Northwest European Seabirds as a Tool for Marine Spatial Planning. Frontiers in Marine Science, 6.

Glorius, S., Craeymeersch, J., Van der Hammen, T., Rippen, A., Cuperus, J., Van der Weide, B., Steenbergen, J., et al. 2015. Effecten van garnalenvisserij in Natura 2000 gebieden. ICES Document Rapport C013/15. $162 \mathrm{pp}$.

Green, R. H. 1979. Sampling design and statistical methods for environmental biologists, Wiley-Interscience, Chichester, England.

Grift, R. E., and Tulp, I. Y. M. 2004. Nulmetingen Maasvlakte 2: meetstrategie vissen.

Heessen, H. J. L., and Jak, R. G. 2009. Plan van Aanpak PMR monitoring natuurcompensatie Voordelta. Deel B: Uitvoeringsplannen per perceel. $137 \mathrm{pp}$.

Heinis, F., Vertegaal, C. T. M., Goderie, C. R. J., and Van Veen, P. C. 2007. Habitattoets, Passende Beoordeling en uitwerking ADC-criteria ten behoeve van vervolgbesluiten van Maasvlakte 2. ICES Document 9S0134.A0/Nb-wet/R0019/PVV/Rott1. 232 pp.

Hiddink, J. G., Jennings, S., Sciberras, M., Szostek, C. L., Hughes, K. M., Ellis, N., Rijnsdorp, A. D., et al. 2017. Global analysis of depletion and recovery of seabed biota after bottom trawling disturbance. Proceedings of the National Academy of Sciences, 114: 8301.

Hintzen, N. 2019. Garnalenvisserij in Natura 2000 gebieden.

Hintzen, N. and Beier, U., 2020. Predicting benthic fauna biomass in the Voordelta under different hypothetical fisheries regimes. Wageningen, Wageningen Marine Research: 15.

Hintzen, N. T., de Vries, P., Looije, D., and Glorius, S. T. 2014. Vergelijking visserij - intensiteit op basis van AIS -VMS in de Voordelta. ICES Document rapport nr C068/14. 50 pp.

Hoekstein, M. S. J., and Lilipaly, S. J. 2003. Vliegtuigtellingen van watervogels en zeezoogdieren in de Voordelta, 2001/2002. ICES Document Rapport RIKZ/2002.051. 50 pp.

Holzhauer, H., and Prins, T. C. 2009. Plan van Aanpak PMR monitoring natuurcompensatie Voordelta. ICES Document rapport 1200672-008-ZKS-0002. 39 pp.

ICES 2005. Report of the Working Group on Seabird Ecology (WGSE), 29 March - 1 April 2005, Texel, The Netherlands. ICES Document ICES CM 2005/G:07. 49 pp.

ICES 2018a. ICES. 2018. Report of the Working Group on Electric Trawling (WGELECTRA). ICES Document ICES Report WGELECTRA 201817 - 19 April 2018. 155 pp.

ICES 2018b. OSPAR request on the production of spatial data layers of fishing intensity/pressure. ICES technical service. https://doi.org/10.17895/ices.pub.4508

IenM 2017. Project Mainportontwikkeling Rotterdam. Ruimte om te groeien en meer.... ICES Document oktober 2017. $67 \mathrm{pp}$

Kaiser, M. J., Clarke, K. R., Hinz, H., Austen, M. C. V., Somerfield, P. J., and Karakassis, I. 2006. Global analysis of response and recovery of benthic biota to fishing. Marine Ecology Progress Series, 311: 114.

Kaiser, M. J., and Spencer, B. E. 1995. Survival of by-catch from a beam trawl. Marine Ecology Progress Series, 126: 31-38.

Kottsieper, J., Schwemmer, P., Markones, N., Fox, A. D., and Garthe, S. 2019. An invasive alien bivalve apparently provides a novel food source for moulting and wintering benthic feeding sea ducks. Helgoland Marine Research, 73: 11

Kröncke, I., Reiss, H., and Dippner, J. W. 2013. Effects of cold winters and regime shifts on macrofauna communities in shallow coastal regions. Estuarine, Coastal and Shelf Science, 119: 79-90.

Leopold, M., van Asch, M., Dijkman, E., Goudswaard, K., Lagerveld, S., Verdaat, H., Camphuysen, K., et al. 2015. Zwarte zee-eenden bij Texel, een reactie op overvloedig voorkomen van Ensis? ICES Document Rapport C084/14. 26 pp.

Leopold, M. F., Baptist, H. J. M., Wolf, P. A., and Offringa, H. R. 1995. De Zwarte Zee-eend Melanitta nigra in Nederland. Limosa, 68: 49-64.

Leopold, M.F., R. van Bemmelen, J. Perdon, M. Poot, C. Heunks, D. Beuker, R.J. Jonkvorst and J. de Jong (2013). Zwarte Zee-eenden in de Noordzeekustzone benoorden de Wadden verspreiding en aantallen in relatie tot voedsel en verstoring. IMARES, C023/13, $47 \mathrm{pp}$.

Lilipaly, S. J., Arts, F. A., Sluijter, M., and Wolf, P. A. 2019. Midwintertelling van zee-eenden in de Waddenzee en Nederlandse kustwateren in januari en maart 2019. ICES Document Rapport RWS - Centrale Informatievoorziening. Rapport BM 19.21 / Deltamilieu Projecten rapport 2019-7. 38 pp.

Lindeboom, H. J., Leopold, M. F., Dankers, N. M. J. A., Brasseur, S. M. J. M., Bezemer, V., and Bervaes, J. C. A. M. 2002. Een zeereservaat in de Voordelta als mariene compensatie voor Maasvlakte II. ICES Document Alterra-rapport 443. 78 pp.

LNV 2008a. Aanwijzingsbesluit Voordelta. ICES Document DRZO/2008-113.

LNV 2008b. Toegangsbeperkingsbesluit bodembeschermingsgebied Voordelta. ICES Document DRZ 2008/2213-1, 9 juni 2008.

LNV 2008c. Toegangsbeperkingsbesluit Hinderplaat, Bollen van de Ooster, Bollen van het Nieuwe Zand. ICES Document DRZ 2008-2213-2, 9 juni 2008.

LNV 2008d. Vergunning Nb-wet 1998 Maasvakte 2. ICES Document DRZW/2008-1670, 17 april 2008.

LNV 2009. Wijzigingsbesluit Natura 2000-gebieden Voordelta, Voornes Duin en Duinen Goeree \& Kwade Hoek. ICES Document Programmadirectie Natura 2000, PDN2009-100.

Perdon, K. J., Troost, K., Asch, v. M., and Jol, J. 2016. WOT schelpdiermonitoring in de Nederlandse kustzone in 2016. ICES Document Wageningen Marine Research report C093/16. 34 pp. 
Perdon, K. J., Troost, K., van Zwol, J., Van Asch, M., and van der Pool, J. 2018. Schelpdierbestanden in de Nederlandse kustzone in 2018. ICES Document CVO rapport: $18.010 .47 \mathrm{pp}$.

Perdon, K. J., Troost, K., van Zwol, J., Van Asch, M., and van der Pool, J. 2019. Schelpdierbestanden in de Nederlandse kustzone in 2019. ICES Document CVO rapport: $19.010 .50 \mathrm{pp}$.

Poot, M. J. M., Fijn, R. C., Boudewijn, T. J., de Jong, J., van Horssen, P. W., Japink, M., van den Boogaard, B. et al. 2014. Perceel vogels - Grote stern en visdief. In PMR monitoring natuurcompensatie Voordelta. Eindrapport 1e fase 2009-2013. Deel B, pp. 419-659. Ed. by T. Prins.

Poot, M. J. M., Heunks, C., Prinsen, H. A. M., Van Horssen, P. W., and Boudewijn, T. J. 2006. Zeevogels in de Voordelta in 2004/2005 en 2005/2006. Nulmeting in het kader van Monitoring en Evaluatie Programma, Project Mainport Rotterdam - MEP MV2 (Perceel 4: Vogels). ICES Document Rapport nr. 06-244. $184 \mathrm{pp}$

Poot, M. J. M., Heunks, C., Van Horssen, P. W., Prinsen, H. A. M., and Boudewijn, T. J. 2005. Evaluatierapportage: november 2004 t/m juni 2005, Perceel 4: Vogels, Nulmeting in kader van Monitoring en Evaluatie Programma, Project Mainport Rotterdam - MEP MV2. ICES Document Rapport 05-170. $184 \mathrm{pp}$.

Prins, T. C., Boon, A. R., and Escaravage, V. 2016. Indicatoren voor de kwaliteit van habitat type H1110 in PMR Natuurcompensatie Voordelta. ICES Document 1209129-000-ZKS-0031. 49 pp.

Prins, T. C., Van der Kolff, G. H., Boon, A. R., Hendriksen, G., Holzhauer, H., Kuijper, C., Langenberg, V. T., et al. 2013. PMR Monitoring natuurcompensatie Voordelta. Jaarrapport 2012 Deel A. ICES Document rapport 1200672-000-ZKS-0039. 124 pp.

Prins, T. C., Van der Kolff, G. H., Boon, A. R., Reinders, J., Kuijper, C., Hendriksen, G., Holzhauer, H., et al. 2014. PMR Monitoring natuurcompensatie Voordelta. Eindrapportage $1^{\mathrm{e}}$ fase 2009-2013. ICES Document Rapport nr 1200672-000-ZKS-0042. 207 pp.

Reiss, H., Meybohm, K., and Kröncke, I. 2006. Cold winter effects on benthic macrofauna communities in nearand offshore regions of the North Sea. Helgoland Marine Research, 60: 224-238.

Rijnsdorp, A. D., Bastardie, F., Bolam, S. G., Buhl-Mortensen, L., Eigaard, O. R., Hamon, K. G., Hiddink, J. G. et al. 2016. Towards a framework for the quantitative assessment of trawling impact on the seabed and benthic ecosystem. ICES Journal of Marine Science, 73: 127-138.

Rijnsdorp, A. D., Bolam, S. G., Garcia, C., Hiddink, J. G., Hintzen, N. T., van Denderen, P. D., and van Kooten, T. 2018. Estimating sensitivity of seabed habitats to disturbance by bottom trawling based on the longevity of benthic fauna. Ecological Applications, 28: 1302-1312.

Rijnsdorp, A. D., Van Stralen, M., Baars, D., Van Hal, R., Jansen, H., Leopold, M. F., Schippers, P., et al. 2006. Rapport Inpassing Visserijactiviteiten Compensatiegebied MV2. ICES Document Rapport C047/06. 123 pp.

RIKZ 2007. Natuurcompensatie Maasvlakte Twee in de Voordelta; De inzet van kennis over de ecologie en morfologie van de Voordelta om het maatregelenpakket ter compensatie van de natuureffecten van de Tweede Maasvlakte te verantwoorden. ICES Document Rapport RIKZ/2007.006. 301 pp.

RWS 2014. Evaluatie MEP Natuurcompensatie Voordelta (NCV) 2013. ICES Document Versienummer 7.0, juni 2014. 96 + VII pp.

RWS 2016. Beheerplan Natura 2000 Voordelta 2015-2021. ICES Document februari 2016. 154 pp.

Schellekens, T., Escaravage, V., Goudswaard, K., Van Asch, M., and Craeymeersch, J. 2014. Garnalenvisserij experiment Voordelta. ICES Document Rapport C154/14. 88 pp.

Schwarz, C. 2013. Sampling, Regression, Experimental Design and Analysis for Environmental Scientists, Biologists, and Resource Managers. $1106 \mathrm{pp}$.

Schwemmer, P., Mendel, B., Sonntag, N., Dierschke, V., and Garthe, S. 2011. Effects of ship traffic on seabirds in offshore waters: implications for marine conservation and spatial planning. Ecological Applications, 21: $1851-1860$.

Schwemmer, P., Volmer, H., Enners, L., Reimers, H.-C., Binder, K., Horn, S., Adler, S., et al. 2019. Modelling distribution of common scoter (Melanitta nigra) by its predominant prey, the American razor clam (Ensis leei) and hydrodynamic parameters. Estuarine, Coastal and Shelf Science, 225: 106260.

Seegers, H. C. M., Hoogvliet, M. C., and Dam, L. A. 2006. Nulmeting Gebruiksfuncties Voordelta, eindrapportage. ICES Document Rapport 04.W029.00/2. $96 \mathrm{pp}$

Seegers, H. C. M., Van Calsteren-De Bruijn, L. M., and Schuur, J. 2014. Perceel Gebruik. In PMR Monitoring natuurcompensatie Voordelta. Eindrapportage $1^{\mathrm{e}}$ fase 2009-2013 deel B, pp. 893-940. Ed. by T. C. Prins, and G. H. Van der Kolff. Deltares, Delft.

Seys, J. 2001. Sea- and coastal bird data as tools in the policy and management of Belgian marine waters In Faculteit Wetenschappen p. 133 + LXIX. Gent, Gent.

Skov, H., Durinck, J., Erichsen, A., Kloster, R. M., Møhlenberg, F., and Leonhard, S. B. 2008. Horns Rev II Offshore Wind Farm. Food Basis for Common Scoter. Baseline Studies 2007-08. 47 pp.

Skov, H., Heinänen, S., Žydelis, R., Bellebaum, J., Bzoma, S., Dagys, M., Durinck, J., et al. 2011. Waterbird populations and pressures in the Baltic Sea. ICES Document TemaNord 2011:550. 201 pp.

Steenbergen, J., and Escaravage, V. 2006. Baseline study MEP-MV2; Lot 2 bodemdieren. Eindrapportage Campagnes 2004-2005. ICES Document Rapport C053/06.

Stewart-Oaten, A. 1996. Problems in the analysis of environmental data. In Detecting ecological impacts. Concepts and applications in coastal habitats, pp. 109-131. Ed. by R. J. Schmitt, and C. W. Osenberg. Academic Press, San Diego.

Swennen, C., Leopold, M. F., and Stock, M. 1985. Notes on growth and behaviour of the American razor clamEnsis directus in the Wadden Sea and the predation on it by birds. Helgoländer Meeresuntersuchungen, 39: 255-261.

Tien, N., Hintzen, N., Verkempynck, R., Kraan, M., Trapman, B., Craeymeersch, J., and van Asch, M. 2017a. De bodemberoerende visserij in de Voordelta sinds 2004 ICES Document rapport C105/17. 106 pp. 
Tien, N. S. H., Craeymeersch, J., van Damme, C., Couperus, A. S., Adema, J., and Tulp, I. 2017b. Burrow distribution of three sandeel species relates to beam trawl fishing, sediment composition and water velocity, in Dutch coastal waters. Journal of Sea Research, 127: 194-202.

Troost, K., Perdon, K. J., van Zwol, J., Jol, J., and Van Asch, M. 2017. Schelpdierbestanden in de Nederlandse kustzone in 2017. ICES Document CVO rapport 17.014. 3 pp.

Troost, K., Van den Ende, D., Van Asch, M., and Van Stralen, M. 2019. Ontwikkeling en verspreiding van schelpdieren en andere bodemdieren in het sublitoraal van de westelijke Waddenzee in de periode 1992-2017. ICES Document Rapport C001/20 43 pp.

Tulp, I., Glorius, S., Rippen, A., Looije, D., and Craeymeersch, J. 2020. Dose-response relationship between shrimp trawl fishery and the macrobenthic fauna community in the coastal zone and Wadden Sea. Journal of Sea Research, 156: 101829.

Tulp, I., Prins, T. C., Craeymeersch, J. A. M., IJff, S., and van der Sluis, M. T., 2018. Syntheserapport PMR NCV. ICES Document WMR rapport nummer 014/18; Deltares rapport nr 1230156-000-ZKS-0004. 294 $\mathrm{pp}$.

Tulp, I. Y. M., Prins, T. C., Tien, N. S. H., Craeymeersch, J. A. M., and Van der Sluis, M. T. 2015. Monitoringsen onderzoeksplan vervolg monitoring PMR-NCV. ICES Document Rapport nr C135a/15. 90 pp.

Tulp, I. Y. M., Van Damme, C. J. G., Quirijns, F. J., Binnendijk, E., and Borges, L. 2006. Vis in de Voordelta: nulmetingen in het kader van de aanleg van de Tweede Maasvlakte. ICES Document IMARES rapport C081/06. $108 \mathrm{pp}$.

Underwood, A. 1992. Beyond BACI: the detection of environmental impacts on populations in the real, but variable, world. Journal of Experimental Marine Biology and Ecology, 161: 145-178.

Underwood, A. 1996. On beyond BACI. Sampling designs that might reliably detect environmental disturbances. In Detecting ecological impacts. Concepts and applications in coastal habitats, pp. 151-175. Ed. by R. J. Schmitt, and C. W. Osenberg. Academic Press, San Diego.

van Aken, H. M. 2010. Meteorological forcing of long-term temperature variations of the Dutch coastal waters. Journal of Sea Research, 63: 143-151.

van de Wolfshaar, K. E., Benden, D. P. L. D., and Brinkman, A. G. 2018. Potentiële draagkracht voor de Zwarte Zee-eend van de Voordelta en de Tweede Maasvlakte. ICES Document Wageningen University \& Research Rapport C005/18. 36 pp.

van Denderen, P. D., Hintzen, N. T., Rijnsdorp, A. D., Ruardij, P., and van Kooten, T. 2014. Habitat-Specific Effects of Fishing Disturbance on Benthic Species Richness in Marine Soft Sediments. Ecosystems, 17: 1216-1226.

Van Denderen, P. D., Van Kooten, T., and Rijnsdorp, A. D. 2013. When does fishing lead to more fish? Community consequences of bottom trawl fisheries in demersal food webs. Proceedings of the Royal Society of London, Series B., 280: 20131883.

van der Meer, J., Dankers, N., Ens, B. J., van Stralen, M., Troost, K., and Waser, A. M. 2019. The Birth, Growth and Death of Intertidal Soft-Sediment Bivalve Beds: No Need for Large-Scale Restoration Programs in the Dutch Wadden Sea. Ecosystems, 22: 1024-1034.

van der Spek, A. J. F., and Elias, E. P. L. 2019. Half a century of morphological change in the Haringvliet and Grevelingen ebb-tidal deltas (SW Netherlands) - Impacts of large-scale engineering 1964-2015. Marine Geology, submitted.

van der Zee, E., Van Horssen, P. W., de Jong, R., and Dirksen, S. 2018. PMR NCV monitoring zwarte zeeeenden Voordelta. Jaarrapport 2017-2018. ICES Document A\&W-rapport 2512. 35 pp.

van der Zee, E., van Horssen, P. W., Poot, M., and de Jong, R. 2019. PMR NCV monitoring zwarte zee-eenden Voordelta. Jaarrapport 2018-2019. ICES Document A\&W-rapport 2526zze.5. 28 pp.

Van Hoey, G., Vincx, M., and Degraer, S. 2007. Temporal variability in the Abra alba community determined by global and local events. Journal of Sea Research, 58: 144-155.

Van Horssen, P., Van der Zee, E., and Poot, M. 2020. PMR NCV monitoring zwarte zee-eenden in de Voordelta. Verstoringsanalyse T1-T2. ICES Document A\&W-rapport 2528.20.

van Moorsel, G., van Horssen, P., Poot, M., and Soldaat, L. 2020. Ruimtelijke analyse en trends benthos Voordelta.

Van Oostveen, M., and Koolmees, E. 2013. Evaluatie Natura-2000 beheerplan Voordelta 2008-2014. ICES Document RD-EW 20130824, december 2013. 127 + bijlagen pp.

van Roomen, M., Arts, F., van Kleunen, A., van Winden, E., Roodbergen, M., and Schekkerman, H. 2020. Status en trends van watervogels in het open water van de Voordelta. ICES Document In prep.

VenW 2008. Beheerplan Voordelta. Spelregels voor natuurbescherming. $146 \mathrm{pp}$.

VenW 2009. Monitoring- en Evaluatieprogramma Maasvlakte 2. Natuurcompensatie Voordelta.

Wetlands International 2016. Waterbird Population Estimates. ICES Document 13 Dec 2016.

Wijnhoven, S., Duineveld, G., Lavaleye, M., Craeymeersch, J., Troost, K., and van Asch, M. 2013. Kaderrichtlijn Marien indicatoren Noordzee. Naar een uitgebalanceerde selectie van indicator soorten ter evaluatie van habitats en gebieden en scenario's hoe die te monitoren.

Williams, C., Dugger, B., Brasher, M., Coluccy, J., Cramer, D., Eadie, J., Gray, M., et al. 2014. Estimating habitat carrying capacity for migrating and wintering waterfowl: Considerations, pitfalls and improvements. Wildfowl, 4: 407-435.

Witbaard, R., Bergman, M. J. N., van Weerlee, E., and Duineveld, G. C. A. 2017. An estimation of the effects of Ensis directus on the transport and burial of silt in the near-shore Dutch coastal zone of the North Sea. Journal of Sea Research, 127: 95-104.

Witbaard, R., Duineveld, G. C. A., Bergman, M. J. N., Witte, H. I. J., Groot, L., and Rozemeijer, M. J. C. 2015. The growth and dynamics of Ensis directus in the near-shore Dutch coastal zone of the North Sea. Journal of Sea Research, 95: 95-105.

Wolff, W. J. 1973. The estuary as a habitat. An analysis of data on the soft-bottom macrofauna of the estuarine area of the rivers Rhine, Meuse, and Scheldt. Zoölogische Verhandelingen, 126: 1-242. 
Zuur, A. F., Van Horssen, P. W., Ieno, E. N., Saveliev, A. A., and Poot, M. J. M. 2014. Zero-inflated and spatial correlated Common Scoter data. In A Beginner's Guide to Generalized Additive Mixed Models with R, pp. 285-318. Ed. by A. F. Zuur, A. A. Saveliev, and E. N. Ieno. Highland Statistics Ltd., Newburgh, UK. 


\section{Kwaliteitsborging}

Wageningen Marine Research beschikt over een ISO 9001:2015 gecertificeerd kwaliteitsmanagementsysteem. Dit certificaat is geldig tot 15 december 2021. De organisatie is gecertificeerd sinds 27 februari 2001. De certificering is uitgevoerd door DNV GL.

Het chemisch laboratorium te IJmuiden beschikt over een EN-ISO/IEC 17025:2017 accreditatie voor testlaboratoria met nummer L097. Deze accreditatie is geldig tot 1 april 2021 en is voor het eerst verleend op 27 maart 1997; deze accreditatie is verleend door de Raad voor Accreditatie. Het chemisch laboratorium heeft hierdoor aangetoond in staat te zijn op technisch bekwame wijze valide resultaten te leveren en te werken volgens de ISO17025 norm. De scope (L097) met de geaccrediteerde analysemethoden is te vinden op de website van de Raad voor Accreditatie (www.rva.nl).

Op grond van deze accreditatie is het kwaliteitskenmerk $\mathrm{Q}$ toegekend aan de resultaten van die componenten die op de scope staan vermeld, mits aan alle kwaliteitseisen is voldaan. Het kwaliteitskenmerk $Q$ staat vermeld in de tabellen met de onderzoeksresultaten. Indien het kwaliteitskenmerk $\mathrm{Q}$ niet staat vermeld is de reden hiervan vermeld.

De kwaliteit van de analysemethoden wordt op verschillende manieren gewaarborgd. De juistheid van de analysemethoden wordt regelmatig getoetst door deelname aan ringonderzoeken waaronder die georganiseerd door QUASIMEME. Indien geen ringonderzoek voorhanden is, wordt een tweede lijnscontrole uitgevoerd. Tevens wordt bij iedere meetserie een eerstelijnscontrole uitgevoerd.

Naast de lijnscontroles wordende volgende algemene kwaliteitscontroles uitgevoerd:

- Blanco onderzoek.

- Terugvinding (recovery).

- Interne standaard voor borging opwerkmethode.

- Injectie standard.

- Gevoeligheid.

Bovenstaande controles staan beschreven in Wageningen Marine Research werkvoorschrift ISW 2.10.2.105.

Indien gewenst kunnen gegevens met betrekking tot de prestatiekenmerken van de analysemethoden bij het chemisch laboratorium worden opgevraagd.

Indien sprake is van onbeheerste kwaliteit worden passende maatregelen genomen. 


\section{Verantwoording}

Rapport

Projectnummer:
WMR: C053/20

WMR: 4316100065
Deltares: 1230156-001-ZKS-0001

Deltares: 1230156

Dit rapport is met grote zorgvuldigheid tot stand gekomen. De wetenschappelijke kwaliteit is intern getoetst door een collega-onderzoeker van WMR en van Deltares en het verantwoordelijk lid van het managementteam van Wageningen Marine Research.

Akkoord:

Dr Ingrid Tulp

Handtekening: $\operatorname{Sighed~}_{16 \text { juni } 2020}^{\text {Senior Onderzoeker WMR }}$

Akkoord: $\quad$ Dr Luca van Duren

Handtekening:

Datum:

\section{Senior]Onderzoeker DELTARES}

Akkoord:

Dr Tammo Bult

Handtekening:

Datum:

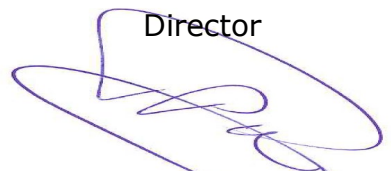

16 juni 2020 


\section{Bijlage 1 Begrippenlijst}

AIS: Automatic Identification System. Het automatisch identificatiesysteem is een autonoom en permanent vaartuigidentificatie- en volgsysteem voor de veiligheid op zee. Vaartuigen kunnen hiermee elektronisch met andere vaartuigen in de buurt en met de autoriteiten aan wal hun identificatiegegevens, positie, koers en snelheid uitwisselen. Alle visserijvaartuigen uit de EU groter dan $15 \mathrm{~m}$ moeten met AIS-apparatuur worden uitgerust. De EU-landen mogen AISgegevens gebruiken om schepen te volgen en te controleren. Met AIS wordt o.a. de positie van schepen met hoge frequentie vastgelegd. Het systeem is gefaseerd ingevoerd, pas in de jaren 2011-2014 is gestart met de invoering van AIS-plicht voor vissersschepen <15 meter, vóór die tijd waren alleen koopvaardijschepen en grotere vissersschepen verplicht uitgerust met AIS (Hintzen et al., 2014). Kleinere schepen (o.a. recreatievaart) hebben vaak geen AIS.

BACI (Before-After-Control-Impact) analyse: (Green, 1979). Het ecologische effect van een ingreep in een gebied wordt bepaald door metingen voor en na de ingreep uit te voeren (Before-After), en een vergelijking te maken met referentiegebieden waar de ingreep niet plaats vindt (ControlImpact). Op deze wijze kunnen de effecten van 'autonome' ontwikkelingen worden onderscheiden van de effecten van de ingreep (Green, 1979; Underwood, 1992; Underwood, 1996).

BBG: Bodembeschermingsgebied

Boomkorvisserij: op platvis gerichte boomkorvisserij met wekkerkettingen, door Eurokotters met een motorvermogen 260-300 pk, te beschrijven. De schepen trekken twee sleepnetten over de zeebodem waarbij de doelsoorten bestaan uit platvis. De netten worden opengehouden door een stalen balk, de boom. Aan de uiteinden van deze boom zitten zware stalen glijders (sloffen, een soort sleeën) die over de zeebodem glijden. Aan deze glijders zijn meerdere rijen kettingen (wekkerkettingen) bevestigd, die over de grond slepen en zo de platvis uit het zand op laten schrikken. De boomkor en kettingen zijn gemiddeld 4,5 meter breed. Een schip trekt zodoende in totaal 9-meter-breed tuig voort. De glijders en wekkerkettingen veroorzaken bodemberoering.

Broedparen: mannetjes- en vrouwtjesvogel die samen broeden

Broedsucces: het aantal vliegvlugge jongen dat per paar wordt geproduceerd

DFS: Demersal Fish Survey

Ebschild: de ondiepe drempel aan het einde van een ebgeul. Een ebgeul wordt per definitie ondieper in de richting van de zee. Als de met zand beladen stroming in dieper water komt en zijn stroomsnelheid verliest, wordt het zand afgezet, waardoor er een ondiepte ontstaat. Deze ondiepte is vaak hoefijzervormig.

Garnalenvisserij: op garnalen gerichte visserij door kotters met een motorvermogen $<300$ pk, uitgerust met garnalen(boom)korren van $9 \mathrm{~m}$ breed. Net als bij de gewone boomkor wordt aan iedere kant van het schip een net voortgesleept over de bodem. Garnalenkorren zijn lichter in gewicht dan boomkorren, en zijn niet voorzien van wekkerkettingen, maar van klossenpezen die over de bodem rollen. Hierdoor is de bodemberoering minder groot dan bij boomkorren. Doelsoort is garnaal en er wordt weinig grote vis bijgevangen $(\sim 7 \%)$, door een verplichte zeeflap die vissen groter dan ca $10 \mathrm{~cm}$ weert.

Hellmann getal: Het koudegetal, ook wel aangeduid als het Hellmanngetal $(\mathrm{H})$ naar de Duitse meteoroloog Gustav Hellmann, is een maat voor de koude in het tijdvak van 1 november van het voorafgaande jaar tot en met 31 maart van het genoemde jaar. Het wordt verkregen door over dit 
tijdvak alle etmaalgemiddelde temperaturen beneden het vriespunt te sommeren met weglating van het minteken.

Kortsluitgeul: de ondiepste vorm van een geul. Een kortsluitgeul vormt de verbinding tussen de ebschaar en de vloedschaar. Een ebschaar of ebgeul zorgt ervoor dat bij eb het water weer terug uit het binnenland stroomt. De stroom in deze ebschaar wordt de ebstroom genoemd. Een Vloedschaar of vloedgeul is een getijgeul die open ligt voor de vloed en aan de bovenzijde een drempel heeft.

Kriging: geostatistische techniek die de interpolatieschatting optimaliseert op basis van de ruimtelijke variantiestructuur van de dataset. Die laatste wordt uitgedrukt in een zogenaamd variogram, een plot die aangeeft hoe de verschillen tussen warnemingen toenemen met de afstand tussen de waarnemingspunten. Na fitting van een theoretisch model op het variogram kan de beste interpolatie met kriging worden gevonden.

MEP-NCV: Monitorings- en Evaluatie Programma Natuurcompensatie Voordelta

MV2: Maasvlakte 2

MWTL programma: Voor het programma Monitoring Waterstaatkundige Toestand des Lands (MWTL) zijn in de zoete en zoute Nederlandse rijkswateren een morfologisch, waterkwantiteit, chemisch, biologisch (inclusief zwemwater) en een afval meetnet ingericht. De data van het MWTLmonitoringprogramma worden gebruikt voor operationeel waterbeheer, bepalen trends, toetsing aan normen en het leveren van nationale en internationale rapportages.

PMR-NCV: Project Mainportontwikkeling Rotterdam - Natuurcompensatie Voordelta

REF: Referentie Gebied

Rustgebieden : Voor de zwarte zee-eend, grote stern en visdief zijn rustgebieden ingesteld: de Hinderplaat (grote stern en visdief), de Bollen van de Ooster (grote stern en zwarte zee-eend) en Bollen van het Nieuwe Zand (zwarte zee-eend). In 2013 is op basis van tussentijdse resultaten geconcludeerd dat de zwarte zee-eenden in de Voordelta zich voornamelijk buiten de rustgebieden Bollen van de Ooster en Bollen van het Nieuwe Zand bevonden (van Oostveen \& Koolmees 2013). In 2016 zijn de begrenzingen van de rustgebieden voor de zwarte zee-eend (Bollen van de Ooster en Bollen van het Nieuwe Zand) daarom ruimer gemaakt en is de periode van sluiting van het gebied aangepast. Door een gerechtelijke uitspraak eind 2018 is deze maatregel echter weer teruggedraaid.

Schelpdiervisserij: Visserij waarbij met behulp van zuigkorren strandschelpen (Spisula) en zwaardschedes (Ensis) uit de bodem worden gezogen.

Soorten naamgeving: ten behoeve van de leesbaarheid is een verschillende werkwijze gehanteerd voor bodemdieren, vissen en vogels. Voor vissen en vogels worden de Nederlandse namen gebruikt. Voor bodemdieren wordt de wetenschappelijke naam (volledig of verkort) gebruikt, omdat niet voor alle soorten bodemdieren Nederlandse namen bestaan of algemeen bekend zijn. In voorkomende gevallen, waar het algemene soorten betreft, wordt soms ook de Nederlandse naam gebruikt. De wetenschappelijke naamgeving is aan verandering onderhevig. De naamgeving in dit rapport is gebaseerd op de stand van zaken van maart 2020 in het World Register of Marine Species en voor de Nederlandse namen op het Soortenregister. De wetenschappelijke naam van de Amerikaanse zwaardschede is recent gewijzigd van Ensis directus in Ensis leei. In eerdere rapportages is nog de naam Ensis directus gebruikt.

Strandhaken: zandbanken die aan de kust vastgroeien

T0: nulmetingen (2004-2007) in de periode vóór aanleg MV2 
T1: eerste periode monitoring en onderzoek PMR-NCV 2009-2015

T2: tweede periode monitoring en onderzoek PMR-NCV 2016-2018

VMS: Vessel Monitoring System. Het VMS is een systeem op basis van satelliettechnologie om visserijvaartuigen te volgen en de visserijautoriteiten regelmatig te informeren over de locatie, koers en snelheid van die vaartuigen. Het is verplicht voor EU-vaartuigen van meer dan $15 \mathrm{~m}$ (en vanaf 1 januari 2012 voor vaartuigen van meer dan $12 \mathrm{~m}$ ).

Vogeldagen : Vogeldagen zijn een veelgebruikte maat om gebruik van een gebied door vogels te kwantificeren. Elke dag dat één vogel in een gebied verblijft, telt als één vogeldag dus aantal vogel dagen is aantal getelde vogels vermenigvuldigd met het aantal dagen dat ze in het gebied verblijven. 


\section{Bijlage 2 Kenmerken van de kwaliteit van habitattype H1110B}

Habitattype $\mathrm{H} 1110$ is in de Habitatrichtlijn omschreven als "Permanent met zeewater van geringe diepte overstroomde zandbanken". Zandbanken van dit type komen wijd verspreid voor langs de Europese zandige kusten, maar de combinatie van de abiotische en biotische kwaliteiten in Nederlandse wateren komt slechts op weinig andere plaatsen op deze schaal voor (EZ, 2014b). Binnen habitattype H1110 worden door Nederland drie subtypen onderscheiden, op basis van verschillen in ecotopen, abiotische randvoorwaarden, soortensamenstelling en de structuur en functie van het habitattype. Het habitattype waarvoor de compensatieopgave geldt, is H1110B:

- Subtype H1110B Permanent overstroomde zandbanken (Noordzee-kustzone) betreft het grootste deel van de Voordelta (ruim 87.000 ha) en komt verder langs de gehele Nederlandse Noordzeekust voor. Dit subtype wordt getypeerd door het feit dat golfwerking belangrijker is dan getijwerking, met een (matig) grofzandig sediment.

Het gehele complex van mariene ecotopen zoals permanent overstroomde zandbanken, tussenliggende laagten en geulen (die in beperkte mate dieper kunnen zijn dan 20 meter), harde structuren, schelpenbanken en de waterkolom erboven wordt gerekend tot het habitattype H1110. De kwaliteit van habitattype H1110 wordt omschreven in het profieldocument (EZ, 2014b) aan de hand van drie aspecten, namelijk:

- $\quad$ typische soorten

- $\quad$ abiotische kenmerken

- $\quad$ overige kenmerken van een goede structuur en functie

\section{Typische soorten}

Voor ieder subtype van habitattype $\mathrm{H} 1110$ is een aantal typische soorten bodemdieren en vis geselecteerd. De typische soorten vormen gezamenlijk een indicator voor de (compleetheid van de) levensgemeenschap, en de set van typische soorten moet als geheel worden gebruikt bij het beoordelen van de staat van instandhouding van het aspect kwaliteit (EZ, 2014a). Voor H1110B zijn alleen zgn. constante soorten gebruikt, dit zijn soorten die bij een goede kwaliteit in het habitattype voorkomen, maar ook in andere habitattypen kunnen voorkomen. De reden hiervoor is het vrijwel ontbreken van exclusieve en karakteristieke soorten (soorten waarvan de ecologische vereisten alleen, respectievelijk vooral voorkomen in het betreffende habitattype).

De lijst van typische soorten bestaat uit soorten die kenmerkend worden geacht voor de dynamische banken en geulen in de kustzone, waarbij een pragmatische keuze is gemaakt voor soorten die al min of meer regulier worden gemeten. De soorten moeten indicatief zijn voor een goede abiotische toestand en/of een goede biotische structuur. Het geheel van de soorten moet de mogelijkheid bieden het habitattype adequaat te beoordelen. Een belangrijke kanttekening met betrekking tot bodemdieren is, dat het Nederlandse beleid is om geen exoten (niet-inheemse soorten geïntroduceerd na 1900) in de lijst op te nemen. Dit betreft onder meer de Amerikaanse zwaardschede (Ensis leei) die zowel in de Voordelta als elders in de Nederlandse kustzone de biomassa van bodemdieren domineert (Troost et al., 2017). Alle typische soorten bodemdieren zijn waargenomen in de monitoring van PMR-NCV, gemiddeld vormen deze soorten ongeveer $40 \%$ van de totale abundantie en $50 \%$ van de totale biomassa in de Voordelta (Prins et al., 2016). Van de typische vissoorten op de lijst wordt schol zeer algemeen gevangen bij bemonsteringen in de Voordelta, een aantal andere soorten (kleine pieterman, slakdolf, zeedonderpad, 
vijfdradige meun) wordt weinig ( $<30 \%$ van de trekken) of zeer weinig (vijfdradige meun; $<10 \%$ van de trekken) gevangen. Een aantal soorten dat in veel vistrekken is aangetroffen komt niet voor in de lijst van typische soorten: rode poon, grondel, schar, bot, dwergtong, zandspiering (Prins et al., 2016).

De typische soorten zijn een kwaliteitsindicator voor de (compleetheid van de) levensgemeenschap. Daarbij geldt dat de beoordeling van de kwaliteit niet gebaseerd wordt op de individuele soorten, maar dat daarbij de gehele set van typische soorten wordt gebruikt. Voor H1110B is een pragmatische selectie gemaakt van soorten die regulier worden gemeten, en zijn exoten niet geselecteerd. Het gevolg is dat de lijst bestaat uit een aantal algemene soorten bodemdieren en vissen. Er zijn slechts enkele soorten in de lijst van typische soorten waarvan verwacht kan worden dat deze gevoelig zijn voor bodemberoering, op basis van kenmerken als langlevendheid, lage groeisnelheid of het vormen van biogene structuren. De set van typische soorten is vanwege het ontbreken van een duidelijke relatie met bodemberoering niet geschikt om de verbetering van de kwaliteit van $\mathrm{H} 1110 \mathrm{~B}$ in de Voordelta als gevolg van de compensatiemaatregel (uitsluiten boomkorvisserij) te beschrijven (Prins et al., 2016).

\section{Abiotische kenmerken}

De abiotische kenmerken geven de condities van het abiotische milieu (voedselrijkdom, zoutgehalte, dynamiek door golven en stroming, helderheid) en worden in de profielbeschrijving als een gegeven beschouwd (EZ, 2014a). Die condities kunnen deels beïnvloed worden door menselijk handelen. Daarbij kan voor de Voordelta gedacht worden aan ingrepen die van invloed zijn op de nutriëntenbelasting en zoetwaterafvoer van dit gebied en ingrepen die de morfologie beïnvloeden.

De compensatiemaatregel is niet van invloed op deze abiotische kenmerken, zodat deze niet gebruikt kunnen worden voor de beschrijving van de veranderingen in kwaliteit als gevolg van de compensatie.

\section{Kenmerken van een goede structuur en functie}

Dit onderdeel in de profielbeschrijving geeft een opsomming van aanvullende, kwalitatief omschreven kenmerken:

- $\quad$ Hoge productiviteit

- Natuurlijke opbouw levensgemeenschap

- De voedselfunctie van schelpdierbanken

- $\quad$ De kinderkamer-/ opgroeifunctie voor vis

Deze kenmerken passen goed bij een kustsysteem als de Voordelta, maar zijn tegelijkertijd nog te algemeen om direct een beoordeling van de kwaliteit van het habitattype mogelijk maken. Er is mogelijk wel een relatie met bodemberoerende visserij. Een aantal indicatoren, dat aansluit op de bovengenoemde biotische kenmerken, is verder uitgewerkt in het kader van PMR-NCV. Deze vormen daarmee feitelijk een operationalisering van het begrip 'kwaliteit van habitattype H1110'. Deze indicatoren zijn gebruikt omdat op theoretische gronden te verwachten was dat er mogelijk een respons is op het verdwijnen van boomkorvisserij (Prins et al., 2016).

Voor de beschrijving van de ontwikkeling van de bodemdierengemeenschap over de jaren zijn de volgende indicatoren gebruikt:

- biomassa (totaal bodemdieren)

Op basis van studies voorafgaand aan de compensatiemaatregel, werd een toename van de totale biomassa van bodemdieren verwacht in het Bodembeschermingsgebied. Dit was de primaire indicator die bij aanvang van het monitoringprogramma gedefinieerd was.

- biomassa (prooien voor zwarte zee-eend)

De biomassa van prooien van zwarte zee-eend (selectie van schelpdiersoorten) neemt mogelijk eveneens toe in het Bodembeschermingsgebied.

- aantal soorten 
De verwachting was dat het aantal soorten toeneemt door terugkeer van visserij-gevoelige soorten.

- $\quad$ aandeel grote soorten

De verwachting was dat het aandeel grote soorten toeneemt door verminderde sterfte van grote en langlevende soorten.

- $\quad$ gemiddeld individueel gewicht

De verwachting was dat het gemiddeld individueel gewicht toeneemt door verminderde sterfte van bodemdieren.

- $\quad$ lengte schelpdieren

De verwachting was dat de maximale lengte van schelpdieren toeneemt door verminderde sterfte van schelpdieren.

- $\quad$ verdeling aantallen/biomassa over biologische eigenschappen (Trait Based Approach)

De verwachting was dat het aandeel van soorten/soortsgroepen met biologische eigenschappen die gevoeliger zijn voor bodemberoerende visserij zou toenemen.

Ook voor de beschrijving van de visgemeenschap zijn indicatoren voorgesteld:

- $\quad$ dichtheden van soorten/ecologische groepen

De verwachting was dat dichtheden toenemen van demersale, residente en marien juveniele soorten en bodemdier-etende soorten, door verminderde sterfte en groter voedselaanbod.

- $\quad$ verandering in vis/epibenthos gemeenschap

De verwachting was dat de soortensamenstelling van de vis- en epibenthos gemeenschap verandert door verminderde sterfte van visserij-gevoelige soorten.

- $\quad$ verandering in prooikeuze

De verwachting was dat het dieet van bodemdier-etende vis verandert door veranderd voedselaanbod.

- $\quad$ leeftijdsopbouw visgemeenschap

De verwachting was dat leeftijdsopbouw van soorten die hun hele leven in het gebied blijven (residente soorten) verandert, met een toename van de oudere leeftijdsgroepen, door een verminderde sterfte.

- $\quad$ gemiddelde vislengte (voor residente soorten; per soort)

De verwachting was dat de verminderde sterfte zal leiden tot een toename van de gemiddelde vislengte voor soorten die hun hele leven in het gebied blijven. Dit wordt niet verwacht voor kinderkamersoorten, die de Voordelta voornamelijk voor de juveniele stadia gebruiken.

- $\quad$ conditie afgeleid uit lengte-gewicht relatie, lengte bij een bepaalde leeftijd, groeisnelheid van jonge levensfasen ( 0 - en 1 -jarigen)

Verbetering van de voedselsituatie door vermindering van de boomkorvisserij kan leiden tot betere conditie en/of groei, wat zichtbaar wordt in lengte-gewicht relaties, lengte bij een bepaalde leeftijd, en groei van levensfasen ( 0 - en 1 -jarigen) waarvan vermoed wordt dat ze niet erg mobiel zijn. 


\section{Bijlage 3 Materiaal en Methoden Benthos en Vis}

\section{Bemonstering en analyse bodemfauna}

De bodemfauna is bemonsterd met een boxcorer en een schaaf. In 2007 zijn alleen boxcores genomen. Deze data zijn in de analyses verder buiten beschouwing gelaten, omdat ze methodologisch verschillen van alle andere jaren.

Een cilindervormige boxcorer met een oppervlakte van $0,078 \mathrm{~m}^{2}$ en een diepte van minimaal $20 \mathrm{~cm}$ is gebruikt. De kwaliteit van het monster (diepte, goede sluiting van de boxcorer) is gecontroleerd nadat het monster aan boord was gehesen. Bij niet voldoen aan de minimale eisen is het monster overgedaan. Het boxcore monster is aan boord op een zeef met circulaire mazen van $1 \mathrm{~mm}$ gebracht en gezeefd. Het zeefresidu is gefixeerd in $\mathrm{pH}$-geneutraliseerde formaldehyde (4\%). In het laboratorium is het monster gekleurd met Bengaals roze, en op een zeef van 0,5 mm gebracht. Alle dieren zijn uitgezocht en waar mogelijk op soort gedetermineerd. Soortsdeterminatie heeft niet plaatsgevonden voor Oligochaeta, Actiniaria en Nemertea, die als groep op dit niveau zijn aangemerkt. Beschadigde of te kleine individuen zijn soms op een hoger taxonomisch niveau (genus, familie, orde) geïdentificeerd, omdat determinatie niet mogelijk was. Asvrij drooggewicht (ADW) is bepaald met één van de volgende methoden, in volgorde van voorkeur: (1) uit een lengte-asvrij drooggewicht regressie die voor iedere soort en monstercampagne is opgesteld, (2) door converteren van natgewicht naar drooggewicht, op basis van een ratio bepaald voor iedere soort en monstercampagne (3) door converteren van natgewicht naar drooggewicht op basis van een ratio voor de soort (4) door direct bepalen van het asvrij drooggewicht, of door (5) het toekennen van een soortsspecifiek drooggewicht. Methode (1) is gebruikt voor alle soorten schelpdieren, en methode (2) voor alle andere soorten waarvan per campagne voldoende individuen voorkwamen; deze methoden zijn daardoor voor de meeste individuen van toepassing geweest. Alle primaire data van dichtheid en biomassa zijn, per soort, uitgedrukt per $\mathrm{m}^{2}$.

Schaafmonsters zijn genomen over een afstand van ongeveer $150 \mathrm{~m}$ met een bodemschaaf die het sediment bemonstert tot een diepte van $7 \mathrm{~cm}$ over een breedte van $10 \mathrm{~cm}$. Het sediment wordt in de schaaf gezeefd over een maas van $5 \mathrm{~mm}$. Een wiel, dat meeloopt tijdens de bemonstering, meet de exacte afstand van de trek. De bemonsterde oppervlakte wordt hieruit berekend. Uit het materiaal dat aan boord komt worden de schelpdieren, stekelhuidigen en vissen geteld en op soort gebracht. Het totale versgewicht (inclusief schelpen) wordt per soort en per trek bepaald, waarbij sommige soorten in grootte- of leeftijdsklassen worden opgedeeld aan boord. Alle materiaal wordt ingevroren, waarna in het lab individuele lengte- of breedtemetingen kunnen worden uitgevoerd. De resultaten geven per soort een waarde voor dichtheid en biomassa van de verschillende grootteklassen. Het versgewicht werd naar drooggewicht geconverteerd aan de hand van soortsspecifieke conversiefactoren. In de loop der jaren zijn kleine aanpassingen en verbeteringen in de schaaf aangebracht, in samenwerking met Havenbedrijf Rotterdam. Details daarover worden vermeld in Prins et al. (2014). Er is bij de data-analyse geen rekening gehouden met deze kleine verschillen, die geen merkbaar effect hebben gehad op de resultaten. 


\section{Tijdvakken}

De bemonstering valt uiteen in drie perioden. De T0 periode omvat de jaren vanaf 2004 tot de instelling van het bodembeschermingsbesluit in 2008. In deze periode was Maasvlakte 2 nog niet geconstrueerd en kon dus het gebied, dat later door Maasvlakte 2 is ingenomen, nog worden bemonsterd.

De periode T1 strekt zich uit van 2009 tot en met 2013. In deze periode is het bemonsteringsprogramma aangepast aan het verdwijnen van het gebied rond Maasvlakte 2. Na afloop is er een interimrapportage geweest (Prins et al., 2014), waarin de resultaten tot dan toe zijn geëvalueerd, en dat is gebruikt als basis voor een heroverweging van de bemonsteringsinspanning.

In de daarop volgende periode 2015 t/m 2018 is het werk voor de bemonstering van bodemdieren en vissen aangepast aan deze conclusies.

\section{Monsterpunten}

Voor de basisopzet van de bemonstering van bodemdieren in de T0 periode $(2004,2005,2007)$ zijn vijf deelgebieden gedefinieerd: het Landaanwinningsgebied dat later (deels) is ingenomen door Maasvlakte 2, het gebied Mond (Haringvlietmond), en de gebieden Noord, Midden en Zuid die respectievelijk zeewaarts van Goeree-Overflakkee, Schouwen-Duiveland en Walcheren liggen. Er is aan elk van deze vakken een ongeveer gelijk aantal monsters toegekend. Om die monsters gelijkmatig over de ruimte te verdelen maar toch tot op zekere hoogte toevallig te kiezen, is elk deelgebied ingedeeld in een raster met zoveel vakken als er monsters zijn genomen. Binnen elk vak is een locatie toevallig bepaald, die dan is bemonsterd. Na de initiële randomisering, zijn deze punten gedurende de rest van het programma zoveel mogelijk vastgehouden (Figuur B3.1). Het bemonsterde raster voor bodemdieren in T0 (links), T1 (midden) en T2 (rechts). Tijdens T0 is in elke rastercel één punt toevallig gekozen en met één bodemdiermonster bemonsterd. Tijdens T1 zijn de rastercellen behouden in het Bodembeschermingsgebied, maar zijn er nieuwere, kleinere en niet-gebiedsdekkende cellen gedefinieerd in het westelijke referentiegebied. Die cellen zijn met vijf monsters per rastercel bemonsterd. Tijdens T2 is de bemonstering in die cellen teruggebracht tot één monster per cel, maar zijn bijkomende monsters genomen in het Bodembeschermingsgebied (ter hoogte van de rustgebieden voor vogels). Mond is tijdens T2 niet meer bemonsterd.

Omdat de deelgebieden verschilden in oppervlakte maar een ongeveer gelijk aantal monsters hadden, is de grootte van het raster per deelgebied verschillend. Dat is meest opvallend in de Haringvlietmond, waar de rastercellen veel kleiner zijn dan in de andere gebieden. Ook in het landaanwinningsgebied lagen de monsters dichter bij elkaar dan in Noord, Midden en Zuid die onderling ongeveer (maar niet precies) gelijke rasters hadden. 


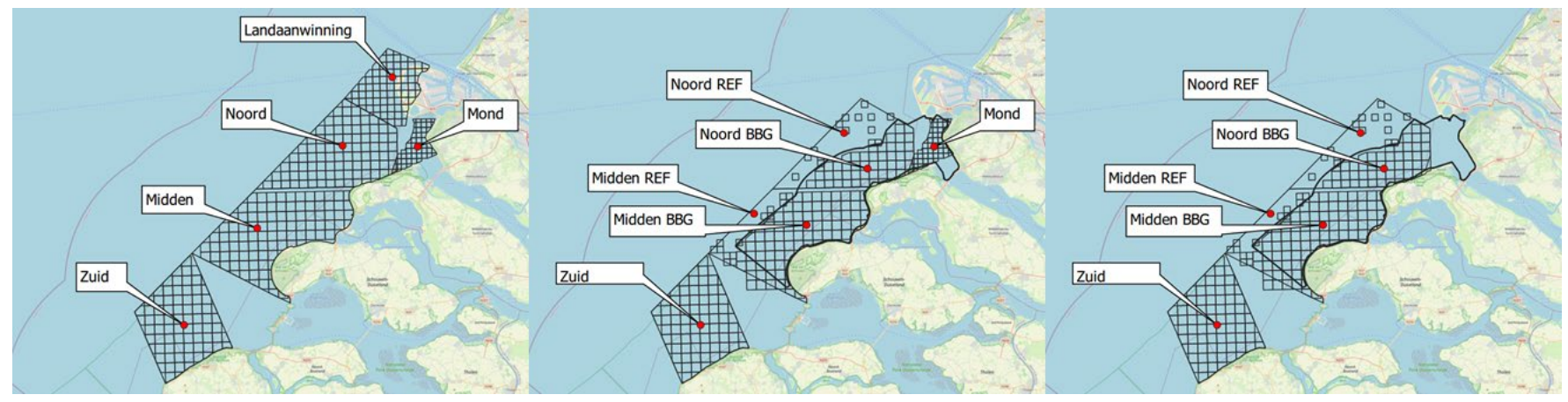

Figuur B3.1. Het bemonsterde raster voor bodemdieren in TO (links), T1 (midden) en T2 (rechts). Tijdens TO is in elke rastercel één punt toevallig gekozen en met één bodemdiermonster bemonsterd. Tijdens T1 zijn de rastercellen behouden in het Bodembeschermingsgebied, maar zijn er nieuwere, kleinere en nietgebiedsdekkende cellen gedefinieerd in het westelijke referentiegebied. Die cellen zijn met vijf monsters per rastercel bemonsterd. Tijdens $T 2$ is de bemonstering in die cellen teruggebracht tot één monster per cel, maar zijn bijkomende monsters genomen in het Bodembeschermingsgebied (ter hoogte van de rustgebieden voor vogels). Mond is tijdens T2 niet meer bemonsterd.

In de loop van het programma zijn er wijzigingen geweest in het monsterprogramma. Achtergronden en details worden gegeven door Craeymeersch et al. (2014, 2016, 2019). Het Landaanwinningsgebied is niet meer bemonsterd in de periodes T1 en T2 (omdat zij deels land waren geworden). In de westelijke referentiegebieden (de delen van Midden en Noord die niet tot het Bodembeschermingsgebied zijn gaan behoren) zijn de oorspronkelijke rastercellen vervallen. Er is een nieuw raster gedefinieerd met kleinere cellen. Uit dat raster is een beperkt aantal rastercellen gekozen, die representatief zijn voor verschillende intensiteiten van visserij (gebaseerd op de T0 periode). Alleen deze selectie van rastercellen is bemonsterd, met een hogere intensiteit van vijf monster per rastercel. Men verwachtte dat de boomkorvisserij geconcentreerd naar dit gebied zou uitwijken, en wilde daarom dit gebied met verhoogde intensiteit bemonsteren.

De Haringvlietmond is gedurende T1 nog bemonsterd zoals tijdens T0. Gedurende T2 is de bemonstering van de Haringvlietmond gestopt. De fauna in de Haringvlietmond is erg verschillend, meer estuarien van karakter, van de fauna in de rest van het gebied. Bovendien is de invloed van visserij op de fauna in deze zone steeds verwaarloosbaar geweest. Daardoor werd verdere bemonstering tijdens T2 niet meer opportuun geacht.

De intensieve bemonstering van de rastercellen in het westelijke referentiegebied is eveneens gestopt, omdat inmiddels duidelijk was geworden dat de zware boomkorvisserij ook in dit gebied zo goed als volledig was verdwenen. De cellen zijn wel aangehouden, maar zijn nu per cel met één enkel monster bemonsterd. Er zijn bijkomende bemonsteringen uitgevoerd in subgebieden van het BBG waar speciale rustcondities voor vogels waren ingesteld.

Een samenvattend overzicht wordt gegeven in Figuur B3.2. In de figuur zijn de punten met kleur gecodeerd afhankelijk van de periode waarin ze zijn bemonsterd. 


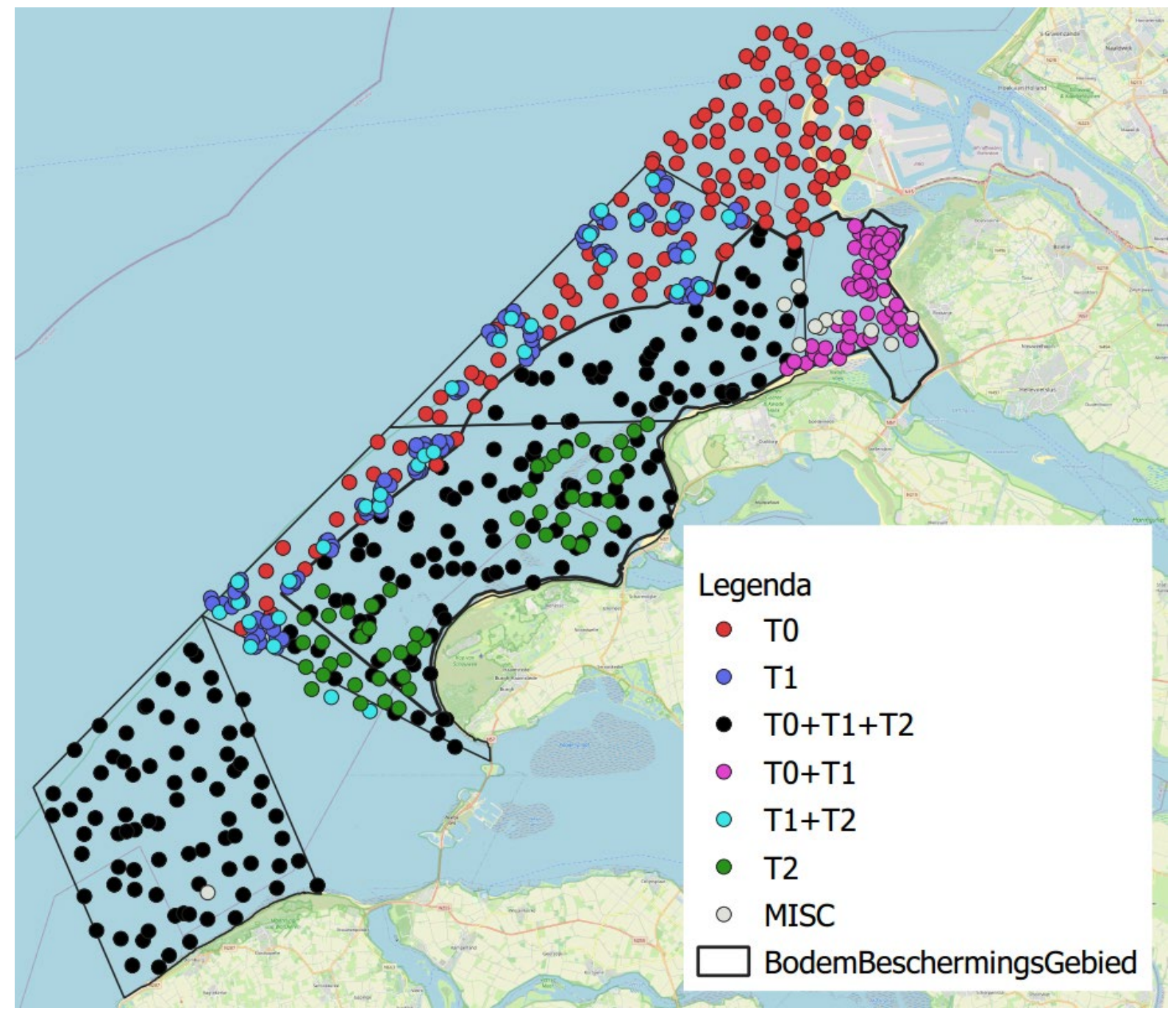

Figuur B3.22. Ligging van de monsterplaatsen en intensiteit van de bemonstering. T0: alleen bemonsterd in 2004-2005; T1: alleen bemonsterd in 2009-2013; T2: alleen bemonsterd in 2015-2018; T0+T1: bemonsterd in TO en T1; T1+T2: bemonsterd in T1 en T2; TO+T1+T2: bemonsterd in alle jaren; MISC: behorend bij één van de andere groepen, maar met missende monsters in één of meer jaren.

Om de verschillende gebieden zo gelijk mogelijk te wegen bij het uitvoeren van de BACI vergelijkingen, zijn niet alle monsters gebruikt. Door de vele additionele punten in het noordwestelijke referentiegebied tijdens T1, waarvan er maar een deel tijdens $\mathrm{T} 2$ zijn behouden, zou een te grote weging van dit gebied tijdens T1 ontstaan. Alleen de extra punten die ook tijdens T2 zijn bemonsterd, zijn gebruikt voor de analyse van T1. Dit zijn de lichtblauwe punten in Figuur B3.2, terwijl de donkerblauwe punten zijn vervallen. Merk op dat geen enkel punt dat tijdens T0 in dit referentiegebied is bemonsterd (rode punten), tijdens de latere perioden nog is bemonsterd. Om toch informatie over het referentiegebied tijdens T0 te hebben, zijn die rode punten wel meegenomen. Een zeker onevenwichtigheid in het wegen van verschillende gebieden was dus onvermijdelijk.

De groene punten in Figuur B3.2, toegevoegd om de aangepaste rustgebieden voor vogels extra te bemonsteren tijdens T2, zijn eveneens uit de analyse weggelaten omdat ze anders dit gebied te zwaar zouden wegen tijdens $\mathrm{T} 2$.

Het noordelijk gebied dat later deels door Maasvlakte 2 is bedekt, is alleen tijdens T0 bemonsterd en dus niet meegenomen in de vergelijking. De Haringvlietmond is tijdens T2 niet meer bemonsterd. De (paarse en grijze) punten in dit gebied tijdens T0 en T1 zijn ook uit de analyse weggelaten. Voor de conclusies maakt dit niet heel veel uit, omdat eerdere analyses in het syntheserapport (Tulp et al., 2018) al hadden 
aangetoond dat de Haringvlietmond een ander type fauna heeft en weinig informatie aanlevert over het effect van visserij.

Praktisch gesproken zijn de BACI analyses in dit rapport gebaseerd op de punten die binnen het studiegebied liggen (dus met uitsluiting van de punten in het gebied Maasvlakte 2 en in de Haringvlietmond) en die in Figuur B3.23 zwart, rood of lichtblauw zijn, dus niet behoren tot de klassen "T1" (extra punten tijdens T1 in het westelijke referentiegebied, donkerblauw) of "T2" (extra punten in rustgebieden, groen).

\section{Opwerking data bodemfauna}

\section{Combinatie van boxcore en schaaf}

Per monsterpunt zijn de resultaten van de boxcore en de schaaf gecombineerd, zodat één waarde voor dichtheid en biomassa per soort en monsterpunt is berekend. Voor soorten die gewoonlijk kleiner zijn dan wat efficiënt kan worden gevangen met de maaswijdte van $5 \mathrm{~mm}$ van de schaaf, is uitsluitend van de boxcore gegevens gebruikgemaakt. Voor grote lengteklassen van grotere soorten is uitsluitend de schaaf gebruikt. Voor grote soorten is gewoonlijk een mix gebruikt van beide gegevens, afhankelijk van de grootteklassen van de individuen. Het algoritme om de gecombineerde dichtheid en biomassa te berekenen is complex. Het wordt in detail uiteengezet in Craeymeersch en Escaravage (2014).

Een analyse van de verschillen tussen boxcore, schaaf en combi toonde aan dat het combineren van bodemschaaf en boxcore leidt tot een verminderde variantie in de schattingen van de biomassa. Waar de biomassaschatting uit de boxcore laag is, ligt de gecombineerde schatting gewoonlijk iets hoger. Dit zijn monsters waar grote organismen, die zeldzaam zijn, door toeval niet in de boxcore zijn bemonsterd. Het omgekeerde geldt wanneer de biomassaschatting aan de hand van de boxcore hoog is, wellicht omdat deze hoge waarden te wijten zijn aan het toevallig invangen van één of meer grote organismen. De schaaf bemonstert een veel groter oppervlak en is efficiënt voor grote organismen, waardoor de schatting minder vatbaar is voor de toevalligheid van het al dan niet invangen van een groot individu. Voor dichtheid worden weinig verschillen gevonden, omdat de gecombineerde waarden voor dichtheid vooral bepaald worden door de waarden gevonden in de boxcore. Totale dichtheden worden sterk bepaald door de dichtheid van de kleine organismen die niet in de bodemschaaf worden gevangen. Voor diversiteitsmaten is er een redelijke correlatie tussen gecombineerde waarden en waarden bepaald uit de boxcore. Diversiteit geschat uit de schaafmonsters is aanzienlijk lager en sterk variabel, omdat de schaaf een veel kleinere species pool bemonstert. Vele soorten worden immers nooit groot genoeg om vangbaar te zijn voor de schaaf. Toch zijn de ruimtelijke patronen van diversiteit, geschat uit boxcore en schaaf, duidelijk gecorreleerd. Voor aan- en afwezigheid van soorten geldt dat de schaaf de aanwezigheid van grote soorten veel betrouwbaarder vaststelt dan de boxcore, die een grote kans heeft om zeldzame grote soorten te missen. Omgekeerd kan de schaaf de aanwezigheid van kleinere soorten niet betrouwbaar vaststellen. De gecombineerde waarnemingen hebben de meest betrouwbare inschatting van aanwezigheid.

Samenvattend kan worden gesteld dat in de analyse geen aanwijzing is gevonden voor systematische bias door het combineren van schaaf en boxcore, terwijl is aangetoond dat biomassaschattingen en aanwezigheidsschattingen betrouwbaarder zijn op basis van de gecombineerde gegevens dan op basis van boxcore of schaaf alleen.

\section{Taxonomische lumping}

In de loop van het bemonsteringsprogramma is de taxonomische kennis geëvolueerd. Tegenwoordig worden in sommige genera meerdere soorten onderscheiden, terwijl dat in de vroege jaren 2000 niet het geval was. In sommige taxonomische groepen konden slechts weinig individuen op soortsniveau worden gedetermineerd en zijn de meeste gegevens voorhanden op genus- of familieniveau. Om over de tijd een consistente taxonomische basis te hebben, zijn gegevens van meerdere soorten, of gegevens van 
bijvoorbeeld genus, en de tot dat genus behorende soorten, gegroepeerd op het hogere taxonomisch niveau.

De samenvoegingen die voor dit rapport zijn gebruikt, zijn exact dezelfde als die door van Moorsel et al. (2020) in detail zijn uitgewerkt, omdat wij geen verschillen tussen de analyses als gevolg van verschillende lumping wilden laten ontstaan. Wij verwijzen naar van Moorsel et al. (2020) voor alle details.

De gehanteerde regels zijn, kort samengevat, als volgt.

- Alle naamgeving volgt het World Register of Marine Species WoRMS (www.marinespecies.org).

- Taxa op te hoog taxonomisch niveau (als extreemste voorbeeld komt één keer in de database "Animalia" voor - het is een dier, meer weten we niet), pelagische, niet-mariene of meiobenthische taxa zijn verwijderd.

- Taxa waarvan de determinatie in de loop der jaren is veranderd zijn samengevoegd op een hoger niveau (meestal genus). Taxa aangeduid met synonieme naamgeving zijn samengevoegd onder de nu geldende naam.

- Hogere taxa waarbinnen maar een enkele soort voorkomt zijn samengevoegd met de soort.

- Hogere taxa waarbinnen meerdere soorten voorkomen zijn niet gebruikt bij multivariate analyses of analyses van biodiversiteit omdat zij artificieel het aantal soorten verhogen.

- Soorten zijn samengevoegd op genusniveau wanneer de frequentie van één van de soorten zeer laag was, het niet zeker was of alle soorten in het genus goed onderscheiden zijn, of opvallende verspringingen in de tijd voorkomen die waarschijnlijk met toenemende taxonomische kennis te maken hebben.

\section{Bemonstering en analyse visfauna}

Voor de bemonstering van de visfauna zijn verschillende technieken gebruikt. In 2005 en 2007 zijn in totaal 192 trekken uitgevoerd met een zes meter brede garnalenkor in drie gebieden: het gebied waar Maasvlakte 2 is geconstrueerd, het potentiële Bodembeschermingsgebied en een zuidelijk referentiegebied. Er is toen zowel een voorjaars- als najaarsbemonstering uitgevoerd. Daarnaast is in die jaren ook bemonsterd met een commerciële boomkor en met fuiken. Die bemonsteringen zijn later niet meer herhaald en niet bij de analyses in dit rapport betrokken. In 2009 en 2010 zijn in voor- en najaar 53 trekken uitgevoerd in het Bodembeschermingsgebied en het zuidelijk referentiegebied. In 2011 zijn op dezelfde locaties alleen in de lente trekken uitgevoerd. In 2012 en 2013 zijn opnieuw in voor- en najaar trekken uitgevoerd, maar is het aantal gereduceerd tot 43, overeenkomend met de locaties die al in 2005 en 2007 (buiten Maasvlakte 2) waren bemonsterd.

De oorspronkelijke opzet van het bemonsteringsprogramma was diepte-gestratificeerd (Couperus et al., 2008). Per deelgebied is in elk dieptestratum een aantal monsters genomen dat ongeveer in verhouding stond tot het relatieve aandeel van dat dieptestratum in de oppervlakte van het gebied. Binnen de dieptestrata is min of meer random gekozen voor een aantal punten. Om praktische redenen konden de oorspronkelijk gekozen punten niet altijd worden gehandhaafd, bijvoorbeeld omdat het substraat niet geschikt was voor bevissing. Dan zijn punten verlegd en later weer op de verlegde plek bemonsterd. Door het verschuiven van monsterpunten is de dieptestratificatie niet helemaal bewaard gebleven. Bovendien blijkt uit de resultaten dat naast diepte ook andere omgevingsfactoren bepalend zijn voor de visfauna. Voor deze factoren is niet gestratificeerd.

$\mathrm{Na} 2013$ is de strategie voor het bemonsteren van vis en epifauna veranderd. Op dat moment was duidelijk dat de BACI opzet niet voldeed vanwege een gebrek aan contrast in behandeling tussen het Bodembeschermingsgebied en het referentiegebied. De opzet wijzigde van een strikte statistische vergelijking binnen de Voordelta, naar een breder opgezette vergelijking met de rest van de Nederlandse kustzone. Om dat zo kostenefficiënt mogelijk te doen is aangesloten bij de Demersal Fish Survey, die jaarlijks in de nazomer-vroege najaar langs de hele Nederlandse kust wordt uitgevoerd. De 
bemonsteringsmethode is gelijk aan de bemonsteringen uitgevoerd in de eerste fase van de PMR visbemonstering. In de Voordelta zijn ten behoeve van PMR 13 stations toegevoegd aan het schema van de DFS. Het voordeel van deze wijziging is dat analyse van de DFS data toelaat trends in de Voordelta te vergelijken met die in andere delen van de Nederlandse kust.

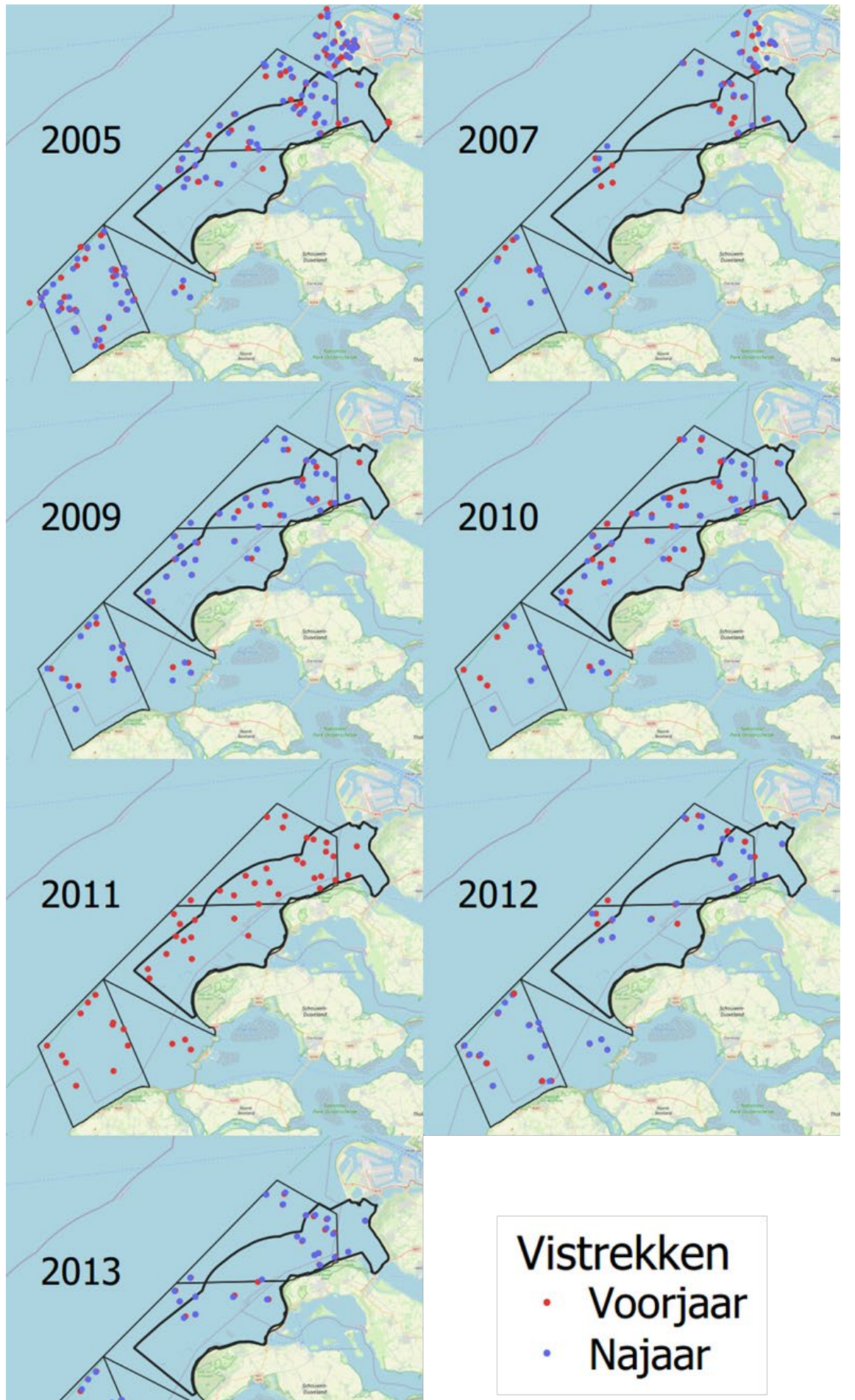

Figuur B3.23. Posities van de vistrekken in de verschillende jaren. In vele gevallen overlappen de posities van voorjaars- en najaarsbemonstering, en wordt alleen de positie van de najaarsbemonstering getoond. 


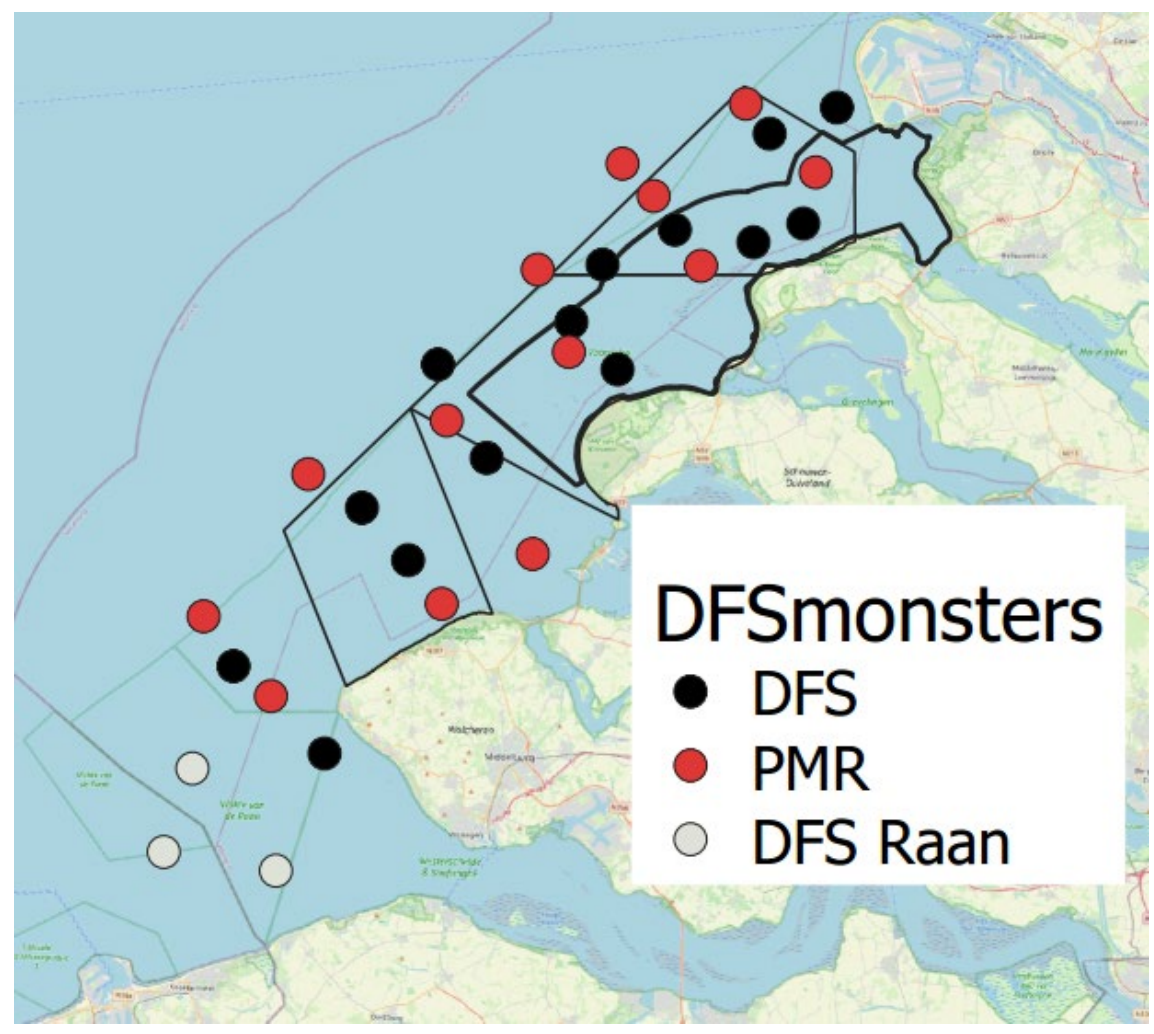

Figuur B3.24. De DFS (zwart) en PMR (rood) stations in de vismonitoring vanaf 2013. De drie meest zuidelijke DFS stations (op de Vlakte van de Raan, aangeduid in grijs) zijn bij de analyses meestal buiten beschouwing gelaten.

De bemonsteringsmethode is in alle gevallen overeenkomstig het protocol van de Demersal Fish Survey. Er wordt gevist met een snelheid van 2-3 knopen en de standaard trekduur is 15 minuten. Daarnaast wordt zoveel mogelijk bij daglicht en met de stroom mee gevist. De afgelegde afstand wordt geregistreerd. Tijdens de trek wordt voor zover mogelijk de uitzetdiepte aangehouden. In de Voordelta wordt de survey uitgevoerd met een $6 \mathrm{~m}$ garnalenkor waarbij gevist wordt met één wekkerketting en een klossenpees (maaswijdte net 35 mm, maaswijdte kuil $20 \mathrm{~mm}$ ).

De vangst van het rechter net is gebruikt om de gegevens te registreren, tenzij er een probleem was met dit net; in dat geval is de vangst uit het linker net gebruikt. Additionele monsters, b.v. voor maaganalyse, zijn uit het linker net verzameld. Aan het net is een CTD sonde bevestigd die tijdens de trek temperatuur, conductiviteit, diepte en turbiditeit registreerde.

De hele vangst is aan boord gesorteerd en van alle vissoorten is aan boord een lengte-frequentie verdeling bepaald en ingevoerd. Sommige soortgroepen konden niet altijd tot op de soort gedetermineerd worden (grondel, zandspiering). Deze soorten zijn meegenomen naar het lab. Vissen zijn aan boord gewogen om lengte-gewicht relaties te bepalen waaruit de conditie kan worden afgeleid. Van de bodemfauna zijn alleen de garnalen geteld en gemeten. In de eerste fase (T0 en T1) is van een aantal soorten de maag-darm inhoud verzameld en geconserveerd in formaline, om in het laboratorium te worden uitgezocht. Magen zijn verzameld van dwergtong, grondels, kleine pieterman, pitvis, schar, schol, schurftvis en tong.

Naast de DFS in de Voordelta is ook gebruik gemaakt van DFS gegevens uit andere kustgebieden. 


\section{Opwerking data visfauna}

Het beviste oppervlak is berekend door de beviste afstand te vermenigvuldigen met de breedte van de boom ( $6 \mathrm{~m}$ ). Dichtheden zijn berekend door de vangsten te delen door het beviste oppervlak en zijn uitgedrukt in aantallen per hectare. Bestaande lengte-gewichtrelaties zijn gebruikt om de vangst ook in biomassa/ha uit te kunnen drukken. Hierbij is geen rekening gehouden met de vangstefficiëntie van het net. De vangstefficiëntie is variabel, is een functie van visgrootte en omstandigheden tijdens het vissen (temperatuur, doorzicht) en wordt geschat op 10-30\% (Aarts et al., 2019).

Voor een aantal soorten is een opsplitsing van de vis in 0 en 1 jarige of 0 -groep en ouder dan 0 jaar gemaakt. Tijdens de surveys zijn daartoe otolieten verzameld. Deze zijn gebruikt om de leeftijd te bepalen. Met deze gegevens zijn lengte/leeftijdssleutels gemaakt aan de hand waarvan een splitsing tussen 0 en $1+$ groep of tussen 0,1 en $1+$ groep vis (tong en schol) is gemaakt. Wanneer er te weinig gegevens voorhanden waren om lengte-leeftijdssleutels te maken zijn gegevens uit andere onderzoeksprogramma's gebruikt. Voor overige soorten is gebruik gemaakt van de lengte-frequentie verdelingen en is de grens tussen 0 -groep en ouder gemaakt op basis van expert judgement.

\section{Gegevens over de abiotische omgeving}

Bij de bemonsteringen van benthos en vis zijn gegevens verzameld over de abiotische omstandigheden op de locatie en het tijdstip van bemonstering. Bij de benthosbemonstering zijn diepte, Secchi diepte, korrelgrootte van het sediment en temperatuur bepaald. Ten behoeve van de korrelgroottebepaling zijn submonsters ( $1 \mathrm{~cm}$ diameter, $5 \mathrm{~cm}$ diep) uit de boxcore genomen, diepgevroren en in het laboratorium m.b.v. een Malvern Laser particle sizer doorgemeten. Voor de analyse is meestal gebruik gemaakt van de mediane korrelgrootte, maar het volledige spectrum is beschikbaar. Bij de visbemonsteringen zijn CTD casts gemeten, alsook Secchi diepte en diepte van de monsterlocatie (ongecorrigeerd voor getij). Van alle metingen verzameld tijdens de bemonstering is alleen de korrelgrootteverdeling van het sediment effectief gebruikt voor de analyses. Overigens is vooral gebruikgemaakt van bathymetriegegevens (Rijkswaterstaat) en modeloutput, omdat deze veel meer context en een langere duur voorstellen dan een puntmeting bij een bemonstering.

Ruimte- en tijdsdekkende berekeningen van waterstanden, stroomsnelheden, golven, bodemschuifspanningen ten gevolge van stroming en golven, watertemperatuur, en saliniteit zijn uitgevoerd door Arcadis en beschikbaar voor de gehele studieperiode 2004-2018. Daarvoor is gebruik gemaakt van het modelleninstrumentarium van Rijkswaterstaat, bestaande uit de SIMONA modellen CSM8 (Continental Shelf Model met 8 kilometer rastercel afmeting), Zuno (Zuidelijk Noordzee model), Kustgrof en Kustzuid (uitsnede van het zuidelijke deel van Kustfijn) en het golfvoortplantingsmodel SWAN. De benodigde gegevens voor waterstanden, meteo-velden, saliniteit- en temperatuurmetingen, afvoer- en lozingsgegevens, de bodemligging in de Voordelta en golfgegevens op zee zijn gebruikt om de modellen aan te sturen en te valideren. Voor de afvoergegevens voor de Maasmond en het Haringvliet zijn de resultaten van de SOBEK-simulaties van Rijkswaterstaat gebruikt. Voor elk van de simulatiejaren is gebruik gemaakt van observaties om door middel van data-assimilatie de hindcasts dicht bij de waarnemingen te houden. Datarapporten documenteren, per jaar, de validatie van het model aan observaties en vatten de modelsimulaties samen. Ten behoeve van de analyse zijn ruimtelijke statistieken van de modelresultaten gebruikt, bijvoorbeeld het $95^{\mathrm{e}}$ percentiel van de bodemschuifspanning ten gevolge van stroming en golven, de onderschrijdingskans van een lage saliniteit, etc. Alle modelresultaten zijn beschikbaar in de database.

\section{Database met resultaten}

De resultaten van alle metingen en onderzoekingen worden beschikbaar gesteld via Informatiehuis Marien (https://www.informatiehuismarien.nl/) . Dit betreft actieve databases, die zo goed mogelijk worden onderhouden. Als er fouten of onnauwkeurigheden in de database worden ontdekt, of er zijn wijzigingen in de gangbare taxonomie, dan worden de actieve databases daaraan aangepast. 
De database zoals ze was op het ogenblik van het uitvoeren van de analyses in dit rapport wordt via de 4TU repository vastgelegd. Deze versie van de dataset zal nooit meer worden aangepast en zal als documentatie van de berekeningen in dit rapport worden bewaard.

De dataset zal worden opgeslagen onder doi: https://doi.org/10.18174/524298 


\section{Bijlage 4 MEP evaluatievragen en onderzoeksvragen van het monitoringprogramma}

Tabel B4.1 Evaluatie- en onderzoeksvragen met betrekking tot $H 1110 B$

\begin{tabular}{|c|c|}
\hline Evaluatievragen & Onderzoeksvragen \\
\hline $\begin{array}{l}\text { 1) Wordt het verlies aan habitattype } \mathrm{H} 1110 \text { als } \\
\text { gevolg van de aanleg van Maasvlakte } 2 \text { voldoende } \\
\text { gecompenseerd? }\end{array}$ & $\begin{array}{l}\text { 1) Wordt het verlies aan habitattype } \mathrm{H} 1110 \mathrm{~B} \text { als } \\
\text { gevolg van de aanleg van Maasvlakte } 2 \text { voldoende } \\
\text { gecompenseerd? }\end{array}$ \\
\hline $\begin{array}{l}\text { a) Is het verlies aan oppervlak van habitattype } \\
\text { H1110 t.g.v. het ruimtebeslag, de ontwikkeling van } \\
\text { de erosiekuil en de toename van de getijslag } \\
\text { inderdaad } 2455 \text { ha? }\end{array}$ & a) wordt behandeld in MEP-Aanleg \\
\hline $\begin{array}{l}\text { b) Wat is het daaraan gerelateerde verlies aan } \\
\text { bodemdieren, in termen van typische soorten, } \\
\text { kenmerken van een goede structuur en functie en } \\
\text { voedsel voor vissen en vogels? }\end{array}$ & b) wordt behandeld in MEP-Aanleg \\
\hline $\begin{array}{l}\text { c) Zijn er positieve trends waar te nemen in de } \\
\text { aanwezigheid en dichtheid van typische soorten en } \\
\text { in de kenmerken van een goede structuur en } \\
\text { functie van het habitattype H1110B in de Voordelta } \\
\text { sinds het begin van de afname van de } \\
\text { boomkorvisserij uit de Voordelta rond de laatste } \\
\text { eeuwwisseling? }\end{array}$ & $\begin{array}{l}\text { c) Zijn er positieve trends waar te nemen in } \\
\text { kwaliteit van het Habitat } 1110 \mathrm{~B} \text { (zoals deze wordt } \\
\text { gedefinieerd in het profieldocument H1110 (versie } \\
18 \text { december } 2008 \text { )), in de Voordelta sinds het } \\
\text { begin van de afname van de boomkorvisserij uit de } \\
\text { Voordelta rond de laatste eeuwwisseling? }\end{array}$ \\
\hline $\begin{array}{l}\text { d) Zijn de waargenomen trends toe te schrijven } \\
\text { aan de afgenomen bodemberoering ten gevolge } \\
\text { van de afname van de grote boomkorvisserij met } \\
\text { wekkerkettingen in de gehele Voordelta of ook aan } \\
\text { andere factoren? }\end{array}$ & d) onderzoeksvraag is gelijk aan evaluatievraag \\
\hline $\begin{array}{l}\text { e) Wat is het effect van verschillende vormen van } \\
\text { bodemberoerende visserij op het ecosysteem (in } \\
\text { termen van geschatte bijvangst, onttrekking van } \\
\text { vis, verstoring) geweest in de periode T0 ( } 2004- \\
2008), \text { T1 (2009-2013) en T2 (2014-2018)? }\end{array}$ & $\begin{array}{l}\text { e) Hoe groot was de onttrekking van vis en andere } \\
\text { (bij)vangsten in de periode T0 (2004-2008), T1 } \\
\text { (2009-2013) en T2 (2014-2018)? }\end{array}$ \\
\hline
\end{tabular}


Tabel B4.2 Evaluatie- en onderzoeksvragen met betrekking tot de zwarte zee-eend

\begin{tabular}{|c|c|}
\hline Evaluatievragen & Onderzoeksvragen \\
\hline $\begin{array}{l}\text { 2) Wordt het verlies aan foerageergebied van de } \\
\text { zwarte zee-eend als gevolg van de aanleg en het } \\
\text { gebruik van Maasvlakte } 2 \text { voldoende } \\
\text { gecompenseerd? }\end{array}$ & $\begin{array}{l}\text { 2) Wordt het verlies aan foerageergebied van de } \\
\text { zwarte zee-eend als gevolg van de aanleg en het } \\
\text { gebruik van Maasvlakte } 2 \text { voldoende } \\
\text { gecompenseerd? }\end{array}$ \\
\hline $\begin{array}{l}\text { a) Hoeveel potentieel foerageergebied is er } \\
\text { daadwerkelijk verloren gegaan a.g.v. het } \\
\text { ruimtebeslag van MV2, de ontwikkeling van de } \\
\text { erosiekuil en het gebruik van MV2? } \\
\text { i) Wat is op basis van voortschrijdend inzicht de } \\
\text { betekenis van het gebied dat verloren is gegaan } \\
\text { voor de zwarte zee-eend in termen van } \\
\text { voedselbeschikbaarheid en rust? } \\
\text { ii) Hoe is, op basis van voortschrijdend inzicht, het } \\
\text { effect van de aanleg en het gebruik van } \\
\text { Maasvlakte } 2 \text { op het instandhoudingsdoel voor } \\
\text { deze soort te beoordelen? }\end{array}$ & $\begin{array}{l}\text { a) Onderzoeksvragen zijn gelijk aan } \\
\text { evaluatievragen }\end{array}$ \\
\hline $\begin{array}{l}\text { b) Leidt het instellen van het } \\
\text { Bodembeschermingsgebied tot een gelijkblijvende } \\
\text { potentiële functie van de Voordelta voor de zwarte } \\
\text { zee-eend in termen van voedselbeschikbaarheid? }\end{array}$ & $\begin{array}{l}\text { b) Onderzoeksvragen zijn gelijk aan } \\
\text { evaluatievragen }\end{array}$ \\
\hline $\begin{array}{l}\text { i) Is de potentiële draagkracht van het gebied } \\
\text { toegenomen door de ingestelde maatregelen n.l. } \\
\text { het beperken van de grote boomkorvisserij? Het } \\
\text { gaat hier om de potentiële draagkracht met } \\
\text { betrekking tot de voedselvoorziening van deze } \\
\text { soort in relatie tot het instandhoudingsdoel; dit } \\
\text { betekent niet de jaarlijkse aanwezigheid van de } \\
\text { zwarte zee-eend in het gebied volgens het } \\
\text { instandhoudingsdoel. } \\
\text { ii) Zijn andere factoren dan } \\
\text { voedselbeschikbaarheid binnen en buiten de } \\
\text { Voordelta bepalend voor het al dan niet aanwezig } \\
\text { zijn van deze soort in de Voordelta? } \\
\text { iii) Is er voldoende oogstbaar voedsel in de totale } \\
\text { Voordelta voor het aantal vogels volgens het } \\
\text { instandhoudingsdoel }{ }^{9} \text { ? }\end{array}$ & \\
\hline
\end{tabular}

\footnotetext{
${ }^{9}$ Met oogstbaar voedsel wordt bedoeld dat deel van de bodemfauna van de juiste afmeting, in de juiste dichtheid, van de juiste soort en op de juiste diepte.
} 


\begin{tabular}{|c|c|}
\hline Evaluatievragen & Onderzoeksvragen \\
\hline $\begin{array}{l}\text { c) Draagt het instellen van rustgebieden, specifiek } \\
\text { voor de zwarte zee-eend, bij aan een } \\
\text { gelijkblijvende potentiële functie van de Voordelta } \\
\text { als foerageer- en rustgebied? } \\
\text { i) Is de potentiële draagkracht van de Voordelta } \\
\text { gelijk gebleven door het instellen van de } \\
\text { rustgebieden? Voor het begrip potentiële } \\
\text { draagkracht, zie hierboven. } \\
\text { ii) Is er voldoende rust in de Voordelta om de } \\
\text { draagkracht voor het gestelde aantal vogels in het } \\
\text { instandhoudingsdoel te kunnen waarborgen? }\end{array}$ & $\begin{array}{l}\text { c) Onderzoeksvragen zijn gelijk aan } \\
\text { evaluatievragen }\end{array}$ \\
\hline $\begin{array}{l}\text { d) Is de aangepaste begrenzing van de extra } \\
\text { rustgebieden vanuit PMR-NCV juist gekozen om bij } \\
\text { te dragen aan het instandhoudingsdoel? }\end{array}$ & $\begin{array}{l}\text { d) Draagt de aangepaste begrenzing van de } \\
\text { rustgebieden, specifiek voor de zwarte zee-eend, } \\
\text { bij aan een gelijkblijvende potentiële functie van } \\
\text { de Voordelta als foerageer- en rustgebied? }\end{array}$ \\
\hline $\begin{array}{l}\text { i) Worden de aangepaste rustgebieden gebruikt } \\
\text { door de aanwezige zwarte zee-eenden? In welke } \\
\text { periode houden zij zich hier op en welke } \\
\text { ecologische functies vervullen de rustgebieden } \\
\text { voor deze soort? } \\
\text { ii) Hoe is de verspreiding van de zwarte zee-eend } \\
\text { in de Voordelta in de wintermaanden (oktober- } \\
\text { maart) en daarbuiten (april-september)? }\end{array}$ & $\begin{array}{l}\text { i) Worden de aangepaste rustgebieden gebruikt } \\
\text { door de aanwezige zwarte zee-eenden? In welke } \\
\text { periode houden zij zich hier op en welke } \\
\text { ecologische functies vervullen de rustgebieden } \\
\text { voor deze soort? } \\
\text { ii) Hoe zijn zwarte zee-eenden verspreid over de } \\
\text { Voordelta in de overwinteringsperiode (oktober- } \\
\text { mei }^{10} \text { )? }\end{array}$ \\
\hline
\end{tabular}

\footnotetext{
${ }^{10}$ De monitoring is beperkt tot de periode oktober-mei, omdat de compensatieopgave gericht is op overwinterende zee-eenden
} 
Tabel B4.3 Evaluatie- en onderzoeksvragen met betrekking tot sterns

\begin{tabular}{|c|c|}
\hline Evaluatievragen & Onderzoeksvragen \\
\hline $\begin{array}{l}\text { 3) Wordt het verlies aan foerageergebied van de } \\
\text { grote stern als gevolg van het ruimtebeslag en het } \\
\text { gebruik van Maasvlakte } 2 \text { voldoende } \\
\text { gecompenseerd? }\end{array}$ & $\begin{array}{l}\text { 3) Wordt het verlies aan foerageergebied van de } \\
\text { grote stern als gevolg van het ruimtebeslag en het } \\
\text { gebruik van Maasvlakte } 2 \text { voldoende } \\
\text { gecompenseerd? }\end{array}$ \\
\hline $\begin{array}{l}\text { a) Hoeveel potentieel foerageergebied is er voor de } \\
\text { grote stern daadwerkelijk verloren gegaan a.g.v. } \\
\text { het ruimtebeslag en het gebruik van MV2? } \\
\text { i) Wat is op basis van voortschrijdend inzicht de } \\
\text { betekenis van het gebied dat door de aanleg van } \\
\text { Maasvlakte } 2 \text { verloren is gegaan in vergelijking } \\
\text { met het nieuwe kustgebied na aanleg van } \\
\text { Maasvlakte } 2 \text { ? } \\
\text { ii) Hoe is, op basis van voortschrijdend inzicht, het } \\
\text { effect van de aanleg en het gebruik van } \\
\text { Maasvlakte } 2 \text { op het instandhoudingsdoel voor } \\
\text { deze soort te beoordelen? }\end{array}$ & $\begin{array}{l}\text { a) Hoe is, op basis van voortschrijdend inzicht, de } \\
\text { inschatting van het effect van de aanleg van } \\
\text { Maasvlakte } 2 \text { op het instandhoudingsdoel voor } \\
\text { deze soort? } \\
\text { i) Wat was, in kwalitatieve termen, de betekenis } \\
\text { van het verdwenen foerageergebied } \\
\text { ii) Wat is, in kwalitatieve termen, de betekenis van } \\
\text { het nieuwe kustgebied na aanleg van Maasvlakte } 2\end{array}$ \\
\hline $\begin{array}{l}\text { b) Leidt het instellen van het } \\
\text { Bodembeschermingsgebied tot een gelijkblijvende } \\
\text { potentiële functie van de Voordelta voor de grote } \\
\text { stern in termen van voedselbeschikbaarheid? } \\
\text { i) Treden veranderingen op in broedsucces, het } \\
\text { voedsel, de verspreidingspatronen en het aantal } \\
\text { vogeldagen van de grote stern t.o.v. de situatie } \\
\text { vóór de aanleg van Maasvlakte } 2 \text { ? } \\
\text { ii) Zijn deze veranderingen toe te schrijven aan } \\
\text { (veranderingen in) de voedselbeschikbaarheid of } \\
\text { zijn andere factoren van (groter) belang? } \\
\text { iii) Is er een causaal verband tussen de } \\
\text { verschillende vormen van bodemberoerende } \\
\text { visserij en de aanwezigheid en dichtheid van } \\
\text { zandspiering in de Voordelta. Zandspiering lijkt } \\
\text { een belangrijke voedselbron te zijn voor de grote } \\
\text { stern. }\end{array}$ & $\begin{array}{l}\text { b) Leidt het instellen van het } \\
\text { Bodembeschermingsgebied tot een gelijkblijvende } \\
\text { potentiële functie van de Voordelta voor de grote } \\
\text { stern in termen van voedselbeschikbaarheid? } \\
\text { i) onderzoeksvraag is gelijk aan evaluatievraag } \\
\text { ii) onderzoeksvraag is gelijk aan evaluatievraag } \\
\text { iii) Is er een correlatie tussen de verschillende } \\
\text { vormen van bodemberoerende visserij en de } \\
\text { aanwezigheid en dichtheid van zandspiering in de } \\
\text { Voordelta. Is het aannemelijk dat het om een } \\
\text { causaal verband gaat? }\end{array}$ \\
\hline
\end{tabular}




\begin{tabular}{|c|c|}
\hline Evaluatievragen & Onderzoeksvragen \\
\hline $\begin{array}{l}\text { c) Draagt het instellen van de rustgebieden bij aan } \\
\text { het verbeteren van het potentiële functioneren van } \\
\text { de Voordelta? } \\
\text { i) Worden de droogvallende platen in de } \\
\text { rustgebieden gebruikt door de aanwezige grote } \\
\text { sterns? En in welke periode houden zij zich hier } \\
\text { op? } \\
\text { ii) Wat is het relatieve belang van de Voordelta } \\
\text { voor de grote stern, welke factoren spelen } \\
\text { daarbij een rol en wat is de jaar tot jaar variantie } \\
\text { en zijn hierin grote veranderingen } \\
\text { waarneembaar? }\end{array}$ & $\begin{array}{l}\text { c) Draagt het instellen van de rustgebieden bij aan } \\
\text { het instandhoudingsdoel ? } \\
\text { i) Worden de droogvallende platen in de } \\
\text { rustgebieden gebruikt door de aanwezige grote } \\
\text { sterns, en/of worden andere gebieden gebruikt om } \\
\text { te rusten? En in welke periode houden zij zich hier } \\
\text { op? } \\
\text { ii) onderzoeksvraag is gelijk aan evaluatievraag }\end{array}$ \\
\hline $\begin{array}{l}\text { 4) Wordt het verlies aan foerageergebied van de } \\
\text { visdief als gevolg van het ruimtebeslag en het } \\
\text { gebruik van Maasvlakte } 2 \text { voldoende } \\
\text { gecompenseerd? }\end{array}$ & $\begin{array}{l}\text { 4) Wordt het verlies aan foerageergebied van de } \\
\text { visdief als gevolg van het ruimtebeslag en het } \\
\text { gebruik van Maasvlakte } 2 \text { voldoende } \\
\text { gecompenseerd? }\end{array}$ \\
\hline $\begin{array}{l}\text { a) Hoeveel potentieel foerageergebied is er voor de } \\
\text { visdief daadwerkelijk verloren gegaan t.g.v. het } \\
\text { ruimtebeslag en het gebruik van MV2? } \\
\text { i) Wat is op basis van voortschrijdend inzicht de } \\
\text { betekenis van het gebied dat door de aanleg van } \\
\text { Maasvlakte } 2 \text { verloren is gegaan in vergelijking } \\
\text { met het nieuwe kustgebied na aanleg van } \\
\text { Maasvlakte } 2 \text { ? } \\
\text { ii) Hoe is, op basis van voortschrijdend inzicht, het } \\
\text { effect van de aanleg en het gebruik van } \\
\text { Maasvlakte } 2 \text { op het instandhoudingsdoel voor } \\
\text { deze soort te beoordelen? }\end{array}$ & $\begin{array}{l}\text { a) Hoe is, op basis van voortschrijdend inzicht, de } \\
\text { inschatting van het effect van de aanleg van } \\
\text { Maasvlakte } 2 \text { op het instandhoudingsdoel voor } \\
\text { deze soort? } \\
\text { i) Wat was, in kwalitatieve termen, de betekenis } \\
\text { van het verdwenen foerageergebied } \\
\text { ii) Wat is, in kwalitatieve termen, de betekenis van } \\
\text { het nieuwe kustgebied na aanleg van Maasvlakte } 2\end{array}$ \\
\hline $\begin{array}{l}\text { b) Leidt het instellen van het } \\
\text { Bodembeschermingsgebied tot een gelijkblijvende } \\
\text { potentiële functie van de Voordelta voor de visdief } \\
\text { in termen van voedselbeschikbaarheid? } \\
\text { i) Treden veranderingen op in broedsucces, het } \\
\text { voedsel, de verspreidingspatronen en het aantal } \\
\text { vogeldagen van de visdief in de Voordelta t.o.v. de } \\
\text { situatie vóór de aanleg van Maasvlakte } 2 \text { ? Het gaat } \\
\text { hierbij om inzicht in het functioneren van de gehele } \\
\text { Voordelta voor deze soort. } \\
\text { iI) Zijn deze veranderingen toe te schrijven aan } \\
\text { (veranderingen in) de voedselbeschikbaarheid of } \\
\text { zijn andere factoren van (groter) belang? }\end{array}$ & $\begin{array}{l}\text { Leidt het instellen van het } \\
\text { Bodembeschermingsgebied tot een gelijkblijvende } \\
\text { potentiële functie van de Voordelta voor de visdief } \\
\text { in termen van voedselbeschikbaarheid? } \\
\text { i) Treden veranderingen op in broedsucces, het } \\
\text { voedsel, de verspreidingspatronen en het aantal } \\
\text { vogeldagen van de visdief in de Voordelta t.o.v. de } \\
\text { situatie vóór de aanleg van Maasvlakte } 2 \text { ? Het gaat } \\
\text { hierbij om inzicht in het functioneren van de gehele } \\
\text { Voordelta voor deze soort. } \\
\text { ii) Zijn deze veranderingen toe te schrijven aan } \\
\text { (veranderingen in) de voedselbeschikbaarheid of } \\
\text { zijn andere factoren van (groter) belang? }\end{array}$ \\
\hline
\end{tabular}




\begin{tabular}{|l|l|}
\hline Evaluatievragen & Onderzoeksvragen \\
\hline $\begin{array}{l}\text { c) Draagt het instellen van de rustgebieden bij aan } \\
\text { het potentiële functioneren van de Voordelta? }\end{array}$ & $\begin{array}{l}\text { Draagt het instellen van de rustgebieden bij aan } \\
\text { het instandhoudingsdoel? }\end{array}$ \\
$\begin{array}{l}\text { i) Worden de platen in de rustgebieden gebruikt } \\
\text { door de aanwezige visdieven? In welke periode } \\
\text { houden zij zich hier op en wat is de functie van de } \\
\text { aanwezigheid van droogvallende platen? }\end{array}$ & $\begin{array}{l}\text { i) Worden de platen in de rustgebieden gebruikt } \\
\text { door de aanwezige visdieven? In welke periode } \\
\text { houden zij zich hier op en wat is de functie van de } \\
\text { aanwezigheid van droogvallende platen? }\end{array}$ \\
$\begin{array}{l}\text { ii) Hoe is de verspreiding van de visdief in de } \\
\text { Voordelta in relatie tot het ecologisch } \\
\text { ruimtegebruik en zijn hierin grote veranderingen } \\
\text { waarneembaar? }\end{array}$ & \\
\hline
\end{tabular}




\section{Bijlage 5 Overzicht van eerder verschenen rapporten 2009-2019}

\section{Overkoepelende rapportages}

\section{9}

Heessen, H.J.L. and R.G. Jak (2009). Plan van Aanpak PMR monitoring natuurcompensatie Voordelta. Deel B: Uitvoeringsplannen per perceel. IJmuiden, IMARES, $137 \mathrm{pp}$.

http://publications.deltares.nl/WeL1809.pdf

Holzhauer, H. and T.C. Prins (2009). Plan van Aanpak PMR monitoring natuurcompensatie Voordelta. Delft, Deltares, rapport 1200672-008-ZKS-0002, 39 pp.

http://publications.deltares. $\mathrm{nl} / 1200672$ 008.pdf

2010

van der Kolff, G.H., T.C. Prins and H. Heessen, Eds. (2010). Jaarrapport 2009. PMR monitoring natuurcompensatie Voordelta. Delft, Deltares, 186 pp.

http://publications.deltares. nl/1200672 000.pdf

2011

Heessen, H.J.L. (2011). PMR monitoring natuurcompensatie Voordelta. Deel B: Jaarrapport 2010 en midterm evaluatie. Delft, Deltares, IMARES, Deltares/IMARES rapport 1200672-000-ZKS-0023., 358 pp. http://publications.deltares.nl/1200672 000 B.pdf

Prins, T.C., A.R. Boon, H. Holzhauer and G.H. Van der Kolff (2011). PMR monitoring natuurcompensatie Voordelta. Deel A: Jaarrapport 2010 en midterm evaluatie. Delft, Deltares, rapport 1200672000-ZKS-0024, 112 pp. http://publications.deltares.nl/1200672 000 A.pdf

\section{2}

Heessen, H.J.L. (2012). PMR monitoring natuurcompensatie Voordelta. Deel B: Jaarrapport 2011. Delft, Deltares, IMARES, Deltares/IMARES rapport 1200672-000-ZKS-0034, 489 pp. http://publications.deltares.nl/Deltares096.pdf

Prins, T.C., G.H. Van der Kolff, A.R. Boon, H. Holzhauer, C. Kuijper, V.T. Langenberg and G. Hendriksen (2012). PMR Monitoring natuurcompensatie Voordelta. Deel A: Jaarrapport 2011. Delft, Deltares, rapport 1200672-000-ZKS-0031, 104 pp. http://publications.deltares.nl/1200672 000 C.pdf

\section{3}

Prins, T.C. and G.H. Van der Kolff, Eds. (2013). PMR Monitoring natuurcompensatie Voordelta.

Jaarrapport 2012 Deel B. Delft, Deltares, 124 pp.

http://publications.deltares.nl/1200672 000E.pdf

Prins, T.C., G.H. Van der Kolff, A.R. Boon, G. Hendriksen, H. Holzhauer, C. Kuijper, V.T. Langenberg and J. Reinders (2013). PMR Monitoring natuurcompensatie Voordelta. Jaarrapport 2012 Deel A. Delft, Deltares, rapport 1200672-000-ZKS-0039, 124 pp. http://publications.deltares.nl/1200672 000E.pdf 
Prins, T.C. and G.H. Van der Kolff, Eds. (2014). PMR Monitoring natuurcompensatie Voordelta. Eindrapportage $1^{\mathrm{e}}$ fase 2009-2013 deel B. Delft, Deltares, $940 \mathrm{pp}$.

http://publications.deltares.nl/1200672 000 0043.pdf

Prins, T.C., G.H. Van der Kolff, A.R. Boon, J. Reinders, C. Kuijper, G. Hendriksen, H. Holzhauer, V.T. Langenberg, J.A.M. Craeymeersch, I.Y.M. Tulp, M.J.M. Poot, H.C.M. Seegers and J. Adema (2014). PMR Monitoring natuurcompensatie Voordelta. Eindrapportage $1^{\mathrm{e}}$ fase 2009-2013. Delft, Deltares, Rapport nr 1200672-000-ZKS-0042, 207 pp.

http://publications.deltares.nl/1200672 000 0042.pdf

2015

Prins, T.C., G.H. Van der Kolff, I.Y.M. Tulp and J.A.M. Craeymeersch (2015). PMR monitoring natuurcompensatie Voordelta. Samenvattende rapportage 2014. Delft, Deltares, 1209129-000ZKS-0034, 45 pp. http://publications.deltares.nl/1209129 000.pdf

Tulp, I.Y.M., T.C. Prins, N.S.H. Tien, J.A.M. Craeymeersch and M.T. Van der Sluis (2015). Monitorings- en onderzoeksplan vervolg monitoring PMR-NCV. IJmuiden, IMARES, Rapport nr C135a/15, 90 pp. http://edepot.wur.nl/360787

Van der Sluis, M.T., I.Y.M. Tulp and T.C. Prins (2016). Uitvoeringsplan PMR-NCV. Tweede fase monitoring. IJmuiden, IMARES, Rapport $\mathrm{nr} 15.014,37 \mathrm{pp}$.

\section{6}

Prins, T.C., I.Y.M. Tulp and M.T. Van der Sluis (2016b). PMR monitoring natuurcompensatie Voordelta. Samenvattende rapportage 2015. Delft, Deltares, 1220260-000-ZKS-0016, 49 pp. http://publications. deltares.nl/1220260 000.pdf

Prins, T.C., A.R. Boon and V. Escaravage (2016). Indicatoren voor de kwaliteit van habitat type $\mathrm{H} 1110$ in PMR Natuurcompensatie Voordelta. Delft, Deltares, 1209129-000-ZKS-0031, 49 pp. http://publications.deltares.nl/1209129 000a.pdf

\section{8}

Tulp, I., T.C. Prins, J.A.M. Craeymeersch, S. Ijff and M.T.v.d. Sluis (2018). Syntheserapport PMR NCV. IJmuiden, Wageningen Marine Research, WMR rapport nummer C014/18, Deltares rapport nr 1230156-000-ZKS-0004, 294 pp. https://doi.org/10.18174/496768 http://publications.deltares.nl/1230156 000.pdf

\section{Achtergrondrapportages Benthos}

Craeymeersch, J.A.M., V. Escaravage, J. Adema, M. Van Asch, I. Tulp and T.C. Prins (2015). PMR Monitoring natuurcompensatie Voordelta - bodemdieren 2004-2013. Yerseke, IMARES, Rapport nr C091/15, 171 pp. http://edepot.wur.nl/357338

Craeymeersch, J.A.M., J. Perdon, J. Jol, E.B.M. Brummelhuis and M. Van Asch (2017). PMR Monitoring Natuurcompensatie Voordelta - bodemdieren. Datarapport campagne bodemschaaf 2015 multivariate analyses 2004-2013 Yerseke, IMARES, rapport C073.16, 35 pp. http://edepot.wur.nl/411104 
Zuur, A.F. and E.N. Ieno (2017). Analysis of PMR monitoring data - Fisheries effects on marine benthic fauna. Newburgh, UK, Highland Statistics, NIOZ, 59 pp.

Craeymeersch, J.A.M., K.J. Perdon, J. Van Zwol, J. Jol, E.B.M. Brummelhuis and M. Van Asch (2019). PMR Monitoring Natuurcompensatie Voordelta - bodemdieren. Veld- en datarapport campagnes met bodemschaaf in 2016, 2017 en 2018. Yerseke, Wageningen Marine Research, rapport C059/19, 28 pp. https://sharepoint.wur.nl/sites/sharepoint onderzoek PMRNCV/Shared\%20Documents/4\%20veld\%20en\%20datarapporten/2018/C059.19\%20Rapport\%20P MR\%20monitoring\%20natuurcompensatie\%20.JA-ih.pdf?Web=1 https://library.wur.nl/WebQuery/wurpubs/fulltext/496166

van Duijn, E., A. Engelberts and T. van Haaren (2019). Veld- en analyserapportage 2017. PMR Natuurcompensatie Voordelta 2016-2020, Benthos Box-corer. Eurofins, 28 maart 2019, pp. https://sharepoint.wur.nl/sites/sharepoint onderzoek PMRNCV/Shared\%20Documents/4\%20veld\%20en\%20datarapporten/2017/20190328 J00002473 Vel drapportage $\% 20$ monitoringsjaar\%202017 definitief.pdf?Web $=1$

\section{Achtergrondrapportages Vis}

Tulp, I., N. Tien and C. Van Damme (2016). PMR Monitoring natuurcompensatie Voordelta; Ontwikkeling vis in de Voordelta na instelling Bodembeschermingsgebied ter compensatie van de aanleg Tweede Maasvlakte. IJmuiden, IMARES, rapport C089/16, 148 pp. http://edepot.wur.nl/393791

Bolle, L. and R. Pasterkamp (2017). PMR monitoring natuurcompensatie Voordelta. Jaarrapport vismonitoring 2016. IJmuiden, Wageningen Marine research, Rapport C104/17, 6 pp. https://sharepoint.wur.nl/sites/sharepoint onderzoek PMRNCV/Shared\%20Documents/4\%20veld\%20en\%20datarapporten/2016/C014.17\%20Vertrouwelijk \%20rapport-PMR\%20vismonitoring\%20jaarrapport\%202016\%20binder-LB-ICS.pdf?Web=1

Bolle, L. and R. Pasterkamp (2019). PMR monitoring natuurcompensatie Voordelta. Jaarrapport vismonitoring 2017 en 2018. IJmuiden, Wageningen Marine Research, rapport C049/1, 21 pp. https://sharepoint.wur.nl/sites/sharepoint onderzoek PMRNCV/Shared\%20Documents/4\%20veld\%20en\%20datarapporten/2018/C049.19\%20PMR\%20Rapp ort $\% 20$ monitoring\%20natuurcompensatie $\% 20$ Voordelta.LB-pdg.pdf?Web $=1$

\section{Achtergrondrapportages Visserij}

Tien, N., N. Hintzen, R. Verkempynck, M. Kraan, B. Trapman, J. Craeymeersch and M. van Asch (2017). De bodemberoerende visserij in de Voordelta sinds 2004 IJmuiden, Wageningen Marine Research, rapport C105/17, 106 pp. https://doi.org/10.18174/429215

\section{Achtergrondrapportages Zwarte zee-eend}

Fijn, R.C., R.-J. Jonkvorst and J. De Jong (2015). Datarapport zee-eend monitoring Voordelta 2014/2015 Culemborg, Bureau Waardenburg, Notitie 1 juli 2015, 6 pp.

Dirksen, S., P.W. Van Horssen, L. Bruinzeel, R. de Jong and E. van der Zee (2016). PMR NCV monitoring zwarte zee-eenden Voordelta. Jaarrapport 2015-2016. Feanwâlden, Altenburg \& Wymenga, A\&W-rapport 224022 pp. https://sharepoint.wur.nl/sites/sharepoint onderzoek PMR- 
NCV/Shared\%20Documents/4\%20veld\%20en\%20datarapporten/2016/Veld\%20en\%20datarappor t\%20zee-eenden $\% 20$ Voordelta\%202016\%20definitief.pdf?Web $=1$

Dirksen, S., P.W. Van Horssen, R. de Jong and E. van der Zee (2017). PMR NCV monitoring zwarte zeeeenden Voordelta. Jaarrapport 2016-2017. Feanwâlden Altenburg \& Wymenga ecologisch onderzoek, A\&W-rapport 2379, 26 pp.

https://sharepoint.wur.nl/sites/sharepoint onderzoek PMRNCV/Shared\%20Documents/4\%20veld\%20en\%20datarapporten/2017/Veld\%20en\%20datarappor t\%20zee-eenden\%20Voordelta\%202017\%20final\%20niet\%20verkleind.pdf?Web=1

van der Zee, E., P.W. Van Horssen, R. de Jong and S. Dirksen (2018). PMR NCV monitoring zwarte zeeeenden Voordelta. Jaarrapport 2017-2018. Feanwâlden Altenburg \& Wymenga ecologisch onderzoek, A\&W-rapport 2512, 35 pp. https://sharepoint.wur.nl/sites/sharepoint onderzoek PMRNCV/Shared\%20Documents/4\%20veld\%20en\%20datarapporten/2018/PMRNCV\%20monitoring\%20Zwarte\%20zeeeenden $\% 20$ Voordelta\%20jaarrapport\%202018 eindversie.pdf?Web=1

Van Horssen, P.W., E. van der Zee, M. Poot and S. Dirksen (2019). PMR NCV monitoring zwarte zeeeenden Voordelta. Analyse verstoring Zwarte zee-eenden. Feanwâlden, Altenburg \& Wymenga, A\&W-rapport 2528, $21 \mathrm{pp}$. https://sharepoint.wur.nl/sites/sharepoint onderzoek PMRNCV/Shared\%20Documents/4\%20veld\%20en\%20datarapporten/2018/C049.19\%20PMR\%20Rapp ort $\% 20$ monitoring\%20natuurcompensatie $\% 20$ Voordelta.LB-pdg.pdf?Web $=1$

van der Zee, E., P.W. van Horssen, M. Poot and R. de Jong (2019). PMR NCV monitoring zwarte zeeeenden Voordelta. Jaarrapport 2018-2019. Feanwâlden, Altenburg \& Wymenga ecologisch onderzoek, A\&W-rapport 2526zze.5, 28 pp.

Van Horssen, P., E. Van der Zee and M. Poot (2020). PMR NCV monitoring zwarte zee-eenden in de Voordelta. Verstoringsanalyse T1-T2. Feanwâlden Altenburg \& Wymenga ecologisch onderzoek, A\&W-rapport 2528.20

\section{Achtergrondrapportages Sterns}

Poot, M.J.M., R.C. Fijn, T.J. Boudewijn, C. Heunks, J. De Jong, W. Courtens, H. Verstraete, N. Vanermen, E.W.M. Stienen, P.A. Wolf, M.S.J. Hoekstein and S.J. Lilipaly (2015). PMR-NCV Jaarrapport Vogels 2014. Voortgang onderzoek sterns \& zee-eenden in de Voordelta en Delta. Culemborg, Bureau Waardenburg, Rapportnr. 15-084, 115 pp.

Fijn, R.C., J. De Jong, R.J. Jonkvorst, B. Engels, A. Gyimesi, C. Heunks, T.J. Boudewijn, M.J.M. Poot, W. Courtens, H. Verstraete, N. Vanermen, E.W.M. Stienen, P.A. Wolf, M.S.J. Hoekstein and S.J. Lilipaly (2016). PMR-NCV Jaarrapport Vogels 2015. Voortgang onderzoek sterns \& zee-eenden in de Voordelta en Delta. Culemborg, Bureau Waardenburg, Rapport nr 16-080, 83 pp.

Fijn, R., A. Gyimesi, J.W. de Jong, R.J. Jonkvorst, B. Engels, T.J. Boudewijn, W. Courtens, H. Verstraete, N. Vanermen, E.W.M. Stienen, P.A. Wolf, M.S.J. Hoekstein, S.J. Lilipaly and F.A. Arts (2016). PMRNCV Fase IIonderzoek sterns in het Deltagebied en Voordelta. Jaarrapport 2016. Culemborg, Bureau Waardenburg, , Rapportnr. 16-247, 51 pp. https://sharepoint.wur.nl/sites/sharepoint onderzoek PMRNCV/Shared\%20Documents/4\%20veld\%20en\%20datarapporten/2016/2016 15755 Eindrapport Sterns 20161216 verkleind.pdf?Web $=1$

Fijn, R., W. Courtens, F.A. Arts, R. Daelemans, A. Gyimesi, M.S.J. Hoekstein, J.W. de Jong, R.J. Jonkvorst, S.J. Lilipaly, Y. Radstake, E.L. Bravo Rebolledo, K.D. van Straalen, N. Vanermen, M. 
Van de Walle, H. Verstraete, P.A. Wolf and E.W.M. Stienen (2017). PMR-NCV onderzoek sterns in de Delta en Voordelta. Jaarrapport 2017. Culemborg, Bureau Waardenburg, , Rapportnr. 17247, 95 pp. https://sharepoint.wur.nl/sites/sharepoint onderzoek PMR-

NCV/Shared\%20Documents/4\%20veld\%20en\%20datarapporten/2017/2017 15-

755 Eindrapport Sterns 20180424.pdf?Web $=1$

Fijn, R., W. Courtens, F.A. Arts, D. Beuker, R. Daelemans, B. Engels, M.S.J. Hoekstein, J.W. de Jong, R.J. Jonkvorst, S.J. Lilipaly, M. Sluijter, K.D. van Straalen, N. Vanermen, M. Van de Walle, H. Verstraete, P.A. Wolf and E.W.M. Stienen (2019a). PMR-NCV onderzoek sterns in de Delta en Voordelta. Jaarrapport 2018. Culemborg, Bureau Waardenburg, , Rapportnr. 18-277, 92 pp. https://sharepoint.wur.nl/sites/sharepoint onderzoek PMR-

NCV/Shared\%20Documents/4\%20veld\%20en\%20datarapporten/2018/2018 15755 Eindrapport Sterns 20190322.pdf?Web=1

Fijn, R.C., E.L. Bravo Rebolledo, R.P. Middelveld and J.W. de Jong (2019b). Het gebruik van ingestelde rustgebieden en de zachte zeewering van de Tweede Maasvlakte door sterns. Culemborg, Bureau Waardenburg, Rapport 18-360, 41 pp.

https://sharepoint.wur.nl/sites/sharepoint onderzoek PMR-

NCV/Shared\%20Documents/4\%20veld\%20en\%20datarapporten/2019/2017 15-

755 Eindrapport Rustgebieden Zachte-Zeewering MVII 20190118.pdf?Web=1

\section{Achtergrondrapportages Abiotiek}

Adema, J. (2015). Datarapport PMR-NCV Perceel Abiotiek. Simulaties 2013. Arcadis, 078312838:0.2 Definitief, $121 \mathrm{pp}$.

Adema, J. (2016). Datarapport PMR-NCV Perceel Abiotiek. Simulaties 2014 en analyse lange termijn trends. Zwolle, Arcadis, 1 april 2016, 64 pp.

Adema, J. (2016). Datarapport PMR-NCV Perceel Abiotiek. Simulaties 2015. Zwolle, Arcadis, $0791114580.2,110$ pp. https://sharepoint.wur.nl/sites/sharepoint onderzoek PMRNCV/Shared\%20Documents/4\%20veld\%20en\%20datarapporten/2016/Datarapport\%20Abiotiek\% 20simulaties $\% 202015 \% 20$ totaal\%20r1.pdf?Web $=1$

Adema, J. (2018). Datarapport PMR-NCV perceel Abiotiek. Simulaties 2016 en analyse alternatieve aanpak bodemschuifspanningen golven. Zwolle, Arcadis, 12 januari 2018, 46 + bijlage pp. https://sharepoint.wur.nl/sites/sharepoint onderzoek PMRNCV/Shared\%20Documents/4\%20veld\%20en\%20datarapporten/2016/Datarapport\%20Abiotiek\% 20simulaties $\% 202016 \% 20$ r1\%20totaal.pdf?Web=1

Adema, J. (2019). Datarapport PMR-NCV Perceel abiotiek. Simulaties 2017. Zwolle, Arcadis, Rapportnr 0838186730.1 , pp. https://sharepoint.wur.nl/sites/sharepoint onderzoek PMR-

NCV/Shared\%20Documents/4\%20veld\%20en\%20datarapporten/2018/Datarapport\%20Abiotiek\% 20simulaties\%202017\%20r1\%20totaal.pdf?Web=1

Adema, J. (2019). Datarapport PMR-NCV perceel abiotiek. Simulaties 2018 en analyse monitoringsperiode 2004-2018. Zwolle, Arcadis, Rapport nr 084022067 0.1, 53 pp.

\section{Achtergrondrapportages menselijk gebruik}

Van Calsteren-De Bruijn, L., J. Schuur and H.C.M. Seegers (2016). PMR-NCV perceel Gebruik. Jaarrapportage 2015. Bunnik, LievenseCSO, Rapport nr 15M1030, 52 pp. 


\section{Wageningen Marine Research}

T: +31(0)317480900

E: marine-research@wur.nl

www.wur.nl/marine-research

Bezoekers adres:

- Ankerpark 271781 AG Den Helder

- Korringaweg 7, 4401 NT Yerseke

- Haringkade 1, 1976 CP IJmuiden

\section{Deltares}

T: +31 (0)88-335 8273

E: :info@deltares.nl

www.deltares.nl

Bezoekers adres:

Boussinesqweg 1, 2629 HV Delft
Wageningen Marine Research levert met kennis, onafhankelijk wetenschappelijk onderzoek en advies een wezenlijke bijdrage aan een duurzamer, zorgvuldiger beheer, gebruik en bescherming van de natuurlijke rijkdommen in zee-, kust- en zoetwatergebieden.

Deltares is een onafhankelijk kennisinstituut op het gebied van water, ondergrond en infrastructuur. Wereldwijd werken we aan slimme innovaties, oplossingen en toepassingen voor mens, milieu en maatschappij.

Wageningen Marine Research is onderdeel van Wageningen University \& Research. Wageningen University \& Research is het samenwerkingsverband tussen Wageningen University en Stichting Wageningen Research en heeft als missie: 'To explore the potential of nature to improve the quality of life' 